\title{
WestVirginiaUniversity
}

THE RESEARCH REPOSITORY @ WVU

Graduate Theses, Dissertations, and Problem Reports

2018

\section{Structural Origins of the Doonerak Anticline, Central Brooks \\ Range, Alaska}

Gregory James Hammond

Follow this and additional works at: https://researchrepository.wvu.edu/etd

\section{Recommended Citation}

Hammond, Gregory James, "Structural Origins of the Doonerak Anticline, Central Brooks Range, Alaska" (2018). Graduate Theses, Dissertations, and Problem Reports. 5746.

https://researchrepository.wvu.edu/etd/5746

This Thesis is protected by copyright and/or related rights. It has been brought to you by the The Research Repository @ WVU with permission from the rights-holder(s). You are free to use this Thesis in any way that is permitted by the copyright and related rights legislation that applies to your use. For other uses you must obtain permission from the rights-holder(s) directly, unless additional rights are indicated by a Creative Commons license in the record and/ or on the work itself. This Thesis has been accepted for inclusion in WVU Graduate Theses, Dissertations, and Problem Reports collection by an authorized administrator of The Research Repository @ WVU. For more information, please contact researchrepository@mail.wvu.edu. 
Structural origins of the Doonerak anticline, central Brooks Range, Alaska

Gregory James Hammond

\author{
Thesis submitted to the \\ Eberly College of Arts and Sciences \\ at West Virginia University \\ in partial fulfillment of the requirements \\ for the degree of \\ Master of Science \\ in \\ Geology \\ Jaime Toro, Ph.D., Chair \\ Graham D. M. Andrews, Ph.D. \\ Kathleen C. Benison, Ph.D. \\ Department of Geology \& Geography \\ Morgantown, West Virginia \\ 2017
}

Keywords: Brooks Range, Arctic Alaska, Doonerak, Endicott Mountains, Ellesmerian, Raman spectroscopy, RSCM, microtectonics

Copyright 2017 Gregory James Hammond 


\section{Abstract \\ Structural origins of the Doonerak anticline, central Brooks Range, Alaska Gregory James Hammond}

The Doonerak anticline in the central Brooks Range, Alaska, exposes a package of Early Paleozoic metavolcanic and metasedimentary rocks overlain by Carboniferous to Triassic sedimentary rocks which have been correlated to the North Slope subsurface. The flanks of the anticline have been interpreted as portions of a single north-vergent nappe system emplaced during the Brookian orogeny. The Doonerak anticline is a key location for understanding the structure of the Brooks Range fold and thrust belt. Field mapping, microstructural analysis, Raman-spectroscopy of carbonaceous material (RSCM) paleothermometry, and detrital zircon geochronology data suggest the structure is not a tectonic window resulting from erosion of a single north-vergent nappe system. Structures in the units to the north of the anticline are southvergent, while structures in units to the south of the anticline are north-vergent. Detrital zircon geochronology and petrographic data show that Devonian clastic units in the Endicott Mountains allochthon north of the anticline are not correlative to slates and phyllites in the Hammond assemblage south of the anticline. RSCM paleothermometry shows the southern units reached temperatures of $368 \pm 16^{\circ} \mathrm{C}$ and were buried $\sim 12 \mathrm{~km}$ while the northern units reached $313 \pm 19^{\circ} \mathrm{C}$ and were buried $\sim 10 \mathrm{~km}$. A new model is proposed which accounts for observed structural and lithologic relationships and calculated paleotemperatures. In this model, the southern assemblage was emplaced by north-directed thrusting and northern assemblage was emplaced by south-directed motion along a later back-thrust during the predominantly north-vergent Brookian orogeny. 


\section{Acknowledgements}

I would like to thank my committee for their support and guidance: Dr. Jaime Toro (chair), Dr. Graham Andrews, and Dr. Kathleen Benison. I am grateful for an advisor I can also call a friend and the strong department community of which I was a part.

This work was made possible by the generosity of the Bob and Beverly Shumaker Fund and Milton Tidd and Doris E. Health Promising Researcher Award. Dr. Qiang Wang of WVU Shared Research Facilities was very helpful with the Raman spectroscopy instrument. Justin Strauss kindly loaned thin sections from his work.

Thanks are due to Patrick Frier and Bertrand Gaschot for our shared time along the North Fork of the Koyukuk River, the Perreault family for logistical support in Fairbanks, R. Craig Silva and Tollef Winslow for introducing me to Alaskan geology, Ben Johnson for many helpful discussions, and the Sanford-Upon-Mon community.

I would not have made it here without lifelong support and encouragement from my family, especially of intellectual and adventurous pursuits. I have missed them more than the frequency of my communication likely indicated. 


\section{Table of Contents}

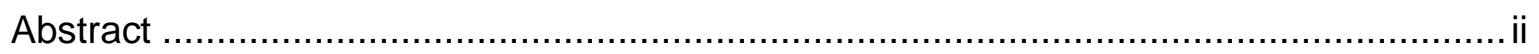

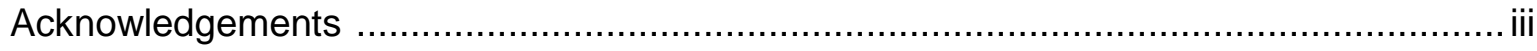

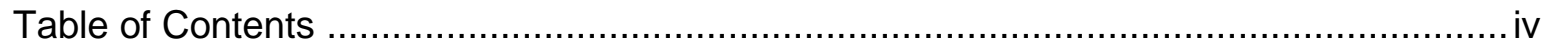

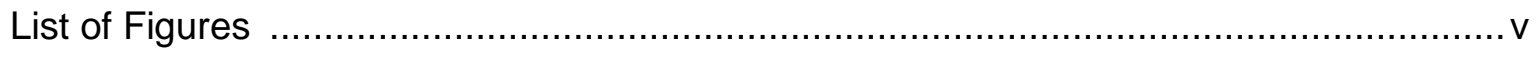

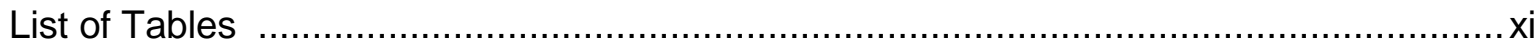

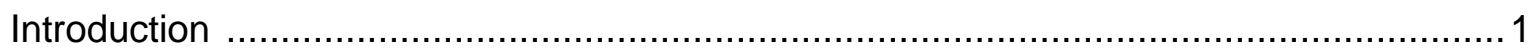

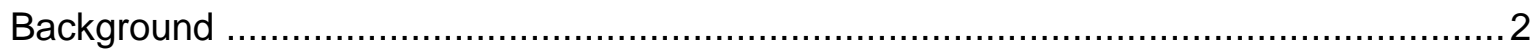

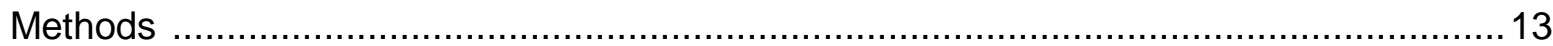

Results

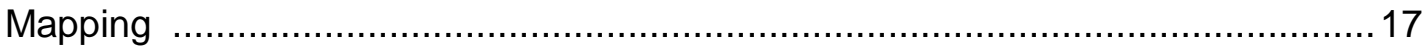

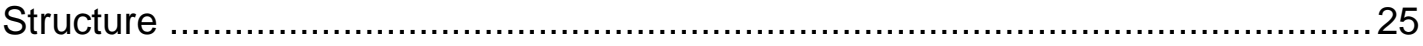

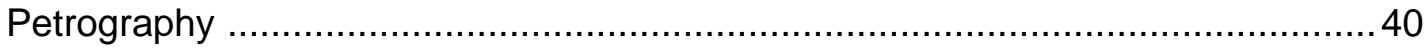

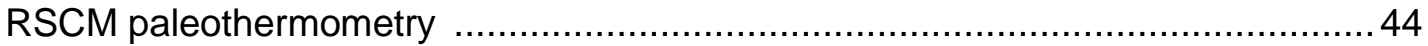

Discussion

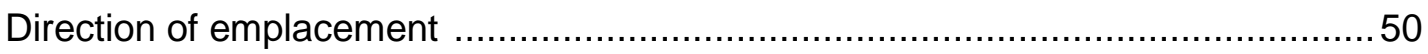

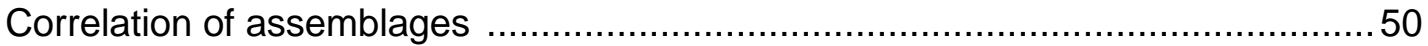

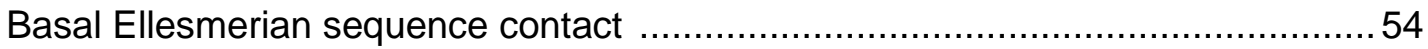

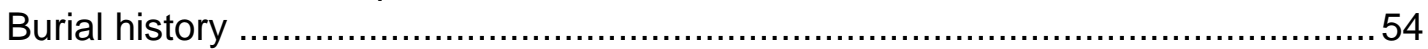

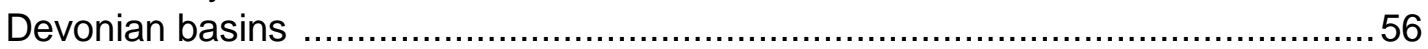

South-directed motion

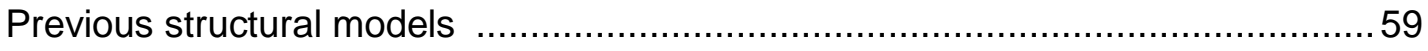

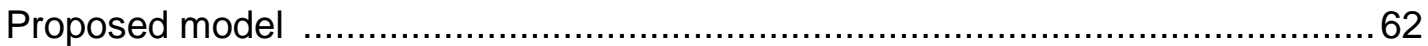

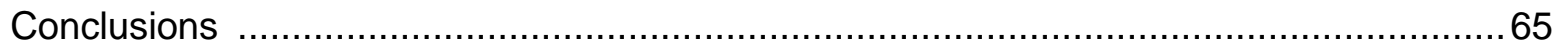

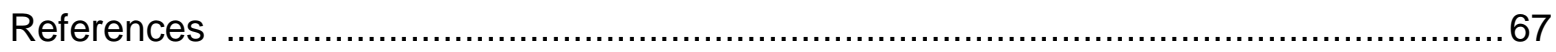

Appendix 1: Expanded discussion of the RSCM method ...................................... 73

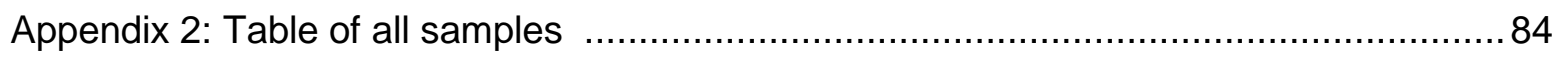

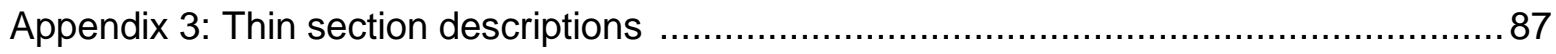

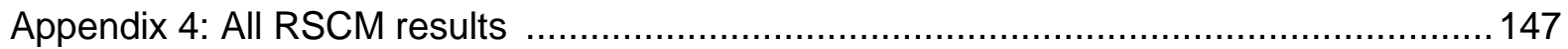




\section{List of Figures}

Figure 1. Generalized geologic map of the Brooks Range, Alaska (after Moore et al., 1994). The white polygon of the Plate 1 map area indicates the study area. .. 2

Figure 2. Generalized map of the Doonerak anticline (simplified from Dillon et al., 1986). White polygon indicates Plate 1 map area.

Figure 3. Prior interpretation of relationships between the units of the Doonerak anticline (modified from Moore et al., 1997). 5

Figure 4. Generalized cross section interpretations of the Doonerak anticline from Dutro et al. (1976). A: north-vergent model similar to that followed by Oldow et al. (1987) and others. B: doubly-vergent model preferred by Dutro et al. (1976). D = Mt. Doonerak, NF = North Fork of the Koyukuk River.

Figure 5. Simplified map of northern Alaska (after Moore et al., 1994) showing the location of the Meade (MD) and Ikpikpuk-Umiat (IB, UB) basins. The seismic line in Figure 35 (Discussion section) is shown in red.

Figure 6. Schematic cross section across the eastern Doonerak anticline showing the Blarney creek thrust below the Amawk thrust on the northern side of the structure (Seidensticker and Oldow, 1998).

Figure 7. Photomicrographs of carbonaceous material in sample 16DF24, plane polarized light, optical microscope (left) and 18DF15, reflected light, Raman spectroscopy instrument microscope (right). Note scale change.

Figure 8. Raman spectroscopy instrument at WVU Shared Research Facilities.

Figure 9. View of the southern margin of the Doonerak anticline looking southwest from the Redstar Mountain vicinity along the approximate contact of the Apoon assemblage to the right and the Hammond assemblage to the left. This view represents typical outcrop exposure and terrain. Distance between

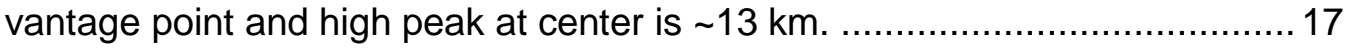

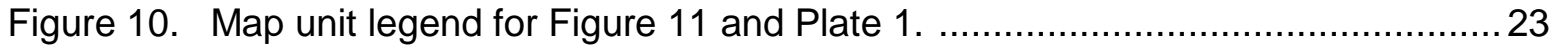

Figure 11. Simplified, scaled version of the study area map. See previous figure for map unit descriptions. See Plate 1 for complete data and references.

Figure 12. Equal area lower hemisphere stereonets for the Apoon assemblage showing S1, best fit great circle and pole to S1 (260/11W, large black dot), and hinge axes.

Figure 13. Equal area lower hemisphere stereonets for the Hammond assemblage showing S1, best fit great circle and pole to S1 (081/26 E, large black dot), hinge axes, and hinge axes mean vector (083/24E, large red dot). 
Figure 14. Outcrop of Trembley Creek phyllite showing an overturned fold. Photo looking west. Axial plane dips south, indicating north-directed motion. Field book is $20 \mathrm{~cm}$ tall. Location: $67.689553 \mathrm{~N}, 151.062599 \mathrm{~W}$.

Figure 15. Equal area lower hemisphere stereonet for the Hammond assemblages showing S2 and best fit great circle and pole to S2 (278/06W, large black dot).

Figure 16. Equal area lower hemisphere stereonet for the Endicott Mountains allochthon showing measurements and mean vectors (large dots) of bedding (097/84E) and S1 cleavage (127/72SE).

Figure 17. Outcrop of Hunt Fork Shale showing gently south-dipping bedding (red) and north dipping cleavage (yellow). Pencil is $15 \mathrm{~cm}$ long. Location: 67.909392 N, 150.902027 W.

Figure 18. Outcrop of Hunt Fork Shale showing steep to slightly overturned bedding (red) and gently north-dipping cleavage (yellow). Fold hinge strikes eastnortheast. Hammer is $35 \mathrm{~cm}$ long. Location: 67.938938 N, 150.777433 W. .. 31

Figure 19. Outcrop of Hunt Fork Shale showing gently southwest-dipping bedding (red) and northwest dipping cleavage (yellow). Hammer is $35 \mathrm{~cm}$ long. Location: $67.919216 \mathrm{~N}, 150.905023 \mathrm{~W}$.

Figure 20. Equal area lower hemisphere stereonet for the Ellesmerian sequence showing bedding, S1 cleavage, and mean vector (135/62SE, large dot).

Figure 21. Outcrop of Kayak Shale showing irregular steeply north-dipping cleavage (yellow) and bedding (red). Large outcrop in center of photo is approximately 30 m. Location: 67.906413 N, 150.794628 W.

Figure 22. Outcrop of Kayak Shale showing tight chevron folding with axial-planar cleavage dipping gently to the north. Visible outcrop is approximately $1.5 \mathrm{~m}$ tall. Location: $67.887604 \mathrm{~N}, 150.932944 \mathrm{~W}$.

Figure 23. Outcrop of Lisburne limestone showing north-dipping thrust faults indicating southward-vergence. Location: $67.906413 \mathrm{~N}, 150.794628 \mathrm{~W}$.

Figure 24. Outcrop of Lisburne limestone showing north-dipping thrust faults indicating southward-vergence. Location: $67.907933 \mathrm{~N}, 150.778226 \mathrm{~W}$.

Figure 25. Outcrop of Lisburne limestone and shale showing north-dipping thrust faults indicating southward-vergence. Visible outcrop is $8 \mathrm{~m}$ tall. Location: 
Figure 26. Figure 26. Outcrop photo of the Sadlerochit Group from Mull (1982) showing $15-25^{\circ}$ south-dipping cleavage in bedding dipping $15^{\circ}$ north, suggesting north-directed vergence. The exact photo location is unknown, but Mull notes that slaty cleavage was observed at multiple locations in the Shublik Formation and Sadlerochit Group.

Figure 27. Simplified, scaled version of the study area map showing locations of thin sectioned samples, detrital zircon geochronology samples, and RSCM paleotemperature results. See Plate 2 for complete data and references. Dashed dark gray line is the location of the RSCM transect plotted on Figure 32.

Figure 28. Map of the southern portion of Plate 1 map area showing sense of shear determined from oriented thin section microstructures. Sense of shear associated with S1 events are all top to the north; S2 events are of mixed sense of shear.

Figure 29. Photomicrograph (XPL) of a rotated clast in sample 16DF09 showing sinistral sense of shear.

Figure 30. Photomicrograph (PPL) of an asymmetric fold in sample 16DF19 indicating sinistral sense of shear.

Figure 31. Representative raw Raman spectra over the acquisition range 1000$1800 \mathrm{~cm}^{-1}$ for individual acquisitions from four samples showing the change in peak character with increasing paleotemperature. Average calculated RSCM paleotemperature of all acquisitions for examples shown with $2 \sigma$-error. Vertical scale arbitrary.

Figure 32. Graph of RSCM maximum paleotemperature results from the Doonerak anticline area plotted along a north-south transect across the Doonerak anticline (location shown on Figure 27). Data collected as part of this study shown with $1 \sigma$ error bars. Data provided by O'Brien and Miller (2017) shown with $2 \sigma$ error bars. Dashed gray line denotes the temperature shift at $11.5 \mathrm{~km}$ discussed in the text.

Figure 33. Stacked detrital zircon geochronology probability density plots from samples of Frier (2017) and accumulated plots from multiple samples from Strauss et al. (2017). Modified from Frier (2017). Color bars represent potential Laurentian source domains.

Figure 34. Published apatite and zircon fission track ages in the vicinity of the Doonerak anticline (Blythe, et al., 1996; O'Sullivan, et al., 1997). Generalized geologic map of the Doonerak anticline simplified from Dillon et al. (1986). 
Figure 35. Seismic cross section and interpretation of a line extending from the northern foothills of the central Brooks Range to the Arctic Ocean (simplified from Cole et al., 1997; location shown on Figure 5). The southern terminus of the line is located approximately $150 \mathrm{~km}$ northwest of the Doonerak anticline. The line shows deposition in the Ikpikpuk-Umiat basin, a small synrift basin. The Inigok \#1 well reached rocks classified as Devonian rocks and pre-Devonian 'argillite' basement in the original well reports (Haywood, 1983; A.O.G.C.C., 2008). Mickey, et al. (2006) classified the deepest samples with identifiable foraminifera as early to middle Mississippian.

Figure 36. Portion of the balanced cross section of Oldow et al. (1987) showing a backthrust in Cretaceous to Tertiary basin fill in the foreland basin north of the Doonerak anticline.

Figure 37. Locations of cross sections by Oldow et al. (1987), Kelly and Brosgé (1995), and the new model presented in this work (Figure 41). The location of the Dutro et al. (1976) cross section is not specified but is in the vicinity of that of Kelly and Brosgé (1995). Generalized geologic map of the Doonerak anticline simplified from Dillon et al. (1986).

Figure 38. Cross section interpretation of the Doonerak anticline by Oldow et al. (1987). Dashed lines added for burial visualization. Endicott Mountains allochthon units shown to the south of the Doonerak anticline are equivalent to the Hammond assemblage.

Figure 39. Cross section interpretation of the Doonerak anticline by Dutro et al. (1976). Pre-Hunt Fork Devonian and Hunt Fork Shale south of the Doonerak anticline equivalent to the Hammond assemblage. Note vertical exaggeration.

Figure 40. Cross section interpretation of the Doonerak anticline by Kelly and Brosgé (1995). Limited structural burial in the area of the Doonerak anticline is apparent.

Figure 41. Schematic cross sections of the interpretation presented in this work. A: At the time of maximum burial. Imbrication of Hammond assemblage thrust north over the Apoon assemblage resulted in approximately $15 \mathrm{~km}$ burial. B: During south-directed back-thrusting of the Endicott Mountains allochthon and Ellesmerian sequence. Burial approximately $12 \mathrm{~km}$ at this time resulted in the lower paleotemperatures observed in these units.

Figure A1. Schematic diagram of Raman scattering (Thermo Fisher Scientific, 2008). ...73 
Figure A2. Raw Raman spectra (thick gray line), component peaks (dashed lines), and summed component peaks (solid black line) for lower grade carbonaceous material (a) and higher grade carbonaceous material (b). Lower grade carbonaceous material exhibits two additional defect peaks not present in the spectra of more well-organized carbonaceous material (modified from Beyssac and Lazzeri, 2012).

Figure A3. Progressive evolution of the Raman spectra of natural samples of carbonaceous material from the western Alps (Beyssac and Lazzeri, 2012). The Raman spectra shown include both the peaks used for the RSCM paleothermometer methods $\left(-1100-1700 \mathrm{~cm}^{-1}\right)$ and the higher-wavenumber peaks $\left(-2500-3300 \mathrm{~cm}^{-1}\right)$ not used in the discussed methods.

Figure A4. Formulas for the R2, RA1, and RA2 parameters used to calculate maximum paleotemperature with the methods of Beyssac et al. (2002) and Lahfid et al (2010). All utilize peak areas for the component peaks.

Figure A5. Sample 16DF10 fit using the procedure of Beyssac et al (2002). Top: residual after fitting. Middle: sum of component peaks (blue line), raw Raman spectra (red), and linear baseline (green). Bottom: component Voigt peaks (Gaussian-Lorenzian sum).

Figure A6. Sample J1409-74.1 fit using the procedure of Lahfid et al (2010). Top: residual after fitting. Middle: sum of component peaks (blue line), raw Raman spectra (red), and linear baseline (green). Bottom: component Lorenzian peaks.

Figure A7. Raman spectra of selected materials compared to carbonaceous material across the spectra range utilized in the RSCM method. The vertical 'counts' scale is arbitrary and depends on signal strength for each sample run.

Figure A8. Top: Photomicrograph of an unknown opaque mineral (circled) in sample 16DF20, 6.3x, PPL. Bottom: Raman spectra of the unknown mineral and the Raman spectra of titanite in the RRUFF database as matched by CrystalSleuth software (Downs, 2006; Lafuente et al., 2015).

Figure A9. Top: Photomicrograph of a feldspar grain (circled) in sample 15JT08, 6.3x, XPL. Bottom: Raman spectra of the the feldpar and the Raman spectra of albite in the RRUFF database as matched by CrystalSleuth software (Downs, 2006; Lafuente et al., 2015).

Figure A10. Left: Cleavage (P/M) domains and microlithons (Q domains). Right: C'-type shear bands. Reproduced from Passchier and Trouw (2005). 
Figure A11. An opaque grain otherwise identified as leucoxene in sample 16DF20 (below) compared to the known spectra of titanite (above) from the RRUFF database using CrystalSleuth software (Downs, 2006; Lafuente et al., 2015).

Figure A12. Formulas for the R2, RA1, and RA2 parameters used to calculate maximum paleotemperature with the methods of Beyssac et al. (2002) and Lahfid et al. (2010). All utilize peak areas of the component peaks. 


\section{List of Tables}

Table 1. Equivalent nomenclature for units in the Doonerak anticline area in this work and selected publications. The notation $(\mathrm{N})$ or $(\mathrm{S})$ refers to the northern or southern portion of units or assemblages mapped across the Doonerak anticline in the cited publication but were split in this work.

Table 2. All RSCM paleothermometry results from the Doonerak anticline area. Map units correspond to Plate 1 . Method refers to the peak fitting procedures and paleotemperature equation used after either Beyssac, et al. (2002) or Lahfid, et al. (2010). See Appendix 4 for detailed results. Asterisk $\left(^{*}\right)$ denotes data provided by O'Brien and Miller (2017).

Table 3. Apatite and zircon fission track data from Blythe, et al. (1996) and O'Sullivan, et al. (1997) shown in Figure 34.

Table A1. Stated applicable range, error, and formulas for published paleothermometers using Raman spectroscopy of carbonaceous material. Beyssac et al. (2002) uses the R2 parameter shown in Figure A4. Lahfid et al. (2010) uses the RA1 and RA2 parameters shown in Figure A4. Kouketsu et al. (2014) use full-width at half-maximum (FWHM) values. Lahfid et al. (2010) does not state an error range associated with the method, although it is assumed to be comparable to the other methods as all are limited by the errors associated with the other paleothermometers they are correlated to, such as CAI and illite crystallinity. .. 76

Table A2. Table of contents for thin sections described in this appendix. 89

Table A3. Stated applicable range and formulas for the RSCM paleothermometers of Beyssac et al. (2002) and Lahfid et al. (2010) used in this work. R2, RA1, and RA2 parameters are shown in Figure A10.

Table A4. List of samples on which RSCM was attempted unsuccessfully.

Table A5. All of my RSCM paleothermometry results from the Doonerak area. Map units correspond to Plate 1 . Method refers to the peak fitting procedures and paleotemperature equation used after either Beyssac et al. (2002) or Lahfid et al. (2010). Results from each sample follow in the same order as the table. 


\section{Introduction}

The Doonerak anticline in the central Brooks Range, Alaska, is considered one of the key locations for studying the structural style of the Brooks Range orogen. The structure has been interpreted as the result of allochthonous nappes emplaced by north-directed thrusting, which were later uplifted and eroded into the current structure. This tectonic window interpretation is primarily based on 1:250,000 reconnaissance-scale mapping and older data. Only the eastern portion of the anticline has been mapped in greater detail.

In this thesis, the areas accessible from the North Fork of the Koyukuk River, which cuts through the center of the Doonerak anticline, were studied. This work seeks to improve understanding of the structure through field mapping, petrography, and Raman-spectroscopy of carbonaceous material (RSCM) paleothermometry.

Based on two seasons of field mapping, an updated 1:63,360 scale geologic map was produced. Structural data for each lithologic assemblage were interpreted. Petrography was described and, if applicable, sense of shear was determined for 52 thin sections. RSCM paleotemperatures were calculated for 38 samples. These methods were used in conjunction with recent detrital zircon geochronology data from others to create a new interpretation of the Doonerak anticline.

In the new model presented here, the units south of the anticline were emplaced by north-directed motion during the Brookian orogeny. Subsequent back-thrusting emplaced the rocks on the northern margin of the anticline with south-directed motion. This interpretation greatly reduces the required shortening estimated by prior workers and has implications for larger-scale reconstructions of the central Brooks Range. 


\section{Background}

The Brooks Range is a fold and thrust belt extending $1100 \mathrm{~km}$ across northern Alaska

(Figure 1). It began forming during the Brookian orogeny in the Late Jurassic to Early

Cretaceous with the collision of the oceanic Angayuchum terrane against the Arctic Alaska superterrane (Moore et al., 1994). Major orogenesis was mostly complete by Albian time ( 100 Ma). Hanging wall units were likely emplaced above the footwall of the Doonerak anticline during this period. Therefore, this a key locality for understanding the development of the Brooks Range (Mull, 1989b). A second phase of shortening and uplift took place in the Cenozoic, uplifting and partially refolding these earlier structures into the Oligocene (O'Sullivan et al., 1998).

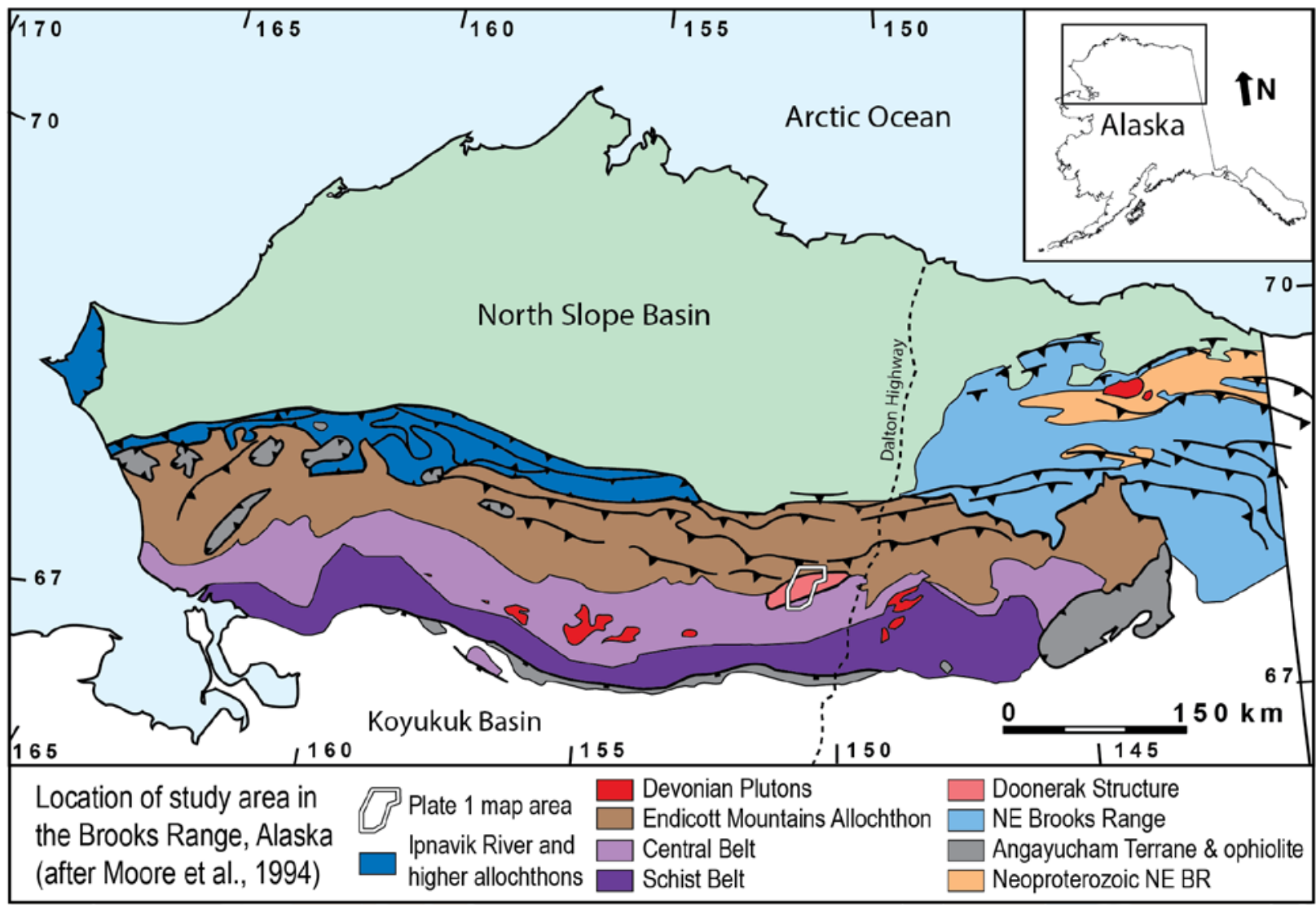

Figure 1. Generalized geologic map of the Brooks Range, Alaska (after Moore et al., 1994). The white polygon of the Plate 1 map area indicates the study area. 


\section{Prior work}

Geologic mapping of the Wiseman Quadrangle, which includes the Doonerak anticline, began in the 1950s and resulted in 1:250,000 reconnaissance scale maps by Brosgé and Reiser (1971) and Dillon et al. (1986). Subsequent mapping was completed at the more accessible eastern end of the anticline adjacent to the Dalton Highway at the $1: 63,360$ scale as part of the Trans-Alaska Crustal Transect (TACT) project (Moore et al., 1997) and the 1:36360 scale by Phelps (1987) and Julian (1989). More recent work in the study area has included geochemical and geochronological sampling, but no major revisions to previous maps (Frier, 2017; Strauss et al., 2017).

Several nomenclatures have been used to classify the rocks of the Doonerak anticline and its vicinity. These are based on both lithostratigraphic and tectonostratigraphic frameworks. The 1:250,000 reconnaissance maps utilized lithostratigraphic units divided primarily based on field characteristics for mapping purposes. These included many informal map units that the authors thought equivalent or correlative, but confidence was limited by the scale of the area and paucity of fossil and geochronological data (Dillon et al., 1986). Other workers have focused on tectonic reconstructions, dividing the units into various autochthonous, parautochthonous, or allochthonous terranes (e.g. Mull, 1982; Jones et al., 1987). This creates confusion and ambiguity when comparing prior work, especially when various workers combine the original units of the 1:250,000 scale maps in different ways (e.g. Oldow et al., 1987; Till et al., 2008). As part of the TACT project, Moore et al. (1997) clarified and grouped many of the previous map units (Figure 3). This scheme was followed by Strauss et al. (2017). A modified version of this system is used in this work.

\section{The Doonerak anticline}

The Doonerak anticline (Figure 2) is an approximately $75 \mathrm{~km}$ long, $15 \mathrm{~km}$ wide, eastnortheast-trending anticline in the central Brooks Range of Alaska. At the core of the anticline 
are an assemblage of Early Paleozoic rocks overlain by Carboniferous to Triassic sedimentary rocks. Collectively, these units have been correlated to both the North Slope subsurface and northeastern Brooks Range. The fault system at the northern side of the anticline has been interpreted as the basal detachment fault of the Endicott Mountains allochthon. Together, these make the Doonerak area a key location for studying the structural style and evolution of the central Brooks Range (Mull et al., 1987). The structure has often been called a fenster, or tectonic window. This suggests that the units in the core of the anticline are exposed beneath an allochthonous nappe, implying tectonic transport of hundreds of kilometers (Oldow et al., 1987). As the structure is subject to interpretation, non-genetic terms will be used herein. Similarly, the term 'assemblage' is preferred to 'terrane'.

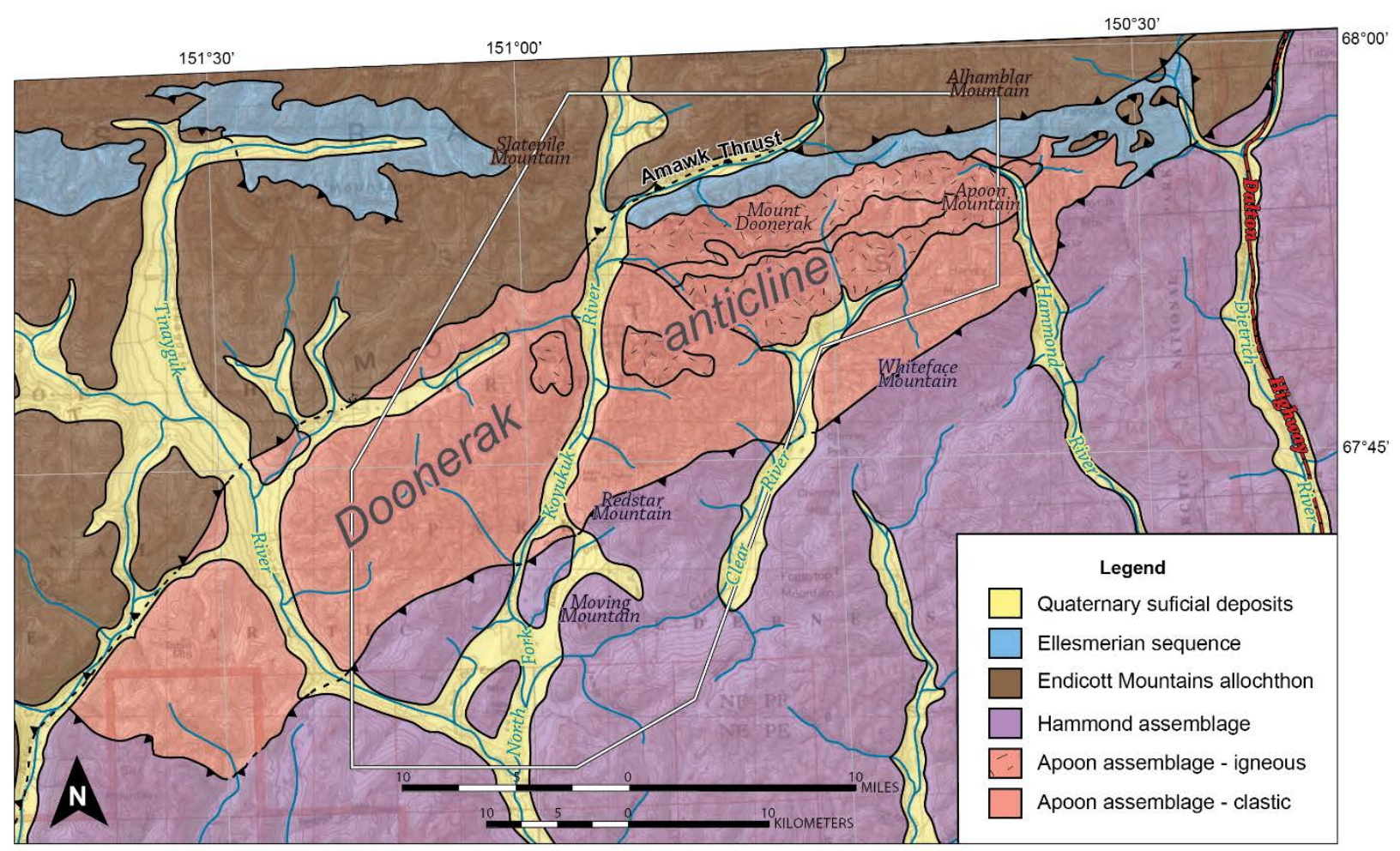

Figure 2. Generalized map of the Doonerak anticline (simplified from Dillon et al., 1986). White polygon indicates Plate 1 map area. 
Figure 3 shows the interpretation of units presented by Moore et al. (1997). In this model, the Hammond assemblage units are structurally below the Endicott Mountains allochthon units. Together they are interpreted to have been thrust northward over the units internal to the anticline. They represent the 'hanging wall' units of the Doonerak anticline. The Hammond assemblage units are internally imbricated and not present on the northern flank of the anticline. The core of the anticline includes the Apoon assemblage and the Ellesmerian sequence, which are in either depositional or structural contact. The Ellesmerian sequence is also present atop the Endicott Mountains allochthon to the north of the Doonerak anticline and in the subsurface of the North Slope. These general relationships between units are an important context for further discussion of the Doonerak anticline.

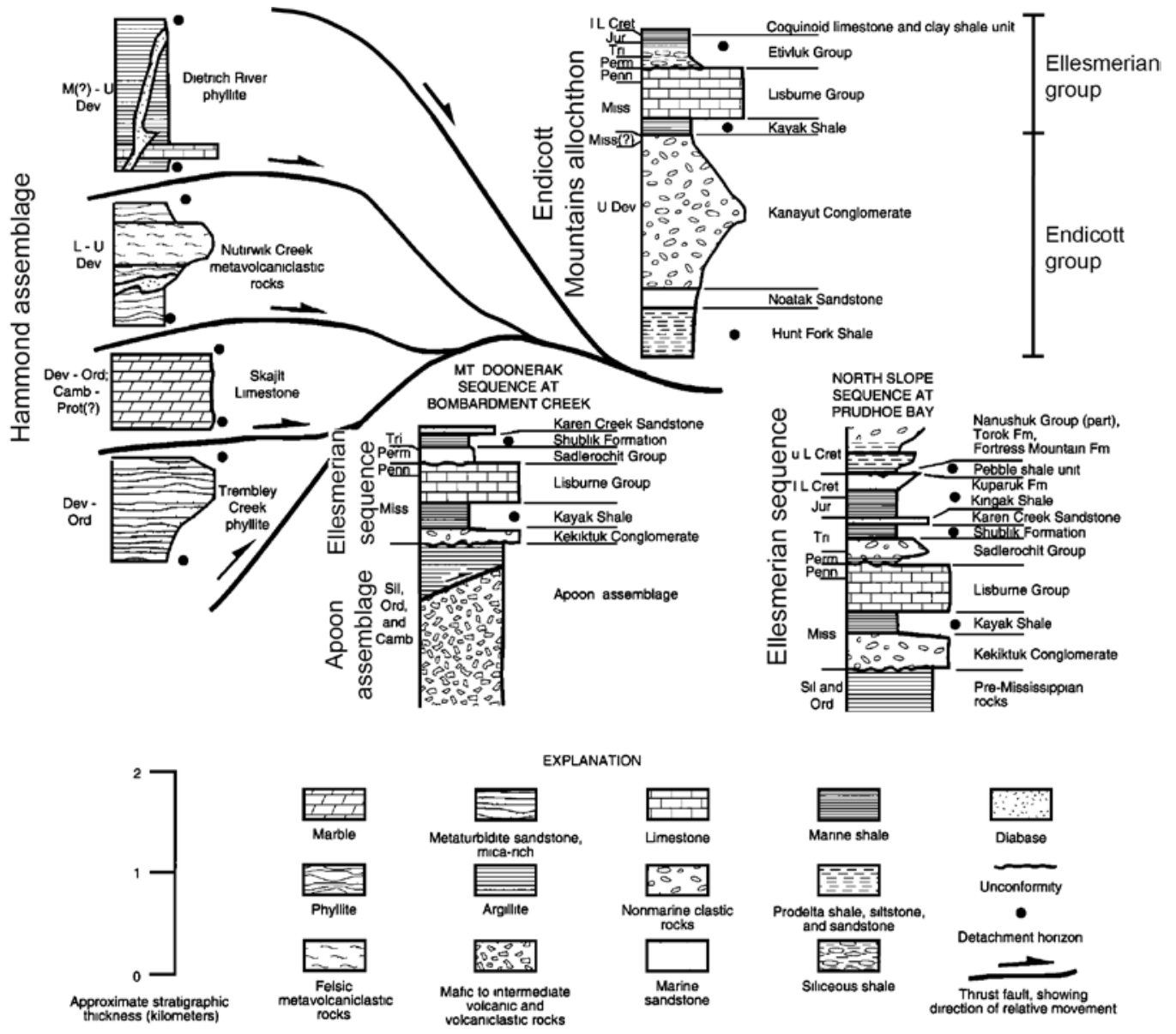

Figure 3. Prior interpretation of relationships between the units of the Doonerak anticline (modified from Moore et al., 1997). 
The interior of the anticline exposes the informally named Apoon assemblage (Oldow et al., 1984), which includes Early Paleozoic metasedimentary and volcanic units. These rocks are interpreted to have formed adjacent to a volcanic island arc off a continental margin (Mull, 1989a) or in the backarc basin of an island arc (Julian, 1989). Age controls of the metasedimentary units in the assemblage are based on rare occurrences of Cambrian trilobites and brachiopods, Ordovician to Silurian graptolites, Silurian conodonts, and geochronological data (Dutro et al., 1984; Repetski et al., 1987; Johnsson et al., 1992). The youngest detrital zircon sampled by Strauss et al. (2017) yielded an age of 395 \pm 11 Ma. Intrusive igneous units in the anticline were dated at 520 to 380 Ma by K-Ar in Hornblende (Dutro et al., 1976; Strauss et al., 2017). The Apoon assemblage is considered equivalent to the pre-Mississippian Franklinian assemblage of the northeast Brooks Range and subsurface of the Arctic Alaska terrane, where it forms economic basement on the North Slope (Mull, 1989a). Julian and Oldow (1998) questioned this link based on the lack of pre-Brookian structures in the Apoon assemblage as are found in the northeastern Brooks Range. However, this difference has been explained as being the result of the southern limit of Devonian deformation within otherwise correlative units (Mull et al., 1987).

The Ellesmerian sequence overlies the Apoon assemblage (Figure 3). This package is composed of Mississippian to Triassic sedimentary rocks correlative to exposures in the northeastern Brooks Range and North Slope subsurface (Armstrong et al., 1976). Together the Ellesmerian sequence and Apoon assemblage form the core of the anticline. The basal contact of the Ellesmerian sequence has been described as both an unconformity (Dutro et al., 1976; Mull et al., 1987) and tectonic (Phelps, 1987). The Ellesmerian sequence is only exposed along the northern margin of the anticline and is absent to the south (Figure 3). This has been explained by the fault that emplaced the hanging walls of the anticline climbing up-section during north-directed motion (Mull et al., 1987). Others have explained the lack of the Ellesmerian sequence along the southern margin as a result of limited original depositional 
extent (Dutro et al., 1976) or erosion, given an alternative structural reconstruction (Kelly and Brosgé, 1995).

The units to the north of the anticline are the Devonian to Mississippian members of the Endicott Mountains allochthon. These have been correlated to more metamorphosed and unfossiliferous rocks south of the anticline and are often considered part of a single package emplaced by north-directed motion (Oldow et al., 1987). This correlation was established by early mapping (Dillon et al., 1986) and was considered confirmed when Phelps (1987) traced the contact between the anticline core footwall and hanging wall rocks around the eastern end of the structure from the northern to southern margins. However, Phelps noted differences between the units, dividing them into northern and southern domains. Two units of the Endicott Mountains allochthon, the Hunt Fork Shale and Beaucoup Formation, were reassigned by Moore et al. (1997) into different units during their updated mapping along the eastern end of the Doonerak anticline. Based on the distinctions of Phelps (1987) and Moore et al. (1997), the previous correlation of the Endicott Mountains allochthon across the anticline remains uncertain.

In the hanging wall on the southern margin of the Doonerak anticline, between the Apoon assemblage and the supposed southern extension of the Endicott Mountains allochthon, are Ordovician to Devonian members of the Hammond assemblage. Original relationships within this group of primarily greenschist facies metasedimentary rocks is uncertain due to internal imbrication, deformation, and limited geochronological and fossil data. The Hammond assemblage has been called a terrane, believed to have been thrust at least $90 \mathrm{~km}$ north. It is not present on the northern limb of the anticline, which has been explained by the north-vergent thrust that emplaced both the Hammond assemblage and Endicott Mountains allochthon climbing up-section to the north (Moore et al., 1997). 


\section{Structural development}

Most workers consider the hanging wall rocks to have been emplaced by northward thrusting of the Hammond assemblage and Endicott Mountains allochthon (Figure 4, A; e.g. Oldow et al., 1987). This shortening and the allochthonous character of the hanging wall is evidenced by (1) lithologic differences between the Ellesmerian units within the anticline and those to the north in the overlying allochthon and (2) the absence of a pre-Mississippian unconformity in the Endicott Mountains allochthon which exists in the North Slope subterrane and in the core of the Doonerak anticline, suggesting the allochthon was transported from a distal position (Mull et al., 1987). Balanced cross-sections based on regional reconnaissance mapping have estimated shortening to be at least $540 \mathrm{~km}$ (Oldow et al., 1987) and as much as 885 km (Kelly and Brosgé, 1995).

Dutro et al. (1976) proposed an autochthonous or para-autochthonous model of the hanging wall units wherein the Hammond assemblage was emplaced by north-vergent thrusting on the southern side and south-vergent thrusting emplaced the Endicott Mountains allochthon along the northern side of the anticline (Figure 4, B). The two-thrust model was proposed to address the differences in units of the hanging wall across the anticline and axial planes of minor folds suggesting vergence toward the anticline from both directions. As with other models, Dutro et al. (1976) correlate the Hunt Fork Shale and members of the Endicott Mountians allochthon across the anticline. This model reduces required shortening by an order of magnitude to approximately $50 \mathrm{~km}$.

Another model invoking significantly less shortening than that of Oldow et al. (1987) was put forth by Kelly and Brosgé (1995). They suggested as little as $90 \mathrm{~km}$ of northward thrusting, with the Endicott Mountains Allochthon being para-autochthonous and the basal thrust being a local in extent. This model is entirely north-vergent, in comparison to the convergent model of Dutro et al. (1976). In their model, the Endicott Mountains allochthon was deposited in a Devonian to Mississippian synrift basin before being thrust northward to its current position. The 
Ikpikpuk-Umiat and Meade basins are examples of comparable basins of similar age found in northern Alaska subsurface (Figure 5).

Each of these models will be revisited in the discussion of the new data presented from this work.
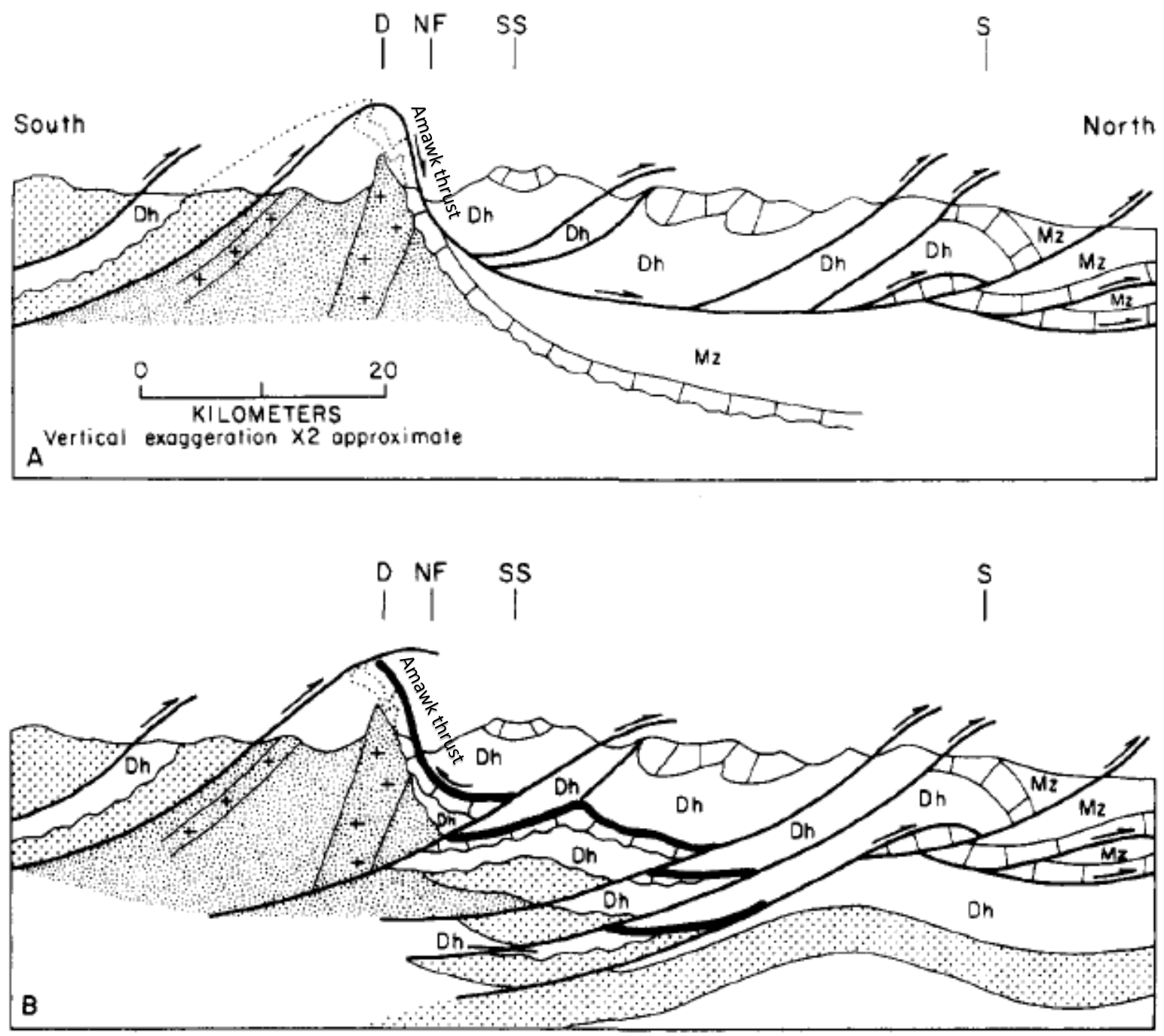

Figure 4. Generalized cross section interpretations of the Doonerak anticline from Dutro et al. (1976). A: north-vergent model similar to that followed by Oldow et al. (1987) and others. B: doubly-vergent model preferred by Dutro et al. (1976). $\mathrm{D}=$ Mt. Doonerak, NF = North Fork of the Koyukuk River. 


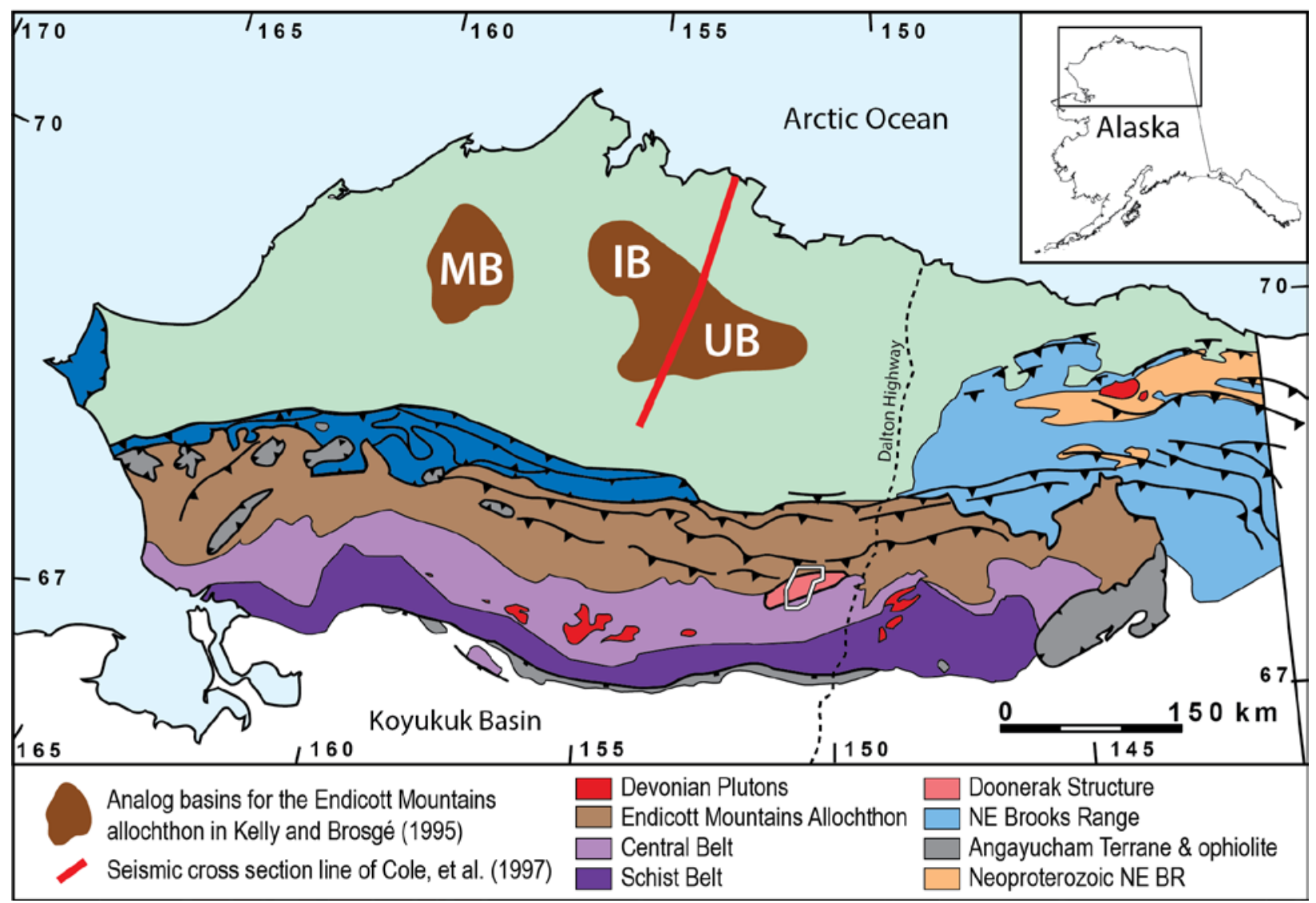

Figure 5. Simplified map of northern Alaska (after Moore et al., 1994) showing the location of the Meade (MD) and Ikpikpuk-Umiat (IB, UB) basins. The seismic line in Figure 35 (Discussion section) is shown in red.

The fault separating the Apoon assemblage and Ellesmerian sequence from the Endicott Mountains allochthon, the Amawk thrust, was originally recognized along the creek of the same name on the northern flank of the anticline (Plate 1). In models wherein the northern and southern hanging wall units were emplaced as a single package, the Amawk thrust name has been extended to the southern margin where the Hammond and Apoon assemblages are in contact.

A variant of the single north-vergent thrust models includes a second north-vergent thrust, the Blarney Creek thrust and associated allochthon (Figure 6). This fault splays off the Amawk thrust over the anticline and is only present on the northern margin (Julian, 1987; Seidensticker and Oldow, 1998). Phelps (1987) suggests an additional splay, the Skajit thrust, 
also only present in the north. These thrusts are interpreted as being north-vergent and relatively small in displacement, with limited implications for broader reconstructions.

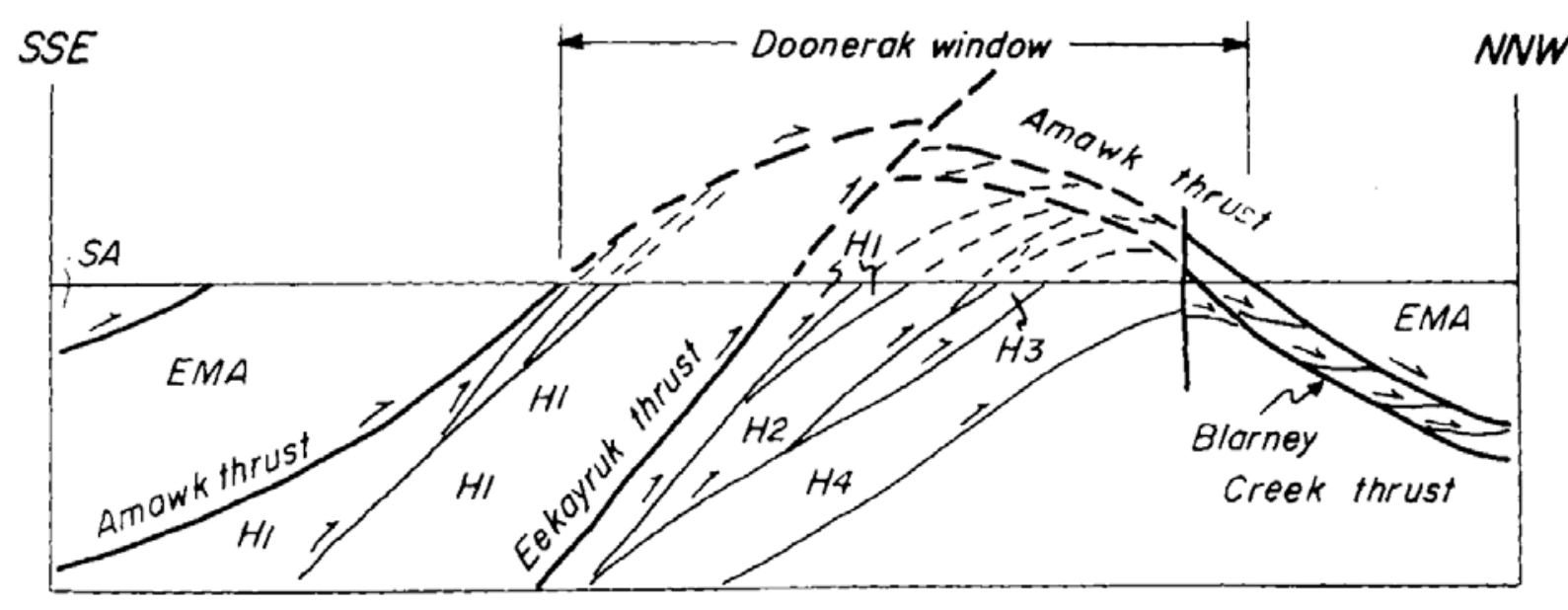

no vertical exaggeration

Figure 6. Schematic cross section across the eastern Doonerak anticline showing the Blarney creek thrust below the Amawk thrust on the northern side of the structure (Seidensticker and Oldow, 1998)

The Brooks Range is an overall north-vergent fold and thrust belt. This creates a bias towards interpretations of the Doonerak structure as the result of similar motion (e.g. Mull, 1982). Ongoing work should consider, however, that these interpretations are based on regional mapping and often without direct evidence for the kinematics of most faults, and with limited knowledge of age relationships across the faults. The implications of newer data will be discussed in conjunction with the results from this work.

Understanding of the more recent history of uplift of the anticline is based on a regional deep-crustal seismic transect and fission track data. Seismic reflection data support $\sim 15 \mathrm{~km}$ of total uplift of the Doonerak anticline (Fuis et al., 1995). Zircon fission track dating indicates 8$12 \mathrm{~km}$ of uplift and denudation since $\sim 70 \mathrm{Ma}$. Apatite fission track dating suggests the last $\sim 4-6$ $\mathrm{km}$ of uplift occurred since the late Oligocene. A period of rapid uplift occurred at $\sim 24 \pm 3 \mathrm{Ma}$ and has been slower since (O'Sullivan, 1998). These periods of rapid uplift and coeval deformation 
in the northeast Brooks Range may be associated with shallow subduction during periods of rapid northward motion of the Kula Plate at the southern Alaska margin (Wallace and

Engebretson, 1984; Blythe et al., 1996). The only published white mica ${ }^{40} \mathrm{Ar} /{ }^{39} \mathrm{Ar}$ cooling age is a sample of the Trembley Creek phyllite unit in the Hammond assemblage (Strauss et al., 2017). The sample had a cooling age of $\sim 465 \mathrm{Ma}$ and experienced partial reheating at a time younger than $\sim 267 \mathrm{Ma}$.

\section{Methods}

Field Mapping

Field work was completed in late July and early August of both 2015 and 2016. Each season included over two weeks of mapping, with additional days moving to, from, and within the mapping areas. The 2015 field season targeted the northern margin of the structure at the contact between the Apoon assemblage, Ellesmerian sequence, and Endicott Mountains allochthon. This first season was principally for the thesis work of W. P. Frier (2017). I served as field assistant, but the 2015 data and observations were integrated with those from the 2016 season for this work. The second season targeted the southern margin of the structure, where the Apoon assemblage contacts the Hammond assemblage. Mapping areas were targeted based on areas of promising exposure shown in aerial imagery and locations of key contacts shown in the published 1:250,000 reconnaissance scale maps of Dillon et al. (1986) and Brosgé and Reiser (1971). The field area was accessed by bush plane via the town of Bettles, Alaska, which landed along the North Fork of the Koyukuk River near Fishless Creek as permitted by Gates of the Arctic National Park. In 2015, the field area was exited via airplane pickup at the same location. In 2016, an inflatable raft was used to float the river to return to Bettles.

Field work consisted of lithologic description, standard structural measurements; description of macroscopic structures, especially evidence of shear or vergence; and collecting samples. The 2016 season included collection of oriented samples for microstructural 
characterization. Field measurements were plotted on stereonets using Stereonet 9.8 (Allmendinger et al., 2013; Cardozo and Allmendinger, 2013).

Field mapping was done using the unit classification of Dillon et al. (1986), with field descriptions, photos, and samples allowing for later reclassification into the updated scheme used in this work. Field data, aided by petrographic unit classification, aerial imagery, and the maps of Dillon et al. (1986), Brosgé and Reiser (1971), Julian (1987), and Phelps (1989) were used to generate an updated 1:63,360 scale (1 inch = 1 mile) geologic map of the study area. Petrography

Petrographic thin sections were made from selected samples collected during both 2015 and 2016 field seasons. Oriented samples from the 2016 season were used to make oriented thin sections. Samples collected in 2015 were not oriented. Additional oriented thin sections were provided by J. Toro from a previous transect of the North Fork of the Koyukuk River through the 2016 field area. Non-oriented thin sections were provided by J. Strauss from field work conducted in 2014 to the east near the confluence of Amawk Creek and the North Fork of the Koyukuk River (Strauss et al., 2017).

For each thin section, mineralogy was described and the sample was photographed with a SPOT 5.0 camera and Olympuc SZX10 binocular microscope with polarizing filter. On occasion, a mineral was not readily identified optically, so Raman spectroscopy was utilized for identification by comparing the spectra of the unknown mineral to the RRUFF database using CrystalSleuth software (Downs, 2006; Lafuente et al., 2015).

Microstructures were characterized using the methods of Passchier and Trouw (1996) and Vernon (2004). Crenulation, shear bands, fringed grains, veins, and folding were commonly observed. When the sample was oriented, these observations were assigned to either a primary S1 event or a secondary S2 event and vergence of one or both events was determined. This determination complemented field observations in establishing directions of structural movement. 


\section{Raman Spectroscopy}

Raman spectroscopy of carbonaceous material (RSCM) is a well-established paleothermometer used for metasedimentary rocks containing carbonaceous and graphitic material (Kouketsu et al., 2014). Raman spectroscopy measures the scattering of photons interacting with the covalent bonds in a material. The degree and nature of the scattering produce unique Raman spectra that can be used to identify and characterize materials. In the case of carbonaceous material, changing peaks in the Raman spectra reflect progressive organization of defects in towards pure crystalline graphite. This progressive organization and resultant Raman spectra has been quantitatively tied to maximum temperature in both natural and synthetic carbonaceous samples. The organization of carbonaceous material towards pure crystalline graphite is dependent primarily on temperature, rather than pressure, and is irreversible--therefore the degree of organization represents the maximum paleotemperature (Beyssac et al., 2002).

Several methods of peak identification and formulas tied to paleotemperature have been proposed, with Beyssac et al. (2002) being the most widely used. Their method is applicable from $330-650^{\circ} \mathrm{C}$, with an accuracy $\pm 50^{\circ} \mathrm{C}$ and the potential to distinguish between samples different by $10-15^{\circ} \mathrm{C}$. This method was used in this study in combination with the method of Lahfid et al. (2010), which has a stated applicability from $\sim 200^{\circ} \mathrm{C}$ to $\sim 330^{\circ} \mathrm{C}$. Together these methods are useful from $\sim 200^{\circ} \mathrm{C}$ to $650^{\circ} \mathrm{C}$ and offer the ability to determine absolute maximum paleotemperature and distinguish between samples across the study area. Additional discussion of the RSCM method and procedures followed can be found in Appendix 1.

Thin sections from the 2015 and 2016 field areas and J. Toro were prepared as standard $30 \mu \mathrm{m}$, non-polished, uncovered thin sections. The thin sections provided by J. Strauss included a glass cover slip, inhibiting their direct use for RSCM. Billets were available for all thin sections and were used for RSCM when thin sections could not be. Several samples from which thin sections were not made were used for RSCM by cutting a piece of the sample perpendicular to 
foliation and mounting on a glass slide. Samples were chosen after a review under an optical microscope based on both carbonaceous material content (Figure 7) and for a representative distribution across the study area.

Raman spectroscopy was conducted at WVU Shared Research Facilities, which has an instrument similar to those used in published RSCM studies (Figure 8). The instrument is a Renishaw InVia Raman Microscope with 532 nm green laser, 1800 l/mm grating, and 50x objective. RSCM studies use lasers of wavelength between 514 and $531 \mathrm{~nm}$ (e.g. Beyssac et al., 2002; Rahl et al., 2005; Lahfid et al., 2010). Each spectral acquisition was typically 30 seconds across the 1000 to $1800 \mathrm{~cm}^{-1}$ range. Prior to each session, the instrument is calibrated to the $521 \mathrm{~cm}^{-1}$ peak of a silicon standard. Data was exported from the instrument WiRE 2 software (Renishaw Ltd., Gloucester, UK) and processed with IgorPro 6.34 software (WaveMetrics Inc., Lake Oswego, Oregon).
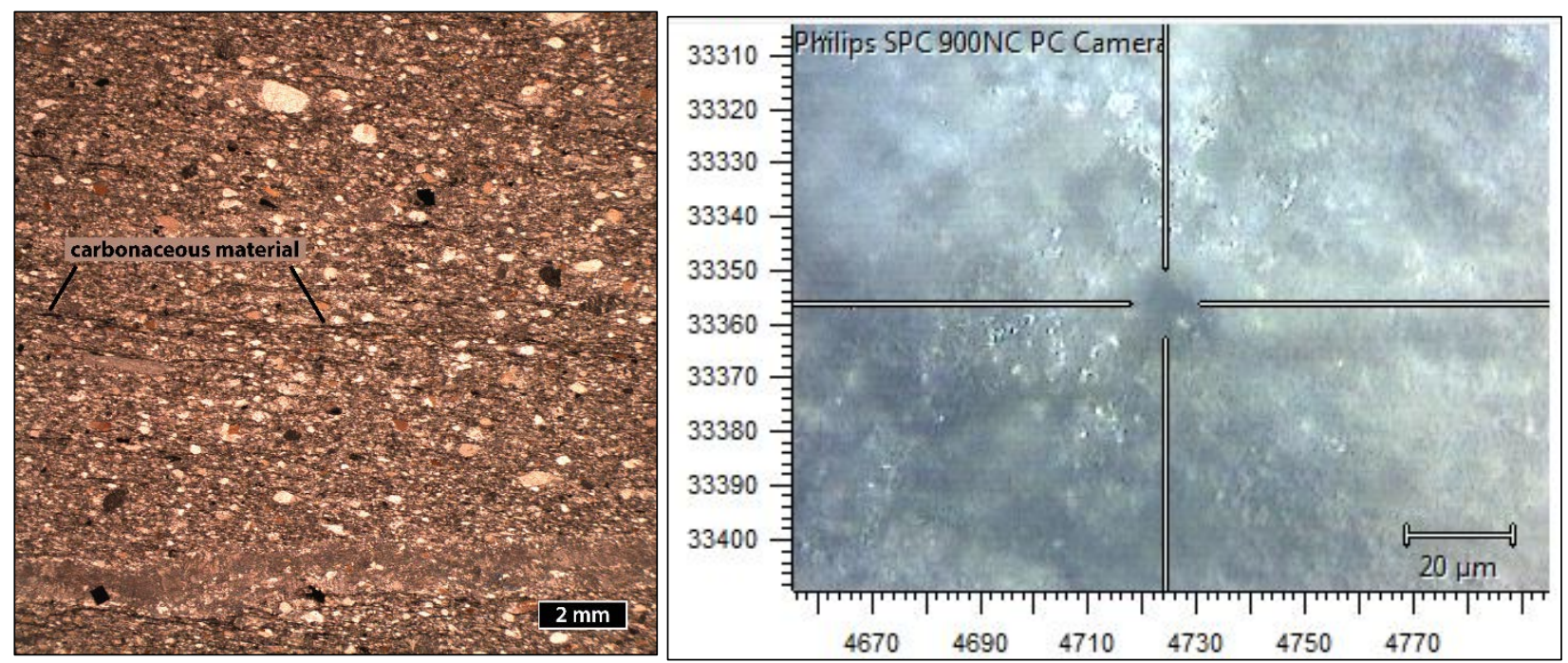

Figure 7. Photomicrographs of carbonaceous material in sample 16DF24, plane polarized light, optical microscope (left) and 18DF15, reflected light, Raman spectroscopy instrument microscope (right). Note scale change. 


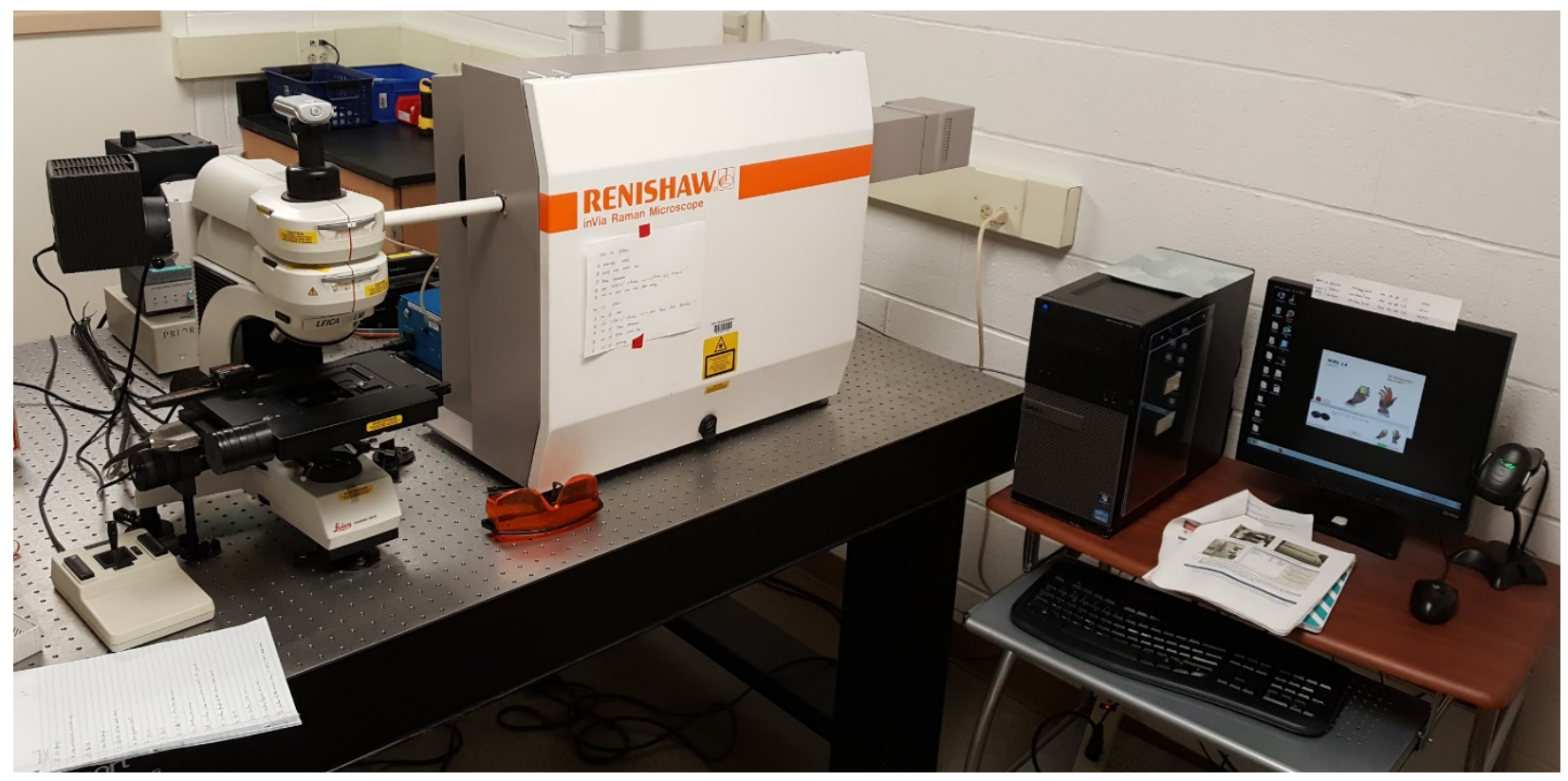

Figure 8. Raman spectroscopy instrument at WVU Shared Research Facilities.

\section{Results: Mapping}

\section{Field mapping}

Field work was focused on the northern and southern margins of the Doonerak anticline in areas accessible from the North Fork of the Koyukuk River. Field work was limited by rough terrain, heavy vegetation, and areas of limited outcrop exposure (Figure 9). This often impeded the direct observation of unit contacts and certainty of whether the contact was depositional or structural. Mapping coverage can be seen by the extent of structural measurement symbols on Plate 1.

Field observations and samples were combined with digital elevation (DEM) data, satellite imagery, and previous maps to generate the 1:63,360 scale map of Plate 1 . A smaller, simplified version of this map is shown in Figure 11. 


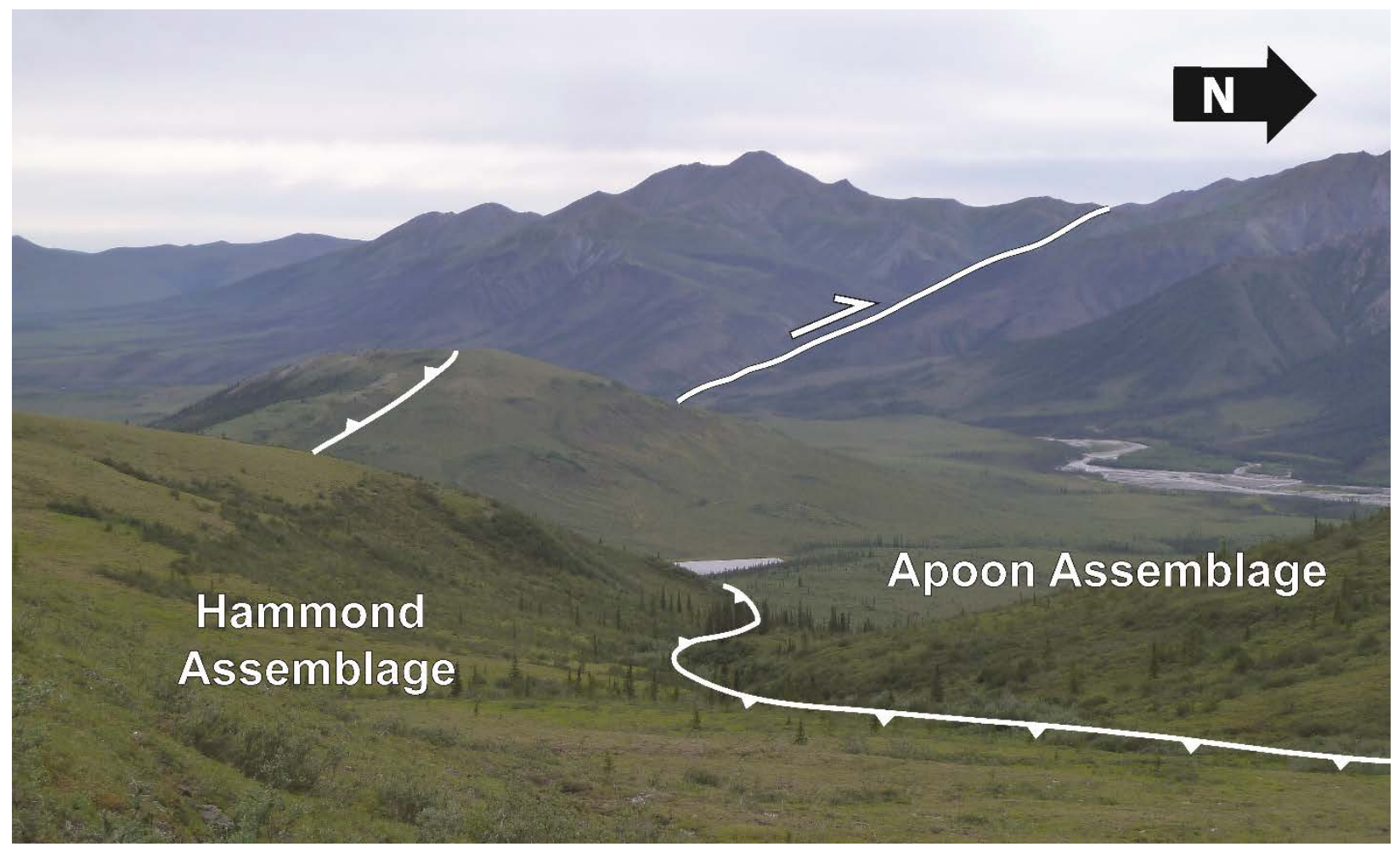

Figure 9. View of the southern margin of the Doonerak anticline looking southwest from the Redstar Mountain vicinity along the approximate contact of the Apoon assemblage to the right and the Hammond assemblage to the left. This view represents typical outcrop exposure and terrain. Distance between vantage point and high peak at center is $\sim 13 \mathrm{~km}$.

\section{Map units}

Prior to making the final map included in this work, appropriate classification of map units was required. The nomenclature of Moore et al. (1997) was modified as dictated by new data into the scheme used here. The study area was divided into four assemblages, each with two to five component mapped units: the Apoon assemblage, Hammond assemblage, Endicott Mountains allochthon, and Ellesmerian sequence. A comparison of the grouping used here and that of selected prior works is shown in Table 1. Descriptions for each map unit are shown in Figure 10 and Plate 1. 


\begin{tabular}{|c|c|c|c|c|c|c|c|}
\hline \multicolumn{2}{|c|}{ This work } & \multirow{2}{*}{$\begin{array}{l}\text { Strauss et } \\
\text { al. (2017) } \\
\text { Assemblage }\end{array}$} & \multirow{2}{*}{$\begin{array}{c}\text { Moore } \\
\text { et al. (1997) }\end{array}$} & \multirow{2}{*}{$\begin{array}{l}\text { Phelps (1987) } \\
\text { Assemblage }\end{array}$} & \multirow{2}{*}{$\begin{array}{c}\begin{array}{c}\text { Dillon et } \\
\text { al. (1986) }\end{array} \\
\text { Map } \\
\text { Units }\end{array}$} & \multirow{2}{*}{$\begin{array}{c}\begin{array}{c}\text { Oldow } \\
\text { (1987) }\end{array} \\
\text { Assemblage }\end{array}$} & \multirow{2}{*}{$\begin{array}{c}\begin{array}{c}\text { Till et al. } \\
\text { (1988) }\end{array} \\
\text { Assemblage }\end{array}$} \\
\hline Assemblage & $\begin{array}{l}\text { Map } \\
\text { Units }\end{array}$ & & & & & & \\
\hline $\begin{array}{l}\text { Ellesmerian } \\
\text { sequence }\end{array}$ & $\begin{array}{l}\text { MPel, } \\
\text { Mek }\end{array}$ & $\begin{array}{l}\text { Ellesmerian } \\
\text { sequence }\end{array}$ & $\begin{array}{l}\text { Ellesmerian } \\
\text { sequence }\end{array}$ & $\begin{array}{l}\text { Blarney Creek } \\
\text { assemblage }\end{array}$ & $\mathrm{kCs}$ & $\begin{array}{l}\text { Lisburne } \\
\text { grp, Kayak/ } \\
\text { Kekiktuk }\end{array}$ & - \\
\hline $\begin{array}{l}\text { Endicott } \\
\text { Mountains } \\
\text { allochthon }\end{array}$ & $\begin{array}{l}\text { Dhf, } \\
\text { MDkn, } \\
\text { Dsg }\end{array}$ & $\begin{array}{l}\text { Endicott } \\
\text { Mountains } \\
\text { Allochthon }\end{array}$ & $\begin{array}{l}\text { Endicott } \\
\text { Mountains } \\
\text { terrane/ } \\
\text { allochthon }\end{array}$ & $\begin{array}{l}\text { northern } \\
\text { Endicott } \\
\text { Mountains } \\
\text { assemblage }\end{array}$ & $\begin{array}{l}\text { Dhf, } \\
\text { Dbc (N), } \\
\text { Dbb (N), } \\
\text { Dw (N) }\end{array}$ & $\begin{array}{l}\text { Endicott } \\
\text { group (N) }\end{array}$ & $\begin{array}{l}\text { Endicott } \\
\text { allochthon }\end{array}$ \\
\hline $\begin{array}{l}\text { Hammond } \\
\text { assemblage }\end{array}$ & $\begin{array}{l}\text { Dv, } \\
\text { Ddr, } \\
\text { Dgw, } \\
\text { Ddm, } \\
\text { Dtc }\end{array}$ & $\begin{array}{l}\text { Hammond } \\
\text { subterrane }\end{array}$ & $\begin{array}{l}\text { Hammond } \\
\text { terrane }\end{array}$ & $\begin{array}{l}\text { southern } \\
\text { Endicott } \\
\text { Mountains } \\
\text { assemblage }\end{array}$ & $\begin{array}{l}\text { Dhf (S), } \\
\text { Dbb (S), } \\
\text { Dc, Dsc, } \\
\text { DEw, } \\
\text { Pzw, Df }\end{array}$ & $\begin{array}{l}\text { Endicott } \\
\text { group (S) } \\
\& \text { Skajit } \\
\text { allochthon }\end{array}$ & Central belt \\
\hline $\begin{array}{l}\text { Apoon } \\
\text { assemblage }\end{array}$ & $\begin{array}{l}\text { ЄOvi, } \\
\text { ЄOve, } \\
\text { €Oac }\end{array}$ & $\begin{array}{l}\text { Apoon } \\
\text { assemblage }\end{array}$ & $\begin{array}{l}\text { North Slope } \\
\text { terrane }\end{array}$ & $\begin{array}{l}\text { Apoon } \\
\text { assemblage }\end{array}$ & $\begin{array}{l}\text { OEv, } \\
\text { SEb, } \\
\text { Dm }\end{array}$ & $\begin{array}{l}\text { Apoon } \\
\text { assemblage }\end{array}$ & $\begin{array}{l}\text { Doonerak } \\
\text { duplex }\end{array}$ \\
\hline
\end{tabular}

Table 1. Equivalent nomenclature for units in the Doonerak anticline area in this work and selected publications. The notation $(\mathrm{N})$ or $(\mathrm{S})$ refers to the northern or southern portion of units or assemblages mapped across the Doonerak anticline in the cited publication but were split in this work.

\section{Apoon Assemblage:}

The Apoon assemblage includes metasedimentary, metavolcaniclastic, and volcanic units. The metasedimentary units were mapped as a single unit by Dillon et al. (1986), while Strauss et al. (2017) divided them into coarser and phyllitic units. This work was more focused on the relationships of the hanging wall units of the anticline, rather than within the Apoon assemblage itself, therefore I did not differentiate these units. The Apoon assemblage is composed of black phyllite and metasiltstone with quartzite, metagraywacke, brown dolomite, minor limestone, and red, purple, and green phyllite. The volcanic units are intrusive and extrusive basaltic to andesitic (Frier, 2017) rocks which are often mixed with local tuffaceous and phyllitic metasedimentary rocks. The extrusive volcanic unit includes pillow basalts. 
Hammond assemblage:

The relationships of the formations within the Hammond assemblage are not well established. This work modifies the designations of Moore et al. (1997) based on their mapping along the Dalton Highway. Their map from the TACT project extends to west of the Hammond River at the eastern end of the Doonerak anticline, overlapping the 1:250,000 map of Dillon et al. (1986), facilitating correlation with the study area. Much of the Hammond assemblage in my study area was originally mapped by Dillon et al. (1986) as either the Beaucoup Formation or Hunt Fork Shale. Moore et al. (1997) advised against the usage of the Beaucoup Formation designation, as it appeared to combine members of the Hammond assemblage that should be separate. Similarly, the updated units have apparent distinctions from the Hunt Fork Shale as it has been mapped south of the anticline. The units of Moore et al. (1997) that appear to correlate to the study area are the Trembley Creek phyllite, Dusty Mountain phyllite, Dietrich River phyllite, and an unnamed metagraywacke and metaconglomerate unit which was described as 'nearly concordant' with Nutirwik Creek metavolcaniclastic rocks. The prominent Skajit Limestone was not observed during this work, although it was mapped just south of the Plate 1 map area by Dillon et al. (1986) and documented there by J. Toro (unpublished field notes, 2015).

The Trembley Creek phyllite (Dtc) was readily correlated west from the TACT map, as it appears to be broadly equivalent to the Paleozoic wacke map (Pzw) unit of Dillon et al. (1986). Moore et al. (1997) consider it Devonian or older, with a maximum age of Late Ordovician ( 450 Ma) constrained by a ${ }^{40} \mathrm{Ar} /{ }^{39} \mathrm{Ar}$ detrital white mica age. Strauss et al. (2017) found the youngest detrital zircon age to be $480 \pm 9 \mathrm{Ma}$.

The Dusty Mountain phyllite (Ddm) appears to correlate to a chloritic siliciclastic unit (Dsc) of the Dillon et al. (1986) based on location and lithologic character. On the TACT map, it is mapped 15 to $20 \mathrm{~km}$ south of its position in the study area, so its correlation is least certain. 
The unit is Devonian, with Middle or Late Devonian conodonts at the base (Johnsson et al., 1992).

The Dietrich River phyllite (Ddr) includes much of the black phyllitic units originally mapped as part of the Beaucoup Formation by Dillon et al. (1986) and is mapped south of the Trembley Creek phyllite on the TACT map, a relationship that is similar to the study area. Moore et al. (1997) consider it Middle(?) and Late Devonian.

The unnamed metagraywacke and metaconglomerate unit (Dgw) appears to be related to the original uncertain designation of chloritic and carbonate rocks (Dc?; Dillon et al., 1986). Both this unit and Nutirwik Creek metavolcaniclastic rocks are mapped south of the Dietrich River phyllite on the TACT map, in similar relative position to the study area. Moore et al. (1997) call it Late Devonian or older. The 'nearly concordant' Nutirwik Creek volcaniclastic unit is Late Devonian its upper part (Moore et al., 1997).

\section{Endicott Mountains allochthon:}

The Endicott Mountains allochthon in the study area includes the Hunt Fork Shale, Noatak Sandstone, and Kanayut Conglomerate. The Kayak Shale and Lisburne Group of the Ellesmerian sequence have been mapped to the north of the study area atop the Kanayut Conglomerate of the Endicott Mountains allochthon (Kelly, 1988). The Beaucoup Formation was mapped by Dillon et al. (1986) below the Hunt Fork Shale at the base of the hanging wall rocks north of the anticline. However, the rocks originally mapped as Beaucoup appear instead to correlate to the Sillyasheen Mountain graywacke, which has been mapped to the west. Rocks of the Endicott Mountains allochthon have been correlated to the south side of the Doonerak anticline in the Hammond assemblage by prior workers, but recent detrital zircon data show that this correlation is incorrect despite of superficial similarities of the rocks. 


\section{Ellesmerian sequence:}

Exposures of the Ellesmerian sequence in the study area are dominated by the Lisburne Group limestone, which forms prominent dip-slopes and ridges. Beneath the Lisburne are the Kayak Shale and Kekiktuk Conglomerate. With an approximate total thickness of $300 \mathrm{~m}$, the Kayak and Kekiktuk were mapped together. Above the Lisburne are the Karen Creek sandstone, Shublik Formation, and Sadlerochit Group (Moore et al., 1997), although these were not found in our mapping. Their absence is attributed to result from erosion along the North Fork of the Koyukuk River or removal during thrust emplacement of the structurally higher Endicott Mountains allochthon.

Map-scale faults

Published maps include a variety of map-scale faults which were followed in this work (Figure 11; Plate 1). The faults can be grouped into the Amawk thrust and potential splays (e.g. Julian, 1987) below the Endicott Mountains allochthon on the northern flank of the Doonerak anticline, the contact between the Hammond and Apoon assemblage and internal thrust imbrication on the southern flank, and the northwest-southeast trending fault within the Apoon assemblage that juxtaposes the clastic and volcanic members of the assemblage (Dillon et al., 1986). Late-stage high angle normal faults were documented in the eastern portion of the Doonerak anticline by Phelps et al. (1987), although were not directly observed in the study area apart from equivocal interpretation of secondary foliation fabrics and joints.

The Amawk thrust is a ubiquitous feature in maps of the northern margin of the Doonerak anticline. This fault is often shown as continuing to the southern margin of the anticline and forming the basal detachment for northward emplacement of the Endicott Mountains allochthon (Figure 4, A). Although that interpretation is questioned in this work, the Amawk thrust usage is retained herein, strictly on the northern margin where it was originally 
located (Mull, 1982). The Blarney Creek and Skajit thrust names are not retained due to limited prior use.

The southern fault contact between the Apoon and Hammond assemblage is unnamed. Internal thrusts between members of the Hammond assemblage are inferred at the base of the Trembley Creek phyllite, which Moore et al. (1997) calls Devonian or older, whereas the other mapped members are dominantly Middle to Late Devonian. Uncertainty of original relationships remains and its internal structure and/or stratigraphy may be more complicated than mapped.

A left-lateral, north-south trending strike-slip fault is interpreted along the North Fork of the Koyukuk River that was not mapped by prior workers (Dillon et al., 1986). Movement of 2 to $3 \mathrm{~km}$ is believed to have occurred during or after uplift of the anticline. This interpretation explains the offset of units across the interpreted fault and the counter-clockwise change in strike of the Endicott Mountains allochthon west of Ernie Creek. 
Surficial deposits: alluvium, colluvium, glacial deposits
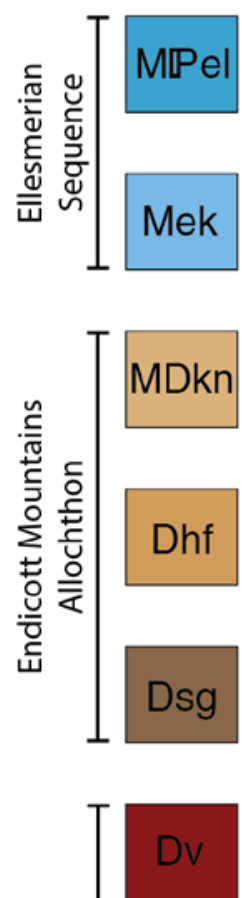

Devonian (?) volcanic rocks: metabasite, basic intrusive and extrusive rocks

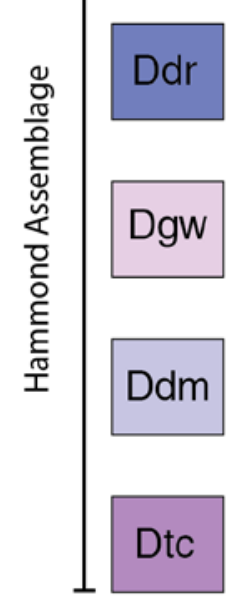

Dietrich River phyllite: medium gray to black phyllite and slate with thin metagraywacke layers; weathers dark reddish brown; black limestone near base

Unnamed metagraywacke and metaconglomerate: greenish gray phyllitic metagraywacke and volcanogenic sandstone with quartzite and siltstone clast sandy metaconglomerate

Dusty Mountain phyllite: greenish to yellowish gray thinly layered to laminated chlorite-quartz-white mica phyllite; possible dark limestone

Trembley Creek phyllite: greenish gray metasandstone, argillite, and phyllite; weathers tan to orange-brown; abundant white mica; common pyrite

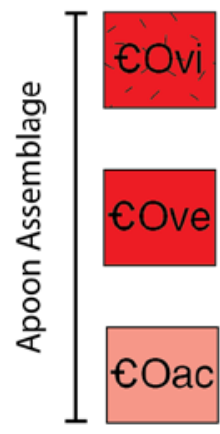

Apoon intrusive volcanic rocks: intermediate to basic plutonic rocks; gabbro and diabase

Apoon extrusive volcanic rocks: andesitc to basaltic volcanic rocks, including pillow lavas, and volcaniclastics with local tuffaceous and black phyllite

Apoon clastic rocks: black phyllite and metasiltstone with quartzite, metagraywacke, brown dolomite, minor limestone, and purple, red, and green phyllite.

Figure 10. Map unit legend for Figure 11 and Plate 1. 


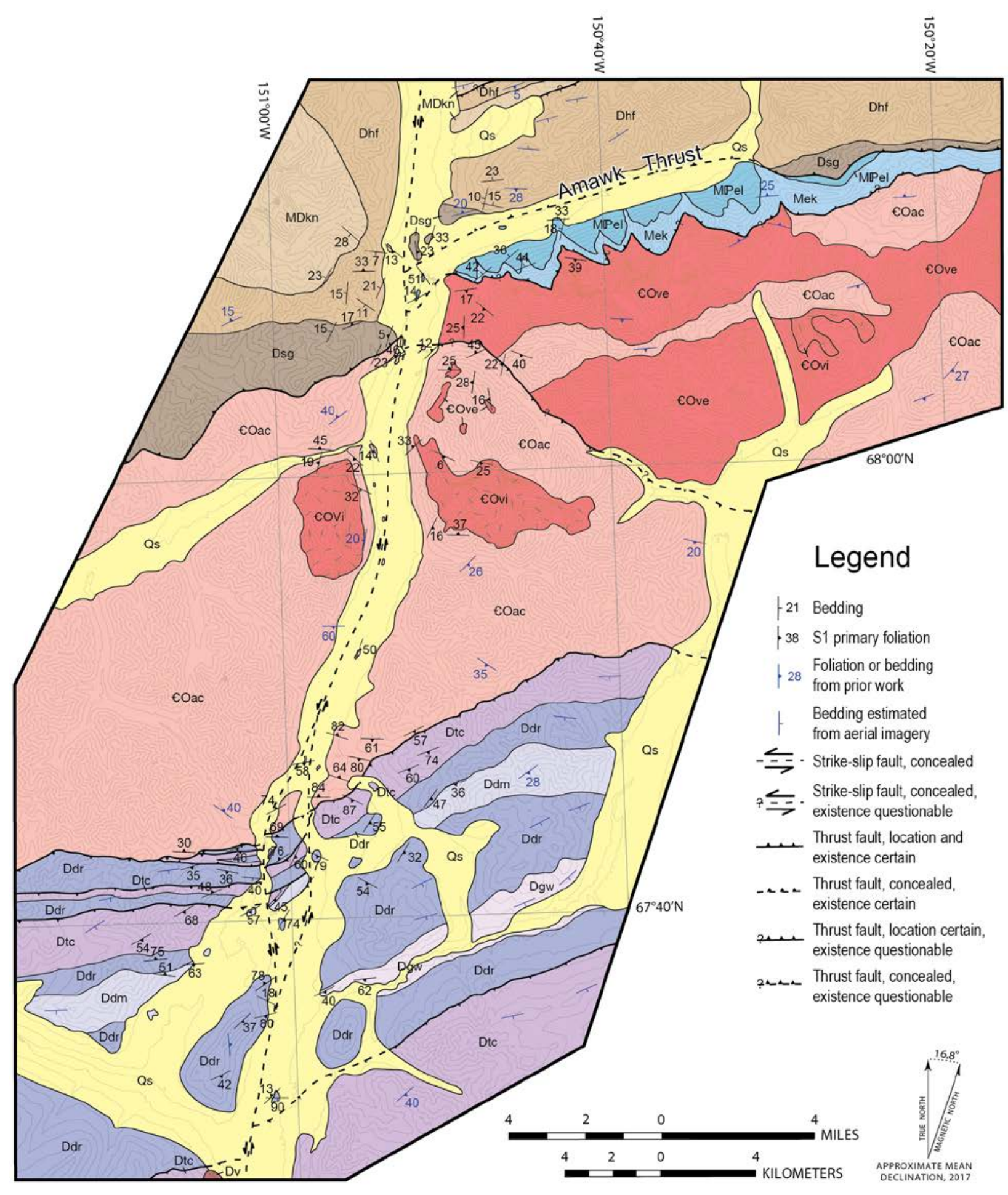

Figure 11. Simplified, scaled version of the study area map. See previous figure for map unit descriptions. See Plate 1 for complete data and references. 


\section{Results: Structure}

\section{Field measurements}

Field measurements were categorized into bedding (S0), primary foliation (S1), secondary foliation (S2), outcrop-scale hinges, and lineations. Lineations mapped are either crenulation or S0/S1 intersection and are plotted collectively, as these have comparable structural implications. In the Apoon and Hammond assemblages, metamorphic fabrics obscure bedding, so only foliations are mapped.

Primary foliation in the Apoon assemblage clusters towards sub-horizontal, with significant scatter. Poles to foliation trend along a sub-vertical great circle, indicating the foliations are folded along an east-west trending axis (260/11W; Figure 12). Although scattered, outcrop-scale hinge axes also trend east-west. These are interpreted as resulting from northsouth compression.

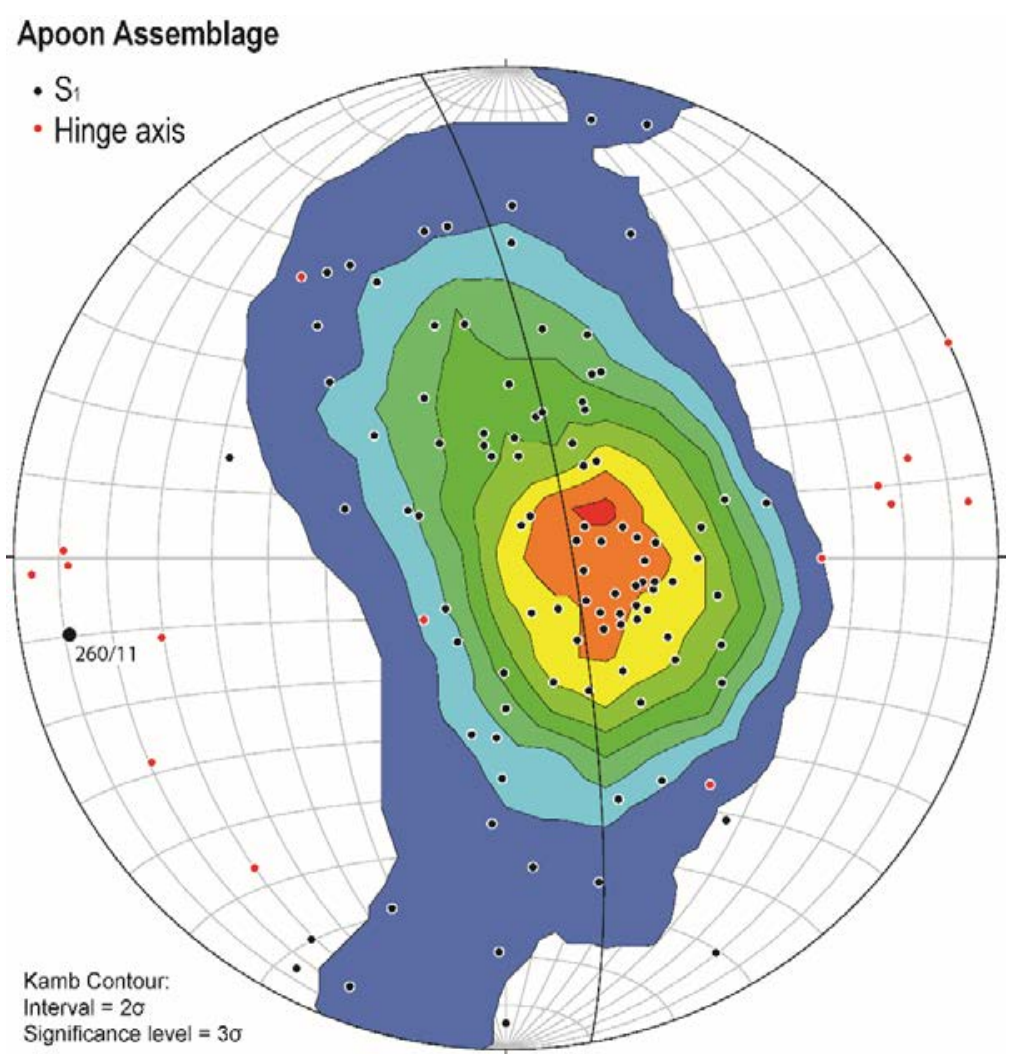

Figure 12. Equal area lower hemisphere stereonets for the Apoon assemblage showing S1, best fit great circle and pole to S1 (260/11W, large black dot), and hinge axes. 
Primary foliation in the Hammond assemblage indicates a predominant south-east dipping trend (Figure 13). The pole to the best-fit great circle to S1 is near the mean vector for outcrop-scale fold hinges. This indicates some S1 measurements are folded by the same northsouth compression that produced the east-west trending hinge axes. The predominant southward dip of S1 measurements suggests north-directed motion of the assemblage, which is also apparent in overturned outcrop-scale folds in the study area (Figure 14). Hinge data are more consistent than the same data in the Apoon assemblage, suggesting more consistent structural history. The slight eastward plunge in both the pole to the best fit great circle to S1 and mean vector for outcrop-scale hinges is evidence of subsequent tilting, which may be related to uneven uplift of the anticline.

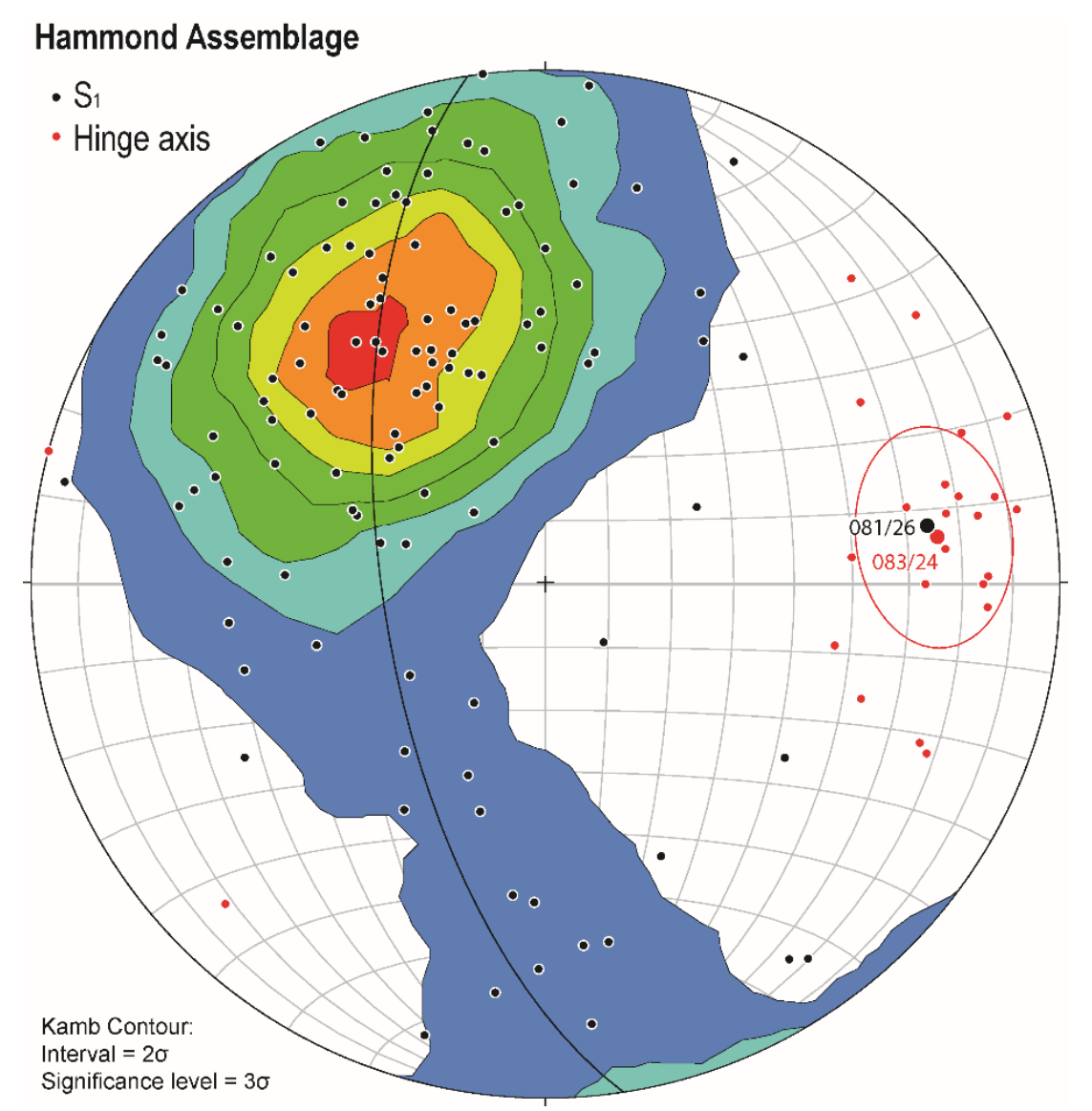

Figure 13. Equal area lower hemisphere stereonets for the Hammond assemblage showing S1, best fit great circle and pole to S1 (081/26 E, large black dot), hinge axes, and hinge axes mean vector (083/24E, large red dot). 

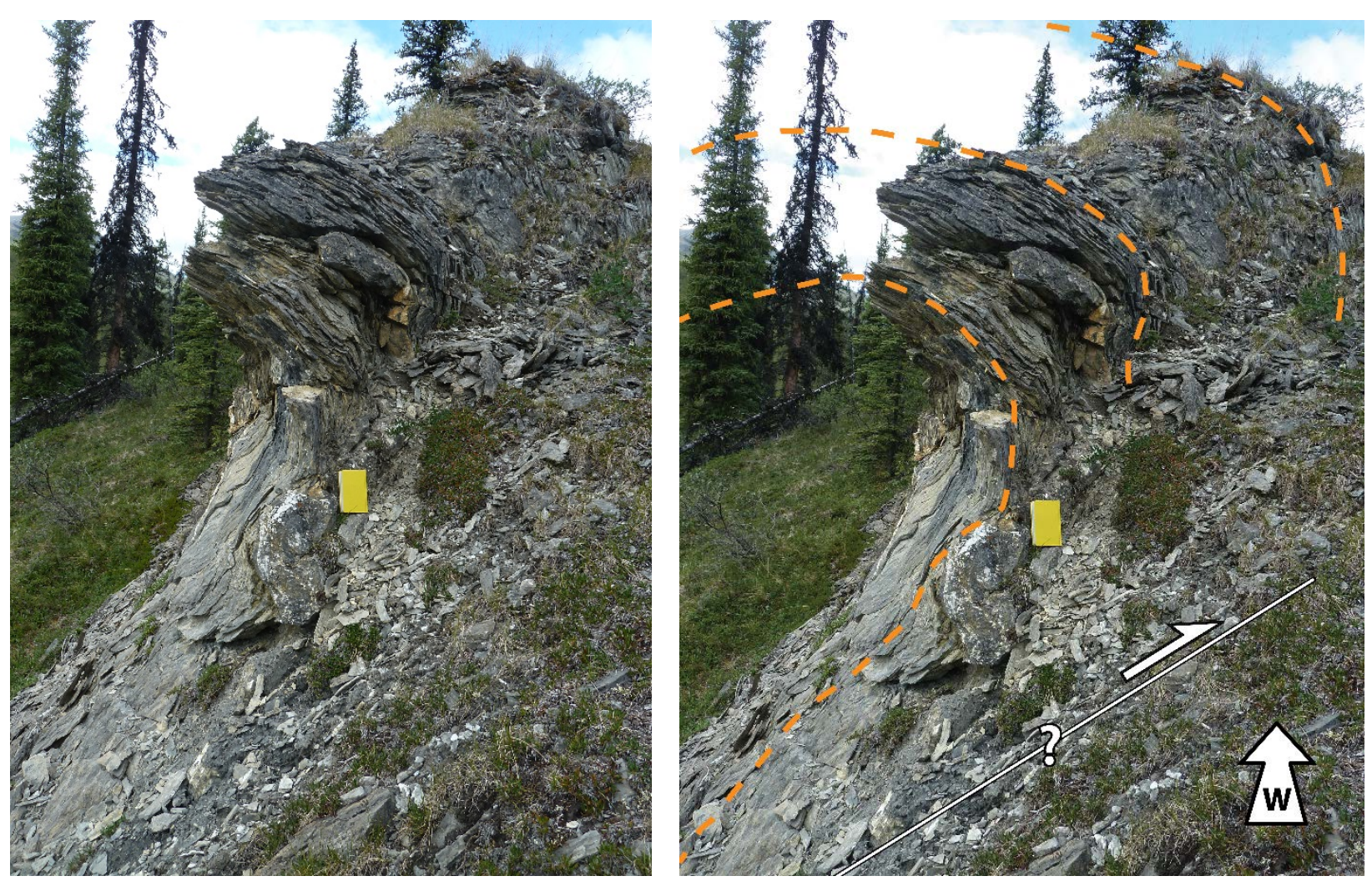

Figure 14. Outcrop of Trembley Creek phyllite showing an overturned fold. Photo looking west. Axial plane dips south, indicating north-directed motion. Field book is $20 \mathrm{~cm}$ tall. Location: $67.689553 \mathrm{~N}, 151.062599 \mathrm{~W}$.

Secondary foliations were not commonly documented in the study area. Only within the Hammond assemblage are they sufficient in number to plot meaningfully on a stereonet (Figure 15). S2 measurements are mostly north-dipping. The second-phase measurements mapped at the eastern end of the anticline within the southern hanging wall by Phelps (1987) show similar clusters of north-dipping foliations. These are interpreted as resulting from late stage uplift of the anticline. 
Hammond Assemblage

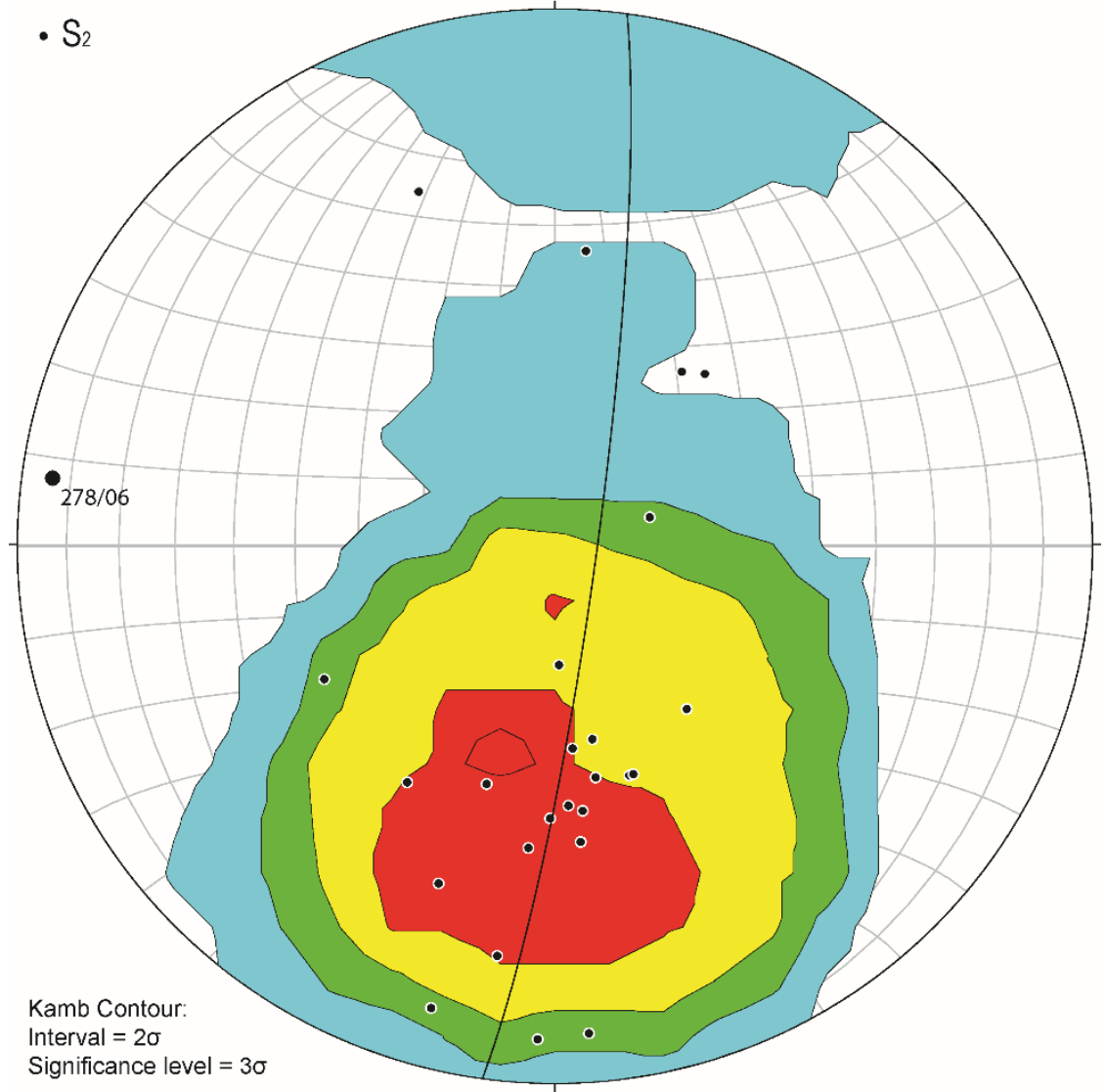

Figure 15. Equal area lower hemisphere stereonet for the Hammond assemblages showing S2 and best fit great circle and pole to S2 (278/06W, large black dot). 
The Endicott Mountains allochthon displayed both bedding and primary foliation (Figure 16). Although scattered, the mean vectors corroborate the observations made at multiple individual outcrops, where bedding/cleavage intersection was visible (Figures 17, 18, 19). The mean vector for poles to SO is nearly vertical. The mean vector for poles to S1 dips slightly northwest. The difference in angle $\left(\sim 13^{\circ}\right)$ between these measurements indicates that cleavage is steeper than bedding with south-vergent motion of the allochthon. There is a possibility that the cleavage is not axial planar and may not be a definitive indicator of vergence; such a fabric could form in the back limb of a fault-bend fold.

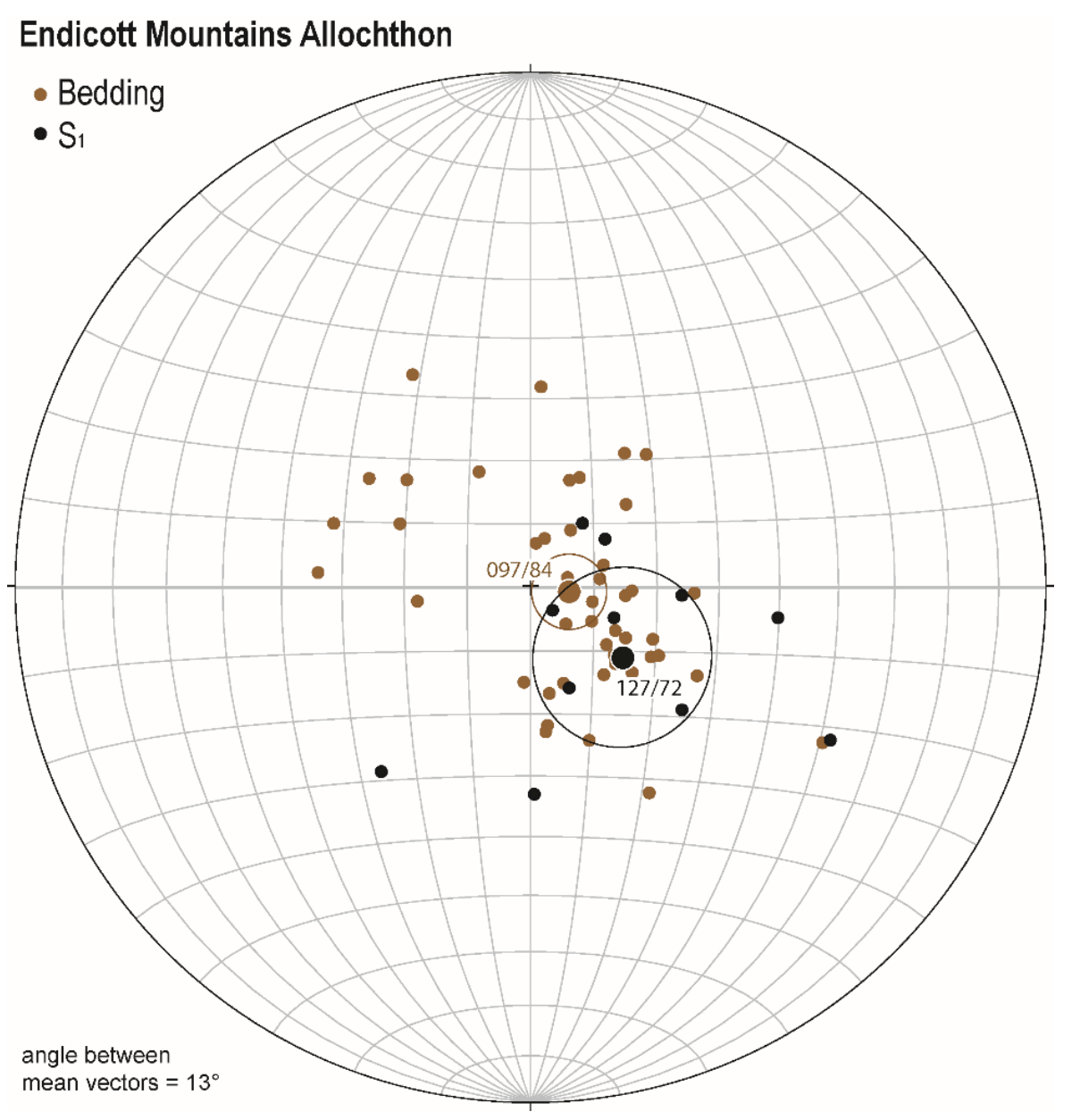

Figure 16. Equal area lower hemisphere stereonet for the Endicott Mountains allochthon showing measurements and mean vectors (large dots) of bedding (097/84E) and S1 cleavage (127/72SE). 

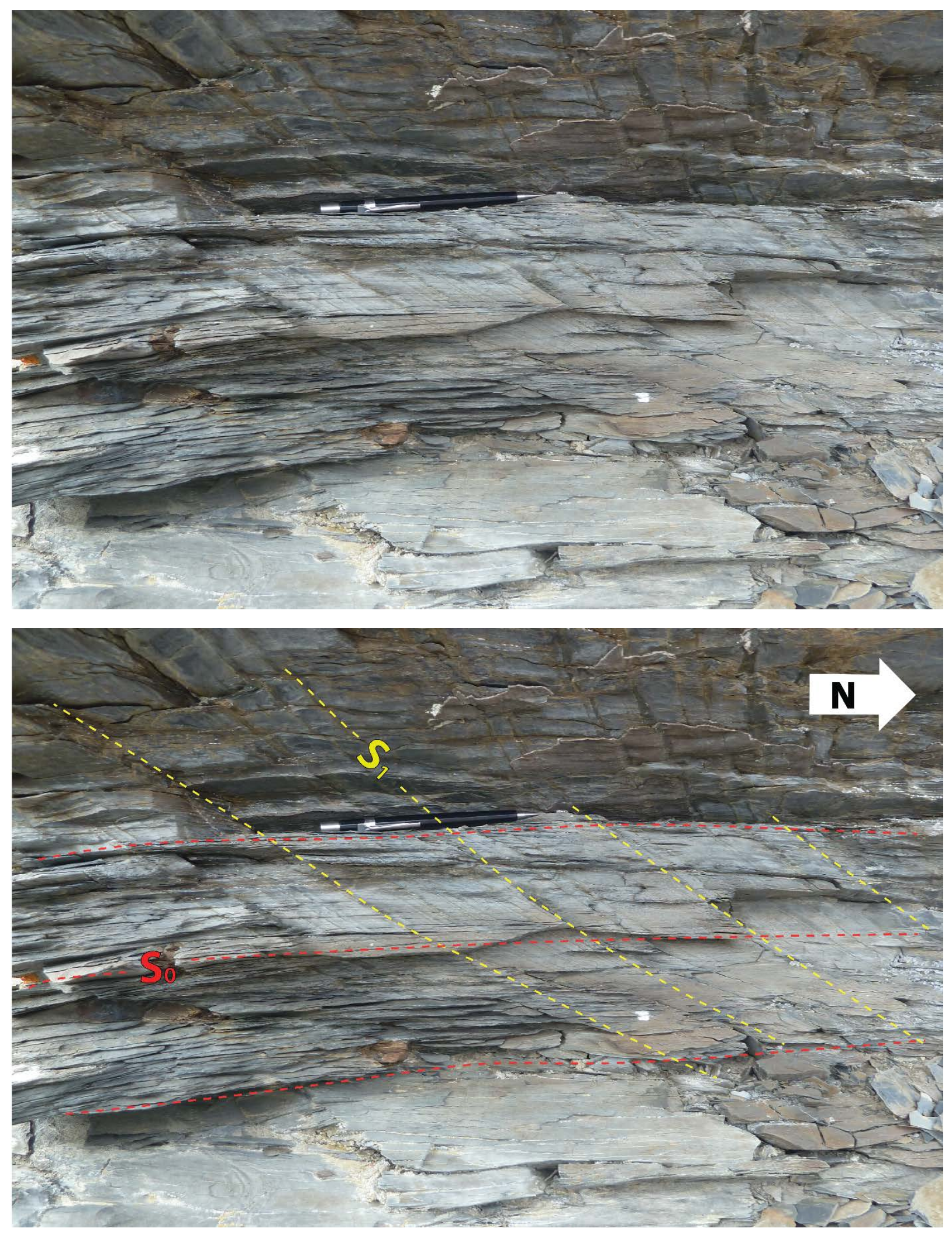

Figure 17. Outcrop of Hunt Fork Shale showing gently south-dipping bedding (red) and north dipping cleavage (yellow). Pencil is 15 cm long. Location: 67.909392, N 150.902027 W. 

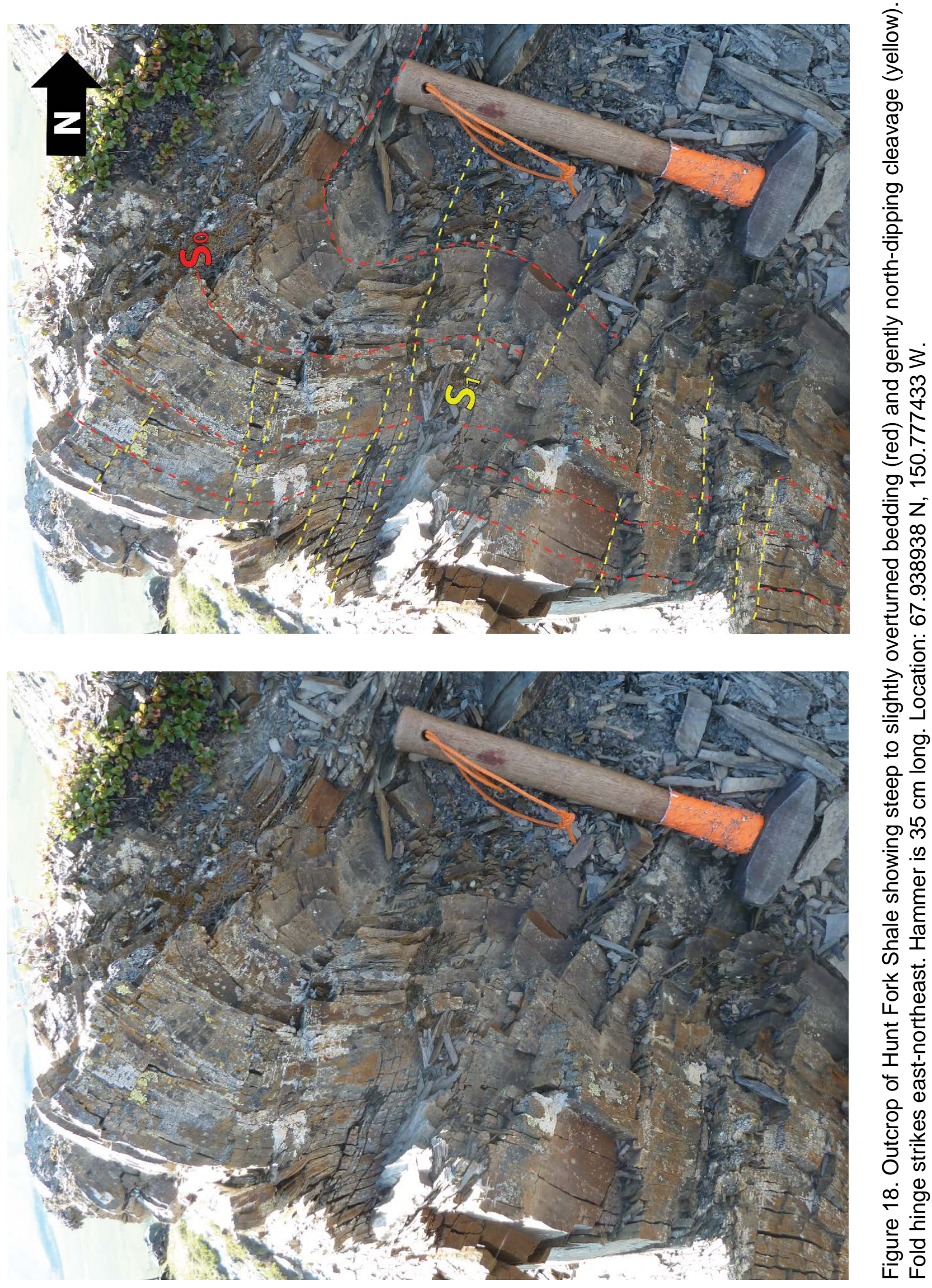


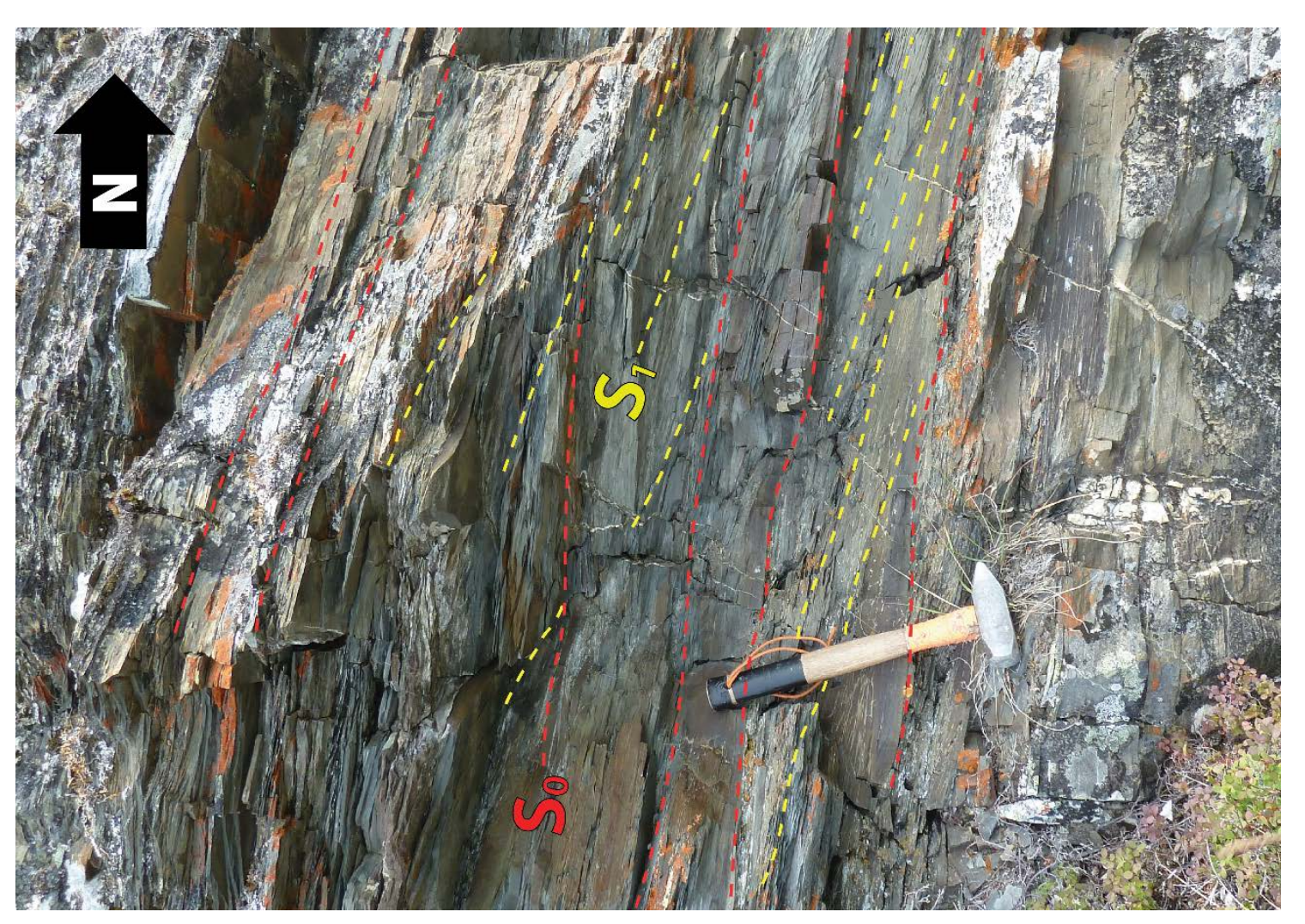

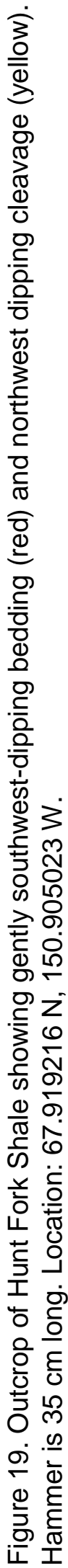


Field measurements in the Ellesmerian sequence were limited to bedding (Figure 20). Foliations do not develop as readily in the predominantly carbonate units mapped in this group and generally less expected in the younger, lower grade rocks. S0 measurements cluster around a northwest-dipping trend, which is consistent with observed outcrops on the northern margin of the anticline. Field indications of vergence in the Ellesmerian sequence include cleavage-bedding intersection and outcrop-scale thrusting. Although measurements of S1 were not well documented in field notes, north-dipping cleavage was observed in field photos of the Kayak Shale (Figures 21, 22). South-directed thrusting was seen in outcrops of Lisburne limestone (Figures 23, 24, 25). These structural observations support south-directed emplacement of the Ellesmerian sequence, and south directed motion of the overlying Amawk thrust.

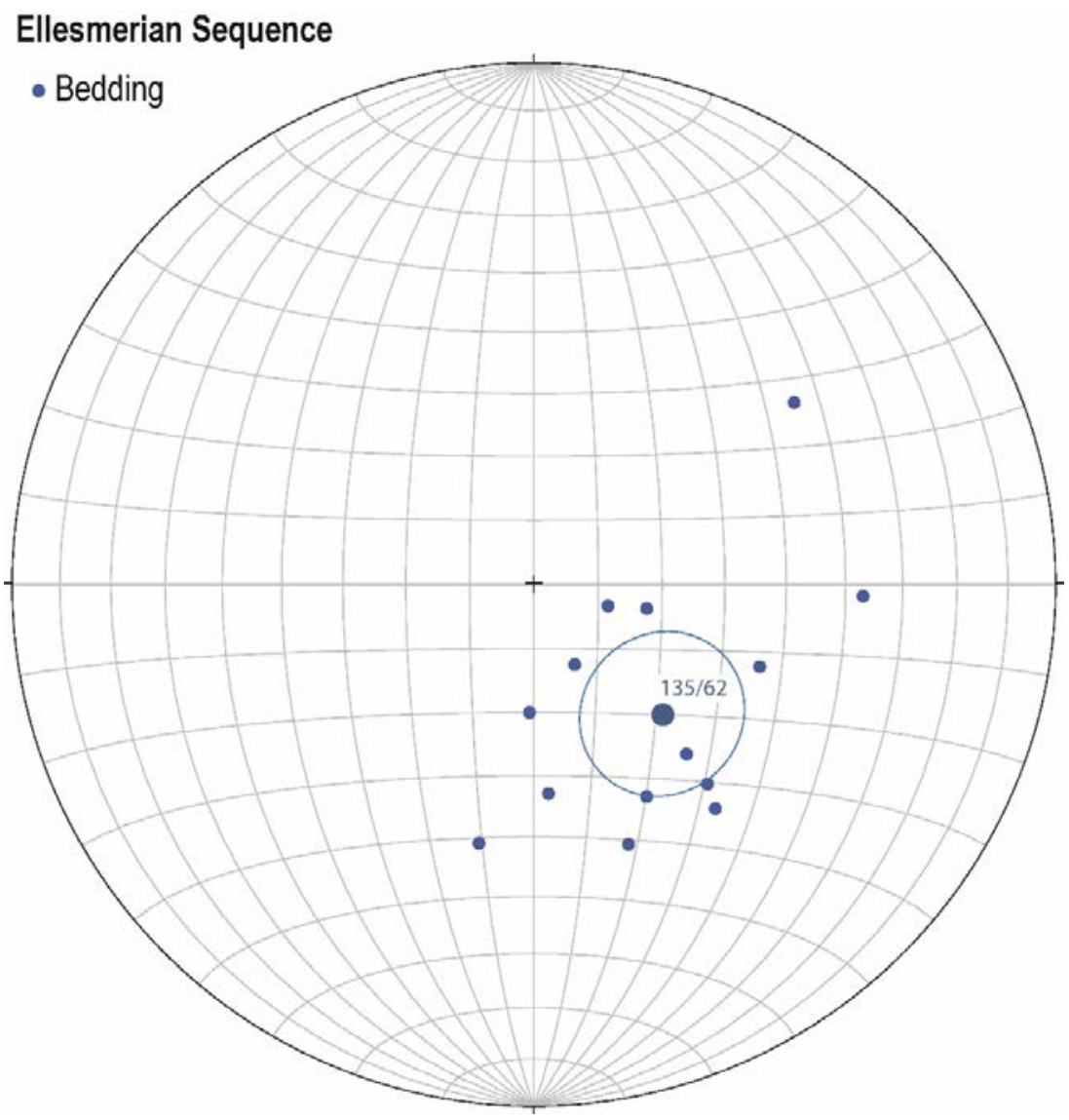

Figure 20. Equal area lower hemisphere stereonet for the Ellesmerian sequence showing bedding, S1 cleavage, and mean vector (135/62SE, large dot). 

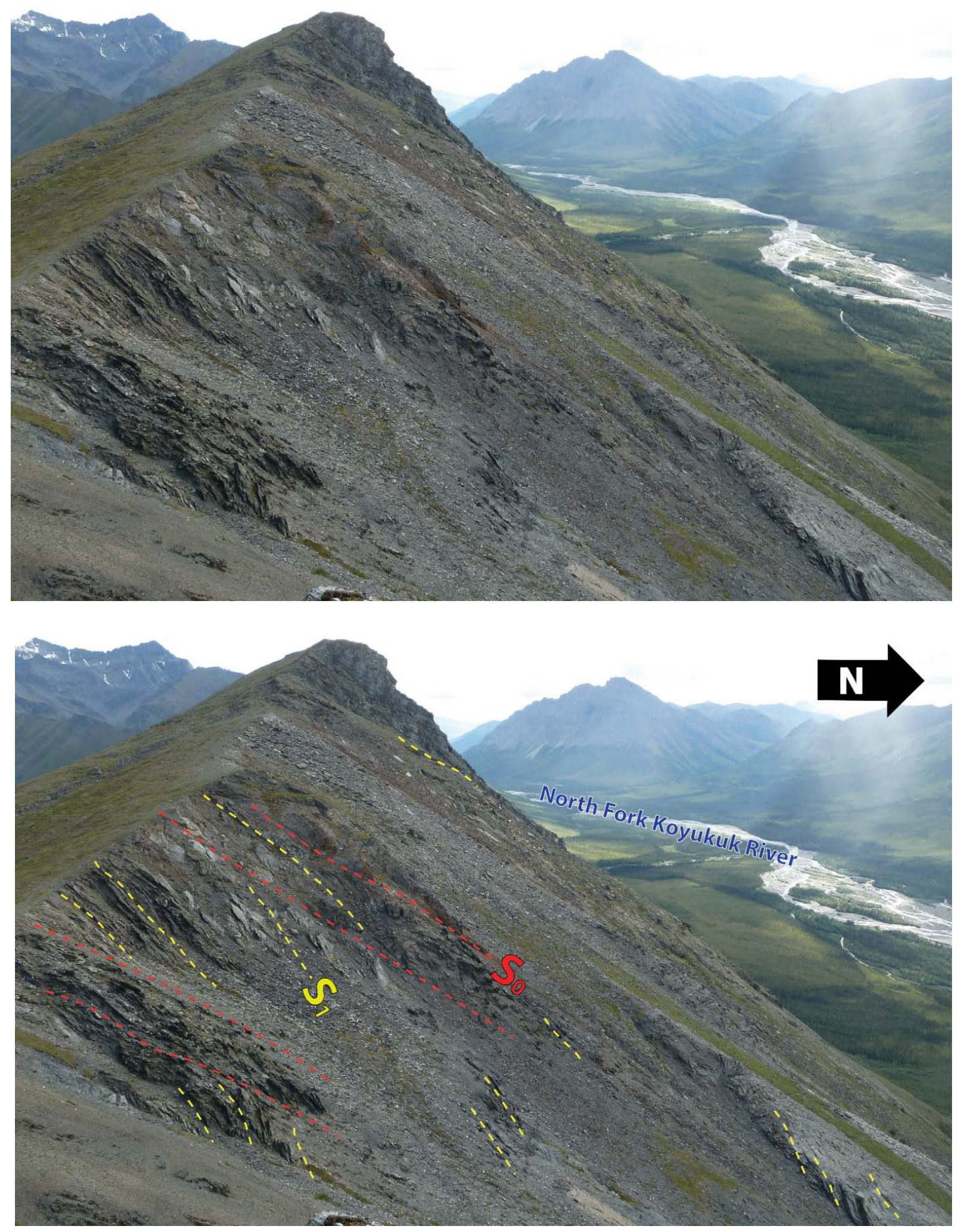

Figure 21. Outcrop of Kayak Shale showing irregular steeply north-dipping cleavage (yellow) and bedding (red). Large outcrop in center of photo is approximately $30 \mathrm{~m}$. Location: 67.906413 N, 150.794628 W. 

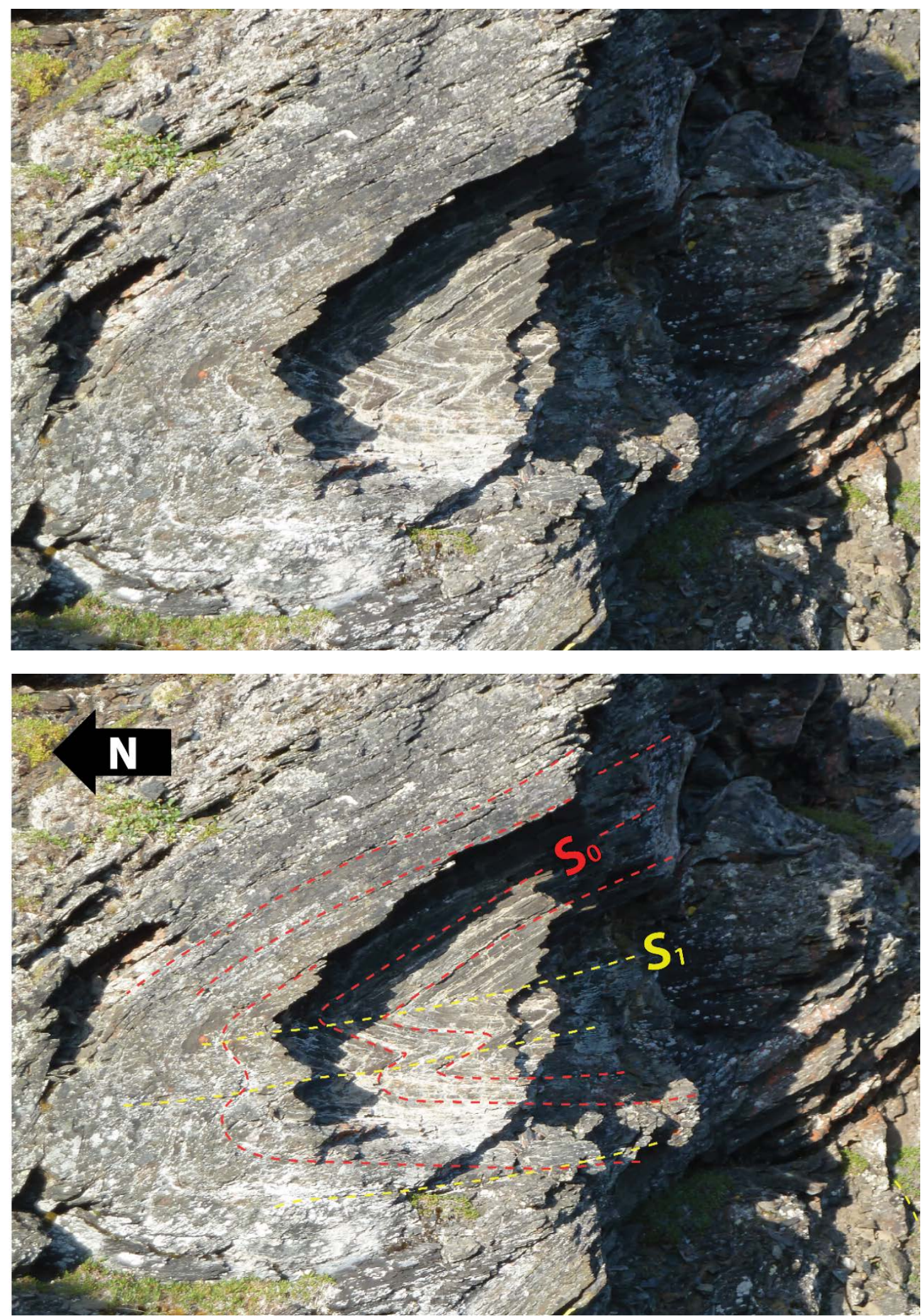

Figure 22. Outcrop of Kayak Shale showing tight chevron folding with axial-planar cleavage dipping gently to the north. Visible outcrop is approximately $1.5 \mathrm{~m}$ tall. Location: $67.887604 \mathrm{~N}$, $150.932944 \mathrm{~W}$. 

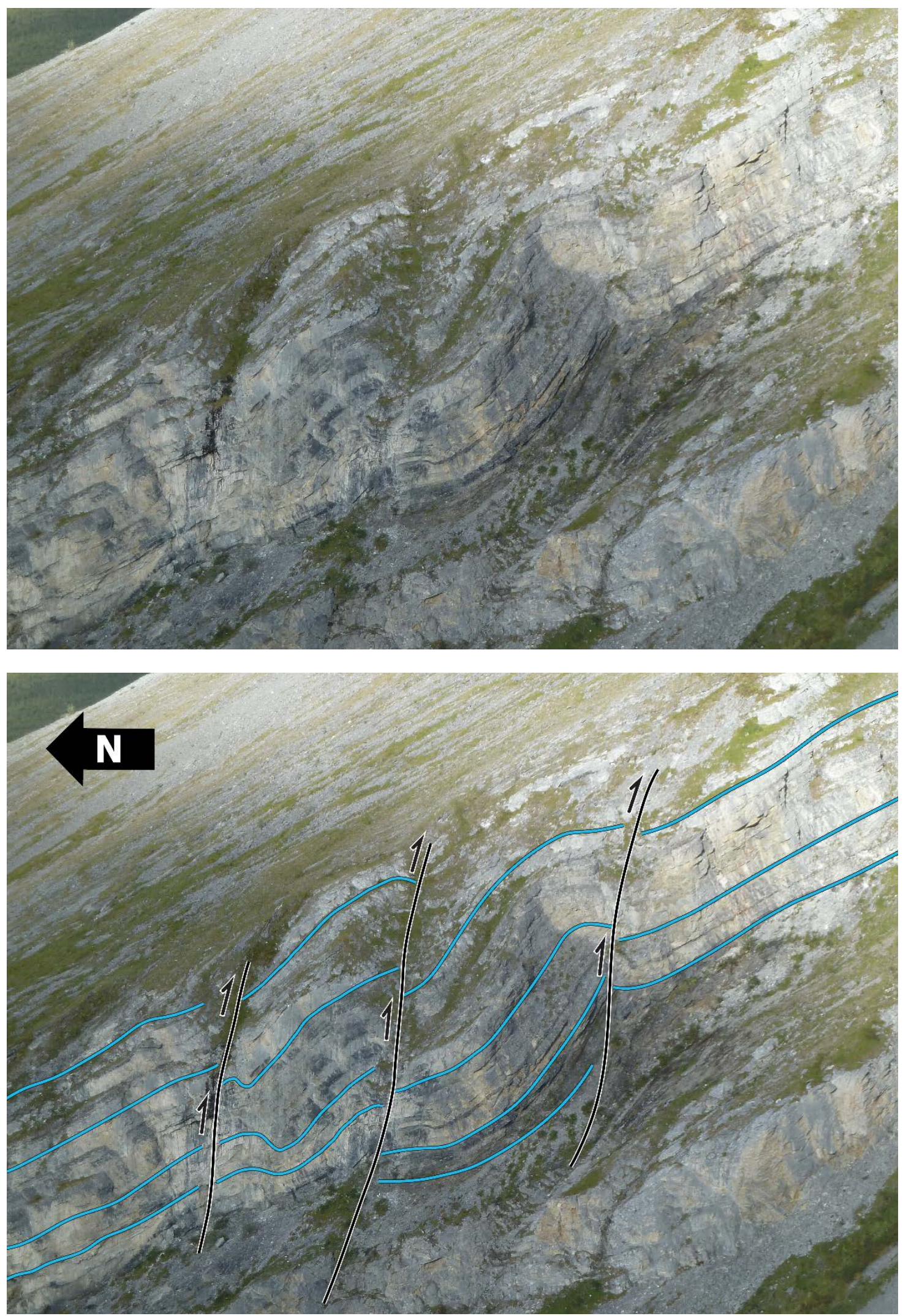

Figure 23. Outcrop of Lisburne limestone showing north-dipping thrust faults indicating southward-vergence. Location: $67.906413 \mathrm{~N}, 150.794628 \mathrm{~W}$. 

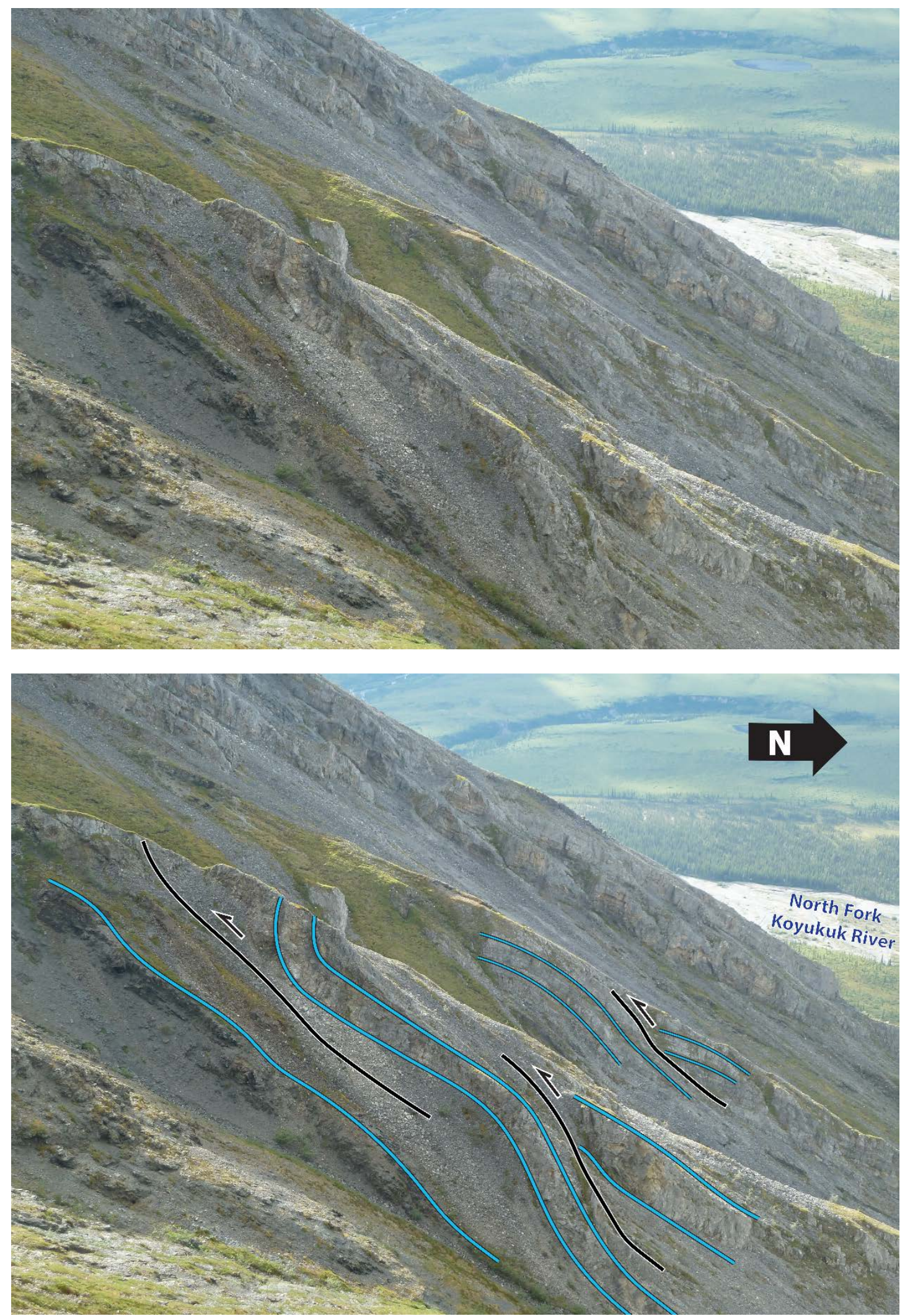

Figure 24. Outcrop of Lisburne limestone showing north-dipping thrust faults indicating southward-vergence. Location: $67.907933 \mathrm{~N}, 150.778226 \mathrm{~W}$. 

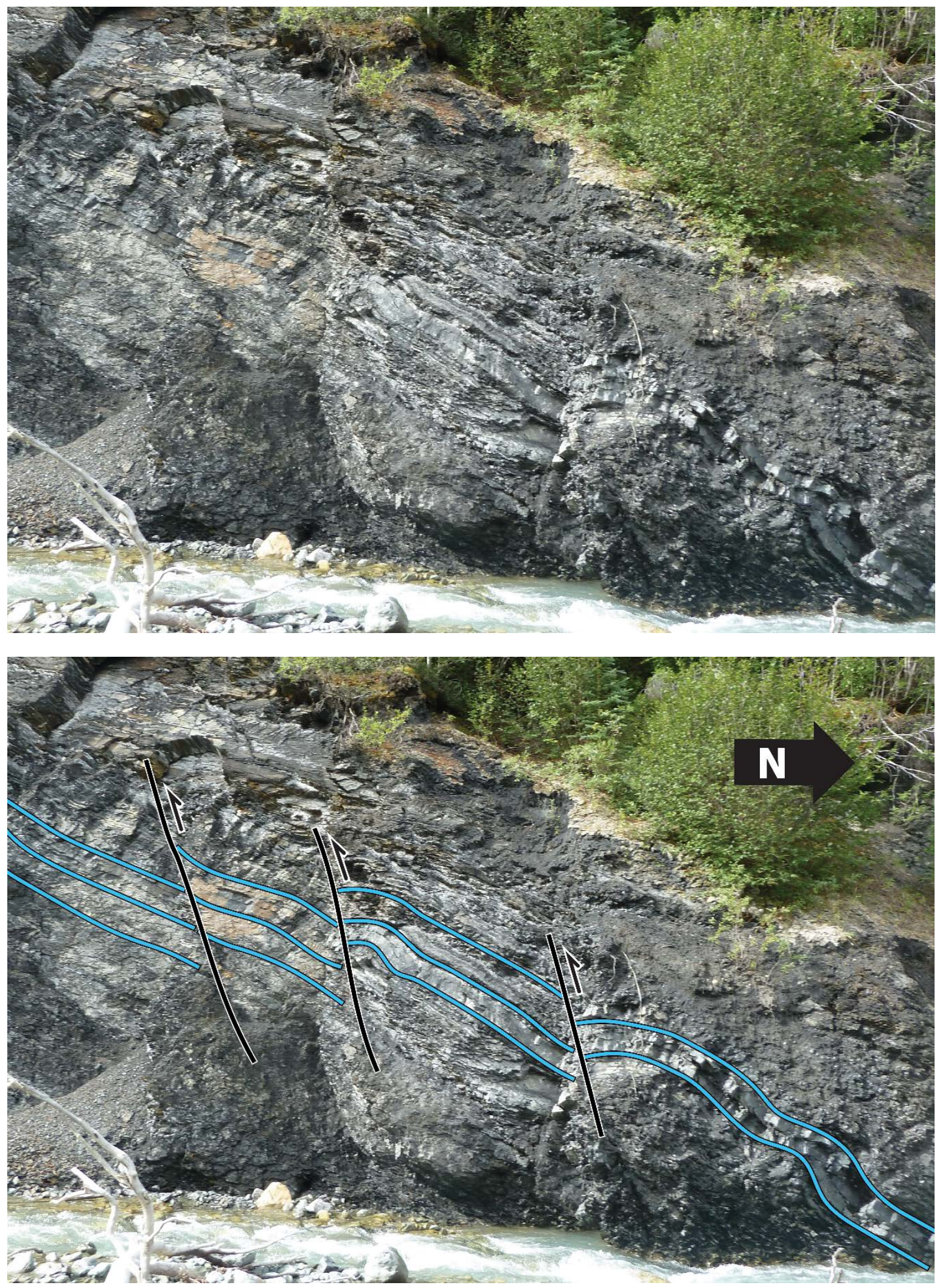

Figure 25. Outcrop of Lisburne limestone and shale showing north-dipping thrust faults indicating southward-vergence. Visible outcrop is $8 \mathrm{~m}$ tall. Location: $67.926367 \mathrm{~N}, 150.714194$ W. 
The south-directed vergence indicators observed in the study area are counter to some observations reported previously. Mull (1982) noted south-dipping cleavage, indicating northdirected motion, in the Shublik Formation and Salderochit Group (Figure 26). These units are above the Lisburne Group limestone in the Ellesmerian sequence and were not found in the study area, but have been mapped to the east.

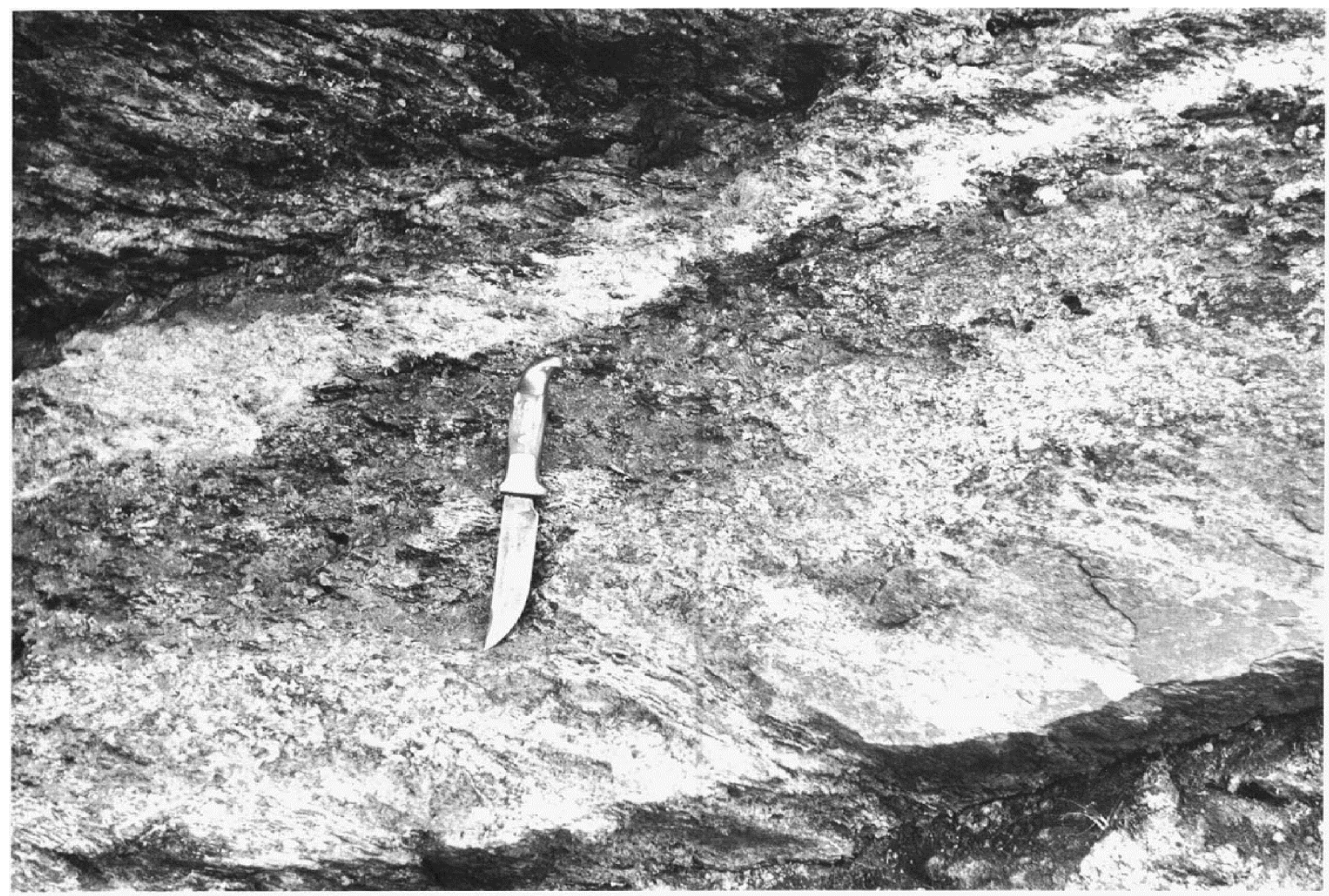

Figure 26. Outcrop photo of the Sadlerochit Group from Mull (1982) showing $15-25^{\circ}$ southdipping cleavage in bedding dipping $15^{\circ}$ north, suggesting north-directed vergence. The exact photo location is unknown, but Mull notes that slaty cleavage was observed at multiple locations in the Shublik Formation and Sadlerochit Group. 


\section{Results: Petrography}

A total of 52 thin sections from the greater study area were described for mineralogy, microstructure, and, if oriented, potential indications of vergence. Locations of samples with thin sections are shown on Figure 27. All sample descriptions and photomicrographs in both plane and cross polarized light are included in Appendix 3. This work aided in the description of map units as well as the determination of boundaries and correlative relationships while producing the $1: 63,360$ scale map (Plate 1$)$.

Samples displayed prehnite-pumpellyite to lower greenschist facies mineral assemblages (Blatt et al., 2006) in agreement with previous descriptions of the map units (e.g. Moore et al., 1997). Metamorphic muscovite, chlorite, and occasional biotite were ubiquitous throughout the metasedimentary samples. Microstructures of corresponding grade, such as domainal cleavage and shear bands, were observed in most non-calcareous samples. Highly calcareous samples often lacked microstructures. The mineral assemblages observed are appropriate for the maximum paleotemperature range as determined by RSCM paleotheremometry.

Sense of shear was determined for 11 samples. From these, 6 indications of primary (S1) vergence and 9 indications of secondary (S2) vergence were determined (Figure 28). All of the oriented samples available were collected along the southern margin of the Doonerak anticline in the Apoon and Hammond assemblages.

Primary indicators, such as rotated clasts (Figure 29) and asymmetric micro-folds (Figure 30), are all top-to-the-north. This suggests the main deformation event was northvergent. This agrees with all previous structural models, for which the southern hanging wall units were emplaced from south to north (Dutro et al., 1976; Kelly and Brosgé 1995; Oldow et al., 1987). 


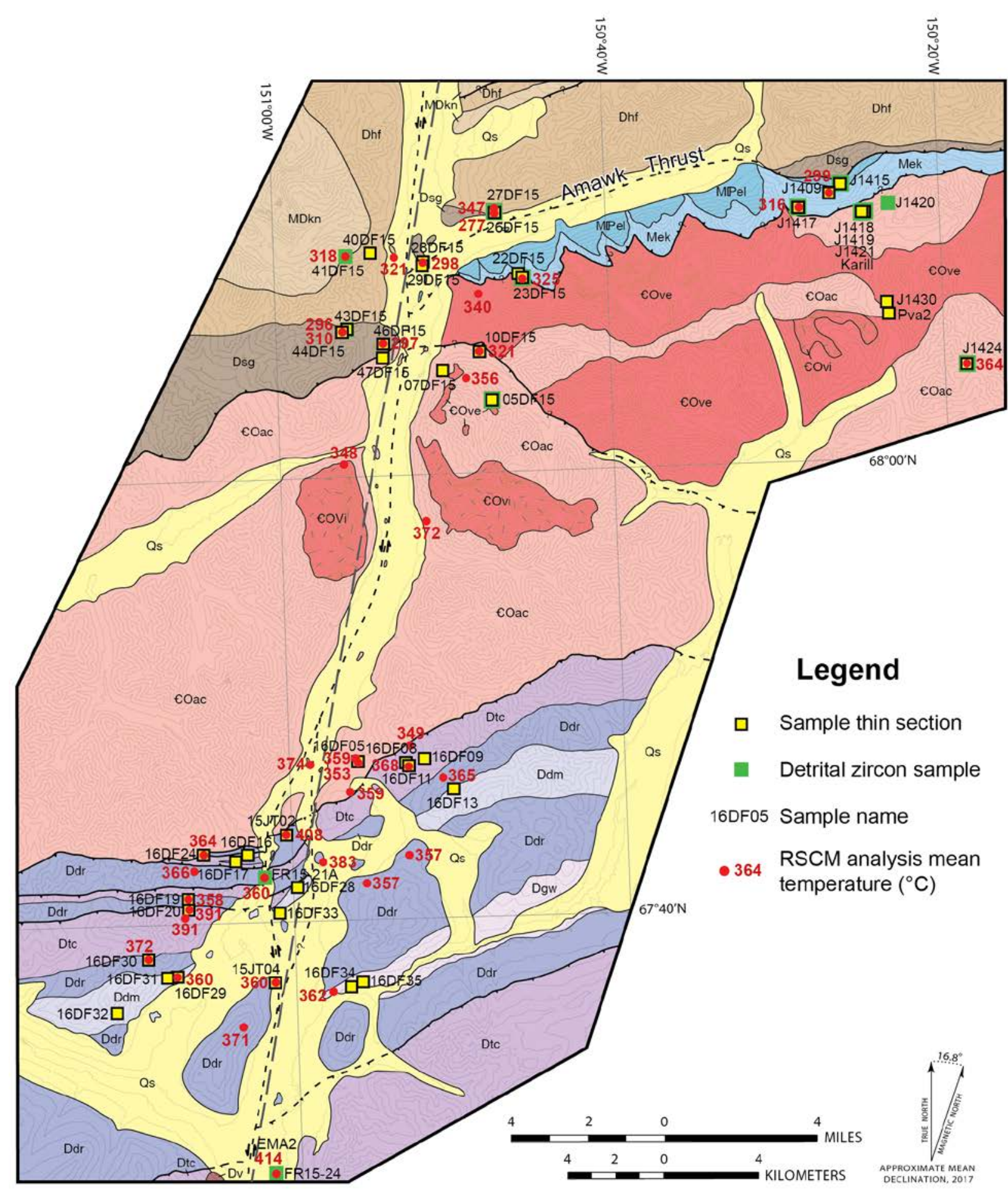

Figure 27. Simplified, scaled version of the study area map showing locations of thin sectioned samples, detrital zircon geochronology samples, and RSCM paleotemperature results. See Plate 2 for complete data and references. Dashed dark gray line is the location of the RSCM transect plotted on Figure 32. 


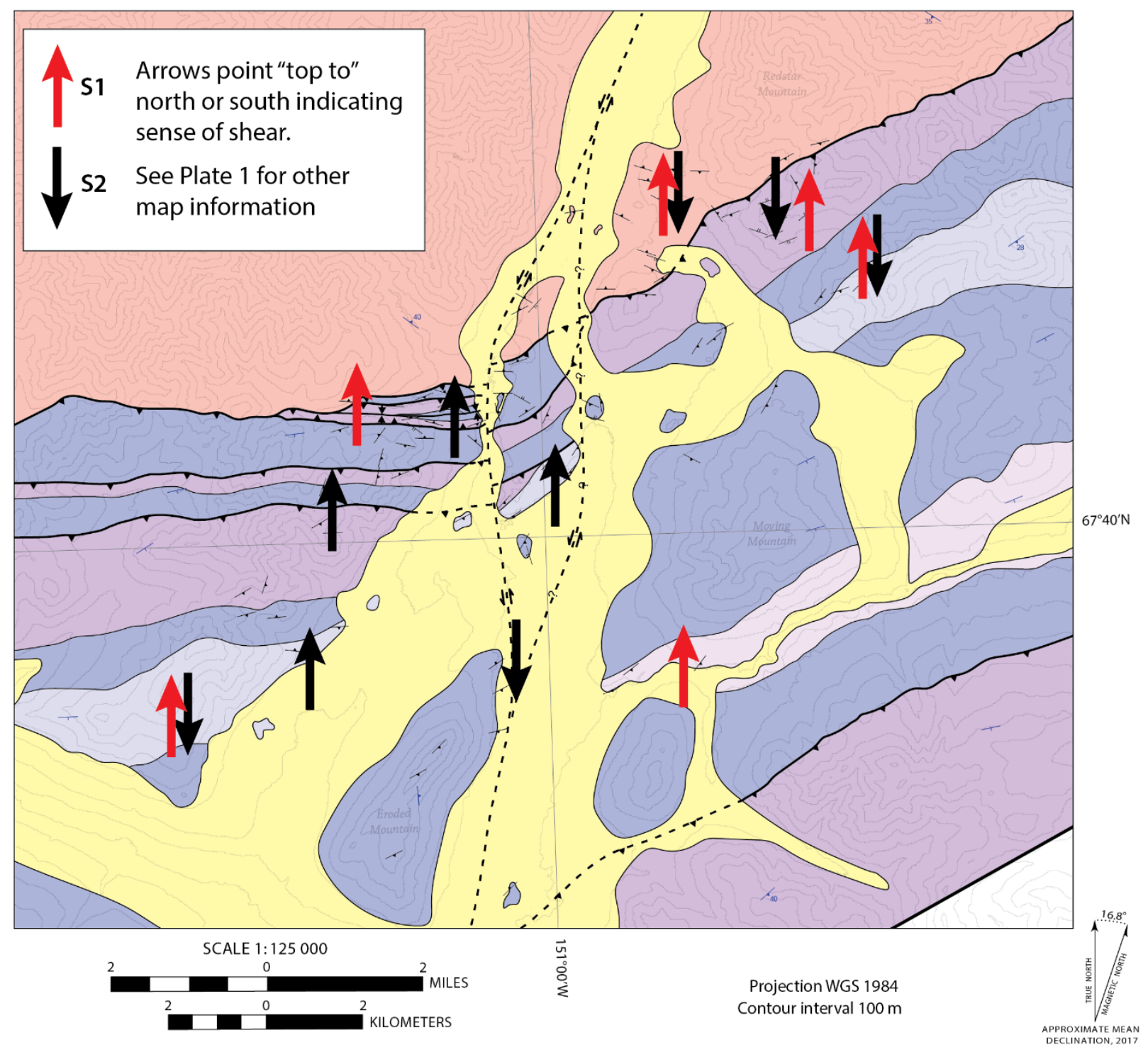

Figure 28. Map of the southern portion of Plate 1 map area showing sense of shear determined from oriented thin section microstructures. Sense of shear associated with S1 events are all top to the north; S2 events are of mixed sense of shear. 


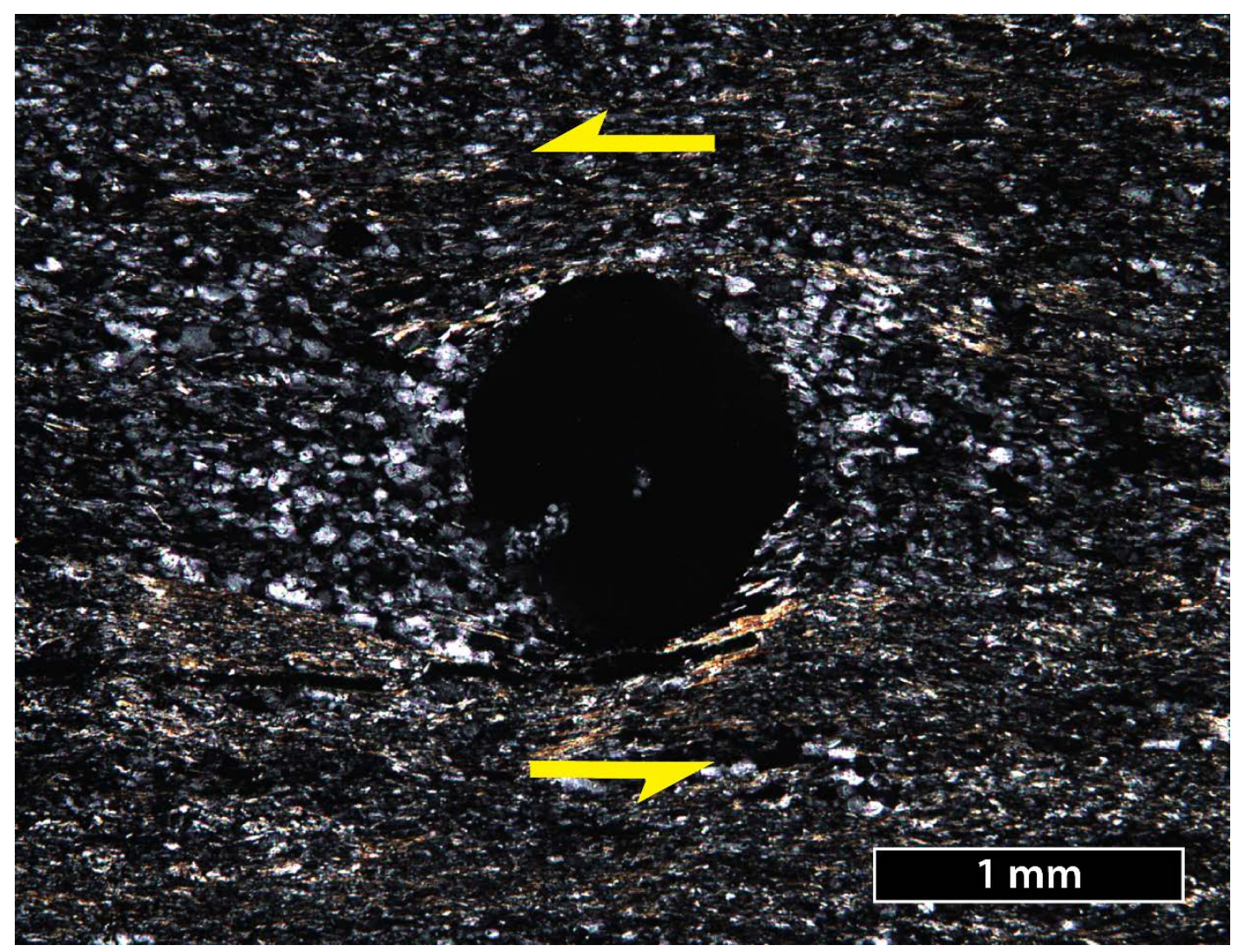

Figure 29. Photomicrograph (XPL) of a rotated clast in sample 16DF09 showing sinistral sense of shear.

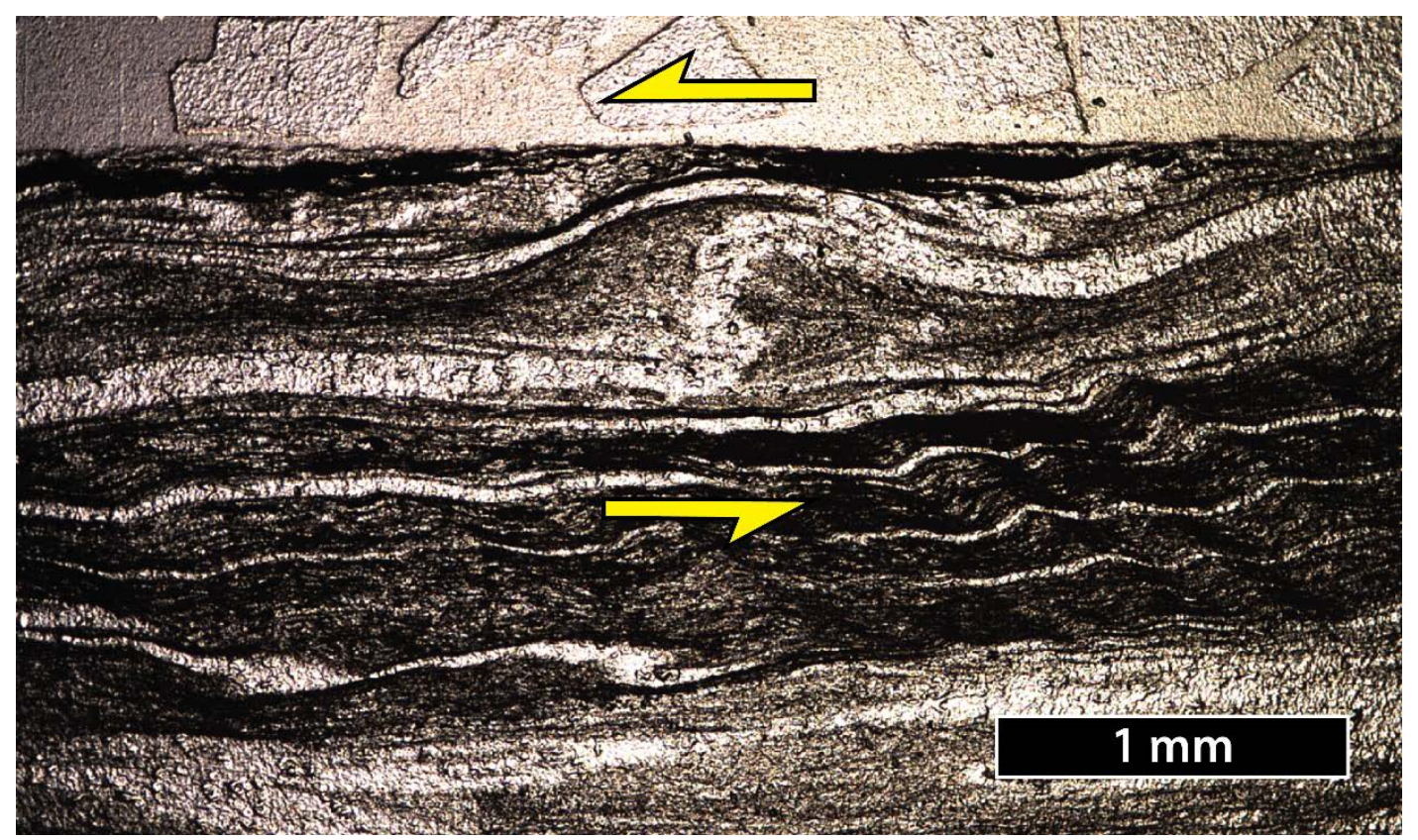

Figure 30. Photomicrograph (PPL) of an asymmetric fold in sample 16DF19 indicating sinistral sense of shear. 
Secondary indicators, such as crenulation bands, show mixed sense of shear. As all lower-strain microstructures were classified as secondary, it may be some of these actually result from primary events and were not overprinted by later fabrics. The mixed sense of shear in secondary fabrics is likely a combined result of this deliberately conservative misclassification and later uplift of the Doonerak anticline (e.g. O'Sullivan et al., 1997), which resulted in faulting and other fabrics directed away from the crest of the anticline (Phelps et al., 1987). For some samples, particularly the fine-grained samples, primary indicators were not visible and only secondary or low-strain fabrics were observed.

\section{Results: RSCM paleothermometry}

Raman spectroscopy of carbonaceous material (RSCM) was attempted on 54 samples. Of these, 38 yielded a sufficient quantity and quality of carbonaceous material spectra for paleotemperature calculation. Unsuccessful attempts were either due to initial misidentification of opaque minerals or when the sample was known to be sparse in carbonaceous material but attempted based on geographic distribution. Representative example raw Raman spectra for four acquisitions shown in Figure 31. The change in peak character with increasing paleotemperature is apparent. RSCM paleotemperature results are listed in Table 2; complete parameters for each spectral acquisition used in the average paleotemperature calculation for all samples are in Appendix 4. 


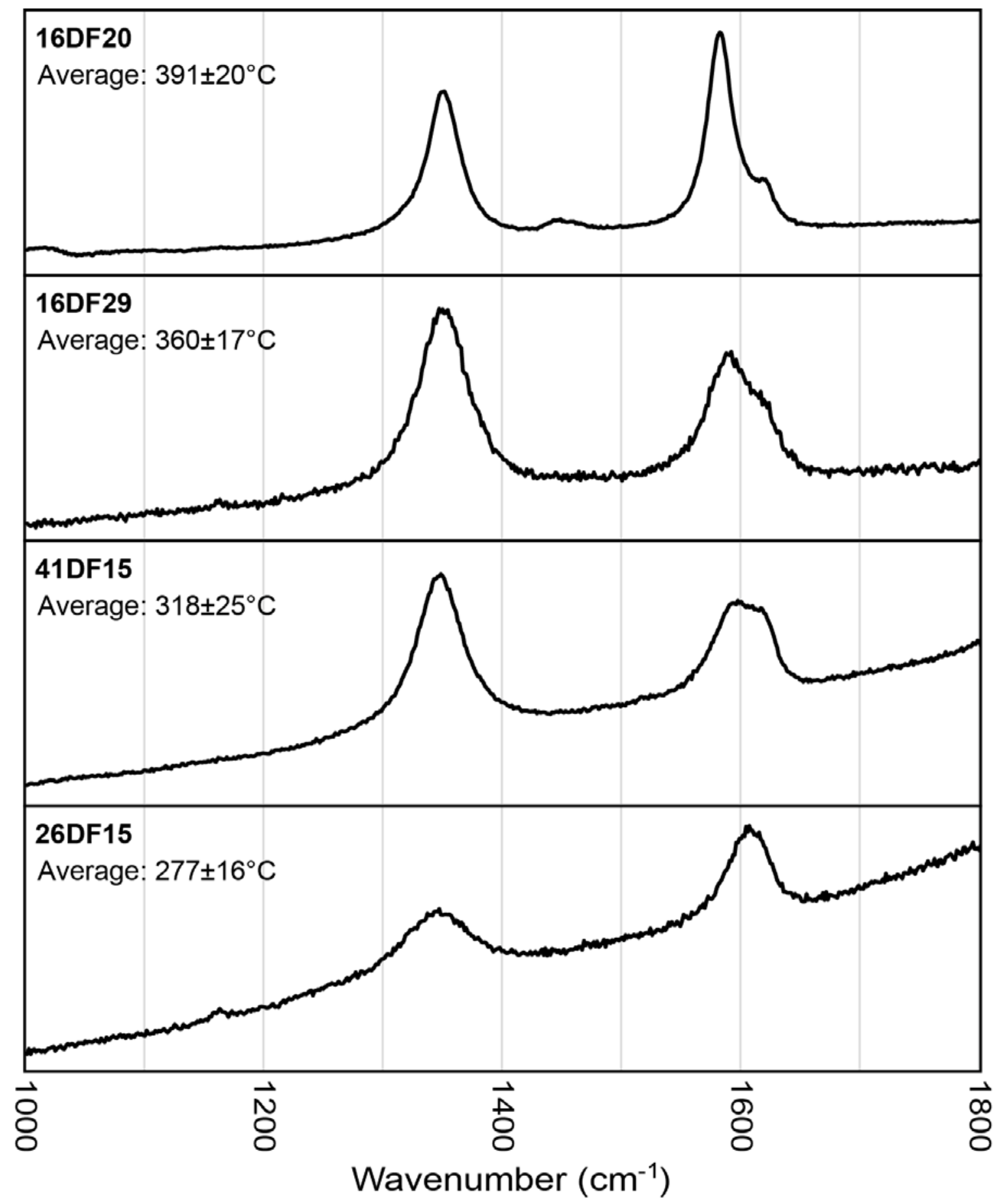

Figure 31. Representative raw Raman spectra over the acquisition range $1000-1800 \mathrm{~cm}^{-1}$ for individual acquisitions from four samples showing the change in peak character with increasing paleotemperature. Average calculated RSCM paleotemperature of all acquisitions for examples shown with $2 \sigma$-error. Vertical scale arbitrary. 
Calculated RSCM paleotemperatures ranged from $277 \pm 16^{\circ} \mathrm{C}$ to $408 \pm 23^{\circ} \mathrm{C}$. The average RSCM paleotemperature for all samples was $350 \pm 31^{\circ} \mathrm{C}$. This is in line with the prehnitepumpellyite to lower greenschist facies mineral assemblages observed, which form at this temperature range and expected burial depths. It is also in agreement with maximum conodont alteration index (CAl) values of 5 to 6 from around the Doonerak anticline (Plate 2; Johnsson et al., 1992). These CAl values correspond to temperatures of 325 to $475^{\circ} \mathrm{C}$ for $10^{7}$ to $10^{8}$ years of heating (Rejebian et al., 1987). Approximately 120 to $220 \mathrm{~km}$ west of the Doonerak anticline at a similar position within the Central belt/Hammond assemblage, Patrick (1995) found maximum paleotermperatures of 325 to $425^{\circ} \mathrm{C}$ at 5 to $9 \mathrm{kbar}$ using two-feldspar solvus thermometry on orthogneiss.

To understand the implications of RSCM paleotemperature, results were plotted along a north-south line transecting the study area (Figure 27). Offset by the strike-slip fault along the North Fork of the Koyukuk River is interpreted as having occurred after maximum paleotemperatures were reached. To correct for this, results were shifted to their position prior to strike-slip motion before being projected onto the north-south transect line in order to best represent their relationships at the time of maximum paleotemperature. Average RSCM

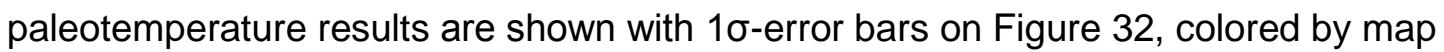
assemblage. Results from three samples provided by O'Brien and Miller (2017) are also shown.

A distinct paleotemperature increase occurs between northern $11.5 \mathrm{~km}$ of the transect and the units to the south (dashed gray line, Figure 32). This suggests the warmer Apoon and Hammond group rocks were more deeply buried than the cooler northern group rocks. The northern group, which includes the Endicott Mountains allochthon, Ellesmerian sequence, and northernmost Apoon assemblage, has an average maximum paleotemperature of $313 \pm 19^{\circ} \mathrm{C}$. The southern group, which includes most of the Apoon assemblage and the Hammond assemblage, has an average maximum paleotemperature of $368 \pm 16^{\circ} \mathrm{C}$. Beyssac et al. (2002) suggests the RSCM method is accurate to $\pm 50^{\circ} \mathrm{C}$, but able to distinguish between samples 
different by $10-15^{\circ} \mathrm{C}$. Therefore the difference in paleotemperatures between the groups is significant, despite the absolute temperature error of the method otherwise suggesting the groups are nearly indistinguishable.

Given a standard geothermal gradient of $25^{\circ} \mathrm{C} / \mathrm{km}$, the northern group was buried approximately $12.5 \mathrm{~km}$ and the southern group approximately $14.7 \mathrm{~km}$. Fuis et al. (1995) suggested the Doonerak anticline has been uplifted as much as $\sim 15 \mathrm{~km}$ based on seismic imaging, in agreement with these results. The $\sim 2.2 \mathrm{~km}$ difference in burial between the two groups indicates a structural contact exists between them. 


\begin{tabular}{|c|c|c|c|c|c|c|c|}
\hline Sample ID & Map Unit & $\mathrm{T}\left({ }^{\circ} \mathrm{C}\right)$ & $1 \sigma\left({ }^{\circ} \mathrm{C}\right)$ & \# spots & Method & Latitude (N) & Longitude (W) \\
\hline 16DF02 & $€ O a c$ & 359 & 15 & 10 & Beyssac & 67.715520 & 150.943149 \\
\hline 16DF05 & $€ O a c$ & 353 & 18 & 12 & Beyssac & 67.726527 & 150.934213 \\
\hline 16DF06 & $€ O a c$ & 359 & 17 & 11 & Beyssac & 67.728021 & 150.936263 \\
\hline 16DF10 & Dtc & 349 & 7 & 13 & Beyssac & 67.732214 & 150.881674 \\
\hline 16DF11 & Dtc & 368 & 12 & 13 & Beyssac & 67.724269 & 150.883287 \\
\hline 16DF12 & Ddr & 365 & 18 & 11 & Beyssac & 67.719700 & 150.849249 \\
\hline 16DF14 & Ddr & 357 & 14 & 10 & Beyssac & 67.690712 & 150.885746 \\
\hline 16DF15 & Ddr & 357 & 14 & 11 & Beyssac & 67.680416 & 150.929359 \\
\hline 16DF19 & Ddr & 358 & 11 & 11 & Beyssac & 67.675959 & 151.108447 \\
\hline 16DF20 & Dtc & 391 & 20 & 13 & Beyssac & 67.672213 & 151.108320 \\
\hline 16DF21 & Dtc & 391 & 19 & 11 & Beyssac & 67.669599 & 151.112092 \\
\hline 16DF22 & Ddr & 366 & 15 & 11 & Beyssac & 67.687022 & 151.101397 \\
\hline 16DF24 & Dtc & 364 & 10 & 9 & Beyssac & 67.692711 & 151.091771 \\
\hline 16DF27 & Ddr & 383 & 19 & 12 & Beyssac & 67.689200 & 150.972217 \\
\hline 16DF29 & Ddm & 360 & 17 & 11 & Beyssac & 67.646595 & 151.121902 \\
\hline 16DF30 & Ddr & 372 & 12 & 12 & Beyssac & 67.653614 & 151.149556 \\
\hline 16DF38 & Dgw & 362 & 18 & 13 & Beyssac & 67.639789 & 150.966109 \\
\hline 16DF39 & Ddr & 371 & 29 & 13 & Beyssac & 67.627249 & 151.057004 \\
\hline 02DF15 & $€ O a c$ & 356 & 28 & 9 & Beyssac & 67.871000 & 150.812000 \\
\hline 10DF15 & $€ O a c$ & 321 & 18 & 18 & Lahfid & 67.881000 & 150.798000 \\
\hline 18DF15 & €Oac & 340 & 19 & 15 & Lahfid & 67.903000 & 150.797000 \\
\hline 23DF15 & Dek & 325 & 21 & 9 & Lahfid & 67.908000 & 150.752000 \\
\hline 26DF15 & Dhf & 277 & 16 & 5 & Lahfid & 67.933000 & 150.778000 \\
\hline 27DF15 & Dhf & 347 & 30 & 12 & Lahfid & 67.935000 & 150.778000 \\
\hline 28DF15 & Dsg & 298 & 16 & 10 & Lahfid & 67.915000 & 150.852000 \\
\hline 31DF15 & $€ O a c$ & 348 & 11 & 14 & Beyssac & 67.839790 & 150.938540 \\
\hline 39DF15 & Dhf & 321 & 37 & 12 & Lahfid & 67.918000 & 150.881000 \\
\hline 41DF15 & MDkn & 318 & 25 & 14 & Lahfid & 67.919000 & 150.930000 \\
\hline 43DF15 & Dsg & 296 & 32 & 10 & Lahfid & 67.890000 & 150.936000 \\
\hline 44DF15 & Dsg & 310 & 31 & 8 & Lahfid & 67.890000 & 150.936000 \\
\hline 46DF15 & Dsg & 297 & 24 & 9 & Lahfid & 67.885000 & 150.895000 \\
\hline 15JT01 & $€ O a c$ & 374 & 16 & 10 & Beyssac & 67.745164 & 150.946694 \\
\hline 15JT02 & Dtc & 408 & 23 & 9 & Beyssac & 67.698167 & 151.005063 \\
\hline 15JT04 & Ddr & 360 & 14 & 12 & Beyssac & 67.642283 & 151.020798 \\
\hline J1409-74.1 & Dek & 316 & 23 & 10 & Lahfid & 67.930500 & 150.470833 \\
\hline J1417 & Dek & 299 & 35 & 12 & Lahfid & 67.935778 & 150.439417 \\
\hline $\mathrm{J} 1424$ & $€ O a c$ & 364 & 8 & 10 & Beyssac & 67.868694 & 150.307306 \\
\hline J1427 & $€ O a c$ & 353 & 17 & 11 & Beyssac & 67.850833 & 150.260639 \\
\hline Doonerak* & $€ O a c$ & 372 & $5(2 \sigma)$ & - & Beyssac & 67.817470 & 150.857510 \\
\hline EMA1* & Ddr & 360 & $5(2 \sigma)$ & - & Beyssac & 67.684020 & 151.031360 \\
\hline EMA2* & Ddr & 414 & $14(2 \sigma)$ & - & Beyssac & 67.570750 & 151.029210 \\
\hline Skagit* & south of map & 474 & $11(2 \sigma)$ & - & Beyssac & 67.485440 & 150.931440 \\
\hline
\end{tabular}

Table 2. All RSCM paleothermometry results from the Doonerak anticline area. Map units correspond to Plate 1 . Method refers to the peak fitting procedures and paleotemperature equation used after either Beyssac et al. (2002) or Lahfid et al. (2010). See Appendix 4 for detailed results. Asterisk $\left(^{*}\right)$ denotes data provided by O'Brien and Miller (2017). 


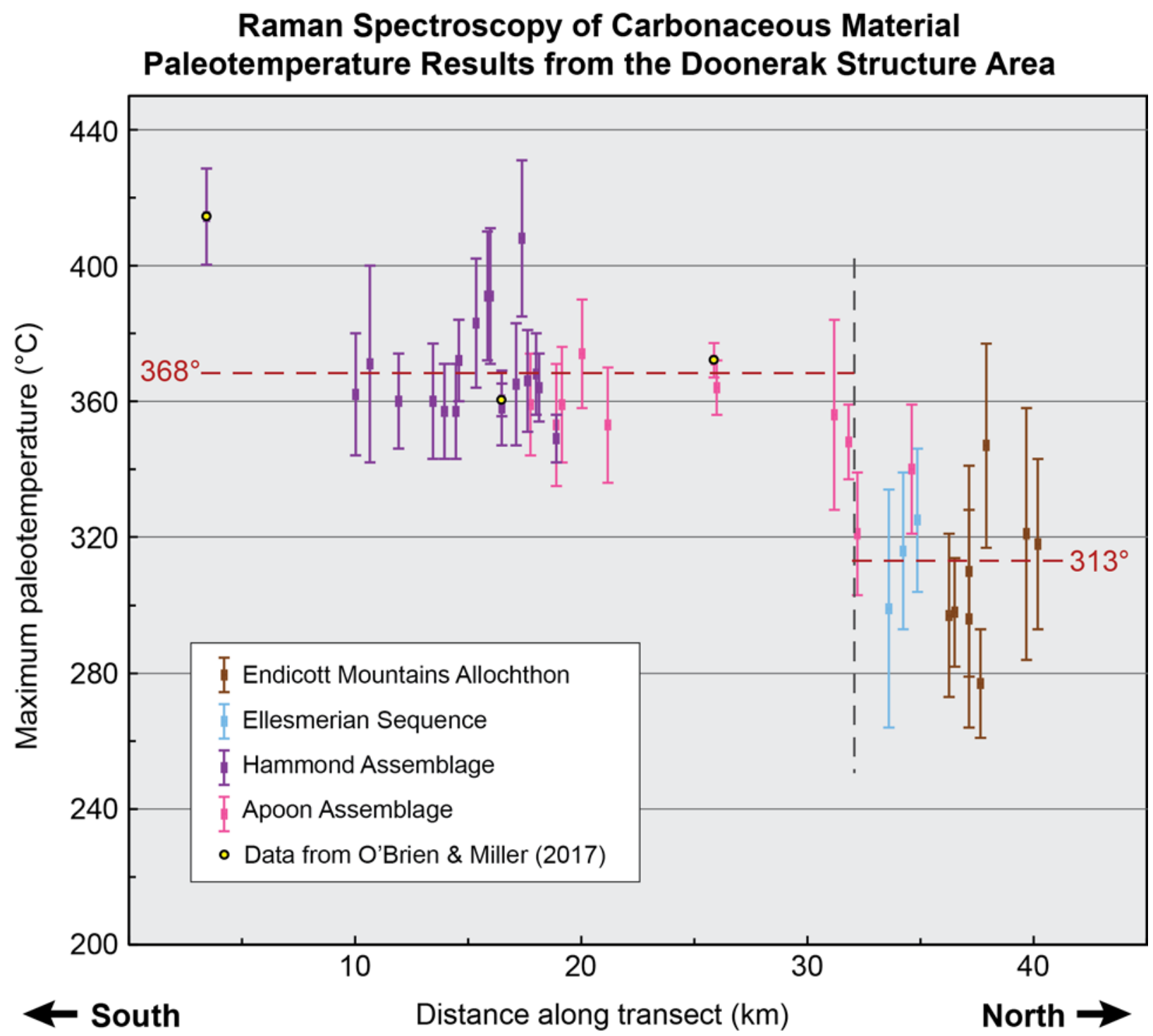

Figure 32. Graph of RSCM maximum paleotemperature results from the Doonerak anticline area plotted along a north-south transect across the Doonerak anticline (location shown on Figure 27). Data collected as part of this study shown with $1 \sigma$ error bars. Data provided by O'Brien and Miller (2017) shown with $2 \sigma$ error bars. Dashed gray line denotes the temperature shift at $11.5 \mathrm{~km}$ discussed in the text. 


\section{Discussion}

\section{Direction of emplacement}

The Hammond assemblage is interpreted as having been transported from an original southern position by all prior workers (e.g. Dutro et al., 1976; Oldow et al., 1987). The predominant south-dipping primary foliation, kinematic indicators related to S1, and outcropscale overturned folds documented in this work support the exiting interpretations.

The Endicott Mountains allochthon has been interpreted as being emplaced from the south along a single primary thrust spanning the anticline (e.g. Oldow et al., 1987). This is the expected direction of transport in a north-directed fold and thrust belt and supported by cleavage observed on the northern margin by Mull (1982), albeit in the Ellesmerian sequence. However, clear south-vergent structures observed in the Ellesmerian sequence and bedding/cleavage intersection both directly observed and calculated on stereonets in both the Endicott Mountains allochthon and Ellesmerian sequence support south-directed motion of the hanging wall units along the Amawk thrust.

If the interpretations of this work are correct and the structures within the Hammond assemblage are north-vergent and the motion of the structures within the Endicott Mountains allochthon along the Amawk thrust are south-vergent, there are two possible explanations: (1) If the units are correlative across the anticline as interpreted by others (e.g. Oldow et al., 1987), having been emplaced atop the Apoon assemblage and Ellesmerian sequence together, later events pushing them toward the center of the current anticline could have imparted the observed fabrics. (2) If the units are not actually correlative, they are likely from separate original positions to the south and north, respectively, and were emplaced independently.

\section{Correlation of assemblages}

Many units of the Endicott Mountains allochthon and Hammond assemblage appear similar to each other in the field. This is reasonable, given similar low-grade metamorphic 
histories and common Devonian to Mississippian age deposition. Overall, the Hammond assemblage is more calcareous and chloritic, whereas the Endicott Mountains allochthon has more coarse clastics and potentially non-marine sediments. However, these differences could reflect facies variations within a single package.

Detrital zircon geochronology has been completed on several samples in the Doonerak anticline and on correlative units to the west. Representative detrital zircon geochronology probability density plots are shown in Figure 33 from published work by Frier (2017) and Strauss et al. (2017). Their work was conducted primarily along the northern portion of the Doonerak anticline. These results were compared to data from the southern portion of the anticline along the North Fork of the Koyukuk River (Robinson et al., 2017) and along the John River to the west (E.L. Miller, personal communication, 2017). Locations of detrital zircon geochronology samples within the study area are shown on Plate 2.

Apoon assemblage samples are dominated by a single pre-Caledonian orogen peak around 480 to $520 \mathrm{Ma}$ (Figure $33 \mathrm{~F}, \mathrm{H}$ ). A single dominant age is consistent with deposition off an active arc system, as interpreted by prior workers (Strauss et al., 2017).

The Hammond assemblage displays a wide range of peaks, with several Timanian orogen-age ( $635 \mathrm{Ma})$, Grenville orogen-age ( $\sim \mathrm{Ga})$, and older peaks (Figure $33 \mathrm{I})$. This character is seen in the Trembley Creek phyllite sample (Strauss et al., 2017) and samples collected by Robinson et al. (2017) in the Dietrich River phyllite and other Hammond assemblage units. One exception in the data from Robinson et al. (2017) is a sample from approximately $1 \mathrm{~km}$ south of the mapped Hammond-Apoon assemblage contact which displays a single peak similar to Apoon samples. This may suggest a possible closer relationship between the Apoon and Hammond assemblages than previously known, but this is speculative without additional data.

Samples from the Endicott Mountains allochthon do not show the variety of older peaks typically seen in Hammond assemblage (Figure 33 C, D, E, G). The Hunt Fork Shale has a pair 
of Caledonian-aged peaks ( $\sim 360$ and $\sim 420 \mathrm{Ma})$ in samples from the Doonerak anticline area and elsewhere. Samples of Sillyasheen Mountain graywacke (Frier, 2017) may have a single peak within this same Caledonian age range. These peaks are younger than the peaks seen in Apoon assemblage samples.

Dillon et al. (1986) correlated the Devonian Hunt Fork Shale and Beaucoup Formation across the Doonerak anticline as members of the Hammond assemblage and Endicott Mountains allochthon. The detrital zircon signatures presented here indicate that these units are not correlative. This means they have a different sedimentary provenance and were likely deposited in a different basin or at a different time. Given the evidence of south and north directed motion in the Hammond assemblage and Endicott Mountains allochthon, respectively, the different-basin interpretation is preferred herein.

Data from the Ellesmerian sequence is consistent with deposition after the Endicott Mountains allochthon in the same basin. Caledonian-aged peaks are dominant, with younger ages not present in the older Hunt Fork Shale and Sillyasheen Mountain graywacke (Figure 33 A, B). 


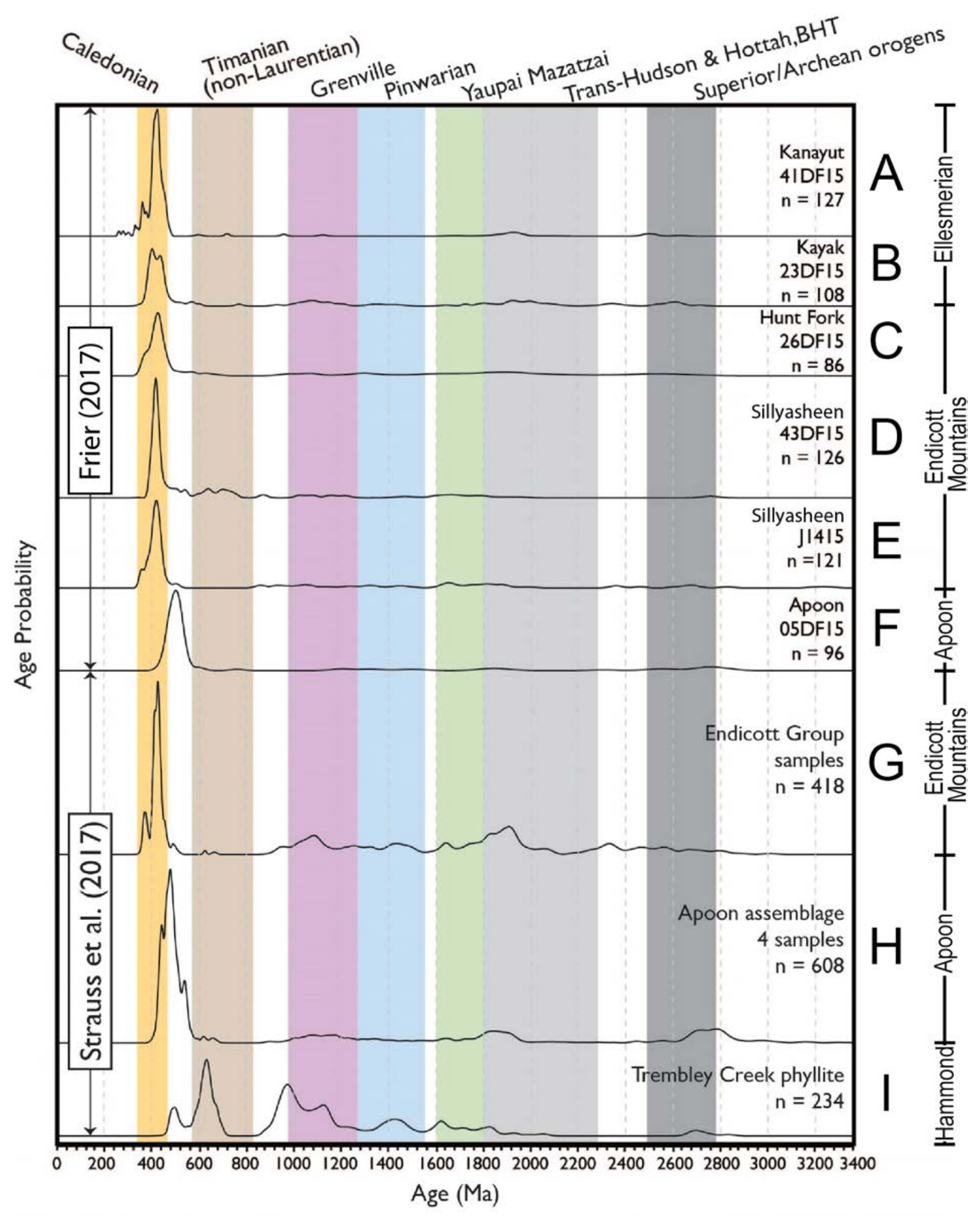

Figure 33. Stacked detrital zircon geochronology probability density plots from samples of Frier (2017) and accumulated plots from multiple samples from Strauss et al. (2017). Modified from Frier (2017). Color bars represent potential Laurentian source domains. 


\section{Basal Ellesmerian sequence contact}

The basal contact of the Ellesmerian sequence and Apoon assemblage has been interpreted as both a depositional unconformity (Mull et al., 1987) and tectonic in nature (Phelps, 1987). In this work, evidence of south-directed motion was observed within the Ellesmerian sequence. This indicates the contact in the study area was tectonic. It is possible the amount of transport was small and results from larger-magnitude motion of the overlying Endicott Mountains allochthon. If the contact was depositional and modest tectonic displacement occurred along only parts of the contact, both previous interpretations may be locally correct. Moderate, uneven transport of the Ellesmerian sequence may also explain the apparent absence of the sequence to the west of the North Fork of the Koyukuk River.

\section{Burial history}

Zircon fission track data (Table 3; Figure 34) shows the area around the Doonerak anticline cooled below $\sim 210^{\circ} \mathrm{C}$ during the Early Cretaceous through early Paleocene (Blythe et al., 1996). The range in zircon fission track ages is interpreted to be the result of slow uplift and fault juxtaposition of units after cooling below $210^{\circ} \mathrm{C}$. This implies that the maximum paleotemperatures determined by the RSCM method in this study were attained before zircon fission track closure during the main phase of the Brookian orogeny in the Early Cretaceous. Blythe et al. (1996) concluded peak temperatures in the area occurred as early as $\sim 185 \mathrm{Ma}$ during the earliest phases of the orogeny. Apatite fission track data (Table 3; Figure 34) indicate the area passed through the $\sim 60^{\circ} \mathrm{C}$ closure temperature in the Oligocene and earliest Miocene (Blythe et al., 1996; O'Sullivan et al., 1997).

Blythe et al. (1996) noted the observed paleotemperatures are greater than expected for the known thickness of sedimentary cover. They suggest this was result of structural thickening, rather than overburden having been thicker than realized or a much higher past geothermal gradient, although their work did not include paleobarometry. Combined RSCM 
paleothermometry and Si-in-phengite paleobarometry work by O'Brien and Miller (2017) 20 km to the west along strike from the Doonerak anticline along the John River offers insight into these possibilities. They found maximum paleotemperatures of $\sim 375^{\circ} \mathrm{C}$ at paleopressures of 2 to $3 \mathrm{kbar}$. For an assumed density of $2700 \mathrm{~kg} / \mathrm{m}^{3}$, these pressures correspond to $\sim 7.6$ to $\sim 11.4$ $\mathrm{km}$ burial and geothermal gradient of 46 to $31^{\circ} \mathrm{C} / \mathrm{km}$. This is in contrast to the $\sim 15 \mathrm{~km}$ burial expected for a normal geothermal gradient of $25^{\circ} \mathrm{C} / \mathrm{km}$. Fold and thrust belts are generally expected to be cooler than average continental crust (Spear, 1995). One explanation which explains the difference between the expected geothermal gradient and the range determined by thermobarometry is the possibility that peak temperatures and peak pressures were not achieved at the same time.

\begin{tabular}{|c|c|c|c|c|c|c|c|c|}
\hline Sample & $\begin{array}{l}\text { Long. } \\
\text { (W) }\end{array}$ & $\begin{array}{l}\text { Lat. } \\
\text { (N) }\end{array}$ & $\begin{array}{l}\text { Elev. } \\
\text { (m) }\end{array}$ & Lithology & Unit & $\begin{array}{c}\text { Strat. } \\
\text { Age }\end{array}$ & $\begin{array}{c}\text { FT } \\
\text { Age }\end{array}$ & $1 \sigma$ \\
\hline \multicolumn{9}{|c|}{ Blythe et al. (1996) zircon fission track } \\
\hline $8-87$ & 150.00 & 67.91 & 1160 & fol. conglomerate & $\mathrm{Mk}$ & Miss. & 65.6 & 3.8 \\
\hline $10-87$ & 149.79 & 67.96 & 705 & conglomerate & Dhf & Dev. & 70.1 & 7.1 \\
\hline $12-89$ & 149.72 & 67.75 & 475 & schist & Obpm & Ord. & 70.3 & 3.5 \\
\hline $18-89$ & 150.10 & 67.86 & 1310 & arkose & Mkt & Miss. & 112.4 & 7.6 \\
\hline $21-89$ & 149.72 & 67.97 & 725 & volcanic schist & Df & Dev. & 102.6 & 5.4 \\
\hline \multicolumn{9}{|c|}{ Blythe et al. (1996) apatite fission track } \\
\hline $21-89$ & 149.72 & 67.97 & 725 & volcanic schist & Df & Dev. & 29.4 & 1.6 \\
\hline $17-89$ & 149.67 & 67.78 & 1430 & gabbro & $\mathrm{Dg}$ & Dev. & 48.3 & 8.7 \\
\hline \multicolumn{9}{|c|}{ O'Sullivan et al. (1997) apatite fission track } \\
\hline 90POS30A & 150.08 & 67.40 & 427 & Qtz-mica schist & Unnamed & Ord.? & 71.5 & 9.4 \\
\hline 90POS29A & 149.78 & 67.97 & 670 & Sandstone & Hunt Fork Sh. & Dev. & 23.6 & 1.9 \\
\hline 90POS28A & 150.65 & 67.03 & 1220 & Sandstone & Beaucoup Fm. & Dev. & 88.4 & 5.5 \\
\hline 89TM299A & 149.97 & 67.91 & 1200 & Metasandstone & Unnamed & Dev.? & 22.0 & 2.0 \\
\hline 90TM491A & 150.24 & 67.93 & 882 & Volcanic & Apoon Volc. & Ord.? & 33.9 & 8.0 \\
\hline 90TM492A & 150.71 & 67.93 & 570 & Sandstone & Karen Creek & Tri. & 24.0 & 2.6 \\
\hline 90TM494A & 150.12 & 67.93 & 1452 & Sandstone & Kekiktuk Fm. & Miss. & 31.5 & 7.2 \\
\hline 90TM495B & 149.91 & 67.96 & 768 & Sandstone & Kekiktuk Fm. & Miss. & 31.8 & 17.0 \\
\hline
\end{tabular}

Table 3. Apatite and zircon fission track data from Blythe et al. (1996) and O'Sullivan et al. (1997) shown in Figure 34. 


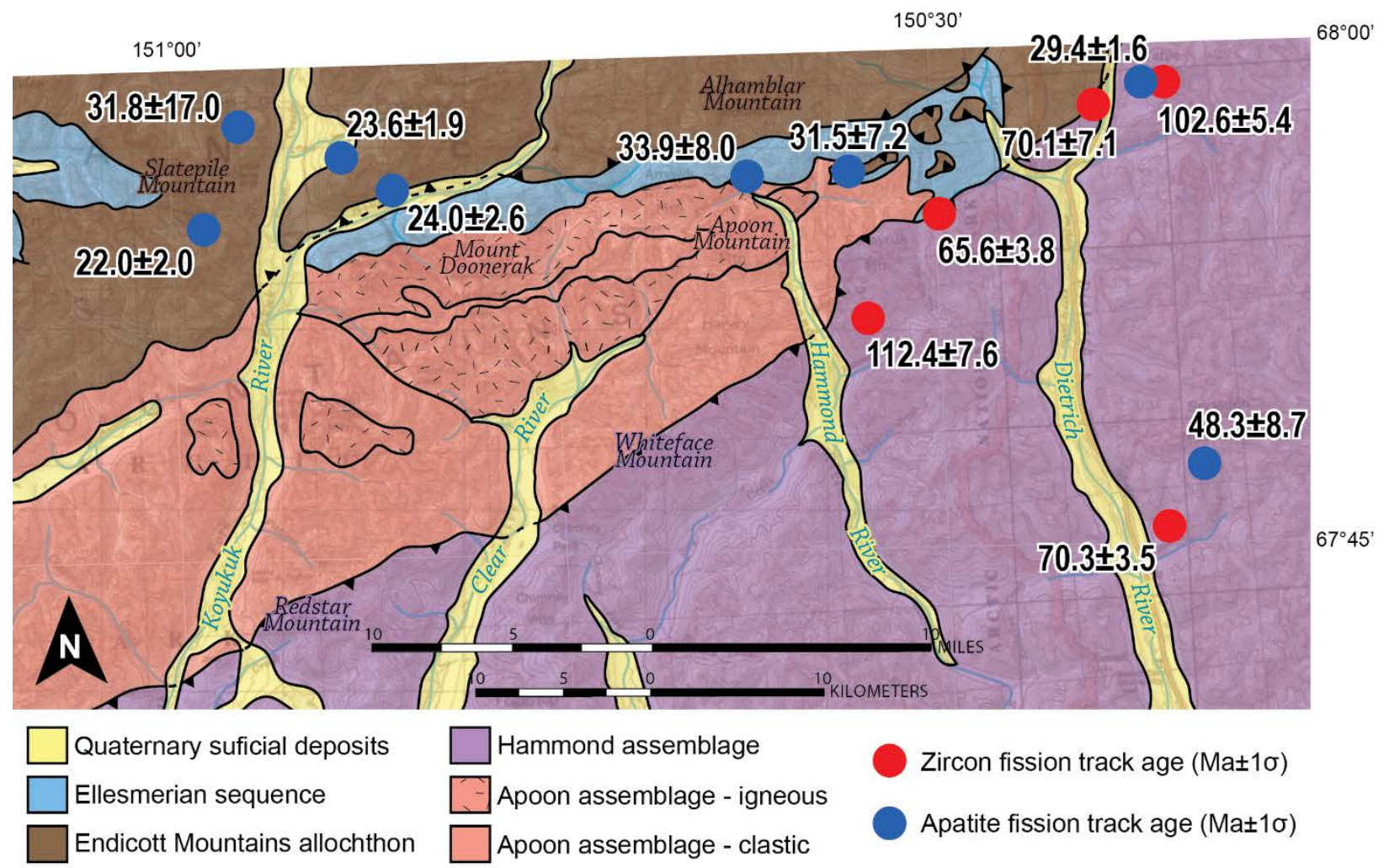

Figure 34. Published apatite and zircon fission track ages in the vicinity of the Doonerak anticline (Blythe et al., 1996; O'Sullivan et al., 1997). Generalized geologic map of the Doonerak anticline simplified from Dillon et al. (1986).

\section{Devonian basins}

Kelly and Brosgé (1995) suggest the Endicott Mountains allochthon was deposited in a synrift basin, similar to the Ikpikpuk-Umiat and Meade basins found in the northern Alaska subsurface (Figure 35). Their model correlates units across the anticline and assumes entirely north-directed emplacement, both of which have been brought into question. Despite these differences, the idea of a relatively small, nearby basin as a source for hanging wall units of the Doonerak anticline has merits.

The Inigok \#1 well (Figure 35) reached total depth in rocks classified as Devonian and pre-Devonian ‘argillite' basement, based on original well reports (Haywood, 1983; A.O.G.C.C., 2008). Mickey et al. (2006) classified foraminifera in the deepest identifiable samples as early to middle Mississippian. Atop the Devonian to early Mississippian units were the Mississippian 
Lisburne Group and younger rocks. This relationship is observed in the Endicott Mountains allochthon to the north of the Doonerak anticline (Dillon et al., 1986). Thrust faulting of such a basin could emplace the Devonian to early Mississippian units above the Lisburne Group, similar to the relationship observed on the northern margin of the Doonerak anticline.

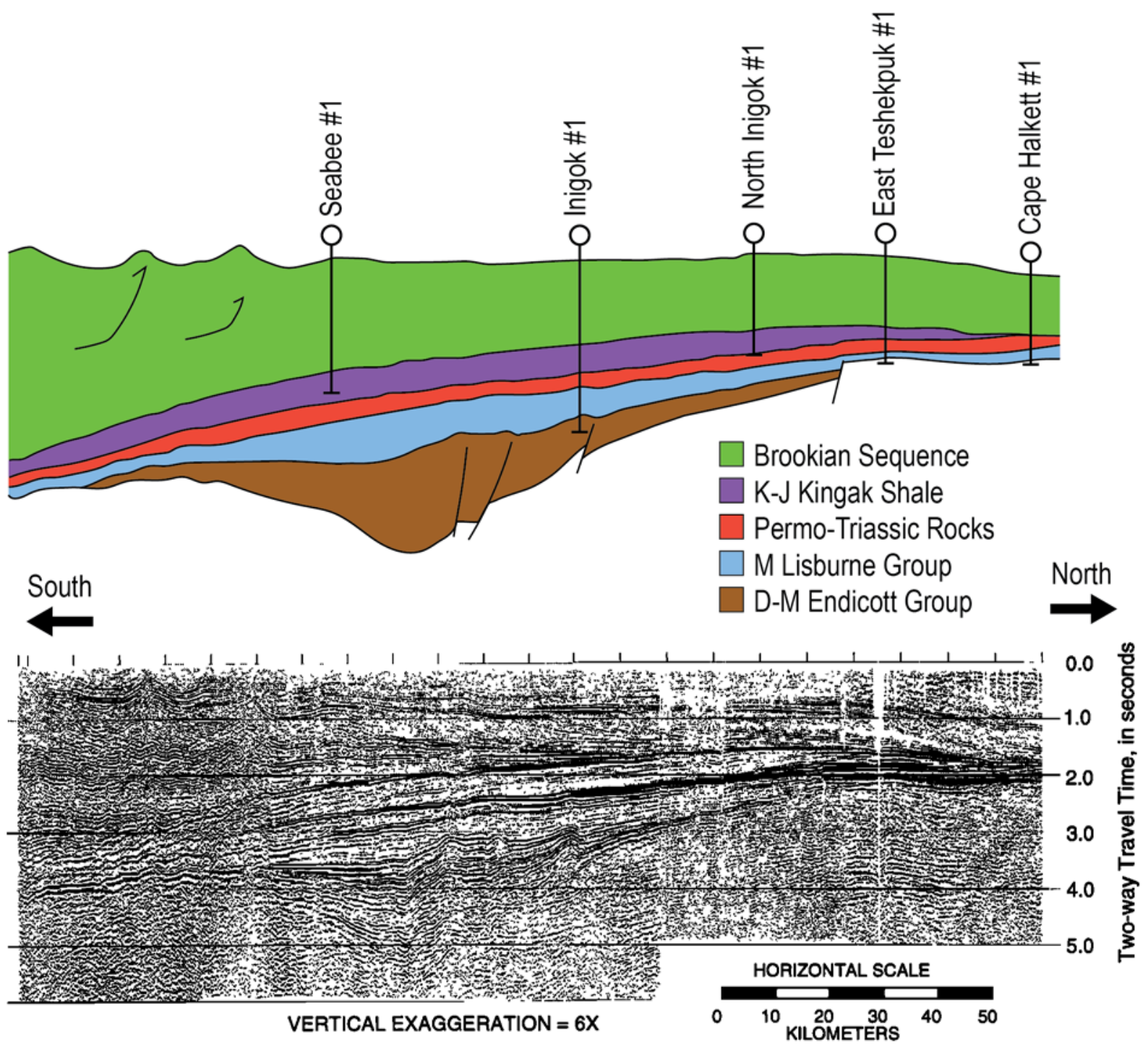

Figure 35. Seismic cross section and interpretation of a line extending from the northern foothills of the central Brooks Range to the Arctic Ocean (simplified from Cole et al., 1997; location shown on Figure 5). The southern terminus of the line is located approximately $150 \mathrm{~km}$ northwest of the Doonerak anticline. The line shows deposition in the Ikpikpuk-Umiat basin, a small synrift basin. The Inigok \#1 well reached rocks classified as Devonian rocks and preDevonian 'argillite' basement in the original well reports (Haywood, 1983; A.O.G.C.C., 2008). Mickey et al. (2006) classified the deepest samples with identifiable foraminifera as early to middle Mississippian. 


\section{South-directed motion}

South-directed motion has been interpreted elsewhere in the Brooks Range at various scales. Mull (1977) observed outcrops-scale south-vergent folds during reconnaissance mapping of the Survey Pass quadrangle, west of the Doonerak area in the southern flank of the Brooks Range. These were best developed in the Skajit Limestone, part of the Hammond assemblage. Dutro et al. (1976) point to small folds and thrusts along the northern flank at the eastern end of the Doonerak anticline as evidence of south-directed motion. Larger-scale southward motion is shown in back-thrusts in Cretaceous to Tertiary units in the foreland basin of the Brooks Range in reconstructions by Oldow et al. (1987; Figure 36). This prior work indicates the south-directed motion interpreted in the Ellesmerian sequence and Endicott Mountains allochthon in the study area is not entirely anomalous.
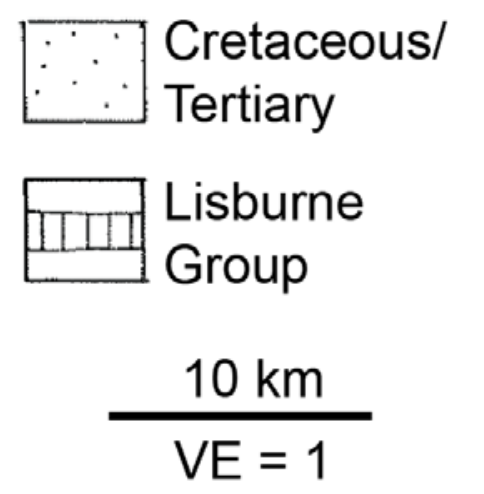

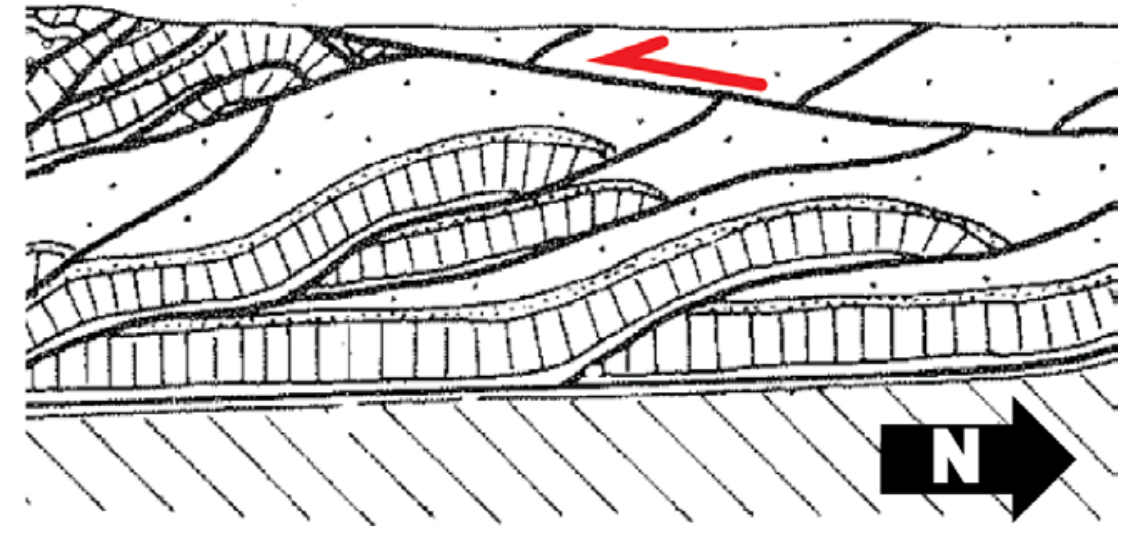

Figure 36. Portion of the balanced cross section of Oldow et al. (1987) showing a back-thrust in Cretaceous to Tertiary basin fill in the foreland basin north of the Doonerak anticline. 


\section{Previous structural models}

Three primary models of the Doonerak anticline structural evolution have been

presented by prior workers. All were constructed based on reconnaissance scale mapping and without the aid of the analytical data such as is presented here. Ideas from each were considered while constructing the new interpretation presented in this work. The locations of each previous cross section and the new model are shown in Figure 37.

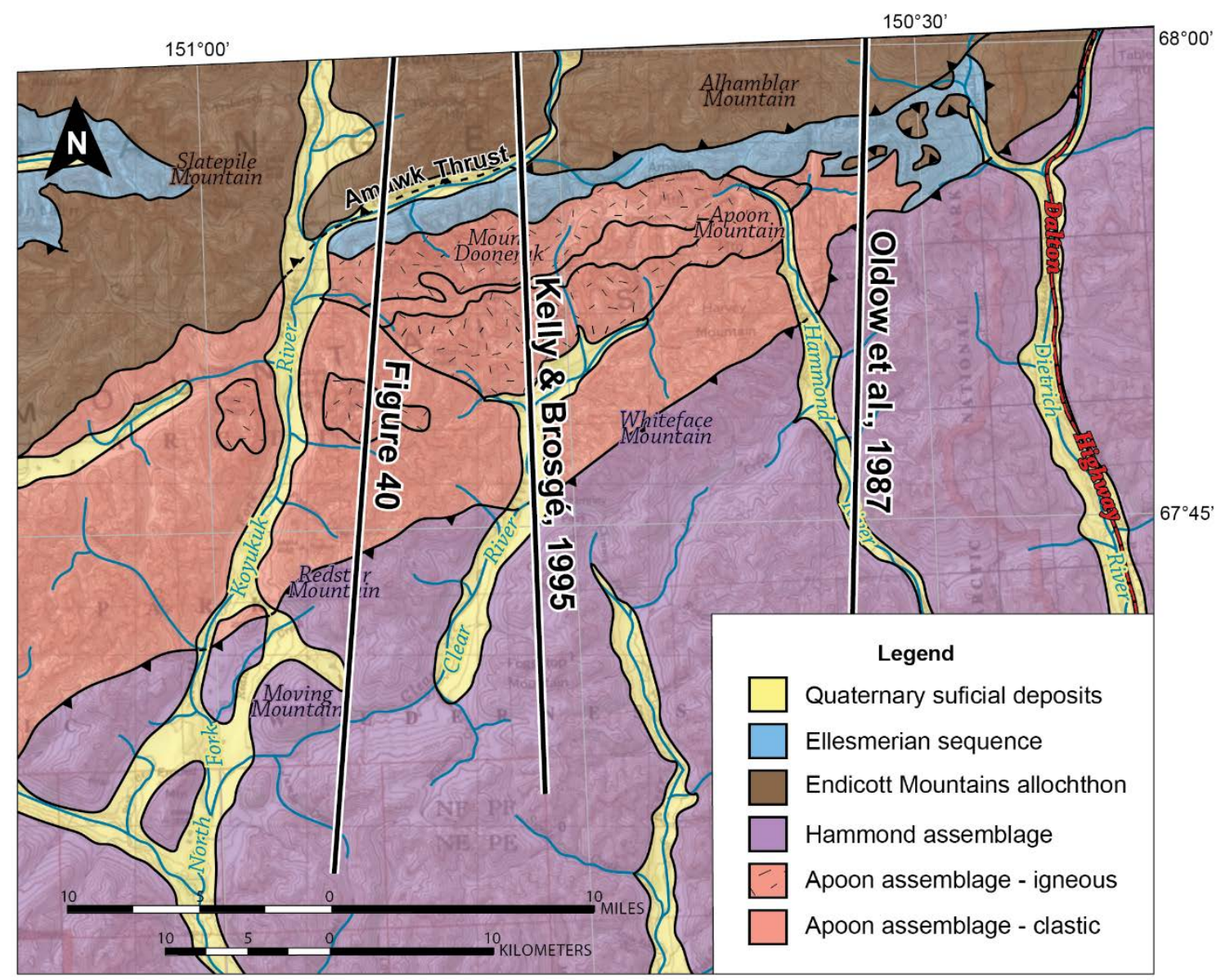

Figure 37. Locations of cross sections by Oldow et al. (1987), Kelly and Brosgé (1995), and the new model presented in this work (Figure 41). The location of the Dutro et al. (1976) cross section is not specified but is in the vicinity of that of Kelly and Brosgé (1995). Generalized geologic map of the Doonerak anticline simplified from Dillon et al. (1986). 
Oldow et al. (1987) constructed a balanced cross section through Atigun Pass, where the Dalton Highway crosses through the Brooks Range at the eastern end of the Doonerak anticline (Figure 38). Their model provides for the structural thickening needed to produce the observed paleotermperatures and pressures. It also correlates units across the anticline and is entirely north-vergent, which does not reflect conclusions of this work.

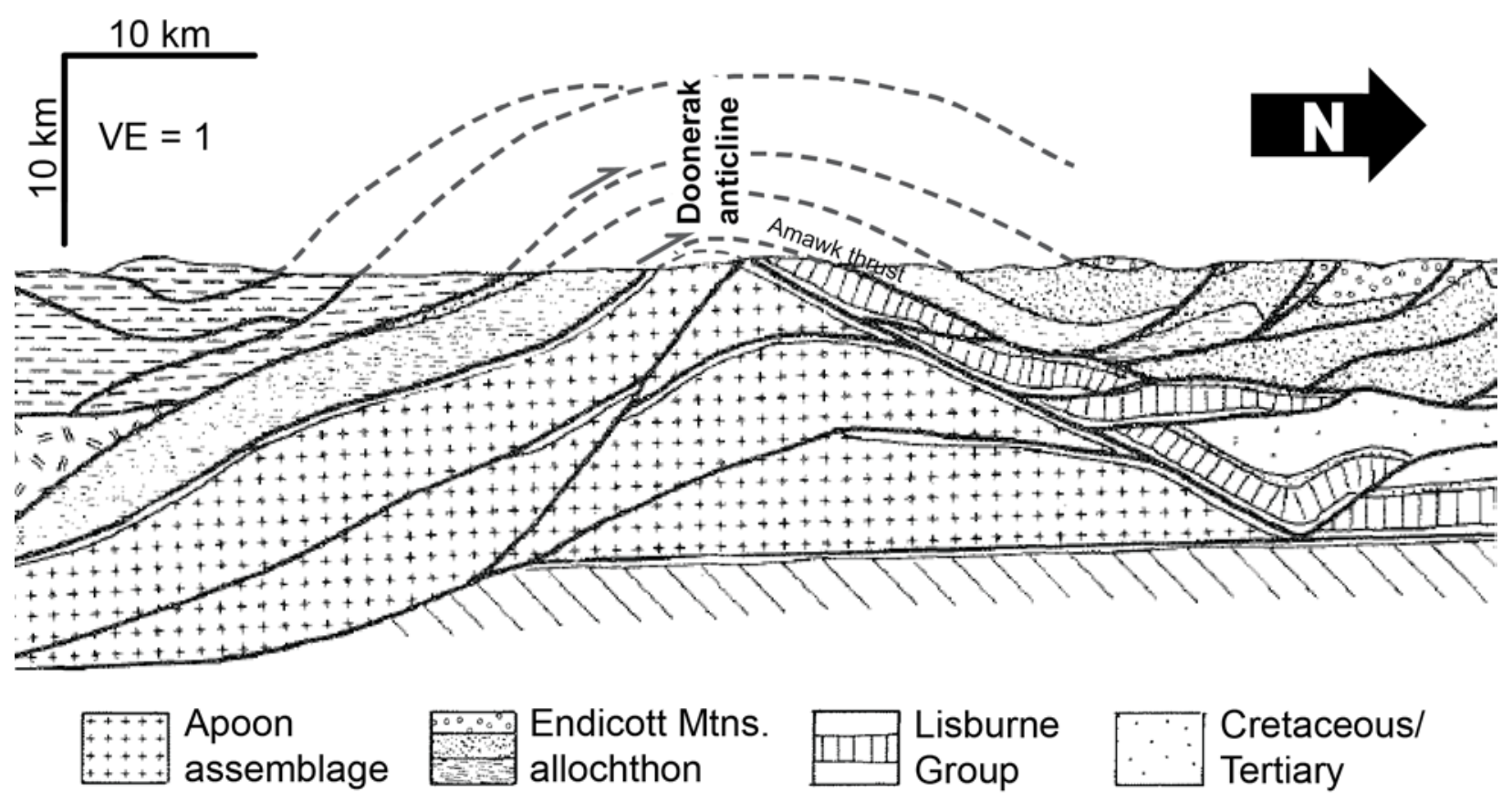

Figure 38. Cross section interpretation of the Doonerak anticline by Oldow et al. (1987). Dashed lines added for burial visualization. Endicott Mountains allochthon units shown to the south of the Doonerak anticline are equivalent to the Hammond assemblage.

Dutro et al. (1976) produced two schematic cross sections. The preferred interpretation included south-directed motion on the northern flank of the anticline and north-directed motion on the southern flank (Figure 39). This is consistent with conclusions from my work. The southdirected motion they interpret, however, occurs before the north-directed thrusting as seen by the offset in the south-directed thrust faults. This is inconsistent with the hypothesis that the 
south-directed motion is a back-thrust, which typically form later than the thrusting oriented in the dominant direction. Their model, as all others, correlates units across the anticline.

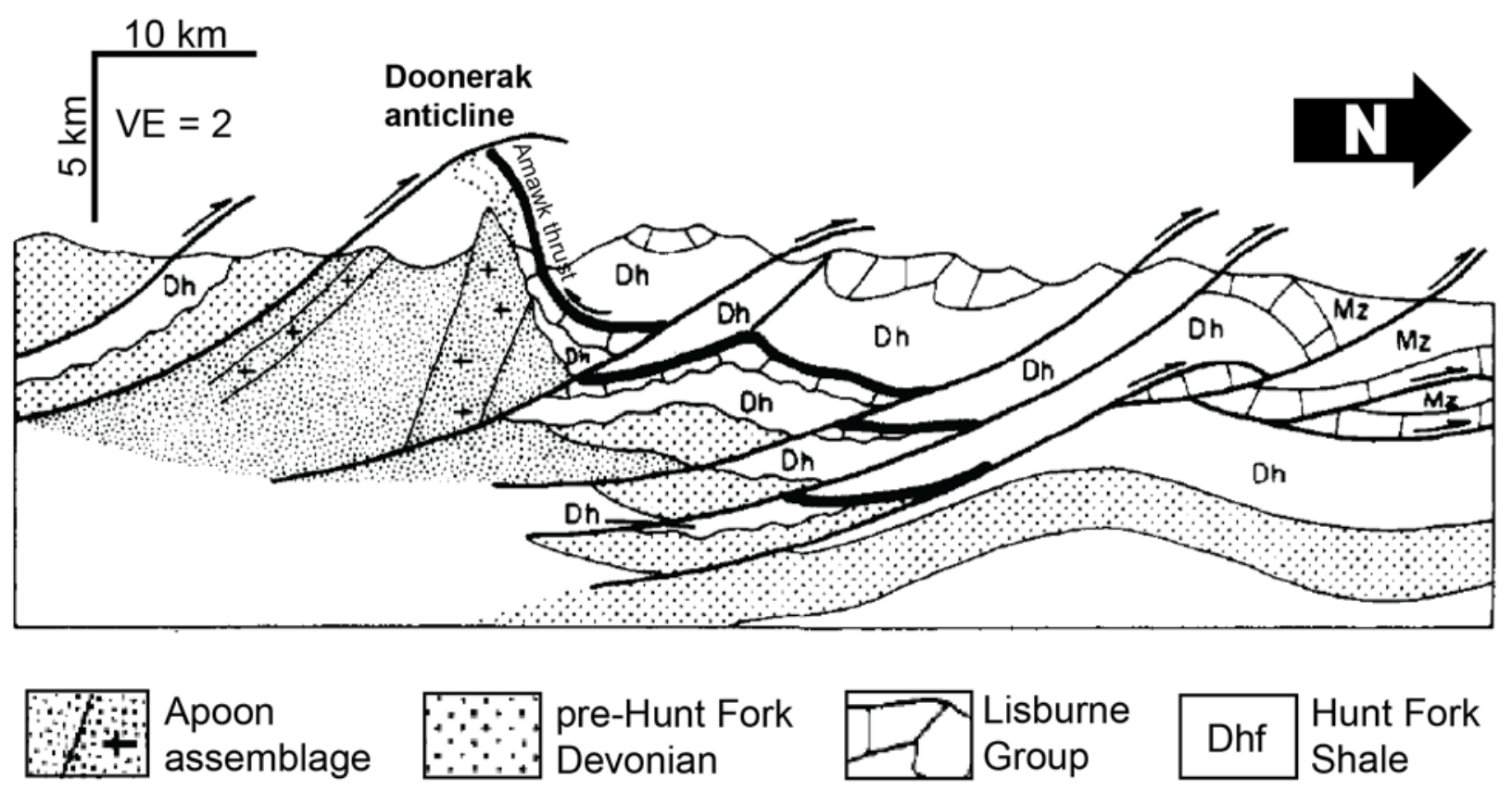

Figure 39. Cross section interpretation of the Doonerak anticline by Dutro et al. (1976). Pre-Hunt Fork Devonian and Hunt Fork Shale south of the Doonerak anticline equivalent to the Hammond assemblage. Note vertical exaggeration.

The cross section of Kelly and Brosgé (1995; Figure 40) is entirely north-directed and correlates units across the anticline. The advantage of their model is suggesting that the Endicott Mountains allochthon units were deposited in a local synrift basin, significantly reducing the required shortening required by other models. They also correlate the units across the anticline. Their model does not invoke sufficient structural burial to generate the observed paleotemperatures and pressures. 


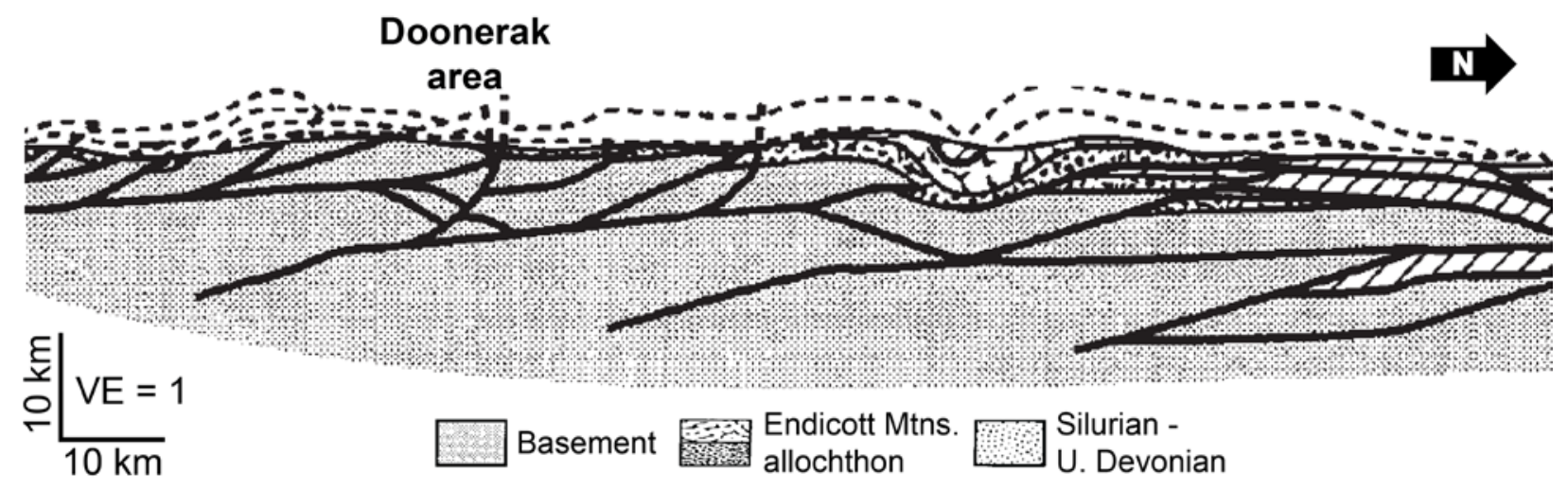

Figure 40. Cross section interpretation of the Doonerak anticline by Kelly and Brosgé (1995). Limited structural burial in the area of the Doonerak anticline is apparent.

\section{Proposed model}

The model proposed in this work combines the imbrication and structural burial of Oldow et al. (1987), the north- and south-directed motion of Dutro et al. (1976), and the Endicott Mountains allochthon depositional setting of Kelly and Brosgé (1995). The hypothesis presented best explains the observations presented in this work, including paleotemperatures, units which do not correlate across the anticline, and evidence of south-directed motion on the northern margin of the Doonerak anticline. The new model suggests the Doonerak anticline resulted from the following series of events:

1. Accretion of an Early Paleozoic arc system (Apoon assemblage) to northern Alaska during the Caledonian orogeny (Strauss et al., 2017; Frier, 2017).

2. Ordovician to Devonian deposition of the Hammond assemblage in a basin to the south of the Apoon assemblage.

3. Formation of an Umiat-Ikpikpuk style rift basin in the Devonian and deposition of the Endicott Mountains allochthon units to the north of the Doonerak area followed by deposition of the Ellesmerian sequence atop both the Endicott Mountains allochthon units and the Apoon assemblage. 
4. North-directed thrusting and imbrication of the Hammond assemblage during the Early Cretaceous Brookian orogeny.

5. Approximately $12 \mathrm{~km}$ of burial establishes observed maximum paleotemperatures in the Hammond and Apoon assemblages (Figure $41 \mathrm{~A}$ ).

6. Partial erosion of the overlying nappes of the Hammond assemblage.

7. Back-thrusting during continued north-directed propagation of the Brooks Range fold and thrust belt emplaced the Endicott Mountains allochthon units atop the overlying Ellesmerian sequence and onto the Apoon assemblage. The location of detachment and distance the Endicott Mountains allochthon was transported is unknown. Approximately $10 \mathrm{~km}$ of burial established maximum temperatures in the Endicott Mountains allochthon and Ellesmerian sequence at this stage (Figure $41 \mathrm{~B}$ )

8. Cenozoic uplift and erosion into the current structure documented by apatite and zircon fission track thermochronology (Blythe et al., 1996; O’Sullivan et al., 1997). Normal faulting directed away from the center of the anticline (Phelps et al., 1987) and secondary low-strain fabrics developed during this uplift.

Uncertainties of this model could be constrained by more detailed mapping both between the study area and the TACT study area closer to the Dalton Highway (Moore et al., 1997) to better establish correlation between units and along the northern margin to the west of the study area to look for evidence of vergence, as this area has only been studied at the reconnaissance scale (Dillon et al., 1986). Detrital zircon geochronology of additional samples would constrain the interpreted character of each assemblage and confirm that no correlation across the structure exists. If south-vergence and non-correlation of units is established over a broader area, new balanced cross sections of cross sections more regional in scale may elucidate broader implications of these results. 

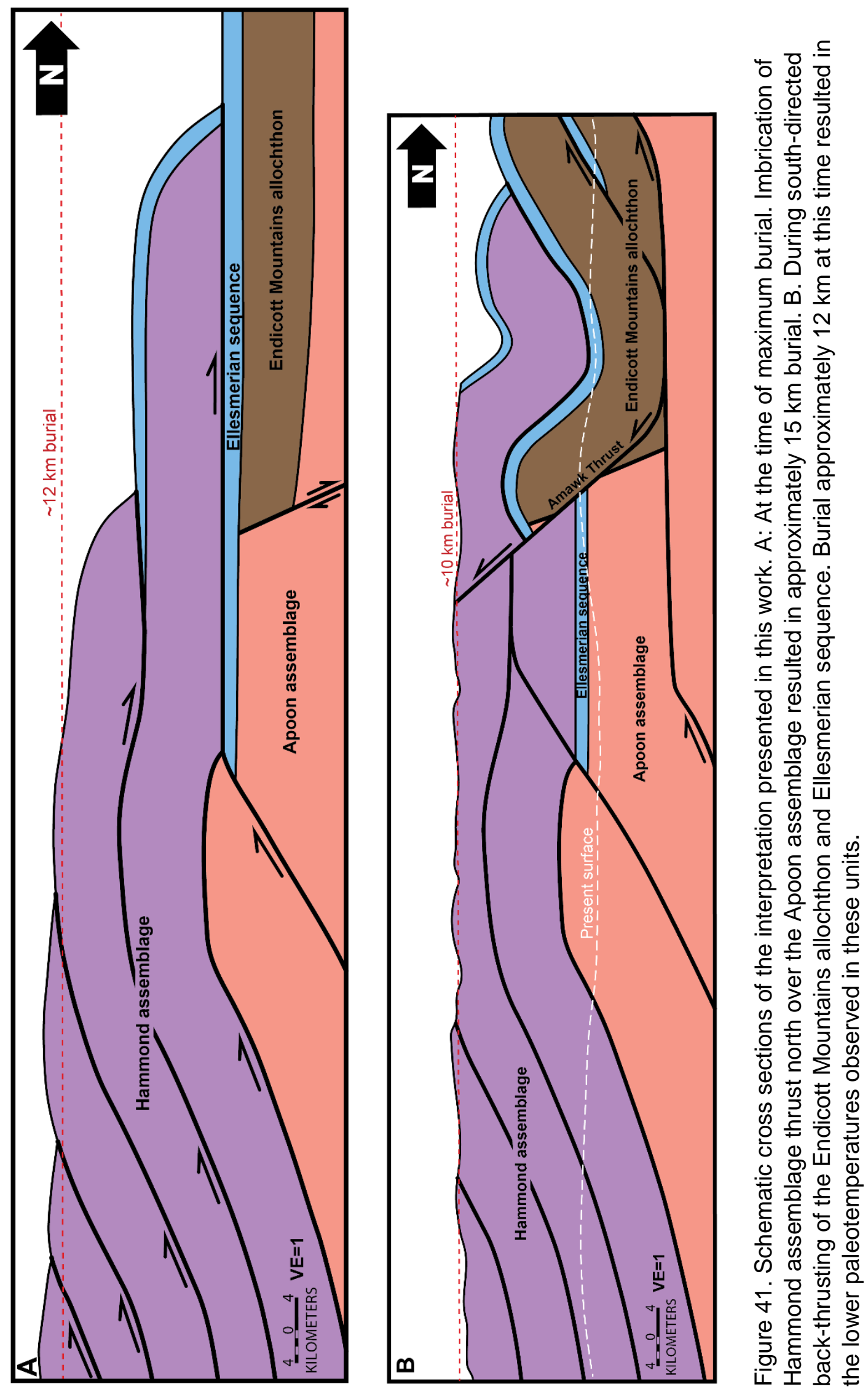


\section{Conclusions}

Prior work interpreted the Doonerak anticline as a tectonic window resulting from erosion of a north-directed nappe of the Endicott Mountains allochthon. Data presented in this work does not support the previous interpretations. Based on field mapping, petrography, RSCM paleothermometry, and detrital zircon geochronology, this work concludes the following:

- The Endicott Mountains allochthon does not correlate to the Hammond assemblage to the south of the anticline. Detrital zircon geochronology data for the Endicott Mountains allochthon is dominated by one or two Caledonian-aged peaks. The Hammond assemblage lacks Caledonian peaks, instead having several older peaks. This suggests the two groups were deposited in separate basins.

- $\quad$ Structural data indicate the Hammond assemblage is north-vergent, consistent with previous interpretations. The Ellesmerian sequence and Endicott Mountains allochthon show south-vergent structures, indicating the motion of the Amawk thrust was to the south. This is in contrast to prior interpretations wherein the both groups were northvergent.

- Maximum temperatures determined by RSCM paleothermometry show the Endicott Mountains allochthon, Ellesmerian sequence, and northernmost Apoon assemblage average $313 \pm 19^{\circ} \mathrm{C}$, indicating burial of approximately $10 \mathrm{~km}$. The Hammond assemblage and the majority of the Apoon assemblage reached $368 \pm 16^{\circ} \mathrm{C}$, indicating burial of approximately $12 \mathrm{~km}$.

These conclusions are best explained by a new model wherein the Doonerak anticline results from two separate packages of rocks being emplaced from separate original basins to the south and north. The Hammond assemblage was deposited to the south and thrust northward over the Apoon assemblage during the Brookian orogeny. Later south-directed backthrusting emplaced the Endicott Mountains allochthon and Ellesmerian sequence from a 
Devonian synrift basin to the north. The model presented here greatly reduces the required shortening invoked in prior interpretations and suggests that the broader interpretations of the structural evolution of the area may need to be revisited. 


\section{References}

Allmendinger, R. W., Cardozo, N. C., and Fisher, D., 2013, Structural Geology Algorithms: Vectors \& Tensors: Cambridge, England, Cambridge University Press, 289 p.

A.O.G.C.C., 2008. Image Project Well History File 100-199, Inigok Test Well \#1 (50-279-2000300-00). Alaska Oil \& Gas Conservation Commission, Anchorage, Alaska.

Armstrong, B.H., 1967. Spectrum line profiles: the Voigt unction. Journal of Quantitative Spectroscopy and Radiative Transfer, 7(1), p. 61-88.

Armstrong, A.K., Mamet, B.L., Brosgé, W.P. and Reiser, H.N., 1976. Carboniferous section and unconformity at Mount Doonerak, Brooks Range, northern Alaska. AAPG Bulletin, 60(6), p. 962-972.

Beyssac, O., Goffé, B., Chopin, C. and Rouzaud, J.N., 2002. Raman spectra of carbonaceous material in metasediments: a new geothermometer. Journal of Metamorphic Geology, 20(9), p. 859-871.

Beyssac, O. and Lazzeri, M., 2012. Application of Raman spectroscopy to the study of graphitic carbons in the Earth Sciences. Applications of Raman spectroscopy to earth sciences and cultural heritage. EMU Notes in Mineralogy, 12, p. 415-454.

Blatt, H., Tracy, R. and Owens, B., 2006. Petrology: igneous, sedimentary, and metamorphic. New York: W. H. Freeman and Company, 530 p.

Blythe, A.E., Bird, J.M. and Omar, G.I., 1996. Deformational history of the central Brooks Range, Alaska: Results from fission-track and ${ }^{40} \mathrm{Ar} /{ }^{39} \mathrm{Ar}$ analyses. Tectonics, $15(2)$, p. 440455.

Brosgé, W., and Reiser, H., 1971, Preliminary bedrock geologic map, Wiseman and eastern Survey Pass Quadrangles, Alaska: USGS Open-File Map 479, scale 1:250000.

Cardozo, N., and Allmendinger, R.W., 2013, Spherical projections with OSXStereonet: Computers \& Geosciences, v. 51, p. 193-205.

Cole, F., Bird, K.J., Toro, J., Roure, F., O'Sullivan, P.B., Pawlewicz, M. and Howelll, D.G., 1997. An integrated model for the tectonic development of the frontal Brooks Range and Colville Basin $250 \mathrm{~km}$ west of the Trans-Alaska Crustal Transect. Journal of Geophysical Research: Solid Earth, 102(B9), p. 20685-20708.

Dillon, J.T., Brosgé, W.P., and Dutro, J.T., 1986, Generalized geologic map of the Wiseman Quadrangle, Alaska: USGS Open-File Report 86-219, scale 1:250000.

Downs, R.T., 2006. The RRUFF Project: an integrated study of the chemistry, crystallography, Raman and infrared spectroscopy of minerals. In Program and Abstracts of the 19th General Meeting of the International Mineralogical Association in Kobe, Japan, 2006. 
Dutro, J.T., Brosge, W.P., Lanphere, M.A. and Reiser, H.N., 1976. Geologic significance of Doonerak structural high, central Brooks Range, Alaska. AAPG Bulletin, 60(6), p. 952-961.

Dutro, J.T., Palmer, A.R., Repetski, J.E. and Brosgé, W.P., 1984. Middle Cambrian fossils from the Doonerak anticlinorium, central Brooks Range, Alaska. Journal of Paleontology, p.1364-1371.

Frier, W.P., 2017, Insights into the assembly of Arctic Alaska: Provenance and geochemical data from the Doonerak fenster and Endicott Mountains allochthon [M.S. thesis]: Morgantown, West Virginia University, 143 p.

Fuis, G.S., Levander, A.R., Lutter, W.J., Wissinger, E.S., Moore, T.E. and Christensen, N.I., 1995. Seismic images of the Brooks Range, Arctic Alaska, reveal crustal-scale duplexing. Geology, 23(1), p. 65-68.

Haywood, H., 1983. Inigok test well no. 1: National Petroleum Reserve in Alaska Geological Report of Husky Oil NPR Operations. Inc., National Geophysical Data Center, NOAS E/GC3 Department, 874(325), p. 80303-3328.

Johnsson, M.J., Pawlewicz, M.J., Harris, A.G. and Valin, Z.C., 1992. Vitrinite reflectance and conodont color alteration index data from Alaska; data to accompany the Thermal maturity map of Alaska (No. 92-409). US Geological Survey.

Jones, D.L., Silberling, N.J., Coney, P.J. and Plafker, G., 1987. Lithotectonic terrane map of Alaska (west of the 141st meridian) (No. 1874-A).

Julian, F.E., 1989, Structure and stratigraphy of lower Paleozoic rocks, Doonerak Window, central Brooks Range, Alaska [Ph.D. thesis]: Houston, Rice University, 127 p.

Julian, F.E., Oldow, J.S., 1998, Structure and lithology of the lower Paleozoic Apoon assemblage, eastern Doonerak window, central Brooks Range, Alaska, in Oldow, J.S. and Avé Lallemant, H.G., eds., Architecture of the Central Brooks Range Fold and Thrust Belt, Arctic Alaska: Boulder, Colorado, GSA Special Paper 324.

Kelly, J.S., 1988. Preliminary geologic map of the Chandler Lake Quadrange, Alaska: USGS Open-File Report 88-42, scale 1:250000.

Kelley, J.S. and Brosgé, W.P., 1995. Geologic framework of a transect of the central Brooks Range: Regional relations and an alternative to the Endicott Mountains allochthon. AAPG bulletin, 79(8), p.1087-1115.

Kouketsu, Y., Mizukami, T., Mori, H., Endo, S., Aoya, M., Hara, H., Nakamura, D. and Wallis, S., 2014. A new approach to develop the Raman carbonaceous material geothermometer for low-grade metamorphism using peak width. Island Arc, 23(1), p.33-50. 
Lafuente B, Downs R T, Yang H, Stone N (2015), The power of databases: the RRUFF project. In: Highlights in Mineralogical Crystallography, T. Armbruster and R.M. Danisi, eds. Berlin, Germany, W. De Gruyter, p. 1-30

Lahfid, A., Beyssac, O., Deville, E., Negro, F., Chopin, C. and Goffé, B., 2010. Evolution of the Raman spectrum of carbonaceous material in low-grade metasediments of the Glarus Alps (Switzerland). Terra Nova, 22(5), p. 354-360.

Lünsdorf, N.K., Dunkl, I., Schmidt, B.C., Rantitsch, G. and Eynatten, H., 2013. Towards a higher comparability of geothermometric data obtained by Raman spectroscopy of carbonaceous material. Part I: evaluation of biasing factors. Geostandards and Geoanalytical Research, 38(1), p. 73-94.

Lünsdorf, N.K., 2016. Raman spectroscopy of dispersed vitrinite-Methodical aspects and correlation with reflectance. International Journal of Coal Geology, 153, p. 75-86.

Mickey, M.B., Haga, H. and Bird, K.J., 2006. Micropaleontology of selected wells and seismic shot holes, northern Alaska. US Department of the Interior, US Geological Survey.

Moore, T.E., Wallace, W.K., Bird, K.J., Karl, S.M., Mull, C.G. and Dillon, J.T., 1994. Geology of northern Alaska. The geology of Alaska: Boulder, Colorado, GSA, Geology of North America 1, p. 49-140.

Moore, T.E., Wallace, W.K., Mull, C.G., Adams, K.E., Plafker, G. and Nokleberg, W.J., 1997. Crustal implications of bedrock geology along the Trans-Alaska Crustal Transect (TACT) in the Brooks Range, northern Alaska. Journal of Geophysical Research: Solid Earth, 102(B9), p. 20645-20684.

Mull, C.G., 1977. Apparent south vergent folding and possible nappes in Schwatka Mountains. The United States Geological Survey in Alaska: Accomplishments during 1975, 733, p. B29-B30. US Geological Survey.

Mull, C.G.,1982. Tectonic evolution and structural style of the Brooks Range, Alaska: An illustrated summary, in Powers, R.B., ed., Geological studies of the Cordilleran thrust belt: Volume 1: Denver, Colorado, Rocky Mountain Association of Geologists, p. 1-45.

Mull, C.G., Adams, K.E. and Dillon, J.T., 1987. Stratigraphy and structure of the Doonerak Fenster and Endicott Mountains Allochthon, central Brooks Range, Alaska, in Alaska North Slope Geology. (eds) I. L. Tailleur and P. Weiner, p. 663-669, Pacific Section, SEPM, Anchorage.

Mull, C.G., 1989a. Generalized Stratigraphy and Structure of the Brooks Range and Arctic Slope, in Mull, C., and Adams, K., eds, Bedrock geology of the eastern Koyukuk basin, central Brooks Range, and east-central Arctic Slope: Division of geological and geophysical surveys, Fairbanks, Alaska, 7, 1, p. 31-45. 
Mull, C.G., 1989b. Summary of structural style and history of Brooks Range deformation, in Mull, C., and Adams, K., eds, Bedrock geology of the eastern Koyukuk basin, central Brooks Range, and east-central Arctic Slope: Division of geological and geophysical surveys, Fairbanks, Alaska, 7, 1, p. 47-56.

O'Brien, T.M. and Miller, E.L., 2017, Exhumation of HP/LT metasedimentary rocks of the Schist Belt, southern Brooks Range as revealed by thermobarometry and ${ }^{40} \mathrm{Ar} /{ }^{39} \mathrm{Ar}$ thermochronology: Geological Society of America Abstracts with Programs. Vol. 49, No. 6.

Oldow, J.S., Avé Lallemant, H.A., Julian, F.E., and Seidensticker, C.M., 1984. The Doonerak window duplex: Regional implications: Geological Society of America Abstracts with Programs. Vol. 16, p. 326.

Oldow, J.S., 1987. Balanced Cross Sections Through the Central Brooks Range and North Slope, Arctic Alaska (eight Plates and Text). American Association of Petroleum Geologists.

O'Sullivan, P.B., Murphy, J.M. and Blythe, A.E., 1997. Late Mesozoic and Cenozoic thermotectonic evolution of the central Brooks Range and adjacent North Slope foreland basin, Alaska: Including fission track results from the Trans-Alaska Crustal Transect (TACT). Journal of Geophysical Research: Solid Earth, 102(B9), p. 20821-20845.

Patrick, B., 1995. High-pressure-low-temperature metamorphism of granitic orthogneiss in the Brooks Range, northern Alaska. Journal of Metamorphic Geology, 13(1), p.111-124.

Passchier, C.W. and Trouw, R.A., 2005. Microtectonics: Berlin, Springer, 366 p.

Pasteris, J.D., 1989. In situ analysis in geological thin-sections by laser Raman microprobe spectroscopy: a cautionary note. Applied Spectroscopy, 43(3), p.567-570.

Phelps, J.C., 1987. Stratigraphy and structure of the northeastern Doonerak window area, central Brooks Range, northern Alaska [Ph. D. thesis]: Houston, Rice University, 171 p.

Phelps, J.C., Avé Lallemant, H.A., Seidensticker, C.M., Julian, F.E. and Oldow, J.S., 1987. Expanded Abstract: Late-Stage High-Angle Faulting, Eastern Doonerak Window, Central Brooks Range, Alaska.

Rahl, J.M., Anderson, K.M., Brandon, M.T. and Fassoulas, C., 2005. Raman spectroscopic carbonaceous material thermometry of low-grade metamorphic rocks: calibration and application to tectonic exhumation in Crete, Greece. Earth and Planetary Science Letters, 240(2), p. 339-354.

Rejebian, V.A., Harris, A.G. and Huebner, J.S., 1987. Conodont color and textural alteration: An index to regional metamorphism, contact metamorphism, and hydrothermal alteration. Geological Society of America Bulletin, 99(4), p. 471-479. 
Repetski, J.E., Carter, C., Harris, A.G. and Dutro Jr, J.T., 1987. Ordovician and Silurian fossils from the Doonerak anticlinorium, central Brooks Range, Alaska. In Geologic Studies in Alaska by the US Geological Survey during 1986, 998, p. 40-42.

Robinson, F., Pease, V., and Toro, J., 2017. U-Pb and O isotope characteristics of Timanianand Caledonian-aged detrital zircons from the Brooks Range, arctic Alaska: Geological Society of America Abstracts with Programs. Vol. 49, No. 6.

Rull, F., 2012. The Raman effect and the vibrational dynamics of molecules and crystalline solids. Applications of Raman spectroscopy to earth sciences and cultural heritage. EMU Notes in Mineralogy, 12, p. 1-60.

Seidensticker, C.M. and Oldow, J.S., 1998. Structural development and kinematic history of ramp-footwall contraction in the Doonerak multiduplex, central Brooks Range, Arctic Alaska. Architecture of the Central Brooks Range Fold and Thrust Belt, Arctic Alaska, p.81108.

Spear, F.S., 1995. Metamorphic phase equilibria and pressure-temperature-time paths, Washington: Mineralogical Society of America. 799 p.

Strauss, J.V., Hoiland, C.W., Ward, W.P., Johnson, B.G., Nelson, L.L., and McClelland, W.C., 2017. Orogen transplant: Taconic-Caledonian arc magmatism in the central Brooks Range of Alaska. Geological Society of America Bulletin, 129(5-6), p.649-676.

Thermo Fisher Scientific, 2008, Introduction to Raman Spectroscopy. PDF. Thermo Electron Scientific Instruments LLC., Madison, WI

Till, A.B., Schmidt, J.M. and Nelson, S.W., 1988. Thrust involvement of metamorphic rocks, southwestern Brooks Range, Alaska. Geology, 16(10), p. 930-933.

Till, A.B., Dumoulin, J.A., Harris, A.G., Moore, T.E., Bleick, H.A. and Siwiec, B.R., 2008. Bedrock geologic map of the southern Brooks Range, Alaska and accompanying conodont data, USGS Open-File Report 2008-1149.

Tuinstra, F. and Koenig, J.L., 1970. Raman spectrum of graphite. The Journal of Chemical Physics, 53(3), p.1126-1130.

Vernon, R.H., 2004. A Practical Guide to Rock Microstructure: New York, Cambridge University Press, $594 \mathrm{p}$.

Wallace, W.K. and Engebretson, D.C., 1984. Relationships between plate motions and Late Cretaceous to Paleogene magmatism in southwestern Alaska. Tectonics, 3(2), p.295-315.

Woodward, L.A. General Introduction, in Szymanski, H.A., ed., Raman Spectroscopy: Theory and Practice: New York, Plenum Press, 1967. p. 1-43. 
Yui, T.F., Huang, E. and Xu, J., 1996. Raman spectrum of carbonaceous material: a possible metamorphic grade indicator for low-grade metamorphic rocks. Journal of Metamorphic Geology, 14(2), p.115-124. 


\section{Appendix 1. Expanded discussion of the RSCM method}

\section{Background}

Raman scattering is the inelastic scattering of photons by interaction with covalent bonds in a material (Rull, 2012). Inelastic scattering is of a different wavelength than the incident photons, as compared to Rayleigh (elastic) scattering, which is of the same wavelength as the incident photons. When a monochromatic light (e.g. filtered laser) is used, the original wavelength can be filtered out from the scattered photons and the Raman frequency, or shift, can be detected (Figure A1). A given material has a set of Raman frequencies unique to its molecular structure, allowing for the identification of materials based on its Raman spectrum (Woodward, 1967; Lafuente et al., 2015). Raman spectra are reported as wavenumbers ( $\Delta \boldsymbol{w})$ in units of $\mathrm{cm}^{-1}$. Wavenumber is calculated from the incident wavelength $\left(\lambda_{0}\right)$ and the Raman shift wavelength $\left(\lambda_{1}\right)$ by the formula:

$$
\Delta \boldsymbol{w}=\left(1 / \lambda_{0}\right)-\left(1 / \lambda_{1}\right)
$$

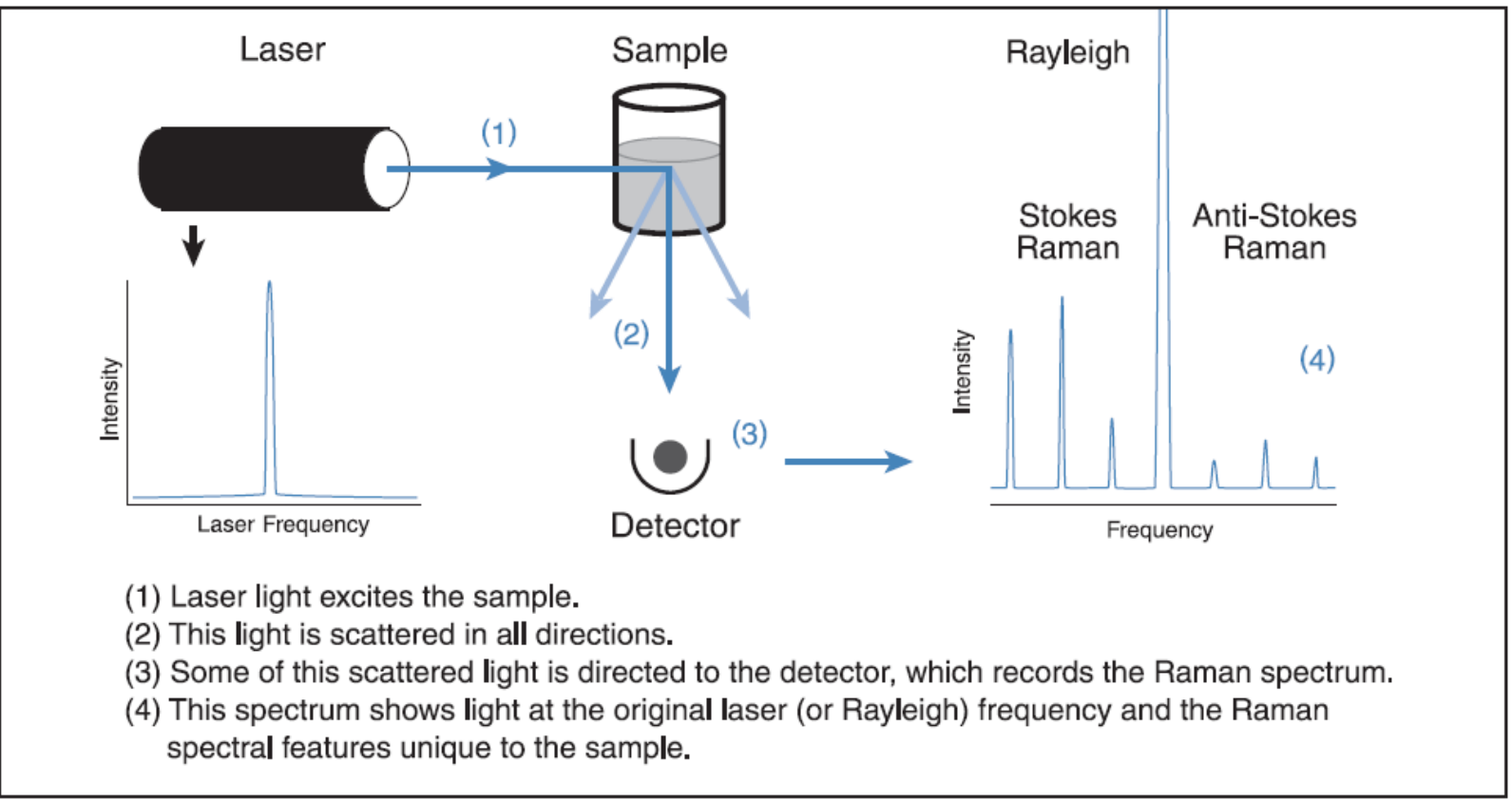

Figure A1. Schematic diagram of Raman scattering (Thermo Fisher Scientific, 2008). 
The original identification of the Raman spectra of graphite included two peaks representing disorganized carbonaceous material and crystalline graphite (Tuinstra and Koenig, 1970). Subsequent study in the materials and earth sciences led to the potential use of the Raman spectra of carbonaceous materials as a gauge of metamorphic grade (Yui et al., 1996). A total of five primary peaks have been recognized in the spectra of carbonaceous material reflecting varying crystallinity (Beyssac et al., 2002; Kouketsu et al., 2014). These five peaks are G peak $\left(1580 \mathrm{~cm}^{-1}\right)$, representing crystalline graphite, and four defect peaks: D1 $\left(1350 \mathrm{~cm}^{-1}\right)$, D2 $\left(1620 \mathrm{~cm}^{-1}\right)$, D3 $\left(1510 \mathrm{~cm}^{-1}\right)$, and D4 $\left(1245 \mathrm{~cm}^{-1}\right)($ Figure A2). An additional peak group called 2D or G' may occur around $2700 \mathrm{~cm}^{-1}$ (Figure A3; Beyssac and Lazzeri, 2012), but is not used for any of the several temperature calibrations discussed below. Component peaks of the measured Raman spectra are isolated using peak fitting procedures specified by the authors of the methods employed.

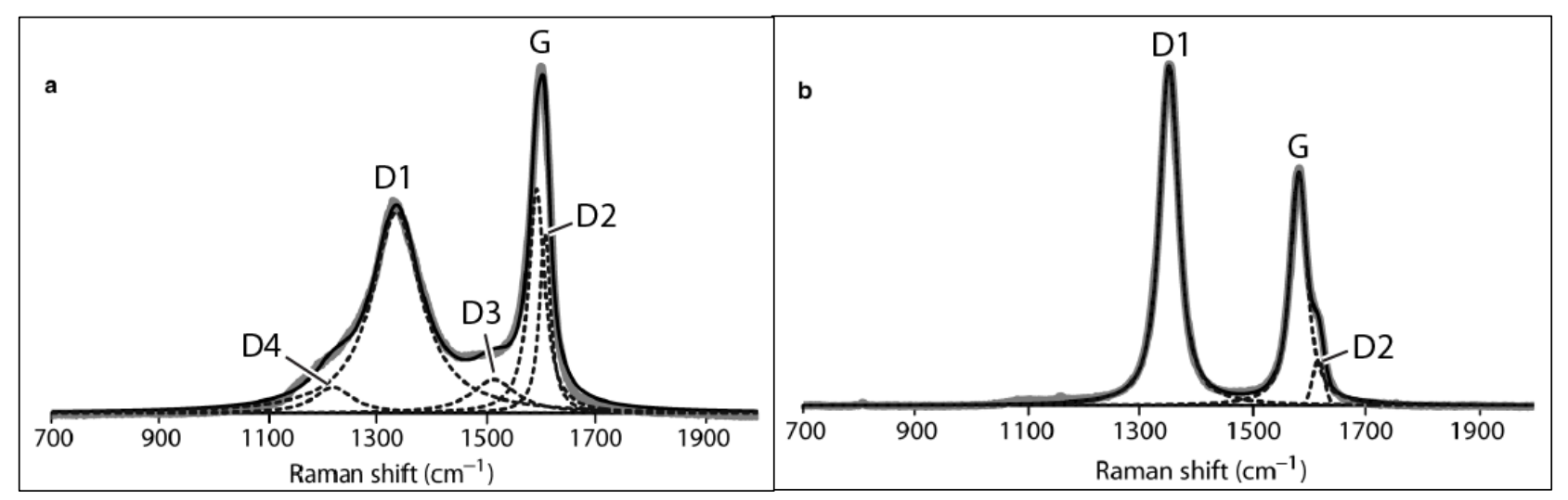

Figure A2. Raw Raman spectra (thick gray line), component peaks (dashed lines), and summed component peaks (solid black line) for lower grade carbonaceous material (a) and higher grade carbonaceous material (b). Lower grade carbonaceous material exhibits two additional defect peaks not present in the spectra of more well-organized carbonaceous material (modified from Beyssac and Lazzeri, 2012). 


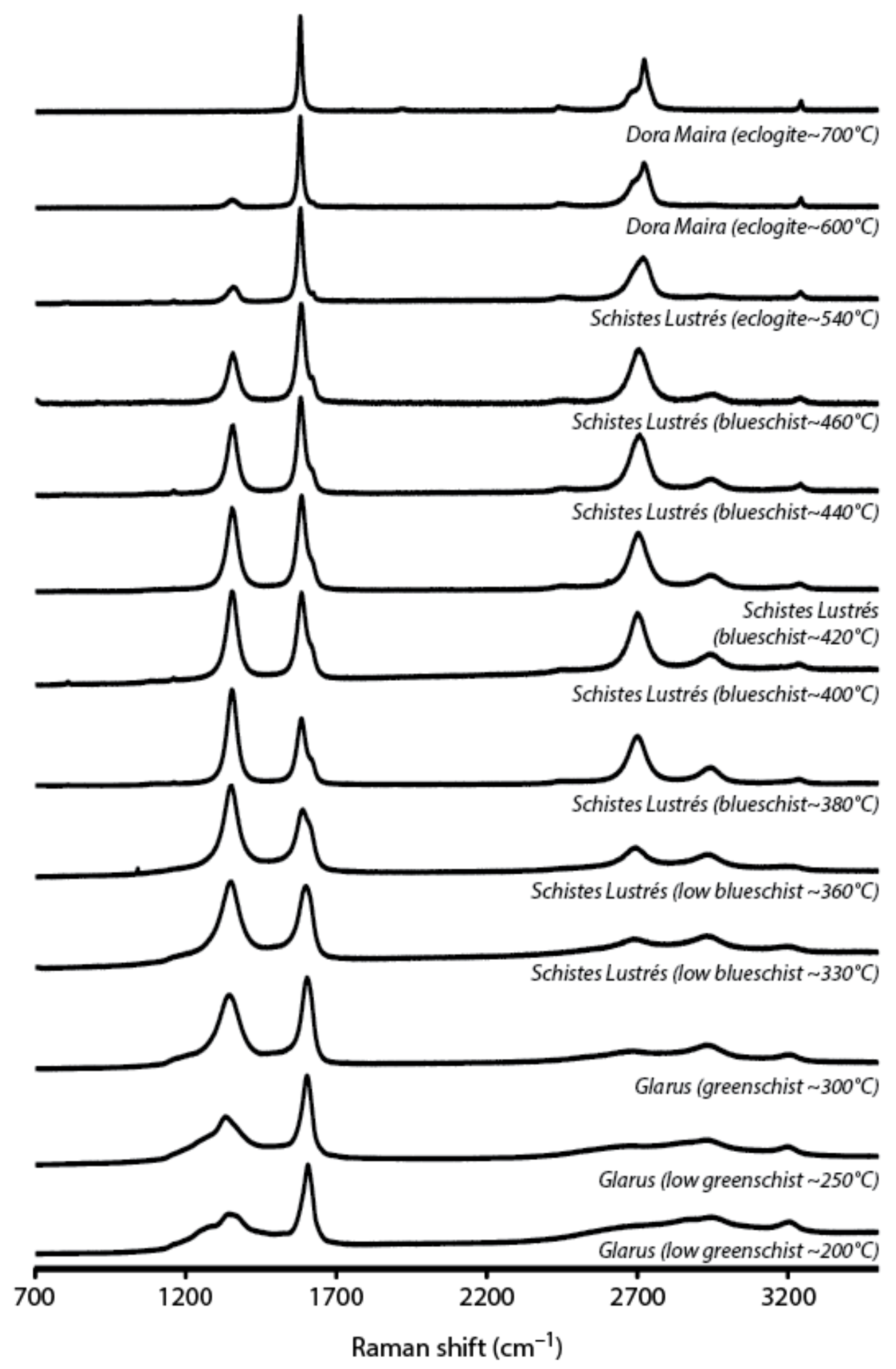

Figure A3. Progressive evolution of the Raman spectra of natural samples of carbonaceous material from the western Alps (Beyssac and Lazzeri, 2012). The Raman spectra shown include both the peaks used for the RSCM paleothermometer methods $\left(-1100-1700 \mathrm{~cm}^{-1}\right)$ and the higher-wavenumber peaks $\left(-2500-3300 \mathrm{~cm}^{-1}\right)$ not used in the discussed methods. 


\section{Methods}

Beyssac et al. (2002) introduced the use of the Raman spectra of carbonaceous material (RSCM) as a geothermometer useful from $330-650^{\circ} \mathrm{C}$, with accuracy $\pm 50^{\circ} \mathrm{C}$. Additional methods that were not used in my study have been introduced by others (Table A1). In this work, the Beyssac et al. (2002) and Lahfid et al. (2010) methods were combined to achieve an applicable range of $\sim 200-650^{\circ} \mathrm{C}$.

Two other methods were considered, but not ultimately used in this work. The method of Rahl et al. (2005) has a stated useful range of $100-700^{\circ} \mathrm{C}$. Their method involves a polynomial function based on data fit in 3D-space and was found to be most accurate in the same range as the simpler method of Beyssac et al. (2002) in a review by Kouketsu et al. (2014).

Kouketsu et al. (2014) introduced a method useful from $150-400^{\circ} \mathrm{C}$. This covers most of the expected temperatures in the study area, but the method is based on single full-width at half maximum (FWHM) values, rather than peak height or area ratios of the aforementioned methods. This makes the method more sensitive to experimental and instrument variation.

\begin{tabular}{|l|c|c|c|c|}
\hline \multicolumn{1}{|c|}{ Study } & $\begin{array}{c}\text { Range } \\
{ }^{\circ} \mathbf{C}\end{array}$ & $\begin{array}{c}\text { Error } \\
{ }^{\circ} \mathbf{C}\end{array}$ & Formula & $\begin{array}{c}\mathbf{R}^{2} \\
\text { value }\end{array}$ \\
\hline $\begin{array}{l}\text { Beyssac } \\
\text { et al. 2002 }\end{array}$ & $330-650$ & \pm 50 & $\mathrm{~T}\left({ }^{\circ} \mathrm{C}\right)=-445^{\star} \mathrm{R} 2+641$ & 0.96 \\
\hline $\begin{array}{l}\text { Rahl et al. } \\
2005\end{array}$ & $100-700$ & \pm 50 & $\mathrm{~T}\left({ }^{\circ} \mathrm{C}\right)=737.3+320.9^{\star} \mathrm{R} 1-1067^{\star} \mathrm{R} 2-80.638^{\star} \mathrm{R} 1^{2}$ & 0.94 \\
\hline $\begin{array}{l}\text { Lahfid et } \\
\text { al. 2010 }\end{array}$ & $200-330$ & $\mathrm{~T}\left({ }^{\circ} \mathrm{C}\right)=(\mathrm{RA} 1-0.3758) / 0.0008$ & 0.97 \\
\hline $\begin{array}{l}\text { Lahfid et } \\
\text { al. 2010 }\end{array}$ & $200-330$ & $\mathrm{~T}\left({ }^{\circ} \mathrm{C}\right)=(\mathrm{RA} 2-0.27) / 0.0045$ & 0.95 \\
\hline $\begin{array}{l}\text { Kouketsu } \\
\text { et al. 2014 }\end{array}$ & $200-400$ & \pm 30 & $\mathrm{Eq} .1: \mathrm{T}\left({ }^{\circ} \mathrm{C}\right)=-2.15^{\star} \mathrm{D} 1_{\mathrm{FWHM}}+478$ & 0.970 \\
\hline $\begin{array}{l}\text { Kouketsu } \\
\text { et al. 2014 }\end{array}$ & $150-200$ & \pm 50 & $\mathrm{Eq.} \mathrm{2:} \mathrm{T}\left({ }^{\circ} \mathrm{C}\right)=-6.78^{\star} \mathrm{D} 2{ }_{\mathrm{FWHM}}+535$ & 0.968 \\
\hline
\end{tabular}

Table A1. Stated applicable range, error, and formulas for published paleothermometers using Raman spectroscopy of carbonaceous material. Beyssac et al. (2002) uses the R2 parameter shown in Figure A4. Lahfid et al. (2010) uses the RA1 and RA2 parameters shown in Figure A4. Kouketsu et al. (2014) use full-width at half-maximum (FWHM) values. Lahfid et al. (2010) does not state an error range associated with the method, although it is assumed to be comparable to the other methods as all are limited by the errors associated with the other paleothermometers they are correlated to, such as CAI and illite crystallinity. 


$$
\begin{gathered}
R 2=\frac{D 1}{G+D 1+D 2} A \\
R A 1=\frac{D 1+D 4}{D 1+D 2+D 3+D 4+G} \quad R A 2=\frac{D 1+D 4}{D 2+D 3+G}
\end{gathered}
$$

Figure A4. Formulas for the R2, RA1, and RA2 parameters used to calculate maximum paleotemperature with the methods of Beyssac et al. (2002) and Lahfid et al. (2010). All utilize peak areas for the component peaks.

\section{Peak Fitting}

Peak fitting procedures vary between RSCM paleothermometry methods (see discussion in Kouketsu et al., 2014). The method of Beyssac et al. (2002) uses Voigt peaks (Figure A5), a commonly used function in spectroscopy (e.g. Armstrong, 1967). This function has difficulties with the more complex Raman spectra of lower-grade carbonaceous material, an issue treated differently between methods. Kouketsu et al. (2014) follows a particular peak fitting procedure wherein peak locations are fixed in lower-grade samples and at the lowest grades a Lorenzian peak is substituted for one of the Voigt peaks. Lahfid et al. (2010) uses all Lorenzian peaks (Figure A6), which has the advantage of arriving at unique solutions without fixing peak locations or other manual procedures that may introduce bias. Rahl et al. (2005) does not specify a preferred peak type, potentially introducing significant variation to results (Lünsdorf et al., 2013). Regardless of method, peak fitting done in this study was completed with IgorPro 6.34 software (WaveMetrics Inc., Lake Oswego, Oregon).

During this study, all of the above methods were attempted while processing RSCM data. The results from Kouketsu,et al. (2014) were inconsistent both due to variation in FWHM values due to device/experimental parameters and difficulty in following the particular peak fitting procedures mandated by the method. The results of Rahl et al. (2005) were often inconsistent, but when they were consistent offered no clear advantage over other methods. 
The methods Beyssac et al. (2002) and Lahfid et al. (2010) were found to be easily followed and yielded consistent results since they rely on ratios of peak areas.
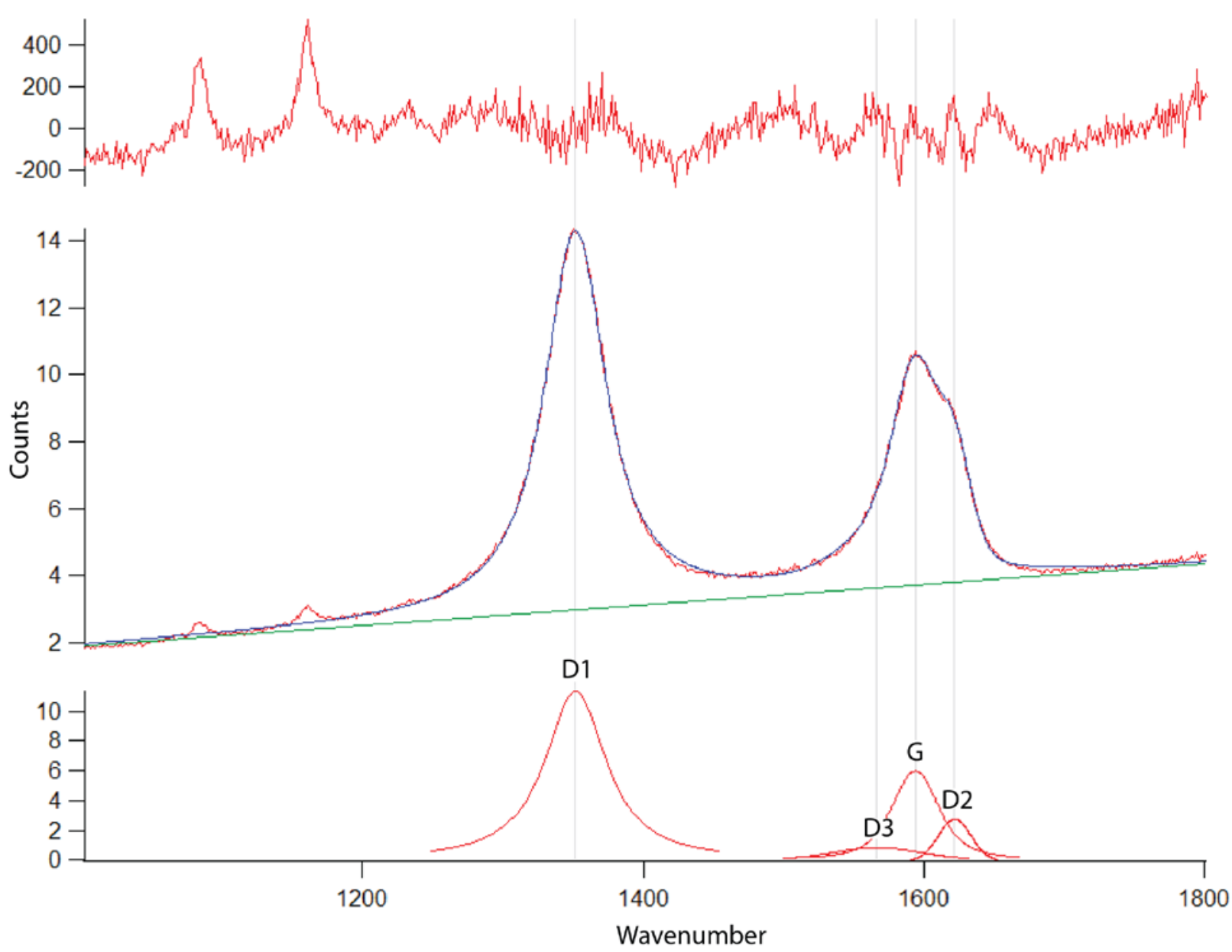

Figure A5. Sample 16DF10 fit using the procedure of Beyssac et al. (2002). Top: residual after fitting. Middle: sum of component peaks (blue line), raw Raman spectra (red), and linear baseline (green). Bottom: component Voigt peaks (Gaussian-Lorenzian sum). 


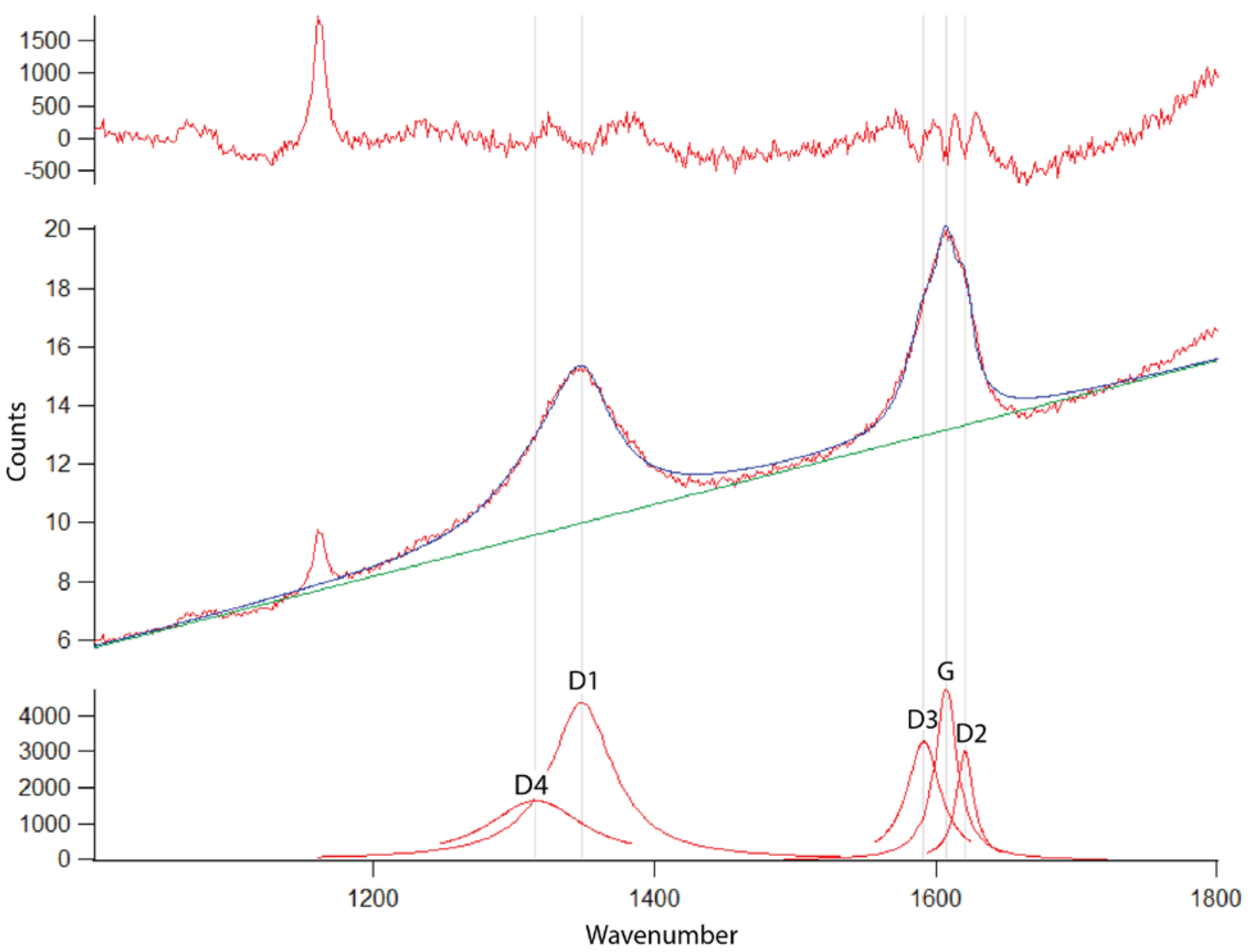

Figure A6. Sample J1409-74.1 fit using the procedure of Lahfid et al. (2010). Top: residual after fitting. Middle: sum of component peaks (blue line), raw Raman spectra (red), and linear baseline (green). Bottom: component Lorenzian peaks.

\section{Sample Preparation}

Pasteris (1989) suggested polishing of thin sections could introduce structural defects to graphite. To avoid this, it was recommended only graphitic material beneath a transparent grain be used for analysis. This would protect the material from being altered by polishing. This concern has been accepted prima facie and repeated by subsequent authors working with samples of various grades of carbonaceous material (e.g. Rahl et al., 2005). Additional ambiguity has been introduced by authors discussing the concern in greater detail (e.g. Beyssac and Lazzeri, 2012; Beyssac et al., 2002) who suggest steps ranging from sawing to polishing may introduce defects. These authors cite Pasteris (1989), whose work only addressed the 
polishing of graphite in thin sections with $1 \mu \mathrm{m}$ diamond paste. Although this polishing effect is more problematic for 'pristine' graphite (Beyssac and Lazzeri, 2012) than the more amorphous carbonaceous material expected from this study area, potential sample alteration was a concern.

Lünsdorf (2016) completed a stepwise analysis of potential mechanical alteration to samples during thin section preparation and polishing. The analysis began with P400 abrasive paper (35 $\mu \mathrm{m}$ average particle diameter) and progressed to $0.05 \mu \mathrm{m}$ alumina slurry, acquiring the Raman spectra of mapped spots on the thin section between each step. It was found only the final $1 \mu \mathrm{m}$ diamond paste and finer polishing affected the Raman spectra of a suite of samples from shale to blueschist-facies metapelite. This range includes the grades of carbonaceous material in the study area.

Thin sections used for RSCM in this study were ground to final $30 \mu \mathrm{m}$ thickness with an $18 \mu \mathrm{m}$ abrasive, well coarser than the polishing stages found to alter Raman spectra by Lünsdorf (2016). To directly test for any alteration from sample preparation on my samples, I acquired spectra for a single sample of black phyllite from its thin section, billet, and a portion of crushed sample mounted on a glass slide. No distinguishable difference between the preparation methods was found.

\section{Identification of Carbonaceous Material}

A potential concern of using Raman spectroscopy as a paleothermometer is misidentification of an opaque mineral during optical mineralogy and processing the resultant Raman spectra of that mineral as if it were carbonaceous material. This concern was not borne out in this work. Non-carbonaceous material was often accidentally sampled during Raman spectroscopy, but the character of the Raman spectra of these other minerals was easily differentiated. Figure A7 shows the Raman spectra of various materials, including titanite/leucoxene and siderite. These were the most common opaque minerals observed in the 
samples that could be confused with carbonaceous material. While pyrite was commonly observed, its cubic shape made it readily identifiable.

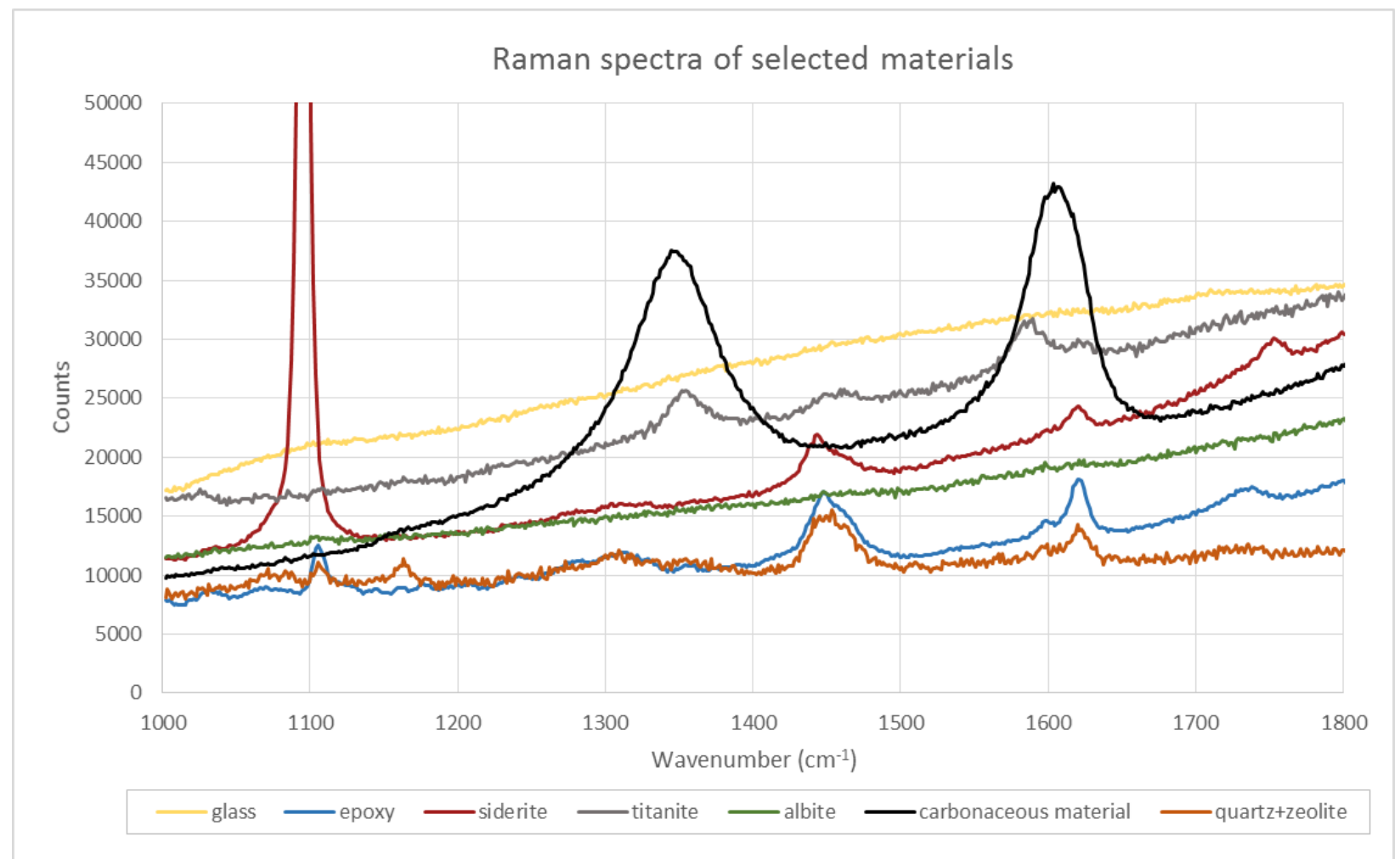

Figure A7. Raman spectra of selected materials compared to carbonaceous material across the spectra range utilized in the RSCM method. The vertical 'counts' scale is arbitrary and depends on signal strength for each sample run.

\section{Other Uses of Raman Spectroscopy}

Raman spectroscopy is widely used to identify minerals. Lafuente et al. (2015) assert $80 \%$ of minerals can be identified by their Raman spectra. In addition to its use in the RSCM paleothermometer method, unknown minerals were identified in this work. The spectra of the unknown minerals were compared to known spectra in the RRUFF database using CrystalSleuth software (Downs, 2006; Lafuente et al., 2015). Examples of use are shown in Figures A8 and A9. 

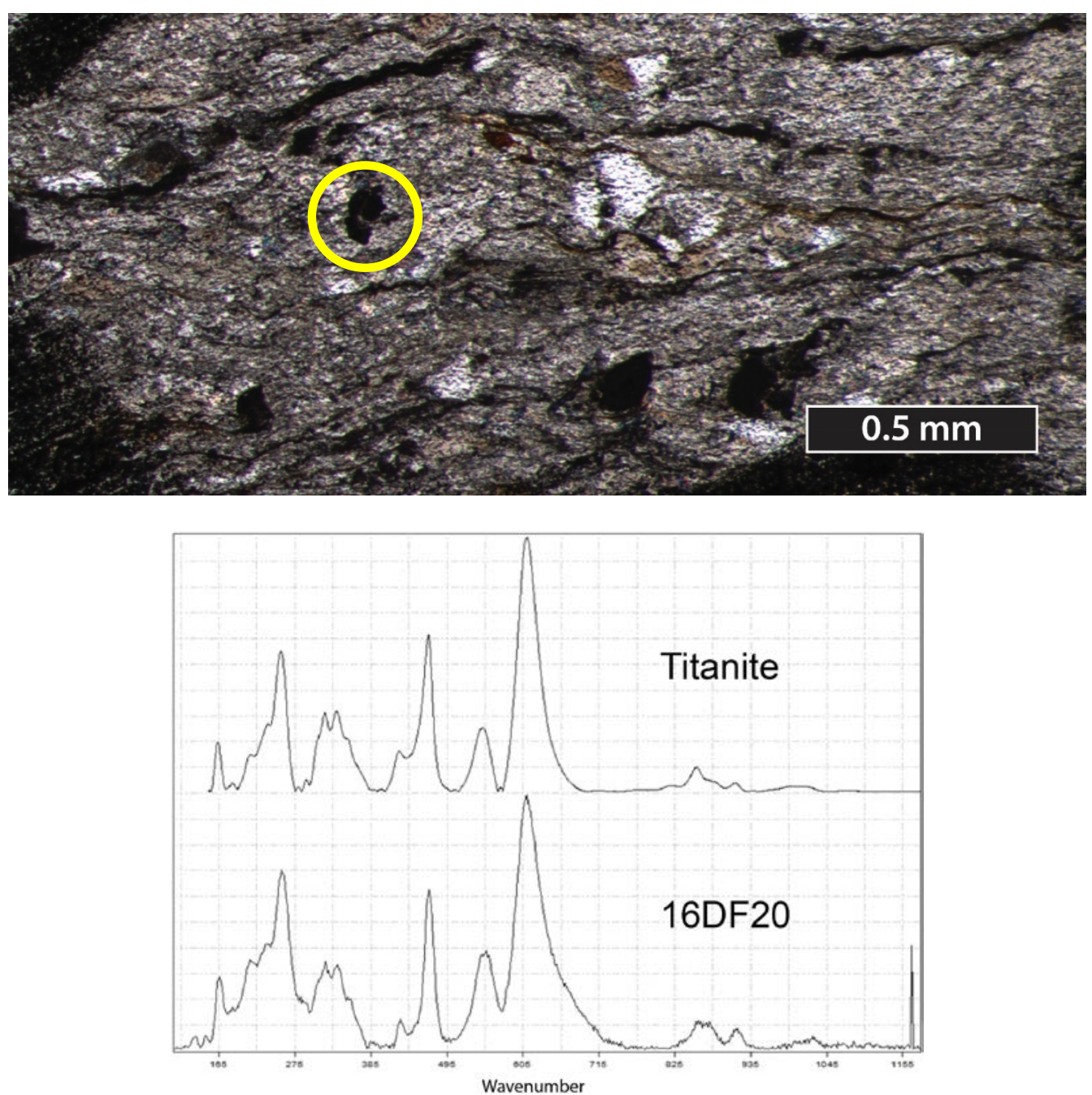

Figure A8. Top: Photomicrograph of an unknown opaque mineral (circled) in sample 16DF20, 6.3x, PPL. Bottom: Raman spectra of the unknown mineral and the Raman spectra of titanite in the RRUFF database as matched by CrystalSleuth software (Downs, 2006; Lafuente et al., 2015). 

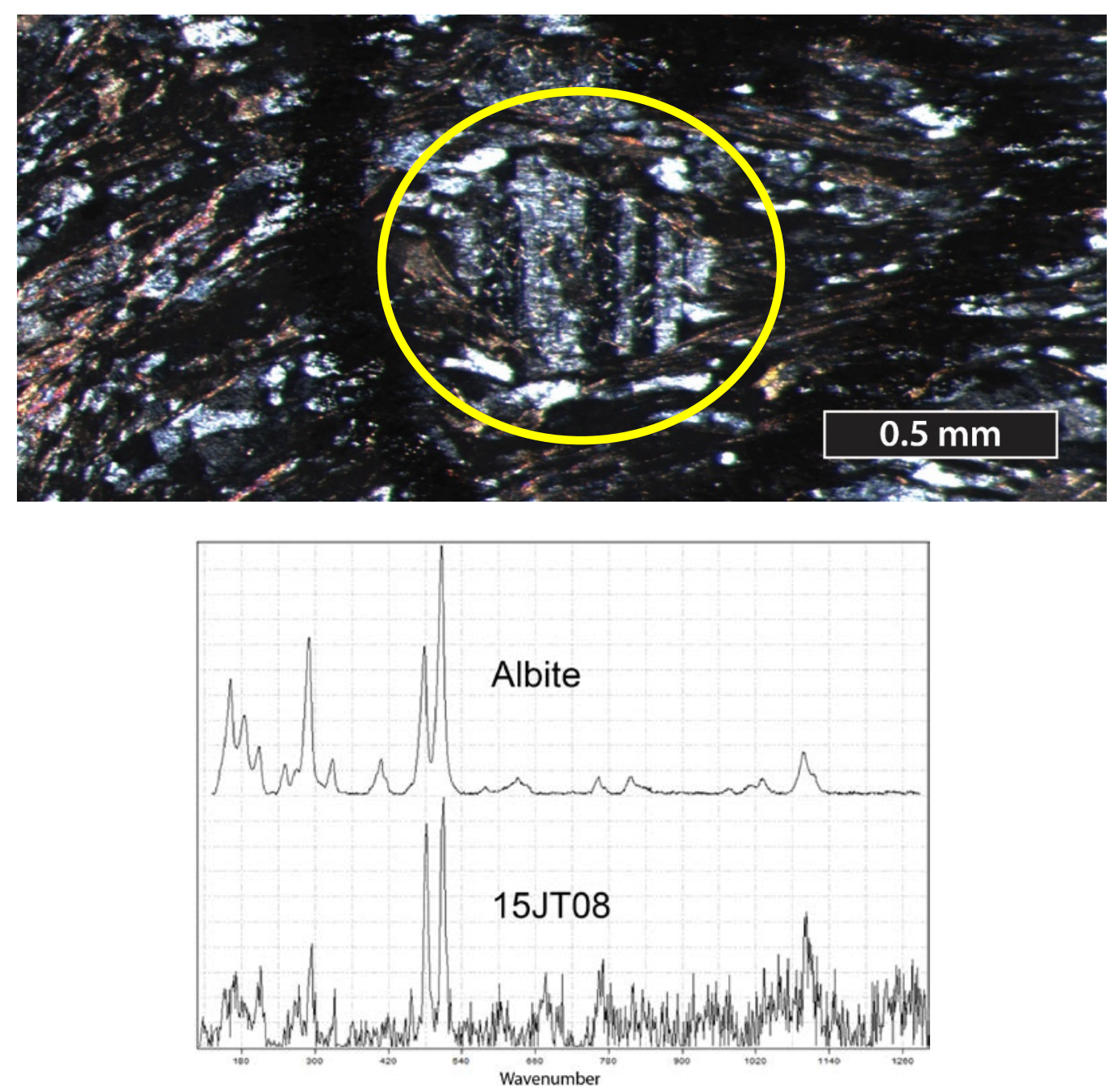

Figure A9. Top: Photomicrograph of a feldspar grain (circled) in sample 15JT08, 6.3x, XPL. Bottom: Raman spectra of the the feldpar and the Raman spectra of albite in the RRUFF database as matched by CrystalSleuth software (Downs, 2006; Lafuente et al., 2015). 


\section{Appendix 2. Table of all samples}

Table of all samples collected in the map area by West Virginia University workers. See Plate 1 map key or Figure 10 for map unit descriptions.

\begin{tabular}{|c|c|c|c|c|c|}
\hline Sample ID & Station & Map Unit & Thin section & Latitude (N) & Longitude (W) \\
\hline \multicolumn{6}{|c|}{ Collected by W.P. Frier (2015) } \\
\hline 01DF15 & PF002 & EOve & $\mathrm{x}$ & 67.87400 & 150.82024 \\
\hline 02DF15 & PF004 & €Oac & & 67.87126 & 150.81210 \\
\hline 03DF15 & PF006 & €Oac & $x$ & 67.86970 & 150.80526 \\
\hline 04DF15 & PF011 & €Oac & $x$ & 67.86203 & 150.78720 \\
\hline 05DF15 & PF012 & €Oac & $x$ & 67.86187 & 150.78703 \\
\hline 06DF15 & PF014 & €Ove & $x$ & 67.86791 & 150.81652 \\
\hline 07DF15 & PF015 & €Oac & $x$ & 67.87386 & 150.83585 \\
\hline 08DF15 & PF017 & EOve & $\mathrm{x}$ & 67.88047 & 150.83175 \\
\hline 09DF15 & PF019 & €Oac & $x$ & 67.88040 & 150.82290 \\
\hline 10DF15 & PF021 & EOac & $x$ & 67.88050 & 150.79842 \\
\hline 11DF15 & PF026 & €Oac & $x$ & 67.87477 & 150.78118 \\
\hline 12DF15 & PF027 & EOac & $x$ & 67.87493 & 150.77756 \\
\hline 13DF15 & PF035 & EOve & $x$ & 67.88961 & 150.80643 \\
\hline 14DF15 & PF037 & EOve & & 67.89037 & 150.80766 \\
\hline 15DF15 & PF037 & €Ove & & 67.89037 & 150.80766 \\
\hline 16DF15 & PF039 & EOve & & 67.89297 & 150.80222 \\
\hline 17DF15 & PF040 & EOve & & 67.89366 & 150.80202 \\
\hline 18DF15 & PF043 & EOve & & 67.90293 & 150.79733 \\
\hline 19DF15 & PF044 & MPel & & 67.90404 & 150.79625 \\
\hline 20DF15 & PF052 & €Ove & $x$ & 67.89337 & 150.79298 \\
\hline 21DF15 & PF054 & €Ove & $x$ & 67.89119 & 150.79447 \\
\hline 22DF15 & PF061 & Dek & $x$ & 67.90948 & 150.75606 \\
\hline 23DF15 & PF062 & Dek & $x$ & 67.90790 & 150.75217 \\
\hline 24DF15 & PF070 & €Ove & $x$ & 67.91151 & 150.70187 \\
\hline 25DF15 & PF072 & €Ove & & 67.90753 & 150.69146 \\
\hline 26DF15 & PF075 & Dhf & $x$ & 67.93312 & 150.77828 \\
\hline 27DF15 & PF076 & Dhf & & 67.93502 & 150.77821 \\
\hline 28DF15 & PF084 & Dsg & $x$ & 67.91529 & 150.85195 \\
\hline 29DF15 & PF085 & Dsg & $x$ & 67.91370 & 150.85324 \\
\hline 30 DF15 & PF092 & €Oac & & 67.83905 & 150.93083 \\
\hline 31DF15 & PF093 & EOac & & 67.83979 & 150.93854 \\
\hline 32DF15 & PF104 & €Ovi & & 67.84524 & 150.84678 \\
\hline 33DF15 & PF107 & €Ovi & $x$ & 67.84036 & 150.84014 \\
\hline 34DF15 & PF108 & €Ovi & $x$ & 67.83988 & 150.83893 \\
\hline 35DF15 & PF114 & €Oac & & 67.81130 & 150.84244 \\
\hline 36DF15 & PF115 & EOac & $x$ & 67.81172 & 150.83903 \\
\hline 37DF15 & PF116 & EOac & & 67.81115 & 150.83646 \\
\hline 38DF15 & PF119 & €Ovi & $x$ & 67.81318 & 150.83291 \\
\hline
\end{tabular}




\begin{tabular}{|c|c|c|c|c|c|}
\hline Sample ID & Station & Map Unit & Thin section & Latitude (N) & Longitude (W) \\
\hline \multicolumn{6}{|c|}{ Collected by W.P. Frier (2015) } \\
\hline 39DF15 & PF124 & Dhf & & 67.91765 & 150.88088 \\
\hline 40DF15 & PF128 & Dhf & $x$ & 67.91922 & 150.90502 \\
\hline 41DF15 & PF133 & MDkn & & 67.91866 & 150.92976 \\
\hline 42DF15 & PF159 & Dsg & $\mathrm{x}$ & 67.89067 & 150.93101 \\
\hline 43DF15 & PF160 & Dsg & $\mathrm{x}$ & 67.88953 & 150.93579 \\
\hline 44DF15 & PF160 & Dsg & $\mathrm{x}$ & 67.88953 & 150.93579 \\
\hline 45DF15 & PF166 & Dsg & $\mathrm{x}$ & 67.88995 & 150.91526 \\
\hline 46DF15 & PF173 & Dsg & $\mathrm{x}$ & 67.88461 & 150.89492 \\
\hline 47DF15 & PF175 & Dsg & $\mathrm{x}$ & 67.87932 & 150.89575 \\
\hline \multicolumn{6}{|c|}{ Collected by J. Toro (2015) } \\
\hline 15JT01 & WP009 & €Oac & & 67.72612 & 150.98203 \\
\hline 15JT02 & WP012 & Dtc & $x$ & 67.69950 & 151.00842 \\
\hline 15JT03 & WP024 & Ddr & & 67.67674 & 151.08247 \\
\hline 15JT04 & WP027 & $\mathrm{Ddr}$ & $x$ & 67.64362 & 151.02414 \\
\hline \multicolumn{6}{|c|}{ Collected by G. Hammond (2016) } \\
\hline 16DF01 & DF004 & €Oac & & 67.71795 & 150.94389 \\
\hline 16DF02 & DF005 & €Oac & & 67.71552 & 150.94315 \\
\hline 16DF03 & DF006 & €Oac & & 67.71356 & 150.94163 \\
\hline 16DF04 & DF008 & Dtc & & 67.71086 & 150.94922 \\
\hline 16DF05 & DF015 & €Oac & $\mathrm{x}$ & 67.72653 & 150.93421 \\
\hline 16DF06 & DF016 & $€ O a c$ & & 67.72802 & 150.93626 \\
\hline 16DF07 & DF023 & Dtc & & 67.72480 & 150.90628 \\
\hline 16DF08 & DF025 & Dtc & $x$ & 67.72530 & 150.88661 \\
\hline 16DF09 & DF028 & Dtc & $x$ & 67.72677 & 150.86780 \\
\hline 16DF10 & DF034 & Dtc & & 67.73221 & 150.88167 \\
\hline 16DF11 & DF035 & Dtc & $x$ & 67.72427 & 150.88329 \\
\hline 16DF12 & DF041 & Ddr & & 67.71970 & 150.84925 \\
\hline 16DF13 & DF042 & Ddm & $x$ & 67.71482 & 150.83953 \\
\hline 16DF14 & DF054 & Ddr & & 67.69071 & 150.88575 \\
\hline 16DF15 & DF056 & Ddr & & 67.68042 & 150.92936 \\
\hline 16DF16 & DF060 & Dtc & $x$ & 67.69229 & 151.04731 \\
\hline 16DF17 & DF061 & Dtc & $x$ & 67.69000 & 151.05996 \\
\hline 16DF18 & DF061 & Dtc & & 67.69000 & 151.05996 \\
\hline 16DF19 & DF068 & Ddr & $x$ & 67.67596 & 151.10845 \\
\hline 16DF20 & DF069 & Dtc & $x$ & 67.67221 & 151.10832 \\
\hline 16DF21 & DF070 & Dtc & & 67.66960 & 151.11209 \\
\hline 16DF22 & DF080 & Ddr & & 67.68702 & 151.10140 \\
\hline 16DF23 & DF081 & Dtc & & 67.69271 & 151.09177 \\
\hline 16DF24 & DF081 & Dtc & $x$ & 67.69271 & 151.09177 \\
\hline 16DF25 & DF081 & Dtc & & 67.69271 & 151.09177 \\
\hline 16DF26 & DF089 & Dtc & & 67.68809 & 150.99839 \\
\hline 16DF27 & DF092 & Ddr & & 67.68920 & 150.97222 \\
\hline 16DF28 & DF098 & $\mathrm{Ddm}$ & $x$ & 67.67932 & 150.99896 \\
\hline
\end{tabular}




\begin{tabular}{|c|c|c|c|c|c|}
\hline Sample ID & Station & Map Unit & Thin section & Latitude (N) & Longitude (W) \\
\hline \multicolumn{6}{|c|}{ Collected by G. Hammond (2016) } \\
\hline 16DF29 & DF107 & $\mathrm{Ddm}$ & $\mathrm{x}$ & 67.64660 & 151.12190 \\
\hline 16DF30 & DF115 & $\mathrm{Ddr}$ & $x$ & 67.65361 & 151.14956 \\
\hline 16DF31 & DF117 & $\mathrm{Ddm}$ & $x$ & 67.64636 & 151.13129 \\
\hline 16DF32 & DF120 & $\mathrm{Ddm}$ & $x$ & 67.63363 & 151.18286 \\
\hline 16DF33 & DF122 & $\mathrm{Ddm}$ & $\mathrm{x}$ & 67.66986 & 151.01748 \\
\hline 16DF34 & DF124 & Dgw & $x$ & 67.64102 & 150.94802 \\
\hline 16DF35 & DF125 & Dgw & $x$ & 67.64283 & 150.93686 \\
\hline 16DF36 & DF125 & Dgw & & 67.64283 & 150.93686 \\
\hline 16DF37 & DF125 & Dgw & & 67.64283 & 150.93686 \\
\hline 16DF38 & DF123 & Dgw & & 67.63979 & 150.96611 \\
\hline 16DF39 & DF129 & Ddr & & 67.62725 & 151.05700 \\
\hline
\end{tabular}




\section{Appendix 3: Thin section descriptions}

Structural nomenclature is that of Passchier and Trouw (1996) and Vernon (2004). Selected terms are defined as follows:

- $\quad \mathrm{P}$ (or M) and Q domains: phyllosilicate- (or mica-) and quartz-rich domains that result from metamorphic differentiation; roughly synonymous "cleavage domains" and "microlithons", respectively.

- C'-type shear band: a narrow zone with stair-stepping offset within a cleavage domain indicating sense of shear.

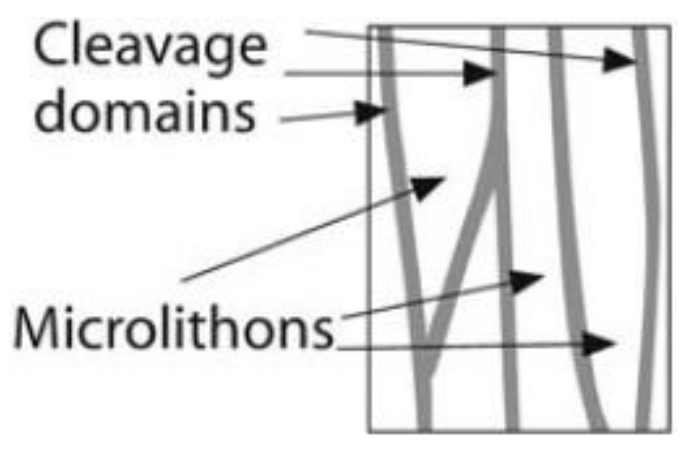

\section{$C^{\prime}$ - type shear bands}

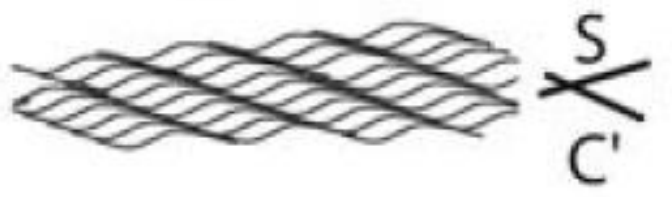

Figure A10. Left: Cleavage (P/M) domains and microlithons (Q domains). Right: C'-type shear bands. Reproduced from Passchier and Trouw (2005).

Units listed correspond to map units on Plate 1; see map legend or Figure 10 for descriptions.

All sample entries include a symbol indicating whether the sample is oriented, and if it is, which way is approximately north. The symbol orientation and that of the photomicrographs is flipped about both the $x$ - and $y$ - axis, resulting in no change in sense of shear (dextral or sinistral) as noted in microstructure descriptions. S1 sense of shear is determined from rotated clasts and asymmetric micro-folds. S2 sense of shear is based on lower-strain deformation such as C'-type shear bands and crenulation. For several fine-grained samples only S2 was visible. 
Grains called ilmenite, titanite, and/or leucoxene were identified by optical properties out of practicality. In reality, these grains likely contain a mixture of titanium- and iron-bearing minerals and their alteration products. This is illustrated by Figure A11, which shows Raman spectra matching titanite collected from a grain that otherwise appeared to be leucoxene. For the purposes of this work, detailed differentiation is not required as all such grains are believed to be detrital, rather than indicative of metamorphic conditions.

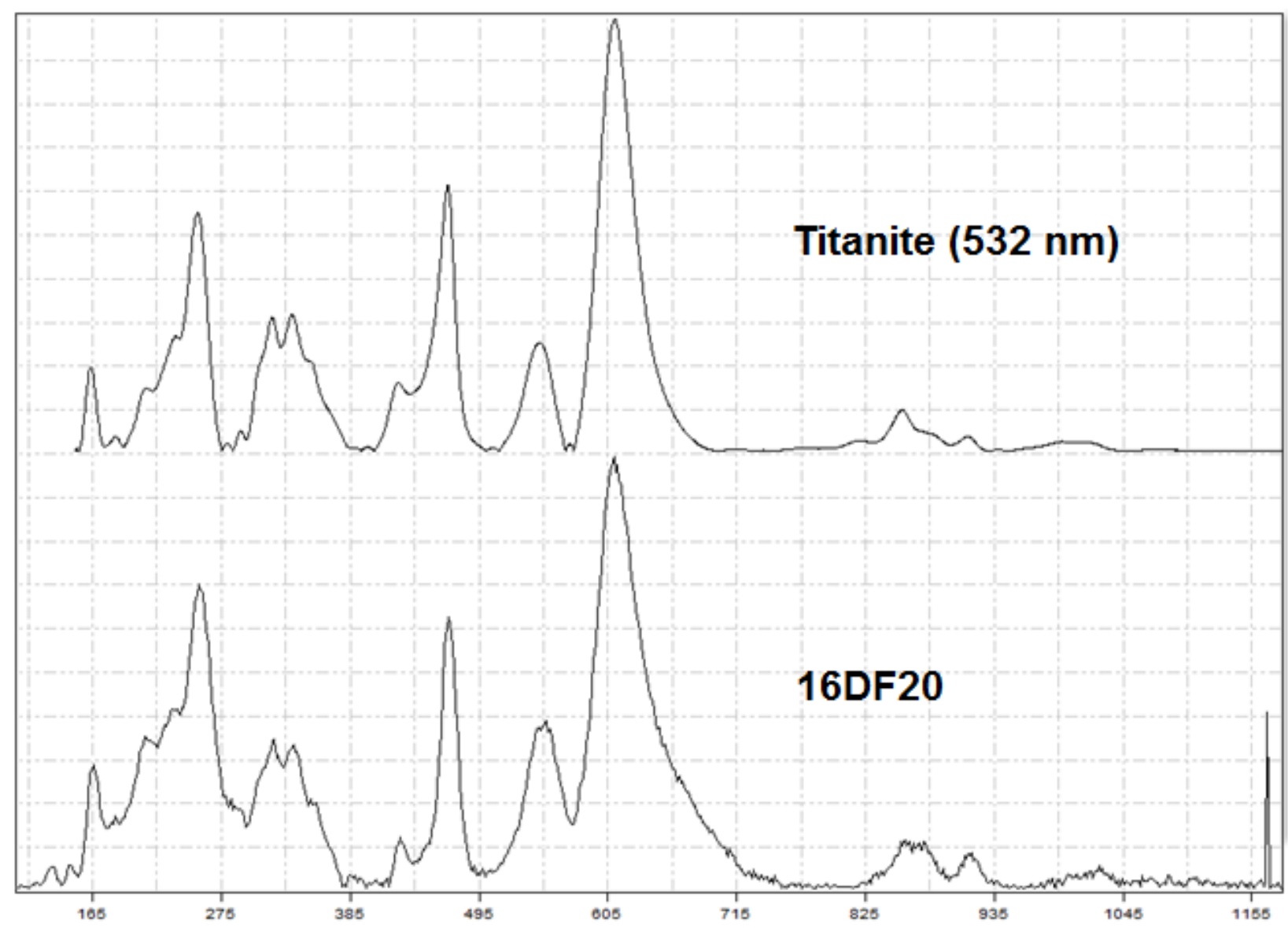

Figure A11. An opaque grain otherwise identified as leucoxene in sample 16DF20 (below) compared to the known spectra of titanite (above) from the RRUFF database using CrystalSleuth software (Downs, 2006; Lafuente, et al., 2015). 


\begin{tabular}{|l|r|l|r|}
\hline Sample & Page & Sample & Page \\
\hline 16DF05 & 89 & 43DF15 & 119 \\
\hline 16DF08 & 90 & $44 D F 15$ & 120 \\
\hline 16DF09 & 91 & $45 D F 15$ & 121 \\
\hline 16DF11 & 92 & $46 D F 15$ & 122 \\
\hline 16DF13 & 93 & $47 D F 15$ & 123 \\
\hline 16DF16 & 94 & 15JT02 & 124 \\
\hline 16DF17 & 95 & 15JT04 & 125 \\
\hline 16DF19 & 96 & $15 J T 06$ & 126 \\
\hline 16DF20 & 97 & $15 J T 07$ & 127 \\
\hline 16DF24 & 98 & J1409-0.6 & 128 \\
\hline 16DF28B & 99 & J1402-14.2 & 129 \\
\hline 16DF29 & 100 & J1409-17.1 & 130 \\
\hline 16DF30 & 101 & J1409-74.1 & 131 \\
\hline 16DF31B & 102 & J1409-WPF & 132 \\
\hline 16DF32 & 103 & J1415 & 133 \\
\hline 16DF33 & 104 & J1415-WPF & 134 \\
\hline 16DF34B & 105 & J1417 & 135 \\
\hline 16DF35 & 107 & J1417-WPF & 136 \\
\hline 05DF15 & 108 & J1418 & 137 \\
\hline 07DF15 & 109 & J1419 & 138 \\
\hline 10DF15 & 111 & J1424 & 139 \\
\hline 22DF15 & 112 & J1426 & 140 \\
\hline 23DF15 & 113 & J1427 & 141 \\
\hline 26DF15 & 114 & J1428 & 142 \\
\hline 28DF15 & 115 & J1430 & 143 \\
\hline 29DF15 & 116 & Karill & 144 \\
\hline 40DF15 & 117 & Pva2 & 145 \\
\hline 42DF15 & 118 & & \\
\hline
\end{tabular}

Table A2. Table of contents for thin sections described in this appendix. 
Sample ID:

Unit:

Lat, Long

Assemblage:

Additional analysis:

Lithology:

Description:

Structure:

Sense of shear:
16DF05

$€ O a c$

$67.72653,-150.93421$

Apoon

RSCM (this study)

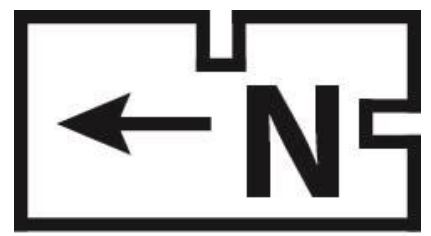

\section{black phyllite}

very fine grained with porphyroclasts to $0.5 \mathrm{~mm}$; quartz, white mica, carbonaceous material with scattered hematite, siderite, and leucoxene; rare very fine detrital garnet

spaced gradational cleavage; well-developed $\mathrm{P}$ and $\mathrm{Q}$ domains; porphyroclasts show both sinistral and dextral sense of shear with sinistral dominant; C'-type shear bands show dextral shear
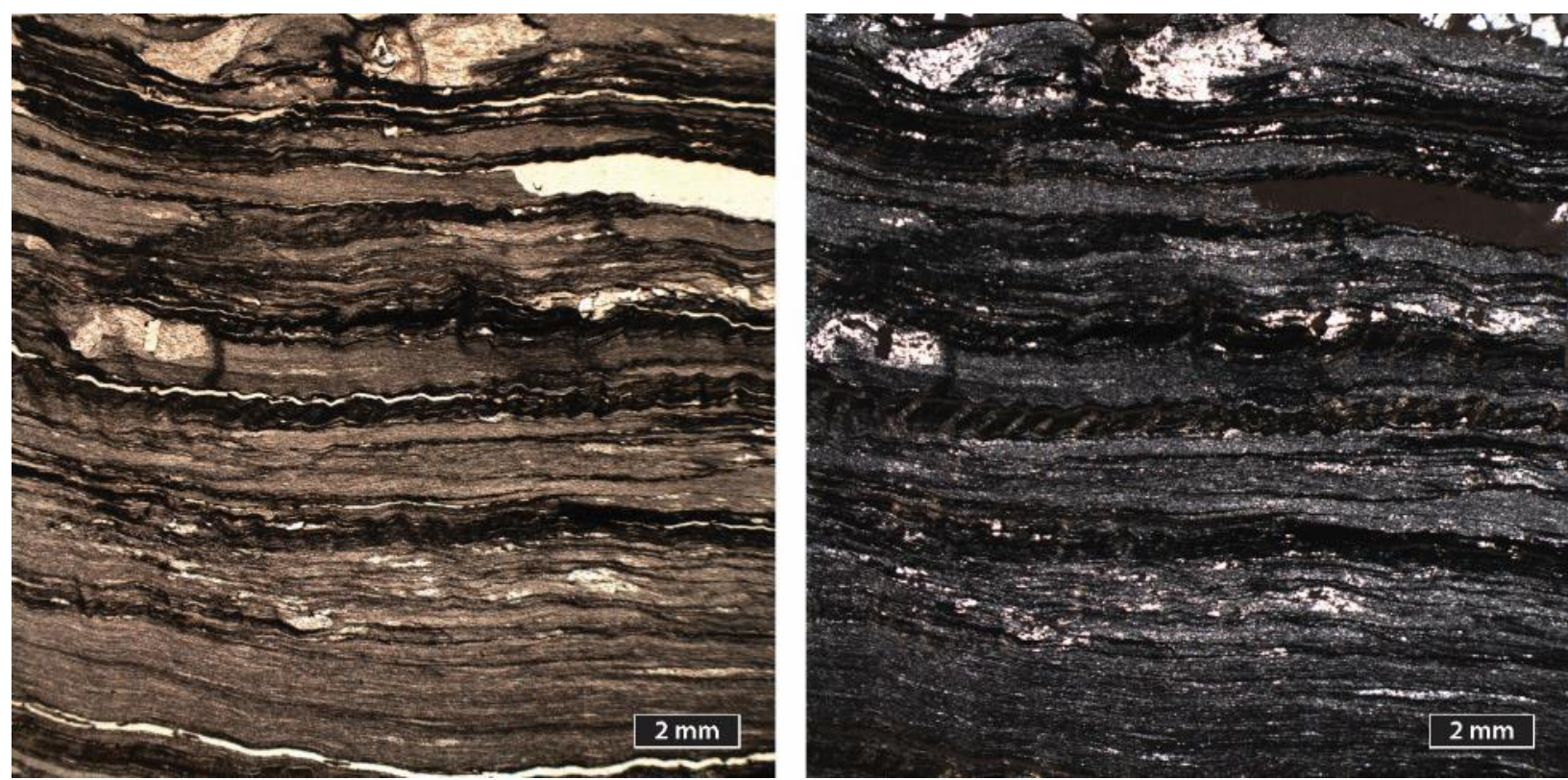

Photomicrographs of thin section, 10x/FOV 15 mm, PPL (left), XPL (right). 
Sample ID:

Unit:

Lat, Long

Assemblage:

Lithology:

Description:

Structure:

Sense of shear:
16DF08

Dtc

$67.72530,-150.88661$

Hammond

phyllite

white mica and quartz with rare very fine zircons; trace calcite in vein smooth, spaced to zonal parallel anastomosing cleavage; well-developed $\mathrm{P}$ and $\mathrm{Q}$ domains; C'-type shear band shows sinistral sense of shear S1 ambiguous, possibly top to north; S2 top to south
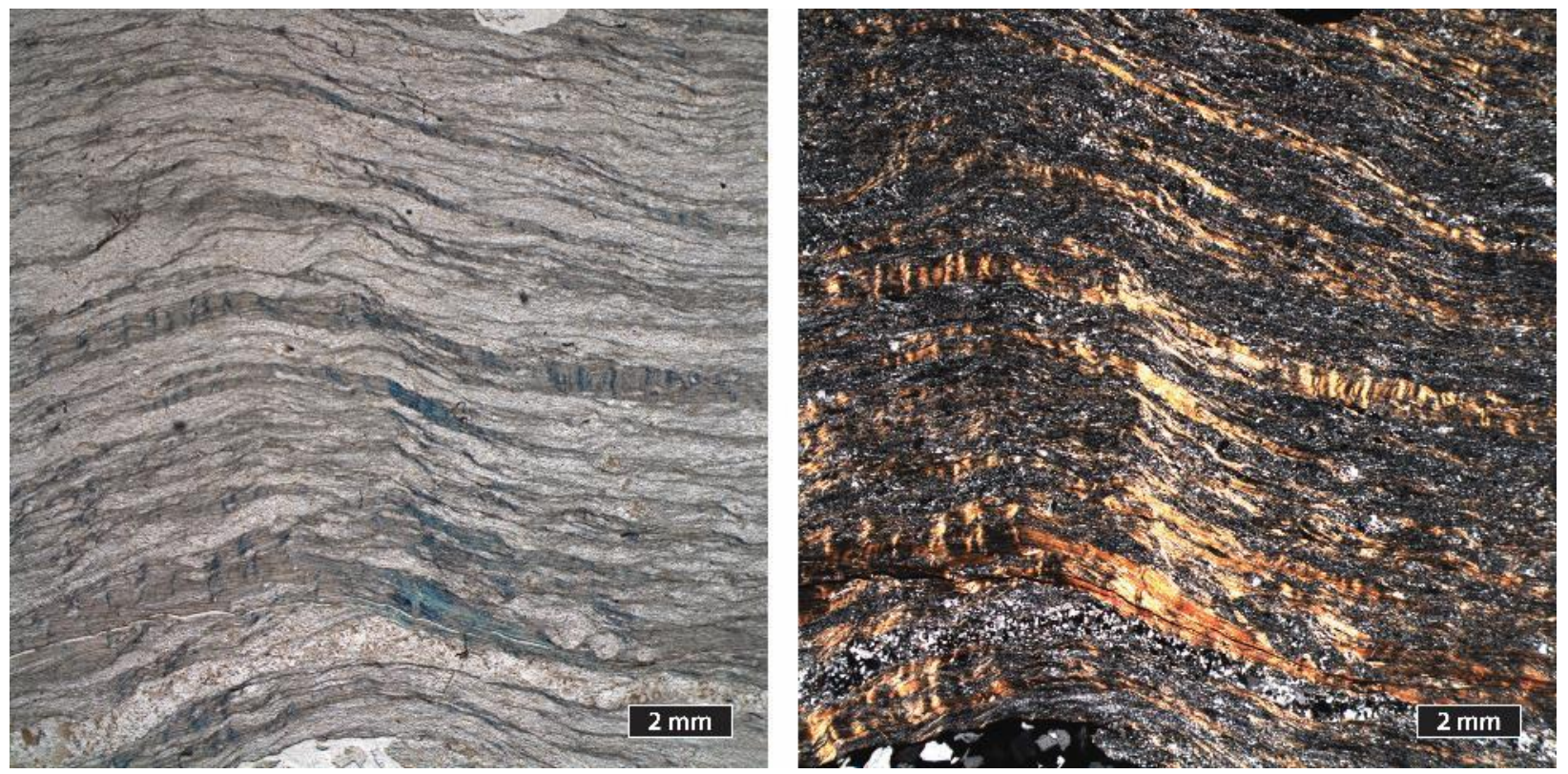

Photomicrographs of thin section, 10x/FOV $15 \mathrm{~mm}$, PPL (left), XPL (right). 
Sample ID:

Unit:

Lat, Long

Assemblage:

Lithology:

Description:

Structure:

Sense of shear:
16DF09

Dtc

$67.72677,-150.86780$

Hammond

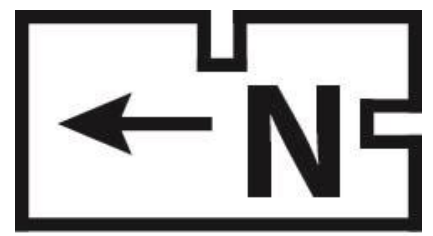

phyllite

quartz, white mica, carbonaceous material, trace leucoxene, rare zircon gradational Q and P domains; parallel to anastomosing smooth cleavage in M domains; C'-type shear bands; sinistral shear in coarser grains S1 top to north
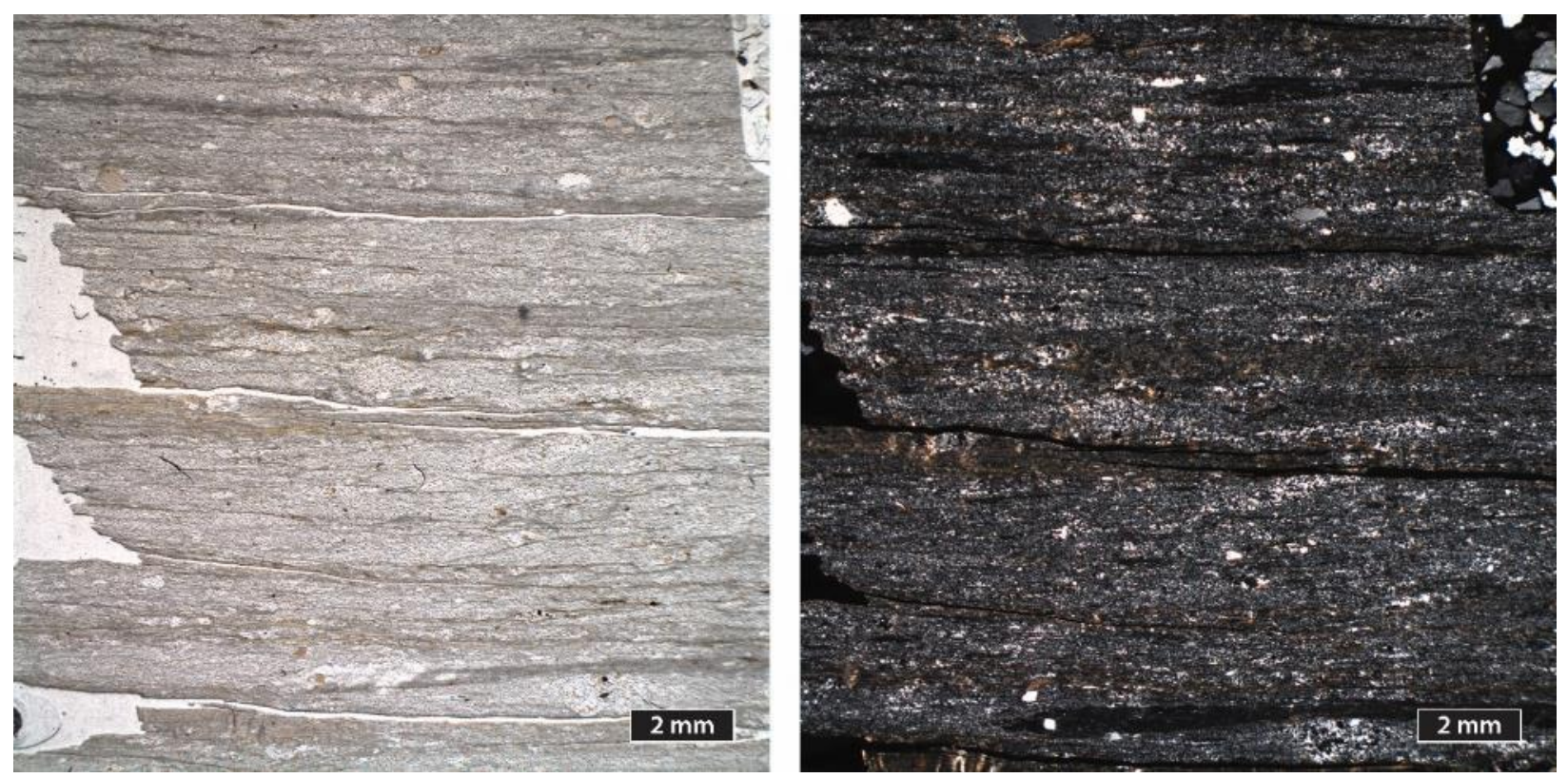

Photomicrographs of thin section, 10x/FOV $15 \mathrm{~mm}$, PPL (left), XPL (right). 
Sample ID:

Unit:

Lat, Long

Assemblage:

Additional analysis:

Lithology:

Description:
16DF11

Dtc

67.72427, -150.88329

Hammond

RSCM (this study)

\section{non-}

oriented

Structure: $\quad$ gradational to zonal continuous cleavage with strong C'-type shear bands showing sinistral shear
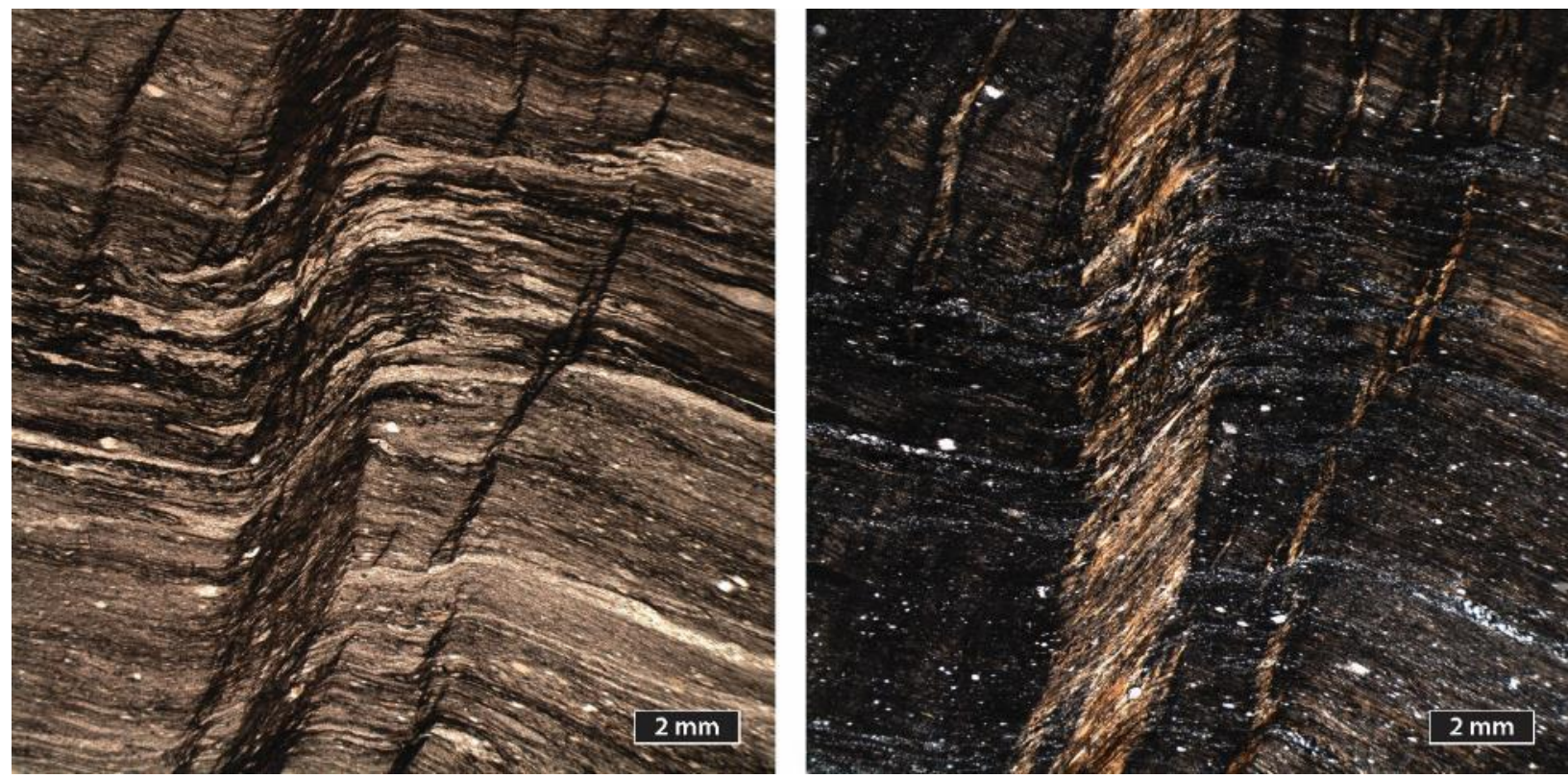

Photomicrographs of thin section, 10x/FOV 15 mm, PPL (left), XPL (right). 
Sample ID:

Unit:

Lat, Long

Assemblage:

Lithology:

Description:

Structure:

Sense of shear:
16DF13

Ddm

$67.71482,-150.83953$

Hammond

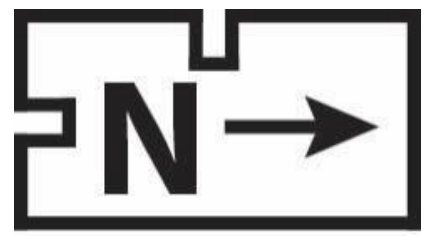

phyllite

very fine grained quartz, siltstone clasts, and white mica; trace chlorite and rare biotite; trace calcite typically mantling rotated quartz clasts parallel gradational cleavage in many thing $\mathrm{P}$ and $\mathrm{Q}$ domains; cleavage primarily disjunctive but micas in $\mathrm{Q}$ domains show nascent crenulation; C'-type shear bands show sinistral sense of shear; deformed siltstone clasts show dextral sense of shear.

S1 top to north; S2 top to south
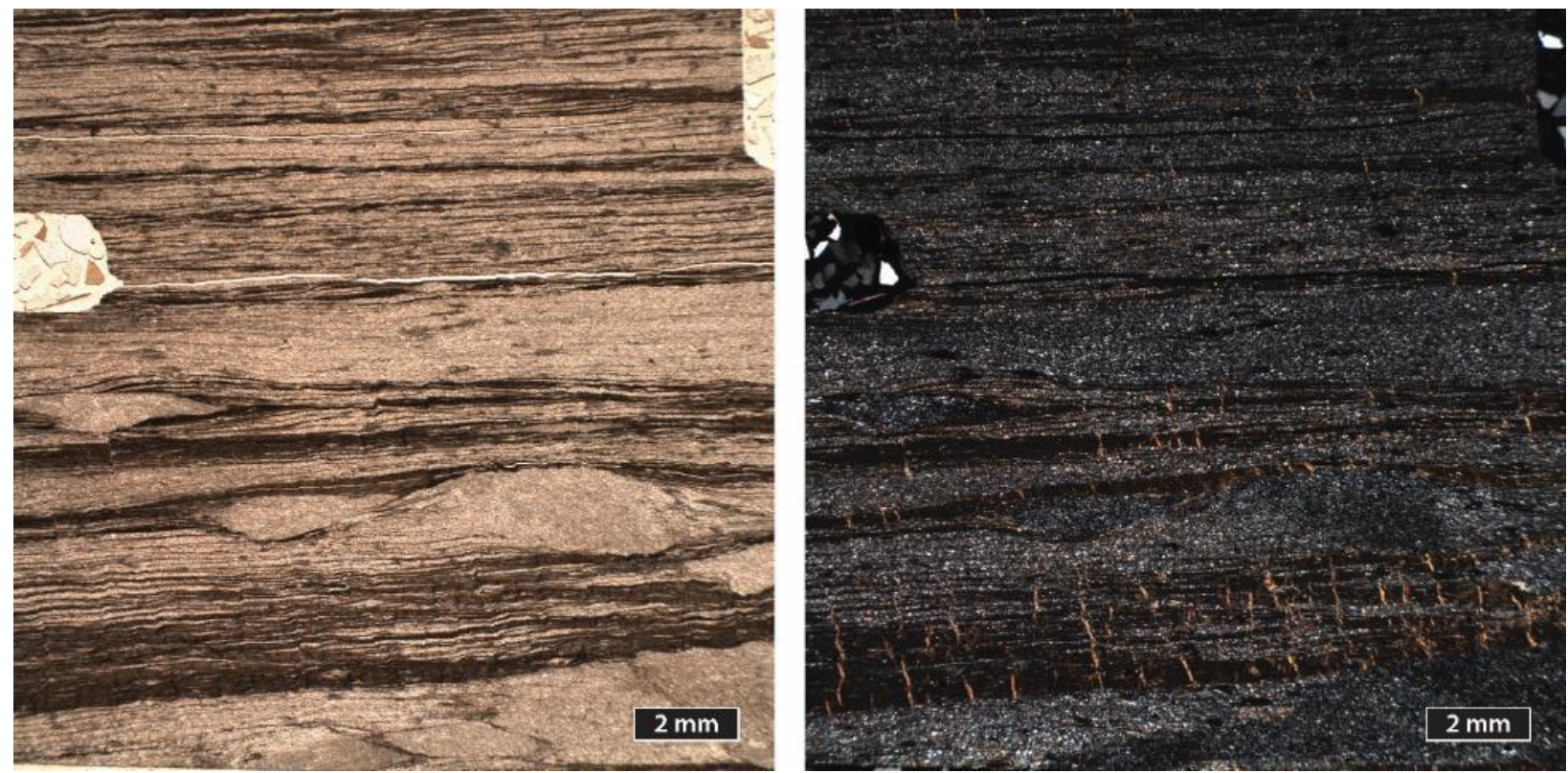

Photomicrographs of thin section, 10x/FOV 15 mm, PPL (left), XPL (right). 
Sample ID:

Unit:

Lat, Long

Assemblage:

Lithology:

Description:

Structure:

Sense of shear:
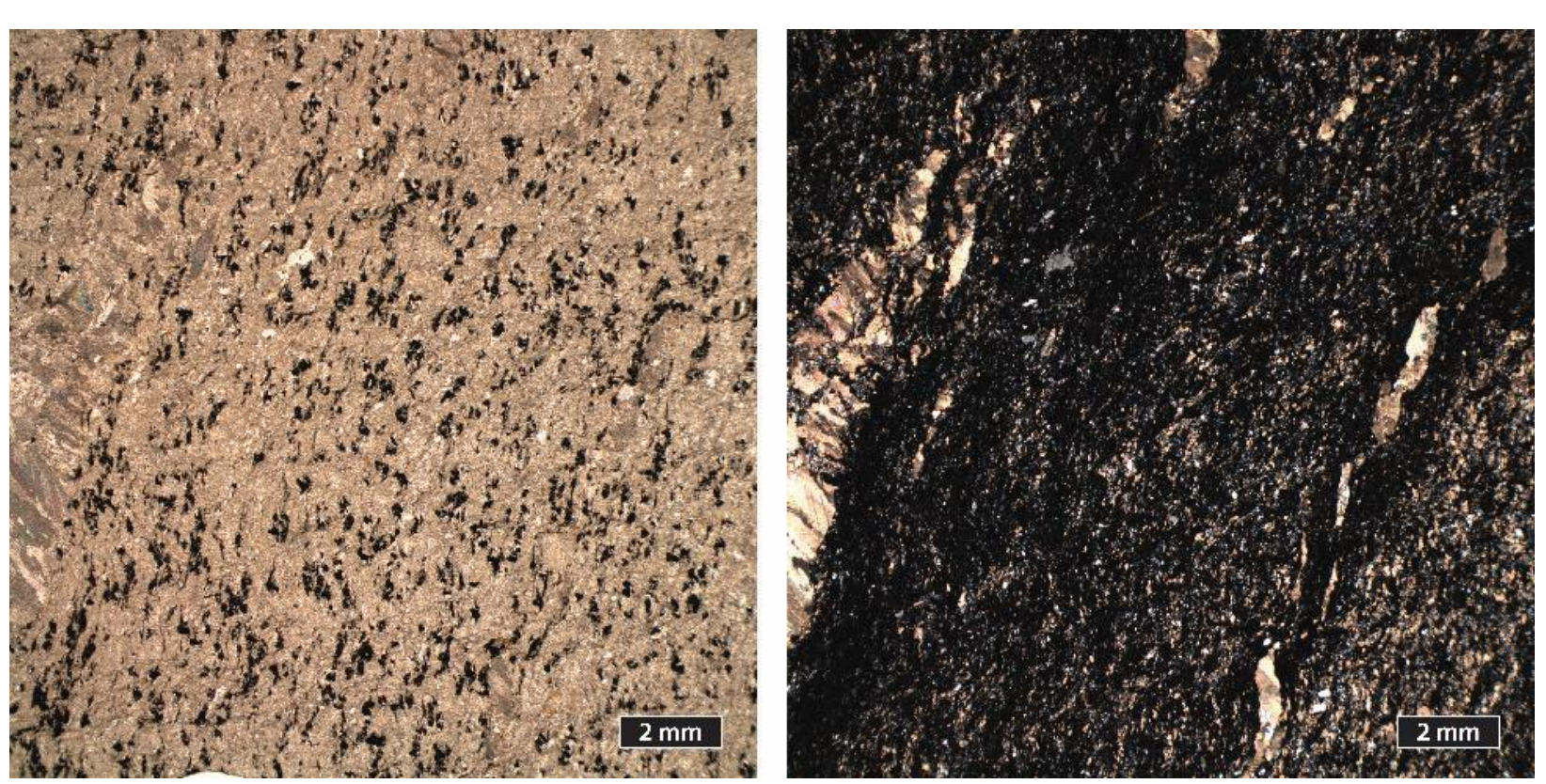

Photomicrographs of thin section, 10x/FOV 15 mm, PPL (left), XPL (right).

16DF16

Dtc

$67.69229,-151.04731$

Hammond

meta- calcareous sandstone

very fine quartz and calcite with abundant leucoxene and chlorite; common siderite; rare biotite; overall highly altered

dextral sense of shear in rough C'-type shear bands obscured by alteration

S2 top to north

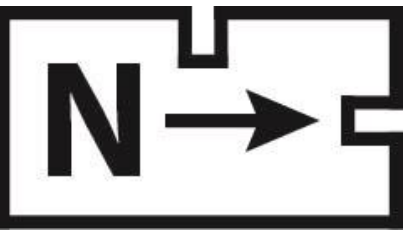


Sample ID:

Unit:

Lat, Long

Assemblage:

Lithology:

Description:

Structure:

Sense of shear:
16DF17

Dtc

$67.69000,-151.05996$

Hammond

meta- calcareous sandstone

very fine to medium quartz in a highly altered mix of calcite, leucoxene, chlorite, and biotite; trace pyrite, hematite, and albite obscured by alteration indeterminate
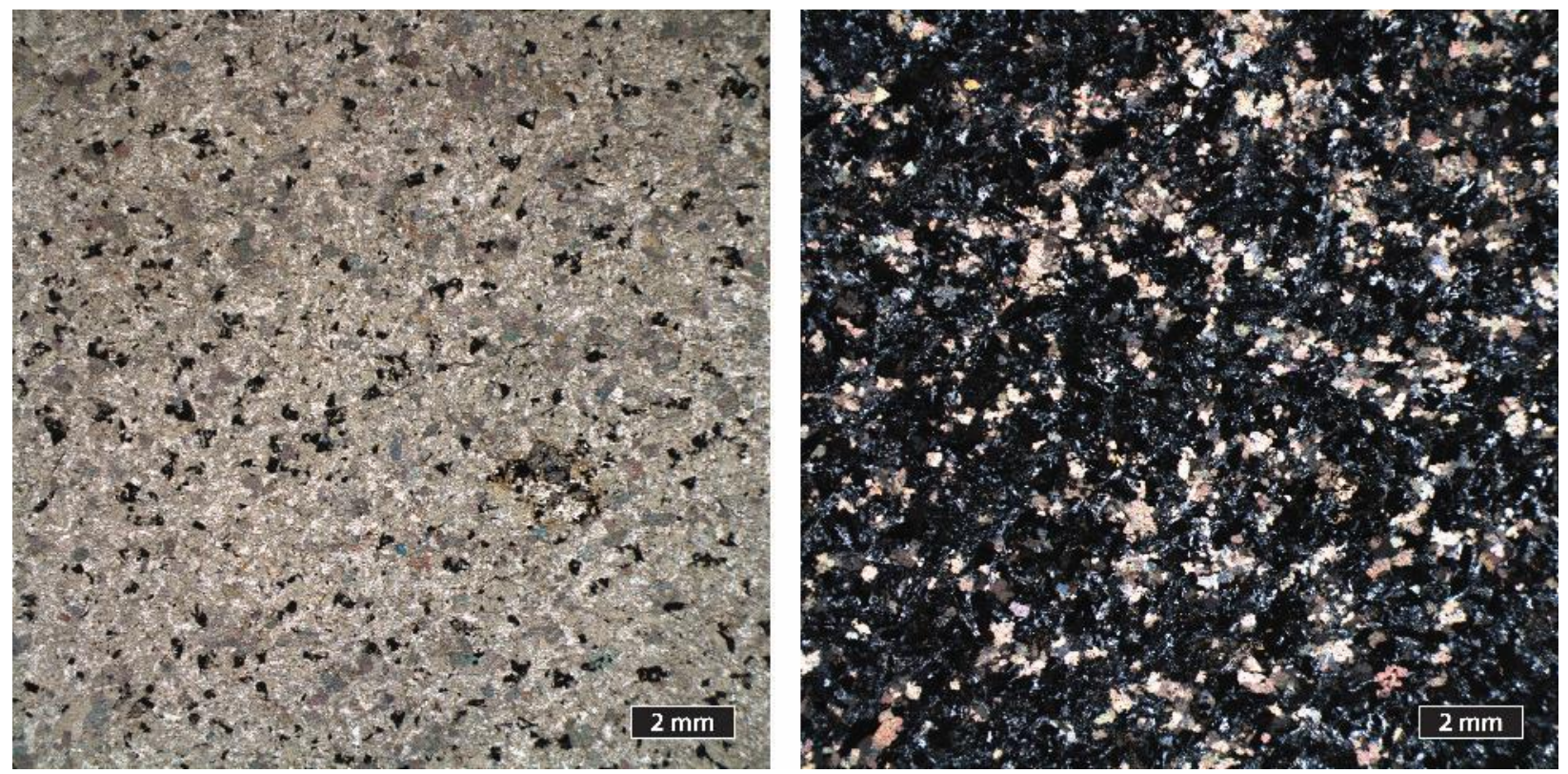

Photomicrographs of thin section, 10x/FOV 15 mm, PPL (left), XPL (right). 
Sample ID:

Unit:

Lat, Long

Assemblage:

Additional analysis:

Lithology:

Description:

Structure:

Sense of shear:
16DF19

Ddr

67.67596, -151.10845

Hammond

RSCM (this study)
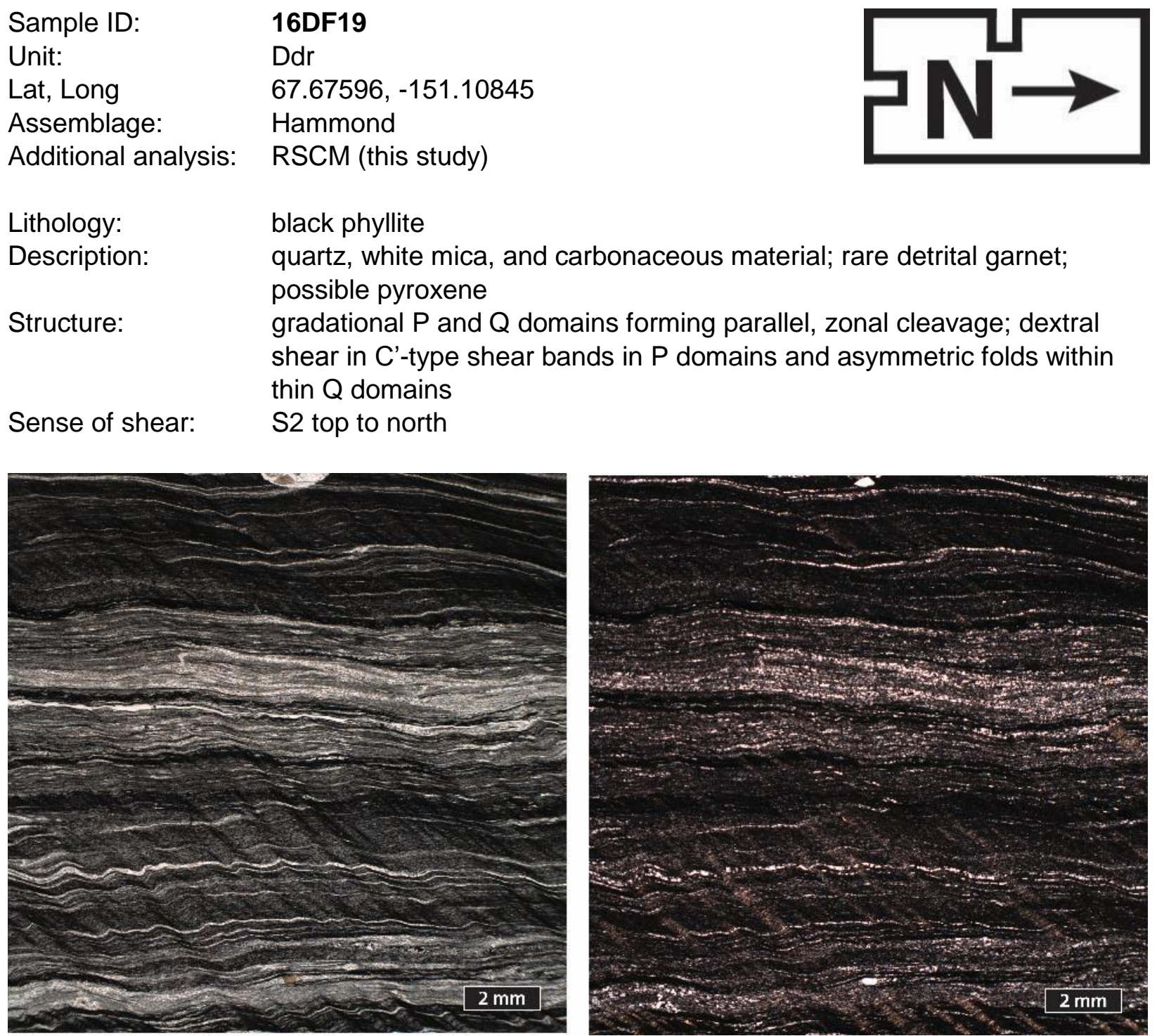

Photomicrographs of thin section, 10x/FOV $15 \mathrm{~mm}$, PPL (left), XPL (right). 
Sample ID:

Unit:

Lat, Long

Assemblage:

Additional analysis:

Lithology:

Description:

Structure:
16DF20

Dtc

67.67221, -151.10832

Hammond

RSCM (this study) nonoriented meta-graywacke

medium to very fine quartz, white mica, and calcite in altered sample; common carbonaceous material, leucoxene, albite, and quartzite clasts; trace hematite and biotite; rare chlorite and zircon; very rare altered possible mafic grains

subtle sinistral sense of shear in altered, poorly developed C'-type shear bands and rotated clasts
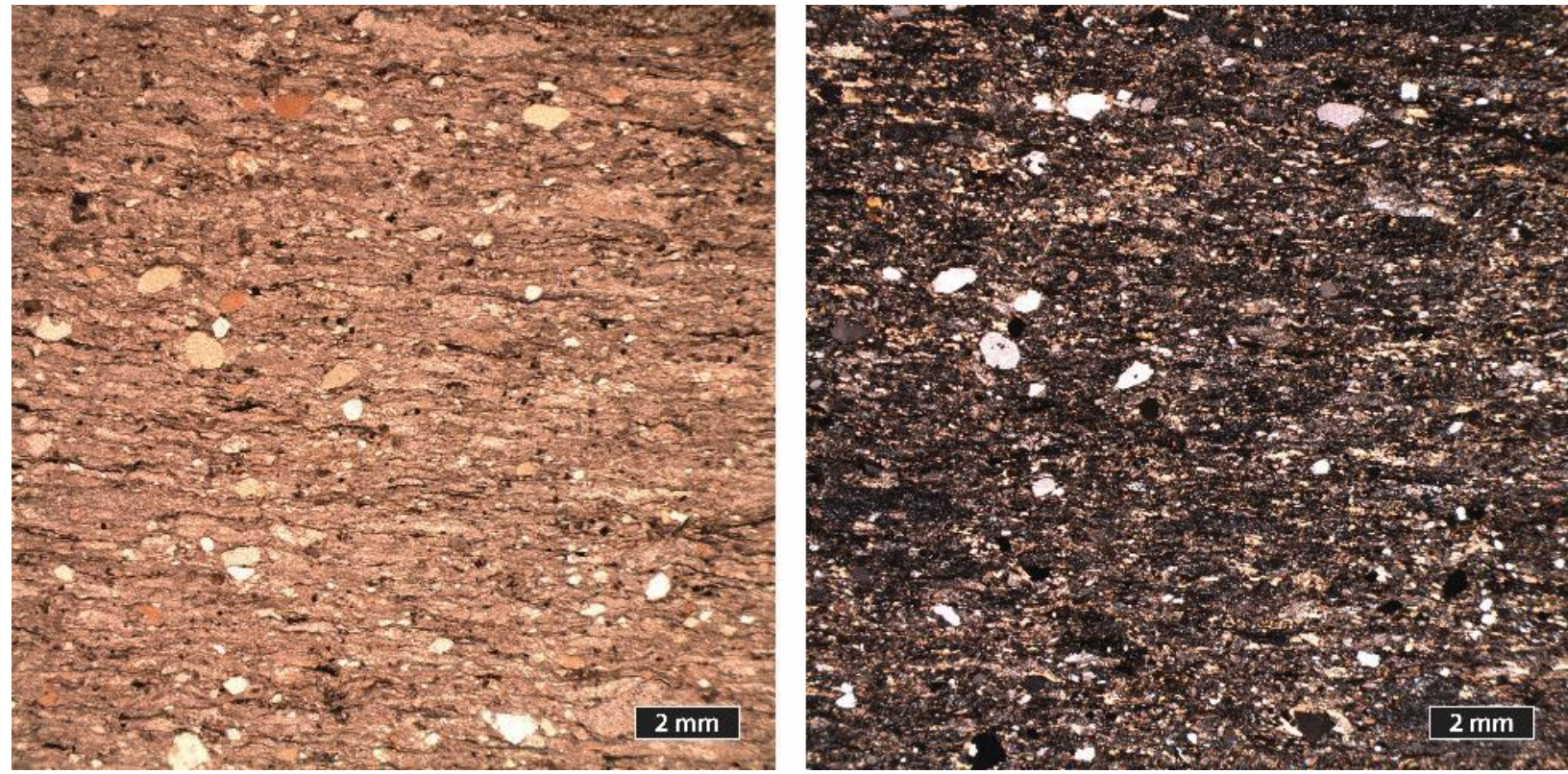

Photomicrographs of thin section, 10x/FOV 15 mm, PPL (left), XPL (right). 
Sample ID:

Unit:

Lat, Long

Assemblage:

Additional analysis:

Lithology:

Description:

Structure:

Sense of shear:
16DF24

Dtc

67.69271, -151.09177

Hammond

RSCM (this study)

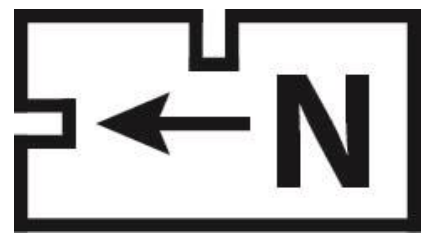

meta-graywacke

fine to medium quartz and quartzite grains up to $1 \mathrm{~mm}$ with abundant calcite; carbonaceous material and fine white mica in $\mathrm{P}$ domains; scattered detrital white mica, albite, titanite/leucoxene; rare pyrite, biotite, zircon, and chlorite; several calcite grains appear to be replacing rounded rotated porphyroclasts

continuous fine domainal cleavage; porphyroclasts show sinistral sense of shear

S1 top to north
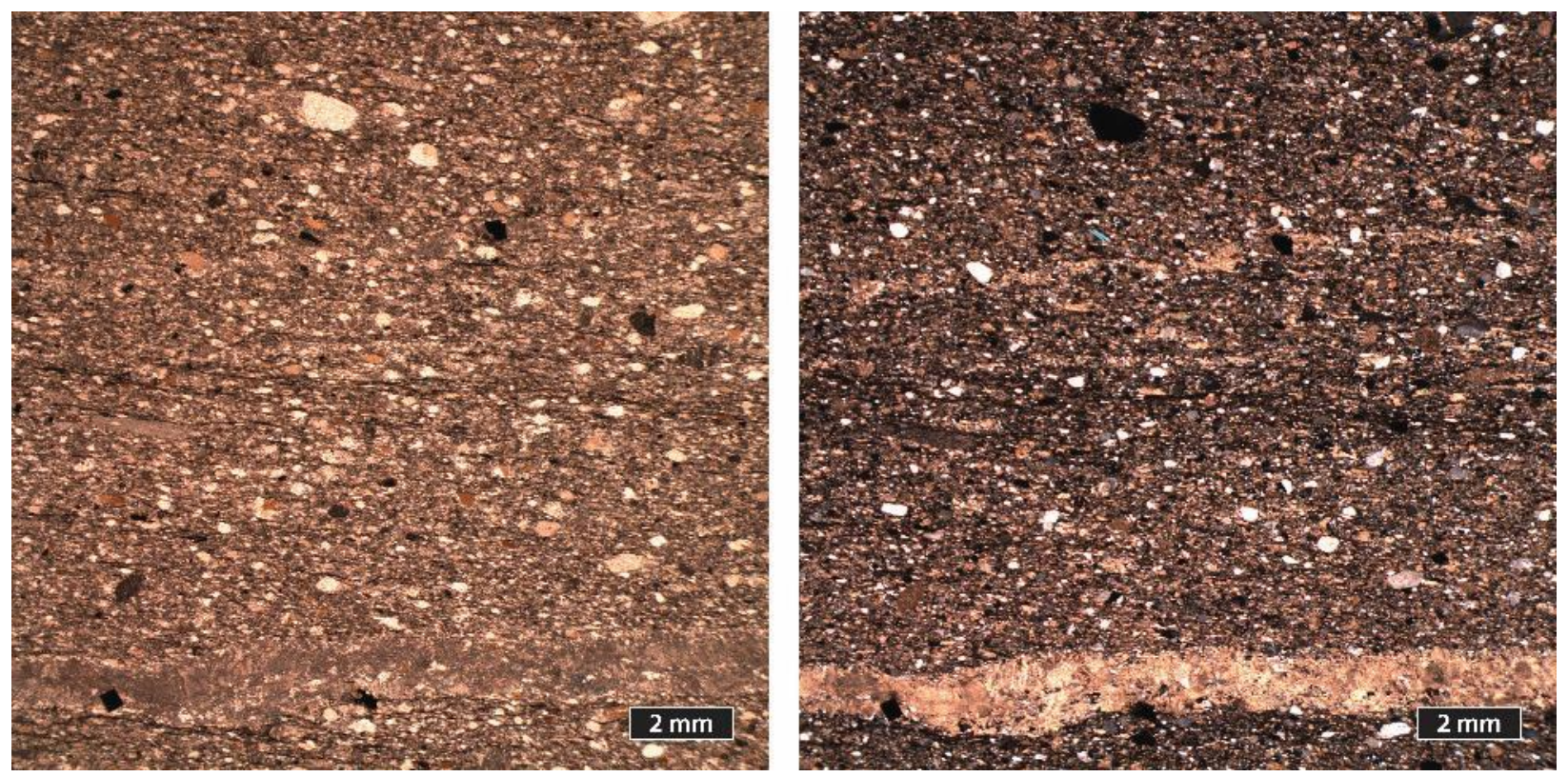

Photomicrographs of thin section, 10x/FOV 15 mm, PPL (left), XPL (right). 
Sample ID:

Unit:

Lat, Long

Assemblage:

Lithology:

Description:

Structure:

Sense of shear:
16DF28B

Ddm

67.67932, -150.99896

Hammond

sandy phyllite

fine to very fine quartz with white mica and calcite, carbonaceous material, biotite, and chlorite; rare pyrite

spaced wiggly cleavage; asymmetric folds, offset veins, and $\mathrm{M}$ domain shear show mixed sense of shear with sinistral shear dominant S2 top to south
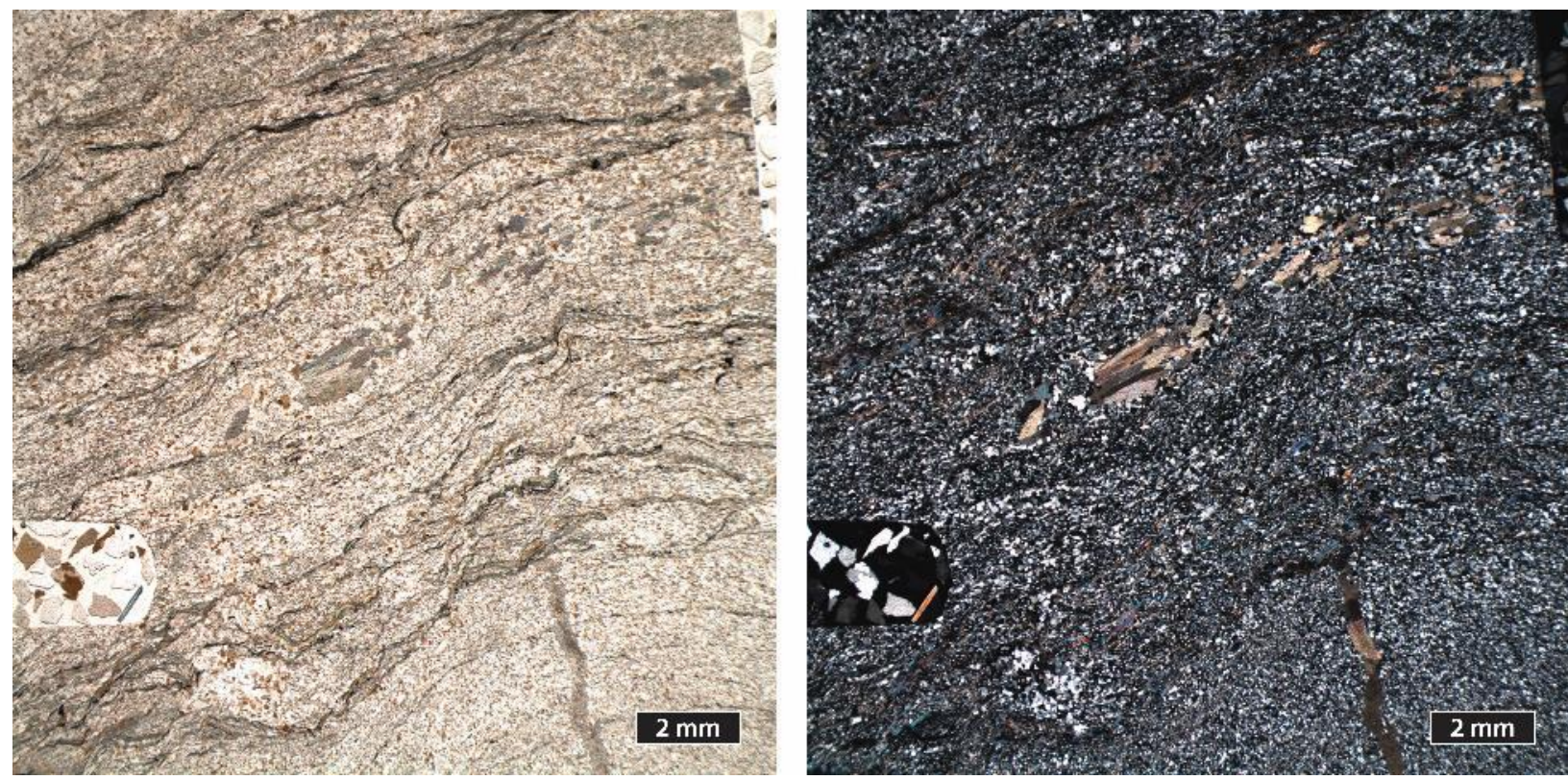

Photomicrographs of thin section, 10x/FOV 15 mm, PPL (left), XPL (right). 
Sample ID:

Unit:

Lat, Long

Assemblage:

Additional analysis:

Lithology:

Description:

Structure:

Sense of shear:
16DF29

Ddm

67.64660, -151.12190

Hammond

RSCM (this study)

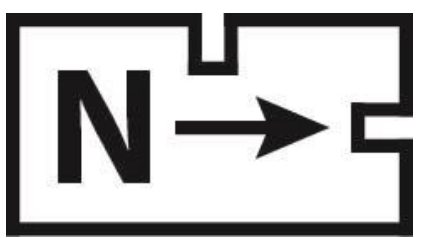

dark gray phyllite

quartz and white mica; trace leucoxene; rare pyrite and chlorite; very rare detrital garnet and zircon

continuous crenulation; discrete C'-type shear bands showing sinistral sense of shear

S2 top to south
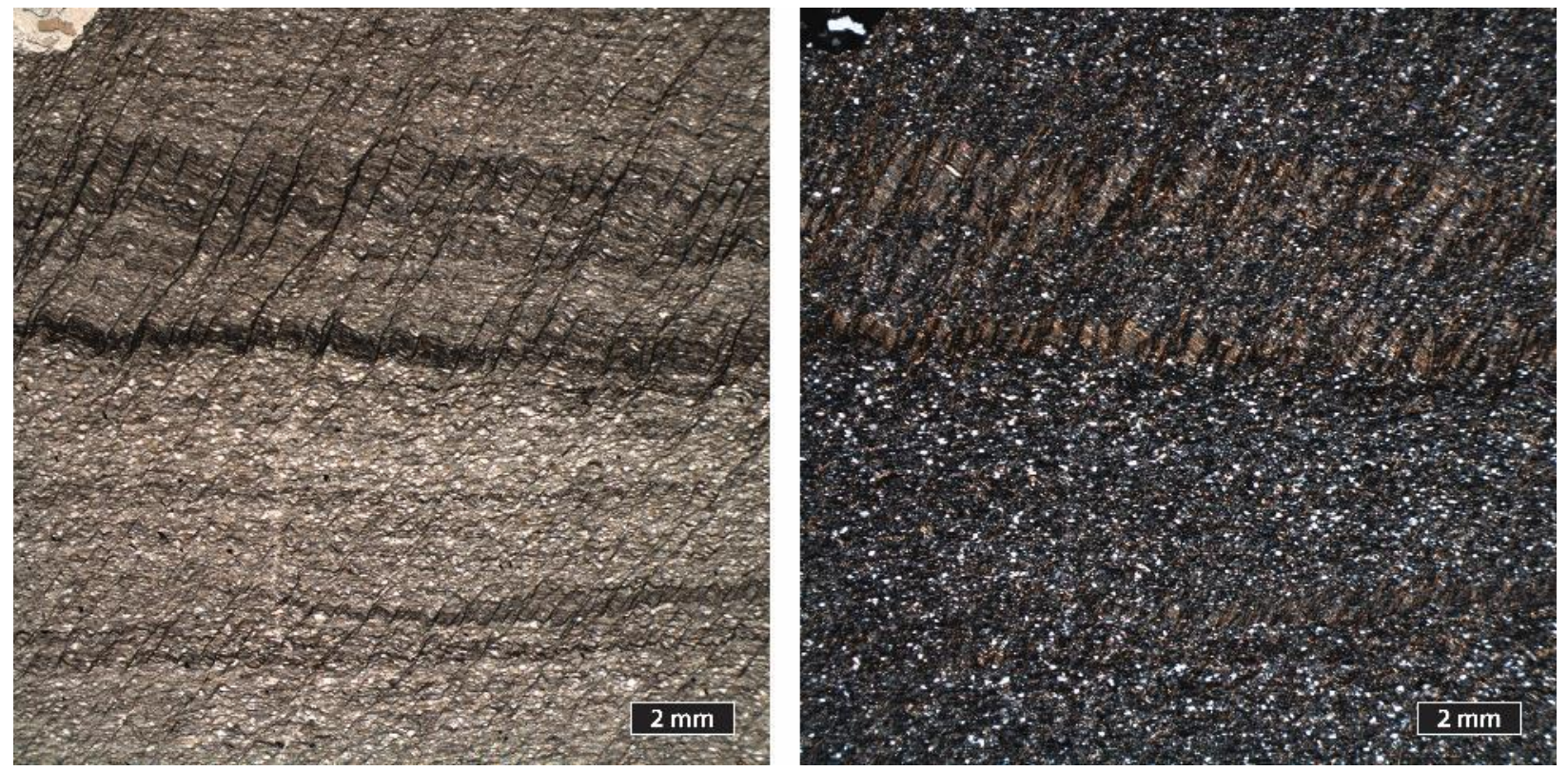

Photomicrographs of thin section, 10x/FOV 15 mm, PPL (left), XPL (right). 
Sample ID:

Unit:

Lat, Long

Assemblage:

Additional analysis:

Lithology:

Description:

Structure:

Sense of shear:
16DF30

Ddr

$67.65361,-151.14956$

Hammond

RSCM (this study)

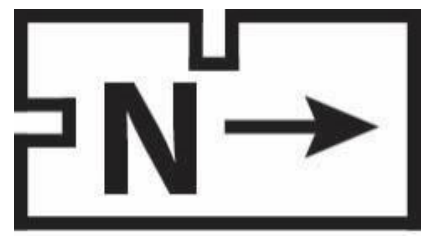

black phyllite

fine quartz predominant with white mica and carbonaceous material in cleavage domains; trace pyrite and hematite; rare biotite spaced M domains with finer continuous cleavage within $Q$ domains; C'type shear bands showing dextral shear; possible sinistral sense of shear in rotated quartz grains.

indeterminate
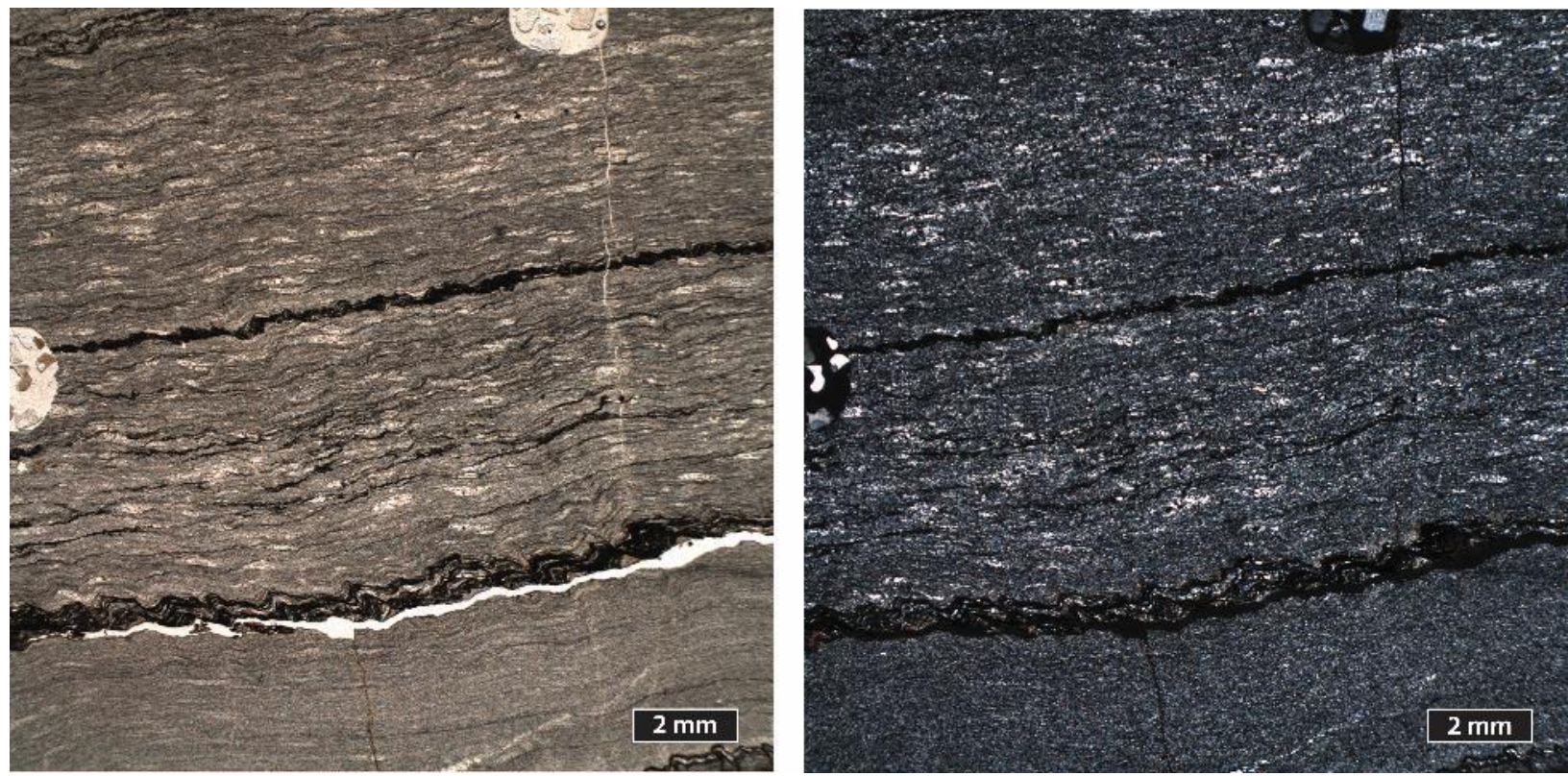

Photomicrographs of thin section, 10x/FOV 15 mm, PPL (left), XPL (right). 
Sample ID:

Unit:

Lat, Long

Assemblage:

Lithology:

Description:
16DF31B

Ddm

67.64636, -151.13129

Hammond non-

oriented

Structure:

mud-clast phyllite

fine to very fine quartz with scattered white mica, carbonaceous material, hematite, and chlorite; rare biotite, siderite, and zircons

spaced anastomosing irregular cleavage and sheared asymmetric folds
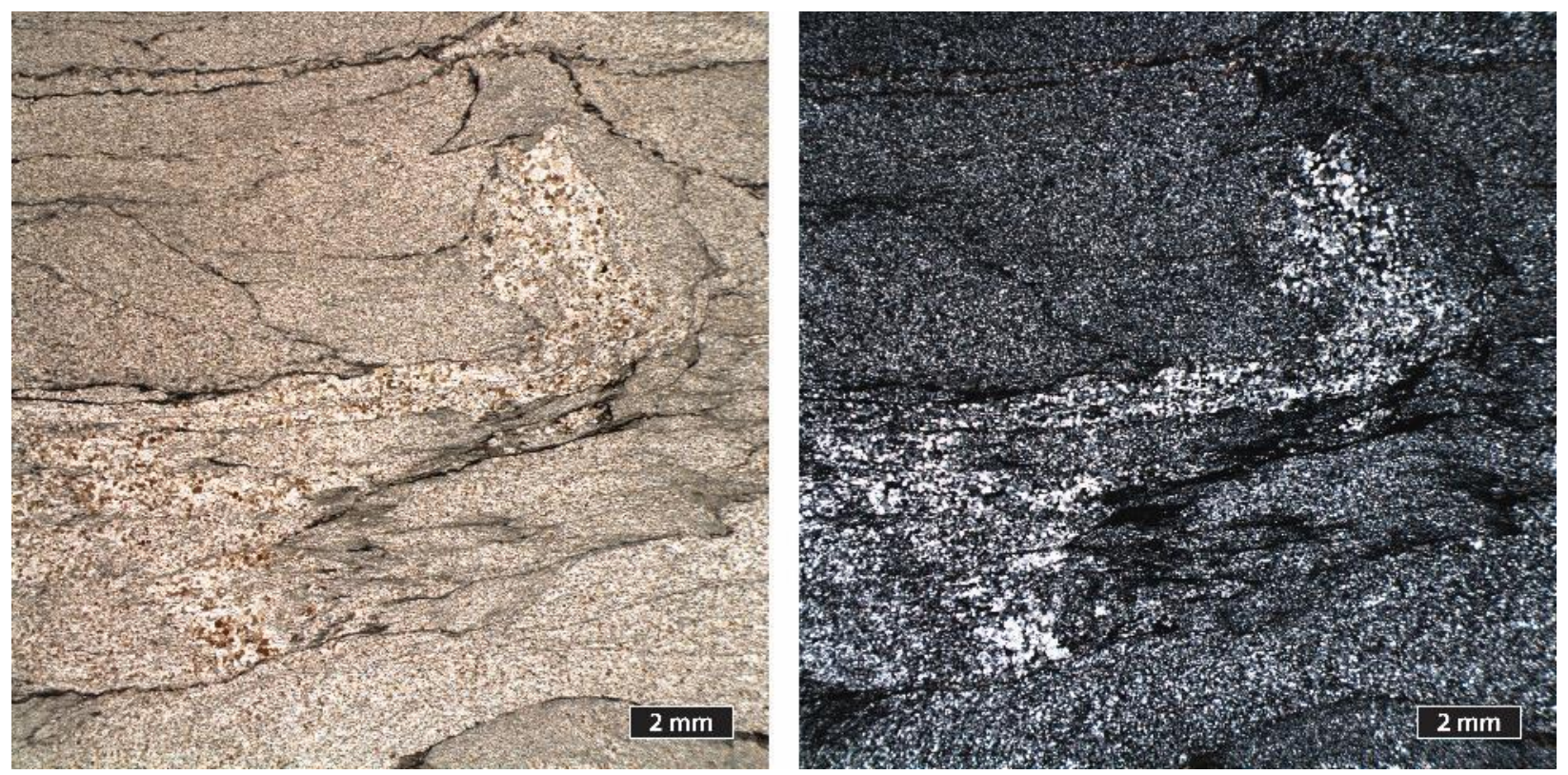

Photomicrographs of thin section, 10x/FOV $15 \mathrm{~mm}$, PPL (left), XPL (right). 


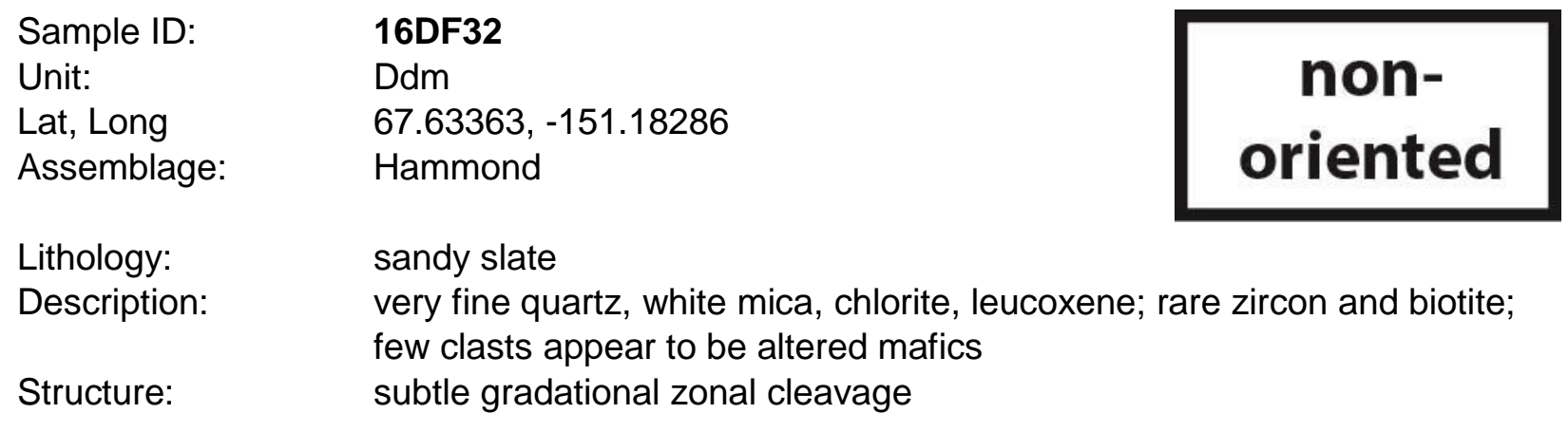
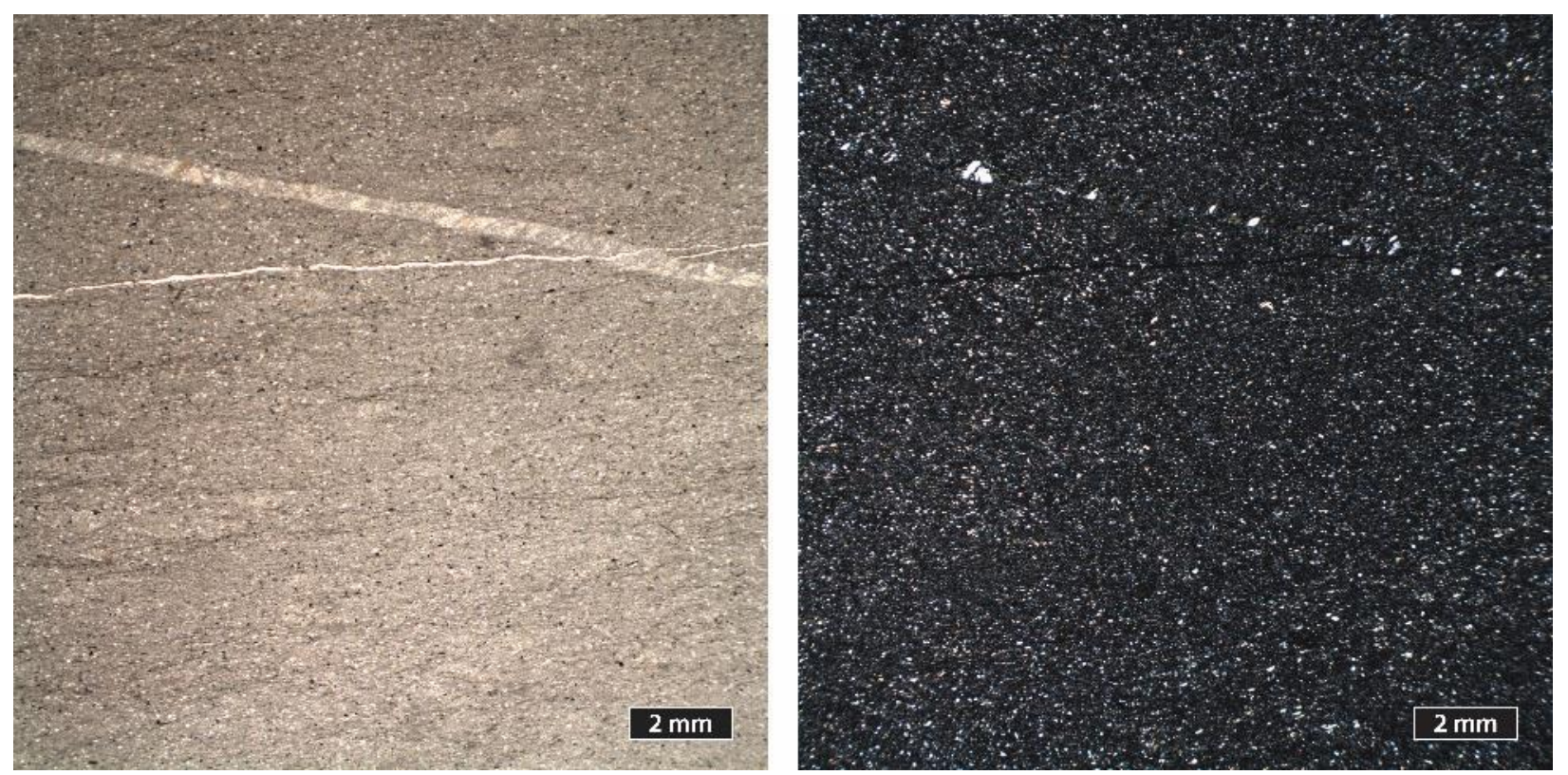

Photomicrographs of thin section, 10x/FOV 15 mm, PPL (left), XPL (right). 
Sample ID:

Unit:

Lat, Long

Assemblage:

Lithology:

Description:

Structure:

Sense of shear:
16DF33

Ddm

67.66986, -151.01748

Hammond

sandy phyllite

quartz with scattered quartzite grains, white mica; trace leucoxene, rare hematite, biotite, and chlorite; possible detrital garnet

gradational spaced cleavage with sinistral shear in C'-type shear bands; rotation of clasts indicates dextral sense of shear.

S1 top to north, S2 top to south
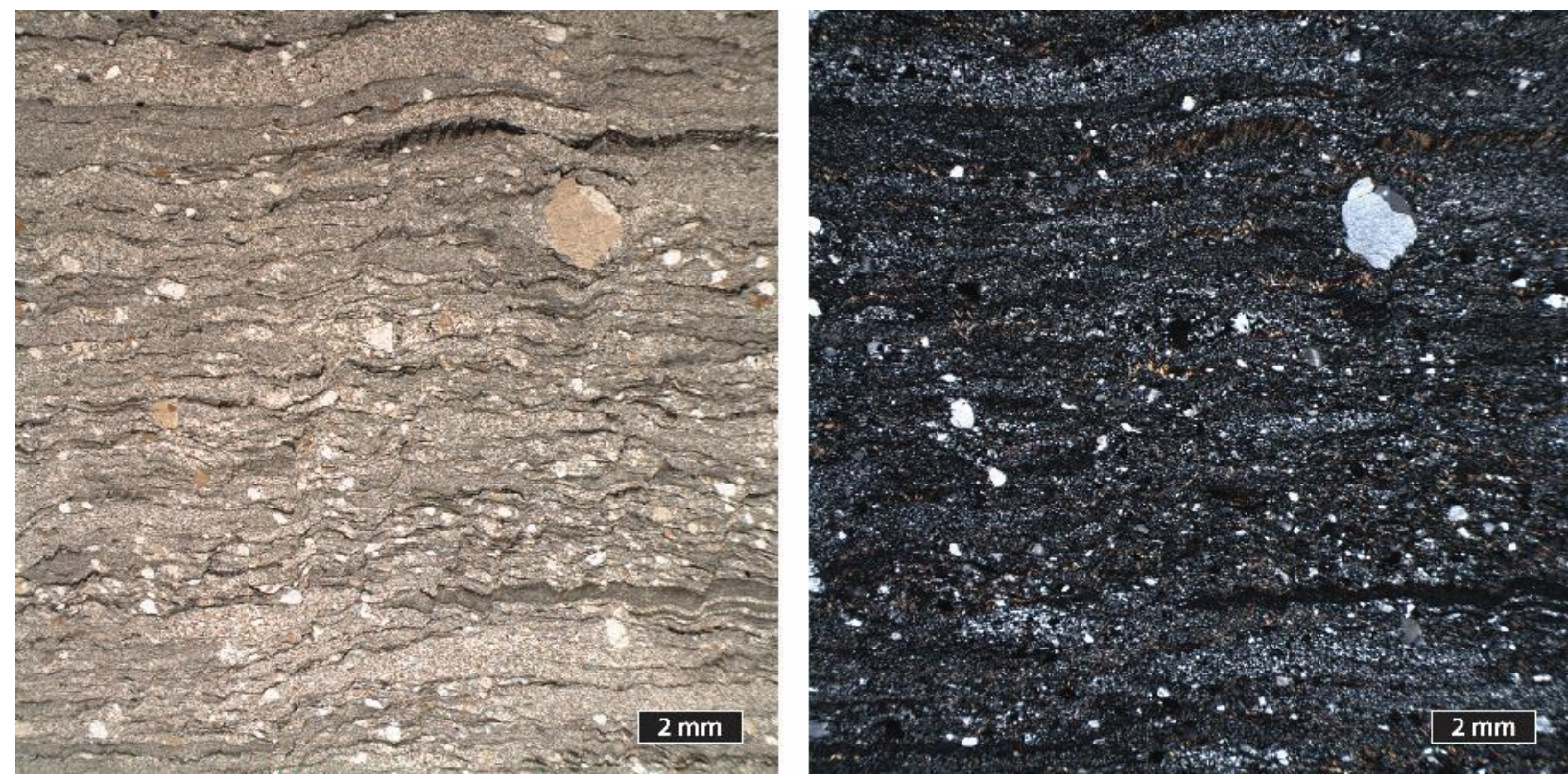

Photomicrographs of thin section, 10x/FOV 15 mm, PPL (left), XPL (right). 
Sample ID:

Unit:

Lat, Long

Assemblage:

Lithology:

Description:

Structure:
16DF34B

Dgw

67.64102, -150.94802

Hammond non-

oriented

meta- pebbly graywacke

fine to very fine quartz with several coarser quartzite grains as porphyroclasts; common white mica and chlorite; rare biotite, carbonaceous material, hematite, leucoxene, biotite, and calcite zonal rough to wiggly gradational to discrete cleavage; rotated porphyroclasts
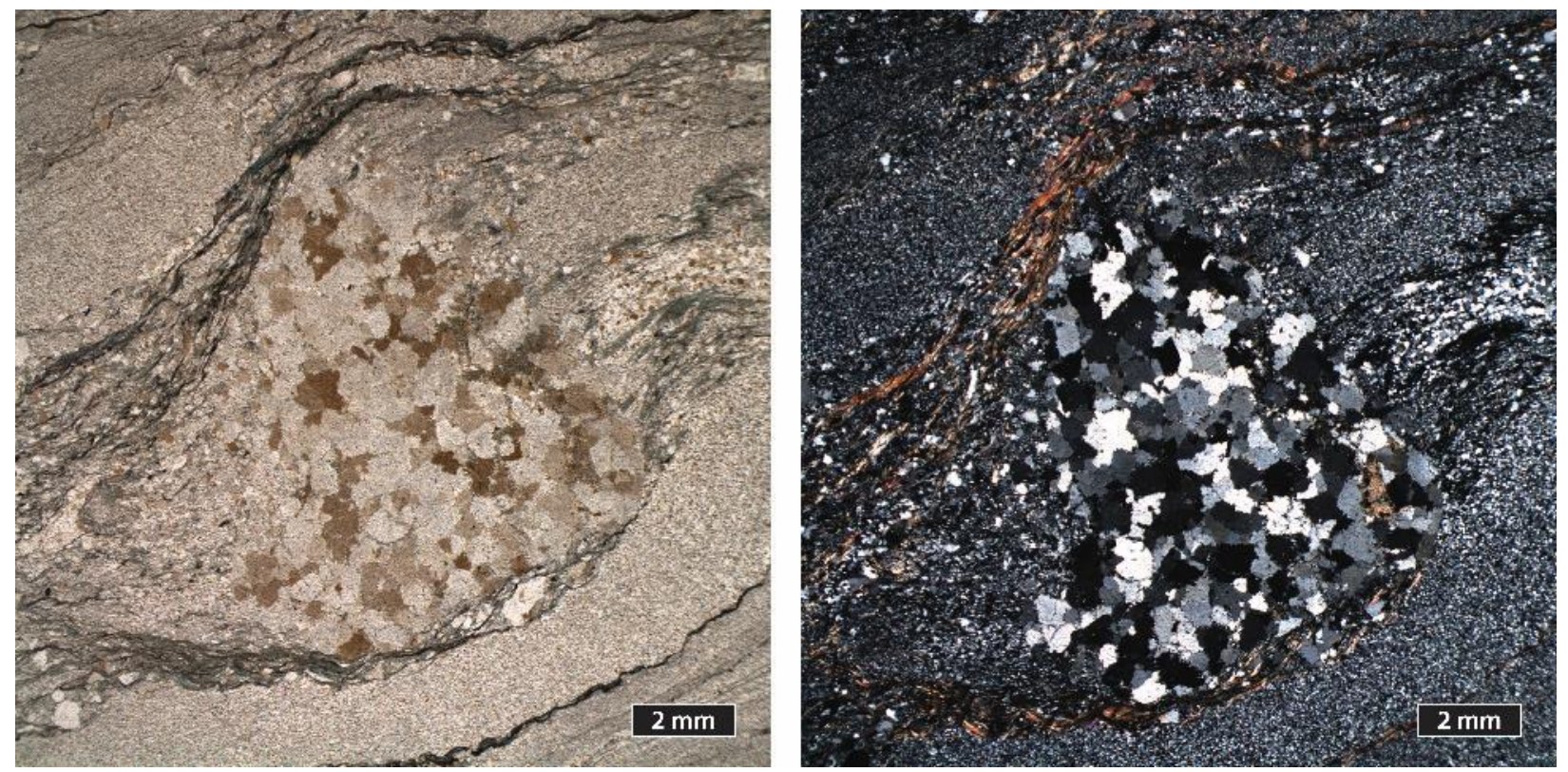

Photomicrographs of thin section, 10x/FOV 15 mm, PPL (left), XPL (right). 
Sample continued: 16DF34B
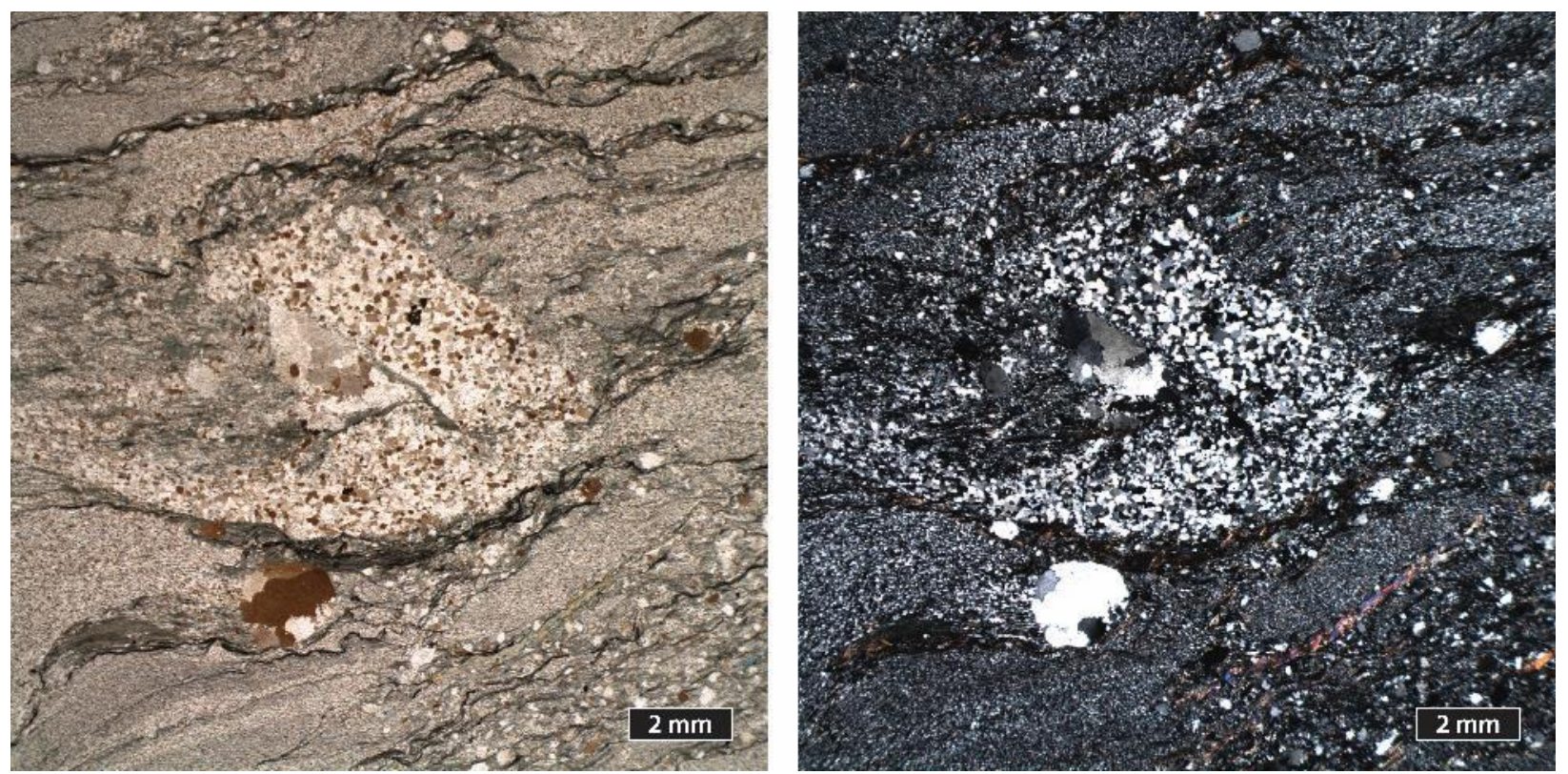

Photomicrographs of thin section, 10x/FOV 15 mm, PPL (left), XPL (right). 
Sample ID:

Unit:

Lat, Long

Assemblage:

Lithology:

Description:

Structure:

Sense of shear:
16DF35

Dgw

67.64283, -150.93686

Hammond

meta-graywacke

very fine to medium quartz with white mica and chlorite; scattered carbonaceous material and calcite; trace albite, siderite, hematite, leucoxene, biotite, and altered volcanic grains

parallel to anastomosing zonal gradational cleavage; altered rotated grains and sparse crenulation show dextral sense of shear S1 top to north
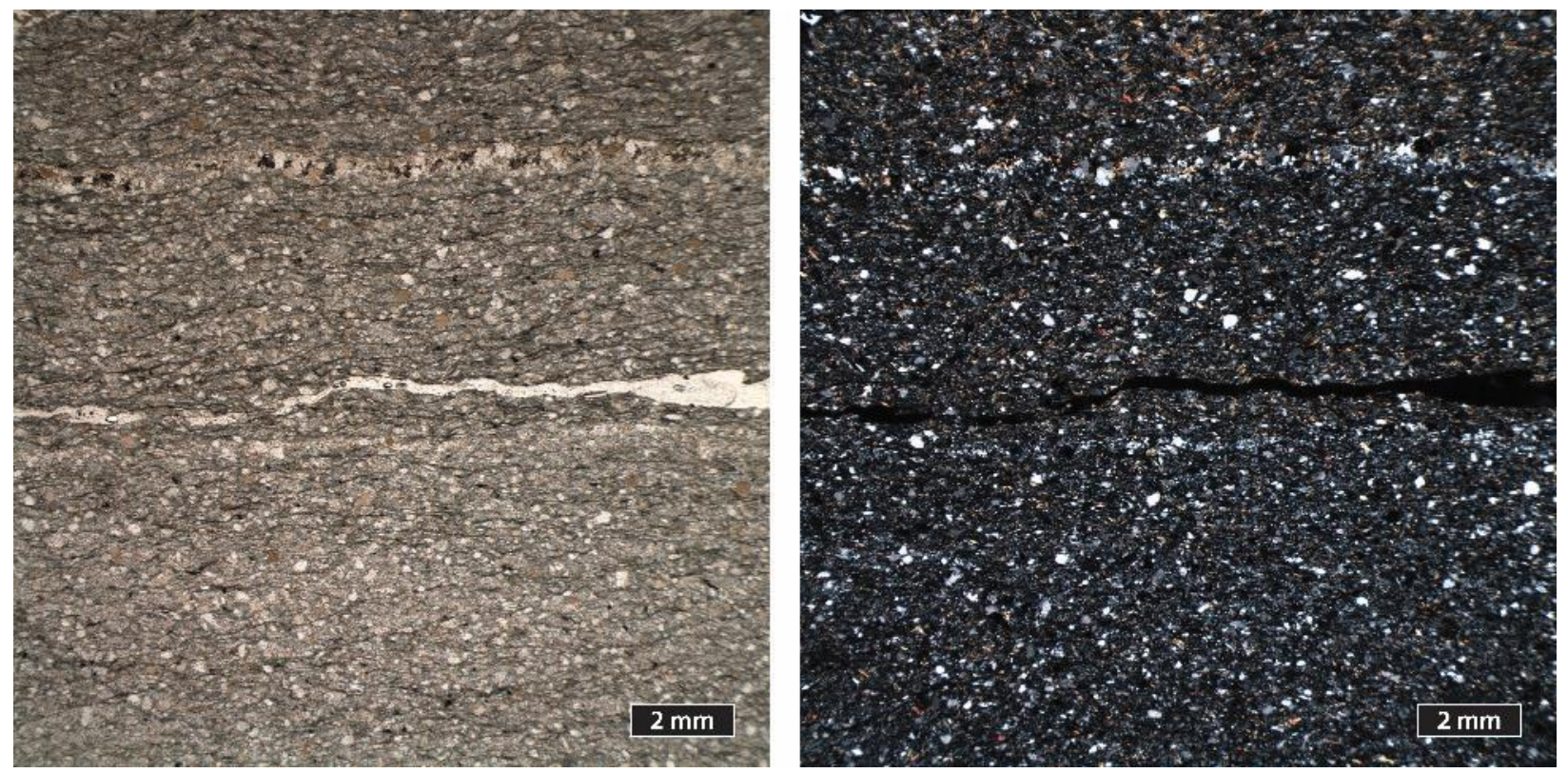

Photomicrographs of thin section, 10x/FOV 15 mm, PPL (left), XPL (right). 
Sample ID:

Unit:

Lat, Long

Assemblage:

Additional analysis:

Lithology:

Description:

Structure:
05DF15

€Oac

$67.86187,-150.78703$

Apoon

U-Pb zircon geochronology (Frier 2017)

meta-graywacke

heavily altered sample; very fine to medium quartz with siltstone clasts, calcite, white mica, quartzite grains, albite, altered volcanic/mafic grains, chlorite, and leucoxene; trace carbonaceous material and hematite; rare detrital garnet

rough gradational cleavage obscured by alteration
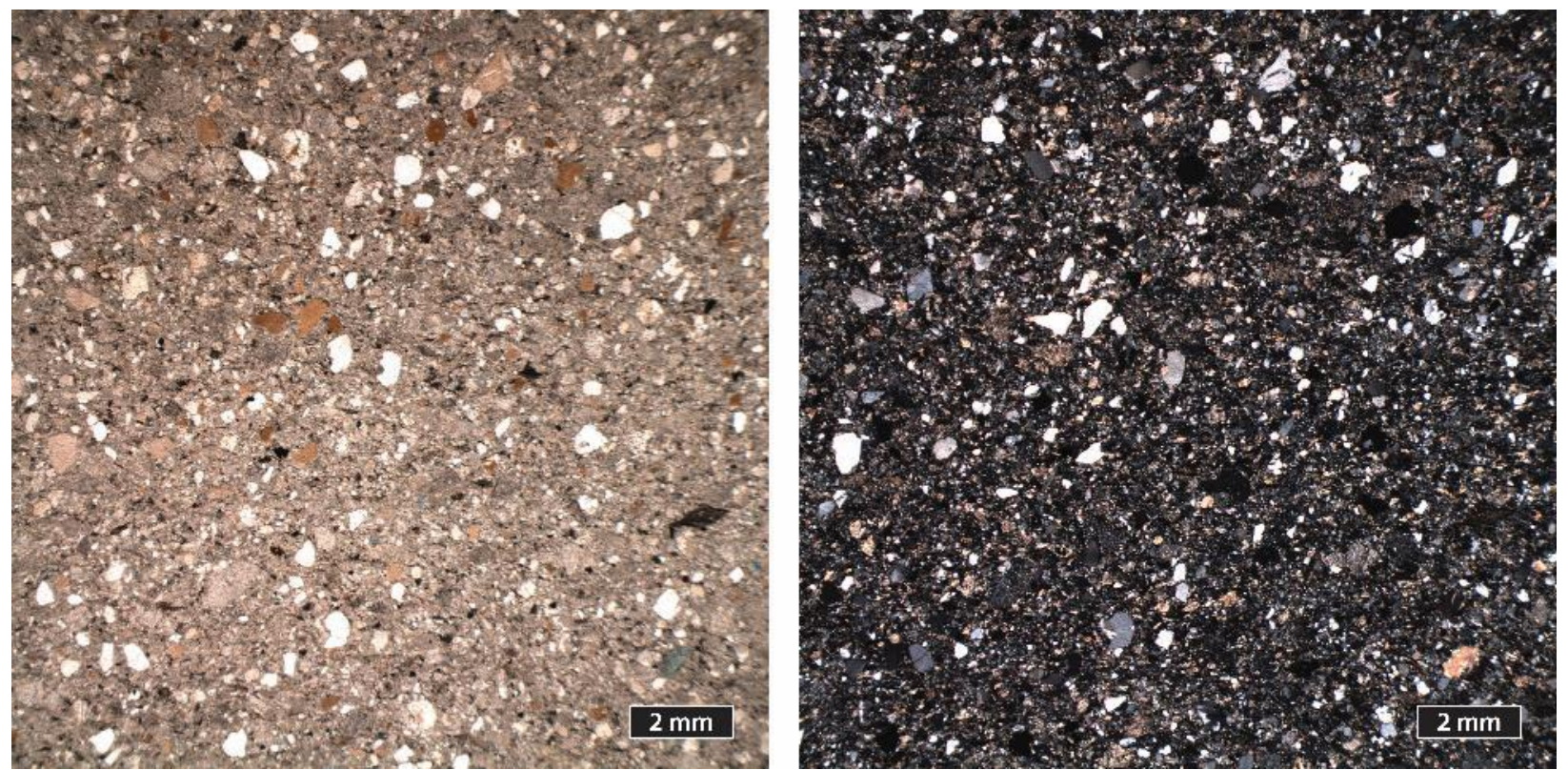

Photomicrographs of thin section, 10x/FOV 15 mm, PPL (left), XPL (right). 
Sample ID:

Unit:

Lat, Long

Assemblage:

Lithology:

Description:

Structure:
07DF15

€Oac

$67.87386,-150.83585$

Apoon nonoriented

meta- conglomeratic graywacke

fine to coarse quartz with abundant calcite as alteration products and veins; common quartzite and altered volcanic clasts, white mica, albite, and carbonaceous material; trace leucoxene

rough to wiggly anastomosing gradational cleavage with discontinuous shear bands in P domains; heavily altered with no clear sense of shear
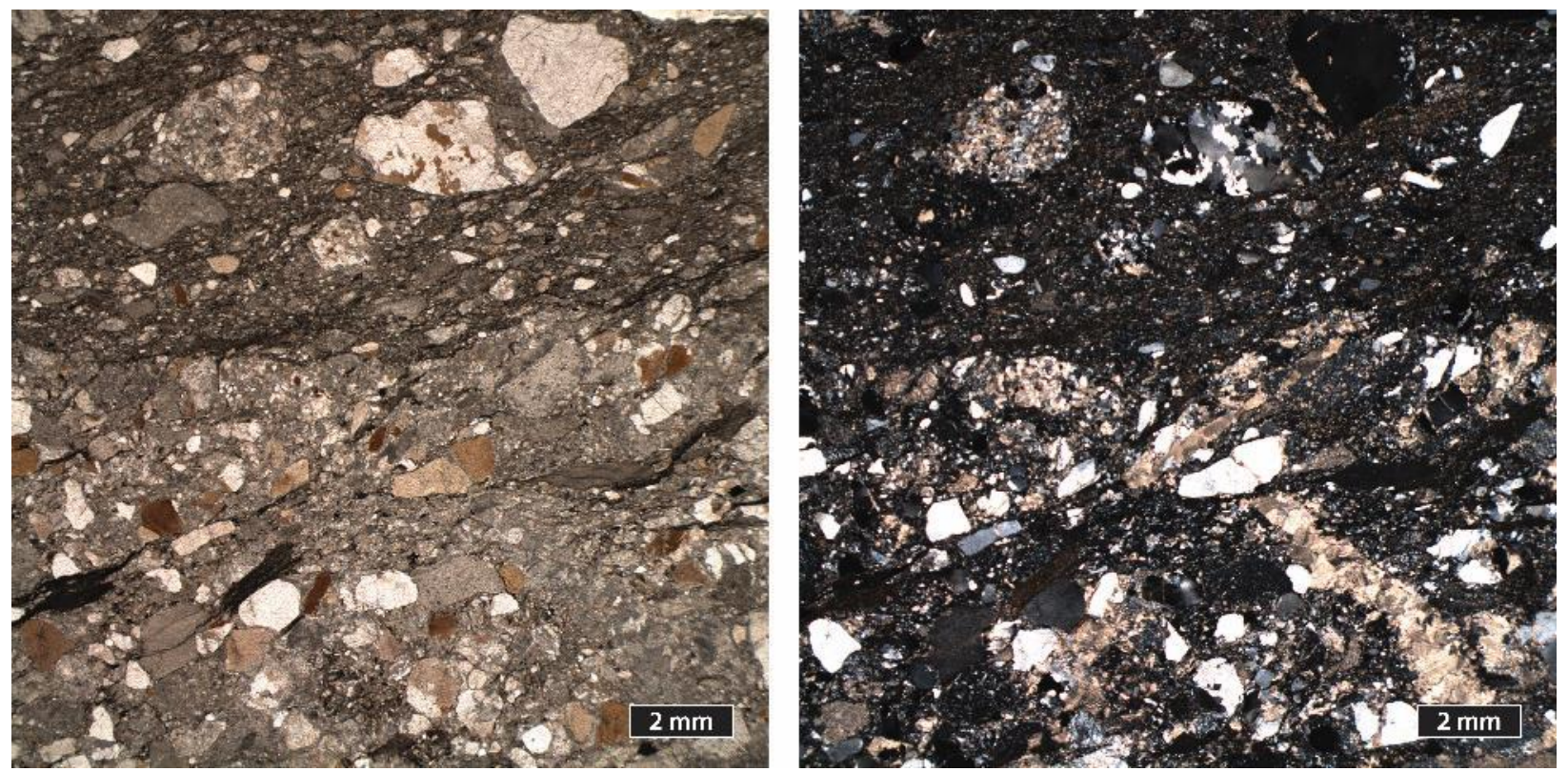

Photomicrographs of thin section, 10x/FOV 15 mm, PPL (left), XPL (right). 
Sample continued 07DF15
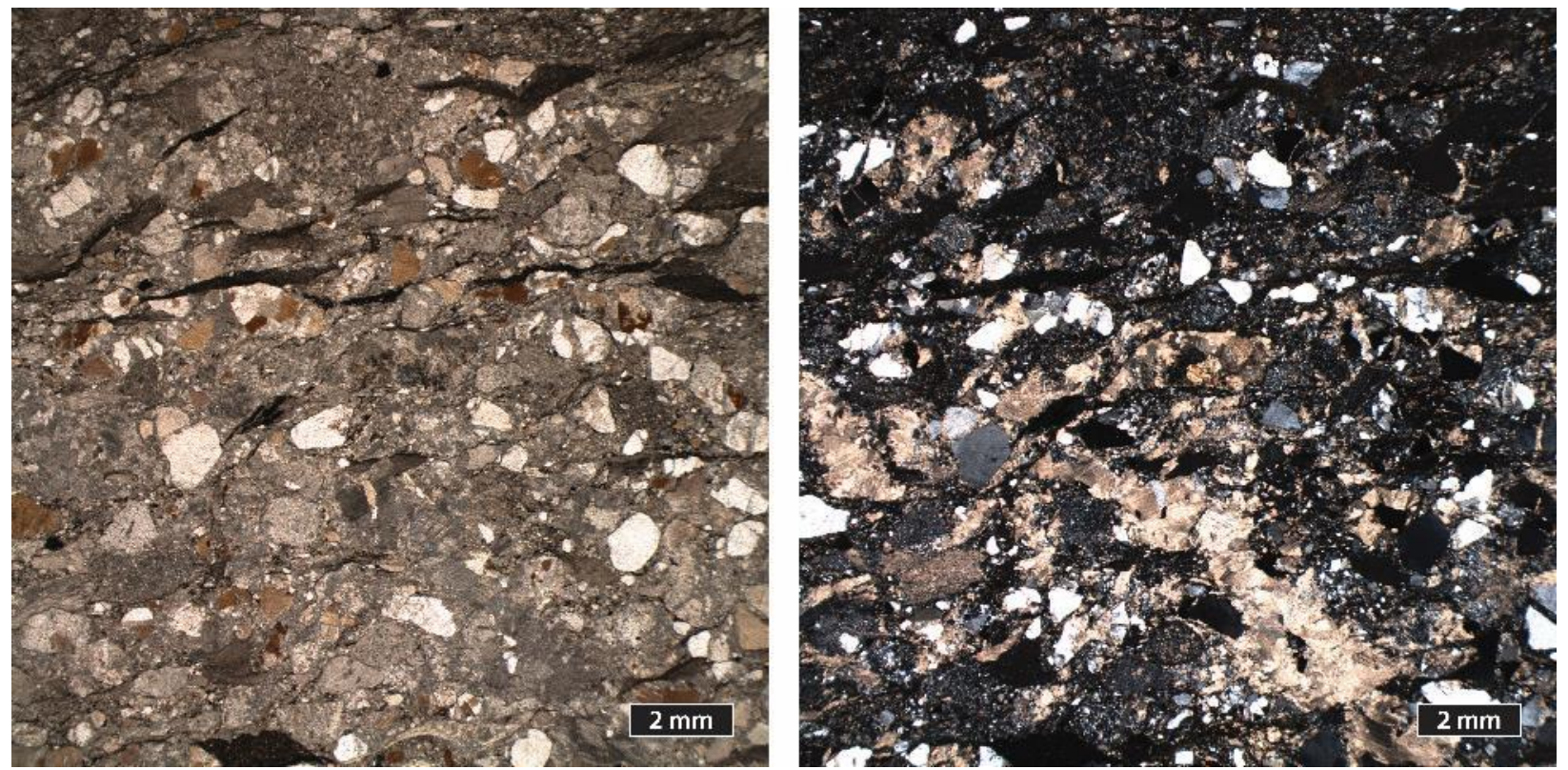

Photomicrographs of thin section, 10x/FOV $15 \mathrm{~mm}$, PPL (left), XPL (right). 
Sample ID:

Unit:

Lat, Long

Assemblage:

Additional analysis:

Lithology:

Description:

Structure:
10DF15

€Oac

67.88050, -150.79842

Apoon

RSCM (this study) nonoriented

black phyllite

very fine quartz, white mica, carbonaceous material, and leucoxene divided into pebble sized zones carbonaceous material-poor zones possibly representing deformed siltstone clasts and darker carbonaceous material-rich zones; calcite occurs as cement within initially bladed quartz-lined veins

anastomosing spaced to zonal cleavage with finer continuous cleavage in $\mathrm{Q}$ domains; $\mathrm{P}$ domains have discontinuous crenulation and some development of C'-type shear bands
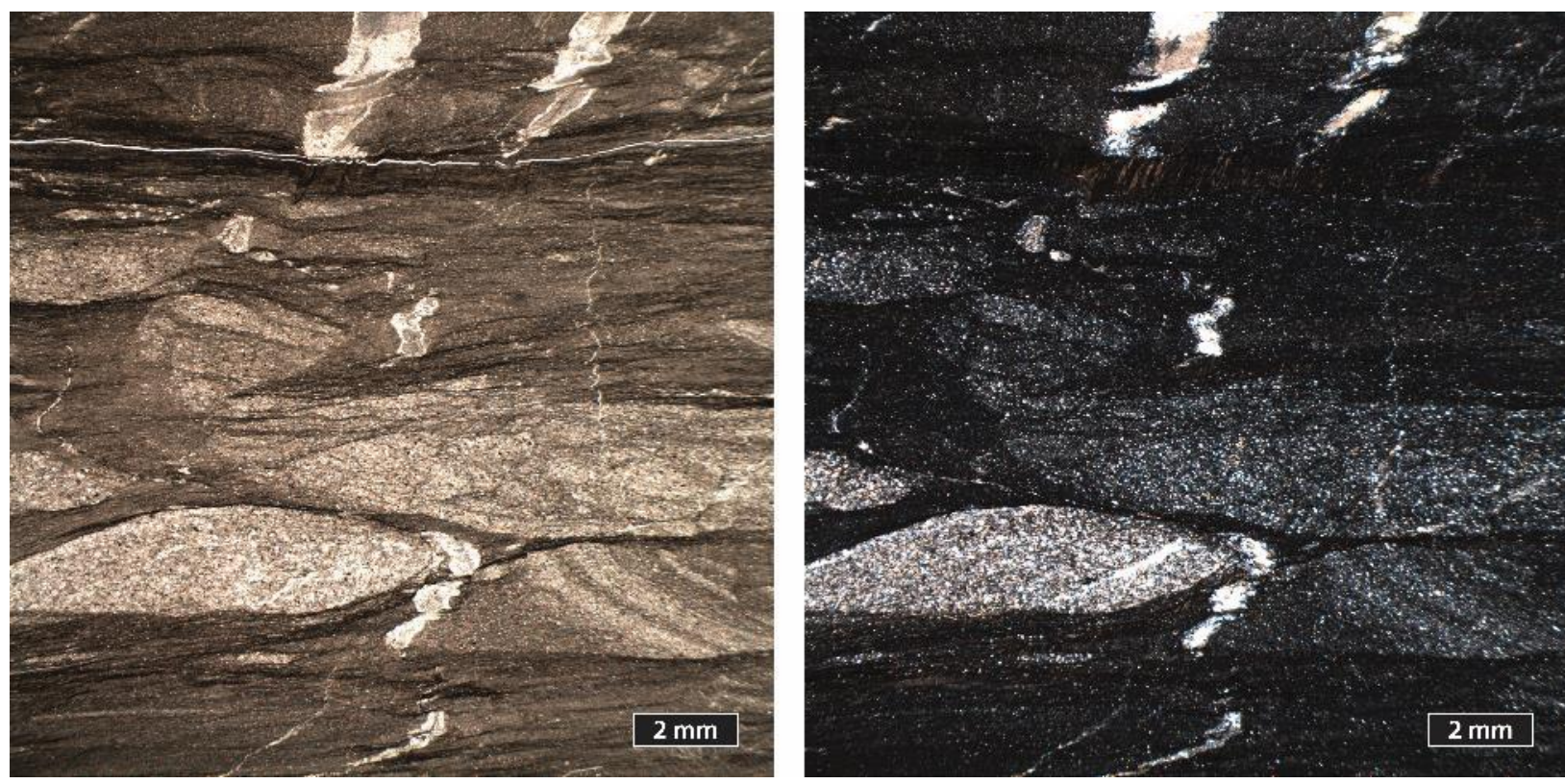

Photomicrographs of thin section, 10x/FOV 15 mm, PPL (left), XPL (right). 
Sample ID:

Unit:

Lat, Long

Assemblage:

Lithology:

Description:

Structure:
22DF15

Dek

$67.90948,-150.75606$

Ellesmerian nonoriented

meta-sandstone

medium quartz to $1 \mathrm{~mm}$ predominant, grades to very fine; common white mica and carbonaceous material; trace quartzite, biotite, chlorite, and calcite; rare leucoxene; very rare possible pyroxene smooth parallel to anastomosing gradational zonal to continuous cleavage
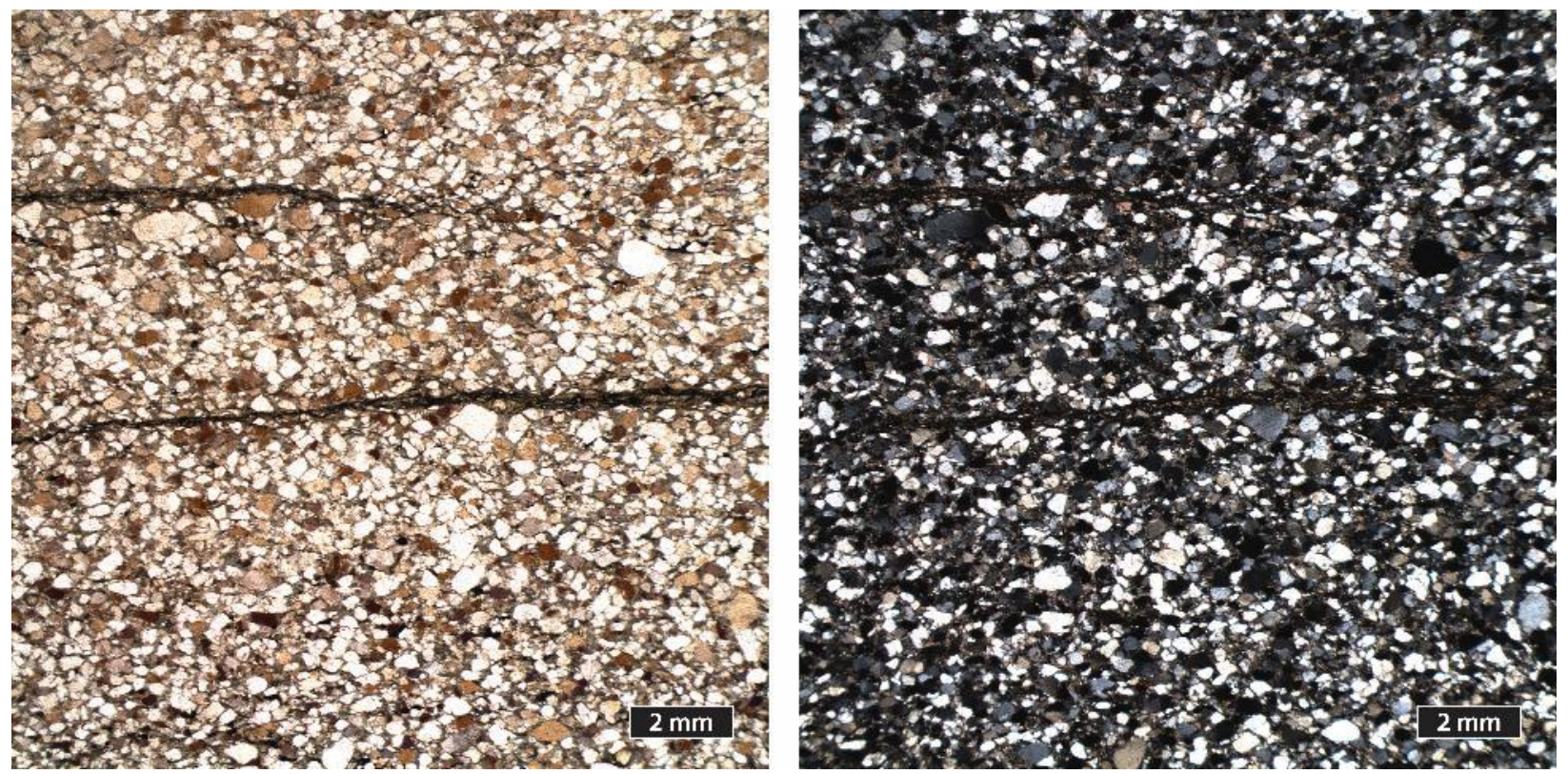

Photomicrographs of thin section, 10x/FOV 15 mm, PPL (left), XPL (right). 
Sample ID:

Unit:

Lat, Long

Assemblage:

Additional analysis:

Lithology:

Description:

\section{DF15}

Dek

$67.90790,-150.75217$

Ellesmerian

U-Pb zircon geochronology (Frier 2017), RSCM (this study)

meta- sandy mud-clast conglomerate

deformed siltstone clasts to pebble size with monocrystalline quartz and quartzite grains to $1 \mathrm{~mm}$; grain size distribution made ambiguous by deformed quartz veins within sample; common white mica; trace carbonaceous material; rare biotite, hematite, and leucoxene rough to wiggly spaced discrete cleavage; abundant deformed veins

Structure:

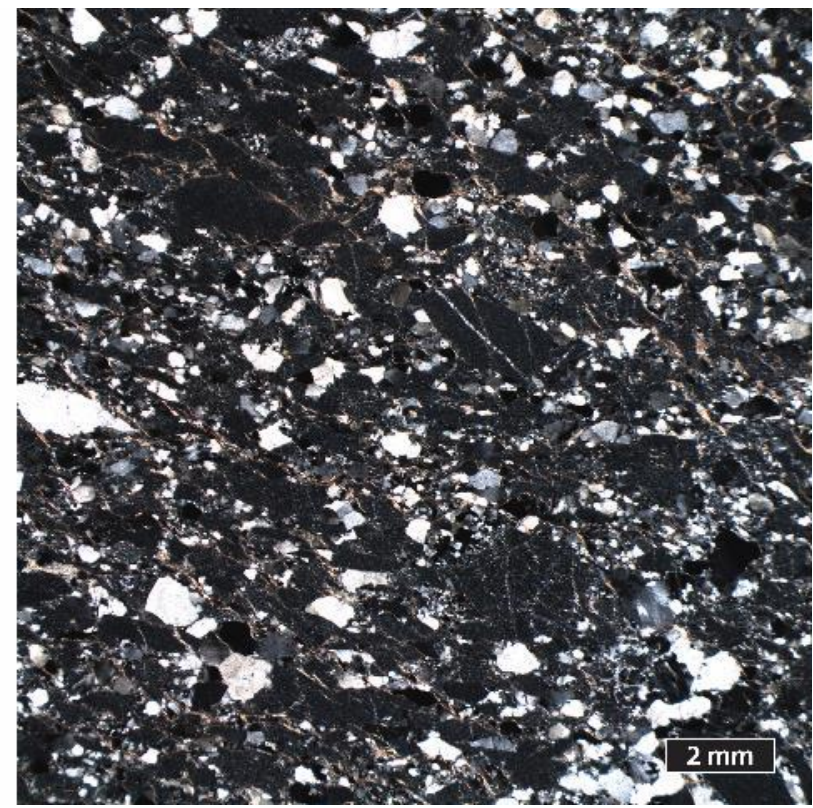

Photomicrographs of thin section, 10x/FOV $15 \mathrm{~mm}$, PPL (left), XPL (right). 
Sample ID:

Unit:

Lat, Long

Assemblage:

Additional analysis:

Lithology:

Description:

Structure:
26DF15

Dhf

67.93312, -150.77828

Endicott Mountains

U-Pb zircon geochronology (Frier 2017), RSCM (this study)

meta-graywacke

fine to medium quartz with abundant microcrystalline quartz as altered volcanic grains; abundant calcite and white mica; common hematite; scattered siderite; rare zircon and albite rough to wiggly continuous domainal cleavage
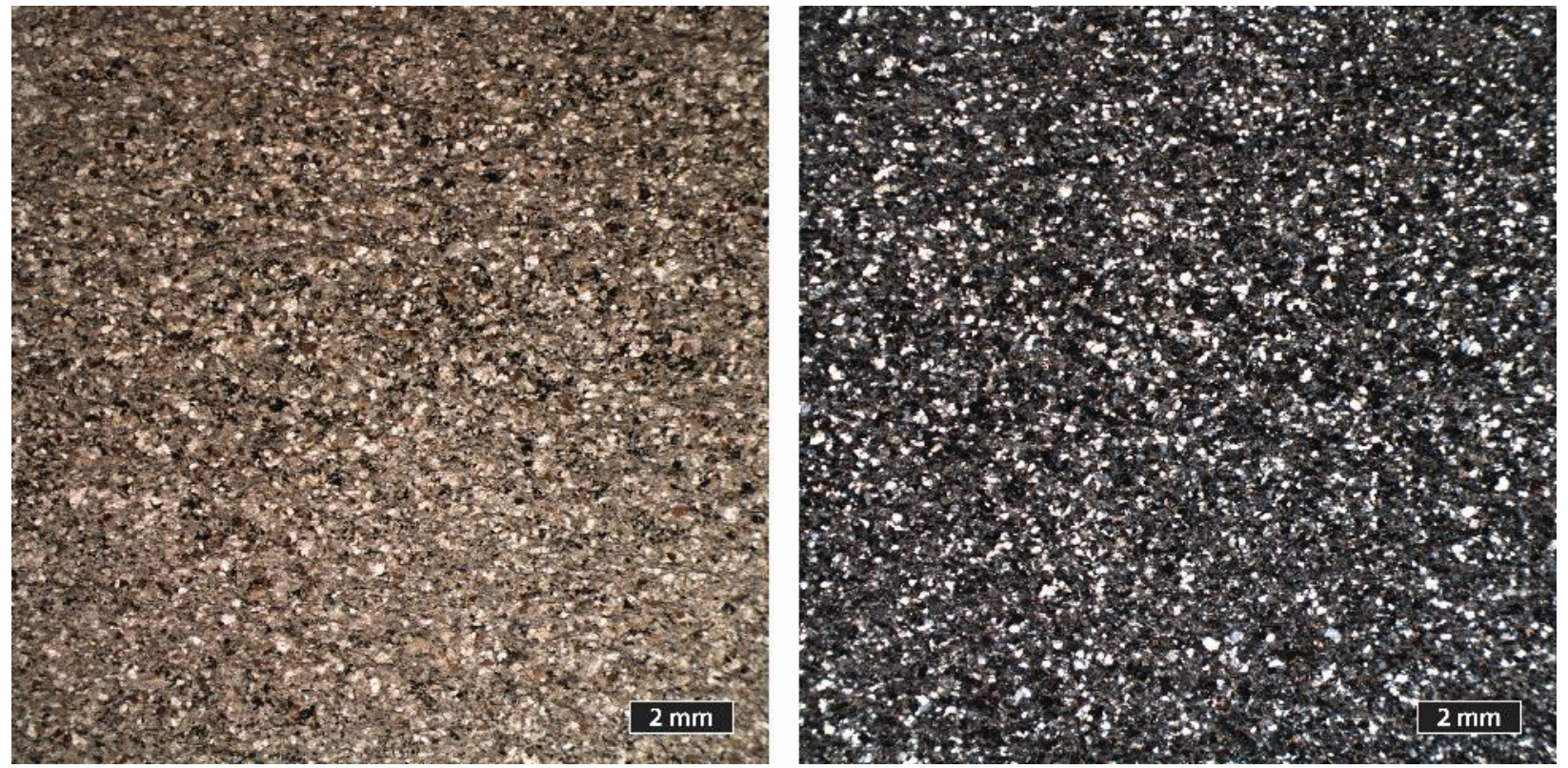

Photomicrographs of thin section, 10x/FOV 15 mm, PPL (left), XPL (right). 
Sample ID:

Unit:

Lat, Long

Assemblage:

Additional analysis:

Lithology:

Description:

Structure:
28DF15

Dsg

67.91529, -150.85195

Endicott Mountains

RSCM (this study) nonoriented

pebbly phyllite

stretched siltstone pebbles with fine to coarse quartz and quartzite grains; common altered volcanic grains, carbonaceous material, and calcite; scattered siderite, biotite, and leucoxene.

spaced rough to wiggly discrete cleavage between elongate deformed pebbles; common veins
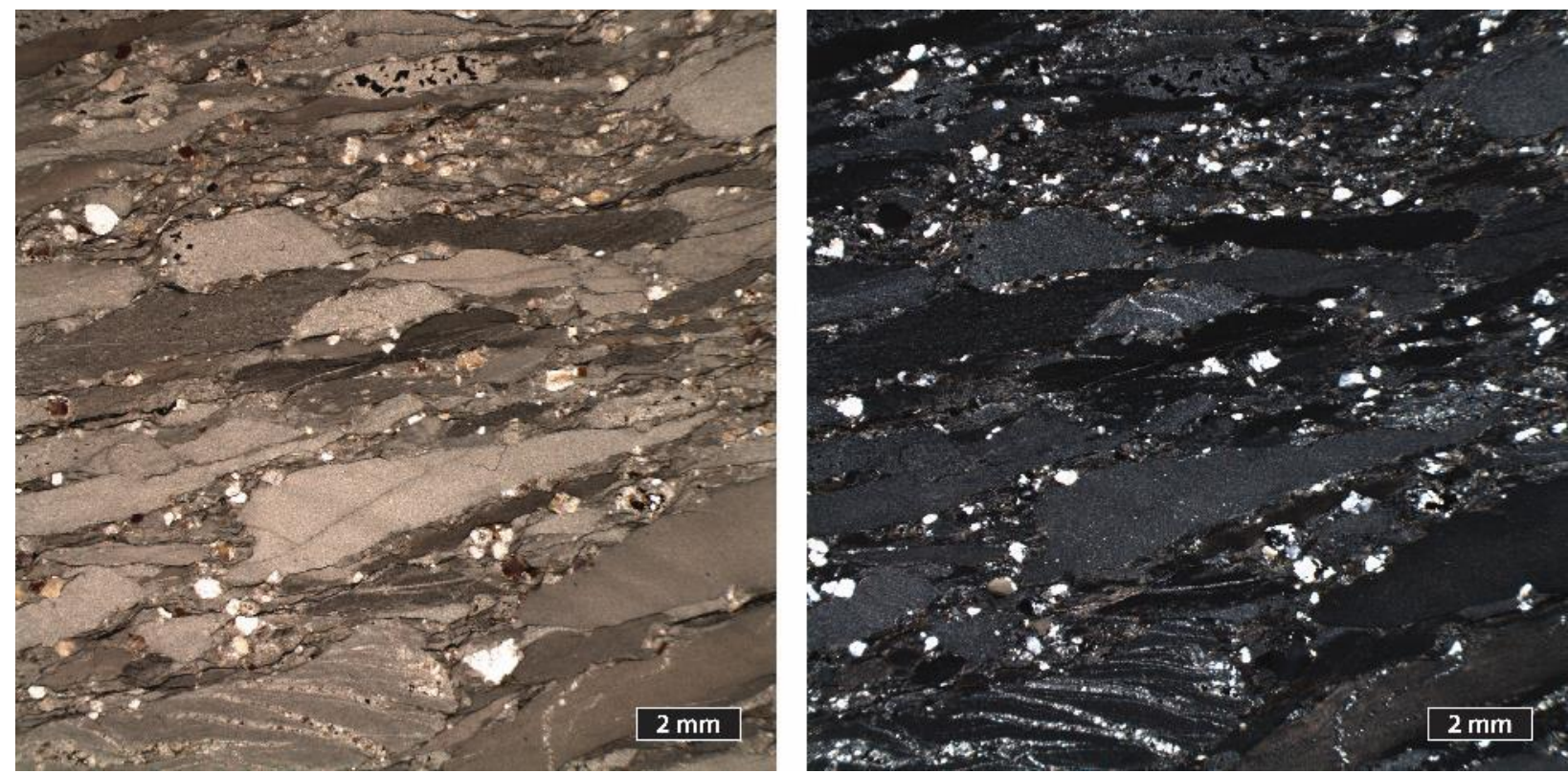

Photomicrographs of thin section, 10x/FOV 15 mm, PPL (left), XPL (right). 
Sample ID:

Unit:

Lat, Long

Assemblage:

Lithology:

Description:

Structure:

\section{DF15}

Dsg

67.91370, -150.85324

Endicott Mountains non-

oriented

pebbly phyllite

stretched siltstone pebbles with fine to coarse quartz and quartzite grains; grain size distribution obscured by altered veins; common altered volcanic grains and white mica; scattered siderite, hematite, carbonaceous material; rare chlorite and leucoxene spaced rough to wiggly discrete cleavage between elongate deformed pebbles; common veins
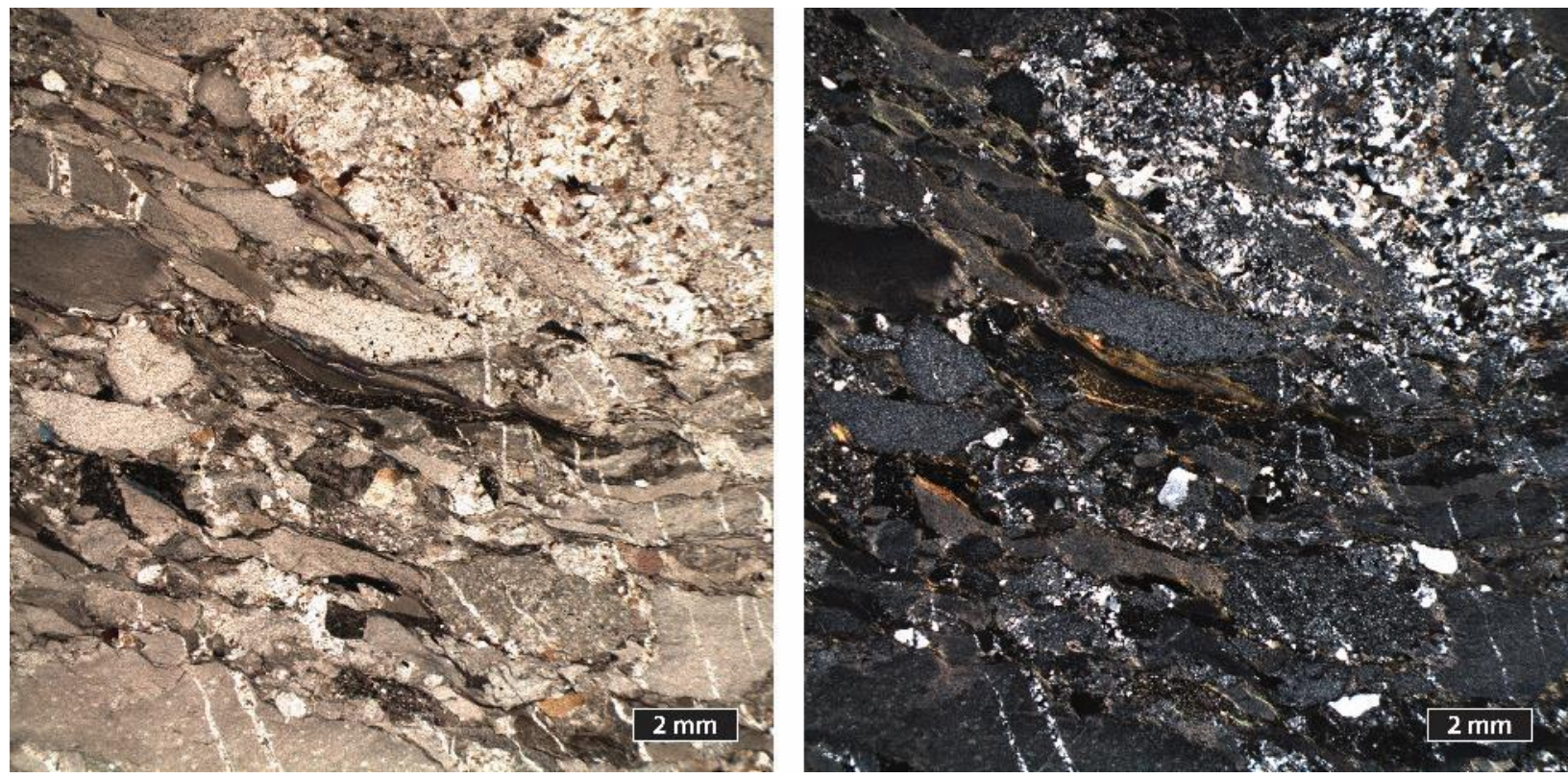

Photomicrographs of thin section, 10x/FOV 15 mm, PPL (left), XPL (right). 
Sample ID:

Unit:

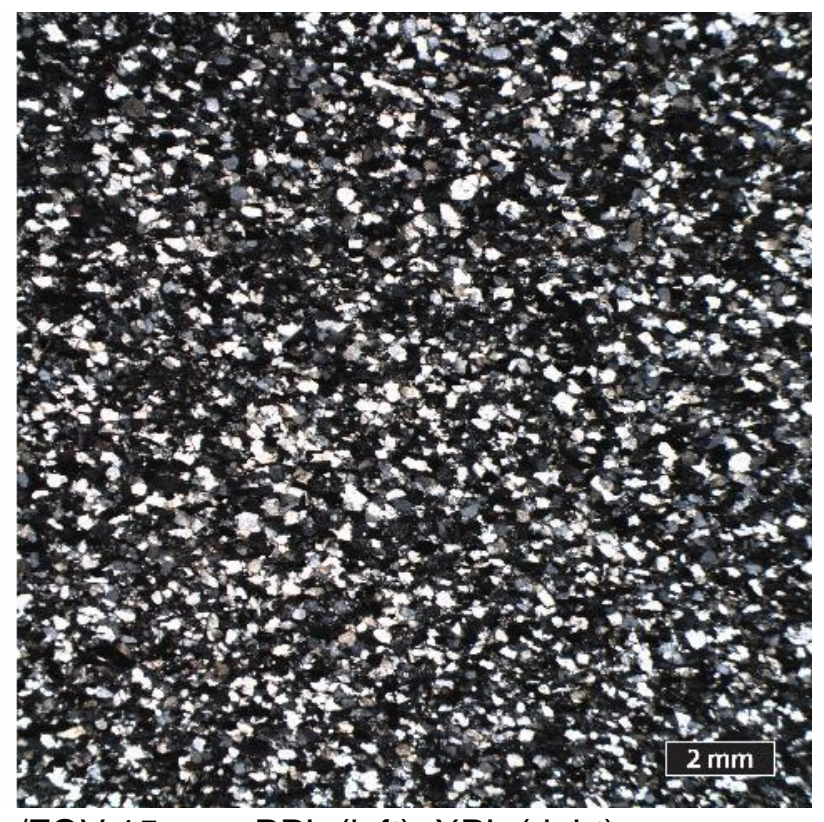

Photomicrographs of thin section, 10x/FOV $15 \mathrm{~mm}$, PPL (left), XPL (right). nonoriented fine to medium quartz and siltstone clasts; scattered white mica and carbonaceous material; trace leucoxene; rare biotite, albite, and chlorite rough to wiggly, discontinuous discrete domainal cleavage
Lat, Long

Assemblage:

Lithology:

Description:

Structure:

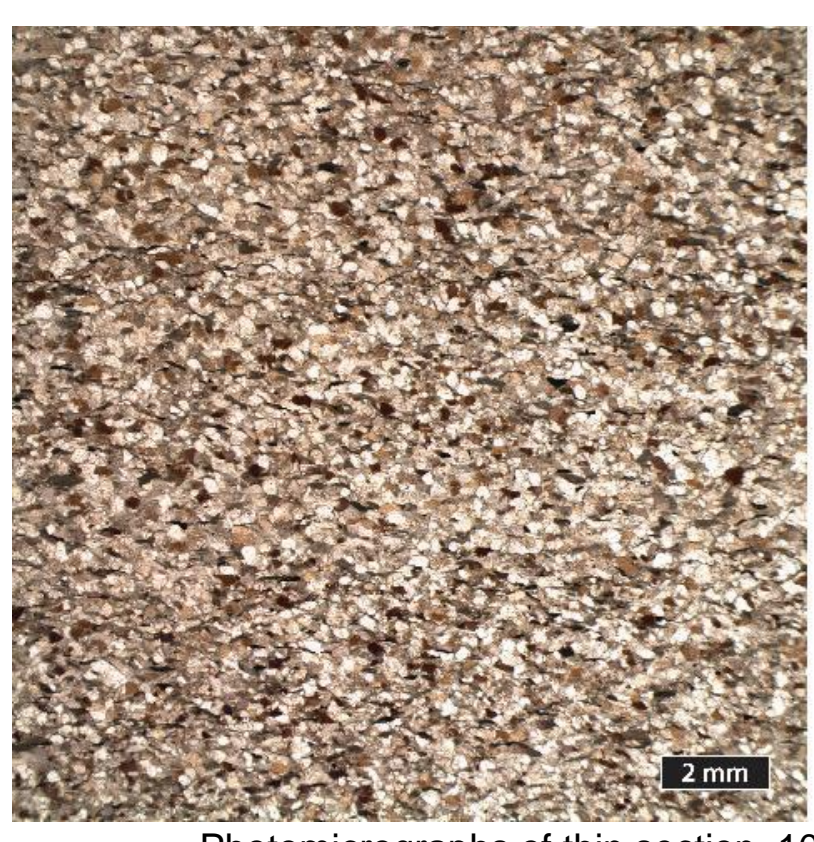

67.91922, -150.90502

Endicott Mountains

$$
\text { i. }
$$


Sample ID:

Unit:

Lat, Long

Assemblage:

Lithology:

Description:

Structure:
42DF15

Dsg

67.89067, -150.93101

Endicott Mountains nonoriented

meta-graywacke

highly altered; quartz and microcrystalline quartz as altered volcanics; abundant calcite; common siderite and leucoxene; trace carbonaceous material; rare white mica and biotite rough spaced discontinuous gradational cleavage; fabric obscured by alteration
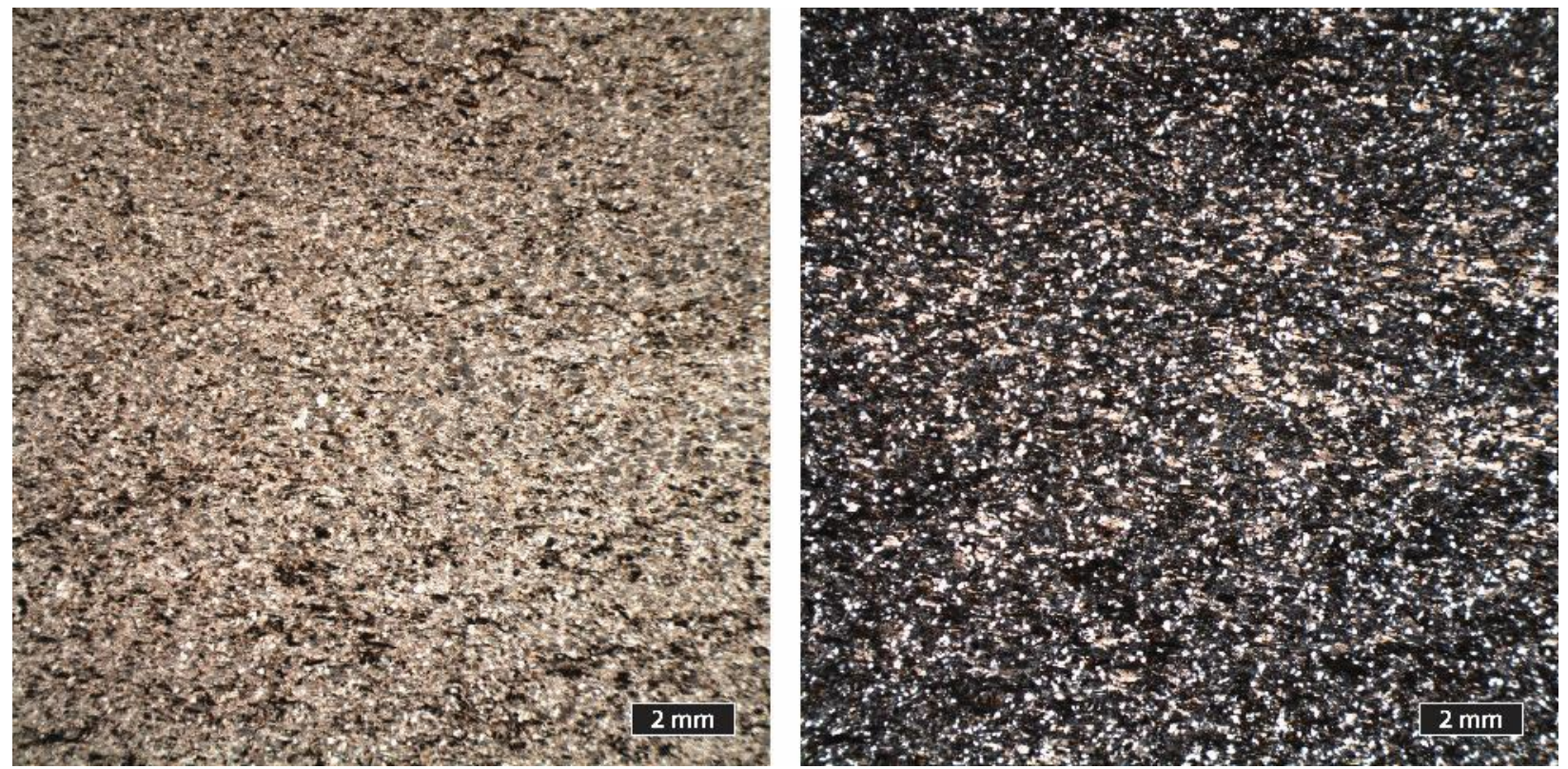

Photomicrographs of thin section, 10x/FOV 15 mm, PPL (left), XPL (right). 
Sample ID:

Unit:

Lat, Long

Assemblage:

Additional analysis:

Lithology:

Description:

Structure:
43DF15

Dsg

67.88953, -150.93579

Endicott Mountains

U-Pb zircon geochronology (Frier 2017), RSCM (this study)

phyllitic sandstone

medium to fine grained quartz and siltstone grains with coarse deformed siltstone clasts between white mica- and carbonaceous material-rich $P$ domains; trace leucoxene and chlorite; trace biotite and zircon continuous spaced parallel to anastomosing discrete disjunctive cleavage
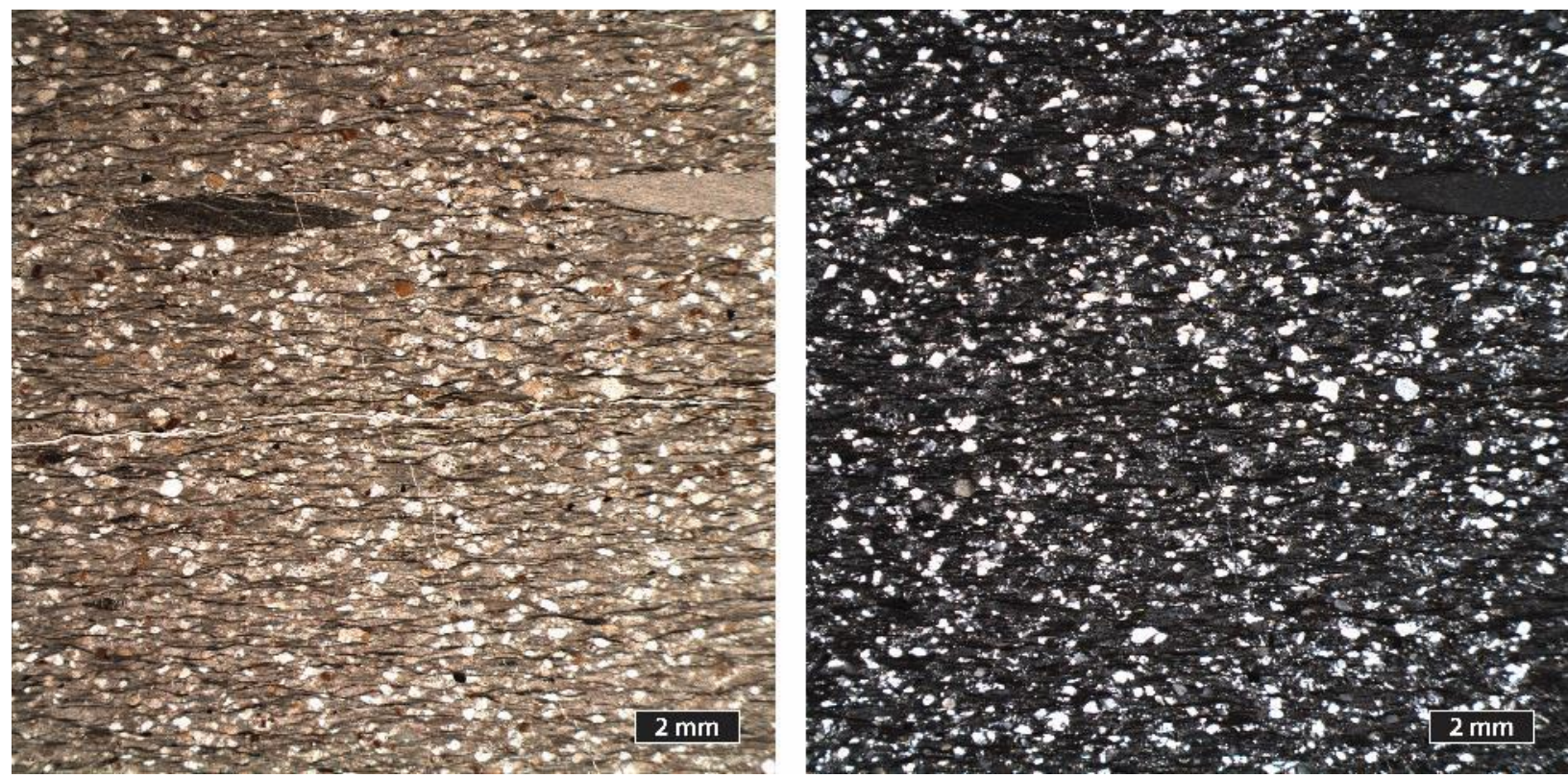

Photomicrographs of thin section, 10x/FOV 15 mm, PPL (left), XPL (right). 
Sample ID:

Unit:

Lat, Long

Assemblage:

Additional analysis:

Lithology:

Description:

Structure:

\section{DF15}

Dsg

67.88953, -150.93579

Endicott Mountains

RSCM (this study)

\section{non-}

oriented

mud-clast phyllite

deformed siltstone clasts predominant with abundant quartz and quartzite; common white mica and carbonaceous material; scattered siderite; rare biotite and leucoxene

spaced smooth to rough parallel to anastomosing disjunctive cleavage; abundant quartz-filled veins
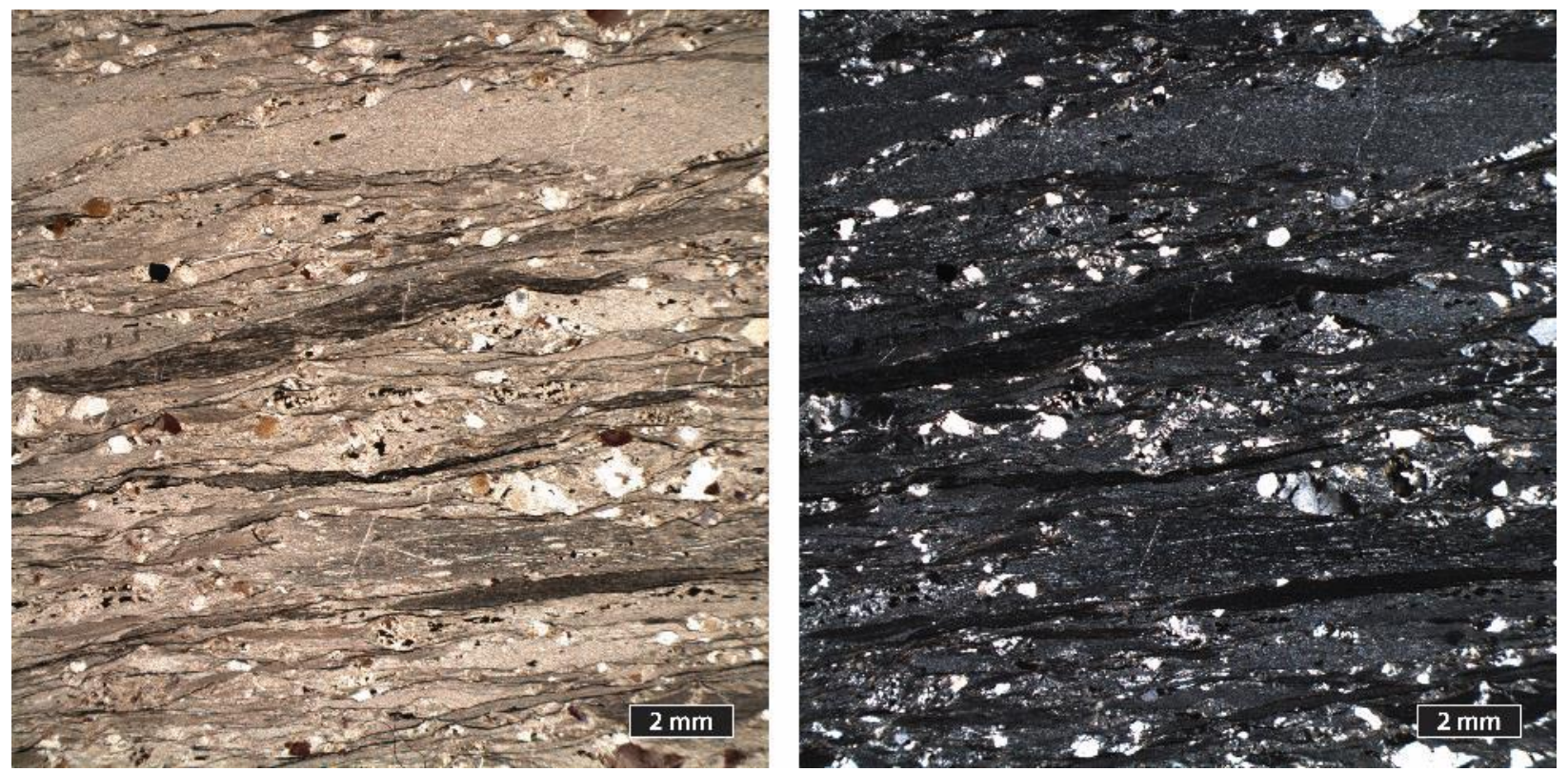

Photomicrographs of thin section, 10x/FOV 15 mm, PPL (left), XPL (right). 
Sample ID:

Unit:

Lat, Long

Assemblage:

Lithology:

Description:
45DF15

Dsg

67.88953, -150.93579

Endicott Mountains nonoriented

Structure:

meta-graywacke

fine grained quartz with siltstone grains and altered muddy fines;

abundant white mica; common carbonaceous material; scattered siderite; rare biotite, leucoxene, and calcite

poorly developed rough to wiggly spaced gradational cleavage
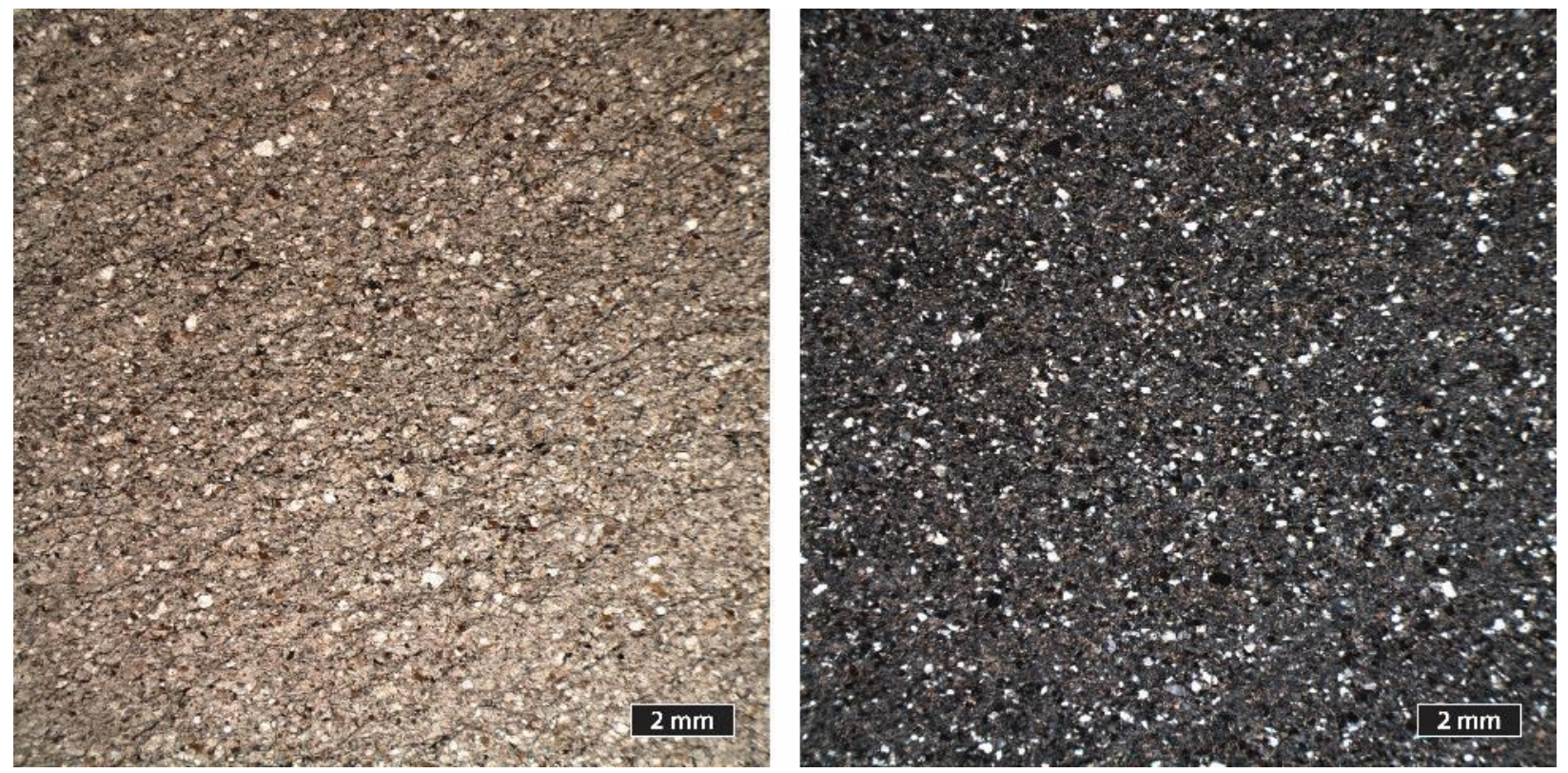

Photomicrographs of thin section, 10x/FOV 15 mm, PPL (left), XPL (right). 
Sample ID:

Unit:

Lat, Long

Assemblage:

Additional analysis:

Lithology:

Description:

Structure:

\section{DF15}

Dsg

67.88461, -150.89492

Endicott Mountains

RSCM (this study) nonoriented
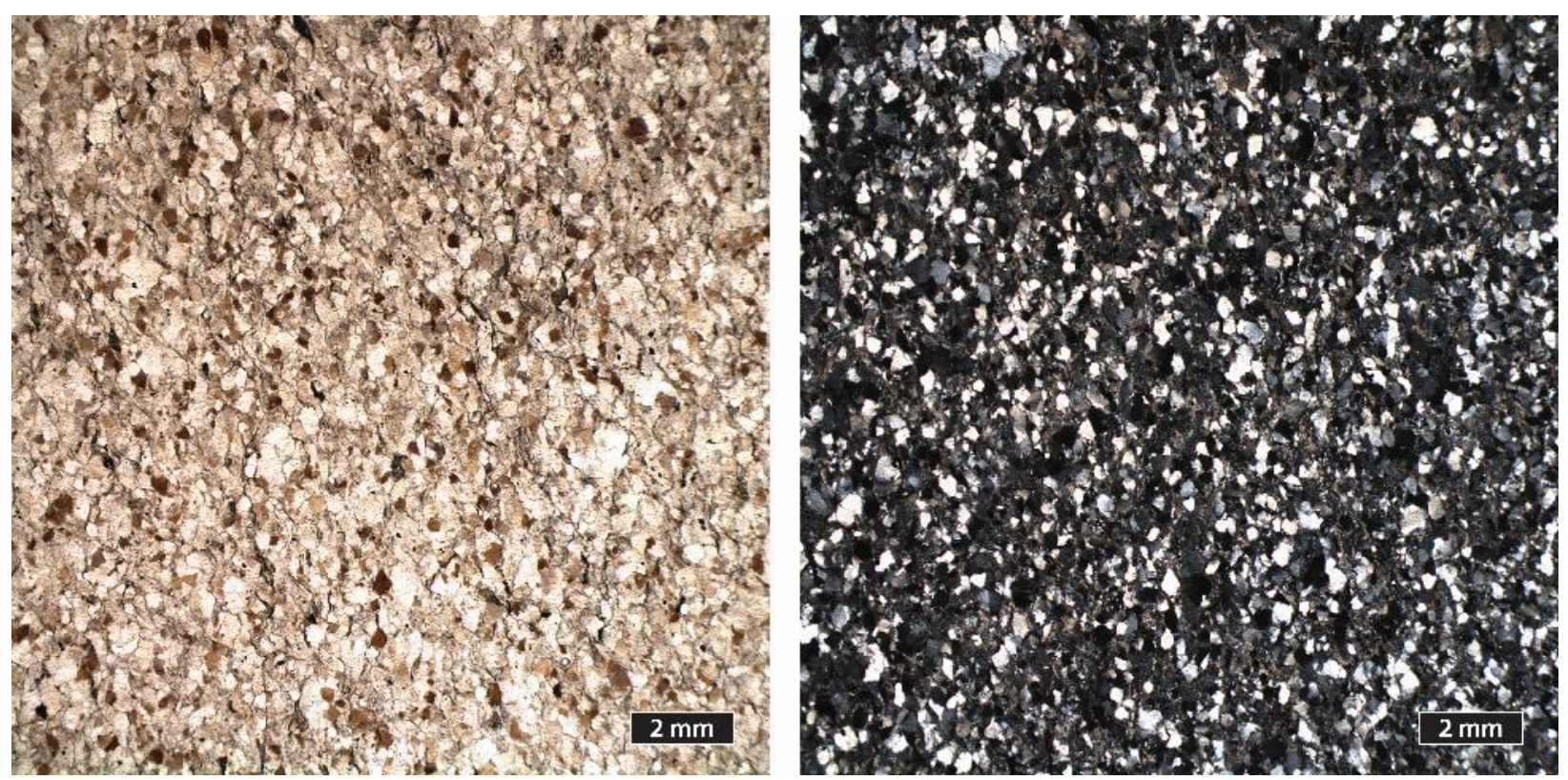

Photomicrographs of thin section, 10x/FOV 15 mm, PPL (left), XPL (right). 
Sample ID:

Unit:

Lat, Long

Assemblage:

Lithology:

Description:
47DF15

Dsg

67.87932, -150.89575

Endicott Mountains nonoriented

meta-volcaniclastic sandstone

highly altered; medium to very fine quartz; common calcite, altered volcanics, albite, white mica, and hematite; scattered carbonaceous material; trace leucoxene and detrital white mica; rare biotite, zircon, and chlorite

Structure: nascent rough gradational cleavage obscured by alteration
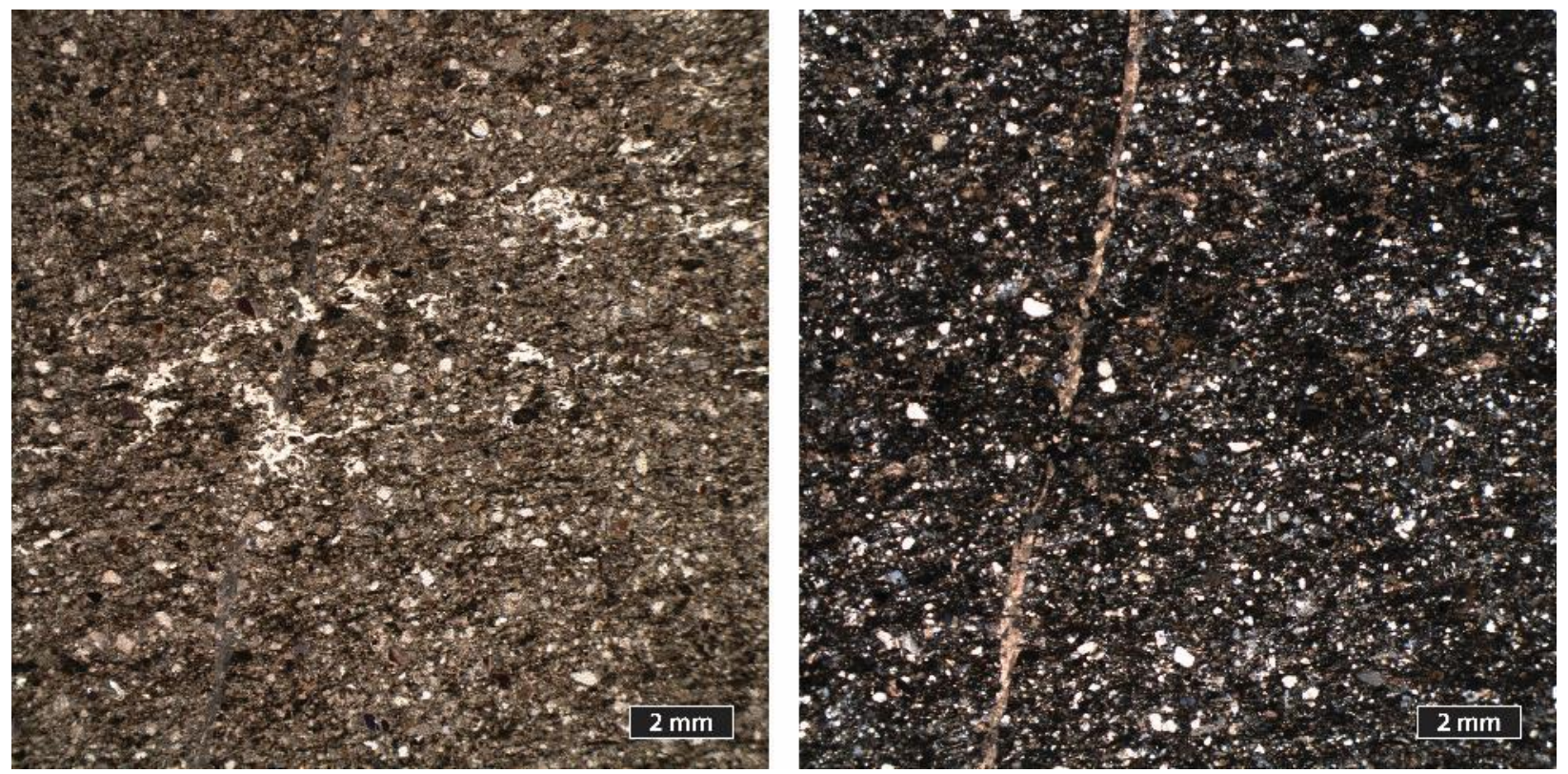

Photomicrographs of thin section, 10x/FOV 15 mm, PPL (left), XPL (right). 
Sample ID:

Unit:

Lat, Long

Assemblage:

Additional analysis:

Lithology:

Description:

Structure:

\section{JT02}

Dtc

67.69817, -151.00506

Hammond

RSCM (this study)

calcareous sandstone

very fine to medium quartz and calcite; scattered carbonaceous material and pyrite; rare hematite; appears mostly recrystallized

spaced poorly developed cleavage in carbonaceous material; appears to follow bedding
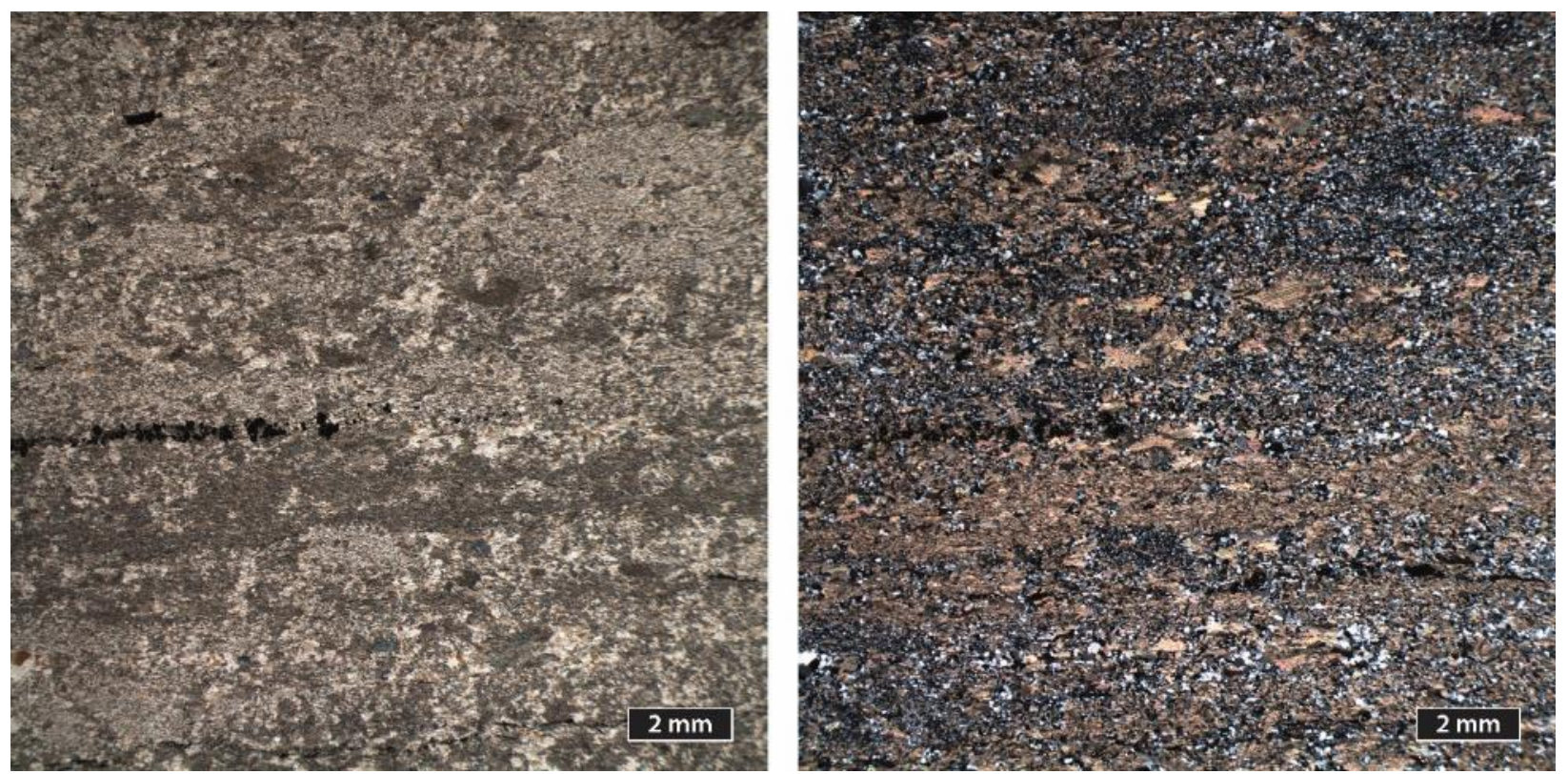

Photomicrographs of thin section, 10x/FOV $15 \mathrm{~mm}$, PPL (left), XPL (right). 
Sample ID:

Unit:

Lat, Long

Assemblage:

Additional analysis:

Lithology:

Description:

Structure:

Sense of shear:

\section{JT04}

Ddr

67.64228, -151.02080

Hammond

RSCM (this study)

black phyllite

very fine quartz with altered very fine matrix of abundant carbonaceous material, white mica, and chlorite; trace biotite and hematite gradational irregular cleavage following bedding with messy C'-type shear bands in poorly developed crenulation; C'-type bands show sinistral sense of shear

S2 top to south
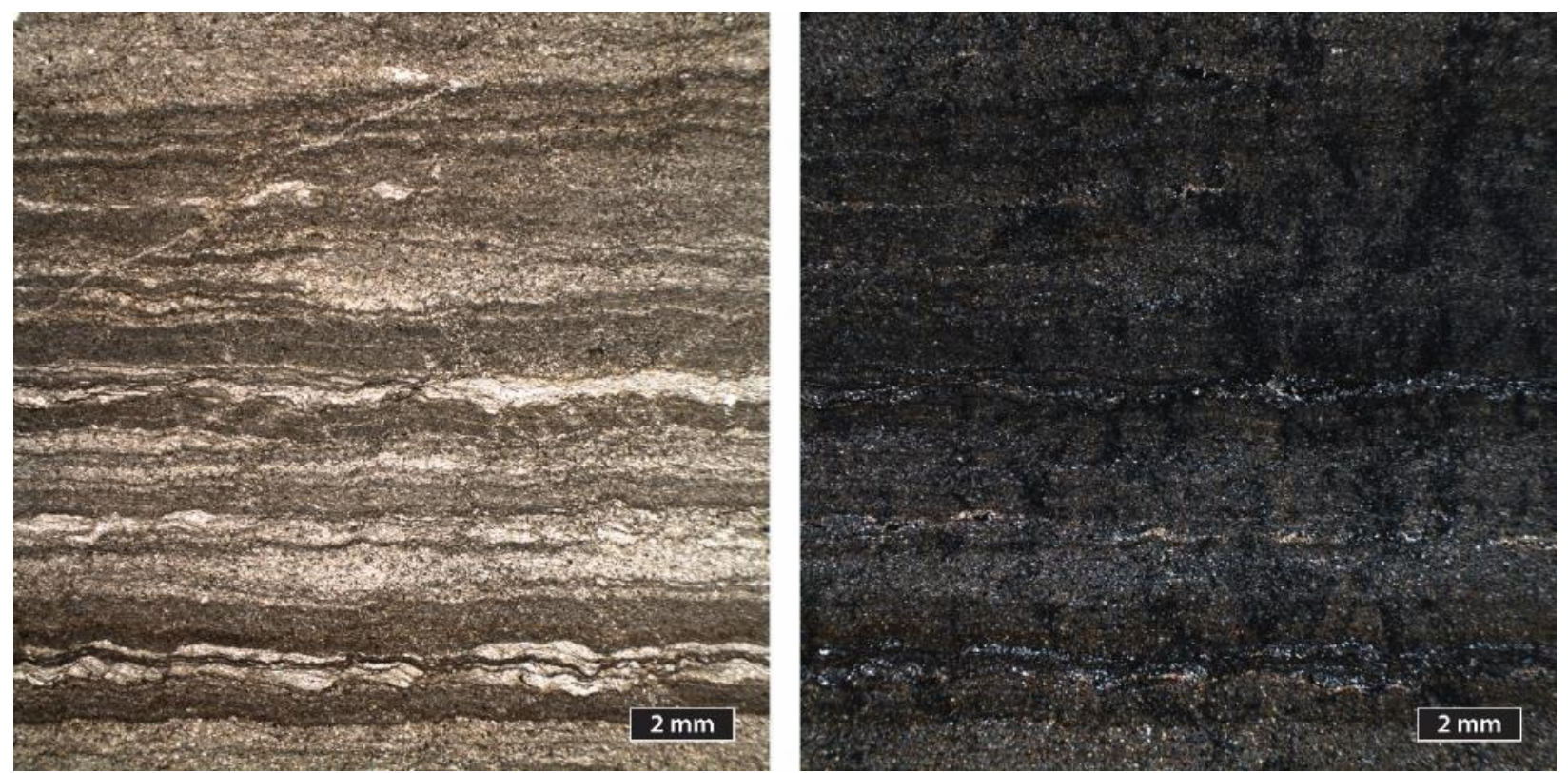

Photomicrographs of thin section, 10x/FOV 15 mm, PPL (left), XPL (right). 
Sample ID:

Unit:

Lat, Long

Assemblage:

Lithology:

Description:

Structure:
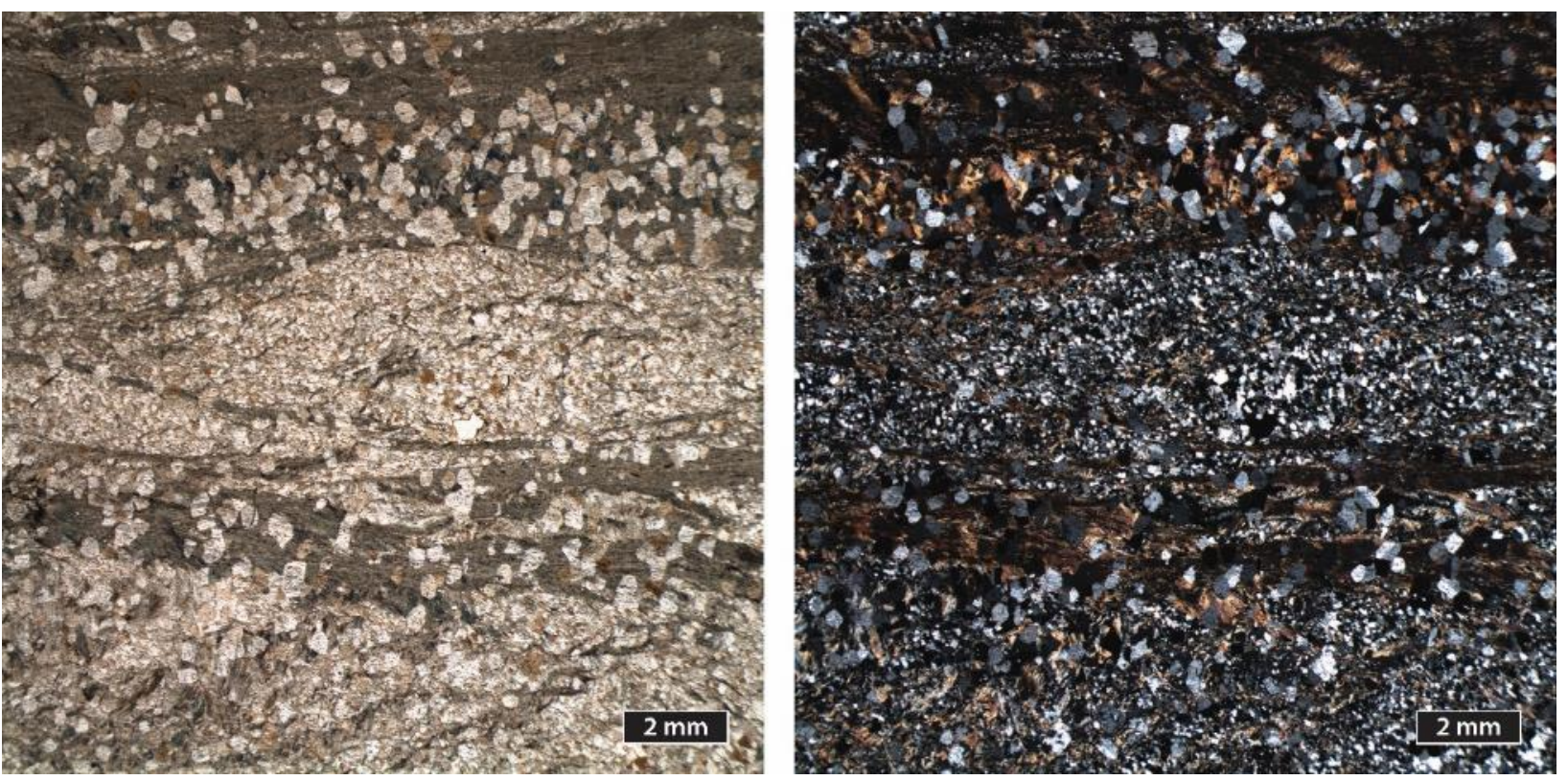

Photomicrographs of thin section, 10x/FOV $15 \mathrm{~mm}$, PPL (left), XPL (right).
15JT06

outside map area

$67.46085,-150.86025$

Hammond

mica schist

quartz, white mica, and metamorphic albite; rare zircon; fine possible carbonaceous material in $\mathrm{P}$ domains

continuous cleavage; well-developed C-type shear bands 
Sample ID:

Unit:

Lat, Long

Assemblage:

Lithology:

Description:

Structure:

Sense of shear:
15JT07

outside map area

$67.45883,-150.83429$

Hammond

chlorite-mica schist

quartz with abundant chlorite and white mica; common calcite; scattered hematite and possible carbonaceous material; trace leucoxene well-developed continuous cleavage; scattered C-type shear bands show dextral sense of shear S2 top to west
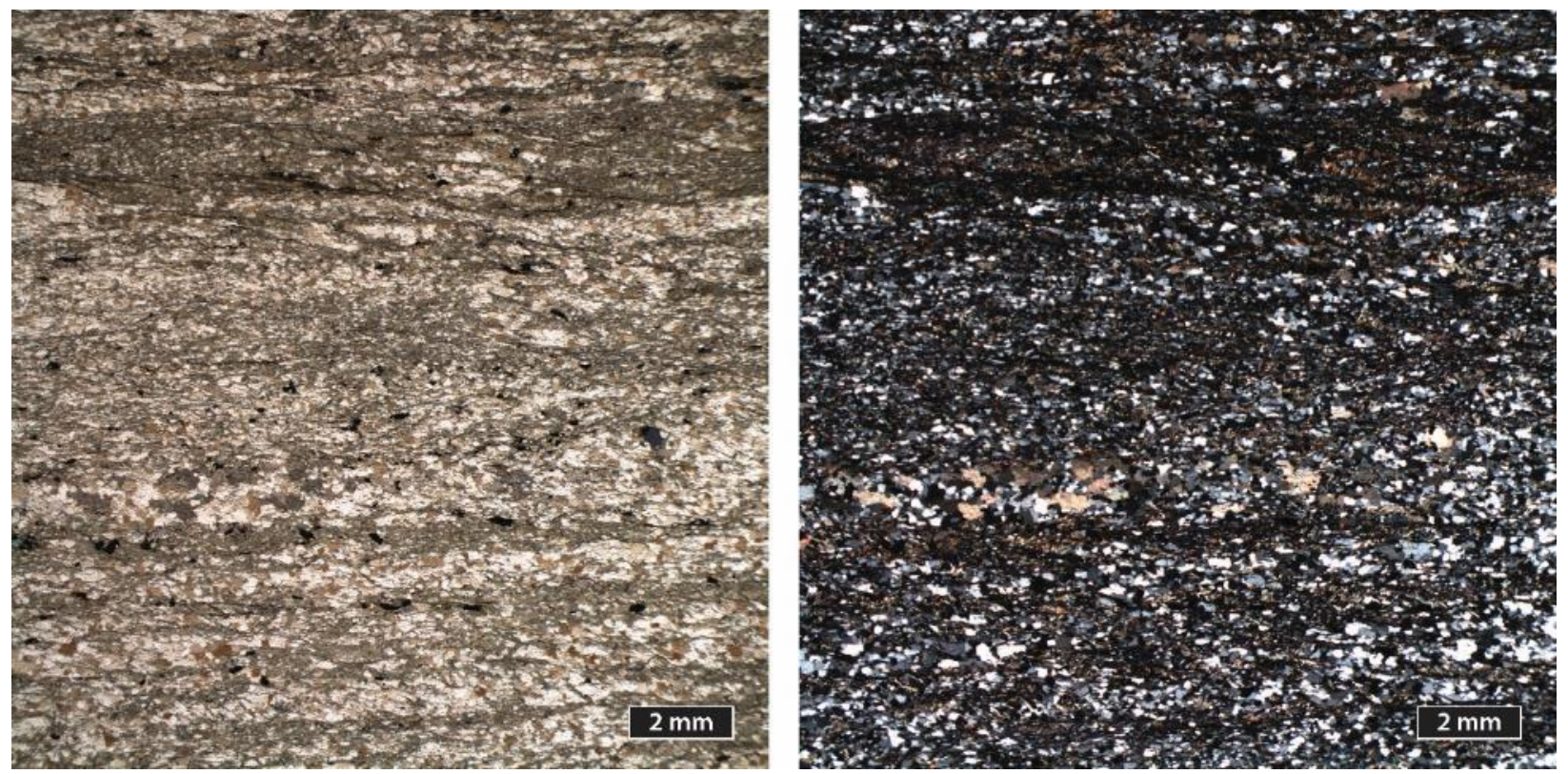

Photomicrographs of thin section, 10x/FOV 15 mm, PPL (left), XPL (right). 
Sample ID:

Unit:

Lat, Long

Assemblage:

Additional analysis:

Lithology:

Description:

Structure:
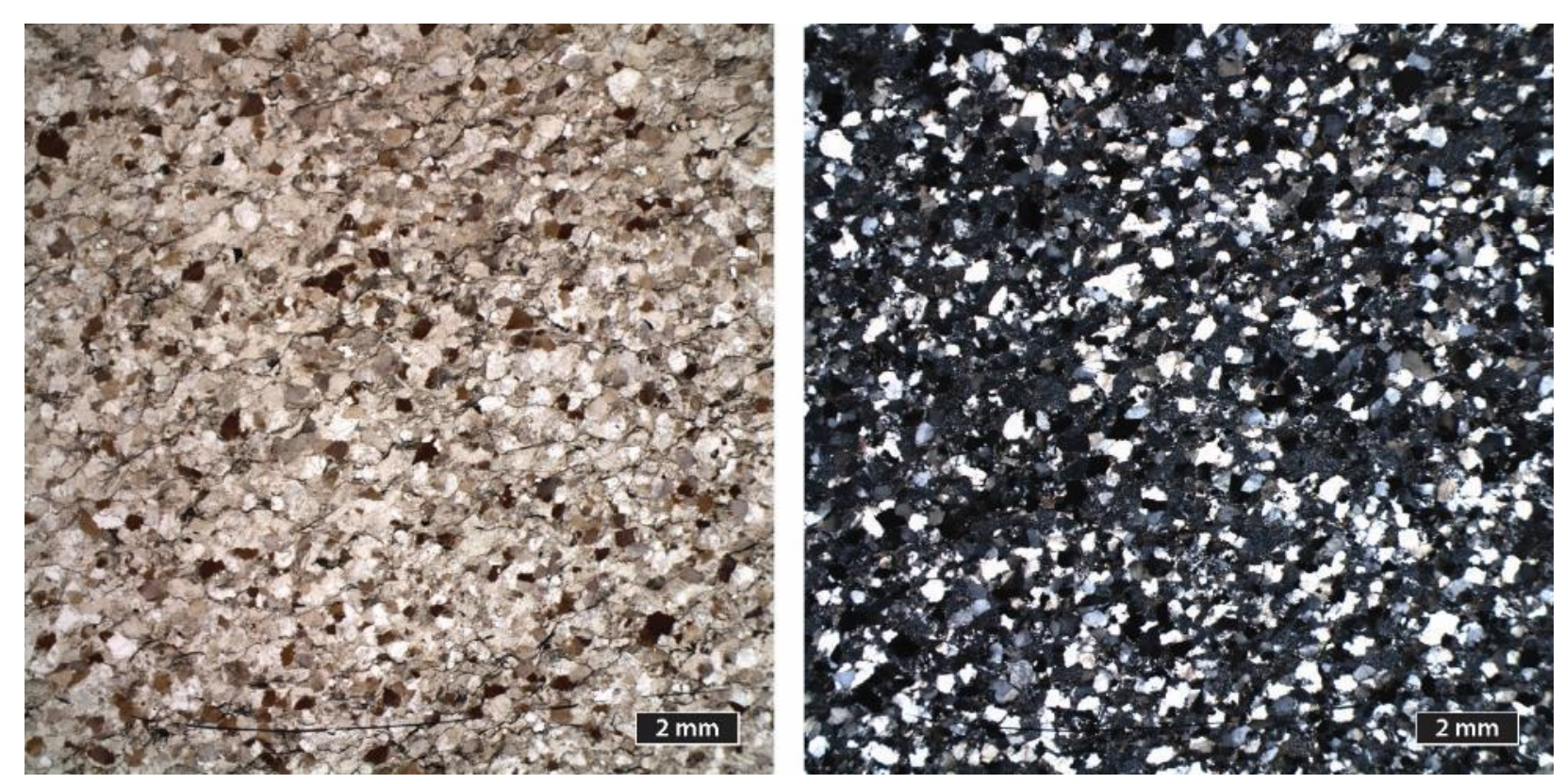

Photomicrographs of thin section, 10x/FOV 15 mm, PPL (left), XPL (right).
J1409-0.6

Dek

67.93050, -150.47083

Ellesmerian

U-Pb zircon geochronology, Lu-HF isotope analysis (Strauss, et al. 2017)

meta-sandstone

medium to coarse quartz and siltstone clasts; abundant quartzite grains; common white mica and carbonaceous material; rare biotite, leucoxene, albite, and calcite

rough to wiggly spaced anastomosing cleavage 
Sample ID:

Unit:

Lat, Long

Assemblage:

Lithology:

Description:

Structure:
$\mathrm{J} 1409-14.2$

Dek

$67.93050,-150.47083$

Ellesmerian

sandy mud-clast meta-conglomerate

medium to coarse quartz and quartzite sand with siltstone and volcanic clasts to pebble size; common white mica; scattered chlorite, hematite, and calcite

very irregular wiggly nascent cleavage in $\mathrm{P}$ domains; abundant quartz filled veins
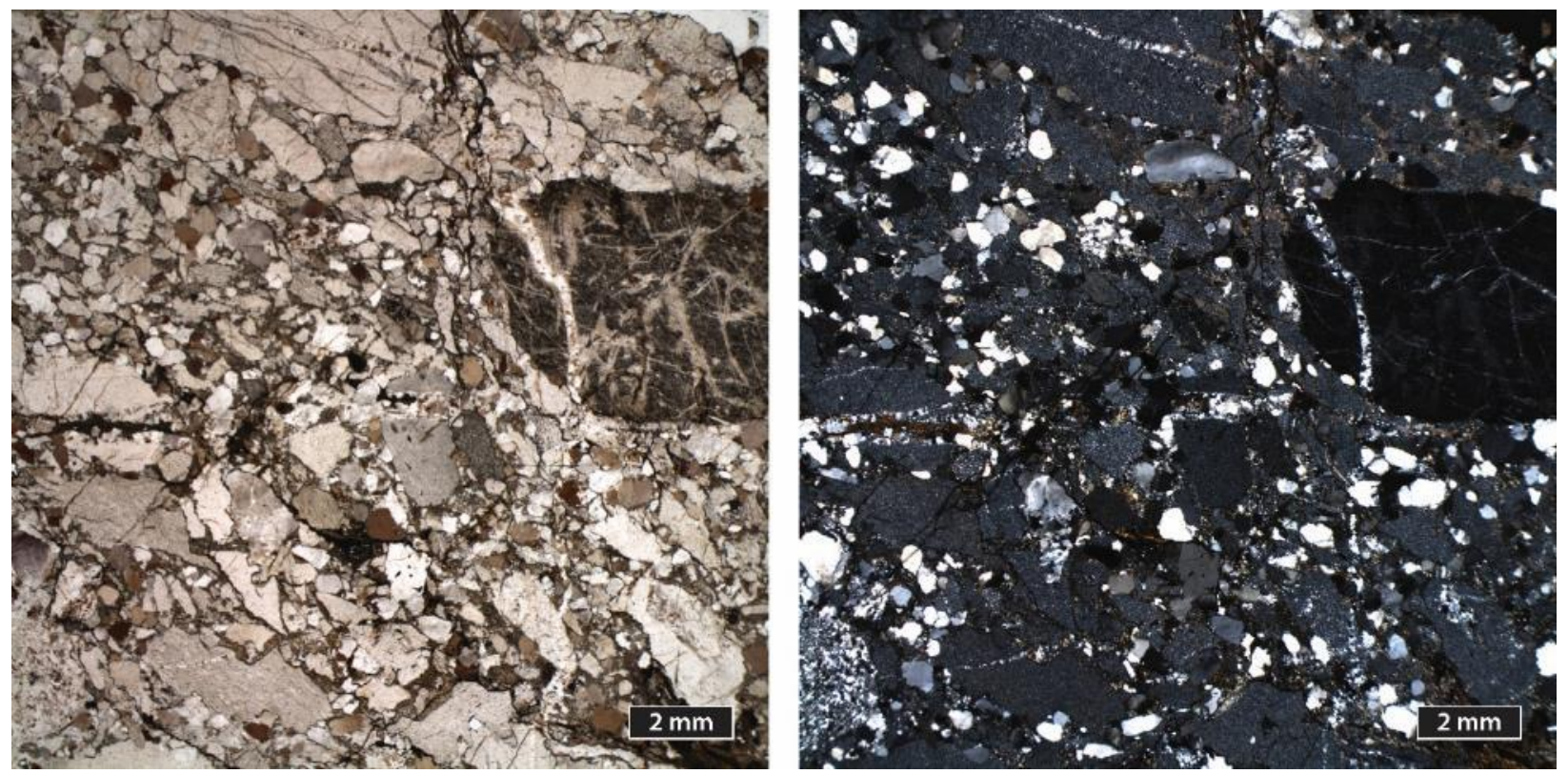

Photomicrographs of thin section, 10x/FOV 15 mm, PPL (left), XPL (right). 
Sample ID:

Unit:

Lat, Long

Assemblage:

Lithology:

Description:

Structure:
J1409-17.1

Dek

$67.93050,-150.47083$

Ellesmerian

meta-graywacke

medium to very fine quartz, siltstone clasts, altered volcanic lithics, and quartzite; abundant white mica and carbonaceous material; rare pyrite, hematite, biotite, and zircon

wiggly anastomosing spaced cleavage with a more white mica-rich zone having zonal to continuous cleavage
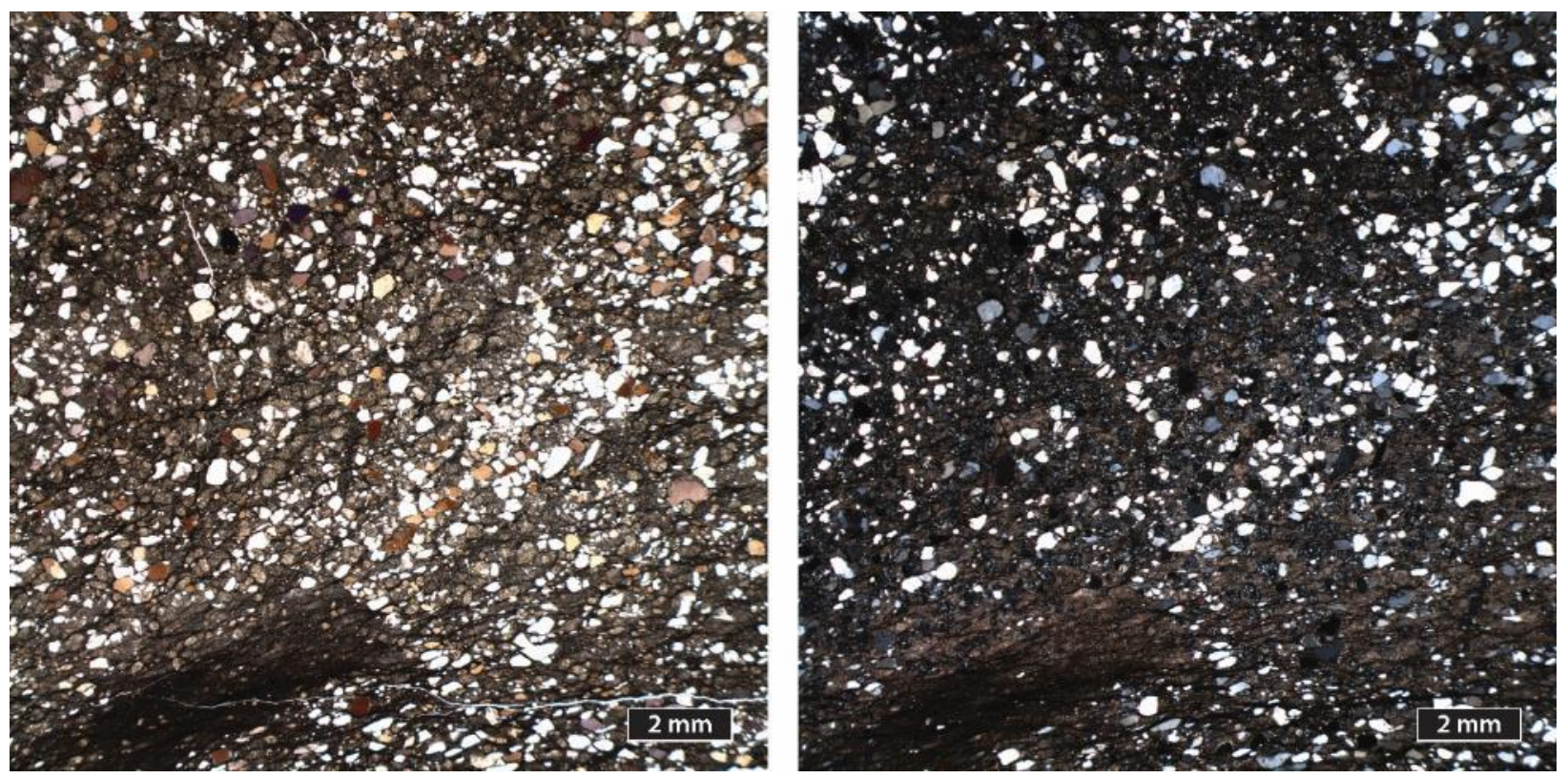

Photomicrographs of thin section, 10x/FOV 15 mm, PPL (left), XPL (right). 
Sample ID:

Unit:

Lat, Long

Assemblage:

Additional analysis:

Lithology:

Description:
J1409-74.1

Dek

$67.93050,-150.47083$

Ellesmerian

RSCM (this study)

black slate

very fine quartz with abundant carbonaceous material and mica; common hematite and leucoxene; rare possible biotite

gradational zonal rough to locally continuous cleavage

Structure:
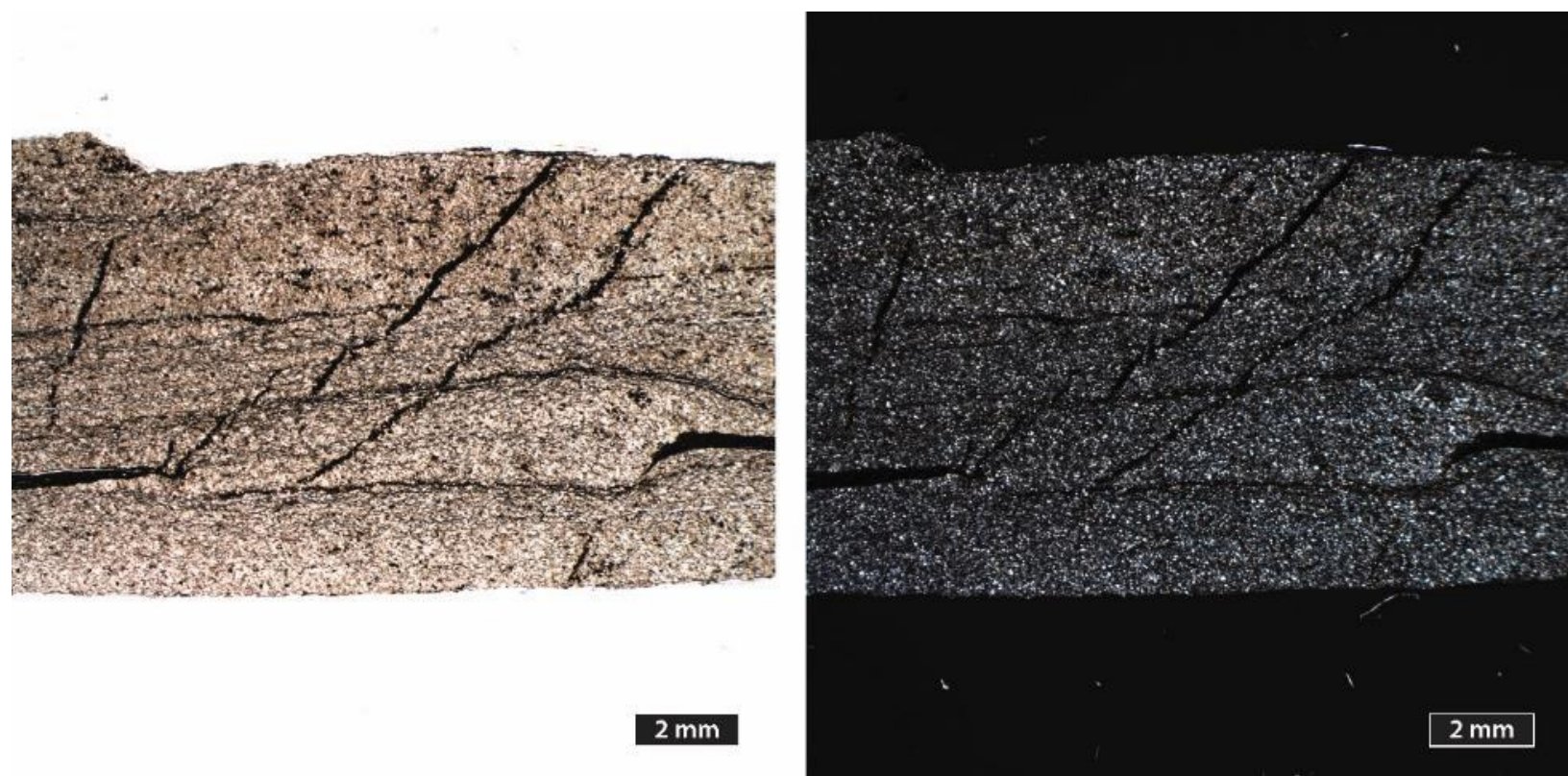

Photomicrographs of thin section, 10x/FOV 15 mm, PPL (left), XPL (right). 
Sample ID:

Unit:

Lat, Long

Assemblage:

Lithology:

Description:
J1409-WPF

Dek

$67.93050,-150.47083$

Ellesmerian

siltstone

very fine grained, $<0.1 \mathrm{~mm}$ predominant; quartz; common hematite and chlorite; scattered white mica; trace pyrite, siderite, and biotite scattered nascent rough irregular cleavage following bedding
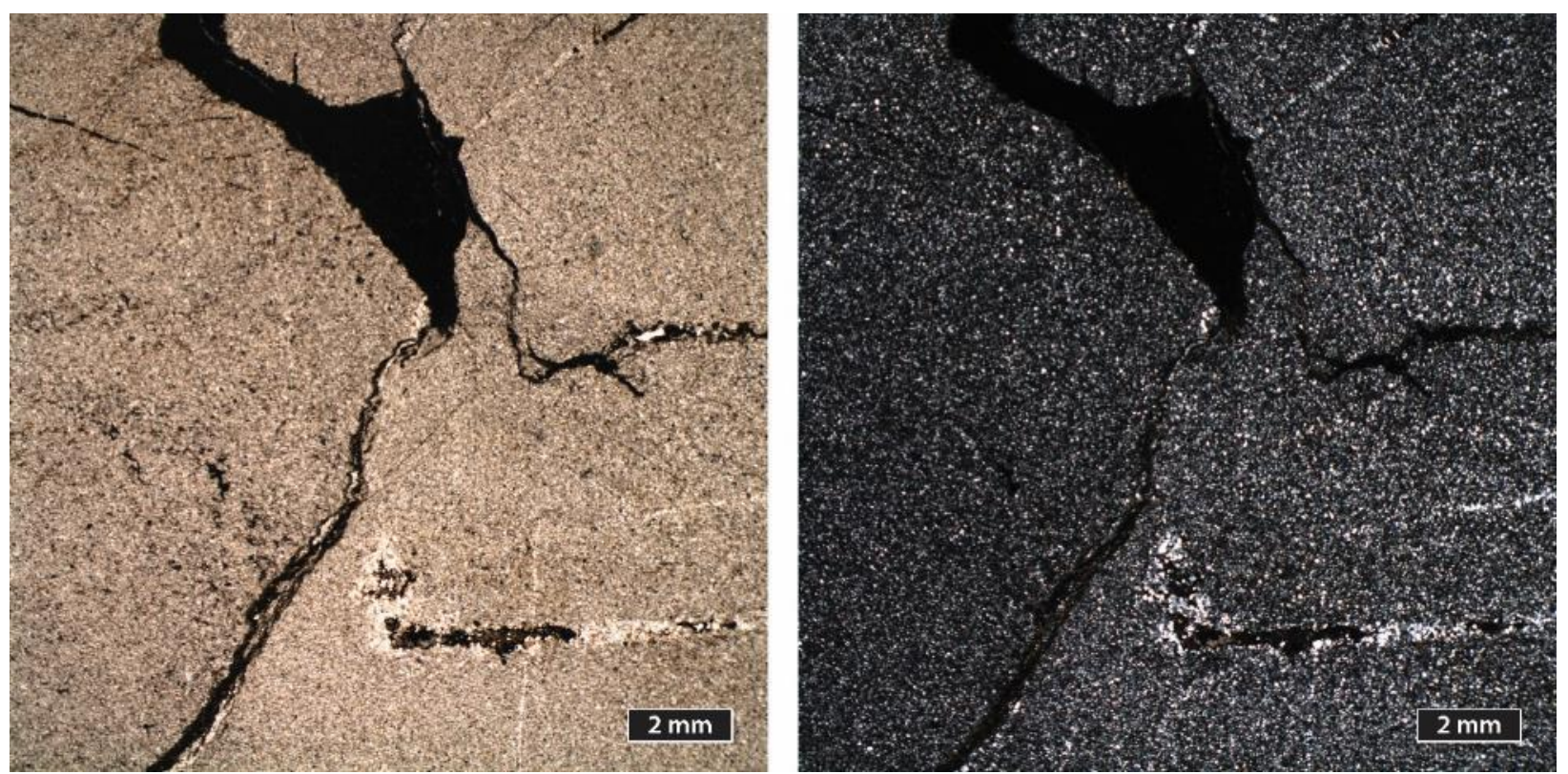

Photomicrographs of thin section, 10x/FOV $15 \mathrm{~mm}$, PPL (left), XPL (right). 
Sample ID:

Unit:

Lat, Long

Assemblage:

Lithology:

Description:

Structure:
J1415

Dsg

67.93886, -150.42783

Endicott Mountains

meta-graywacke

medium to fine quartz and siltstone grains; abundant hematite, carbonaceous material, and white mica; scattered chlorite

spaced irregular wiggly to rough gradational cleavage in P domains; one large quartz vein across thin section and scattered smaller veins in diffuse zones of stretching
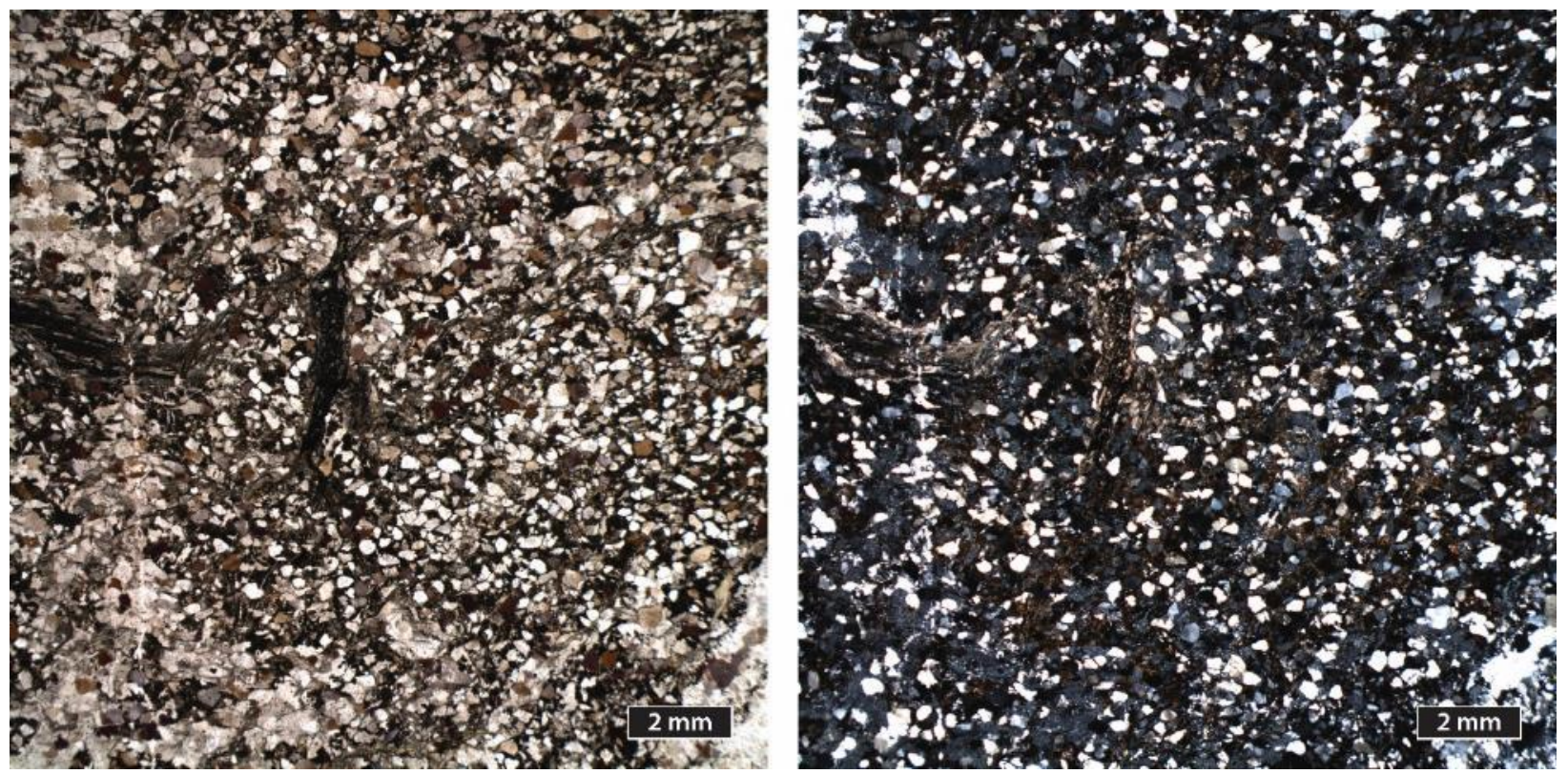

Photomicrographs of thin section, 10x/FOV 15 mm, PPL (left), XPL (right). 
Sample ID:

Unit:

Lat, Long

Assemblage:

Additional analysis:

Lithology:

Description:

Structure:

\section{J1415-WPF}

Dsg

67.93886, - 150.42783

Endicott Mountains

U-Pb zircon geochronology (Frier 2017)

sandy mud-clast meta-conglomerate

elongate pebble sized clasts of siltstone with medium to find quartz; common hematite, siderite, and white mica; scattered carbonaceous material and calcite; rare biotite and zircon rough discrete spaced cleavage anastomosing around elongate siltstone pebbles; one large and several fine quartz filled veins
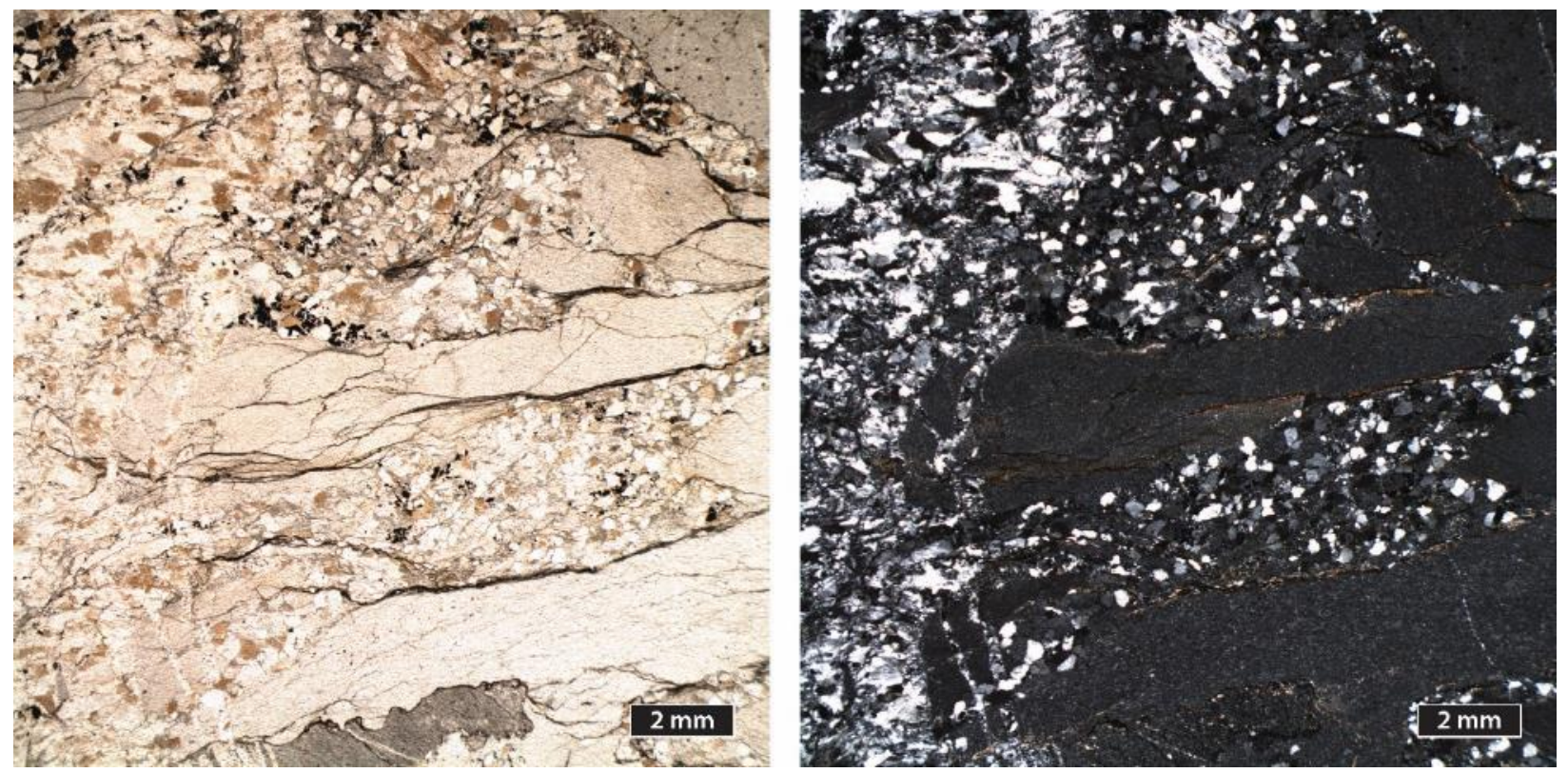

Photomicrographs of thin section, 10x/FOV 15 mm, PPL (left), XPL (right). 
Sample ID:

Unit:

Lat, Long

Assemblage:

Additional analysis:

Lithology:

Description:
J1417

Dek

$67.93578,-150.43942$

Ellesmerian

RSCM (this study)

slate

very fine quartz in altered matrix of white mica, carbonaceous material, and chlorite; scattered hematite; rare biotite and pyrite

gradational zonal parallel to anastomosing cleavage parallel to bedding; nascent crenulation perpendicular to bedding
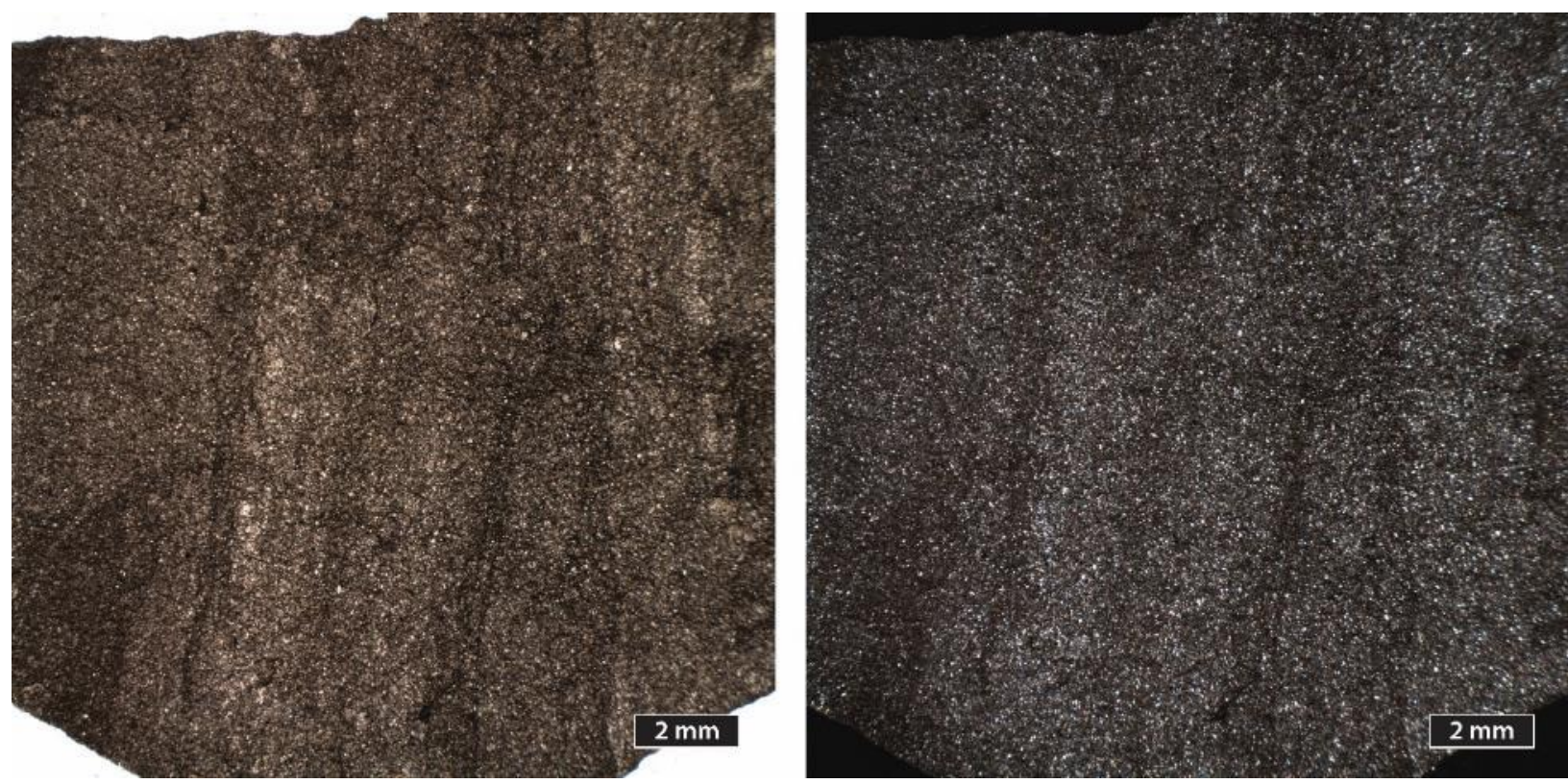

Photomicrographs of thin section, 10x/FOV 15 mm, PPL (left), XPL (right). 
Sample ID:

Unit:

Lat, Long

Assemblage:

Lithology:

Description:

Structure:

\section{J1417-WPF}

Dek

$67.93578,-150.43942$

Ellesmerian

slate

very fine quartz in altered matrix of white mica, carbonaceous material, calcite and chlorite; scattered hematite; rare biotite and pyrite gradational zonal parallel to anastomosing cleavage parallel to bedding; nascent crenulation perpendicular to bedding
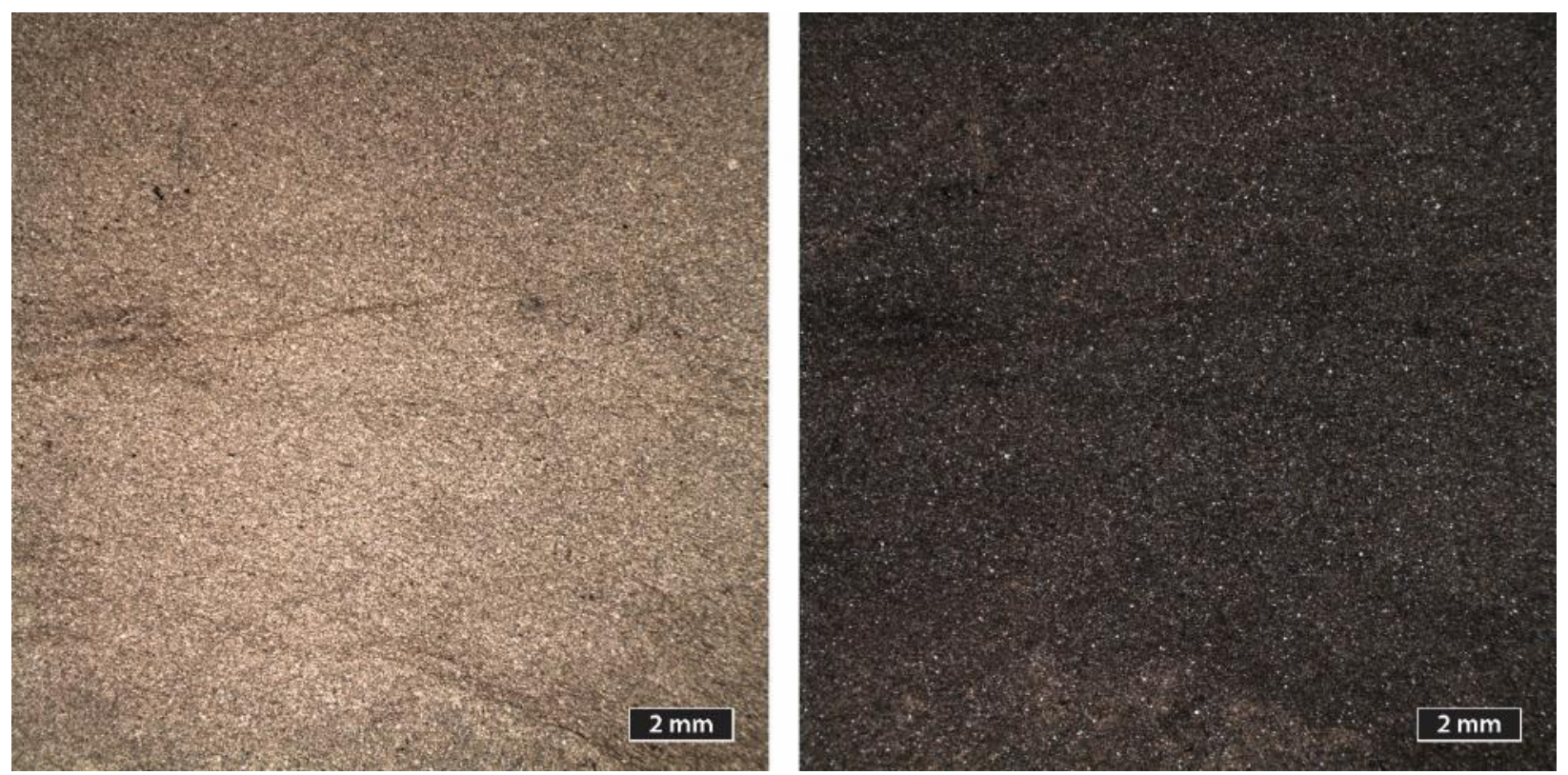

Photomicrographs of thin section, 10x/FOV 15 mm, PPL (left), XPL (right). 
Sample ID:

Unit:

Lat, Long

Assemblage:

Additional analysis:

Lithology:

Description:

Structure:
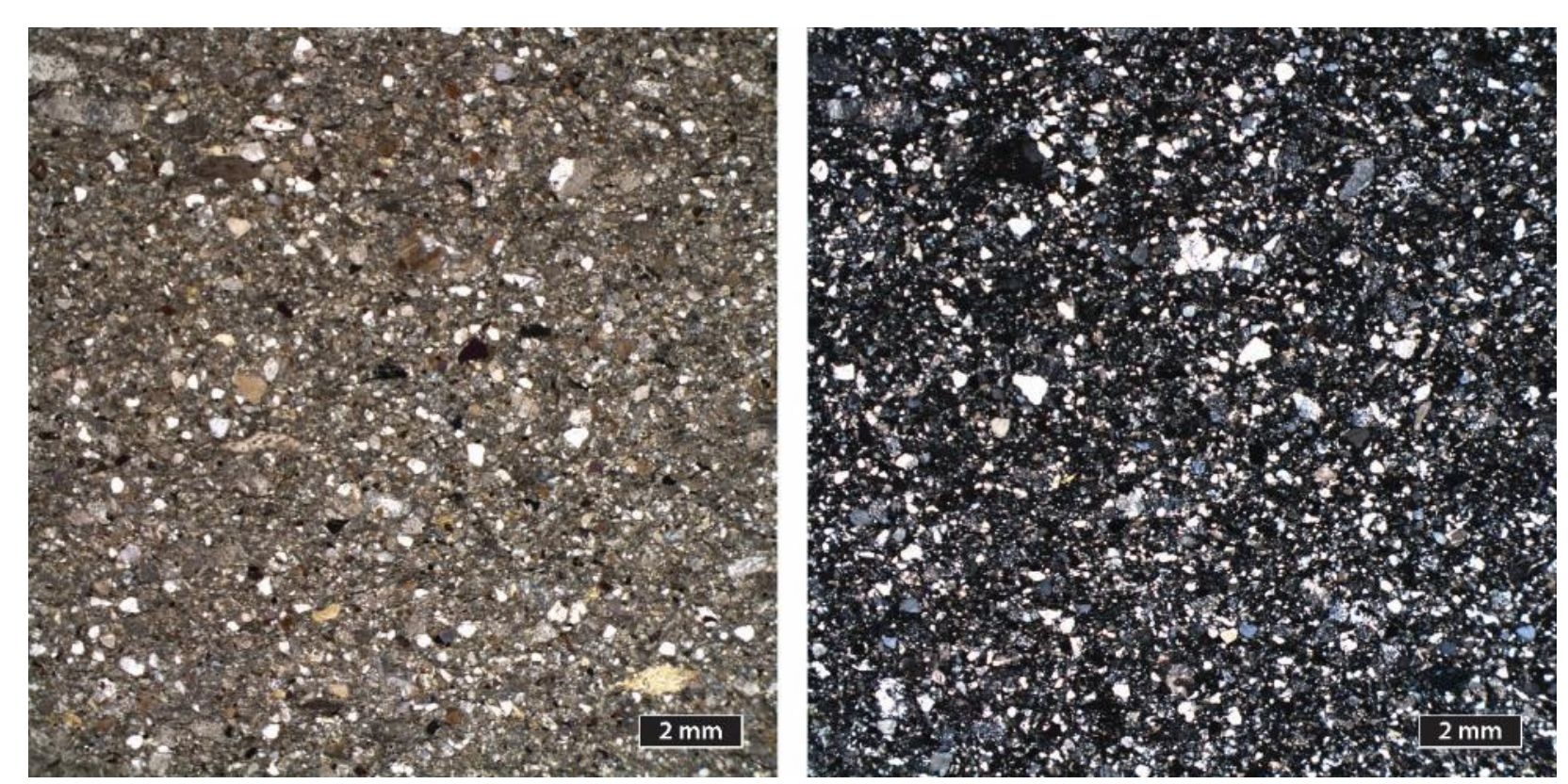

Photomicrographs of thin section, 10x/FOV 15 mm, PPL (left), XPL (right).
$\mathrm{J} 1418$

€Oac

$67.92789,-150.40461$

Apoon

U-Pb zircon geochronology, Lu-HF isotope analysis (Strauss, et al. 2017)

meta-volcaniclastic sandstone

fine to coarse grained; quartz, altered volcanics, albite, calcite, and quartzite; common white mica and chlorite; trace leucoxene and carbonaceous material rough spaced gradational cleavage 
Sample ID:

Unit:

Lat, Long

Assemblage:

Additional analysis:

Lithology:

Description:
J1419

€Oac

$67.92789,-150.40461$

Apoon

U-Pb zircon geochronology, Lu-HF isotope analysis (Strauss, et al. 2017)

calcareous slate

very fine grained calcite and quartz; common carbonaceous material, hematite, and white mica; trace albite

rough gradational zonal cleavage

\section{Structure:}

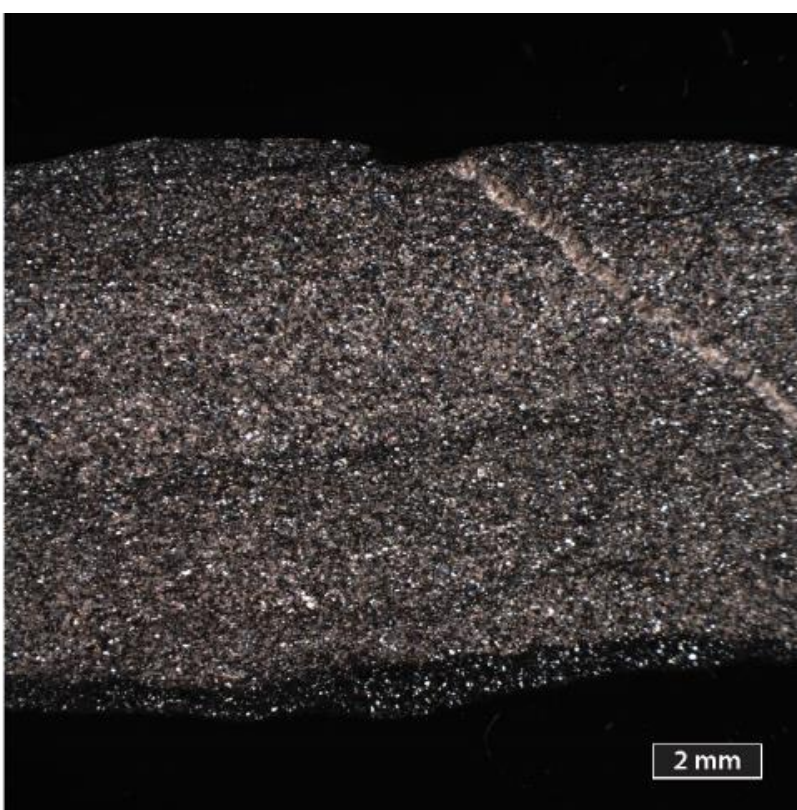

Photomicrographs of thin section, 10x/FOV 15 mm, PPL (left), XPL (right). 
Sample ID:

Unit:

Lat, Long

Assemblage:

Additional analysis:

Lithology:

Description:

Structure:
J1424

€Oac

$67.86869,-150.30731$

Apoon

U-Pb zircon geochronology, Lu-HF isotope analysis (Strauss, et al. 2017); RSCM (this study)

meta-volcaniclastic sandstone

abundant opaque medium lithics (ilmenite?) and altered volcanics in altered matrix of quartz, calcite, white mica, and hematite; scattered siderite and carbonaceous material

poorly developed cleavage parallel to bedding; one $C^{\prime}$-type shear zone in a $\mathrm{P}$ domain along sample edge; one vein with quartz following calcite
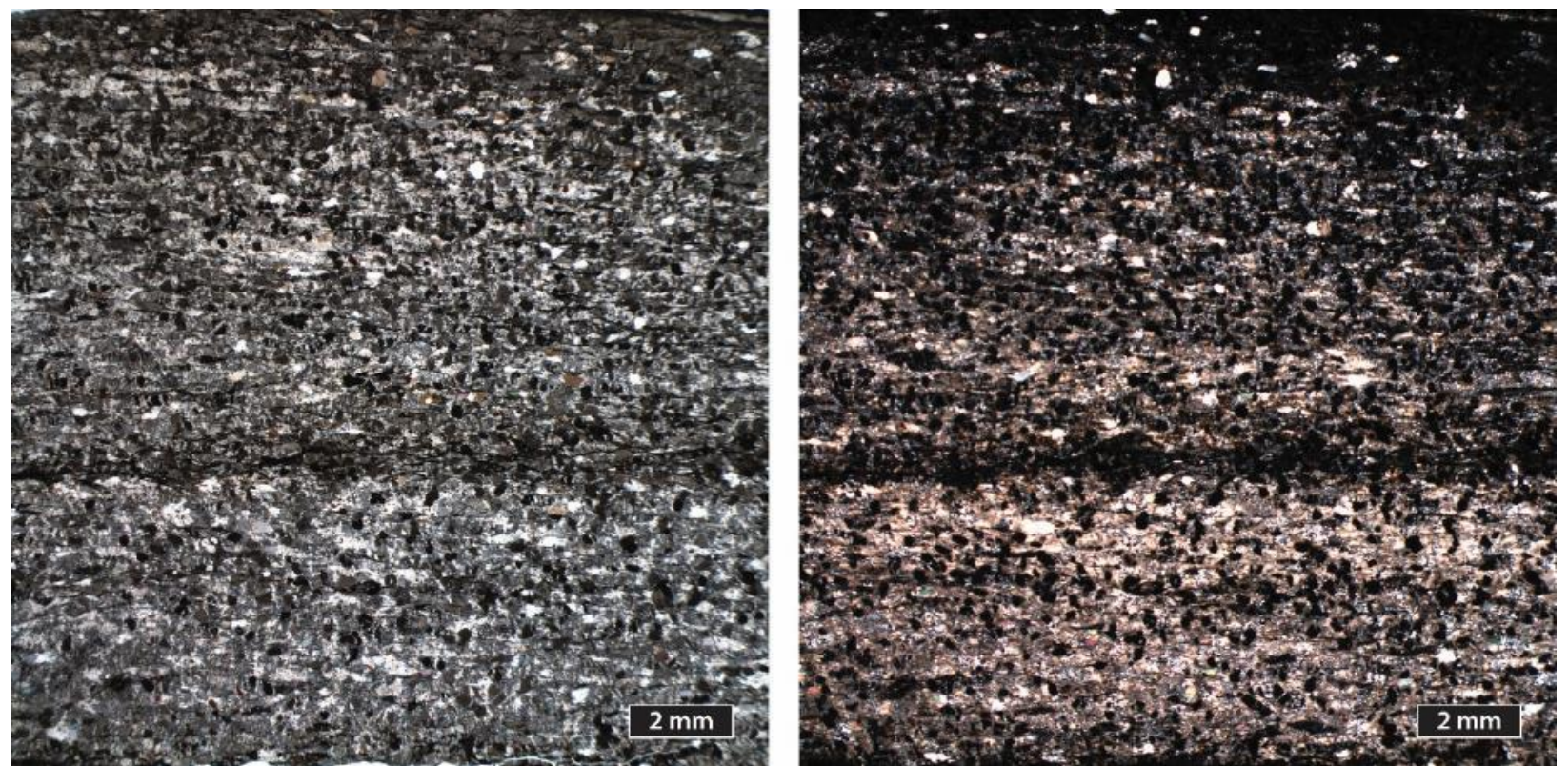

Photomicrographs of thin section, 10x/FOV 15 mm, PPL (left), XPL (right). 
Sample ID:

Unit:

Lat, Long

Assemblage:

Additional analysis:

Lithology:

Description:

Structure:
J1426

Dtc

$67.84933,-150.26047$

Hammond

${ }^{40} \mathrm{Ar} /{ }^{39} \mathrm{Ar}$ geochronology (Strauss, et al. 2017)

volcaniclastic phyllite

medium to fine quartz and altered volcanics in calcite and very fine quartz; abundant metamorphic and detrital white mica; common carbonaceous material; trace quartzite; rare biotite, albite, chlorite, and zircon zonal to continuous parallel to anastomosing cleavage

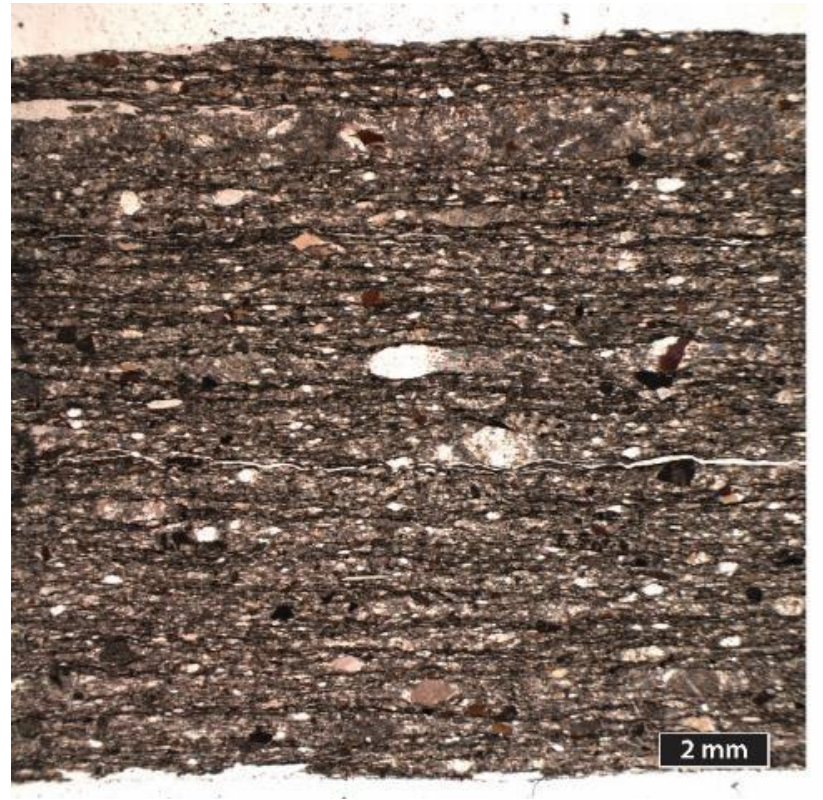

Photomicrographs of thin section, 10x/FOV 15 mm, PPL (left), XPL (right).

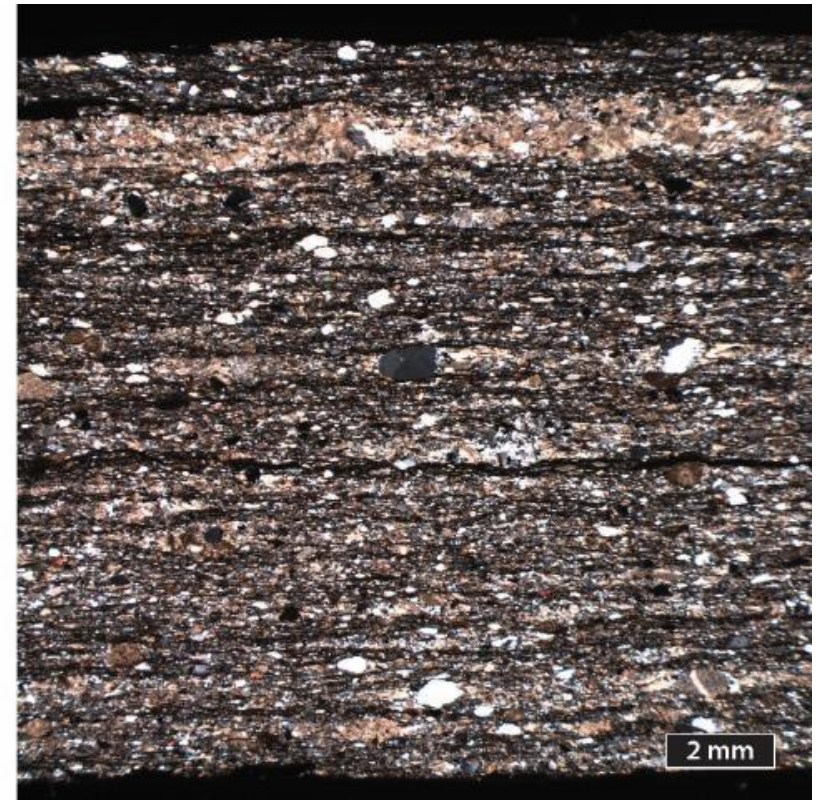


Sample ID:

Unit:

Lat, Long

Assemblage:

Additional analysis:

Lithology:

Description:

Structure:
$\mathrm{J1427}$

€Oac

$67.85083,-150.26064$

Apoon

U-Pb zircon geochronology, Lu-HF isotope analysis (Strauss, et al. 2017); RSCM (this study)

meta-graywacke

medium to fine quartz, altered volcanics, and calcite; abundant siltstone grains, albite, and white mica; scattered chlorite and carbonaceous material; trace biotite and leucoxene; rare pyrite

wiggly anastomosing zonal discrete cleavage with nascent shear bands
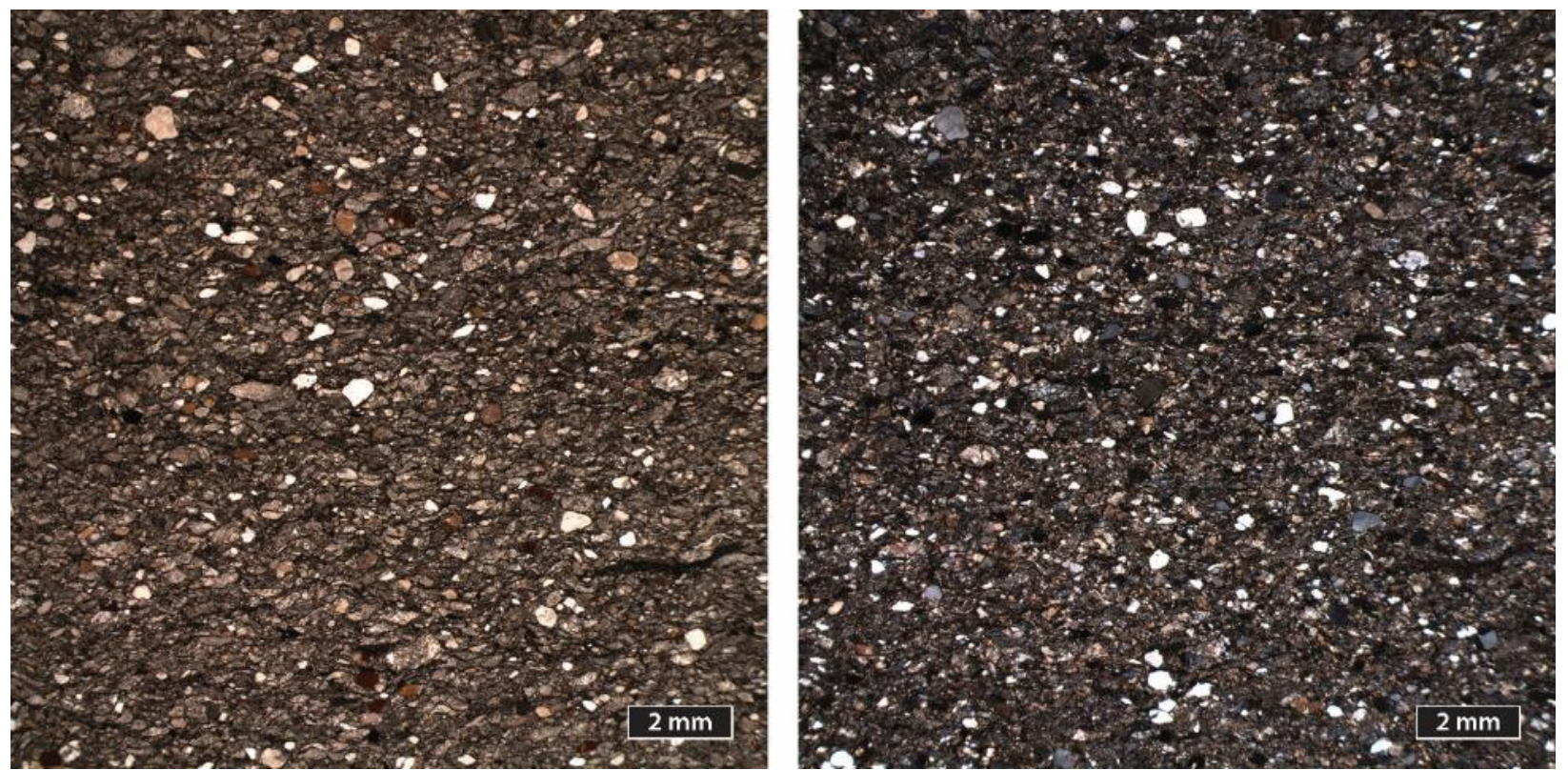

Photomicrographs of thin section, 10x/FOV 15 mm, PPL (left), XPL (right). 
Sample ID:

Unit:

Lat, Long

Assemblage:

Lithology:

Description:
J1428

$€ O a c$

$67.85531,-150.26817$

Apoon

meta-graywacke

fine to very fine quartz, altered volcanics, and calcite; abundant siltstone grains, albite, and white mica; scattered chlorite and carbonaceous material; trace biotite and leucoxene; rare pyrite wiggly anastomosing zonal discrete cleavage
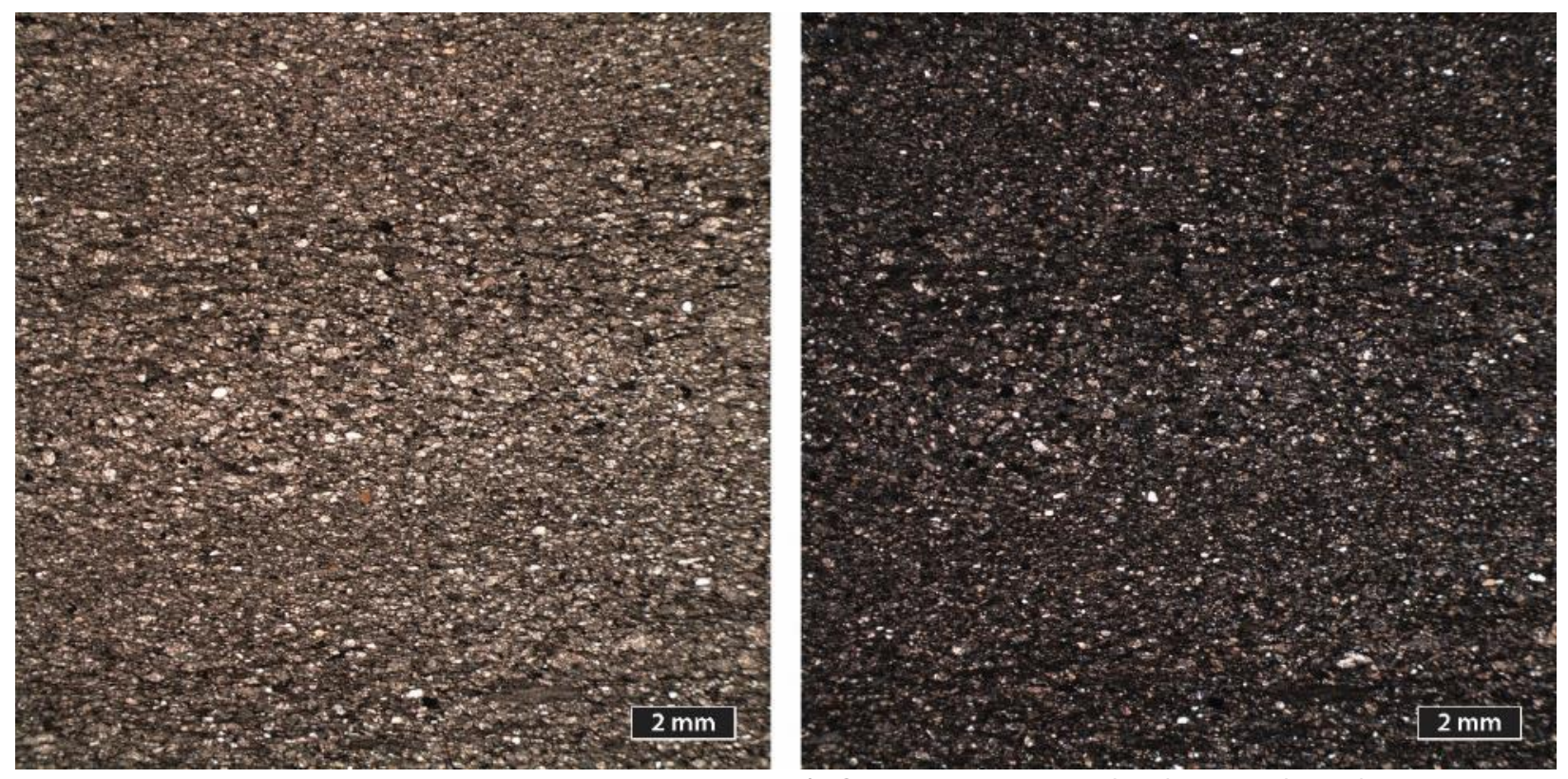

Photomicrographs of thin section, 10x/FOV 15 mm, PPL (left), XPL (right). 
Sample ID:

Unit:

Lat, Long

Assemblage:

Lithology:

Description:
$\mathrm{J} 1430$

$€ O a c$

$67.89342,-150.38528$

Apoon

calcareous slate

very fine quartz and calcite; common carbonaceous material, chlorite, and white mica; scattered albite; trace leucoxene; rare biotite

rough to wiggly gradational spaced cleavage parallel to bedding

Structure:

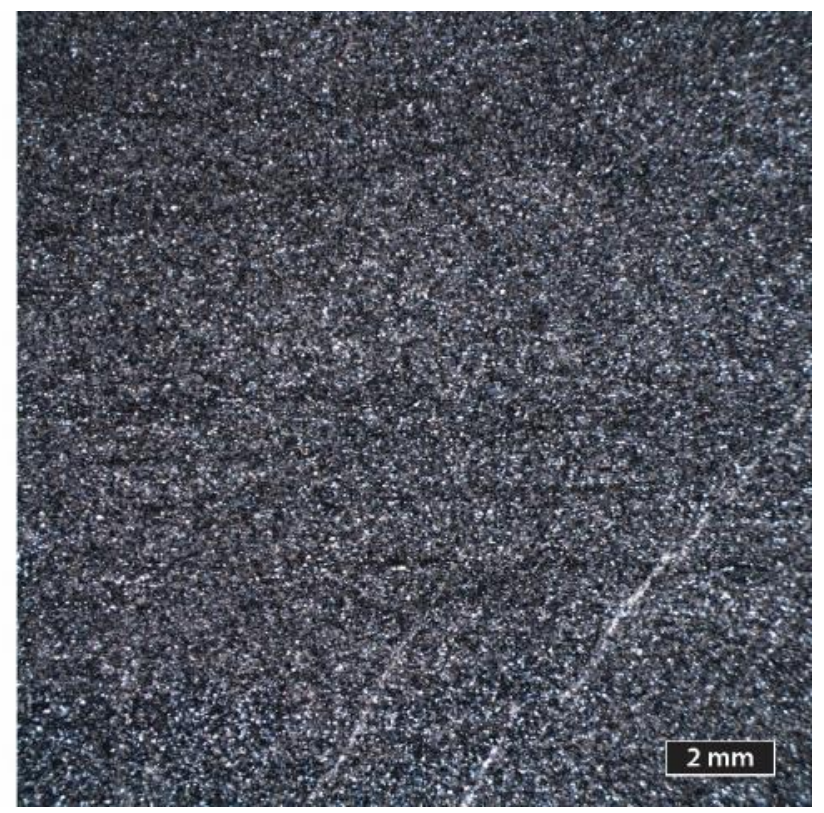

Photomicrographs of thin section, 10x/FOV $15 \mathrm{~mm}$, PPL (left), XPL (right). 
Sample ID:

Unit:

Lat, Long

Assemblage:

Lithology:

Description:

Structure:
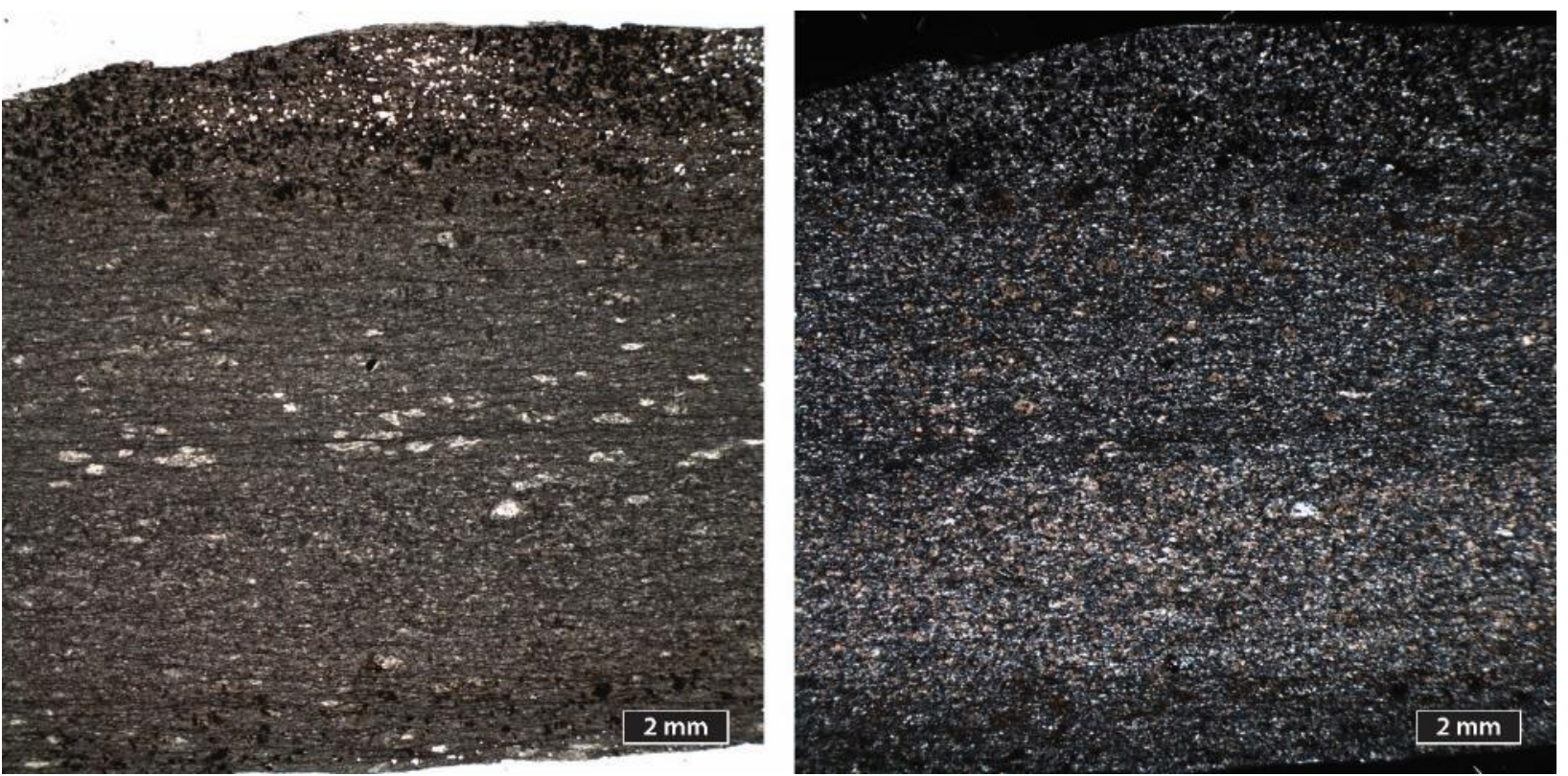

Photomicrographs of thin section, 10x/FOV 15 mm, PPL (left), XPL (right).

\section{Karill}

€Oac

$67.92789,-150.40728$

Apoon

fine quartz and calcite; abundant siderite; common hematite, carbonaceous material, and albite; scattered white mica and chlorite; rare pyrite and biotite

continuous to gradational zonal parallel to anastomosing cleavage calcareous phyllite 
Sample ID:

Unit:

Lat, Long

Assemblage:

Additional analysis:

Lithology:

Description:

Structure:
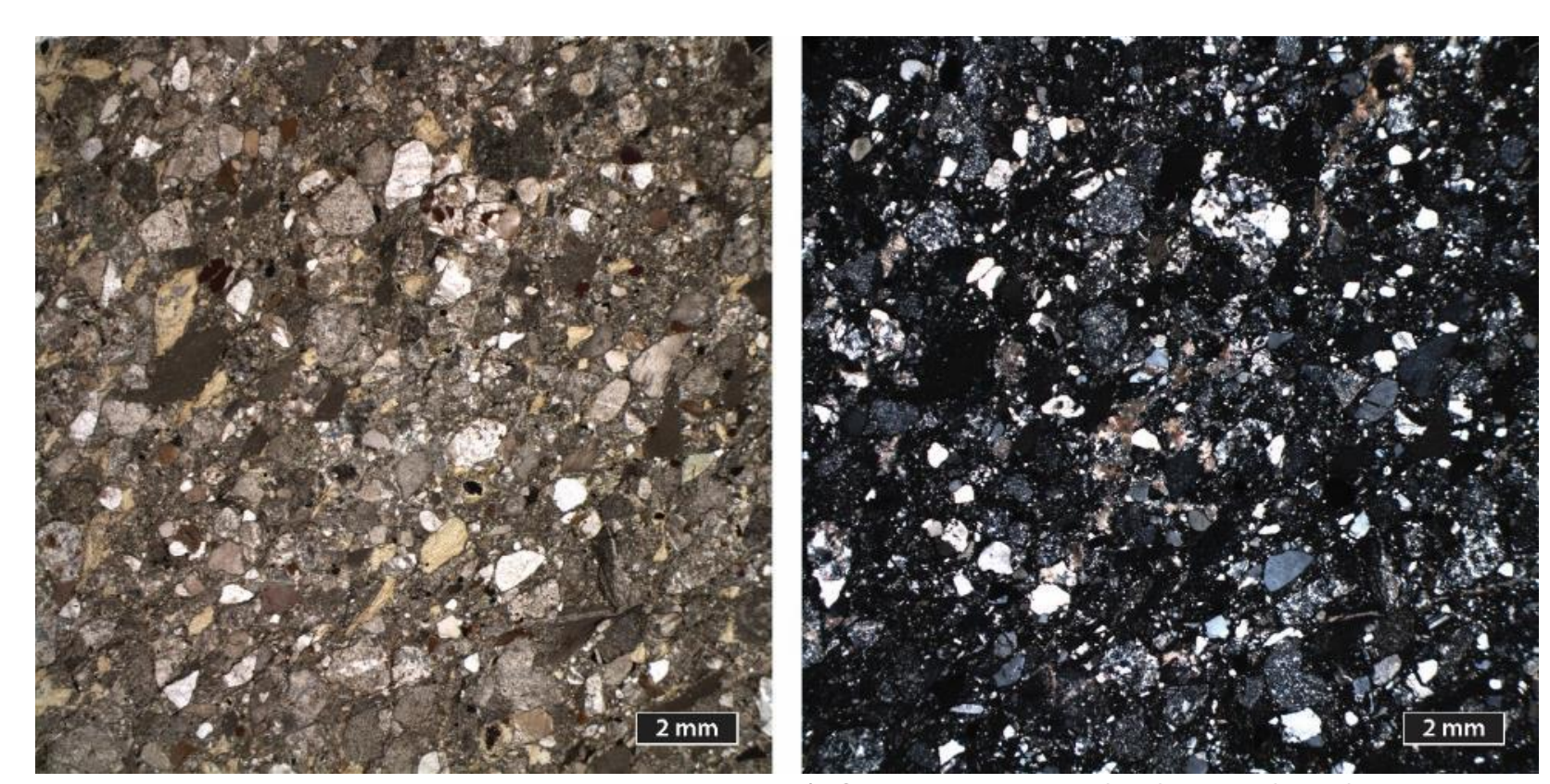

Photomicrographs of thin section, 10x/FOV $15 \mathrm{~mm}$, PPL (left), XPL (right).

\section{Pva2}

€Oac

$67.88889,-150.38417$

Apoon

RSCM (this study)

meta-volcaniclastic sandstone

coarse to fine altered volcanics, quartz, albite, quartzite, calcite, and chlorite; scattered white mica and leucoxene; trace biotite; rare detrital garnet

irregular rough to wiggly spaced cleavage 


\section{Appendix 4: All RSCM results}

This appendix contains all results for each sample analyzed with the RSCM paleotemperature methods presented in this work. All generated parameters are shown for each individual spectral acquisition processed with IgorPro 6.34 software (WaveMetrics Inc., Lake Oswego, Oregon) as well as the relevant R2 or RA1/RA2 parameters as required for the paleotemperature calculations of Beyssac et al. (2002) or Lahfid et al. (2010), respectively (Figure A12, Table A3). When using the Lahfid et al. (2010) method, the average result of the RA1 and RA2 equations was used as the final paleotemperature; all are presented in applicable tables.

Results are presented in the order of Table A5. Sample numbers are in the upper left cell. Average temperature $\left({ }^{\circ} \mathrm{C}\right)$ and standard deviation $(1-\sigma)$ are in the upper right cells with the method used for calculation. Notation above the "Peak" cell refers to the file name suffix. In addition to the included results, RSCM was unsuccessfully attempted on samples listed in Table A4.

$$
\begin{gathered}
R 2=\frac{D 1}{G+D 1+D 2} A \\
R A 1=\frac{D 1+D 4}{D 1+D 2+D 3+D 4+G} \quad R A 2=\frac{D 1+D 4}{D 2+D 3+G}
\end{gathered}
$$

Figure A12. Formulas for the R2, RA1, and RA2 parameters used to calculate maximum paleotemperature with the methods of Beyssac et al. (2002) and Lahfid et al. (2010). All utilize peak areas of the component peaks.

\begin{tabular}{|l|c|c|c|}
\hline \multicolumn{1}{|c|}{ Study } & Range ${ }^{\circ} \mathbf{C}$ & Formula & $\mathbf{R}^{2}$ value \\
\hline Beyssac et al. 2002 & $330-650$ & $\mathrm{~T}\left({ }^{\circ} \mathrm{C}\right)=-445^{*} \mathrm{R} 2+641$ & 0.96 \\
\hline Lahfid et al. 2010 & $200-330$ & $\mathrm{~T}\left({ }^{\circ} \mathrm{C}\right)=(\mathrm{RA} 1-0.3758) / 0.0008$ & 0.97 \\
\hline Lahfid et al. 2010 & $200-330$ & $\mathrm{~T}\left({ }^{\circ} \mathrm{C}\right)=(\mathrm{RA} 2-0.27) / 0.0045$ & 0.95 \\
\hline
\end{tabular}

Table A3. Stated applicable range and formulas for the RSCM paleothermometers of Beyssac et al. (2002) and Lahfid et al. (2010) used in this work. R2, RA1, and RA2 parameters are shown in Figure A10.

\begin{tabular}{|l|l|l|l|l|l|}
\hline 16DF03 & 16DF04 & 16DF07 & 16DF13 & 16DF16 & 16DF28B \\
\hline 16DF31B & 16DF32 & 16DF33 & 16DF34B & 16DF35 & 07DF15 \\
\hline 15DF15 & 22DF15 & 30DF15 & 40DF15 & 47DF15 & Pva2 \\
\hline
\end{tabular}

Table A4. List of samples on which RSCM was attempted unsuccessfully. 


\begin{tabular}{|c|c|c|c|c|c|c|c|}
\hline Sample ID & Map Unit & $\mathrm{T}\left({ }^{\circ} \mathrm{C}\right)$ & $1 \sigma\left({ }^{\circ} \mathrm{C}\right)$ & \# spots & Method & Latitude (N) & Longitude (W) \\
\hline 16DF02 & $€ O a c$ & 359 & 15 & 10 & Beyssac & 67.715520 & 150.943149 \\
\hline 16DF05 & $€ O a c$ & 353 & 18 & 12 & Beyssac & 67.726527 & 150.934213 \\
\hline 16DF06 & $€ O a c$ & 359 & 17 & 11 & Beyssac & 67.728021 & 150.936263 \\
\hline 16DF10 & Dtc & 349 & 7 & 13 & Beyssac & 67.732214 & 150.881674 \\
\hline 16DF11 & Dtc & 368 & 12 & 13 & Beyssac & 67.724269 & 150.883287 \\
\hline 16DF12 & Ddr & 365 & 18 & 11 & Beyssac & 67.719700 & 150.849249 \\
\hline 16DF14 & Ddr & 357 & 14 & 10 & Beyssac & 67.690712 & 150.885746 \\
\hline 16DF15 & Ddr & 357 & 14 & 11 & Beyssac & 67.680416 & 150.929359 \\
\hline 16DF19 & Ddr & 358 & 11 & 11 & Beyssac & 67.675959 & 151.108447 \\
\hline 16DF20 & Dtc & 391 & 20 & 13 & Beyssac & 67.672213 & 151.108320 \\
\hline 16DF21 & Dtc & 391 & 19 & 11 & Beyssac & 67.669599 & 151.112092 \\
\hline 16DF22 & Ddr & 366 & 15 & 11 & Beyssac & 67.687022 & 151.101397 \\
\hline 16DF24 & Dtc & 364 & 10 & 9 & Beyssac & 67.692711 & 151.091771 \\
\hline 16DF27 & Ddr & 383 & 19 & 12 & Beyssac & 67.689200 & 150.972217 \\
\hline 16DF29 & Ddm & 360 & 17 & 11 & Beyssac & 67.646595 & 151.121902 \\
\hline 16DF30 & Ddr & 372 & 12 & 12 & Beyssac & 67.653614 & 151.149556 \\
\hline 16DF38 & Dgw & 362 & 18 & 13 & Beyssac & 67.639789 & 150.966109 \\
\hline 16DF39 & Ddr & 371 & 29 & 13 & Beyssac & 67.627249 & 151.057004 \\
\hline 02DF15 & $€ O a c$ & 356 & 28 & 9 & Beyssac & 67.871000 & 150.812000 \\
\hline 10DF15 & $€ O a c$ & 321 & 18 & 18 & Lahfid & 67.881000 & 150.798000 \\
\hline 18DF15 & $€ O a c$ & 340 & 19 & 15 & Lahfid & 67.903000 & 150.797000 \\
\hline 23DF15 & Dek & 325 & 21 & 9 & Lahfid & 67.908000 & 150.752000 \\
\hline $26 \mathrm{DF} 15$ & Dhf & 277 & 16 & 5 & Lahfid & 67.933000 & 150.778000 \\
\hline 27DF15 & Dhf & 347 & 30 & 12 & Lahfid & 67.935000 & 150.778000 \\
\hline 28DF15 & Dsg & 298 & 16 & 10 & Lahfid & 67.915000 & 150.852000 \\
\hline 31DF15 & $€ O a c$ & 348 & 11 & 14 & Beyssac & 67.839790 & 150.938540 \\
\hline 39DF15 & Dhf & 321 & 37 & 12 & Lahfid & 67.918000 & 150.881000 \\
\hline 41DF15 & MDkn & 318 & 25 & 14 & Lahfid & 67.919000 & 150.930000 \\
\hline 43DF15 & Dsg & 296 & 32 & 10 & Lahfid & 67.890000 & 150.936000 \\
\hline 44DF15 & Dsg & 310 & 31 & 8 & Lahfid & 67.890000 & 150.936000 \\
\hline 46DF15 & Dsg & 297 & 24 & 9 & Lahfid & 67.885000 & 150.895000 \\
\hline 15JT01 & $€ O a c$ & 374 & 16 & 10 & Beyssac & 67.745164 & 150.946694 \\
\hline 15JT02 & Dtc & 408 & 23 & 9 & Beyssac & 67.698167 & 151.005063 \\
\hline 15JT04 & Ddr & 360 & 14 & 12 & Beyssac & 67.642283 & 151.020798 \\
\hline J1409-74.1 & Dek & 316 & 23 & 10 & Lahfid & 67.930500 & 150.470833 \\
\hline J1417 & Dek & 299 & 35 & 12 & Lahfid & 67.935778 & 150.439417 \\
\hline J1424 & $€ O a c$ & 364 & 8 & 10 & Beyssac & 67.868694 & 150.307306 \\
\hline J1427 & $€ O a c$ & 353 & 17 & 11 & Beyssac & 67.850833 & 150.260639 \\
\hline
\end{tabular}

Table A5. All of my RSCM paleothermometry results from the Doonerak area. Map units correspond to Plate 1 . Method refers to the peak fitting procedures and paleotemperature equation used after either Beyssac et al. (2002) or Lahfid et al. (2010). Results from each sample follow in the same order as the table. 


\begin{tabular}{|c|c|c|c|c|c|c|c|}
\hline \multirow[t]{2}{*}{ 16DF02 } & & & & Method: & \multicolumn{3}{|c|}{ Beyssac et al. 2002} \\
\hline & & & & & & $\operatorname{avg} T$ & std dev \\
\hline & & & & \multicolumn{2}{|c|}{ Avg each run } & 359.2 & 15.1 \\
\hline Peak & Location & Amplitude & Area & FWHM & R1 & R2 & $\mathrm{T}\left({ }^{\circ} \mathrm{C}\right)$ \\
\hline D1 & 1349 & 17507 & 1883380 & 67.7 & 1.252 & 0.584 & 381.1 \\
\hline $\mathrm{G}$ & 1587 & 13983 & 1253290 & 57.0 & & & \\
\hline D2 & 1617 & 3874 & 88563.3 & -0.6 & & & \\
\hline \multicolumn{8}{|l|}{01} \\
\hline Peak & Location & Amplitude & Area & FWHM & R1 & R2 & $\mathrm{T}\left({ }^{\circ} \mathrm{C}\right)$ \\
\hline D1 & 1348 & 17024 & 1630130 & 60.5 & 1.338 & 0.626 & 362.6 \\
\hline G & 1585 & 12728 & 803007 & 35.8 & & & \\
\hline D2 & 1616 & 5512 & 172159 & 0.0 & & & \\
\hline \multicolumn{8}{|l|}{02} \\
\hline Peak & Location & Amplitude & Area & FWHM & R1 & R2 & $\mathrm{T}\left({ }^{\circ} \mathrm{C}\right)$ \\
\hline D1 & 1347 & 16820 & 1523110 & 55.0 & 1.228 & 0.625 & 362.7 \\
\hline G & 1585 & 13701 & 791392 & 18.2 & & & \\
\hline D2 & 1617 & 4256 & 120806 & 0.1 & & & \\
\hline \multicolumn{8}{|l|}{03} \\
\hline Peak & Location & Amplitude & Area & FWHM & R1 & R2 & $\mathrm{T}\left({ }^{\circ} \mathrm{C}\right)$ \\
\hline D1 & 1350 & 7513 & 675879 & 56.8 & 1.523 & 0.684 & 336.7 \\
\hline $\mathrm{G}$ & 1593 & 4933 & 242702 & 14.3 & & & \\
\hline D2 & 1622 & 2438 & 69962.7 & 0.1 & & & \\
\hline \multicolumn{8}{|l|}{04} \\
\hline Peak & Location & Amplitude & Area & FWHM & R1 & $\mathrm{R} 2$ & $\mathrm{~T}\left({ }^{\circ} \mathrm{C}\right)$ \\
\hline D1 & 1346 & 15179 & 1525240 & 63.6 & 1.198 & 0.589 & 379.0 \\
\hline G & 1581 & 12669 & 957167 & 43.1 & & & \\
\hline $\mathrm{D} 2$ & 1613 & 3527 & 108576 & 0.0 & & & \\
\hline \multicolumn{8}{|l|}{05} \\
\hline Peak & Location & Amplitude & Area & FWHM & $\mathrm{R} 1$ & R2 & $\mathrm{T}\left({ }^{\circ} \mathrm{C}\right)$ \\
\hline D1 & 1351 & 2521 & 210356 & 53.0 & 0.614 & 0.628 & 361.7 \\
\hline G & 1595 & 4106 & 111923 & -17.5 & & & \\
\hline $\mathrm{D} 2$ & 1623 & 617 & 12815.7 & -0.3 & & & \\
\hline \multicolumn{8}{|l|}{07} \\
\hline Peak & Location & Amplitude & Area & FWHM & $\mathrm{R} 1$ & R2 & $\mathrm{T}\left({ }^{\circ} \mathrm{C}\right)$ \\
\hline D1 & 1346 & 32647 & 3060490 & 58.8 & 1.533 & 0.649 & 352.2 \\
\hline G & 1582 & 21298 & 1362240 & 33.5 & & & \\
\hline D2 & 1613 & 9147 & 292637 & 0.0 & & & \\
\hline \multicolumn{8}{|l|}{08} \\
\hline Peak & Location & Amplitude & Area & FWHM & R1 & R2 & $\mathrm{T}\left({ }^{\circ} \mathrm{C}\right)$ \\
\hline D1 & 1350 & 12995 & 1209090 & 59.2 & 1.648 & 0.676 & 340.0 \\
\hline G & 1592 & 7884 & 445652 & 29.6 & & & \\
\hline D2 & 1620 & 5241 & 132839 & -2.3 & & & \\
\hline \multicolumn{8}{|l|}{09} \\
\hline Peak & Location & Amplitude & Area & FWHM & R1 & R2 & $\mathrm{T}\left({ }^{\circ} \mathrm{C}\right)$ \\
\hline $\mathrm{D} 1$ & 1347 & 30584 & 2976560 & 62.0 & 1.498 & 0.660 & 347.2 \\
\hline G & 1587 & 20421 & 1319600 & 27.0 & & & \\
\hline D2 & 1617 & 7700 & 212884 & 1.8 & & & \\
\hline \multicolumn{8}{|l|}{010} \\
\hline Peak & Location & Amplitude & Area & FWHM & R1 & R2 & $\mathrm{T}\left({ }^{\circ} \mathrm{C}\right)$ \\
\hline D1 & 1347 & 27389 & 2555480 & 59.4 & 1.378 & 0.612 & 368.8 \\
\hline
\end{tabular}




\begin{tabular}{|l|r|r|r|r|r|r|r|} 
G & 1582 & 19872 & 1356860 & 40.6 & & & \\
\hline D2 & 1613 & 8463 & 265124 & 0.0 & & & \\
\hline
\end{tabular}

\begin{tabular}{|c|c|c|c|c|c|c|c|}
\hline \multirow[t]{2}{*}{ 16DF05 } & & & & Method: & \multicolumn{3}{|c|}{ Beyssac et al. 2002} \\
\hline & & & & & & $\operatorname{avg} \mathrm{T}$ & std dev \\
\hline & & & & \multicolumn{2}{|c|}{ Avg each run } & 353.1 & 18.4 \\
\hline Peak & Location & Amplitude & Area & FWHM & R1 & R2 & $\mathrm{T}\left({ }^{\circ} \mathrm{C}\right)$ \\
\hline $\mathrm{D} 1$ & 1355 & 1115 & 72860.3 & 26.2 & 1.243 & 0.586 & 380.1 \\
\hline G & 1595 & 897 & 44483.5 & 0.0 & & & \\
\hline D2 & 1624 & 326 & 6927.89 & 0.0 & & & \\
\hline \multicolumn{8}{|l|}{ 05-b8 } \\
\hline Peak & Location & Amplitude & Area & FWHM & R1 & $\mathrm{R} 2$ & $\mathrm{~T}\left({ }^{\circ} \mathrm{C}\right)$ \\
\hline D1 & 1351 & 835 & 64152.5 & 36.8 & 1.442 & 0.660 & 347.3 \\
\hline G & 1596 & 579 & 27295.1 & 6.7 & & & \\
\hline D2 & 1624 & 302 & 5767.05 & -0.3 & & & \\
\hline \multicolumn{8}{|l|}{ 05-b9 } \\
\hline Peak & Location & Amplitude & Area & FWHM & R1 & $\mathrm{R} 2$ & $\mathrm{~T}\left({ }^{\circ} \mathrm{C}\right)$ \\
\hline D1 & 1351 & 1015 & 79703.6 & 41.1 & 1.488 & 0.657 & 348.6 \\
\hline G & 1589 & 682 & 27903.1 & 11.0 & & & \\
\hline $\mathrm{D} 2$ & 1619 & 486 & 13687.9 & -0.2 & & & \\
\hline \multicolumn{8}{|l|}{ 05-c1 } \\
\hline Peak & Location & Amplitude & Area & FWHM & R1 & R2 & $\mathrm{T}\left({ }^{\circ} \mathrm{C}\right)$ \\
\hline D1 & 1352 & 1146 & 90724.4 & 45.6 & 1.659 & 0.679 & 338.6 \\
\hline G & 1595 & 691 & 34374.5 & 11.9 & & & \\
\hline D2 & 1623 & 331 & 8428.38 & 0.1 & & & \\
\hline \multicolumn{8}{|l|}{$05-c 2$} \\
\hline Peak & Location & Amplitude & Area & FWHM & R1 & $\mathrm{R} 2$ & $\mathrm{~T}\left({ }^{\circ} \mathrm{C}\right)$ \\
\hline D1 & 1350 & 2768 & 306612 & 68.4 & 1.178 & 0.622 & 364.3 \\
\hline$G$ & 1589 & 2351 & 163511 & 36.3 & & & \\
\hline D2 & 1620 & 899 & 23022.7 & -0.1 & & & \\
\hline \multicolumn{8}{|l|}{$05-c 3$} \\
\hline Peak & Location & Amplitude & Area & FWHM & $\mathrm{R} 1$ & $\mathrm{R} 2$ & $\mathrm{~T}\left({ }^{\circ} \mathrm{C}\right)$ \\
\hline D1 & 1352 & 1267 & 118723 & 59.0 & 1.509 & 0.688 & 334.8 \\
\hline $\mathrm{G}$ & 1593 & 840 & 37745.3 & 3.1 & & & \\
\hline $\mathrm{D} 2$ & 1622 & 4815 & 16092.4 & -12.3 & & & \\
\hline \multicolumn{8}{|l|}{ 05-c4 } \\
\hline Peak & Location & Amplitude & Area & FWHM & $\mathrm{R} 1$ & R2 & $\mathrm{T}\left({ }^{\circ} \mathrm{C}\right)$ \\
\hline $\mathrm{D} 1$ & 1352 & 1577 & 147592 & 58.2 & 1.374 & 0.613 & 368.3 \\
\hline G & 1592 & 1148 & 82026.8 & 42.3 & & & \\
\hline D2 & 1621 & 476 & 11199 & 0.0 & & & \\
\hline \multicolumn{8}{|l|}{ 05-c5 } \\
\hline Peak & Location & Amplitude & Area & FWHM & $\mathrm{R} 1$ & R2 & $\mathrm{T}\left({ }^{\circ} \mathrm{C}\right)$ \\
\hline $\mathrm{D} 1$ & 1346 & 792 & 73097.7 & 50.6 & 1.357 & 0.663 & 346.1 \\
\hline$G$ & 1597 & 583 & 32450.6 & 0.1 & & & \\
\hline D2 & 1621 & 372 & 4760.36 & 2.0 & & & \\
\hline \multicolumn{8}{|l|}{$05-c 7$} \\
\hline Peak & Location & Amplitude & Area & FWHM & $\mathrm{R} 1$ & $\mathrm{R} 2$ & $\mathrm{~T}\left({ }^{\circ} \mathrm{C}\right)$ \\
\hline D1 & 1351 & 1200 & 102863 & 51.1 & 1.847 & 0.735 & 313.8 \\
\hline G & 1595 & 650 & 21747 & 7.5 & & & \\
\hline
\end{tabular}




\begin{tabular}{|l|r|r|r|r|r|r|r|} 
D2 & 1621 & 556 & 15266 & -0.1 & & & \\
\hline 05-c8 & & & & & & & \\
\hline Peak & Location & Amplitude & Area & FWHM & R1 & R2 & $\mathrm{T}\left({ }^{\circ} \mathrm{C}\right)$ \\
\hline D1 & 1351 & 1511 & 122457 & 46.4 & 1.476 & 0.617 & 366.6 \\
\hline G & 1594 & 1024 & 67248 & 41.1 & & & \\
\hline D2 & 1622 & 379 & 8860.07 & 0.0 & & & \\
\hline 05-c11 & & & & & & & \\
\hline Peak & Location & Amplitude & Area & FWHM & R1 & R2 & $\mathrm{T}\left({ }^{\circ} \mathrm{C}\right)$ \\
\hline D1 & 1352 & 2170 & 177149 & 49.7 & 1.541 & 0.617 & 366.2 \\
\hline G & 1592 & 1408 & 97480 & 38.8 & & & \\
\hline D2 & 1621 & 522 & 12279.6 & 0.0 & & & \\
\hline 05-a & & & & & & & \\
\hline Peak & Location & Amplitude & Area & FWHM & R1 & R2 & $\mathrm{T}\left({ }^{\circ} \mathrm{C}\right)$ \\
\hline D1 & 1348 & 5374 & 554512 & 65.7 & 1.394 & 0.627 & 362.0 \\
\hline G & 1587 & 3856 & 292388 & 41.7 & & & \\
\hline D2 & 1618 & 1317 & 37406.6 & -0.5 & & & \\
\hline
\end{tabular}

\begin{tabular}{|c|c|c|c|c|c|c|c|}
\hline \multirow[t]{2}{*}{ 16DF06 } & & & & Method: & \multicolumn{3}{|c|}{ Beyssac et al. 2002} \\
\hline & & & & & & $\operatorname{avg} T$ & std dev \\
\hline & & & & \multicolumn{2}{|c|}{ Avg each run } & 358.8 & 17.3 \\
\hline Peak & Location & Amplitude & Area & FWHM & R1 & R2 & $\mathrm{T}\left({ }^{\circ} \mathrm{C}\right)$ \\
\hline D1 & 1351 & 14839 & 1214430 & 50.0 & 1.772 & 0.694 & 332.2 \\
\hline G & 1592 & 8373 & 412391 & 19.7 & & & \\
\hline D2 & 1621 & 4012 & 122984 & 0.1 & & & \\
\hline \multicolumn{8}{|l|}{01} \\
\hline Peak & Location & Amplitude & Area & FWHM & R1 & $\mathrm{R} 2$ & $\mathrm{~T}\left({ }^{\circ} \mathrm{C}\right)$ \\
\hline D1 & 1351 & 23981 & 1916500 & 47.2 & 1.475 & 0.620 & 365.3 \\
\hline G & 1591 & 16254 & 1049050 & 33.4 & & & \\
\hline D2 & 1621 & 5095 & 127965 & 0.0 & & & \\
\hline \multicolumn{8}{|l|}{02} \\
\hline Peak & Location & Amplitude & Area & FWHM & R1 & R2 & $\mathrm{T}\left({ }^{\circ} \mathrm{C}\right)$ \\
\hline D1 & 1350 & 22538 & 1884840 & 53.0 & 1.576 & 0.661 & 346.9 \\
\hline G & 1591 & 14296 & 813739 & 24.8 & & & \\
\hline D2 & 1621 & 5304 & 153112 & -0.1 & & & \\
\hline \multicolumn{8}{|l|}{03} \\
\hline Peak & Location & Amplitude & Area & FWHM & R1 & R2 & $\mathrm{T}\left({ }^{\circ} \mathrm{C}\right)$ \\
\hline D1 & 1351 & 16368 & 1343040 & 51.0 & 1.596 & 0.655 & 349.4 \\
\hline $\mathrm{G}$ & 1593 & 10253 & 590880 & 29.4 & & & \\
\hline D2 & 1621 & 4061 & 115435 & -0.1 & & & \\
\hline \multicolumn{8}{|l|}{04} \\
\hline Peak & Location & Amplitude & Area & FWHM & $\mathrm{R} 1$ & R2 & $\mathrm{T}\left({ }^{\circ} \mathrm{C}\right)$ \\
\hline D1 & 1350 & 22123 & 1915510 & 51.7 & 1.698 & 0.699 & 330.1 \\
\hline $\mathrm{G}$ & 1591 & 13029 & 655387 & 14.5 & & & \\
\hline D2 & 1621 & 5817 & 171264 & -0.1 & & & \\
\hline \multicolumn{8}{|l|}{05} \\
\hline Peak & Location & Amplitude & Area & FWHM & $\mathrm{R} 1$ & $\mathrm{R} 2$ & $\mathrm{~T}\left({ }^{\circ} \mathrm{C}\right)$ \\
\hline D1 & 1351 & 6759 & 585562 & 51.6 & 0.289 & 0.626 & 362.6 \\
\hline$G$ & 1596 & 23356 & 325546 & -27.7 & & & \\
\hline D2 & 1624 & 1210 & 24719.7 & 0.0 & & & \\
\hline
\end{tabular}




\begin{tabular}{|c|c|c|c|c|c|c|c|}
\hline \multicolumn{8}{|l|}{07} \\
\hline Peak & Location & Amplitude & Area & FWHM & R1 & R2 & $\mathrm{T}\left({ }^{\circ} \mathrm{C}\right)$ \\
\hline D1 & 1349 & 19845 & 1636160 & 51.6 & 1.204 & 0.606 & 371.2 \\
\hline G & 1587 & 16488 & 1146270 & 40.9 & & & \\
\hline D2 & 1619 & 3413 & -83808 & 0.0 & & & \\
\hline \multicolumn{8}{|l|}{08} \\
\hline Peak & Location & Amplitude & Area & FWHM & R1 & $\mathrm{R} 2$ & $\mathrm{~T}\left({ }^{\circ} \mathrm{C}\right)$ \\
\hline D1 & 1348 & 22188 & 1871810 & 51.0 & 1.225 & 0.616 & 367.0 \\
\hline G & 1585 & 18109 & 988786 & 14.0 & & & \\
\hline D2 & 1618 & 5831 & 179333 & -0.3 & & & \\
\hline \multicolumn{8}{|l|}{09} \\
\hline Peak & Location & Amplitude & Area & FWHM & $\mathrm{R} 1$ & $\mathrm{R} 2$ & $\mathrm{~T}\left({ }^{\circ} \mathrm{C}\right)$ \\
\hline D1 & 1347 & 23396 & 2032880 & 52.7 & 1.213 & 0.628 & 361.6 \\
\hline G & 1582 & 19280 & 1019080 & 7.3 & & & \\
\hline D2 & 1616 & 5716 & 186133 & 0.0 & & & \\
\hline \multicolumn{8}{|l|}{010} \\
\hline Peak & Location & Amplitude & Area & FWHM & R1 & $\mathrm{R} 2$ & $\mathrm{~T}\left({ }^{\circ} \mathrm{C}\right)$ \\
\hline D1 & 1348 & 28335 & 2379720 & 53.4 & 1.215 & 0.586 & 380.2 \\
\hline G & 1584 & 23329 & 1483570 & 33.2 & & & \\
\hline $\mathrm{D} 2$ & 1617 & 6545 & 196636 & 0.0 & & & \\
\hline \multicolumn{8}{|l|}{011} \\
\hline Peak & Location & Amplitude & Area & FWHM & R1 & $\mathrm{R} 2$ & $\mathrm{~T}\left({ }^{\circ} \mathrm{C}\right)$ \\
\hline D1 & 1350 & 21861 & 1798090 & 51.0 & 1.218 & 0.584 & 380.9 \\
\hline G & 1586 & 17943 & 1130150 & 38.9 & & & \\
\hline D2 & 1618 & 4897 & 148346 & 0.0 & & & \\
\hline
\end{tabular}

\begin{tabular}{|c|c|c|c|c|c|c|c|}
\hline \multirow[t]{2}{*}{ 16DF10 } & & & & Method: & \multicolumn{3}{|c|}{ Beyssac et al. 2002} \\
\hline & & & & & & $\operatorname{avg} T$ & std dev \\
\hline & & & & \multicolumn{2}{|c|}{ Avg each run } & 348.6 & 6.7 \\
\hline Peak & Location & Amplitude & Area & FWHM & R1 & R2 & $\mathrm{T}\left({ }^{\circ} \mathrm{C}\right)$ \\
\hline D1 & 1349 & 22803 & 2012990 & 56.2 & 1.715 & 0.677 & 339.5 \\
\hline $\mathrm{G}$ & 1589 & 13295 & 833637 & 18.0 & & & \\
\hline D2 & 1621 & 3759 & 124742 & 10.2 & & & \\
\hline \multicolumn{8}{|l|}{0} \\
\hline Peak & Location & Amplitude & Area & FWHM & R1 & R2 & $\mathrm{T}\left({ }^{\circ} \mathrm{C}\right)$ \\
\hline D1 & 1345 & 15649 & 1589890 & 64.7 & 1.443 & 0.638 & 356.9 \\
\hline G & 1577 & 10843 & 683479 & 29.0 & & & \\
\hline D2 & 1608 & 5292 & 217383 & -0.1 & & & \\
\hline \multicolumn{8}{|l|}{01} \\
\hline Peak & Location & Amplitude & Area & FWHM & R1 & R2 & $\mathrm{T}\left({ }^{\circ} \mathrm{C}\right)$ \\
\hline D1 & 1347 & 18279 & 1628770 & 56.7 & 1.641 & 0.654 & 350.1 \\
\hline G & 1586 & 11137 & 731865 & 34.2 & & & \\
\hline D2 & 1616 & 8089 & 130715 & -8.7 & & & \\
\hline \multicolumn{8}{|l|}{02} \\
\hline Peak & Location & Amplitude & Area & FWHM & R1 & R2 & $\mathrm{T}\left({ }^{\circ} \mathrm{C}\right)$ \\
\hline D1 & 1344 & 19685 & 1780970 & 57.6 & 1.506 & 0.647 & 352.9 \\
\hline $\mathrm{G}$ & 1576 & 13070 & 734412 & 24.7 & & & \\
\hline D2 & 1609 & 5625 & 235271 & 15.4 & & & \\
\hline 03 & & & & & & & \\
\hline
\end{tabular}




\begin{tabular}{|c|c|c|c|c|c|c|c|}
\hline Peak & Location & Amplitude & Area & FWHM & R1 & $\mathrm{R} 2$ & $\mathrm{~T}\left({ }^{\circ} \mathrm{C}\right)$ \\
\hline D1 & 1344 & 24180 & 2108490 & 55.5 & 1.437 & 0.635 & 358.3 \\
\hline $\mathrm{G}$ & 1575 & 16832 & 943162 & 25.9 & & & \\
\hline $\mathrm{D} 2$ & 1608 & 7206 & 267659 & 5.7 & & & \\
\hline \multicolumn{8}{|l|}{04} \\
\hline Peak & Location & Amplitude & Area & FWHM & R1 & $\mathrm{R} 2$ & $\mathrm{~T}\left({ }^{\circ} \mathrm{C}\right)$ \\
\hline D1 & 1352 & 11430 & 939256 & 52.3 & 1.768 & 0.670 & 342.7 \\
\hline G & 1595 & 6464 & 400086 & 27.5 & & & \\
\hline $\mathrm{D} 2$ & 1623 & 2270 & 61857.5 & 5.7 & & & \\
\hline \multicolumn{8}{|l|}{05} \\
\hline Peak & Location & Amplitude & Area & FWHM & $\mathrm{R} 1$ & R2 & $\mathrm{T}\left({ }^{\circ} \mathrm{C}\right)$ \\
\hline $\mathrm{D} 1$ & 1346 & 27474 & 2478580 & 57.4 & 1.747 & 0.678 & 339.4 \\
\hline $\mathrm{G}$ & 1583 & 15728 & 941546 & 25.5 & & & \\
\hline $\mathrm{D} 2$ & 1614 & 6614 & 236751 & 1.5 & & & \\
\hline \multicolumn{8}{|l|}{07} \\
\hline Peak & Location & Amplitude & Area & FWHM & R1 & $\mathrm{R} 2$ & $\mathrm{~T}\left({ }^{\circ} \mathrm{C}\right)$ \\
\hline D1 & 1345 & 23122 & 2012750 & 55.4 & 1.607 & 0.655 & 349.4 \\
\hline$G$ & 1580 & 14390 & 856848 & 25.7 & & & \\
\hline $\mathrm{D} 2$ & 1613 & 5642 & 202212 & 5.4 & & & \\
\hline \multicolumn{8}{|l|}{08} \\
\hline Peak & Location & Amplitude & Area & FWHM & $\mathrm{R} 1$ & $\mathrm{R} 2$ & $\mathrm{~T}\left({ }^{\circ} \mathrm{C}\right)$ \\
\hline D1 & 1344 & 21472 & 1928980 & 57.2 & 1.543 & 0.655 & 349.7 \\
\hline G & 1578 & 13912 & 819280 & 25.9 & & & \\
\hline D2 & 1610 & 5558 & 198693 & 8.6 & & & \\
\hline \multicolumn{8}{|l|}{09} \\
\hline Peak & Location & Amplitude & Area & FWHM & $\mathrm{R} 1$ & $\mathrm{R} 2$ & $\mathrm{~T}\left({ }^{\circ} \mathrm{C}\right)$ \\
\hline $\mathrm{D} 1$ & 1345 & 23055 & 2074060 & 57.3 & 1.649 & 0.671 & 342.2 \\
\hline $\mathrm{G}$ & 1582 & 13985 & 808214 & 18.4 & & & \\
\hline D2 & 1614 & 5513 & 206834 & 10.5 & & & \\
\hline \multicolumn{8}{|l|}{10} \\
\hline Peak & Location & Amplitude & Area & FWHM & R1 & $\mathrm{R} 2$ & $\mathrm{~T}\left({ }^{\circ} \mathrm{C}\right)$ \\
\hline D1 & 1346 & 18055 & 1822790 & 64.3 & 1.471 & 0.638 & 357.0 \\
\hline G & 1583 & 12275 & 815429 & 33.0 & & & \\
\hline D2 & 1613 & 4747 & 217991 & 27.6 & & & \\
\hline \multicolumn{8}{|l|}{11} \\
\hline Peak & Location & Amplitude & Area & FWHM & R1 & R2 & $\mathrm{T}\left({ }^{\circ} \mathrm{C}\right)$ \\
\hline $\mathrm{D} 1$ & 1345 & 24708 & 2232040 & 57.5 & 1.615 & 0.650 & 351.6 \\
\hline$G$ & 1581 & 15300 & 989597 & 26.3 & & & \\
\hline D2 & 1613 & 5469 & 210036 & 16.0 & & & \\
\hline \multicolumn{8}{|l|}{12} \\
\hline Peak & Location & Amplitude & Area & FWHM & $\mathrm{R} 1$ & $\mathrm{R} 2$ & $\mathrm{~T}\left({ }^{\circ} \mathrm{C}\right)$ \\
\hline D1 & 1346 & 24603 & 2218230 & 57.4 & 1.709 & 0.671 & 342.6 \\
\hline$G$ & 1583 & 14399 & 879202 & 25.8 & & & \\
\hline D2 & 1614 & 5868 & 210307 & 4.9 & & & \\
\hline
\end{tabular}




\begin{tabular}{|c|c|c|c|c|c|c|c|}
\hline \multirow[t]{3}{*}{ 16DF11 } & & & & Method: & \multicolumn{3}{|c|}{ Beyssac et al. 2002} \\
\hline & & & & & & $\operatorname{avg} \mathrm{T}$ & std dev \\
\hline & & & & \multicolumn{2}{|c|}{ Avg each run } & 367.9 & 12.4 \\
\hline Peak & Location & Amplitude & Area & FWHM & R1 & $\mathrm{R} 2$ & $\mathrm{~T}\left({ }^{\circ} \mathrm{C}\right)$ \\
\hline D1 & 1349 & 5048 & 399377 & 50.3 & 1.391 & 0.572 & 386.3 \\
\hline G & 1587 & 3628 & 260542 & 43.0 & & & \\
\hline D2 & 1619 & 1182 & 37937.7 & 1.4 & & & \\
\hline \multicolumn{8}{|l|}{$11-1$} \\
\hline Peak & Location & Amplitude & Area & FWHM & R1 & $\mathrm{R} 2$ & $\mathrm{~T}\left({ }^{\circ} \mathrm{C}\right)$ \\
\hline D1 & 1351 & 1962 & 141562 & 43.6 & 1.197 & 0.571 & 386.8 \\
\hline G & 1588 & 1639 & 93119 & 31.2 & & & \\
\hline $\mathrm{D} 2$ & 1620 & 549 & 13106.6 & 0.1 & & & \\
\hline \multicolumn{8}{|l|}{$11-2$} \\
\hline Peak & Location & Amplitude & Area & FWHM & R1 & $\mathrm{R} 2$ & $\mathrm{~T}\left({ }^{\circ} \mathrm{C}\right)$ \\
\hline D1 & 1347 & 6006 & 471036 & 48.2 & 1.455 & 0.621 & 364.5 \\
\hline G & 1584 & 4129 & 245846 & 24.2 & & & \\
\hline D2 & 1618 & 1175 & 41083.2 & 18.0 & & & \\
\hline \multicolumn{8}{|l|}{$11-3$} \\
\hline Peak & Location & Amplitude & Area & FWHM & $\mathrm{R} 1$ & $\mathrm{R} 2$ & $\mathrm{~T}\left({ }^{\circ} \mathrm{C}\right)$ \\
\hline D1 & 1351 & 1783 & 126754 & 43.7 & 1.414 & 0.597 & 375.4 \\
\hline $\mathrm{G}$ & 1589 & 1261 & 75240.2 & 34.9 & & & \\
\hline D2 & 1620 & 399 & 10355.5 & 0.0 & & & \\
\hline \multicolumn{8}{|l|}{$11-4$} \\
\hline Peak & Location & Amplitude & Area & FWHM & R1 & $\mathrm{R} 2$ & $\mathrm{~T}\left({ }^{\circ} \mathrm{C}\right)$ \\
\hline D1 & 1350 & 4000 & 259028 & 34.5 & 1.680 & 0.626 & 362.6 \\
\hline G & 1588 & 2381 & 135009 & 27.4 & & & \\
\hline D2 & 1621 & 791 & 19938.2 & 0.0 & & & \\
\hline \multicolumn{8}{|l|}{$11-5$} \\
\hline Peak & Location & Amplitude & Area & FWHM & R1 & $\mathrm{R} 2$ & $\mathrm{~T}\left({ }^{\circ} \mathrm{C}\right)$ \\
\hline D1 & 1348 & 5252 & 395353 & 47.6 & 1.639 & 0.614 & 367.8 \\
\hline G & 1587 & 3204 & 227808 & 34.0 & & & \\
\hline D2 & 1620 & 800 & 20756.2 & -0.2 & & & \\
\hline \multicolumn{8}{|l|}{$11-6$} \\
\hline Peak & Location & Amplitude & Area & FWHM & R1 & R2 & $\mathrm{T}\left({ }^{\circ} \mathrm{C}\right)$ \\
\hline D1 & 1349 & 3965 & 303122 & 48.1 & 1.718 & 0.642 & 355.3 \\
\hline G & 1589 & 2307 & 148695 & 39.2 & & & \\
\hline D2 & 1618 & 733 & 20302.2 & -0.1 & & & \\
\hline \multicolumn{8}{|l|}{$11-7$} \\
\hline Peak & Location & Amplitude & Area & FWHM & R1 & R2 & $\mathrm{T}\left({ }^{\circ} \mathrm{C}\right)$ \\
\hline D1 & 1350 & 1276 & 91662.2 & 35.0 & 1.349 & 0.606 & 371.5 \\
\hline G & 1587 & 946 & 54165.7 & 28.0 & & & \\
\hline D2 & 1620 & 280 & 5543.82 & -0.3 & & & \\
\hline \multicolumn{8}{|l|}{$11-8$} \\
\hline Peak & Location & Amplitude & Area & FWHM & R1 & R2 & $\mathrm{T}\left({ }^{\circ} \mathrm{C}\right)$ \\
\hline D1 & 1351 & 1055 & 70085 & 39.6 & 1.569 & 0.625 & 362.8 \\
\hline G & 1591 & 673 & 35711.6 & 19.1 & & & \\
\hline D2 & 1622 & 213 & 6327.56 & 0.1 & & & \\
\hline \multicolumn{8}{|l|}{$11-9$} \\
\hline Peak & Location & Amplitude & Area & FWHM & R1 & $\mathrm{R} 2$ & $\mathrm{~T}\left({ }^{\circ} \mathrm{C}\right)$ \\
\hline $\mathrm{D} 1$ & 1351 & 1519 & 124564 & 50.8 & 1.369 & 0.604 & 372.2 \\
\hline
\end{tabular}




\begin{tabular}{|l|r|r|r|r|r|r|r|}
\hline G & 1590 & 1110 & 71200.4 & 37.7 & & & \\
\hline D2 & 1621 & 411 & 10426 & 0.2 & & & \\
\hline $11-13$ & & & & & & & \\
\hline Peak & Location & Amplitude & Area & FWHM & R1 & R2 & $\mathrm{T}\left({ }^{\circ} \mathrm{C}\right)$ \\
\hline D1 & 1348 & 3980 & 320902 & 50.9 & 1.341 & 0.589 & 379.1 \\
\hline G & 1584 & 2968 & 197800 & 37.4 & & & \\
\hline D2 & 1617 & 919 & 26483.8 & 0.0 & & & \\
\hline 11-14 & & & & & & & \\
\hline Peak & Location & Amplitude & Area & FWHM & R1 & R2 & $\mathrm{T}\left({ }^{\circ} \mathrm{C}\right)$ \\
\hline D1 & 1349 & 4921 & 362544 & 46.5 & 1.614 & 0.647 & 353.3 \\
\hline G & 1587 & 3049 & 168278 & 26.1 & & & \\
\hline D2 & 1619 & 1063 & 29955.5 & -0.9 & & & \\
\hline 11-15 & & & & & & & \\
\hline Peak & Location & Amplitude & Area & FWHM & R1 & R2 & $\mathrm{T}\left({ }^{\circ} \mathrm{C}\right)$ \\
\hline D1 & 1350 & 3953 & 272750 & 43.6 & 1.792 & 0.664 & 345.7 \\
\hline G & 1588 & 2206 & 110435 & 24.5 & & & \\
\hline D2 & 1620 & 1302 & 27832.4 & -4.9 & & & \\
\hline
\end{tabular}

\begin{tabular}{|c|c|c|c|c|c|c|c|}
\hline \multirow[t]{2}{*}{ 16DF12 } & & & & Method: & \multicolumn{3}{|c|}{ Beyssac et al. 2002} \\
\hline & & & & & & $\operatorname{avg} \mathrm{T}$ & std dev \\
\hline & & & & \multicolumn{2}{|c|}{ Avg each run } & 364.9 & 18.2 \\
\hline Peak & Location & Amplitude & Area & FWHM & R1 & $\mathrm{R} 2$ & $\mathrm{~T}\left({ }^{\circ} \mathrm{C}\right)$ \\
\hline $\mathrm{D} 1$ & 1352 & 8459 & 512967 & 28.3 & 1.722 & 0.656 & 349.3 \\
\hline G & 1590 & 4912 & 206309 & 11.3 & & & \\
\hline D2 & 1620 & 2181 & 63190 & -0.2 & & & \\
\hline \multicolumn{8}{|l|}{12} \\
\hline Peak & Location & Amplitude & Area & FWHM & R1 & R2 & $\mathrm{T}\left({ }^{\circ} \mathrm{C}\right)$ \\
\hline D1 & 1351 & 7959 & 620196 & 49.5 & 1.455 & 0.556 & 393.4 \\
\hline G & 1590 & 5470 & 473432 & 51.4 & & & \\
\hline D2 & 1620 & 977 & 20848.3 & 0.5 & & & \\
\hline \multicolumn{8}{|l|}{13} \\
\hline Peak & Location & Amplitude & Area & FWHM & R1 & $\mathrm{R} 2$ & $\mathrm{~T}\left({ }^{\circ} \mathrm{C}\right)$ \\
\hline D1 & 1351 & 5865 & 435986 & 41.8 & 1.471 & 0.635 & 358.5 \\
\hline$G$ & 1587 & 3986 & 210219 & 10.6 & & & \\
\hline D2 & 1619 & 1149 & 40685.2 & 0.0 & & & \\
\hline \multicolumn{8}{|l|}{14} \\
\hline Peak & Location & Amplitude & Area & FWHM & $\mathrm{R} 1$ & $\mathrm{R} 2$ & $\mathrm{~T}\left({ }^{\circ} \mathrm{C}\right)$ \\
\hline D1 & 1350 & 5294 & 339829 & 34.5 & 1.263 & 0.567 & 388.9 \\
\hline$G$ & 1586 & 4192 & 226492 & 27.9 & & & \\
\hline D2 & 1618 & 1211 & 33432.7 & 0.1 & & & \\
\hline \multicolumn{8}{|l|}{15} \\
\hline Peak & Location & Amplitude & Area & FWHM & $\mathrm{R} 1$ & $\mathrm{R} 2$ & $\mathrm{~T}\left({ }^{\circ} \mathrm{C}\right)$ \\
\hline D1 & 1349 & \#\#\#\#\#\#\#\# & 705895 & -47.6 & \#\#\#\#\#\#\# & 0.620 & 364.9 \\
\hline $\mathrm{G}$ & 1587 & 20970 & 397063 & -21.1 & & & \\
\hline $\mathrm{D} 2$ & 1621 & 1373 & 34711.2 & 0.0 & & & \\
\hline \multicolumn{8}{|l|}{17} \\
\hline Peak & Location & Amplitude & Area & FWHM & $\mathrm{R} 1$ & $\mathrm{R} 2$ & $\mathrm{~T}\left({ }^{\circ} \mathrm{C}\right)$ \\
\hline D1 & 1350 & 7870 & 540452 & 43.2 & 1.746 & 0.662 & 346.5 \\
\hline G & 1589 & 4507 & 218022 & -0.1 & & & \\
\hline
\end{tabular}




\begin{tabular}{|l|r|r|l|r|r|l|l|} 
D2 & 1620 & 1607 & 58163.6 & 16.7 & & & \\
\hline 18 & & & & & & & \\
\hline Peak & Location & Amplitude & Area & FWHM & R1 & R2 & $\mathrm{T}\left({ }^{\circ} \mathrm{C}\right)$ \\
\hline D1 & 1351 & 5865 & 386941 & 34.9 & 1.548 & 0.651 & 351.2 \\
\hline G & 1587 & 3788 & 151290 & 9.5 & & & \\
\hline D2 & 1618 & 1709 & 55834.8 & -0.2 & & & \\
\hline 19 & & & & & & & \\
\hline Peak & Location & Amplitude & Area & FWHM & R1 & R2 & $\mathrm{T}\left({ }^{\circ} \mathrm{C}\right)$ \\
\hline D1 & 1351 & 6771 & 445881 & 35.3 & 1.499 & 0.632 & 359.7 \\
\hline G & 1588 & 4518 & 198127 & 13.4 & & & \\
\hline D2 & 1619 & 1873 & 61328.5 & -0.1 & & & \\
\hline 110 & & & & & & & \\
\hline Peak & Location & Amplitude & Area & FWHM & R1 & R2 & $\mathrm{T}\left({ }^{\circ} \mathrm{C}\right)$ \\
\hline D1 & 1353 & 439 & 24568.2 & 23.4 & 1.354 & 0.575 & 385.2 \\
\hline G & 1590 & 324 & 14482.2 & 1.0 & & & \\
\hline D2 & 1623 & 2756 & 3695.66 & -14.4 & & & \\
\hline 111 & & & & & & & \\
\hline Peak & Location & Amplitude & Area & FWHM & R1 & R2 & $\mathrm{T}\left({ }^{\circ} \mathrm{C}\right)$ \\
\hline D1 & 1350 & 5962 & 442653 & 43.5 & 1.378 & 0.602 & 373.2 \\
\hline G & 1588 & 4325 & 261168 & 29.0 & & & \\
\hline D2 & 1620 & 1205 & 31827.2 & 0.0 & & & \\
\hline 112 & & & & & & & \\
\hline Peak & Location & Amplitude & Area & FWHM & R1 & R2 & $\mathrm{T}\left({ }^{\circ} \mathrm{C}\right)$ \\
\hline D1 & 1351 & 8399 & 531511 & 39.5 & 1.424 & 0.604 & 372.2 \\
\hline G & 1588 & 5896 & 309973 & 12.9 & & & \\
\hline D2 & 1620 & 1515 & 38335.6 & 0.0 & & & \\
\hline 16 & & & & & & & \\
\hline Peak & Location & Amplitude & Area & FWHM & R1 & R2 & $\mathrm{T}\left({ }^{\circ} \mathrm{C}\right)$ \\
\hline D1 & 1349 & 1451610 & 221799 & -47.0 & $\# \# \# \# \#$ & 0.687 & 335.4 \\
\hline G & 1617 & 503 & 22485.1 & 20.1 & & & \\
\hline D2 & 1587 & 1463 & 78642.6 & 0.0 & & & \\
\hline
\end{tabular}

\begin{tabular}{|c|c|c|c|c|c|c|c|}
\hline \multirow[t]{2}{*}{ 16DF14 } & & & & Method: & \multicolumn{3}{|c|}{ Beyssac et al. 2002} \\
\hline & & & & & & $\operatorname{avg} T$ & std dev \\
\hline & & & & \multicolumn{2}{|c|}{ Avg each run } & 356.6 & 13.6 \\
\hline Peak & Location & Amplitude & Area & FWHM & R1 & R2 & $\mathrm{T}\left({ }^{\circ} \mathrm{C}\right)$ \\
\hline D1 & 1351 & 3992 & 91844.4 & -26.9 & 4.286 & 0.603 & 372.8 \\
\hline G & 1602 & 931 & 57097.4 & -0.2 & & & \\
\hline $\mathrm{D} 2$ & 1622 & 131 & 3470.35 & 16.8 & & & \\
\hline \multicolumn{8}{|l|}{1} \\
\hline Peak & Location & Amplitude & Area & FWHM & R1 & R2 & $\mathrm{T}\left({ }^{\circ} \mathrm{C}\right)$ \\
\hline D1 & 1351 & 16149 & 1372220 & 54.0 & 0.221 & 0.647 & 352.9 \\
\hline G & 1593 & 73050 & 690741 & -31.3 & & & \\
\hline D2 & 1622 & 2447 & 56346.4 & -0.3 & & & \\
\hline \multicolumn{8}{|l|}{02} \\
\hline Peak & Location & Amplitude & Area & FWHM & R1 & $\mathrm{R} 2$ & $\mathrm{~T}\left({ }^{\circ} \mathrm{C}\right)$ \\
\hline D1 & 1352 & 3453 & 241370 & 30.3 & 1.459 & 0.612 & 368.5 \\
\hline G & 1597 & 2366 & 147670 & 3.5 & & & \\
\hline D2 & 1624 & 382 & 5100.85 & 0.4 & & & \\
\hline
\end{tabular}




\begin{tabular}{|c|c|c|c|c|c|c|c|}
\hline \multicolumn{8}{|l|}{11} \\
\hline Peak & Location & Amplitude & Area & FWHM & R1 & $\mathrm{R} 2$ & $\mathrm{~T}\left({ }^{\circ} \mathrm{C}\right)$ \\
\hline D1 & 1352 & 9355 & 746774 & 48.3 & 1.732 & 0.668 & 343.9 \\
\hline G & 1594 & 5401 & 318180 & 17.9 & & & \\
\hline D2 & 1624 & 1790 & 53665.6 & 9.6 & & & \\
\hline \multicolumn{8}{|l|}{12} \\
\hline Peak & Location & Amplitude & Area & FWHM & $\mathrm{R} 1$ & $\mathrm{R} 2$ & $\mathrm{~T}\left({ }^{\circ} \mathrm{C}\right)$ \\
\hline D1 & 1352 & 5321 & 308329 & 8.3 & 1.400 & 0.584 & 380.9 \\
\hline G & 1594 & 3801 & 198585 & 0.0 & & & \\
\hline D2 & 1624 & 1008 & 20686.2 & -0.1 & & & \\
\hline \multicolumn{8}{|l|}{14} \\
\hline Peak & Location & Amplitude & Area & FWHM & R1 & $\mathrm{R} 2$ & $\mathrm{~T}\left({ }^{\circ} \mathrm{C}\right)$ \\
\hline $\mathrm{D} 1$ & 1351 & 5996 & 368675 & 14.0 & 1.658 & 0.638 & 357.2 \\
\hline G & 1594 & 3617 & 174281 & 0.1 & & & \\
\hline D2 & 1624 & 1236 & 35179.4 & 6.1 & & & \\
\hline \multicolumn{8}{|l|}{15} \\
\hline Peak & Location & Amplitude & Area & FWHM & $\mathrm{R} 1$ & $\mathrm{R} 2$ & $\mathrm{~T}\left({ }^{\circ} \mathrm{C}\right)$ \\
\hline $\mathrm{D} 1$ & 1352 & 3350 & 267067 & 48.7 & 1.630 & 0.668 & 343.8 \\
\hline G & 1595 & 2055 & 125196 & 7.9 & & & \\
\hline D2 & 1623 & 390 & 7602.75 & 0.0 & & & \\
\hline \multicolumn{8}{|l|}{16} \\
\hline Peak & Location & Amplitude & Area & FWHM & R1 & $\mathrm{R} 2$ & $\mathrm{~T}\left({ }^{\circ} \mathrm{C}\right)$ \\
\hline D1 & 1350 & 9700 & 808653 & 50.4 & 1.591 & 0.635 & 358.5 \\
\hline G & 1594 & 6096 & 420137 & 30.4 & & & \\
\hline D2 & 1621 & 1567 & 44883.7 & 1.4 & & & \\
\hline \multicolumn{8}{|l|}{17} \\
\hline Peak & Location & Amplitude & Area & FWHM & R1 & $\mathrm{R} 2$ & $\mathrm{~T}\left({ }^{\circ} \mathrm{C}\right)$ \\
\hline D1 & 1350 & 11492 & 981190 & 46.3 & 1.017 & 0.667 & 344.0 \\
\hline$G$ & 1597 & 11305 & 448731 & -9.2 & & & \\
\hline $\mathrm{D} 2$ & 1625 & 1885 & 40122 & -1.6 & & & \\
\hline \multicolumn{8}{|l|}{19} \\
\hline Peak & Location & Amplitude & Area & FWHM & R1 & $\mathrm{R} 2$ & $\mathrm{~T}\left({ }^{\circ} \mathrm{C}\right)$ \\
\hline D1 & 1351 & 13496 & 1068180 & 42.0 & 1.226 & 0.668 & 343.7 \\
\hline G & 1597 & 11011 & 502543 & -6.2 & & & \\
\hline D2 & 1625 & 1500 & 28030.9 & -0.1 & & & \\
\hline
\end{tabular}

\begin{tabular}{|c|c|c|c|c|c|c|c|}
\hline \multirow[t]{2}{*}{ 16DF15 } & & & & Method: & \multicolumn{3}{|c|}{ Beyssac et al. 2002} \\
\hline & & & & & & $\operatorname{avg} \mathrm{T}$ & std dev \\
\hline & & & & \multicolumn{2}{|c|}{ Avg each run } & 356.5 & 14.0 \\
\hline Peak & Location & Amplitude & Area & FWHM & R1 & R2 & $\mathrm{T}\left({ }^{\circ} \mathrm{C}\right)$ \\
\hline D1 & 1350 & 18135 & 1455800 & 49.5 & 1.685 & 0.679 & 338.9 \\
\hline $\mathrm{G}$ & 1590 & 10761 & 553129 & 20.1 & & & \\
\hline D2 & 1620 & 4455 & 135797 & -0.3 & & & \\
\hline 02 & & & & & & & \\
\hline Peak & Location & Amplitude & Area & FWHM & R1 & R2 & $\mathrm{T}\left({ }^{\circ} \mathrm{C}\right)$ \\
\hline D1 & 1350 & 22798 & 1799040 & 49.0 & 1.619 & 0.633 & 359.2 \\
\hline G & 1590 & 14078 & 920298 & 32.0 & & & \\
\hline D2 & 1620 & 4443 & 121577 & -0.1 & & & \\
\hline 03 & & & & & & & \\
\hline
\end{tabular}




\begin{tabular}{|c|c|c|c|c|c|c|c|}
\hline Peak & Location & Amplitude & Area & FWHM & R1 & $\mathrm{R} 2$ & $\mathrm{~T}\left({ }^{\circ} \mathrm{C}\right)$ \\
\hline D1 & 1347 & 13357 & 1373660 & 65.4 & 1.474 & 0.688 & 334.8 \\
\hline $\mathrm{G}$ & 1590 & 9064 & 522329 & 17.5 & & & \\
\hline D2 & 1618 & 5338 & 100396 & -9.0 & & & \\
\hline \multicolumn{8}{|l|}{05} \\
\hline Peak & Location & Amplitude & Area & FWHM & R1 & $\mathrm{R} 2$ & $\mathrm{~T}\left({ }^{\circ} \mathrm{C}\right)$ \\
\hline D1 & 1349 & 10209 & 710995 & 44.3 & 2.229 & 0.585 & 380.8 \\
\hline G & 1591 & 4580 & 293160 & -0.2 & & & \\
\hline $\mathrm{D} 2$ & 1610 & 2914 & 211676 & 24.3 & & & \\
\hline \multicolumn{8}{|l|}{06} \\
\hline Peak & Location & Amplitude & Area & FWHM & $\mathrm{R} 1$ & R2 & $\mathrm{T}\left({ }^{\circ} \mathrm{C}\right)$ \\
\hline $\mathrm{D} 1$ & 1350 & 18275 & 1325100 & 46.1 & 1.688 & 0.649 & 352.0 \\
\hline $\mathrm{G}$ & 1590 & 10825 & 615980 & 22.7 & & & \\
\hline $\mathrm{D} 2$ & 1621 & 3605 & 99376.6 & 0.0 & & & \\
\hline \multicolumn{8}{|l|}{07} \\
\hline Peak & Location & Amplitude & Area & FWHM & R1 & $\mathrm{R} 2$ & $\mathrm{~T}\left({ }^{\circ} \mathrm{C}\right)$ \\
\hline D1 & 1350 & 5857 & 317496 & 0.0 & 1.632 & 0.627 & 361.9 \\
\hline$G$ & 1594 & 3588 & 172934 & 0.0 & & & \\
\hline $\mathrm{D} 2$ & 1624 & 907 & 15791.7 & 6.2 & & & \\
\hline \multicolumn{8}{|l|}{09} \\
\hline Peak & Location & Amplitude & Area & FWHM & $\mathrm{R} 1$ & $\mathrm{R} 2$ & $\mathrm{~T}\left({ }^{\circ} \mathrm{C}\right)$ \\
\hline D1 & 1350 & 7328 & 485289 & 36.1 & 1.664 & 0.666 & 344.7 \\
\hline G & 1589 & 4403 & 197672 & 9.0 & & & \\
\hline $\mathrm{D} 2$ & 1621 & 1632 & 45992 & -0.2 & & & \\
\hline \multicolumn{8}{|l|}{010} \\
\hline Peak & Location & Amplitude & Area & FWHM & $\mathrm{R} 1$ & R2 & $\mathrm{T}\left({ }^{\circ} \mathrm{C}\right)$ \\
\hline $\mathrm{D} 1$ & 1351 & 4660 & 356687 & 48.7 & 1.538 & 0.603 & 372.5 \\
\hline $\mathrm{G}$ & 1590 & 3029 & 201681 & 42.3 & & & \\
\hline $\mathrm{D} 2$ & 1619 & 1082 & 32785.9 & 0.2 & & & \\
\hline \multicolumn{8}{|l|}{011} \\
\hline Peak & Location & Amplitude & Area & FWHM & R1 & $\mathrm{R} 2$ & $\mathrm{~T}\left({ }^{\circ} \mathrm{C}\right)$ \\
\hline D1 & 1349 & 20270 & 1656040 & 51.1 & 1.541 & 0.654 & 350.1 \\
\hline G & 1589 & 13154 & 773523 & 19.1 & & & \\
\hline D2 & 1621 & 3781 & 103638 & -0.1 & & & \\
\hline \multicolumn{8}{|l|}{04} \\
\hline Peak & Location & Amplitude & Area & FWHM & $\mathrm{R} 1$ & $\mathrm{R} 2$ & $\mathrm{~T}\left({ }^{\circ} \mathrm{C}\right)$ \\
\hline $\mathrm{D} 1$ & 1348 & 19361 & 2182440 & 71.8 & 1.187 & 0.618 & 365.8 \\
\hline$G$ & 1587 & 16310 & 1221420 & 32.6 & & & \\
\hline D2 & 1618 & 3551 & 125356 & -1.5 & & & \\
\hline \multicolumn{8}{|l|}{01} \\
\hline Peak & Location & Amplitude & Area & FWHM & $\mathrm{R} 1$ & $\mathrm{R} 2$ & $\mathrm{~T}\left({ }^{\circ} \mathrm{C}\right)$ \\
\hline D1 & 1351 & 3632 & 249788 & 43.4 & 1.568 & 0.630 & 360.8 \\
\hline$G$ & 1591 & 2316 & 122794 & 33.6 & & & \\
\hline D2 & 1619 & 899 & 24103.9 & 0.9 & & & \\
\hline
\end{tabular}




\begin{tabular}{|c|c|c|c|c|c|c|c|}
\hline \multirow[t]{3}{*}{ 16DF19 } & & & & Method: & \multicolumn{3}{|c|}{ Beyssac et al. 2002} \\
\hline & & & & & & $\operatorname{avg} \mathrm{T}$ & std dev \\
\hline & & & & \multicolumn{2}{|c|}{ Avg each run } & 357.8 & 11.0 \\
\hline Peak & Location & Amplitude & Area & FWHM & R1 & $\mathrm{R} 2$ & $\mathrm{~T}\left({ }^{\circ} \mathrm{C}\right)$ \\
\hline D1 & 1352 & 1034 & 90418.9 & 54.9 & 1.375 & 0.645 & 353.9 \\
\hline G & 1596 & 752 & 46128.8 & 11.4 & & & \\
\hline D2 & 1624 & 207 & 3576.53 & 0.0 & & & \\
\hline \multicolumn{8}{|l|}{$19-4$} \\
\hline Peak & Location & Amplitude & Area & FWHM & $\mathrm{R} 1$ & $\mathrm{R} 2$ & $\mathrm{~T}\left({ }^{\circ} \mathrm{C}\right)$ \\
\hline D1 & 1349 & 3958 & 349522 & 56.1 & 1.297 & 0.582 & 382.1 \\
\hline G & 1588 & 3052 & 225777 & 41.6 & & & \\
\hline $\mathrm{D} 2$ & 1619 & 1035 & 25517.3 & -0.1 & & & \\
\hline \multicolumn{8}{|l|}{$19-5$} \\
\hline Peak & Location & Amplitude & Area & FWHM & $\mathrm{R} 1$ & $\mathrm{R} 2$ & $\mathrm{~T}\left({ }^{\circ} \mathrm{C}\right)$ \\
\hline D1 & 1351 & 981 & 87690.3 & 52.3 & 1.433 & 0.629 & 361.0 \\
\hline G & 1593 & 685 & 43861.7 & 34.7 & & & \\
\hline D2 & 1621 & 350 & 7832.7 & 0.0 & & & \\
\hline \multicolumn{8}{|l|}{$19-6$} \\
\hline Peak & Location & Amplitude & Area & FWHM & R1 & $\mathrm{R} 2$ & $\mathrm{~T}\left({ }^{\circ} \mathrm{C}\right)$ \\
\hline D1 & 1349 & 3711 & 360489 & 61.3 & 1.477 & 0.638 & 357.2 \\
\hline G & 1590 & 2513 & 173701 & 43.4 & & & \\
\hline D2 & 1619 & 1110 & 31070.2 & 0.1 & & & \\
\hline \multicolumn{8}{|l|}{$19-7$} \\
\hline Peak & Location & Amplitude & Area & FWHM & $\mathrm{R} 1$ & $\mathrm{R} 2$ & $\mathrm{~T}\left({ }^{\circ} \mathrm{C}\right)$ \\
\hline D1 & 1352 & 1413 & 131611 & 58.1 & 1.401 & 0.615 & 367.2 \\
\hline G & 1592 & 1008 & 71898.9 & 44.3 & & & \\
\hline D2 & 1621 & 382 & 10409.2 & -0.3 & & & \\
\hline \multicolumn{8}{|l|}{$19-8$} \\
\hline Peak & Location & Amplitude & Area & FWHM & R1 & R2 & $\mathrm{T}\left({ }^{\circ} \mathrm{C}\right)$ \\
\hline D1 & 1349 & 4287 & 395389 & 58.3 & 1.564 & 0.654 & 350.0 \\
\hline G & 1588 & 2741 & 176709 & 28.9 & & & \\
\hline D2 & 1619 & 1645 & 32485.9 & -5.7 & & & \\
\hline \multicolumn{8}{|l|}{$19-9$} \\
\hline Peak & Location & Amplitude & Area & FWHM & R1 & R2 & $\mathrm{T}\left({ }^{\circ} \mathrm{C}\right)$ \\
\hline D1 & 1352 & 2586 & 239856 & 58.6 & 1.379 & 0.641 & 356.0 \\
\hline G & 1592 & 1875 & 113706 & 32.7 & & & \\
\hline D2 & 1622 & 853 & 20885.5 & 0.0 & & & \\
\hline \multicolumn{8}{|l|}{$19-10$} \\
\hline Peak & Location & Amplitude & Area & FWHM & R1 & R2 & $\mathrm{T}\left({ }^{\circ} \mathrm{C}\right)$ \\
\hline D1 & 1351 & 1997 & 161873 & 51.0 & 1.885 & 0.679 & 339.1 \\
\hline G & 1590 & 1059 & 50651.7 & 18.2 & & & \\
\hline D2 & 1618 & 705 & 26038 & 0.8 & & & \\
\hline \multicolumn{8}{|l|}{$19-11$} \\
\hline Peak & Location & Amplitude & Area & FWHM & R1 & $\mathrm{R} 2$ & $\mathrm{~T}\left({ }^{\circ} \mathrm{C}\right)$ \\
\hline D1 & 1351 & 1382 & 114100 & 44.5 & 1.404 & 0.624 & 363.4 \\
\hline G & 1590 & 985 & 59644.3 & 28.5 & & & \\
\hline D2 & 1621 & 381 & 9170.56 & 0.0 & & & \\
\hline \multicolumn{8}{|l|}{$19-12$} \\
\hline Peak & Location & Amplitude & Area & FWHM & R1 & R2 & $\mathrm{T}\left({ }^{\circ} \mathrm{C}\right)$ \\
\hline D1 & 1350 & 3131 & 268432 & 54.0 & 1.600 & 0.643 & 354.8 \\
\hline
\end{tabular}




\begin{tabular}{|l|r|r|r|r|r|r|r|} 
G & 1591 & 1957 & 130270 & 24.0 & & & \\
\hline D2 & 1622 & 702 & 18652.2 & 7.6 & & & \\
\hline $19-13$ & & & & & & & \\
\hline Peak & Location & Amplitude & Area & FWHM & R1 & R2 & T $\left({ }^{\circ} \mathrm{C}\right)$ \\
\hline D1 & 1346 & 4209 & 389718 & 58.9 & 1.544 & 0.651 & 351.3 \\
\hline G & 1582 & 2726 & 159664 & 16.9 & & & \\
\hline D2 & 1615 & 1166 & 49199.5 & 22.2 & & & \\
\hline
\end{tabular}

\begin{tabular}{|c|c|c|c|c|c|c|c|}
\hline \multirow{2}{*}{ 16DF20 } & & & & Method: & \multicolumn{3}{|c|}{ Beyssac et al. 2002} \\
\hline & & & & & & $\operatorname{avg} T$ & std dev \\
\hline & & & & \multicolumn{2}{|c|}{ Avg each run } & 390.6 & 20.4 \\
\hline Peak & Location & Amplitude & Area & FWHM & R1 & $\mathrm{R} 2$ & $\mathrm{~T}\left({ }^{\circ} \mathrm{C}\right)$ \\
\hline D1 & 1349 & 3296 & 222898 & 39.6 & 1.517 & 0.631 & 360.4 \\
\hline G & 1589 & 2173 & 111574 & 14.2 & & & \\
\hline D2 & 1621 & 822 & 19033.5 & -1.1 & & & \\
\hline \multicolumn{8}{|l|}{ bl1 } \\
\hline Peak & Location & Amplitude & Area & FWHM & R1 & R2 & $\mathrm{T}\left({ }^{\circ} \mathrm{C}\right)$ \\
\hline D1 & 1350 & 4407 & 292192 & 41.8 & 1.268 & 0.585 & 380.6 \\
\hline G & 1584 & 3475 & 176078 & 26.0 & & & \\
\hline D2 & 1618 & 1147 & 31078 & -0.2 & & & \\
\hline \multicolumn{8}{|l|}{$\mathrm{bl} 2$} \\
\hline Peak & Location & Amplitude & Area & FWHM & R1 & $\mathrm{R} 2$ & $\mathrm{~T}\left({ }^{\circ} \mathrm{C}\right)$ \\
\hline D1 & 1347 & 6902 & 545130 & 49.7 & 1.083 & 0.537 & 402.2 \\
\hline G & 1581 & 6374 & 425893 & 32.4 & & & \\
\hline D2 & 1617 & 1557 & 44947.2 & 0.0 & & & \\
\hline \multicolumn{8}{|l|}{$\mathrm{bl} 4$} \\
\hline Peak & Location & Amplitude & Area & FWHM & $\mathrm{R} 1$ & $\mathrm{R} 2$ & $\mathrm{~T}\left({ }^{\circ} \mathrm{C}\right)$ \\
\hline D1 & 1347 & 6902 & 545130 & 49.7 & 1.083 & 0.537 & 402.2 \\
\hline G & 1581 & 6374 & 425893 & 32.4 & & & \\
\hline D2 & 1617 & 1557 & 44947.2 & 0.0 & & & \\
\hline \multicolumn{8}{|l|}{ bl5 } \\
\hline Peak & Location & Amplitude & Area & FWHM & $\mathrm{R} 1$ & $\mathrm{R} 2$ & $\mathrm{~T}\left({ }^{\circ} \mathrm{C}\right)$ \\
\hline D1 & 1350 & 3894 & 234575 & 37.8 & 1.391 & 0.587 & 379.8 \\
\hline G & 1585 & 2799 & 148363 & 29.4 & & & \\
\hline D2 & 1619 & 716 & 16632.7 & 0.0 & & & \\
\hline \multicolumn{8}{|l|}{ bl6 } \\
\hline Peak & Location & Amplitude & Area & FWHM & $\mathrm{R} 1$ & R2 & $\mathrm{T}\left({ }^{\circ} \mathrm{C}\right)$ \\
\hline D1 & 1349 & 5252 & 369187 & 44.6 & 0.999 & 0.540 & 400.7 \\
\hline G & 1581 & 5258 & 275654 & 27.8 & & & \\
\hline D2 & 1616 & 1313 & 38841.3 & 0.6 & & & \\
\hline \multicolumn{8}{|l|}{ bl8 } \\
\hline Peak & Location & Amplitude & Area & FWHM & $\mathrm{R} 1$ & $\mathrm{R} 2$ & $\mathrm{~T}\left({ }^{\circ} \mathrm{C}\right)$ \\
\hline D1 & 1351 & 3875 & 201934 & 26.6 & 1.063 & 0.523 & 408.2 \\
\hline G & 1584 & 3646 & 162646 & 28.2 & & & \\
\hline D2 & 1617 & 797 & 21469 & 0.0 & & & \\
\hline \multicolumn{8}{|l|}{ bl9 } \\
\hline Peak & Location & Amplitude & Area & FWHM & R1 & R2 & $\mathrm{T}\left({ }^{\circ} \mathrm{C}\right)$ \\
\hline D1 & 1349 & 4271 & 269645 & 40.1 & 1.257 & 0.581 & 382.3 \\
\hline G & 1584 & 3398 & 167660 & 24.0 & & & \\
\hline
\end{tabular}




\begin{tabular}{|l|r|r|r|r|r|r|r|} 
D2 & 1618 & 980 & 26466.7 & 0.0 & & & \\
\hline bl10 & & & & & & & \\
\hline Peak & Location & Amplitude & Area & FWHM & R1 & R2 & $\mathrm{T}\left({ }^{\circ} \mathrm{C}\right)$ \\
\hline D1 & 1349 & 5203 & 317812 & 38.7 & 1.014 & 0.524 & 407.9 \\
\hline G & 1583 & 5131 & 260126 & 27.6 & & & \\
\hline D2 & 1616 & 1077 & 28714.5 & 0.0 & & & \\
\hline bl11 & & & & & & & \\
\hline Peak & Location & Amplitude & Area & FWHM & R1 & R2 & $\mathrm{T}\left({ }^{\circ} \mathrm{C}\right)$ \\
\hline D1 & 1350 & 5945 & 379144 & 40.2 & 1.337 & 0.590 & 378.5 \\
\hline G & 1584 & 4446 & 227747 & 27.9 & & & \\
\hline D2 & 1616 & 1152 & 35905.1 & -0.2 & & & \\
\hline bl12 & & & & & & & \\
\hline Peak & Location & Amplitude & Area & FWHM & R1 & R2 & $\mathrm{T}\left({ }^{\circ} \mathrm{C}\right)$ \\
\hline D1 & 1351 & 3829 & 237326 & 38.7 & 1.158 & 0.565 & 389.7 \\
\hline G & 1584 & 3306 & 157134 & 27.5 & & & \\
\hline D2 & 1615 & 848 & 25800.7 & -1.2 & & & \\
\hline b2 & & & & & & & \\
\hline Peak & Location & Amplitude & Area & FWHM & R1 & R2 & $\mathrm{T}\left({ }^{\circ} \mathrm{C}\right)$ \\
\hline D1 & 1348 & 4668 & 403093 & 54.8 & 1.419 & 0.640 & 356.3 \\
\hline G & 1590 & 3290 & 190832 & 26.9 & & & \\
\hline D2 & 1619 & 1331 & 36213.6 & 0.0 & & & \\
\hline TS0 & & & & & & & \\
\hline Peak & Location & Amplitude & Area & FWHM & R1 & R2 & $\mathrm{T}\left({ }^{\circ} \mathrm{C}\right)$ \\
\hline D1 & 1351 & 19728 & 1057290 & 34.0 & 0.749 & 0.475 & 429.5 \\
\hline G & 1583 & 26328 & 1076570 & 25.9 & & & \\
\hline D2 & 1621 & 3699 & 91061.1 & 7.6 & & & \\
\hline
\end{tabular}

\begin{tabular}{|c|c|c|c|c|c|c|c|}
\hline \multirow[t]{2}{*}{ 16DF21 } & & & & Method: & \multicolumn{3}{|c|}{ Beyssac et al. 2002} \\
\hline & & & & & & $\operatorname{avg} T$ & std dev \\
\hline & & & & \multicolumn{2}{|c|}{ Avg each run } & 390.8 & 19.4 \\
\hline Peak & Location & Amplitude & Area & FWHM & R1 & $\mathrm{R} 2$ & $\mathrm{~T}\left({ }^{\circ} \mathrm{C}\right)$ \\
\hline $\mathrm{D} 1$ & 1348 & 16022 & 1138090 & 42.9 & 1.174 & 0.566 & 389.0 \\
\hline G & 1581 & 13645 & 761170 & 33.3 & & & \\
\hline D2 & 1614 & 3550 & 110433 & 0.0 & & & \\
\hline \multicolumn{8}{|l|}{02} \\
\hline Peak & Location & Amplitude & Area & FWHM & R1 & R2 & $\mathrm{T}\left({ }^{\circ} \mathrm{C}\right)$ \\
\hline D1 & 1347 & 18189 & 1173210 & 33.0 & 1.043 & 0.522 & 408.5 \\
\hline $\mathrm{G}$ & 1576 & 17439 & 914537 & 28.0 & & & \\
\hline D2 & 1609 & 4292 & 157864 & 0.0 & & & \\
\hline \multicolumn{8}{|l|}{04} \\
\hline Peak & Location & Amplitude & Area & FWHM & $\mathrm{R} 1$ & $\mathrm{R} 2$ & $\mathrm{~T}\left({ }^{\circ} \mathrm{C}\right)$ \\
\hline D1 & 1348 & 25946 & 1632290 & 31.0 & 1.537 & 0.612 & 368.7 \\
\hline$G$ & 1583 & 16877 & 926002 & 25.6 & & & \\
\hline D2 & 1616 & 4446 & 108752 & -0.2 & & & \\
\hline \multicolumn{8}{|l|}{05} \\
\hline Peak & Location & Amplitude & Area & FWHM & R1 & $\mathrm{R} 2$ & $\mathrm{~T}\left({ }^{\circ} \mathrm{C}\right)$ \\
\hline D1 & 1345 & 11457 & 822294 & 40.0 & 1.230 & 0.570 & 387.5 \\
\hline G & 1578 & 9313 & 560351 & 26.9 & & & \\
\hline D2 & 1613 & 2161 & 60855 & -0.1 & & & \\
\hline
\end{tabular}




\begin{tabular}{|c|c|c|c|c|c|c|c|}
\hline \multicolumn{8}{|l|}{07} \\
\hline Peak & Location & Amplitude & Area & FWHM & R1 & R2 & $\mathrm{T}\left({ }^{\circ} \mathrm{C}\right)$ \\
\hline D1 & 1350 & 12342 & 769147 & 35.9 & 1.102 & 0.551 & 395.6 \\
\hline G & 1583 & 11198 & 528685 & 25.8 & & & \\
\hline D2 & 1616 & 3321 & 97128.4 & 0.0 & & & \\
\hline \multicolumn{8}{|l|}{08} \\
\hline Peak & Location & Amplitude & Area & FWHM & $\mathrm{R} 1$ & $\mathrm{R} 2$ & $\mathrm{~T}\left({ }^{\circ} \mathrm{C}\right)$ \\
\hline D1 & 1351 & 13990 & 941377 & 41.5 & 1.377 & 0.635 & 358.3 \\
\hline G & 1583 & 10163 & 421669 & 2.4 & & & \\
\hline D2 & 1616 & 4115 & 118925 & 0.5 & & & \\
\hline \multicolumn{8}{|l|}{09} \\
\hline Peak & Location & Amplitude & Area & FWHM & R1 & $\mathrm{R} 2$ & $\mathrm{~T}\left({ }^{\circ} \mathrm{C}\right)$ \\
\hline $\mathrm{D} 1$ & 1348 & 5424 & 296484 & 18.8 & 0.932 & 0.479 & 428.0 \\
\hline G & 1579 & 5820 & 265729 & 22.2 & & & \\
\hline $\mathrm{D} 2$ & 1612 & 1785 & 57161.9 & -0.1 & & & \\
\hline \multicolumn{8}{|l|}{010} \\
\hline Peak & Location & Amplitude & Area & FWHM & $\mathrm{R} 1$ & $\mathrm{R} 2$ & $\mathrm{~T}\left({ }^{\circ} \mathrm{C}\right)$ \\
\hline D1 & 1350 & 32518 & 2025050 & 39.1 & 1.359 & 0.583 & 381.7 \\
\hline G & 1584 & 23935 & 1290430 & 31.8 & & & \\
\hline D2 & 1619 & 6116 & 159284 & 0.0 & & & \\
\hline \multicolumn{8}{|l|}{011} \\
\hline Peak & Location & Amplitude & Area & FWHM & R1 & $\mathrm{R} 2$ & $\mathrm{~T}\left({ }^{\circ} \mathrm{C}\right)$ \\
\hline D1 & 1350 & 23180 & 1365660 & 37.0 & 1.315 & 0.573 & 386.2 \\
\hline G & 1583 & 17632 & 892147 & 28.1 & & & \\
\hline D2 & 1616 & 4533 & 126880 & -0.2 & & & \\
\hline \multicolumn{8}{|l|}{012} \\
\hline Peak & Location & Amplitude & Area & FWHM & R1 & R2 & $\mathrm{T}\left({ }^{\circ} \mathrm{C}\right)$ \\
\hline D1 & 1348 & 16856 & 1142050 & 42.7 & 0.946 & 0.521 & 409.3 \\
\hline G & 1579 & 17824 & 918072 & 29.0 & & & \\
\hline D2 & 1613 & 4747 & 133259 & 0.1 & & & \\
\hline \multicolumn{8}{|l|}{017} \\
\hline Peak & Location & Amplitude & Area & FWHM & R1 & $\mathrm{R} 2$ & $\mathrm{~T}\left({ }^{\circ} \mathrm{C}\right)$ \\
\hline D1 & 1352 & 7261 & 437180 & 33.4 & 1.339 & 0.572 & 386.5 \\
\hline G & 1585 & 5421 & 284506 & 31.6 & & & \\
\hline D2 & 1618 & 1345 & 42789.5 & 2.6 & & & \\
\hline
\end{tabular}

\begin{tabular}{|c|c|c|c|c|c|c|c|}
\hline \multirow[t]{2}{*}{ 16DF22 } & & & & Method: & \multicolumn{3}{|c|}{ Beyssac et al. 2002} \\
\hline & & & & & & $\operatorname{avg} \mathrm{T}$ & std dev \\
\hline & & & & \multicolumn{2}{|c|}{ Avg each run } & 366.2 & 14.7 \\
\hline Peak & Location & Amplitude & Area & FWHM & R1 & R2 & $\mathrm{T}\left({ }^{\circ} \mathrm{C}\right)$ \\
\hline $\mathrm{D} 1$ & 1351 & 20574 & 1291030 & 28.4 & 1.595 & 0.649 & 352.3 \\
\hline $\mathrm{G}$ & 1588 & 12899 & 591004 & 11.0 & & & \\
\hline D2 & 1622 & 4497 & 108232 & 0.1 & & & \\
\hline 01 & & & & & & & \\
\hline Peak & Location & Amplitude & Area & FWHM & R1 & R2 & $\mathrm{T}\left({ }^{\circ} \mathrm{C}\right)$ \\
\hline D1 & 1351 & 16241 & -882781 & -16.6 & 4.024 & 0.632 & 359.8 \\
\hline G & 1613 & 4036 & -118584 & -0.1 & & & \\
\hline D2 & 1586 & 3911170 & -395488 & 21.2 & & & \\
\hline 04 & & & & & & & \\
\hline
\end{tabular}




\begin{tabular}{|c|c|c|c|c|c|c|c|}
\hline Peak & Location & Amplitude & Area & FWHM & $\mathrm{R} 1$ & $\mathrm{R} 2$ & $\mathrm{~T}\left({ }^{\circ} \mathrm{C}\right)$ \\
\hline D1 & 1351 & 8865 & 488021 & 17.8 & 1.543 & 0.638 & 357.0 \\
\hline $\mathrm{G}$ & 1588 & 5744 & 233201 & 0.0 & & & \\
\hline $\mathrm{D} 2$ & 1622 & 1917 & 43483.7 & 0.0 & & & \\
\hline \multicolumn{8}{|l|}{05} \\
\hline Peak & Location & Amplitude & Area & FWHM & R1 & R2 & $\mathrm{T}\left({ }^{\circ} \mathrm{C}\right)$ \\
\hline D1 & 1350 & 11594 & 601370 & 4.6 & 1.343 & 0.595 & 376.4 \\
\hline G & 1586 & 8635 & 334133 & 4.1 & & & \\
\hline $\mathrm{D} 2$ & 1618 & 2895 & 76050.2 & -0.1 & & & \\
\hline \multicolumn{8}{|l|}{07} \\
\hline Peak & Location & Amplitude & Area & FWHM & $\mathrm{R} 1$ & R2 & $\mathrm{T}\left({ }^{\circ} \mathrm{C}\right)$ \\
\hline D1 & 1349 & 38225 & 2612550 & 37.9 & 1.589 & 0.634 & 358.7 \\
\hline $\mathrm{G}$ & 1586 & 24057 & 1339790 & 22.1 & & & \\
\hline D2 & 1620 & 6815 & 165303 & 0.0 & & & \\
\hline \multicolumn{8}{|l|}{08} \\
\hline Peak & Location & Amplitude & Area & FWHM & R1 & $\mathrm{R} 2$ & $\mathrm{~T}\left({ }^{\circ} \mathrm{C}\right)$ \\
\hline D1 & 1350 & 16144 & 937122 & 19.0 & 1.418 & 0.620 & 365.3 \\
\hline$G$ & 1586 & 11384 & 462689 & 0.0 & & & \\
\hline D2 & 1620 & 4137 & 112561 & 0.0 & & & \\
\hline \multicolumn{8}{|l|}{09} \\
\hline Peak & Location & Amplitude & Area & FWHM & $\mathrm{R} 1$ & $\mathrm{R} 2$ & $\mathrm{~T}\left({ }^{\circ} \mathrm{C}\right)$ \\
\hline D1 & 1349 & 21893 & 1561550 & 40.0 & 1.638 & 0.636 & 357.9 \\
\hline G & 1587 & 13368 & 798222 & 25.7 & & & \\
\hline $\mathrm{D} 2$ & 1621 & 3750 & 95086.1 & 0.1 & & & \\
\hline \multicolumn{8}{|l|}{010} \\
\hline Peak & Location & Amplitude & Area & FWHM & $\mathrm{R} 1$ & R2 & $\mathrm{T}\left({ }^{\circ} \mathrm{C}\right)$ \\
\hline D1 & 1351 & 17063 & 1113390 & 35.6 & 1.541 & 0.633 & 359.2 \\
\hline $\mathrm{G}$ & 1587 & 11071 & 536175 & 20.8 & & & \\
\hline $\mathrm{D} 2$ & 1619 & 3720 & 108360 & 0.0 & & & \\
\hline \multicolumn{8}{|l|}{012} \\
\hline Peak & Location & Amplitude & Area & FWHM & $\mathrm{R} 1$ & $\mathrm{R} 2$ & $\mathrm{~T}\left({ }^{\circ} \mathrm{C}\right)$ \\
\hline D1 & 1349 & 20449 & 1440090 & 39.7 & 1.230 & 0.567 & 388.5 \\
\hline G & 1584 & 16627 & 1015290 & 32.4 & & & \\
\hline D2 & 1619 & 3571 & 82368.4 & -0.1 & & & \\
\hline \multicolumn{8}{|l|}{013} \\
\hline Peak & Location & Amplitude & Area & FWHM & $\mathrm{R} 1$ & $\mathrm{R} 2$ & $\mathrm{~T}\left({ }^{\circ} \mathrm{C}\right)$ \\
\hline D1 & 1350 & 21145 & 1483180 & 38.7 & 1.684 & 0.641 & 355.6 \\
\hline G & 1588 & 12553 & 726851 & 28.2 & & & \\
\hline D2 & 1621 & 3961 & 102278 & 0.0 & & & \\
\hline \multicolumn{8}{|l|}{06} \\
\hline Peak & Location & Amplitude & Area & FWHM & $\mathrm{R} 1$ & $\mathrm{R} 2$ & $\mathrm{~T}\left({ }^{\circ} \mathrm{C}\right)$ \\
\hline D1 & 1350 & 13135 & 646382 & -0.1 & 3.317 & 0.548 & 397.1 \\
\hline$G$ & 1619 & 3960 & 82844.1 & 3.1 & & & \\
\hline D2 & 1585 & 11181 & 450135 & 0.5 & & & \\
\hline
\end{tabular}




\begin{tabular}{|c|c|c|c|c|c|c|c|}
\hline \multirow[t]{3}{*}{ 16DF24 } & & & & Method: & \multicolumn{3}{|c|}{ Beyssac et al. 2002} \\
\hline & & & & & & $\operatorname{avg} \mathrm{T}$ & std dev \\
\hline & & & & \multicolumn{2}{|c|}{ Avg each run } & 364.1 & 10.5 \\
\hline Peak & Location & Amplitude & Area & FWHM & R1 & R2 & $\mathrm{T}\left({ }^{\circ} \mathrm{C}\right)$ \\
\hline D1 & 1346 & 6169 & 460566 & 47.5 & 1.557 & 0.606 & 371.2 \\
\hline $\mathrm{G}$ & 1579 & 3963 & 263494 & 35.8 & & & \\
\hline D2 & 1615 & 1025 & 35586.9 & 4.3 & & & \\
\hline \multicolumn{8}{|l|}{$24-0$} \\
\hline Peak & Location & Amplitude & Area & FWHM & R1 & $\mathrm{R} 2$ & $\mathrm{~T}\left({ }^{\circ} \mathrm{C}\right)$ \\
\hline D1 & 1352 & 922 & 54116.5 & 33.3 & 1.497 & 0.610 & 369.7 \\
\hline G & 1588 & 616 & 28574 & 14.6 & & & \\
\hline $\mathrm{D} 2$ & 1622 & 284 & 6062.14 & 0.8 & & & \\
\hline \multicolumn{8}{|l|}{$24-14$} \\
\hline Peak & Location & Amplitude & Area & FWHM & $\mathrm{R} 1$ & $\mathrm{R} 2$ & $\mathrm{~T}\left({ }^{\circ} \mathrm{C}\right)$ \\
\hline D1 & 1344 & 6272 & 461936 & 46.9 & 1.580 & 0.630 & 360.5 \\
\hline $\mathrm{G}$ & 1576 & 3971 & 224259 & 27.7 & & & \\
\hline D2 & 1611 & 1247 & 46761 & 5.6 & & & \\
\hline \multicolumn{8}{|l|}{$24-1$} \\
\hline Peak & Location & Amplitude & Area & FWHM & R1 & $\mathrm{R} 2$ & $\mathrm{~T}\left({ }^{\circ} \mathrm{C}\right)$ \\
\hline D1 & 1351 & 664 & 39691.1 & 32.4 & 0.265 & 0.609 & 370.0 \\
\hline $\mathrm{G}$ & 1589 & 2504 & 19382.3 & -17.7 & & & \\
\hline D2 & 1619 & 319 & 6100.16 & 0.2 & & & \\
\hline \multicolumn{8}{|l|}{$24-18$} \\
\hline Peak & Location & Amplitude & Area & FWHM & R1 & $\mathrm{R} 2$ & $\mathrm{~T}\left({ }^{\circ} \mathrm{C}\right)$ \\
\hline D1 & 1351 & 4061 & 249614 & 36.9 & 1.869 & 0.629 & 361.2 \\
\hline G & 1587 & 2172 & 122459 & 33.5 & & & \\
\hline D2 & 1620 & 781 & 24910 & 20.2 & & & \\
\hline \multicolumn{8}{|l|}{$24-20$} \\
\hline Peak & Location & Amplitude & Area & FWHM & $\mathrm{R} 1$ & $\mathrm{R} 2$ & $\mathrm{~T}\left({ }^{\circ} \mathrm{C}\right)$ \\
\hline D1 & 1351 & 3349 & 192487 & 30.7 & 1.985 & 0.652 & 350.9 \\
\hline G & 1587 & 1687 & 89006.3 & 26.7 & & & \\
\hline D2 & 1621 & 562 & 13734.6 & 0.7 & & & \\
\hline \multicolumn{8}{|l|}{$24-22$} \\
\hline Peak & Location & Amplitude & Area & FWHM & R1 & $\mathrm{R} 2$ & $\mathrm{~T}\left({ }^{\circ} \mathrm{C}\right)$ \\
\hline D1 & 1347 & 4764 & 322571 & 42.3 & 1.558 & 0.587 & 379.9 \\
\hline G & 1580 & 3057 & 203074 & 39.8 & & & \\
\hline $\mathrm{D} 2$ & 1613 & 717 & 24155 & -0.3 & & & \\
\hline \multicolumn{8}{|l|}{$24-23$} \\
\hline Peak & Location & Amplitude & Area & FWHM & R1 & R2 & $\mathrm{T}\left({ }^{\circ} \mathrm{C}\right)$ \\
\hline $\mathrm{D} 1$ & 1351 & 1565 & 97211 & 33.0 & 1.729 & 0.616 & 367.0 \\
\hline $\mathrm{G}$ & 1584 & 905 & 40132.2 & 20.3 & & & \\
\hline D2 & 1610 & 450 & 20535 & -0.1 & & & \\
\hline \multicolumn{8}{|l|}{$24-24$} \\
\hline Peak & Location & Amplitude & Area & FWHM & R1 & $\mathrm{R} 2$ & $\mathrm{~T}\left({ }^{\circ} \mathrm{C}\right)$ \\
\hline $\mathrm{D} 1$ & 1348 & 4835 & 320247 & 40.3 & 1.887 & 0.661 & 346.7 \\
\hline$G$ & 1585 & 2562 & 139895 & 24.6 & & & \\
\hline $\mathrm{D} 2$ & 1619 & 873 & 24031.4 & 0.4 & & & \\
\hline
\end{tabular}




\begin{tabular}{|c|c|c|c|c|c|c|c|}
\hline \multirow[t]{3}{*}{ 16DF27 } & & & & Method: & \multicolumn{3}{|c|}{ Beyssac et al. 2002} \\
\hline & & & & & & $\operatorname{avg} T$ & std dev \\
\hline & & & & \multicolumn{2}{|c|}{ Avg each run } & 382.9 & 18.9 \\
\hline Peak & Location & Amplitude & Area & FWHM & R1 & R2 & $\mathrm{T}\left({ }^{\circ} \mathrm{C}\right)$ \\
\hline D1 & 1351 & 5530 & 304293 & 15.8 & 1.497 & 0.549 & 396.5 \\
\hline $\mathrm{G}$ & 1589 & 3693 & 176192 & 14.1 & & & \\
\hline D2 & 1622 & 1601 & 73372.7 & 29.2 & & & \\
\hline \multicolumn{8}{|l|}{01} \\
\hline Peak & Location & Amplitude & Area & FWHM & R1 & R2 & $\mathrm{T}\left({ }^{\circ} \mathrm{C}\right)$ \\
\hline D1 & 1351 & 4599 & 256999 & 21.6 & 1.718 & 0.562 & 390.8 \\
\hline G & 1588 & 2677 & 111765 & 0.1 & & & \\
\hline $\mathrm{D} 2$ & 1620 & 1488 & 88406.3 & 36.9 & & & \\
\hline \multicolumn{8}{|l|}{05} \\
\hline Peak & Location & Amplitude & Area & FWHM & $\mathrm{R} 1$ & $\mathrm{R} 2$ & $\mathrm{~T}\left({ }^{\circ} \mathrm{C}\right)$ \\
\hline D1 & 1348 & 17918 & 1646060 & 58.3 & 0.018 & 0.600 & 374.1 \\
\hline $\mathrm{G}$ & 1585 & 998769 & 1253330 & -40.1 & & & \\
\hline $\mathrm{D} 2$ & 1616 & 4809 & -154730 & -20.4 & & & \\
\hline \multicolumn{8}{|l|}{07} \\
\hline Peak & Location & Amplitude & Area & FWHM & $\mathrm{R} 1$ & R2 & $\mathrm{T}\left({ }^{\circ} \mathrm{C}\right)$ \\
\hline $\mathrm{D} 1$ & 1349 & 13608 & 1156110 & 54.1 & 1.072 & 0.537 & 402.2 \\
\hline $\mathrm{G}$ & 1585 & 12695 & 918861 & 44.0 & & & \\
\hline $\mathrm{D} 2$ & 1618 & 2999 & 79029.8 & -0.1 & & & \\
\hline \multicolumn{8}{|l|}{06} \\
\hline Peak & Location & Amplitude & Area & FWHM & $\mathrm{R} 1$ & $\mathrm{R} 2$ & $\mathrm{~T}\left({ }^{\circ} \mathrm{C}\right)$ \\
\hline $\mathrm{D} 1$ & 1350 & 12382 & 985312 & 50.7 & 1.161 & 0.596 & 375.9 \\
\hline G & 1585 & 10663 & 598703 & 35.7 & & & \\
\hline D2 & 1617 & 2781 & 69903.5 & 0.5 & & & \\
\hline \multicolumn{8}{|l|}{08} \\
\hline Peak & Location & Amplitude & Area & FWHM & R1 & $\mathrm{R} 2$ & $\mathrm{~T}\left({ }^{\circ} \mathrm{C}\right)$ \\
\hline D1 & 1349 & 15812 & 1275390 & 42.9 & 1.635 & 0.686 & 335.9 \\
\hline G & 1593 & 9674 & 503070 & 7.2 & & & \\
\hline D2 & 1623 & 2749 & 81674.6 & -0.2 & & & \\
\hline \multicolumn{8}{|l|}{010} \\
\hline Peak & Location & Amplitude & Area & FWHM & R1 & R2 & $\mathrm{T}\left({ }^{\circ} \mathrm{C}\right)$ \\
\hline D1 & 1352 & 4645 & 404639 & 55.4 & 1.121 & 0.521 & 409.1 \\
\hline G & 1588 & 4144 & 353415 & 54.0 & & & \\
\hline $\mathrm{D} 2$ & 1620 & 775 & 18284.3 & 0.0 & & & \\
\hline \multicolumn{8}{|l|}{012} \\
\hline Peak & Location & Amplitude & Area & FWHM & $\mathrm{R} 1$ & $\mathrm{R} 2$ & $\mathrm{~T}\left({ }^{\circ} \mathrm{C}\right)$ \\
\hline D1 & 1350 & 12420 & 553414 & -4.1 & 1.432 & 0.562 & 390.7 \\
\hline $\mathrm{G}$ & 1587 & 8671 & 360569 & -0.2 & & & \\
\hline $\mathrm{D} 2$ & 1621 & 2922 & 70067.9 & 0.4 & & & \\
\hline \multicolumn{8}{|l|}{013} \\
\hline Peak & Location & Amplitude & Area & FWHM & R1 & $\mathrm{R} 2$ & $\mathrm{~T}\left({ }^{\circ} \mathrm{C}\right)$ \\
\hline D1 & 1348 & 23824 & 2048900 & 54.7 & 1.184 & 0.562 & 390.8 \\
\hline G & 1585 & 20118 & 1446580 & 45.4 & & & \\
\hline $\mathrm{D} 2$ & 1616 & 5383 & 148849 & 0.0 & & & \\
\hline \multicolumn{8}{|l|}{016} \\
\hline Peak & Location & Amplitude & Area & FWHM & R1 & $\mathrm{R} 2$ & $\mathrm{~T}\left({ }^{\circ} \mathrm{C}\right)$ \\
\hline $\mathrm{D} 1$ & 1351 & 2992 & 187433 & 22.9 & 1.275 & 0.601 & 373.6 \\
\hline
\end{tabular}




\begin{tabular}{|l|r|r|r|r|r|r|r|} 
G & 1590 & 2346 & 105224 & -1.6 & & & \\
\hline D2 & 1624 & 801 & 19272.1 & -2.9 & & & \\
\hline 12 & & & & & & & \\
\hline Peak & Location & Amplitude & Area & FWHM & R1 & R2 & $\mathrm{T}\left({ }^{\circ} \mathrm{C}\right)$ \\
\hline D1 & 1348 & 12331 & 986473 & 49.8 & 0.443 & 0.602 & 373.3 \\
\hline G & 1581 & 27805 & 564053 & -17.6 & & & \\
\hline D2 & 1615 & 3139 & 89084.4 & 0.2 & & & \\
\hline 13 & & & & & & & \\
\hline Peak & Location & Amplitude & Area & FWHM & R1 & R2 & $\mathrm{T}\left({ }^{\circ} \mathrm{C}\right)$ \\
\hline D1 & 1352 & 5774 & 281438 & 0.4 & 1.322 & 0.582 & 382.2 \\
\hline G & 1592 & 4366 & 164919 & 3.4 & & & \\
\hline D2 & 1621 & 1713 & 37585.2 & -0.7 & & & \\
\hline
\end{tabular}

\begin{tabular}{|c|c|c|c|c|c|c|c|}
\hline \multirow[t]{3}{*}{ 16DF29 } & & & & Method: & \multicolumn{3}{|c|}{ Beyssac et al. 2002} \\
\hline & & & & & & $\operatorname{avg} T$ & std dev \\
\hline & & & & \multicolumn{2}{|c|}{ Avg each run } & 360.0 & 16.8 \\
\hline Peak & Location & Amplitude & Area & FWHM & $\mathrm{R} 1$ & $\mathrm{R} 2$ & $\mathrm{~T}\left({ }^{\circ} \mathrm{C}\right)$ \\
\hline D1 & 1348 & 4149 & 420593 & 59.3 & 1.427 & 0.645 & 353.9 \\
\hline G & 1591 & 2908 & 190785 & 38.0 & & & \\
\hline D2 & 1617 & 1403 & 40478.7 & 0.0 & & & \\
\hline \multicolumn{8}{|l|}{0} \\
\hline Peak & Location & Amplitude & Area & FWHM & R1 & R2 & $\mathrm{T}\left({ }^{\circ} \mathrm{C}\right)$ \\
\hline D1 & 1350 & 1653 & 138298 & 52.5 & 1.517 & 0.623 & 363.6 \\
\hline G & 1592 & 1089 & 74653.1 & 43.5 & & & \\
\hline D2 & 1620 & 320 & 8864.16 & 0.0 & & & \\
\hline \multicolumn{8}{|l|}{1} \\
\hline Peak & Location & Amplitude & Area & FWHM & R1 & $\mathrm{R} 2$ & $\mathrm{~T}\left({ }^{\circ} \mathrm{C}\right)$ \\
\hline D1 & 1352 & 1142 & 91948.8 & 50.7 & 1.467 & 0.617 & 366.5 \\
\hline$G$ & 1589 & 778 & 46494.3 & 38.0 & & & \\
\hline D2 & 1617 & 322 & 10623.6 & 0.0 & & & \\
\hline \multicolumn{8}{|l|}{2} \\
\hline Peak & Location & Amplitude & Area & FWHM & $\mathrm{R} 1$ & $\mathrm{R} 2$ & $\mathrm{~T}\left({ }^{\circ} \mathrm{C}\right)$ \\
\hline D1 & 1350 & 2866 & 230938 & 51.1 & 1.548 & 0.633 & 359.3 \\
\hline G & 1590 & 1851 & 121996 & 32.8 & & & \\
\hline D2 & 1622 & 462 & 11881.6 & 0.8 & & & \\
\hline \multicolumn{8}{|l|}{3} \\
\hline Peak & Location & Amplitude & Area & FWHM & $\mathrm{R} 1$ & $\mathrm{R} 2$ & $\mathrm{~T}\left({ }^{\circ} \mathrm{C}\right)$ \\
\hline D1 & 1351 & 2237 & 125430 & 35.5 & 0.930 & 0.651 & 351.2 \\
\hline $\mathrm{G}$ & 1584 & 2405 & 86459.3 & 1.4 & & & \\
\hline D2 & 1619 & 896 & -19276 & 0.1 & & & \\
\hline \multicolumn{8}{|l|}{11} \\
\hline Peak & Location & Amplitude & Area & FWHM & $\mathrm{R} 1$ & $\mathrm{R} 2$ & $\mathrm{~T}\left({ }^{\circ} \mathrm{C}\right)$ \\
\hline D1 & 1350 & 1409 & 104048 & 45.6 & 1.620 & 0.669 & 343.3 \\
\hline $\mathrm{G}$ & 1594 & 870 & 45154.9 & 0.0 & & & \\
\hline D2 & 1623 & 589 & 6349.07 & -5.3 & & & \\
\hline \multicolumn{8}{|l|}{13} \\
\hline Peak & Location & Amplitude & Area & FWHM & R1 & R2 & $\mathrm{T}\left({ }^{\circ} \mathrm{C}\right)$ \\
\hline D1 & 1350 & 2687 & 212453 & 50.2 & 1.496 & 0.637 & 357.8 \\
\hline G & 1590 & 1797 & 107575 & 28.4 & & & \\
\hline
\end{tabular}




\begin{tabular}{|l|r|r|r|r|r|r|r|} 
D2 & 1621 & 542 & 13750.4 & -0.3 & & & \\
\hline 14 & & & & & & & \\
\hline Peak & Location & Amplitude & Area & FWHM & R1 & R2 & $\mathrm{T}\left({ }^{\circ} \mathrm{C}\right)$ \\
\hline D1 & 1351 & 1643 & 130792 & 49.8 & 1.494 & 0.703 & 328.3 \\
\hline G & 1590 & 1100 & 66923.5 & 30.4 & & & \\
\hline D2 & 1620 & 457 & -11562 & 0.0 & & & \\
\hline 15 & & & & & & & \\
\hline Peak & Location & Amplitude & Area & FWHM & R1 & R2 & T $\left({ }^{\circ} \mathrm{C}\right)$ \\
\hline D1 & 1351 & 821 & 66156.8 & 45.7 & 1.103 & 0.557 & 393.2 \\
\hline G & 1588 & 744 & 46320.8 & 35.3 & & & \\
\hline D2 & 1621 & 245 & 6331.45 & 0.1 & & & \\
\hline 19 & & & & & & & \\
\hline Peak & Location & Amplitude & Area & FWHM & R1 & R2 & $\mathrm{T}\left({ }^{\circ} \mathrm{C}\right)$ \\
\hline D1 & 1352 & 1775 & 144936 & 51.9 & 1.337 & 0.607 & 370.9 \\
\hline G & 1591 & 1327 & 82332.1 & 31.8 & & & \\
\hline D2 & 1622 & 516 & 11487.6 & 0.1 & & & \\
\hline 20 & & & & & & & \\
\hline Peak & Location & Amplitude & Area & FWHM & R1 & R2 & $\mathrm{T}\left({ }^{\circ} \mathrm{C}\right)$ \\
\hline D1 & 1351 & 1769 & 182586 & 64.5 & 1.115 & 0.605 & 371.6 \\
\hline G & 1590 & 1586 & 106648 & 33.2 & & & \\
\hline D2 & 1621 & 641 & 12351.9 & -0.3 & & & \\
\hline
\end{tabular}

\begin{tabular}{|c|c|c|c|c|c|c|c|}
\hline \multirow[t]{2}{*}{ 16DF30 } & & & & Method: & \multicolumn{3}{|c|}{ Beyssac et al. 2002} \\
\hline & & & & & & $\operatorname{avg} \mathrm{T}$ & std dev \\
\hline & & & & \multicolumn{2}{|c|}{ Avg each run } & 371.5 & 11.7 \\
\hline Peak & Location & Amplitude & Area & FWHM & R1 & $\mathrm{R} 2$ & $\mathrm{~T}\left({ }^{\circ} \mathrm{C}\right)$ \\
\hline D1 & 1352 & 2785 & 178367 & 40.6 & 1.098 & 0.576 & 384.8 \\
\hline G & 1587 & 2537 & 104944 & 17.8 & & & \\
\hline D2 & 1619 & 1121 & 26501.8 & 0.3 & & & \\
\hline \multicolumn{8}{|l|}{3} \\
\hline Peak & Location & Amplitude & Area & FWHM & R1 & $\mathrm{R} 2$ & $\mathrm{~T}\left({ }^{\circ} \mathrm{C}\right)$ \\
\hline D1 & 1351 & 3829 & 296587 & 49.1 & 1.170 & 0.573 & 385.9 \\
\hline G & 1586 & 3273 & 193941 & 35.5 & & & \\
\hline D2 & 1620 & 1281 & 26866.9 & 0.0 & & & \\
\hline \multicolumn{8}{|l|}{4} \\
\hline Peak & Location & Amplitude & Area & FWHM & $\mathrm{R} 1$ & $\mathrm{R} 2$ & $\mathrm{~T}\left({ }^{\circ} \mathrm{C}\right)$ \\
\hline D1 & 1352 & 2547 & 178569 & 44.5 & 1.353 & 0.610 & 369.6 \\
\hline G & 1589 & 1882 & 94532.3 & 23.4 & & & \\
\hline D2 & 1620 & 837 & 19684.5 & -2.1 & & & \\
\hline \multicolumn{8}{|l|}{5} \\
\hline Peak & Location & Amplitude & Area & FWHM & R1 & R2 & $\mathrm{T}\left({ }^{\circ} \mathrm{C}\right)$ \\
\hline D1 & 1351 & 2474 & 151526 & 38.8 & 1.369 & 0.623 & 363.7 \\
\hline G & 1588 & 1807 & 72664 & 4.6 & & & \\
\hline D2 & 1621 & 862 & 18997.4 & 1.1 & & & \\
\hline \multicolumn{8}{|l|}{8} \\
\hline Peak & Location & Amplitude & Area & FWHM & R1 & $\mathrm{R} 2$ & $\mathrm{~T}\left({ }^{\circ} \mathrm{C}\right)$ \\
\hline D1 & 1353 & 755 & 41344.9 & 34.8 & 1.115 & 0.566 & 389.3 \\
\hline G & 1588 & 677 & 24132.9 & 13.4 & & & \\
\hline D2 & 1619 & 369 & 7621.43 & 0.0 & & & \\
\hline
\end{tabular}




\begin{tabular}{|l|r|r|l|r|r|r|r|}
10 & & & & & & & \\
\hline Peak & Location & Amplitude & Area & FWHM & R1 & R2 & $\mathrm{T}\left({ }^{\circ} \mathrm{C}\right)$ \\
\hline D1 & 1352 & 1602 & 87337.8 & 34.6 & 1.210 & 0.579 & 383.3 \\
\hline G & 1587 & 1324 & 51472.8 & 14.4 & & & \\
\hline D2 & 1620 & 576 & 11991.5 & 0.3 & & & \\
\hline 14 & & & & & & & \\
\hline Peak & Location & Amplitude & Area & FWHM & R1 & R2 & $\mathrm{T}\left({ }^{\circ} \mathrm{C}\right)$ \\
\hline D1 & 1352 & 1478 & 109452 & 38.6 & 1.265 & 0.613 & 368.3 \\
\hline G & 1591 & 1168 & 59452.3 & 10.7 & & & \\
\hline D2 & 1623 & 506 & 9705.75 & 0.2 & & & \\
\hline 16 & & & & & & & \\
\hline Peak & Location & Amplitude & Area & FWHM & R1 & R2 & $\mathrm{T}\left({ }^{\circ} \mathrm{C}\right)$ \\
\hline D1 & 1351 & 679 & 50309.5 & 47.1 & 1.852 & 0.645 & 353.9 \\
\hline G & 1593 & 367 & 22105.5 & 26.9 & & & \\
\hline D2 & 1620 & 239 & 5551.81 & 11.6 & & & \\
\hline 17 & & & & & & & \\
\hline Peak & Location & Amplitude & Area & FWHM & R1 & R2 & $\mathrm{T}\left({ }^{\circ} \mathrm{C}\right)$ \\
\hline D1 & 1350 & 1089 & 71022.1 & 25.1 & 1.633 & 0.635 & 358.5 \\
\hline G & 1591 & 667 & 34152.4 & 13.8 & & & \\
\hline D2 & 1621 & 279 & 6686.19 & 0.0 & & & \\
\hline 19 & & & & & & & \\
\hline Peak & Location & Amplitude & Area & FWHM & R1 & R2 & $\mathrm{T}\left({ }^{\circ} \mathrm{C}\right)$ \\
\hline D1 & 1350 & 2284 & 180963 & 50.3 & 1.282 & 0.609 & 369.9 \\
\hline G & 1587 & 1781 & 100599 & 30.6 & & & \\
\hline D2 & 1620 & 636 & 15461.8 & -1.3 & & & \\
\hline 20 & & & & & & & \\
\hline Peak & Location & Amplitude & Area & FWHM & R1 & R2 & $\mathrm{T}\left({ }^{\circ} \mathrm{C}\right)$ \\
\hline D1 & 1350 & 3118 & 240709 & 48.9 & 1.521 & 0.629 & 360.9 \\
\hline G & 1591 & 2049 & 126724 & 31.3 & & & \\
\hline D2 & 1621 & 589 & 14994.9 & 0.6 & & & \\
\hline 21 & & & & & & & \\
\hline Peak & Location & Amplitude & Area & FWHM & R1 & $\mathrm{R} 2$ & $\mathrm{~T}\left({ }^{\circ} \mathrm{C}\right)$ \\
\hline D1 & 1350 & 4088 & 296710 & 45.8 & 1.382 & 0.608 & 370.3 \\
\hline G & 1586 & 2957 & 164267 & 23.0 & & & \\
\hline D2 & 1620 & 1157 & 26695.8 & 0.3 & & & \\
\hline & & & & & & & \\
\hline
\end{tabular}

\begin{tabular}{|c|c|c|c|c|c|c|c|}
\hline \multirow[t]{2}{*}{ 16DF38 } & & & & Method: & \multicolumn{3}{|c|}{ Beyssac et al. 2002} \\
\hline & & & & & & $\operatorname{avg} \mathrm{T}$ & std dev \\
\hline & & & & \multicolumn{2}{|c|}{ Avg each run } & 361.7 & 18.3 \\
\hline Peak & Location & Amplitude & Area & FWHM & R1 & R2 & $\mathrm{T}\left({ }^{\circ} \mathrm{C}\right)$ \\
\hline $\mathrm{D} 1$ & 1352 & 9505 & 661973 & 37.1 & 1.343 & 0.571 & 387.0 \\
\hline G & 1590 & 7080 & 448209 & 33.5 & & & \\
\hline D2 & 1621 & 2035 & 49464.7 & 0.2 & & & \\
\hline 0 & & & & & & & \\
\hline Peak & Location & Amplitude & Area & FWHM & R1 & $\mathrm{R} 2$ & $\mathrm{~T}\left({ }^{\circ} \mathrm{C}\right)$ \\
\hline $\mathrm{D} 1$ & 1352 & 9537 & 667551 & 38.2 & 1.321 & 0.556 & 393.4 \\
\hline G & 1589 & 7219 & 476732 & 41.4 & & & \\
\hline D2 & 1619 & 2095 & 55544.7 & 0.0 & & & \\
\hline 01 & & & & & & & \\
\hline
\end{tabular}




\begin{tabular}{|c|c|c|c|c|c|c|c|}
\hline Peak & Location & Amplitude & Area & FWHM & $\mathrm{R} 1$ & R2 & $\mathrm{T}\left({ }^{\circ} \mathrm{C}\right)$ \\
\hline D1 & 1352 & 8848 & 641190 & 42.5 & 1.752 & 0.636 & 358.1 \\
\hline $\mathrm{G}$ & 1586 & 5051 & 287022 & 35.9 & & & \\
\hline D2 & 1614 & 2159 & 80488.1 & 0.3 & & & \\
\hline \multicolumn{8}{|l|}{03} \\
\hline Peak & Location & Amplitude & Area & FWHM & $\mathrm{R} 1$ & R2 & $\mathrm{T}\left({ }^{\circ} \mathrm{C}\right)$ \\
\hline D1 & 1352 & 3808 & 286502 & 45.5 & 1.590 & 0.631 & 360.2 \\
\hline G & 1592 & 2394 & 152499 & 30.8 & & & \\
\hline D2 & 1620 & 596 & 15081 & -0.3 & & & \\
\hline \multicolumn{8}{|l|}{04} \\
\hline Peak & Location & Amplitude & Area & FWHM & $\mathrm{R} 1$ & $\mathrm{R} 2$ & $\mathrm{~T}\left({ }^{\circ} \mathrm{C}\right)$ \\
\hline D1 & 1352 & 5531 & 398009 & 41.0 & 1.538 & 0.631 & 360.0 \\
\hline $\mathrm{G}$ & 1591 & 3596 & 209308 & 21.5 & & & \\
\hline $\mathrm{D} 2$ & 1623 & 970 & 23008.3 & 0.2 & & & \\
\hline \multicolumn{8}{|l|}{05} \\
\hline Peak & Location & Amplitude & Area & FWHM & $\mathrm{R} 1$ & $\mathrm{R} 2$ & $\mathrm{~T}\left({ }^{\circ} \mathrm{C}\right)$ \\
\hline D1 & 1352 & 7746 & 545803 & 40.3 & 1.596 & 0.627 & 362.0 \\
\hline G & 1590 & 4855 & 288246 & 28.5 & & & \\
\hline D2 & 1622 & 1486 & 36352.8 & -0.1 & & & \\
\hline \multicolumn{8}{|l|}{06} \\
\hline Peak & Location & Amplitude & Area & FWHM & R1 & $\mathrm{R} 2$ & $\mathrm{~T}\left({ }^{\circ} \mathrm{C}\right)$ \\
\hline D1 & 1352 & 4503 & 324662 & 42.5 & 1.430 & 0.614 & 367.8 \\
\hline G & 1589 & 3149 & 182645 & 26.6 & & & \\
\hline D2 & 1622 & 888 & 21496.5 & -0.2 & & & \\
\hline \multicolumn{8}{|l|}{07} \\
\hline Peak & Location & Amplitude & Area & FWHM & $\mathrm{R} 1$ & R2 & $\mathrm{T}\left({ }^{\circ} \mathrm{C}\right)$ \\
\hline D1 & 1352 & 5806 & 427217 & 44.2 & 1.442 & 0.608 & 370.7 \\
\hline $\mathrm{G}$ & 1590 & 4027 & 253004 & 32.3 & & & \\
\hline D2 & 1623 & 995 & 23009.8 & 0.0 & & & \\
\hline \multicolumn{8}{|l|}{07} \\
\hline Peak & Location & Amplitude & Area & FWHM & $\mathrm{R} 1$ & R2 & $\mathrm{T}\left({ }^{\circ} \mathrm{C}\right)$ \\
\hline D1 & 1352 & 5825 & 428767 & 44.4 & 1.474 & 0.627 & 362.0 \\
\hline G & 1590 & 3951 & 223465 & 28.8 & & & \\
\hline D2 & 1622 & 1155 & 31709.5 & 0.1 & & & \\
\hline \multicolumn{8}{|l|}{08} \\
\hline Peak & Location & Amplitude & Area & FWHM & R1 & $\mathrm{R} 2$ & $\mathrm{~T}\left({ }^{\circ} \mathrm{C}\right)$ \\
\hline D1 & 1351 & 7308 & 599728 & 50.6 & 1.701 & 0.657 & 348.4 \\
\hline G & 1590 & 4297 & 251707 & 27.0 & & & \\
\hline D2 & 1620 & 1666 & 60710.6 & 23.0 & & & \\
\hline \multicolumn{8}{|l|}{09} \\
\hline Peak & Location & Amplitude & Area & FWHM & R1 & $\mathrm{R} 2$ & $\mathrm{~T}\left({ }^{\circ} \mathrm{C}\right)$ \\
\hline D1 & 1351 & 11094 & 763334 & 40.2 & 1.551 & 0.631 & 360.1 \\
\hline$G$ & 1589 & 7153 & 395205 & 21.0 & & & \\
\hline D2 & 1622 & 2159 & 50810.7 & 0.1 & & & \\
\hline \multicolumn{8}{|l|}{011} \\
\hline Peak & Location & Amplitude & Area & FWHM & R1 & $\mathrm{R} 2$ & $\mathrm{~T}\left({ }^{\circ} \mathrm{C}\right)$ \\
\hline $\mathrm{D} 1$ & 1350 & 7720 & 658566 & 53.5 & 1.664 & 0.728 & 316.9 \\
\hline G & 1589 & 4639 & 298585 & 38.6 & & & \\
\hline D2 & 1617 & 1604 & -52941 & -0.2 & & & \\
\hline \multicolumn{8}{|l|}{012} \\
\hline Peak & Location & Amplitude & Area & FWHM & R1 & $\mathrm{R} 2$ & $\mathrm{~T}\left({ }^{\circ} \mathrm{C}\right)$ \\
\hline
\end{tabular}




\begin{tabular}{|l|r|r|r|r|r|r|r|} 
D1 & 1352 & 4383 & 269211 & 25.8 & 1.599 & 0.641 & 355.9 \\
\hline G & 1591 & 2740 & 131421 & 6.3 & & & \\
\hline D2 & 1623 & 696 & 19515.8 & 2.9 & & & \\
\hline
\end{tabular}

\begin{tabular}{|c|c|c|c|c|c|c|c|}
\hline \multirow[t]{2}{*}{ 16DF39 } & & & & Method: & \multicolumn{3}{|c|}{ Beyssac et al. 2002} \\
\hline & & & & & & $\operatorname{avg} T$ & std dev \\
\hline & & & & \multicolumn{2}{|c|}{ Avg each run } & 371.3 & 29.3 \\
\hline Peak & Location & Amplitude & Area & FWHM & R1 & R2 & $\mathrm{T}\left({ }^{\circ} \mathrm{C}\right)$ \\
\hline D1 & 1349 & 16118 & 1115050 & 31.8 & 1.264 & 0.593 & 377.3 \\
\hline G & 1585 & 12747 & 636421 & 0.4 & & & \\
\hline D2 & 1619 & 4206 & 129921 & 10.2 & & & \\
\hline \multicolumn{8}{|l|}{00} \\
\hline Peak & Location & Amplitude & Area & FWHM & R1 & R2 & $\mathrm{T}\left({ }^{\circ} \mathrm{C}\right)$ \\
\hline D1 & 1350 & 14482 & 1047840 & 36.1 & 1.251 & 0.609 & 370.2 \\
\hline G & 1585 & 11574 & 509901 & 0.0 & & & \\
\hline D2 & 1618 & 4983 & 163892 & -0.1 & & & \\
\hline \multicolumn{8}{|l|}{0} \\
\hline Peak & Location & Amplitude & Area & FWHM & R1 & R2 & $\mathrm{T}\left({ }^{\circ} \mathrm{C}\right)$ \\
\hline D1 & 1354 & 2846 & 209250 & 41.8 & 0.000 & 0.474 & 430.2 \\
\hline G & 1588 & \#\#\#\#\#\#\# & 201164 & -45.3 & & & \\
\hline D2 & 1618 & 946 & 31267.5 & 20.8 & & & \\
\hline \multicolumn{8}{|l|}{001} \\
\hline Peak & Location & Amplitude & Area & FWHM & R1 & $\mathrm{R} 2$ & $\mathrm{~T}\left({ }^{\circ} \mathrm{C}\right)$ \\
\hline D1 & 1352 & 2429 & 154373 & 24.6 & 1.235 & 0.536 & 402.3 \\
\hline G & 1589 & 1967 & 115347 & 34.5 & & & \\
\hline D2 & 1620 & 620 & 18118.5 & -0.1 & & & \\
\hline \multicolumn{8}{|l|}{002} \\
\hline Peak & Location & Amplitude & Area & FWHM & R1 & $\mathrm{R} 2$ & $\mathrm{~T}\left({ }^{\circ} \mathrm{C}\right)$ \\
\hline D1 & 1351 & 9081 & 636710 & 38.9 & 1.143 & 0.525 & 407.3 \\
\hline G & 1585 & 7946 & 477328 & 36.9 & & & \\
\hline $\mathrm{D} 2$ & 1616 & 2574 & 98413.1 & 6.4 & & & \\
\hline \multicolumn{8}{|l|}{003} \\
\hline Peak & Location & Amplitude & Area & FWHM & $\mathrm{R} 1$ & $\mathrm{R} 2$ & $\mathrm{~T}\left({ }^{\circ} \mathrm{C}\right)$ \\
\hline D1 & 1352 & 3432 & 271006 & 50.0 & 1.551 & 0.668 & 343.7 \\
\hline G & 1589 & 2212 & 119028 & 6.7 & & & \\
\hline D2 & 1620 & 586 & 15609.3 & -0.5 & & & \\
\hline \multicolumn{8}{|l|}{004} \\
\hline Peak & Location & Amplitude & Area & FWHM & R1 & R2 & $\mathrm{T}\left({ }^{\circ} \mathrm{C}\right)$ \\
\hline D1 & 1350 & 8972 & 711378 & 49.8 & 1.515 & 0.611 & 369.0 \\
\hline G & 1589 & 5923 & 415098 & 39.7 & & & \\
\hline D2 & 1620 & 1565 & 37461.7 & -0.4 & & & \\
\hline \multicolumn{8}{|l|}{005} \\
\hline Peak & Location & Amplitude & Area & FWHM & R1 & $\mathrm{R} 2$ & $\mathrm{~T}\left({ }^{\circ} \mathrm{C}\right)$ \\
\hline D1 & 1348 & 16169 & 1343140 & 52.6 & 1.318 & 0.597 & 375.4 \\
\hline G & 1585 & 12264 & 844327 & 33.3 & & & \\
\hline $\mathrm{D} 2$ & 1618 & 2457 & 63271.1 & 0.0 & & & \\
\hline \multicolumn{8}{|l|}{006} \\
\hline Peak & Location & Amplitude & Area & FWHM & R1 & R2 & $\mathrm{T}\left({ }^{\circ} \mathrm{C}\right)$ \\
\hline D1 & 1343 & 21943 & 2409790 & 69.7 & 1.704 & 0.664 & 345.4 \\
\hline
\end{tabular}




\begin{tabular}{|l|r|r|r|r|r|r|r|}
\hline G & 1579 & 12880 & 995709 & 44.7 & & & \\
\hline D2 & 1606 & 5206 & 222233 & 0.1 & & & \\
\hline 007 & & & & & & & \\
\hline Peak & Location & Amplitude & Area & FWHM & R1 & R2 & $\mathrm{T}\left({ }^{\circ} \mathrm{C}\right)$ \\
\hline D1 & 1343 & 23250 & 2590720 & 70.7 & 1.602 & 0.705 & 327.2 \\
\hline G & 1587 & 14517 & 1010330 & 17.1 & & & \\
\hline D2 & 1616 & 1834 & 72859.5 & 21.4 & & & \\
\hline 008 & & & & & & & \\
\hline Peak & Location & Amplitude & Area & FWHM & R1 & R2 & $\mathrm{T}\left({ }^{\circ} \mathrm{C}\right)$ \\
\hline D1 & 1349 & 12136 & 937250 & 49.0 & 1.313 & 0.592 & 377.7 \\
\hline G & 1586 & 9246 & 574525 & 36.4 & & & \\
\hline D2 & 1617 & 2446 & 72245 & 0.1 & & & \\
\hline 009 & & & & & & & \\
\hline Peak & Location & Amplitude & Area & FWHM & R1 & R2 & $\mathrm{T}\left({ }^{\circ} \mathrm{C}\right)$ \\
\hline D1 & 1352 & 4783 & 372859 & 49.5 & 1.740 & 0.677 & 339.7 \\
\hline G & 1590 & 2749 & 160795 & 25.5 & & & \\
\hline D2 & 1620 & 768 & 17027.5 & 7.0 & & & \\
\hline 011 & & & & & & & \\
\hline Peak & Location & Amplitude & Area & FWHM & R1 & R2 & $\mathrm{T}\left({ }^{\circ} \mathrm{C}\right)$ \\
\hline D1 & 1352 & 5208 & 189581 & -11.6 & 2.342 & 0.628 & 361.5 \\
\hline G & 1589 & 2224 & 92222.5 & -1.5 & & & \\
\hline D2 & 1620 & 697 & 20014.2 & 2.7 & & & \\
\hline
\end{tabular}

\begin{tabular}{|c|c|c|c|c|c|c|c|}
\hline \multirow[t]{2}{*}{ 02DF15 } & & & & Method: & \multicolumn{3}{|c|}{ Beyssac et al. 2002} \\
\hline & & & & & & $\operatorname{avg} T$ & std dev \\
\hline & & & & \multicolumn{2}{|c|}{ Avg each run } & 356.2 & 27.9 \\
\hline Peak & Location & Amplitude & Area & FWHM & $\mathrm{R} 1$ & R2 & $\mathrm{T}\left({ }^{\circ} \mathrm{C}\right)$ \\
\hline D1 & 1347 & 4513 & 472881 & 65.8 & 1.348 & 0.731 & 315.9 \\
\hline G & 1605 & 3347 & 161880 & 0.4 & & & \\
\hline D2 & 1621 & 461 & 12449.9 & 13.6 & & & \\
\hline \multicolumn{8}{|l|}{01} \\
\hline Peak & Location & Amplitude & Area & FWHM & R1 & $\mathrm{R} 2$ & $\mathrm{~T}\left({ }^{\circ} \mathrm{C}\right)$ \\
\hline D1 & 1344 & 2676 & 212481 & 49.4 & 1.487 & 0.636 & 358.1 \\
\hline G & 1585 & 1800 & 99204.2 & -0.2 & & & \\
\hline D2 & 1617 & 691 & 22518.2 & 20.5 & & & \\
\hline \multicolumn{8}{|l|}{03} \\
\hline Peak & Location & Amplitude & Area & FWHM & R1 & $\mathrm{R} 2$ & $\mathrm{~T}\left({ }^{\circ} \mathrm{C}\right)$ \\
\hline D1 & 1347 & 35522 & 2882150 & 41.1 & 1.638 & 0.569 & 387.8 \\
\hline$G$ & 1591 & 21686 & 1476910 & 41.9 & & & \\
\hline D2 & 1612 & 18640 & 706855 & 3.8 & & & \\
\hline \multicolumn{8}{|l|}{05} \\
\hline Peak & Location & Amplitude & Area & FWHM & R1 & $\mathrm{R} 2$ & $\mathrm{~T}\left({ }^{\circ} \mathrm{C}\right)$ \\
\hline $\mathrm{D} 1$ & 1350 & 23317 & 1786280 & 43.6 & 1.842 & 0.611 & 369.0 \\
\hline $\mathrm{G}$ & 1587 & 12660 & 813724 & 40.1 & & & \\
\hline D2 & 1612 & 9121 & 322322 & -1.4 & & & \\
\hline \multicolumn{8}{|l|}{07} \\
\hline Peak & Location & Amplitude & Area & FWHM & R1 & $\mathrm{R} 2$ & $\mathrm{~T}\left({ }^{\circ} \mathrm{C}\right)$ \\
\hline D1 & 1346 & 24459 & 2284080 & 55.1 & 16.390 & 0.708 & 326.1 \\
\hline G & 1616 & 1492 & 28182.4 & 0.9 & & & \\
\hline
\end{tabular}




\begin{tabular}{|l|r|r|r|r|r|r|r|}
\hline D2 & 1597 & 16056 & 915401 & -0.4 & & & \\
\hline 08 & & & & & & & \\
\hline Peak & Location & Amplitude & Area & FWHM & R1 & R2 & $\mathrm{T}\left({ }^{\circ} \mathrm{C}\right)$ \\
\hline D1 & 1349 & 13728 & 1124480 & 47.0 & 1.733 & 0.595 & 376.3 \\
\hline G & 1589 & 7924 & 557294 & 44.2 & & & \\
\hline D2 & 1613 & 5858 & 208855 & -0.1 & & & \\
\hline 09 & & & & & & & \\
\hline Peak & Location & Amplitude & Area & FWHM & R1 & R2 & $\mathrm{T}\left({ }^{\circ} \mathrm{C}\right)$ \\
\hline D1 & 1347 & 5459 & 358639 & 18.4 & 1.614 & 0.559 & 392.4 \\
\hline G & 1582 & 3382 & 194695 & 26.2 & & & \\
\hline D2 & 1610 & 2440 & 88680.1 & -0.4 & & & \\
\hline 011 & & & & & & & \\
\hline Peak & Location & Amplitude & Area & FWHM & R1 & R2 & $\mathrm{T}\left({ }^{\circ} \mathrm{C}\right)$ \\
\hline D1 & 1350 & 9299 & 784622 & 48.1 & 1.617 & 0.648 & 352.5 \\
\hline G & 1596 & 5751 & 357056 & 27.7 & & & \\
\hline D2 & 1619 & 2238 & 68557.4 & -0.7 & & & \\
\hline 012 & & & & & & & \\
\hline Peak & Location & Amplitude & Area & FWHM & R1 & R2 & $\mathrm{T}\left({ }^{\circ} \mathrm{C}\right)$ \\
\hline D1 & 1348 & 35304 & 3099950 & 53.6 & 1.415 & 0.704 & 327.8 \\
\hline G & 1599 & 24944 & 1277580 & -3.9 & & & \\
\hline D2 & 1619 & 1812 & 26255.8 & -0.4 & & & \\
\hline
\end{tabular}

\begin{tabular}{|c|c|c|c|c|c|c|c|}
\hline \multirow[t]{2}{*}{ 10DF15 } & \multirow[t]{2}{*}{ Method: } & \multicolumn{2}{|c|}{ Lahfid et al. (2010) } & \multirow{2}{*}{$\begin{array}{l}\text { RA1 } \\
\text { avg T }\end{array}$} & \multirow[b]{2}{*}{ std dev } & \multirow{2}{*}{$\begin{array}{l}\text { RA2 } \\
\operatorname{avg} T\end{array}$} & \multirow[b]{2}{*}{ std dev } \\
\hline & & & & & & & \\
\hline & & \multicolumn{2}{|c|}{ Avg each run } & 320.0 & 15.5 & 322.1 & 20.5 \\
\hline & & \multicolumn{2}{|c|}{ Avg RA1,RA2 } & $\mathrm{T}\left({ }^{\circ} \mathrm{C}\right)$ & 321.0 & std dev & 18.0 \\
\hline & & & & & & & \\
\hline 2 & & & & & RA1 & RA2 & $\mathrm{T}\left({ }^{\circ} \mathrm{C}\right)$ \\
\hline Peak & Location & Amplitude & Area & FWHM & 0.657 & 1.915 & 351.4 \\
\hline D4 & 1253 & 2759 & 1097890 & 253.4 & & & \\
\hline $\mathrm{D} 1$ & 1346 & 28381 & 3269570 & 73.3 & & & \\
\hline D3 & 1541 & 2652 & 429968 & 103.2 & & & \\
\hline G & 1598 & 24090 & 1366830 & 36.1 & & & \\
\hline $\mathrm{D} 2$ & 1617 & 13688 & 483816 & 22.5 & & & \\
\hline 3 & & & & & RA1 & RA2 & $\mathrm{T}\left({ }^{\circ} \mathrm{C}\right)$ \\
\hline Peak & Location & Amplitude & Area & FWHM & 0.632 & 1.720 & 320.6 \\
\hline D4 & 1314 & 2208 & 348741 & 100.6 & & & \\
\hline $\mathrm{D} 1$ & 1349 & 8346 & 808985 & 61.7 & & & \\
\hline D3 & 1564 & 1041 & 97147.4 & 59.4 & & & \\
\hline $\mathrm{G}$ & 1600 & 7668 & 381408 & 31.7 & & & \\
\hline D2 & 1619 & 6492 & 194663 & 19.1 & & & \\
\hline 4 & & & & & RA1 & RA2 & $\mathrm{T}\left({ }^{\circ} \mathrm{C}\right)$ \\
\hline Peak & Location & Amplitude & Area & FWHM & 0.617 & 1.611 & 301.5 \\
\hline D4 & 1348 & 9845 & 1017220 & 65.8 & & & \\
\hline $\mathrm{D} 1$ & 1316 & 2245 & 472797 & 134.0 & & & \\
\hline D3 & 1549 & 1171 & 183638 & 99.8 & & & \\
\hline $\mathrm{G}$ & 1600 & 9771 & 548662 & 35.7 & & & \\
\hline D2 & 1619 & 5954 & 192476 & 20.6 & & & \\
\hline 7 & & & & & RA1 & RA2 & $\mathrm{T}\left({ }^{\circ} \mathrm{C}\right)$ \\
\hline Peak & Location & Amplitude & Area & FWHM & 0.615 & 1.600 & 299.5 \\
\hline
\end{tabular}




\begin{tabular}{|c|c|c|c|c|c|c|c|}
\hline D4 & 1352 & 7977 & 728437 & 58.1 & & & \\
\hline D1 & 1327 & 5147 & 777526 & 96.2 & & & \\
\hline D3 & 1563 & 1157 & 141706 & 78.0 & & & \\
\hline G & 1600 & 10848 & 565708 & 33.2 & & & \\
\hline D2 & 1619 & 7472 & 233755 & 19.9 & & & \\
\hline 8 & & & & & RA1 & RA2 & $\mathrm{T}\left({ }^{\circ} \mathrm{C}\right)$ \\
\hline Peak & Location & Amplitude & Area & FWHM & 0.629 & 1.698 & 317.0 \\
\hline D4 & 1354 & 6187 & 451460 & 46.5 & & & \\
\hline D1 & 1324 & 3853 & 365741 & 60.4 & & & \\
\hline D3 & 1593 & 5023 & 172621 & 21.9 & & & \\
\hline G & 1620 & 6377 & 148059 & 14.8 & & & \\
\hline D2 & 1606 & 6008 & 160527 & 17.0 & & & \\
\hline 0 & & & & & RA1 & RA2 & $\mathrm{T}\left({ }^{\circ} \mathrm{C}\right)$ \\
\hline Peak & Location & Amplitude & Area & FWHM & 0.636 & 1.749 & 325.5 \\
\hline D4 & 1351 & 8844 & 793450 & 57.1 & & & \\
\hline D1 & 1322 & 3481 & 453526 & 82.9 & & & \\
\hline D3 & 1580 & 2285 & 111223 & 31.0 & & & \\
\hline G & 1601 & 8830 & 362947 & 26.2 & & & \\
\hline D2 & 1618 & 7748 & 238920 & 19.6 & & & \\
\hline 1 & & & & & RA1 & RA2 & $\mathrm{T}\left({ }^{\circ} \mathrm{C}\right)$ \\
\hline Peak & Location & Amplitude & Area & FWHM & 0.631 & 1.713 & 319.5 \\
\hline D4 & 1351 & 9847 & 865942 & 56.0 & & & \\
\hline D1 & 1323 & 4020 & 511428 & 81.0 & & & \\
\hline D3 & 1587 & 3801 & 212531 & 35.6 & & & \\
\hline G & 1603 & 9138 & 365338 & 25.5 & & & \\
\hline D2 & 1619 & 7558 & 226171 & 19.1 & & & \\
\hline 12 & & & & & RA1 & RA2 & $\mathrm{T}\left({ }^{\circ} \mathrm{C}\right)$ \\
\hline Peak & Location & Amplitude & Area & FWHM & 0.645 & 1.813 & 336.0 \\
\hline D4 & 1338 & 8372 & 1464200 & 111.3 & & & \\
\hline D1 & 1348 & 9590 & 820504 & 54.5 & & & \\
\hline D3 & 1577 & 4573 & 342274 & 47.6 & & & \\
\hline G & 1600 & 14101 & 609893 & 27.5 & & & \\
\hline D2 & 1618 & 10022 & 307680 & 19.5 & & & \\
\hline 11 & & & & & RA1 & RA2 & $\mathrm{T}\left({ }^{\circ} \mathrm{C}\right)$ \\
\hline Peak & Location & Amplitude & Area & FWHM & 0.633 & 1.728 & 322.0 \\
\hline D4 & 1346 & 16539 & 2087620 & 80.4 & & & \\
\hline D1 & 1262 & 1965 & 820762 & 265.9 & & & \\
\hline D3 & 1540 & 2268 & 398286 & 111.8 & & & \\
\hline G & 1599 & 15055 & 965665 & 40.8 & & & \\
\hline D2 & 1617 & 8845 & 319129 & 23.0 & & & \\
\hline 3 & & & & & RA1 & RA2 & $\mathrm{T}\left({ }^{\circ} \mathrm{C}\right)$ \\
\hline Peak & Location & Amplitude & Area & FWHM & 0.647 & 1.833 & 339.0 \\
\hline D4 & 1294 & 723 & 97192.6 & 85.6 & & & \\
\hline D1 & 1346 & 9263 & 1047200 & 72.0 & & & \\
\hline D3 & 1573 & 1199 & 102537 & 54.5 & & & \\
\hline G & 1619 & 6560 & 186663 & 18.1 & & & \\
\hline D2 & 1600 & 7399 & 335270 & 28.8 & & & \\
\hline 31 & & & & & RA1 & RA2 & $\mathrm{T}\left({ }^{\circ} \mathrm{C}\right)$ \\
\hline Peak & Location & Amplitude & Area & FWHM & 0.638 & 1.759 & 327.2 \\
\hline D4 & 1263 & 7922 & 3822480 & 307.2 & & & \\
\hline D1 & 1345 & 57087 & 6971250 & 77.7 & & & \\
\hline
\end{tabular}




\begin{tabular}{|c|c|c|c|c|c|c|c|}
\hline D3 & 1527 & 9115 & 1837200 & 128.3 & & & \\
\hline G & 1595 & 47717 & 3174640 & 42.4 & & & \\
\hline D2 & 1614 & 27100 & 1124320 & 26.4 & & & \\
\hline 32 & & & & & RA1 & RA2 & $\mathrm{T}\left({ }^{\circ} \mathrm{C}\right)$ \\
\hline Peak & Location & Amplitude & Area & FWHM & 0.650 & 1.858 & 342.9 \\
\hline D4 & 1299 & 6759 & 3124610 & 294.3 & & & \\
\hline D1 & 1345 & 41817 & 4768900 & 72.6 & & & \\
\hline D3 & 1536 & 6606 & 1137550 & 109.6 & & & \\
\hline G & 1595 & 34788 & 2263440 & 41.4 & & & \\
\hline D2 & 1615 & 20869 & 847137 & 25.8 & & & \\
\hline 204 & & & & & RA1 & RA2 & $\mathrm{T}\left({ }^{\circ} \mathrm{C}\right)$ \\
\hline Peak & Location & Amplitude & Area & FWHM & 0.626 & 1.674 & 312.8 \\
\hline D4 & 1291 & 608 & 225841 & 236.5 & & & \\
\hline D1 & 1347 & 4971 & 571430 & 73.2 & & & \\
\hline D3 & 1522 & 515 & 114169 & 141.3 & & & \\
\hline G & 1618 & 2418 & 83174.9 & 21.9 & & & \\
\hline D2 & 1600 & 4486 & 278825 & 39.6 & & & \\
\hline 202 & & & & & RA1 & RA2 & $\mathrm{T}\left({ }^{\circ} \mathrm{C}\right)$ \\
\hline Peak & Location & Amplitude & Area & FWHM & 0.623 & 1.656 & 309.5 \\
\hline D4 & 1321 & 857 & 128033 & 95.1 & & & \\
\hline D1 & 1351 & 2408 & 222560 & 58.8 & & & \\
\hline D3 & 1560 & 248 & 20820.8 & 53.4 & & & \\
\hline G & 1620 & 1882 & 57453.5 & 19.4 & & & \\
\hline D2 & 1600 & 2594 & 133490 & 32.8 & & & \\
\hline 205 & & & & & RA1 & RA2 & $\mathrm{T}\left({ }^{\circ} \mathrm{C}\right)$ \\
\hline Peak & Location & Amplitude & Area & FWHM & 0.612 & 1.577 & 295.3 \\
\hline D4 & 1357 & 4175 & 251775 & 38.4 & & & \\
\hline D1 & 1330 & 4359 & 365316 & 53.3 & & & \\
\hline D3 & 1590 & 3311 & 108861 & 20.9 & & & \\
\hline G & 1618 & 4442 & 123283 & 17.7 & & & \\
\hline D2 & 1604 & 5653 & 159081 & 17.9 & & & \\
\hline 208 & & & & & RA1 & RA2 & $\mathrm{T}\left({ }^{\circ} \mathrm{C}\right)$ \\
\hline Peak & Location & Amplitude & Area & FWHM & 0.634 & 1.733 & 322.9 \\
\hline D4 & 1331 & 1817 & 173269 & 60.7 & & & \\
\hline D1 & 1356 & 2040 & 138261 & 43.1 & & & \\
\hline D3 & 1591 & 1562 & 60210 & -24.5 & & & \\
\hline $\mathrm{G}$ & 1605 & 2303 & 71084.3 & 19.7 & & & \\
\hline D2 & 1620 & 1861 & 48461.2 & 16.6 & & & \\
\hline 2010 & & & & & RA1 & RA2 & $\mathrm{T}\left({ }^{\circ} \mathrm{C}\right)$ \\
\hline Peak & Location & Amplitude & Area & FWHM & 0.633 & 1.726 & 321.7 \\
\hline D4 & 1325 & 1642 & 141434 & 54.8 & & & \\
\hline D1 & 1354 & 2410 & 163195 & 43.1 & & & \\
\hline D3 & 1593 & 2135 & 73691.9 & -22.0 & & & \\
\hline G & 1608 & 2430 & 61525.9 & 16.1 & & & \\
\hline D2 & 1621 & 1959 & 41274.7 & 13.4 & & & \\
\hline 2011 & & & & & RA1 & RA2 & $\mathrm{T}\left({ }^{\circ} \mathrm{C}\right)$ \\
\hline Peak & Location & Amplitude & Area & FWHM & 0.613 & 1.583 & 296.3 \\
\hline D4 & 1327 & 1587 & 125622 & 50.4 & & & \\
\hline D1 & 1354 & 2588 & 167121 & 41.1 & & & \\
\hline D3 & 1589 & 1429 & 45321.8 & 20.2 & & & \\
\hline G & 1619 & 2584 & 66034.4 & 16.3 & & & \\
\hline
\end{tabular}


\begin{tabular}{|l|l|l|l|l|l|l|}
$\mathrm{D} 2$ & 1604 & 2580 & 73565.4 & 18.2 & & \\
\hline
\end{tabular}

\begin{tabular}{|c|c|c|c|c|c|c|c|}
\hline \multirow[t]{2}{*}{ 18DF15 } & \multirow[t]{2}{*}{ Method: } & \multicolumn{2}{|c|}{ Lahfid et al. (2010) } & \multirow{2}{*}{$\begin{array}{l}\text { RA1 } \\
\operatorname{avg~T}\end{array}$} & \multirow[b]{2}{*}{ std dev } & \multirow{2}{*}{$\begin{array}{l}\text { RA2 } \\
\operatorname{avg~T}\end{array}$} & \multirow[b]{2}{*}{ std dev } \\
\hline & & & & & & & \\
\hline & & Avg each $\mathrm{rl}$ & & 335.7 & 16.3 & 343.3 & 22.2 \\
\hline & & Avg RA1,R & & $\mathrm{T}\left({ }^{\circ} \mathrm{C}\right)$ & 339.5 & std dev & 19.2 \\
\hline & & & & & & & $\left.\mathrm{T} /{ }^{\circ} \mathrm{C}\right)$ \\
\hline 0 & & & & & RA1 & RA2 & $\mathrm{T}\left({ }^{\circ} \mathrm{C}\right)$ \\
\hline Peak & Location & Amplitude & Area & FWHM & 0.660 & 1.945 & 355.8 \\
\hline D4 & 1289 & 6613 & 3152790 & 303.5 & & & \\
\hline D1 & 1345 & 34037 & 4008790 & 75.0 & & & \\
\hline D3 & 1527 & 4844 & 941661 & 123.8 & & & \\
\hline G & 1593 & 27374 & 1877050 & 43.7 & & & \\
\hline D2 & 1612 & 19860 & 863446 & 27.7 & & & \\
\hline 01 & & & & & RA1 & RA2 & $\mathrm{T}\left({ }^{\circ} \mathrm{C}\right)$ \\
\hline Peak & Location & Amplitude & Area & FWHM & 0.650 & 1.858 & 343.0 \\
\hline D4 & 1295 & 7318 & 3009660 & 261.8 & & & \\
\hline $\mathrm{D} 1$ & 1342 & 34516 & 4242690 & 78.3 & & & \\
\hline D3 & 1522 & 4817 & 861739 & 113.9 & & & \\
\hline G & 1587 & 29309 & 2082220 & 45.2 & & & \\
\hline D2 & 1608 & 20752 & 958360 & 29.4 & & & \\
\hline 02 & & & & & RA1 & RA2 & $\mathrm{T}\left({ }^{\circ} \mathrm{C}\right)$ \\
\hline Peak & Location & Amplitude & Area & FWHM & 0.646 & 1.821 & 337.1 \\
\hline D4 & 1290 & 9908 & 4058270 & 260.8 & & & \\
\hline D1 & 1344 & 57229 & 6140460 & 68.3 & & & \\
\hline D3 & 1525 & 6723 & 1240740 & 117.5 & & & \\
\hline G & 1592 & 45324 & 3038890 & 42.7 & & & \\
\hline D2 & 1612 & 32047 & 1321230 & 26.2 & & & \\
\hline 03 & & & & & RA1 & RA2 & $\mathrm{T}\left({ }^{\circ} \mathrm{C}\right)$ \\
\hline Peak & Location & Amplitude & Area & FWHM & 0.645 & 1.816 & 336.4 \\
\hline D4 & 1299 & 5797 & 2367160 & 260.0 & & & \\
\hline $\mathrm{D} 1$ & 1343 & 43444 & 4291530 & 62.9 & & & \\
\hline D3 & 1529 & 3966 & 689139 & 110.6 & & & \\
\hline G & 1587 & 27308 & 1925900 & 44.9 & & & \\
\hline $\mathrm{D} 2$ & 1609 & 22753 & 1051230 & 29.4 & & & \\
\hline 04 & & & & & RA1 & RA2 & $\mathrm{T}\left({ }^{\circ} \mathrm{C}\right)$ \\
\hline Peak & Location & Amplitude & Area & FWHM & 0.661 & 1.948 & 356.2 \\
\hline D4 & 1275 & 6032 & 2699200 & 284.9 & & & \\
\hline $\mathrm{D} 1$ & 1347 & 35417 & 3710230 & 66.7 & & & \\
\hline D3 & 1526 & 3815 & 731094 & 122.0 & & & \\
\hline$G$ & 1598 & 29862 & 1878570 & 40.0 & & & \\
\hline D2 & 1616 & 17998 & 680591 & 24.1 & & & \\
\hline 05 & & & & & RA1 & RA2 & $\mathrm{T}\left({ }^{\circ} \mathrm{C}\right)$ \\
\hline Peak & Location & Amplitude & Area & FWHM & 0.625 & 1.665 & 311.2 \\
\hline D4 & 1222 & 1931 & 579239 & 191.0 & & & \\
\hline D1 & 1342 & 14033 & 2142510 & 97.2 & & & \\
\hline D3 & 1526 & 2139 & 416013 & 123.8 & & & \\
\hline $\mathrm{G}$ & 1599 & 14379 & 882386 & 39.1 & & & \\
\hline $\mathrm{D} 2$ & 1616 & 8758 & 336248 & 24.4 & & & \\
\hline 06 & & & & & RA1 & RA2 & $\mathrm{T}\left({ }^{\circ} \mathrm{C}\right)$ \\
\hline
\end{tabular}




\begin{tabular}{|c|c|c|c|c|c|c|c|}
\hline Peak & Location & Amplitude & Area & FWHM & 0.643 & 1.802 & 334.2 \\
\hline D4 & 1260 & 4731 & 2012530 & 270.8 & & & \\
\hline D1 & 1341 & 25101 & 3612950 & 91.6 & & & \\
\hline D3 & 1516 & 4102 & 844125 & 131.0 & & & \\
\hline G & 1588 & 20307 & 1482870 & 46.5 & & & \\
\hline D2 & 1608 & 16494 & 794440 & 30.7 & & & \\
\hline 07 & & & & & RA1 & RA2 & $\mathrm{T}\left({ }^{\circ} \mathrm{C}\right)$ \\
\hline Peak & Location & Amplitude & Area & FWHM & 0.647 & 1.834 & 339.2 \\
\hline D4 & 1270 & 12158 & 5227930 & 273.7 & & & \\
\hline D1 & 1345 & 64050 & 7628670 & 75.8 & & & \\
\hline D3 & 1525 & 8787 & 1793140 & 129.9 & & & \\
\hline$G$ & 1596 & 58587 & 3793420 & 41.2 & & & \\
\hline D2 & 1614 & 35882 & 1422100 & 25.2 & & & \\
\hline 08 & & & & & RA1 & RA2 & $\mathrm{T}\left({ }^{\circ} \mathrm{C}\right)$ \\
\hline Peak & Location & Amplitude & Area & FWHM & 0.653 & 1.885 & 347.0 \\
\hline D4 & 1259 & 1399 & 594581 & 270.6 & & & \\
\hline D1 & 1346 & 8718 & 996481 & 72.8 & & & \\
\hline D3 & 1535 & 1022 & 200957 & 125.2 & & & \\
\hline G & 1600 & 8012 & 472210 & 37.5 & & & \\
\hline D2 & 1617 & 4685 & 170755 & 23.2 & & & \\
\hline 09 & & & & & RA1 & RA2 & $\mathrm{T}\left({ }^{\circ} \mathrm{C}\right)$ \\
\hline Peak & Location & Amplitude & Area & FWHM & 0.655 & 1.900 & 349.2 \\
\hline D4 & 1267 & 4821 & 2099580 & 277.3 & & & \\
\hline $\mathrm{D} 1$ & 1346 & 29032 & 3148320 & 69.0 & & & \\
\hline D3 & 1528 & 3218 & 645637 & 127.7 & & & \\
\hline G & 1599 & 25707 & 1579300 & 39.1 & & & \\
\hline D2 & 1617 & 14669 & 537086 & 23.3 & & & \\
\hline 010 & & & & & RA1 & RA2 & $\mathrm{T}\left({ }^{\circ} \mathrm{C}\right)$ \\
\hline Peak & Location & Amplitude & Area & FWHM & 0.651 & 1.864 & 343.8 \\
\hline D4 & 1260 & 3739 & 1712410 & 291.6 & & & \\
\hline D1 & 1347 & 20917 & 2604910 & 79.3 & & & \\
\hline D3 & 1526 & 2786 & 562080 & 128.4 & & & \\
\hline G & 1599 & 20612 & 1304540 & 40.3 & & & \\
\hline D2 & 1617 & 11711 & 449139 & 24.4 & & & \\
\hline 1 & & & & & RA1 & RA2 & $\mathrm{T}\left({ }^{\circ} \mathrm{C}\right)$ \\
\hline Peak & Location & Amplitude & Area & FWHM & 0.648 & 1.837 & 339.6 \\
\hline D4 & 1260 & 1979 & 819505 & 263.6 & & & \\
\hline D1 & 1346 & 13188 & 1611120 & 77.8 & & & \\
\hline D3 & 1531 & 1613 & 295364 & 116.6 & & & \\
\hline G & 1599 & 12091 & 752166 & 39.6 & & & \\
\hline D2 & 1617 & 7331 & 275675 & 23.9 & & & \\
\hline 11 & & & & & RA1 & RA2 & $\mathrm{T}\left({ }^{\circ} \mathrm{C}\right)$ \\
\hline Peak & Location & Amplitude & Area & FWHM & 0.635 & 1.739 & 324.0 \\
\hline D4 & 1238 & 3106 & 1215500 & 249.1 & & & \\
\hline $\mathrm{D} 1$ & 1339 & 21836 & 3755680 & 109.5 & & & \\
\hline D3 & 1517 & 3856 & 760087 & 125.5 & & & \\
\hline$G$ & 1585 & 17919 & 1319830 & 46.9 & & & \\
\hline D2 & 1605 & 15106 & 777918 & 32.8 & & & \\
\hline 12 & & & & & RA1 & RA2 & $\mathrm{T}\left({ }^{\circ} \mathrm{C}\right)$ \\
\hline Peak & Location & Amplitude & Area & FWHM & 0.614 & 1.590 & 297.7 \\
\hline D4 & 1246 & 4955 & 1708120 & 219.5 & & & \\
\hline
\end{tabular}




\begin{tabular}{|l|r|r|r|r|r|r|r|} 
D1 & 1340 & 33210 & 5081540 & 97.4 & & & \\
\hline D3 & 1589 & 27224 & 1887120 & 44.1 & & & \\
\hline G & 1515 & 5401 & 1112340 & 131.1 & & & \\
\hline D2 & 1608 & 27764 & 1269970 & 29.1 & & & \\
\hline 13 & & & & & RA1 & RA2 & T $\left({ }^{\circ} \mathrm{C}\right)$ \\
\hline Peak & Location & Amplitude & Area & FWHM & 0.632 & 1.719 & 320.6 \\
\hline D4 & 1267 & 3051 & 903521 & 188.5 & & & \\
\hline D1 & 1344 & 25516 & 3639550 & 90.8 & & & \\
\hline D3 & 1545 & 3503 & 531257 & 96.6 & & & \\
\hline G & 1596 & 23936 & 1417720 & 37.7 & & & \\
\hline D2 & 1614 & 17656 & 693482 & 25.0 & & & \\
\hline
\end{tabular}

\begin{tabular}{|c|c|c|c|c|c|c|c|}
\hline \multirow[t]{2}{*}{ 23DF15 } & \multirow[t]{2}{*}{ Method: } & \multicolumn{2}{|c|}{ Lahfid et al. (2010) } & \multirow{2}{*}{$\begin{array}{l}\text { RA1 } \\
\text { avg T }\end{array}$} & \multirow{2}{*}{ std dev } & \multirow{2}{*}{$\begin{array}{l}\text { RA2 } \\
\text { avg T }\end{array}$} & \multirow[b]{2}{*}{ std dev } \\
\hline & & & & & & & \\
\hline & & \multicolumn{2}{|c|}{ Avg each run } & 323.4 & 17.6 & 326.6 & 23.7 \\
\hline & & \multicolumn{2}{|c|}{ Avg RA1,RA2 } & $\mathrm{T}\left({ }^{\circ} \mathrm{C}\right)$ & 325.0 & std dev & 20.6 \\
\hline 02 & & & & & RA1 & RA2 & $\mathrm{T}\left({ }^{\circ} \mathrm{C}\right)$ \\
\hline Peak & Location & Amplitude & Area & FWHM & 0.638 & 1.761 & 327.5 \\
\hline D4 & 1282 & 378 & 65798.9 & 110.8 & & & \\
\hline D1 & 1348 & 5535 & 521661 & 60.0 & & & \\
\hline D3 & 1585 & 1664 & 102019 & 39.0 & & & \\
\hline G & 1602 & 3594 & 138434 & 24.5 & & & \\
\hline $\mathrm{D} 2$ & 1619 & 2904 & 93113.8 & 20.4 & & & \\
\hline 03 & & & & & RA1 & RA2 & $\mathrm{T}\left({ }^{\circ} \mathrm{C}\right)$ \\
\hline Peak & Location & Amplitude & Area & FWHM & 0.659 & 1.931 & 353.8 \\
\hline D4 & 1298 & 776 & 266791 & 218.9 & & & \\
\hline $\mathrm{D} 1$ & 1349 & 7263 & 707138 & 62.0 & & & \\
\hline D3 & 1573 & 1129 & 114368 & 64.5 & & & \\
\hline G & 1601 & 5516 & 275458 & 31.8 & & & \\
\hline $\mathrm{D} 2$ & 1619 & 3569 & 114556 & 20.4 & & & \\
\hline 05 & & & & & RA1 & RA2 & $\mathrm{T}\left({ }^{\circ} \mathrm{C}\right)$ \\
\hline Peak & Location & Amplitude & Area & FWHM & 0.644 & 1.810 & 335.3 \\
\hline D4 & 1284 & 1043 & 455077 & 277.8 & & & \\
\hline $\mathrm{D} 1$ & 1346 & 12309 & 1315750 & 68.1 & & & \\
\hline D3 & 1561 & 1585 & 211690 & 85.0 & & & \\
\hline $\mathrm{G}$ & 1600 & 10288 & 537872 & 33.3 & & & \\
\hline $\mathrm{D} 2$ & 1618 & 6787 & 229039 & 21.5 & & & \\
\hline 06 & & & & & RA1 & RA2 & $\mathrm{T}\left({ }^{\circ} \mathrm{C}\right)$ \\
\hline Peak & Location & Amplitude & Area & FWHM & 0.636 & 1.748 & 325.4 \\
\hline D4 & 1259 & 217 & 65853.7 & 193.3 & & & \\
\hline D1 & 1347 & 5025 & 500118 & 63.4 & & & \\
\hline D3 & 1585 & 1573 & 112693 & 45.6 & & & \\
\hline$G$ & 1603 & 3371 & 135404 & 25.6 & & & \\
\hline $\mathrm{D} 2$ & 1619 & 2404 & 75623.8 & 20.0 & & & \\
\hline 07 & & & & & RA1 & RA2 & $\mathrm{T}\left({ }^{\circ} \mathrm{C}\right)$ \\
\hline Peak & Location & Amplitude & Area & FWHM & 0.639 & 1.772 & 329.3 \\
\hline D4 & 1322 & 844 & 230712 & 174.1 & & & \\
\hline $\mathrm{D} 1$ & 1347 & 6183 & 607260 & 62.5 & & & \\
\hline D3 & 1570 & 909 & 94951.2 & 66.5 & & & \\
\hline
\end{tabular}




\begin{tabular}{|l|r|r|r|r|r|r|r|}
\hline G & 1600 & 5255 & 261394 & 31.7 & & & \\
\hline D2 & 1619 & 3655 & 116599 & 20.3 & & & \\
\hline Peak & & & & & RA1 & RA2 & $\mathrm{T}\left({ }^{\circ} \mathrm{C}\right)$ \\
\hline D4 & 1333 & 712 & 150984 & 135.0 & & & \\
\hline D1 & 1348 & 4648 & 435783 & 59.7 & & & \\
\hline D3 & 1583 & 1432 & 116500 & 51.8 & & & \\
\hline G & 1603 & 3676 & 167696 & 29.0 & & & \\
\hline D2 & 1620 & 2371 & 70819.2 & 19.0 & & & \\
\hline 03 & & & & & RA1 & RA2 & $\mathrm{T}\left({ }^{\circ} \mathrm{C}\right)$ \\
\hline Peak & Location & Amplitude & Area & FWHM & 0.615 & 1.596 & 298.7 \\
\hline D4 & 1268 & 1347 & 477048 & 225.5 & & & \\
\hline D1 & 1346 & 13138 & 1417430 & 68.7 & & & \\
\hline D3 & 1527 & 1444 & 330010 & 145.5 & & & \\
\hline G & 1599 & 10521 & 648128 & 39.2 & & & \\
\hline D2 & 1618 & 5928 & 208879 & 22.4 & & & \\
\hline 010 & & & & & RA1 & RA2 & $\mathrm{T}\left({ }^{\circ} \mathrm{C}\right)$ \\
\hline Peak & Location & Amplitude & Area & FWHM & 0.622 & 1.648 & 308.2 \\
\hline D4 & 1292 & 343 & 42198.7 & 78.2 & & & \\
\hline D1 & 1348 & 5214 & 498133 & 60.8 & & & \\
\hline D3 & 1581 & 1322 & 89889.3 & 43.3 & & & \\
\hline G & 1601 & 3517 & 147313 & 26.7 & & & \\
\hline D2 & 1618 & 2832 & 90646.6 & 20.4 & & & \\
\hline 011 & & & & & RA1 & RA2 & $\mathrm{T}\left({ }^{\circ} \mathrm{C}\right)$ \\
\hline Peak & Location & Amplitude & Area & FWHM & 0.630 & 1.704 & 318.0 \\
\hline D4 & 1273 & 1292 & 494906 & 243.9 & & & \\
\hline D1 & 1346 & 13073 & 1456050 & 70.9 & & & \\
\hline D3 & 1543 & 1460 & 248282 & 108.3 & & & \\
\hline G & 1600 & 11409 & 629830 & 35.1 & & & \\
\hline D2 & 1617 & 7670 & 266700 & 22.1 & & & \\
\hline & & & & & & & \\
\hline
\end{tabular}

\begin{tabular}{|c|c|c|c|c|c|c|c|}
\hline \multirow[t]{2}{*}{ 26DF15 } & \multirow[t]{2}{*}{ Method: } & \multicolumn{2}{|c|}{ Lahfid et al. (2010) } & \multirow{2}{*}{$\begin{array}{l}\text { RA1 } \\
\operatorname{avg~T}\end{array}$} & \multirow{2}{*}{ std dev } & \multirow{2}{*}{$\begin{array}{l}\text { RA2 } \\
\operatorname{avg~T}\end{array}$} & \multirow[b]{2}{*}{ std dev } \\
\hline & & & & & & & \\
\hline & & \multicolumn{2}{|c|}{ Avg each run } & 280.1 & 15.2 & 273.6 & 17.2 \\
\hline & & \multicolumn{2}{|c|}{ Avg RA1,RA2 } & $\mathrm{T}\left({ }^{\circ} \mathrm{C}\right)$ & 276.8 & std dev & 16.2 \\
\hline & & & & & & & \\
\hline 3 & & & & & RA1 & RA2 & $\mathrm{T}\left({ }^{\circ} \mathrm{C}\right)$ \\
\hline Peak & Location & Amplitude & Area & FWHM & 0.597 & 1.483 & 276.9 \\
\hline D4 & 1247 & 1371 & 440510 & 204.5 & & & \\
\hline D1 & 1347 & 11818 & 1719310 & 92.6 & & & \\
\hline D3 & 1531 & 2119 & 461964 & 138.8 & & & \\
\hline$G$ & 1599 & 11110 & 717248 & 41.1 & & & \\
\hline D2 & 1617 & 7131 & 276983 & 24.7 & & & \\
\hline 31 & & & & & RA1 & RA2 & $\mathrm{T}\left({ }^{\circ} \mathrm{C}\right)$ \\
\hline Peak & Location & Amplitude & Area & FWHM & 0.619 & 1.623 & 303.8 \\
\hline D4 & 1267 & 673 & 81521.6 & 77.1 & & & \\
\hline D1 & 1342 & 12010 & 1840520 & 97.6 & & & \\
\hline D3 & 1581 & 5497 & 433253 & 50.2 & & & \\
\hline G & 1602 & 11514 & 478004 & 26.4 & & & \\
\hline D2 & 1618 & 8778 & 272693 & 19.8 & & & \\
\hline
\end{tabular}




\begin{tabular}{|l|r|r|r|r|r|r|r|} 
33 & & & & & RA1 & RA2 & $\mathrm{T}\left({ }^{\circ} \mathrm{C}\right)$ \\
\hline Peak & Location & Amplitude & Area & FWHM & 0.603 & 1.520 & 284.3 \\
\hline D4 & 1285 & 1621 & 186573 & 73.3 & & & \\
\hline D1 & 1345 & 14866 & 2001730 & 85.7 & & & \\
\hline D3 & 1583 & 8546 & 555115 & 41.4 & & & \\
\hline G & 1602 & 14900 & 578103 & 24.7 & & & \\
\hline D2 & 1618 & 10522 & 306138 & 18.5 & & & \\
\hline 38 & & & & & RA1 & RA2 & T $\left({ }^{\circ} \mathrm{C}\right)$ \\
\hline Peak & Location & Amplitude & Area & FWHM & 0.587 & 1.419 & 263.5 \\
\hline D4 & 1352 & 1928 & 134136 & 44.3 & & & \\
\hline D1 & 1326 & 1525 & 158571 & 66.2 & & & \\
\hline D3 & 1589 & 1287 & 55126.4 & 27.3 & & & \\
\hline G & 1604 & 2559 & 83250.6 & 20.7 & & & \\
\hline D2 & 1618 & 2157 & 67874.8 & 20.0 & & & \\
\hline 32 & & & & & RA1 & RA2 & T $\left({ }^{\circ} \mathrm{C}\right)$ \\
\hline Peak & Location & Amplitude & Area & FWHM & 0.593 & 1.459 & 272.0 \\
\hline D4 & 1324 & 7311 & 887486 & 77.3 & & & \\
\hline D1 & 1357 & 7662 & 713051 & 59.2 & & & \\
\hline D3 & 1587 & 7612 & 389740 & 32.6 & & & \\
\hline G & 1605 & 13034 & 446888 & 21.8 & & & \\
\hline D3 & 1619 & 9516 & 260050 & 17.4 & & & \\
\hline
\end{tabular}

\begin{tabular}{|c|c|c|c|c|c|c|c|}
\hline \multirow[t]{2}{*}{ 27DF15 } & \multirow[t]{2}{*}{ Method: } & \multicolumn{2}{|c|}{ Lahfid et al. (2010) } & \multirow{2}{*}{$\begin{array}{l}\text { RA1 } \\
\text { avg T }\end{array}$} & \multirow{2}{*}{ std dev } & \multirow{2}{*}{$\begin{array}{l}\text { RA2 } \\
\text { avg T }\end{array}$} & \multirow[b]{2}{*}{ std dev } \\
\hline & & & & & & & \\
\hline & & \multicolumn{2}{|c|}{ Avg each run } & 341.2 & 24.9 & 352.2 & 34.6 \\
\hline & & \multicolumn{2}{|c|}{ Avg RA1,RA2 } & $\mathrm{T}\left({ }^{\circ} \mathrm{C}\right)$ & 346.7 & std dev & 29.8 \\
\hline & & & & & & & \\
\hline 012 & & & & & RA1 & RA2 & $\mathrm{T}\left({ }^{\circ} \mathrm{C}\right)$ \\
\hline Peak & Location & Amplitude & Area & FWHM & 0.655 & 1.895 & 348.5 \\
\hline D4 & 1248 & 3433 & 1441280 & 267.3 & & & \\
\hline D1 & 1345 & 28514 & 3566140 & 79.6 & & & \\
\hline D3 & 1538 & 3512 & 628889 & 114.0 & & & \\
\hline G & 1597 & 24227 & 1468580 & 38.6 & & & \\
\hline $\mathrm{D} 2$ & 1616 & 14833 & 544751 & 23.4 & & & \\
\hline 0 & & & & & RA1 & RA2 & $\mathrm{T}\left({ }^{\circ} \mathrm{C}\right)$ \\
\hline Peak & Location & Amplitude & Area & FWHM & 0.660 & 1.945 & 355.9 \\
\hline D4 & 1247 & 5270 & 2289210 & 276.5 & & & \\
\hline D1 & 1344 & 47577 & 5283730 & 70.7 & & & \\
\hline D3 & 1530 & 4921 & 872083 & 112.8 & & & \\
\hline G & 1594 & 33419 & 2110110 & 40.2 & & & \\
\hline $\mathrm{D} 2$ & 1614 & 22924 & 910615 & 25.3 & & & \\
\hline 01 & & & & & RA1 & RA2 & $\mathrm{T}\left({ }^{\circ} \mathrm{C}\right)$ \\
\hline Peak & Location & Amplitude & Area & FWHM & 0.645 & 1.820 & 337.0 \\
\hline D4 & 1229 & 4189 & 1512470 & 229.8 & & & \\
\hline D1 & 1342 & 41295 & 5486400 & 84.6 & & & \\
\hline D3 & 1594 & 34583 & 2047540 & 37.7 & & & \\
\hline G & 1612 & 24541 & 952315 & 24.7 & & & \\
\hline D2 & 1541 & 5206 & 846121 & 103.5 & & & \\
\hline 02 & & & & & RA1 & RA2 & $\mathrm{T}\left({ }^{\circ} \mathrm{C}\right)$ \\
\hline Peak & Location & Amplitude & Area & FWHM & 0.642 & 1.790 & 332.2 \\
\hline
\end{tabular}




\begin{tabular}{|c|c|c|c|c|c|c|c|}
\hline D4 & 1229 & 2450 & 788542 & 204.9 & & & \\
\hline D1 & 1344 & 22902 & 2971290 & 82.6 & & & \\
\hline D3 & 1539 & 2752 & 491239 & 113.6 & & & \\
\hline G & 1598 & 19990 & 1162540 & 37.0 & & & \\
\hline D2 & 1616 & 12445 & 446596 & 22.8 & & & \\
\hline 05 & & & & & RA1 & RA2 & $\mathrm{T}\left({ }^{\circ} \mathrm{C}\right)$ \\
\hline Peak & Location & Amplitude & Area & FWHM & 0.660 & 1.944 & 355.6 \\
\hline D4 & 1225 & 3551 & 1309700 & 234.8 & & & \\
\hline D1 & 1343 & 46318 & 5353290 & 73.6 & & & \\
\hline D3 & 1569 & 8271 & 752274 & 57.9 & & & \\
\hline G & 1596 & 34147 & 1692290 & 31.6 & & & \\
\hline D2 & 1614 & 26488 & 983038 & 23.6 & & & \\
\hline 06 & & & & & RA1 & RA2 & $\mathrm{T}\left({ }^{\circ} \mathrm{C}\right)$ \\
\hline Peak & Location & Amplitude & Area & FWHM & 0.678 & 2.106 & 377.8 \\
\hline D4 & 1286 & 1299 & 622539 & 305.1 & & & \\
\hline D1 & 1346 & 9768 & 1276270 & 83.2 & & & \\
\hline D3 & 1575 & 2595 & 253607 & 62.2 & & & \\
\hline G & 1601 & 9153 & 437748 & 30.4 & & & \\
\hline D2 & 1618 & 6286 & 210206 & 21.3 & & & \\
\hline 07 & & & & & RA1 & RA2 & $\mathrm{T}\left({ }^{\circ} \mathrm{C}\right)$ \\
\hline Peak & Location & Amplitude & Area & FWHM & 0.645 & 1.818 & 336.7 \\
\hline D4 & 1235 & 3696 & 1276800 & 219.9 & & & \\
\hline D1 & 1344 & 39804 & 5302290 & 84.8 & & & \\
\hline D3 & 1539 & 4858 & 721718 & 94.6 & & & \\
\hline G & 1596 & 33072 & 1980470 & 38.1 & & & \\
\hline D2 & 1614 & 23848 & 916865 & 24.5 & & & \\
\hline 08 & & & & & RA1 & RA2 & $\mathrm{T}\left({ }^{\circ} \mathrm{C}\right)$ \\
\hline Peak & Location & Amplitude & Area & FWHM & 0.669 & 2.020 & 366.4 \\
\hline D4 & 1313 & 6422 & 2885380 & 286.0 & & & \\
\hline D1 & 1346 & 25768 & 3493260 & 86.3 & & & \\
\hline D3 & 1546 & 5237 & 875365 & 106.4 & & & \\
\hline G & 1594 & 23333 & 1515010 & 41.3 & & & \\
\hline D2 & 1613 & 18377 & 767232 & 26.6 & & & \\
\hline 09 & & & & & RA1 & RA2 & $\mathrm{T}\left({ }^{\circ} \mathrm{C}\right)$ \\
\hline Peak & Location & Amplitude & Area & FWHM & 0.650 & 1.859 & 343.1 \\
\hline D4 & 1288 & 3561 & 1579810 & 282.4 & & & \\
\hline D1 & 1344 & 28035 & 4031620 & 91.6 & & & \\
\hline D3 & 1567 & 8064 & 876738 & 69.2 & & & \\
\hline G & 1596 & 27143 & 1434120 & 33.6 & & & \\
\hline $\mathrm{D} 2$ & 1614 & 19224 & 707400 & 23.4 & & & \\
\hline 010 & & & & & RA1 & RA2 & $\mathrm{T}\left({ }^{\circ} \mathrm{C}\right)$ \\
\hline Peak & Location & Amplitude & Area & FWHM & 0.604 & 1.522 & 284.6 \\
\hline D4 & 1226 & 4855 & 1593620 & 209.0 & & & \\
\hline D1 & 1342 & 38139 & 6593160 & 110.1 & & & \\
\hline D3 & 1521 & 8026 & 1830090 & 145.2 & & & \\
\hline G & 1590 & 31952 & 2328760 & 46.4 & & & \\
\hline D2 & 1609 & 25856 & 1219540 & 30.0 & & & \\
\hline 011 & & & & & RA1 & RA2 & $\mathrm{T}\left({ }^{\circ} \mathrm{C}\right)$ \\
\hline Peak & Location & Amplitude & Area & FWHM & 0.623 & 1.653 & 309.2 \\
\hline D4 & 1253 & 2103 & 597426 & 180.8 & & & \\
\hline D1 & 1345 & 25072 & 4300750 & 109.2 & & & \\
\hline
\end{tabular}




\begin{tabular}{|l|r|r|r|r|r|r|r|}
\hline D3 & 1548 & 5397 & 872283 & 102.9 & & & \\
\hline G & 1593 & 22166 & 1407380 & 40.4 & & & \\
\hline D2 & 1613 & 16663 & 682755 & 26.1 & & & \\
\hline 013 & & & & & RA1 & RA2 & T $\left({ }^{\circ} \mathrm{C}\right)$ \\
\hline Peak & Location & Amplitude & Area & FWHM & 0.654 & 1.888 & 347.4 \\
\hline D4 & 1273 & 5005 & 2223940 & 282.9 & & & \\
\hline D1 & 1345 & 33777 & 4393420 & 82.8 & & & \\
\hline D3 & 1536 & 4842 & 899114 & 118.2 & & & \\
\hline G & 1595 & 28497 & 1811770 & 40.5 & & & \\
\hline D2 & 1615 & 19933 & 794952 & 25.4 & & & \\
\hline
\end{tabular}

\begin{tabular}{|c|c|c|c|c|c|c|c|}
\hline \multirow[t]{3}{*}{ 28DF15 } & \multirow[t]{2}{*}{ Method: } & \multicolumn{2}{|c|}{ Lahfid et al. (2010) } & \multirow{2}{*}{$\begin{array}{l}\text { RA1 } \\
\text { avg T }\end{array}$} & \multirow{2}{*}{ std dev } & \multirow{2}{*}{$\begin{array}{l}\text { RA2 } \\
\operatorname{avg~T~}\end{array}$} & \multirow[b]{2}{*}{ std dev } \\
\hline & & & & & & & \\
\hline & & \multicolumn{2}{|c|}{ Avg each run } & 300.1 & 14.4 & 296.8 & 17.7 \\
\hline & & \multicolumn{2}{|c|}{ Avg RA1,RA2 } & $\mathrm{T}\left({ }^{\circ} \mathrm{C}\right)$ & 298.4 & std dev & 16.0 \\
\hline & & & & & & & \\
\hline 0 & & & & & RA1 & RA2 & $\mathrm{T}\left({ }^{\circ} \mathrm{C}\right)$ \\
\hline Peak & Location & Amplitude & Area & FWHM & 0.620 & 1.628 & 304.7 \\
\hline D4 & 1213 & 2495 & 624504 & 159.3 & & & \\
\hline D1 & 1344 & 30442 & 5289460 & 110.6 & & & \\
\hline D3 & 1536 & 5471 & 1050340 & 122.2 & & & \\
\hline G & 1598 & 26835 & 1716330 & 40.7 & & & \\
\hline $\mathrm{D} 2$ & 1616 & 21527 & 865204 & 25.6 & & & \\
\hline 01 & & & & & RA1 & RA2 & $\mathrm{T}\left({ }^{\circ} \mathrm{C}\right)$ \\
\hline Peak & Location & Amplitude & Area & FWHM & 0.625 & 1.664 & 311.1 \\
\hline D4 & 1209 & 1551 & 323956 & 133.0 & & & \\
\hline $\mathrm{D} 1$ & 1343 & 22365 & 3538920 & 100.7 & & & \\
\hline D3 & 1548 & 3411 & 552973 & 103.2 & & & \\
\hline G & 1600 & 21191 & 1190370 & 35.8 & & & \\
\hline D2 & 1617 & 15531 & 577657 & 23.7 & & & \\
\hline 02 & & & & & RA1 & RA2 & $\mathrm{T}\left({ }^{\circ} \mathrm{C}\right)$ \\
\hline Peak & Location & Amplitude & Area & FWHM & 0.639 & 1.767 & 328.5 \\
\hline D4 & 1206 & 1008 & 207657 & 131.1 & & & \\
\hline $\mathrm{D} 1$ & 1342 & 14441 & 2226010 & 98.1 & & & \\
\hline D3 & 1558 & 2306 & 307687 & 84.9 & & & \\
\hline$G$ & 1601 & 14336 & 746235 & 33.1 & & & \\
\hline D2 & 1618 & 9385 & 323349 & 21.9 & & & \\
\hline 04 & & & & & RA1 & RA2 & $\mathrm{T}\left({ }^{\circ} \mathrm{C}\right)$ \\
\hline Peak & Location & Amplitude & Area & FWHM & 0.604 & 1.526 & 285.4 \\
\hline D4 & 1214 & 673 & 127247 & 120.3 & & & \\
\hline $\mathrm{D} 1$ & 1343 & 13051 & 2118340 & 103.3 & & & \\
\hline D3 & 1548 & 2385 & 374776 & 100.0 & & & \\
\hline$G$ & 1598 & 12089 & 700302 & 36.9 & & & \\
\hline $\mathrm{D} 2$ & 1616 & 10050 & 396650 & 25.1 & & & \\
\hline 07 & & & & & RA1 & RA2 & $\mathrm{T}\left({ }^{\circ} \mathrm{C}\right)$ \\
\hline Peak & Location & Amplitude & Area & FWHM & 0.625 & 1.665 & 311.3 \\
\hline D4 & 1208 & 896 & 208689 & 148.2 & & & \\
\hline $\mathrm{D} 1$ & 1343 & 12376 & 1962130 & 100.9 & & & \\
\hline D3 & 1543 & 1803 & 312525 & 110.4 & & & \\
\hline$G$ & 1600 & 11900 & 690175 & 36.9 & & & \\
\hline
\end{tabular}




\begin{tabular}{|c|c|c|c|c|c|c|c|}
\hline D2 & 1617 & 8169 & 300717 & 23.4 & & & \\
\hline 08 & & & & & RA1 & RA2 & $\mathrm{T}\left({ }^{\circ} \mathrm{C}\right)$ \\
\hline Peak & Location & Amplitude & Area & FWHM & 0.609 & 1.554 & 290.9 \\
\hline D4 & 1208 & 3307 & 737019 & 141.9 & & & \\
\hline $\mathrm{D} 1$ & 1343 & 34060 & 5580420 & 104.3 & & & \\
\hline D3 & 1534 & 5932 & 1238770 & 133.0 & & & \\
\hline G & 1600 & 32735 & 1998150 & 38.9 & & & \\
\hline D2 & 1617 & 21594 & 827585 & 24.4 & & & \\
\hline 09 & & & & & RA1 & RA2 & $\mathrm{T}\left({ }^{\circ} \mathrm{C}\right)$ \\
\hline Peak & Location & Amplitude & Area & FWHM & 0.608 & 1.552 & 290.5 \\
\hline D4 & 1206 & 2966 & 761227 & 163.4 & & & \\
\hline $\mathrm{D} 1$ & 1343 & 30767 & 5273130 & 109.1 & & & \\
\hline D3 & 1527 & 5791 & 1249450 & 137.4 & & & \\
\hline G & 1596 & 24861 & 1722870 & 44.1 & & & \\
\hline $\mathrm{D} 2$ & 1614 & 20552 & 914546 & 28.3 & & & \\
\hline 10 & & & & & RA1 & RA2 & $\mathrm{T}\left({ }^{\circ} \mathrm{C}\right)$ \\
\hline Peak & Location & Amplitude & Area & FWHM & 0.615 & 1.596 & 298.7 \\
\hline D4 & 1208 & 3426 & 810727 & 150.6 & & & \\
\hline D1 & 1343 & 41927 & 6912070 & 105.0 & & & \\
\hline D3 & 1534 & 7026 & 1352120 & 122.5 & & & \\
\hline G & 1600 & 39292 & 2429310 & 39.4 & & & \\
\hline D2 & 1617 & 27631 & 1057740 & 24.4 & & & \\
\hline 11 & & & & & RA1 & RA2 & $\mathrm{T}\left({ }^{\circ} \mathrm{C}\right)$ \\
\hline Peak & Location & Amplitude & Area & FWHM & 0.616 & 1.602 & 299.9 \\
\hline D4 & 1206 & 3042 & 743881 & 155.7 & & & \\
\hline D1 & 1343 & 32168 & 5257670 & 104.1 & & & \\
\hline D3 & 1532 & 5459 & 1087960 & 126.9 & & & \\
\hline$G$ & 1600 & 29881 & 1837860 & 39.2 & & & \\
\hline $\mathrm{D} 2$ & 1616 & 21173 & 820348 & 24.7 & & & \\
\hline 03 & & & & & RA1 & RA2 & $\mathrm{T}\left({ }^{\circ} \mathrm{C}\right)$ \\
\hline Peak & Location & Amplitude & Area & FWHM & 0.600 & 1.499 & 280.1 \\
\hline D4 & 1209 & 3054 & 567460 & 118.3 & & & \\
\hline D1 & 1342 & 48418 & 7809990 & 102.7 & & & \\
\hline D3 & 1539 & 8117 & 1506510 & 118.2 & & & \\
\hline G & 1600 & 48949 & 2935810 & 38.2 & & & \\
\hline $\mathrm{D} 2$ & 1617 & 30969 & 1145720 & 23.6 & & & \\
\hline
\end{tabular}

\begin{tabular}{|c|c|c|c|c|c|c|c|}
\hline 31DF15 & & & & Method: & \multicolumn{3}{|c|}{ Beyssac et al. 2002} \\
\hline & & & & & & $\operatorname{avg} T$ & std dev \\
\hline & & & & \multicolumn{2}{|c|}{ Avg each run } & 347.8 & 11.2 \\
\hline Peak & Location & Amplitude & Area & FWHM & $\mathrm{R} 1$ & R2 & $\mathrm{T}\left({ }^{\circ} \mathrm{C}\right)$ \\
\hline D1 & 1349 & 25291 & 1995610 & 46.9 & 1.849 & 0.704 & 327.8 \\
\hline $\mathrm{G}$ & 1595 & 13682 & 637924 & 13.4 & & & \\
\hline D2 & 1621 & 6890 & 201798 & 0.2 & & & \\
\hline 0 & & & & & & & \\
\hline Peak & Location & Amplitude & Area & FWHM & R1 & R2 & $\mathrm{T}\left({ }^{\circ} \mathrm{C}\right)$ \\
\hline D1 & 1350 & 17327 & 1352670 & 44.1 & 1.749 & 0.656 & 349.0 \\
\hline G & 1595 & 9906 & 605726 & 25.4 & & & \\
\hline D2 & 1620 & 3798 & 103240 & 0.4 & & & \\
\hline
\end{tabular}




\begin{tabular}{|c|c|c|c|c|c|c|c|}
\hline \multicolumn{8}{|l|}{02} \\
\hline Peak & Location & Amplitude & Area & FWHM & R1 & $\mathrm{R} 2$ & $\mathrm{~T}\left({ }^{\circ} \mathrm{C}\right)$ \\
\hline D1 & 1350 & 7291 & 562340 & 47.2 & 1.778 & 0.676 & 340.3 \\
\hline G & 1591 & 4100 & 205401 & 20.2 & & & \\
\hline D2 & 1617 & 2286 & 64573.4 & 0.4 & & & \\
\hline \multicolumn{8}{|l|}{01} \\
\hline Peak & Location & Amplitude & Area & FWHM & R1 & $\mathrm{R} 2$ & $\mathrm{~T}\left({ }^{\circ} \mathrm{C}\right)$ \\
\hline D1 & 1350 & 19975 & 1609340 & 50.4 & 1.807 & 0.681 & 337.8 \\
\hline G & 1596 & 11052 & 612061 & 23.1 & & & \\
\hline D2 & 1621 & 4993 & 140936 & -0.1 & & & \\
\hline \multicolumn{8}{|l|}{03} \\
\hline Peak & Location & Amplitude & Area & FWHM & $\mathrm{R} 1$ & $\mathrm{R} 2$ & $\mathrm{~T}\left({ }^{\circ} \mathrm{C}\right)$ \\
\hline D1 & 1350 & 11655 & 814485 & 41.0 & 1.724 & 0.687 & 335.5 \\
\hline G & 1600 & 6760 & 354365 & 0.0 & & & \\
\hline D2 & 1624 & 1154 & 17423.1 & 5.1 & & & \\
\hline \multicolumn{8}{|l|}{04} \\
\hline Peak & Location & Amplitude & Area & FWHM & R1 & $\mathrm{R} 2$ & $\mathrm{~T}\left({ }^{\circ} \mathrm{C}\right)$ \\
\hline $\mathrm{D} 1$ & 1349 & 5627 & 317465 & 0.4 & 1.541 & 0.626 & 362.4 \\
\hline G & 1600 & 3652 & 173900 & 0.9 & & & \\
\hline D2 & 1622 & 937 & 15753.6 & 5.4 & & & \\
\hline \multicolumn{8}{|l|}{05} \\
\hline Peak & Location & Amplitude & Area & FWHM & R1 & R2 & $\mathrm{T}\left({ }^{\circ} \mathrm{C}\right)$ \\
\hline D1 & 1349 & 4035 & 221897 & -0.1 & 1.638 & 0.642 & 355.4 \\
\hline G & 1594 & 2464 & 95781.9 & 7.9 & & & \\
\hline D2 & 1618 & 1249 & 28112.3 & -0.1 & & & \\
\hline \multicolumn{8}{|l|}{06} \\
\hline Peak & Location & Amplitude & Area & FWHM & R1 & $\mathrm{R} 2$ & $\mathrm{~T}\left({ }^{\circ} \mathrm{C}\right)$ \\
\hline D1 & 1349 & 16707 & 1232490 & 41.8 & 1.750 & 0.694 & 332.3 \\
\hline G & 1599 & 9548 & 510073 & 0.0 & & & \\
\hline $\mathrm{D} 2$ & 1622 & 1745 & 34334 & 8.4 & & & \\
\hline \multicolumn{8}{|l|}{08} \\
\hline Peak & Location & Amplitude & Area & FWHM & $\mathrm{R} 1$ & $\mathrm{R} 2$ & $\mathrm{~T}\left({ }^{\circ} \mathrm{C}\right)$ \\
\hline D1 & 1349 & 4772 & 260389 & -0.2 & 1.581 & 0.633 & 359.4 \\
\hline G & 1601 & 3018 & 140026 & -0.8 & & & \\
\hline D2 & 1622 & 635 & 11077.1 & 6.9 & & & \\
\hline \multicolumn{8}{|l|}{010} \\
\hline Peak & Location & Amplitude & Area & FWHM & R1 & $\mathrm{R} 2$ & $\mathrm{~T}\left({ }^{\circ} \mathrm{C}\right)$ \\
\hline D1 & 1349 & 7865 & 474847 & 7.1 & 1.640 & 0.641 & 355.8 \\
\hline G & 1600 & 4797 & 252268 & -0.1 & & & \\
\hline D2 & 1621 & 774 & 13769.2 & 0.0 & & & \\
\hline \multicolumn{8}{|l|}{011} \\
\hline Peak & Location & Amplitude & Area & FWHM & $\mathrm{R} 1$ & $\mathrm{R} 2$ & $\mathrm{~T}\left({ }^{\circ} \mathrm{C}\right)$ \\
\hline D1 & 1350 & 4742 & 249055 & -0.4 & 1.741 & 0.637 & 357.7 \\
\hline $\mathrm{G}$ & 1600 & 2723 & 131566 & 1.1 & & & \\
\hline D2 & 1622 & 704 & 10533.5 & 6.4 & & & \\
\hline \multicolumn{8}{|l|}{012} \\
\hline Peak & Location & Amplitude & Area & FWHM & R1 & R2 & $\mathrm{T}\left({ }^{\circ} \mathrm{C}\right)$ \\
\hline D1 & 1350 & 3919 & 209867 & 0.0 & 1.902 & 0.663 & 346.0 \\
\hline $\mathrm{G}$ & 1593 & 2060 & 68056.2 & -0.2 & & & \\
\hline D2 & 1619 & 1540 & 38693 & 0.2 & & & \\
\hline 013 & & & & & & & \\
\hline
\end{tabular}




\begin{tabular}{|l|r|r|r|r|r|r|r|} 
Peak & Location & Amplitude & Area & FWHM & R1 & R2 & $\mathrm{T}\left({ }^{\circ} \mathrm{C}\right)$ \\
\hline D1 & 1350 & 4084 & 215816 & 0.0 & 1.638 & 0.645 & 354.2 \\
\hline G & 1597 & 2494 & 94972.6 & -0.2 & & & \\
\hline D2 & 1622 & 1045 & 24026.3 & -0.2 & & & \\
\hline 014 & & & & & & & \\
\hline Peak & Location & Amplitude & Area & FWHM & R1 & R2 & T ( $\left.{ }^{\circ} \mathrm{C}\right)$ \\
\hline D2 & 1350 & 4204 & 225848 & -0.1 & 1.722 & 0.641 & 355.8 \\
\hline G & 1596 & 2441 & 87577 & 9.5 & & & \\
\hline D2 & 1619 & 2760 & 38921.3 & -4.5 & & & \\
\hline
\end{tabular}

\begin{tabular}{|c|c|c|c|c|c|c|c|}
\hline \multirow[t]{2}{*}{ 39DF15 } & \multirow[t]{2}{*}{ Method: } & \multicolumn{2}{|c|}{ Lahfid et al. (2010) } & \multirow{2}{*}{$\begin{array}{l}\text { RA1 } \\
\text { avg T }\end{array}$} & \multirow[b]{2}{*}{ std dev } & \multirow{2}{*}{$\begin{array}{l}\text { RA2 } \\
\operatorname{avg} T\end{array}$} & \multirow[b]{2}{*}{ std dev } \\
\hline & & & & & & & \\
\hline & & \multicolumn{2}{|c|}{ Avg each run } & 318.8 & 31.8 & 322.4 & 41.9 \\
\hline & & \multicolumn{2}{|c|}{ Avg RA1,RA2 } & $\mathrm{T}\left({ }^{\circ} \mathrm{C}\right)$ & 320.6 & std dev & 36.8 \\
\hline & & & & & & & \\
\hline 0 & & & & & RA1 & RA2 & $\mathrm{T}\left({ }^{\circ} \mathrm{C}\right)$ \\
\hline Peak & Location & Amplitude & Area & FWHM & 0.590 & 1.441 & 268.1 \\
\hline D4 & 1328 & 3955 & 359687 & 57.9 & & & \\
\hline D1 & 1355 & 4002 & 256524 & 40.8 & & & \\
\hline D3 & 1593 & 4123 & 138654 & 21.4 & & & \\
\hline G & 1607 & 6650 & 181565 & -17.4 & & & \\
\hline $\mathrm{D} 2$ & 1621 & 4462 & 107445 & 15.3 & & & \\
\hline 3 & & & & & RA1 & RA2 & $\mathrm{T}\left({ }^{\circ} \mathrm{C}\right)$ \\
\hline Peak & Location & Amplitude & Area & FWHM & 0.630 & 1.700 & 317.2 \\
\hline D4 & 1293 & 800 & 142824 & 113.7 & & & \\
\hline D1 & 1346 & 8136 & 811973 & 63.5 & & & \\
\hline D3 & 1593 & 4282 & 255055 & 37.9 & & & \\
\hline G & 1608 & 5828 & 213729 & 23.3 & & & \\
\hline $\mathrm{D} 2$ & 1622 & 3492 & 93003.2 & 17.0 & & & \\
\hline 4 & & & & & RA1 & RA2 & $\mathrm{T}\left({ }^{\circ} \mathrm{C}\right)$ \\
\hline Peak & Location & Amplitude & Area & FWHM & 0.656 & 1.908 & 350.4 \\
\hline D4 & 1237 & 837 & 174828 & 133.0 & & & \\
\hline D1 & 1344 & 8459 & 1159110 & 87.2 & & & \\
\hline D3 & 1578 & 1960 & 170654 & 55.4 & & & \\
\hline $\mathrm{G}$ & 1603 & 8326 & 363565 & 27.8 & & & \\
\hline D2 & 1619 & 5289 & 164909 & 19.8 & & & \\
\hline 5 & & & & & RA1 & RA2 & $\mathrm{T}\left({ }^{\circ} \mathrm{C}\right)$ \\
\hline Peak & Location & Amplitude & Area & FWHM & 0.655 & 1.896 & 348.6 \\
\hline D4 & 1302 & 1768 & 711409 & 256.2 & & & \\
\hline D1 & 1346 & 11580 & 1254650 & 69.0 & & & \\
\hline D3 & 1551 & 1344 & 210742 & 99.9 & & & \\
\hline G & 1601 & 10825 & 594552 & 35.0 & & & \\
\hline $\mathrm{D} 2$ & 1619 & 6727 & 231872 & 21.9 & & & \\
\hline 6 & & & & & RA1 & RA2 & $\mathrm{T}\left({ }^{\circ} \mathrm{C}\right)$ \\
\hline Peak & Location & Amplitude & Area & FWHM & 0.610 & 1.564 & 292.7 \\
\hline D4 & 1334 & 1945 & 154509 & 50.6 & & & \\
\hline $\mathrm{D} 1$ & 1357 & 1391 & 75599.9 & 34.6 & & & \\
\hline D3 & 1596 & 2275 & 80022.3 & 22.4 & & & \\
\hline$G$ & 1611 & 1987 & 44960.7 & 14.4 & & & \\
\hline $\mathrm{D} 2$ & 1622 & 1189 & 22164.7 & -11.9 & & & \\
\hline
\end{tabular}




\begin{tabular}{|c|c|c|c|c|c|c|c|}
\hline 7 & & & & & RA1 & RA2 & $\mathrm{T}\left({ }^{\circ} \mathrm{C}\right)$ \\
\hline Peak & Location & Amplitude & Area & FWHM & 0.595 & 1.467 & 273.6 \\
\hline D4 & 1333 & 1266 & 80913.2 & 40.7 & & & \\
\hline D1 & 1357 & 1305 & 64039.2 & 31.3 & & & \\
\hline D3 & 1589 & 759 & 17319.3 & 14.5 & & & \\
\hline G & 1604 & 1695 & 48829.9 & 18.3 & & & \\
\hline D2 & 1618 & 1253 & 32644.3 & 16.6 & & & \\
\hline 8 & & & & & RA1 & RA2 & $\mathrm{T}\left({ }^{\circ} \mathrm{C}\right)$ \\
\hline Peak & Location & Amplitude & Area & FWHM & 0.633 & 1.728 & 322.0 \\
\hline D4 & 1325 & 2026 & 195361 & 61.4 & & & \\
\hline D1 & 1353 & 3391 & 210162 & 39.5 & & & \\
\hline D3 & 1587 & 1152 & 30324.6 & 16.8 & & & \\
\hline G & 1602 & 2959 & 86987.2 & 18.7 & & & \\
\hline D2 & 1616 & 3174 & 117405 & 23.6 & & & \\
\hline 9 & & & & & RA1 & RA2 & $\mathrm{T}\left({ }^{\circ} \mathrm{C}\right)$ \\
\hline Peak & Location & Amplitude & Area & FWHM & 0.626 & 1.672 & 312.5 \\
\hline D4 & 1221 & 2031 & 482695 & 151.3 & & & \\
\hline D1 & 1342 & 22914 & 3316780 & 92.2 & & & \\
\hline D3 & 1547 & 3119 & 462066 & 94.3 & & & \\
\hline G & 1599 & 22799 & 1234660 & 34.5 & & & \\
\hline D2 & 1616 & 16327 & 575460 & 22.4 & & & \\
\hline 10 & & & & & RA1 & RA2 & $\mathrm{T}\left({ }^{\circ} \mathrm{C}\right)$ \\
\hline Peak & Location & Amplitude & Area & FWHM & 0.674 & 2.066 & 372.6 \\
\hline D4 & 1294 & 1634 & 624682 & 243.3 & & & \\
\hline D1 & 1347 & 13323 & 1328950 & 63.5 & & & \\
\hline D3 & 1564 & 1413 & 158738 & 71.5 & & & \\
\hline G & 1601 & 10854 & 557651 & 32.7 & & & \\
\hline D2 & 1618 & 6885 & 229226 & 21.2 & & & \\
\hline 11 & & & & & RA1 & RA2 & $\mathrm{T}\left({ }^{\circ} \mathrm{C}\right)$ \\
\hline Peak & Location & Amplitude & Area & FWHM & 0.617 & 1.610 & 301.3 \\
\hline D4 & 1331 & 4065 & 463723 & 72.6 & & & \\
\hline D1 & 1354 & 4211 & 326084 & 49.3 & & & \\
\hline D3 & 1595 & 4709 & 219892 & 29.7 & & & \\
\hline G & 1609 & 5701 & 172875 & 19.3 & & & \\
\hline D2 & 1622 & 3889 & 97898.6 & 16.0 & & & \\
\hline 12 & & & & & RA1 & RA2 & $\mathrm{T}\left({ }^{\circ} \mathrm{C}\right)$ \\
\hline Peak & Location & Amplitude & Area & FWHM & 0.652 & 1.872 & 345.0 \\
\hline D4 & 1241 & 3889 & 1572660 & 257.4 & & & \\
\hline D1 & 1346 & 30365 & 3355090 & 70.3 & & & \\
\hline D3 & 1530 & 3257 & 644870 & 126.0 & & & \\
\hline G & 1618 & 15488 & 555796 & 22.8 & & & \\
\hline D2 & 1600 & 24689 & 1431650 & 36.9 & & & \\
\hline 13 & & & & & RA1 & RA2 & $\mathrm{T}\left({ }^{\circ} \mathrm{C}\right)$ \\
\hline Peak & Location & Amplitude & Area & FWHM & 0.634 & 1.729 & 322.2 \\
\hline D4 & 1229 & 1806 & 584681 & 206.1 & & & \\
\hline D1 & 1342 & 15143 & 2386480 & 100.3 & & & \\
\hline D3 & 1532 & 2799 & 496658 & 113.0 & & & \\
\hline G & 1591 & 11494 & 757661 & 42.0 & & & \\
\hline D2 & 1610 & 10545 & 464141 & 28.0 & & & \\
\hline
\end{tabular}




\begin{tabular}{|c|c|c|c|c|c|c|c|}
\hline \multirow[t]{3}{*}{ 41DF15 } & \multirow[t]{2}{*}{ Method: } & \multicolumn{2}{|c|}{ Lahfid et al. (2010) } & \multirow{2}{*}{$\begin{array}{l}\text { RA1 } \\
\operatorname{avg~T}\end{array}$} & \multirow[b]{2}{*}{ std dev } & \multirow{2}{*}{$\begin{array}{l}\text { RA2 } \\
\operatorname{avg~T}\end{array}$} & \multirow[b]{2}{*}{ std dev } \\
\hline & & & & & & & \\
\hline & & \multicolumn{2}{|c|}{ Avg each run } & 316.9 & 22.4 & 318.6 & 28.6 \\
\hline & & \multicolumn{2}{|c|}{ Avg RA1,RA2 } & $\mathrm{T}\left({ }^{\circ} \mathrm{C}\right)$ & 317.8 & std dev & 25.5 \\
\hline & & & & & & & \\
\hline 0 & & & & & RA1 & RA2 & $\mathrm{T}\left({ }^{\circ} \mathrm{C}\right)$ \\
\hline Peak & Location & Amplitude & Area & FWHM & 0.636 & 1.748 & 325.4 \\
\hline D4 & 1235 & 4404 & 1734790 & 250.8 & & & \\
\hline $\mathrm{D} 1$ & 1345 & 34465 & 4073680 & 75.2 & & & \\
\hline D3 & 1527 & 4376 & 912365 & 132.7 & & & \\
\hline G & 1601 & 32105 & 1844230 & 36.6 & & & \\
\hline D2 & 1618 & 16968 & 565906 & 21.2 & & & \\
\hline 01 & & & & & RA1 & RA2 & $\mathrm{T}\left({ }^{\circ} \mathrm{C}\right)$ \\
\hline Peak & Location & Amplitude & Area & FWHM & 0.620 & 1.630 & 305.0 \\
\hline D4 & 1219 & 4414 & 1372220 & 197.9 & & & \\
\hline D1 & 1344 & 39482 & 4793710 & 77.3 & & & \\
\hline D3 & 1528 & 5076 & 1115800 & 139.9 & & & \\
\hline$G$ & 1602 & 36294 & 2052560 & 36.0 & & & \\
\hline $\mathrm{D} 2$ & 1618 & 18783 & 614606 & 20.8 & & & \\
\hline 02 & & & & & RA1 & RA2 & $\mathrm{T}\left({ }^{\circ} \mathrm{C}\right)$ \\
\hline Peak & Location & Amplitude & Area & FWHM & 0.619 & 1.621 & 303.4 \\
\hline D4 & 1219 & 5918 & 1836900 & 197.6 & & & \\
\hline $\mathrm{D} 1$ & 1344 & 51085 & 6441000 & 80.3 & & & \\
\hline D3 & 1525 & 7022 & 1550910 & 140.6 & & & \\
\hline $\mathrm{G}$ & 1601 & 47393 & 2724780 & 36.6 & & & \\
\hline $\mathrm{D} 2$ & 1618 & 24680 & 829796 & 21.4 & & & \\
\hline 04 & & & & & RA1 & RA2 & $\mathrm{T}\left({ }^{\circ} \mathrm{C}\right)$ \\
\hline Peak & Location & Amplitude & Area & FWHM & 0.596 & 1.477 & 275.6 \\
\hline D4 & 1346 & 48337 & 3292080 & 43.4 & & & \\
\hline $\mathrm{D} 1$ & 1327 & 5451 & 419227 & 49.0 & & & \\
\hline D3 & 1583 & 23200 & 1444480 & 39.6 & & & \\
\hline$G$ & 1616 & 15601 & 419745 & 17.1 & & & \\
\hline D2 & 1600 & 17659 & 648810 & 23.4 & & & \\
\hline 11 & & & & & RA1 & RA2 & $\mathrm{T}\left({ }^{\circ} \mathrm{C}\right)$ \\
\hline Peak & Location & Amplitude & Area & FWHM & 0.649 & 1.851 & 341.8 \\
\hline D4 & 1355 & 6780 & 345965 & 32.5 & & & \\
\hline $\mathrm{D} 1$ & 1342 & 8694 & 579526 & 42.4 & & & \\
\hline D3 & 1590 & 5594 & 265696 & 30.2 & & & \\
\hline$G$ & 1621 & 3906 & 96276.7 & 15.7 & & & \\
\hline $\mathrm{D} 2$ & 1605 & 4077 & 137988 & 21.5 & & & \\
\hline 12 & & & & & RA1 & RA2 & $\mathrm{T}\left({ }^{\circ} \mathrm{C}\right)$ \\
\hline Peak & Location & Amplitude & Area & FWHM & 0.643 & 1.799 & 333.6 \\
\hline D4 & 1341 & 6017 & 369534 & 39.1 & & & \\
\hline D1 & 1356 & 5784 & 284937 & 31.4 & & & \\
\hline D3 & 1606 & 3589 & 111012 & 19.7 & & & \\
\hline$G$ & 1590 & 4315 & 178627 & 26.4 & & & \\
\hline D2 & 1621 & 3225 & 74196 & 14.6 & & & \\
\hline 13 & & & & & RA1 & RA2 & $\mathrm{T}\left({ }^{\circ} \mathrm{C}\right)$ \\
\hline Peak & Location & Amplitude & Area & FWHM & 0.640 & 1.781 & 330.7 \\
\hline D4 & 1353 & 8094 & 472662 & 37.2 & & & \\
\hline D1 & 1340 & 4616 & 331640 & 45.7 & & & \\
\hline
\end{tabular}




\begin{tabular}{|c|c|c|c|c|c|c|c|}
\hline D3 & 1593 & 5621 & 283994 & 32.2 & & & \\
\hline G & 1623 & 3109 & 67360.4 & 13.8 & & & \\
\hline D2 & 1609 & 3245 & 100300 & 19.7 & & & \\
\hline 14 & & & & & RA1 & RA2 & $\mathrm{T}\left({ }^{\circ} \mathrm{C}\right)$ \\
\hline Peak & Location & Amplitude & Area & FWHM & 0.608 & 1.551 & 290.3 \\
\hline D4 & 1231 & 2013 & 506899 & 160.3 & & & \\
\hline D1 & 1342 & 13594 & 1974060 & 92.4 & & & \\
\hline D3 & 1602 & 16764 & 918631 & 34.9 & & & \\
\hline G & 1525 & 2029 & 426721 & 133.9 & & & \\
\hline D2 & 1617 & 7787 & 254030 & 20.8 & & & \\
\hline 15 & & & & & RA1 & RA2 & $\mathrm{T}\left({ }^{\circ} \mathrm{C}\right)$ \\
\hline Peak & Location & Amplitude & Area & FWHM & 0.616 & 1.604 & 300.3 \\
\hline D4 & 1233 & 1196 & 301476 & 160.5 & & & \\
\hline $\mathrm{D} 1$ & 1342 & 7958 & 1131870 & 90.6 & & & \\
\hline D3 & 1602 & 8896 & 485961 & 34.8 & & & \\
\hline G & 1524 & 1101 & 213250 & 123.3 & & & \\
\hline D2 & 1616 & 5441 & 194234 & 22.7 & & & \\
\hline 16 & & & & & RA1 & RA2 & $\mathrm{T}\left({ }^{\circ} \mathrm{C}\right)$ \\
\hline Peak & Location & Amplitude & Area & FWHM & 0.608 & 1.553 & 290.7 \\
\hline D4 & 1342 & 12219 & 1788970 & 93.2 & & & \\
\hline D1 & 1231 & 1887 & 466029 & 157.2 & & & \\
\hline D3 & 1521 & 1782 & 366246 & 130.9 & & & \\
\hline G & 1616 & 9072 & 328660 & 23.1 & & & \\
\hline D2 & 1601 & 13701 & 756701 & 35.2 & & & \\
\hline 18 & & & & & RA1 & RA2 & $\mathrm{T}\left({ }^{\circ} \mathrm{C}\right)$ \\
\hline Peak & Location & Amplitude & Area & FWHM & 0.631 & 1.713 & 319.4 \\
\hline D4 & 1316 & 791 & 100575 & 80.9 & & & \\
\hline D1 & 1349 & 3803 & 321533 & 53.8 & & & \\
\hline D3 & 1607 & 2905 & 91450.3 & 20.0 & & & \\
\hline G & 1593 & 2181 & 100573 & 29.4 & & & \\
\hline D2 & 1621 & 2117 & 54454.1 & 16.4 & & & \\
\hline 110 & & & & & RA1 & RA2 & $\mathrm{T}\left({ }^{\circ} \mathrm{C}\right)$ \\
\hline Peak & Location & Amplitude & Area & FWHM & 0.648 & 1.844 & 340.8 \\
\hline D4 & 1341 & 9848 & 595794 & 38.5 & & & \\
\hline $\mathrm{D} 1$ & 1357 & 6860 & 334890 & 31.1 & & & \\
\hline D3 & 1605 & 4971 & 153214 & 19.6 & & & \\
\hline G & 1588 & 5979 & 232831 & 24.8 & & & \\
\hline D2 & 1621 & 4928 & 118624 & 15.3 & & & \\
\hline 111 & & & & & RA1 & RA2 & $\mathrm{T}\left({ }^{\circ} \mathrm{C}\right)$ \\
\hline Peak & Location & Amplitude & Area & FWHM & 0.648 & 1.840 & 340.1 \\
\hline D4 & 1340 & 10276 & 768695 & 47.6 & & & \\
\hline D1 & 1353 & 10624 & 606275 & 36.3 & & & \\
\hline D3 & 1606 & 5769 & 180916 & 20.0 & & & \\
\hline$G$ & 1590 & 8605 & 408027 & 30.2 & & & \\
\hline D2 & 1621 & 6389 & 158298 & 15.8 & & & \\
\hline 112 & & & & & RA1 & RA2 & $\mathrm{T}\left({ }^{\circ} \mathrm{C}\right)$ \\
\hline Peak & Location & Amplitude & Area & FWHM & 0.648 & 1.840 & 340.1 \\
\hline D4 & 1341 & 10771 & 739251 & 43.7 & & & \\
\hline D1 & 1354 & 8775 & 494696 & 35.9 & & & \\
\hline D3 & 1606 & 5134 & 157536 & 19.5 & & & \\
\hline G & 1589 & 7884 & 373059 & 30.1 & & & \\
\hline
\end{tabular}


D2 1621 \begin{tabular}{l|l}
5757 & 140088
\end{tabular} 15.5

\begin{tabular}{|c|c|c|c|c|c|c|c|}
\hline \multirow[t]{2}{*}{ 43DF15 } & \multirow[t]{2}{*}{ Method: } & \multicolumn{2}{|c|}{ Lahfid et al. (2010) } & \multirow{2}{*}{$\begin{array}{l}\text { RA1 } \\
\operatorname{avg} T\end{array}$} & \multirow{2}{*}{ std dev } & \multirow{2}{*}{$\begin{array}{l}\text { RA2 } \\
\operatorname{avg} T\end{array}$} & \multirow[b]{2}{*}{ std dev } \\
\hline & & & & & & & \\
\hline & & \multicolumn{2}{|c|}{ Avg each run } & 296.8 & 29.1 & 294.2 & 35.4 \\
\hline & & \multicolumn{2}{|c|}{ Avg RA1,RA2 } & $\mathrm{T}\left({ }^{\circ} \mathrm{C}\right)$ & 295.5 & std dev & 32.3 \\
\hline & & & & & & & \\
\hline 44 & & & & & RA1 & RA2 & $\mathrm{T}\left({ }^{\circ} \mathrm{C}\right)$ \\
\hline Peak & Location & Amplitude & Area & FWHM & 0.649 & 1.852 & 341.9 \\
\hline D4 & 1244 & 1551 & 392648 & 161.2 & & & \\
\hline $\mathrm{D} 1$ & 1340 & 20328 & 2578360 & 80.7 & & & \\
\hline D3 & 1590 & 10727 & 582759 & 34.6 & & & \\
\hline G & 1605 & 18706 & 621291 & 21.1 & & & \\
\hline D2 & 1619 & 14181 & 400339 & 18.0 & & & \\
\hline 11 & & & & & RA1 & RA2 & $\mathrm{T}\left({ }^{\circ} \mathrm{C}\right)$ \\
\hline Peak & Location & Amplitude & Area & FWHM & 0.621 & 1.638 & 306.4 \\
\hline D4 & 1255 & 811 & 132189 & 103.7 & & & \\
\hline D1 & 1344 & 12340 & 1873990 & 96.7 & & & \\
\hline D3 & 1572 & 4323 & 411402 & 60.6 & & & \\
\hline G & 1599 & 11806 & 551738 & 29.8 & & & \\
\hline $\mathrm{D} 2$ & 1616 & 8022 & 261684 & 20.8 & & & \\
\hline 12 & & & & & RA1 & RA2 & $\mathrm{T}\left({ }^{\circ} \mathrm{C}\right)$ \\
\hline Peak & Location & Amplitude & Area & FWHM & 0.647 & 1.830 & 338.6 \\
\hline D4 & 1264 & 1441 & 522366 & 230.7 & & & \\
\hline D1 & 1343 & 14379 & 1941730 & 86.0 & & & \\
\hline D3 & 1571 & 3154 & 330242 & 66.7 & & & \\
\hline G & 1599 & 14034 & 704663 & 32.0 & & & \\
\hline $\mathrm{D} 2$ & 1616 & 9019 & 311608 & 22.0 & & & \\
\hline 13 & & & & & RA1 & RA2 & $\mathrm{T}\left({ }^{\circ} \mathrm{C}\right)$ \\
\hline Peak & Location & Amplitude & Area & FWHM & 0.608 & 1.554 & 290.7 \\
\hline D4 & 1326 & 6133 & 726776 & 75.4 & & & \\
\hline D1 & 1354 & 7940 & 685902 & 55.0 & & & \\
\hline D3 & 1587 & 5732 & 280492 & 31.2 & & & \\
\hline G & 1603 & 10321 & 360396 & 22.2 & & & \\
\hline $\mathrm{D} 2$ & 1618 & 8649 & 268406 & 19.8 & & & \\
\hline 14 & & & & & RA1 & RA2 & $\mathrm{T}\left({ }^{\circ} \mathrm{C}\right)$ \\
\hline Peak & Location & Amplitude & Area & FWHM & 0.605 & 1.529 & 286.0 \\
\hline D4 & 1330 & 10561 & 1195050 & 72.0 & & & \\
\hline D1 & 1357 & 8202 & 642985 & 49.9 & & & \\
\hline D3 & 1589 & 9256 & 446672 & 30.7 & & & \\
\hline G & 1605 & 14291 & 470138 & 20.9 & & & \\
\hline $\mathrm{D} 2$ & 1619 & 10150 & 285370 & 17.9 & & & \\
\hline 111 & & & & & RA1 & RA2 & $\mathrm{T}\left({ }^{\circ} \mathrm{C}\right)$ \\
\hline Peak & Location & Amplitude & Area & FWHM & 0.579 & 1.378 & 254.5 \\
\hline D4 & 1358 & 6399 & 364900 & 36.3 & & & \\
\hline $\mathrm{D} 1$ & 1329 & 6735 & 515424 & 48.7 & & & \\
\hline D3 & 1591 & 6504 & 206927 & 20.3 & & & \\
\hline G & 1619 & 7533 & 185633 & 15.7 & & & \\
\hline $\mathrm{D} 2$ & 1605 & 9381 & 246403 & 16.7 & & & \\
\hline 17 & & & & & RA1 & RA2 & $\mathrm{T}\left({ }^{\circ} \mathrm{C}\right)$ \\
\hline
\end{tabular}




\begin{tabular}{|l|r|r|r|r|r|r|r|}
\hline Peak & Location & Amplitude & \multicolumn{1}{l|}{ Area } & FWHM & 0.591 & 1.444 & 268.8 \\
\hline D4 & 1357 & 4651 & 301066 & 41.2 & & & \\
\hline D1 & 1326 & 5091 & 478464 & 59.8 & & & \\
\hline D3 & 1590 & 5779 & 187844 & 20.7 & & & \\
\hline G & 1606 & 8275 & 229225 & 17.6 & & & \\
\hline D2 & 1618 & 5545 & 122744 & 14.1 & & & \\
\hline 110 & & & & & RA1 & RA2 & T $\left({ }^{\circ} \mathrm{C}\right)$ \\
\hline Peak & Location & Amplitude & Area & FWHM & 0.592 & 1.451 & 270.2 \\
\hline D4 & 1357 & 7501 & 526682 & 44.7 & & & \\
\hline D1 & 1328 & 8338 & 826776 & 63.1 & & & \\
\hline D3 & 1582 & 4404 & 168558 & 24.4 & & & \\
\hline G & 1617 & 9574 & 306631 & 20.4 & & & \\
\hline D2 & 1601 & 12132 & 457617 & 24.0 & & & \\
\hline 4 & & & & & RA1 & RA2 & T $\left({ }^{\circ} \mathrm{C}\right)$ \\
\hline Peak & Location & Amplitude & Area & FWHM & 0.612 & 1.578 & 295.3 \\
\hline D4 & 1330 & 17038 & 1950500 & 72.9 & & & \\
\hline D1 & 1359 & 10547 & 800837 & 48.3 & & & \\
\hline D3 & 1588 & 12538 & 576796 & 29.3 & & & \\
\hline G & 1604 & 22316 & 705639 & 20.1 & & & \\
\hline D2 & 1619 & 17062 & 461603 & 17.2 & & & \\
\hline & & & & & RA1 & RA2 & T $\left({ }^{\circ} \mathrm{C}\right)$ \\
\hline Peak & Location & Amplitude & Area & FWHM & 0.628 & 1.689 & 315.3 \\
\hline D4 & 1303 & 1469 & 219935 & 95.3 & & & \\
\hline D1 & 1345 & 9591 & 1006780 & 66.8 & & & \\
\hline D3 & 1589 & 5840 & 271321 & 29.6 & & & \\
\hline G & 1605 & 8855 & 280366 & 20.2 & & & \\
\hline D2 & 1619 & 6664 & 174794 & 16.7 & & & \\
\hline
\end{tabular}

\begin{tabular}{|c|c|c|c|c|c|c|c|}
\hline \multirow[t]{2}{*}{ 44DF15 } & \multirow[t]{2}{*}{ Method: } & \multicolumn{2}{|c|}{ Lahfid et al. (2010) } & \multirow{2}{*}{$\begin{array}{l}\text { RA1 } \\
\operatorname{avg~T}\end{array}$} & \multirow{2}{*}{ std dev } & \multirow{2}{*}{$\begin{array}{l}\text { RA2 } \\
\operatorname{avg~T~}\end{array}$} & \multirow[b]{2}{*}{ std dev } \\
\hline & & & & & & & \\
\hline & & Avg each ru & & 309.7 & 28.0 & 309.9 & 33.8 \\
\hline & & Avg RA1,RA & & $\mathrm{T}\left({ }^{\circ} \mathrm{C}\right)$ & 309.8 & std dev & 30.9 \\
\hline & & & & & & & \\
\hline 2 & & & & & RA1 & RA2 & $\mathrm{T}\left({ }^{\circ} \mathrm{C}\right)$ \\
\hline Peak & Location & Amplitude & Area & FWHM & 0.602 & 1.512 & 282.7 \\
\hline D4 & 1229 & 164 & 44904 & 174.7 & & & \\
\hline $\mathrm{D} 1$ & 1345 & 1996 & 351916 & 112.3 & & & \\
\hline D3 & 1534 & 378 & 80198.6 & 135.0 & & & \\
\hline G & 1601 & 2183 & 142098 & 41.4 & & & \\
\hline D2 & 1618 & 1120 & 40092.1 & 22.8 & & & \\
\hline 3 & & & & & RA1 & RA2 & $\mathrm{T}\left({ }^{\circ} \mathrm{C}\right)$ \\
\hline Peak & Location & Amplitude & Area & FWHM & 0.639 & 1.769 & 328.8 \\
\hline D4 & 1264 & 305 & 31805.3 & 66.4 & & & \\
\hline $\mathrm{D} 1$ & 1353 & 2856 & 516068 & 115.0 & & & \\
\hline D3 & 1574 & 1438 & 128281 & 56.8 & & & \\
\hline G & 1599 & 1997 & 96418.3 & 30.7 & & & \\
\hline D2 & 1617 & 2106 & 85066 & 25.7 & & & \\
\hline 7 & & & & & RA1 & RA2 & $\mathrm{T}\left({ }^{\circ} \mathrm{C}\right)$ \\
\hline Peak & Location & Amplitude & Area & FWHM & 0.611 & 1.568 & 293.6 \\
\hline D4 & 1252 & 73 & 603.59 & 5.3 & & & \\
\hline
\end{tabular}




\begin{tabular}{|c|c|c|c|c|c|c|c|}
\hline D1 & 1348 & 1158 & 236744 & 130.1 & & & \\
\hline D3 & 1569 & 519 & 68415.9 & 83.9 & & & \\
\hline G & 1600 & 1040 & 54339 & 33.3 & & & \\
\hline D2 & 1618 & 782 & 28571.5 & 23.3 & & & \\
\hline 20 & & & & & RA1 & RA2 & $\mathrm{T}\left({ }^{\circ} \mathrm{C}\right)$ \\
\hline Peak & Location & Amplitude & Area & FWHM & 0.643 & 1.799 & 333.7 \\
\hline D4 & 1344 & 2715 & 335364 & 78.6 & & & \\
\hline D1 & 1237 & 159 & 46169.2 & 185.3 & & & \\
\hline D3 & 1575 & 459 & 35887.4 & 49.8 & & & \\
\hline G & 1601 & 2501 & 113490 & 28.9 & & & \\
\hline D2 & 1618 & 1822 & 62645.1 & 21.9 & & & \\
\hline 19 & & & & & RA1 & RA2 & $\mathrm{T}\left({ }^{\circ} \mathrm{C}\right)$ \\
\hline Peak & Location & Amplitude & Area & FWHM & 0.640 & 1.776 & 329.9 \\
\hline D4 & 1344 & 2424 & 295906 & 77.7 & & & \\
\hline D1 & 1265 & 161 & 43129.8 & 170.1 & & & \\
\hline D3 & 1576 & 450 & 26172.6 & 37.0 & & & \\
\hline G & 1600 & 2184 & 94062.6 & 27.4 & & & \\
\hline D2 & 1616 & 2028 & 70672.5 & 22.2 & & & \\
\hline 21 & & & & & RA1 & RA2 & $\mathrm{T}\left({ }^{\circ} \mathrm{C}\right)$ \\
\hline Peak & Location & Amplitude & Area & FWHM & 0.640 & 1.774 & 329.7 \\
\hline D4 & 1235 & 270 & 76318.3 & 180.0 & & & \\
\hline D1 & 1344 & 3798 & 512236 & 85.9 & & & \\
\hline D3 & 1570 & 697 & 71174.3 & 65.1 & & & \\
\hline G & 1601 & 3619 & 170589 & 30.0 & & & \\
\hline D2 & 1618 & 2593 & 89949.5 & 22.1 & & & \\
\hline 22 & & & & & RA1 & RA2 & $\mathrm{T}\left({ }^{\circ} \mathrm{C}\right)$ \\
\hline Peak & Location & Amplitude & Area & FWHM & 0.633 & 1.721 & 320.9 \\
\hline D4 & 1217 & 269 & 52445.6 & 124.1 & & & \\
\hline D1 & 1344 & 3566 & 504242 & 90.0 & & & \\
\hline D3 & 1558 & 517 & 67816.5 & 83.4 & & & \\
\hline G & 1601 & 3514 & 178464 & 32.3 & & & \\
\hline D2 & 1618 & 2230 & 77114.2 & 22.0 & & & \\
\hline 16 & & & & & RA1 & RA2 & $\mathrm{T}\left({ }^{\circ} \mathrm{C}\right)$ \\
\hline Peak & Location & Amplitude & Area & FWHM & 0.582 & 1.395 & 258.3 \\
\hline D4 & 1323 & 862 & 77308.5 & 57.1 & & & \\
\hline D1 & 1355 & 1097 & 73576.5 & 42.7 & & & \\
\hline D3 & 1594 & 1257 & 43245 & 21.9 & & & \\
\hline G & 1609 & 1719 & 42842.4 & 15.9 & & & \\
\hline D2 & 1621 & 1001 & 22068.8 & 14.0 & & & \\
\hline
\end{tabular}

\begin{tabular}{|c|c|c|c|c|c|c|c|}
\hline \multirow[t]{2}{*}{ 46DF15 } & \multirow[t]{2}{*}{ Method: } & \multicolumn{2}{|c|}{ Lahfid et al. (2010) } & \multirow{2}{*}{$\frac{\text { RA1 }}{\operatorname{avg~T}}$} & \multirow{2}{*}{ std dev } & \multirow{2}{*}{$\begin{array}{l}\text { RA2 } \\
\text { avg T }\end{array}$} & \multirow[b]{2}{*}{ std dev } \\
\hline & & & & & & & \\
\hline & & \multicolumn{2}{|c|}{ Avg each run } & 298.4 & 21.8 & 295.3 & 25.8 \\
\hline & & \multicolumn{2}{|c|}{ Avg RA1,RA2 } & $\mathrm{T}\left({ }^{\circ} \mathrm{C}\right)$ & 296.8 & std dev & 23.8 \\
\hline & & & & & & & \\
\hline 18 & & & & & RA1 & RA2 & $\mathrm{T}\left({ }^{\circ} \mathrm{C}\right)$ \\
\hline Peak & Location & Amplitude & Area & FWHM & 0.629 & 1.692 & 315.9 \\
\hline D4 & 1263 & 1186 & 204065 & 109.5 & & & \\
\hline D1 & 1344 & 13589 & 1739350 & 81.5 & & & \\
\hline D3 & 1586 & 6420 & 414938 & 41.1 & & & \\
\hline
\end{tabular}




\begin{tabular}{|c|c|c|c|c|c|c|c|}
\hline G & 1604 & 12920 & 486921 & 24.0 & & & \\
\hline D2 & 1619 & 8400 & 246666 & 18.7 & & & \\
\hline 52 & & & & & RA1 & RA2 & $\mathrm{T}\left({ }^{\circ} \mathrm{C}\right)$ \\
\hline Peak & Location & Amplitude & Area & FWHM & 0.628 & 1.690 & 315.6 \\
\hline D4 & 1265 & 736 & 47729.3 & 41.3 & & & \\
\hline D1 & 1346 & 13269 & 2187760 & 105.0 & & & \\
\hline D3 & 1579 & 6677 & 520304 & 49.6 & & & \\
\hline $\mathrm{G}$ & 1602 & 12565 & 526996 & 26.7 & & & \\
\hline D2 & 1618 & 8933 & 275446 & 19.6 & & & \\
\hline 14 & & & & & RA1 & RA2 & $\mathrm{T}\left({ }^{\circ} \mathrm{C}\right)$ \\
\hline Peak & Location & Amplitude & Area & FWHM & 0.640 & 1.780 & 330.5 \\
\hline D4 & 1256 & 1386 & 276632 & 127.0 & & & \\
\hline D1 & 1343 & 17035 & 2376870 & 88.8 & & & \\
\hline D3 & 1576 & 5003 & 379248 & 48.3 & & & \\
\hline$G$ & 1600 & 16354 & 706272 & 27.5 & & & \\
\hline D2 & 1617 & 11783 & 405608 & 21.9 & & & \\
\hline 15 & & & & & RA1 & RA2 & $\mathrm{T}\left({ }^{\circ} \mathrm{C}\right)$ \\
\hline Peak & Location & Amplitude & Area & FWHM & 0.614 & 1.593 & 298.3 \\
\hline D4 & 1244 & 2737 & 833223 & 193.8 & & & \\
\hline D1 & 1342 & 20999 & 2979520 & 90.3 & & & \\
\hline D3 & 1531 & 3169 & 616330 & 123.8 & & & \\
\hline G & 1595 & 20049 & 1248960 & 39.7 & & & \\
\hline D2 & 1613 & 13398 & 527581 & 25.1 & & & \\
\hline 16 & & & & & RA1 & RA2 & $\mathrm{T}\left({ }^{\circ} \mathrm{C}\right)$ \\
\hline Peak & Location & Amplitude & Area & FWHM & 0.582 & 1.391 & 257.4 \\
\hline D4 & 1330 & 6978 & 681706 & 62.2 & & & \\
\hline D1 & 1359 & 5200 & 324202 & 39.7 & & & \\
\hline D3 & 1591 & 7287 & 295832 & 25.8 & & & \\
\hline G & 1606 & 9612 & 272137 & 18.0 & & & \\
\hline D2 & 1620 & 6865 & 155348 & 14.4 & & & \\
\hline 112 & & & & & RA1 & RA2 & $\mathrm{T}\left({ }^{\circ} \mathrm{C}\right)$ \\
\hline Peak & Location & Amplitude & Area & FWHM & 0.611 & 1.573 & 294.5 \\
\hline D4 & 1232 & 534 & 164004 & 195.5 & & & \\
\hline D1 & 1343 & 4993 & 730680 & 93.2 & & & \\
\hline D3 & 1529 & 752 & 152772 & 129.3 & & & \\
\hline G & 1617 & 2739 & 93780.1 & 21.8 & & & \\
\hline D2 & 1601 & 5439 & 322092 & 37.7 & & & \\
\hline 4 & & & & & RA1 & RA2 & $\mathrm{T}\left({ }^{\circ} \mathrm{C}\right)$ \\
\hline Peak & Location & Amplitude & Area & FWHM & 0.600 & 1.501 & 280.5 \\
\hline D4 & 1292 & 580 & 75213.6 & 82.6 & & & \\
\hline D1 & 1344 & 4628 & 394000 & 54.2 & & & \\
\hline D3 & 1590 & 2556 & 92826.9 & 23.1 & & & \\
\hline G & 1605 & 4903 & 143164 & 18.6 & & & \\
\hline D2 & 1619 & 3187 & 76508.2 & 15.3 & & & \\
\hline 5 & & & & & RA1 & RA2 & $\mathrm{T}\left({ }^{\circ} \mathrm{C}\right)$ \\
\hline Peak & Location & Amplitude & Area & FWHM & 0.606 & 1.536 & 287.4 \\
\hline D4 & 1256 & 1139 & 505802 & 282.6 & & & \\
\hline D1 & 1349 & 11978 & 2505880 & 133.2 & & & \\
\hline D3 & 1523 & 2920 & 715946 & 156.1 & & & \\
\hline G & 1593 & 9048 & 772098 & 54.3 & & & \\
\hline D2 & 1614 & 9014 & 472239 & 33.4 & & & \\
\hline
\end{tabular}




\begin{tabular}{|l|r|r|r|r|r|r|r|}
51 & & & & RA1 & RA2 & T $\left({ }^{\circ} \mathrm{C}\right)$ \\
\hline Peak & Location & Amplitude & Area & FWHM & 0.620 & 1.632 & 305.3 \\
\hline D4 & 1253 & 978 & 107707 & 70.1 & & & \\
\hline D1 & 1348 & 22993 & 4846350 & 134.2 & & & \\
\hline D3 & 1532 & 4231 & 804664 & 121.1 & & & \\
\hline G & 1592 & 18176 & 1347910 & 47.2 & & & \\
\hline D2 & 1614 & 18886 & 883270 & 29.8 & & & \\
\hline
\end{tabular}

\begin{tabular}{|c|c|c|c|c|c|c|c|}
\hline \multirow[t]{2}{*}{ 15JT01 } & & & & Method: & \multicolumn{3}{|c|}{ Beyssac et al. 2002} \\
\hline & & & & & & $\operatorname{avg} T$ & std dev \\
\hline & & & & \multicolumn{2}{|c|}{ Avg each run } & 374.3 & 15.7 \\
\hline Peak & Location & Amplitude & Area & FWHM & R1 & R2 & $\mathrm{T}\left({ }^{\circ} \mathrm{C}\right)$ \\
\hline $\mathrm{D} 1$ & 1352 & 9934 & 535240 & 15.8 & 1.380 & 0.604 & 372.3 \\
\hline G & 1588 & 7200 & 300074 & -0.3 & & & \\
\hline $\mathrm{D} 2$ & 1624 & 2348 & 51157.6 & -1.2 & & & \\
\hline \multicolumn{8}{|l|}{01} \\
\hline Peak & Location & Amplitude & Area & FWHM & R1 & $\mathrm{R} 2$ & $\mathrm{~T}\left({ }^{\circ} \mathrm{C}\right)$ \\
\hline D1 & 1350 & 11825 & 602126 & 0.2 & 0.000 & 0.536 & 402.4 \\
\hline G & 1587 & \#\#\#\#\#\#\#\# & 429991 & -28.7 & & & \\
\hline D2 & 1615 & 2992 & 91054.9 & 14.5 & & & \\
\hline \multicolumn{8}{|l|}{02} \\
\hline Peak & Location & Amplitude & Area & FWHM & $\mathrm{R} 1$ & R2 & $\mathrm{T}\left({ }^{\circ} \mathrm{C}\right)$ \\
\hline D1 & 1353 & 3563 & 177831 & 10.1 & 1.625 & 0.626 & 362.3 \\
\hline G & 1588 & 2193 & 81001.1 & -0.2 & & & \\
\hline D2 & 1621 & 937 & 25154.7 & -0.3 & & & \\
\hline \multicolumn{8}{|l|}{04} \\
\hline Peak & Location & Amplitude & Area & FWHM & $\mathrm{R} 1$ & R2 & $\mathrm{T}\left({ }^{\circ} \mathrm{C}\right)$ \\
\hline D1 & 1352 & 2813 & 116907 & -0.5 & 1.734 & 0.620 & 365.1 \\
\hline $\mathrm{G}$ & 1589 & 1623 & 54632.9 & 1.1 & & & \\
\hline $\mathrm{D} 2$ & 1620 & 750 & 16996.7 & 2.7 & & & \\
\hline \multicolumn{8}{|l|}{05} \\
\hline Peak & Location & Amplitude & Area & FWHM & $\mathrm{R} 1$ & R2 & $\mathrm{T}\left({ }^{\circ} \mathrm{C}\right)$ \\
\hline D1 & 1352 & 3956 & 216717 & 16.6 & 1.566 & 0.635 & 358.3 \\
\hline G & 1588 & 2525 & 92892.6 & -0.2 & & & \\
\hline D2 & 1621 & 1136 & 31504.8 & -0.3 & & & \\
\hline \multicolumn{8}{|l|}{010} \\
\hline Peak & Location & Amplitude & Area & FWHM & R1 & $\mathrm{R} 2$ & $\mathrm{~T}\left({ }^{\circ} \mathrm{C}\right)$ \\
\hline D1 & 1351 & 9823 & 513870 & 13.9 & 1.118 & 0.574 & 385.5 \\
\hline G & 1586 & 8787 & 322736 & -2.2 & & & \\
\hline D2 & 1622 & 2530 & 58333.8 & -1.0 & & & \\
\hline \multicolumn{8}{|l|}{011} \\
\hline Peak & Location & Amplitude & Area & FWHM & R1 & R2 & $\mathrm{T}\left({ }^{\circ} \mathrm{C}\right)$ \\
\hline D1 & 1348 & 4288 & 400651 & 58.7 & 0.572 & 0.611 & 369.0 \\
\hline$G$ & 1587 & 7495 & 236074 & -18.2 & & & \\
\hline $\mathrm{D} 2$ & 1621 & 709 & 18814.9 & -0.1 & & & \\
\hline \multicolumn{8}{|l|}{014} \\
\hline Peak & Location & Amplitude & Area & FWHM & R1 & R2 & $\mathrm{T}\left({ }^{\circ} \mathrm{C}\right)$ \\
\hline D1 & 1351 & 16157 & 1003070 & 31.0 & 1.262 & 0.638 & 357.0 \\
\hline G & 1586 & 12807 & 651129 & 22.1 & & & \\
\hline
\end{tabular}




\begin{tabular}{|l|r|r|r|r|r|r|r|} 
D2 & 1620 & 3215 & -82334 & 0.0 & & & \\
\hline 013 & & & & & & & \\
\hline Peak & Location & Amplitude & Area & FWHM & R1 & R2 & T $\left({ }^{\circ} \mathrm{C}\right)$ \\
\hline D1 & 1351 & 10908 & 804164 & 46.7 & 1.149 & 0.599 & 374.5 \\
\hline G & 1585 & 9497 & 595923 & 35.2 & & & \\
\hline D2 & 1619 & 2454 & -57527 & 0.3 & & & \\
\hline 012 & & & & & & & \\
\hline Peak & Location & Amplitude & Area & FWHM & R1 & R2 & $\mathrm{T}\left({ }^{\circ} \mathrm{C}\right)$ \\
\hline D1 & 1347 & 12116 & 916868 & 44.0 & 0.789 & 0.550 & 396.1 \\
\hline G & 1574 & 15361 & 878148 & 31.7 & & & \\
\hline D2 & 1608 & 4063 & -128772 & 2.0 & & & \\
\hline
\end{tabular}

\begin{tabular}{|c|c|c|c|c|c|c|c|}
\hline \multirow[t]{2}{*}{ 15JT02 } & & & & Method: & \multicolumn{3}{|c|}{ Beyssac et al. 2002} \\
\hline & & & & & & $\operatorname{avg} \mathrm{T}$ & std dev \\
\hline & & & & \multicolumn{2}{|c|}{ Avg each run } & 407.6 & 22.6 \\
\hline Peak & Location & Amplitude & Area & FWHM & R1 & $\mathrm{R} 2$ & $\mathrm{~T}\left({ }^{\circ} \mathrm{C}\right)$ \\
\hline D1 & 1351 & 5733 & 423379 & 41.8 & 1.665 & 0.629 & 361.0 \\
\hline G & 1590 & 3444 & 210834 & 30.1 & & & \\
\hline D2 & 1621 & 1383 & 38628.4 & 1.2 & & & \\
\hline \multicolumn{8}{|l|}{02} \\
\hline Peak & Location & Amplitude & Area & FWHM & R1 & R2 & $\mathrm{T}\left({ }^{\circ} \mathrm{C}\right)$ \\
\hline D1 & 1351 & 9998 & 483557 & 0.3 & 0.997 & 0.504 & 416.6 \\
\hline G & 1585 & 10029 & 389068 & 9.9 & & & \\
\hline D2 & 1617 & 3022 & 86497.4 & -0.6 & & & \\
\hline \multicolumn{8}{|l|}{03} \\
\hline Peak & Location & Amplitude & Area & FWHM & $\mathrm{R} 1$ & $\mathrm{R} 2$ & $\mathrm{~T}\left({ }^{\circ} \mathrm{C}\right)$ \\
\hline D1 & 1351 & 20277 & 519420 & -19.6 & 3.734 & 0.580 & 382.9 \\
\hline $\mathrm{G}$ & 1587 & 5430 & 278200 & 31.8 & & & \\
\hline $\mathrm{D} 2$ & 1615 & 2676 & 97879 & 0.0 & & & \\
\hline \multicolumn{8}{|l|}{05} \\
\hline Peak & Location & Amplitude & Area & FWHM & R1 & $\mathrm{R} 2$ & $\mathrm{~T}\left({ }^{\circ} \mathrm{C}\right)$ \\
\hline D1 & 1349 & 14576 & 824605 & 12.3 & 3.896 & 0.491 & 422.5 \\
\hline G & 1616 & 3741 & 100030 & 0.0 & & & \\
\hline D2 & 1581 & 16436 & 754419 & 13.7 & & & \\
\hline \multicolumn{8}{|l|}{06} \\
\hline Peak & Location & Amplitude & Area & FWHM & $\mathrm{R} 1$ & $\mathrm{R} 2$ & $\mathrm{~T}\left({ }^{\circ} \mathrm{C}\right)$ \\
\hline D1 & 1352 & 812 & 32076.6 & 1.9 & 1.171 & 0.475 & 429.4 \\
\hline$G$ & 1590 & 694 & 23524 & 0.8 & & & \\
\hline $\mathrm{D} 2$ & 1621 & 404 & 11858.4 & 12.9 & & & \\
\hline \multicolumn{8}{|l|}{013} \\
\hline Peak & Location & Amplitude & Area & FWHM & $\mathrm{R} 1$ & R2 & $\mathrm{T}\left({ }^{\circ} \mathrm{C}\right)$ \\
\hline $\mathrm{D} 1$ & 1351 & 6546 & 289325 & -0.1 & 1.056 & 0.514 & 412.4 \\
\hline $\mathrm{G}$ & 1584 & 6200 & 239221 & -0.2 & & & \\
\hline D2 & 1619 & 1737 & 34582.2 & 9.5 & & & \\
\hline \multicolumn{8}{|l|}{09} \\
\hline Peak & Location & Amplitude & Area & FWHM & R1 & $\mathrm{R} 2$ & $\mathrm{~T}\left({ }^{\circ} \mathrm{C}\right)$ \\
\hline D1 & 1352 & 10016 & 471047 & -0.1 & 0.879 & 0.491 & 422.3 \\
\hline G & 1584 & 11400 & 419650 & -0.1 & & & \\
\hline D2 & 1620 & 3244 & 67899.7 & 0.0 & & & \\
\hline
\end{tabular}




\begin{tabular}{|l|r|r|l|r|r|r|r|} 
010 & & & & & & & \\
\hline Peak & Location & Amplitude & Area & FWHM & R1 & R2 & $\mathrm{T}\left({ }^{\circ} \mathrm{C}\right)$ \\
\hline D1 & 1350 & 11822 & 490286 & 16.3 & 1.182 & 0.544 & 398.8 \\
\hline G & 1581 & 9998 & 315044 & -0.2 & & & \\
\hline D2 & 1609 & 2947 & 95608.6 & 0.2 & & & \\
\hline 011 & & & & & & & \\
\hline Peak & Location & Amplitude & Area & FWHM & R1 & R2 & $\mathrm{T}\left({ }^{\circ} \mathrm{C}\right)$ \\
\hline D1 & 1350 & 12550 & 577259 & 0.4 & 0.923 & 0.492 & 422.2 \\
\hline G & 1582 & 13595 & 493046 & -0.3 & & & \\
\hline D2 & 1617 & 4166 & 103870 & 8.9 & & & \\
\hline
\end{tabular}

\begin{tabular}{|c|c|c|c|c|c|c|c|}
\hline \multirow{3}{*}{ 15JT04 } & & & & Method: & \multicolumn{3}{|c|}{ Beyssac et al. 2002} \\
\hline & & & & & & $\operatorname{avg} \mathrm{T}$ & std dev \\
\hline & & & & \multicolumn{2}{|c|}{ Avg each run } & 359.8 & 13.7 \\
\hline Peak & Location & Amplitude & Area & FWHM & R1 & $\mathrm{R} 2$ & $\mathrm{~T}\left({ }^{\circ} \mathrm{C}\right)$ \\
\hline D1 & 1345 & 31089 & 2618520 & 53.5 & 0.084 & 0.603 & 372.5 \\
\hline G & 1580 & 369622 & 1510060 & -31.5 & & & \\
\hline D2 & 1612 & 6381 & 211082 & 0.0 & & & \\
\hline \multicolumn{8}{|l|}{03} \\
\hline Peak & Location & Amplitude & Area & FWHM & $\mathrm{R} 1$ & $\mathrm{R} 2$ & $\mathrm{~T}\left({ }^{\circ} \mathrm{C}\right)$ \\
\hline D1 & 1348 & 29224 & 2249500 & 48.8 & 0.082 & 0.630 & 360.8 \\
\hline G & 1585 & 356832 & 1125360 & -29.5 & & & \\
\hline D2 & 1616 & 6108 & 197087 & 0.6 & & & \\
\hline \multicolumn{8}{|l|}{04} \\
\hline Peak & Location & Amplitude & Area & FWHM & $\mathrm{R} 1$ & $\mathrm{R} 2$ & $\mathrm{~T}\left({ }^{\circ} \mathrm{C}\right)$ \\
\hline D1 & 1351 & 6006 & 298385 & 0.0 & 1.694 & 0.600 & 374.2 \\
\hline G & 1587 & 3545 & 136618 & 14.6 & & & \\
\hline D2 & 1614 & 1899 & 62707.2 & 0.0 & & & \\
\hline \multicolumn{8}{|l|}{05} \\
\hline Peak & Location & Amplitude & Area & FWHM & R1 & $\mathrm{R} 2$ & $\mathrm{~T}\left({ }^{\circ} \mathrm{C}\right)$ \\
\hline D1 & 1349 & 29094 & 1968090 & 42.9 & 0.018 & 0.639 & 356.4 \\
\hline $\mathrm{G}$ & 1585 & 1652820 & 894850 & -30.1 & & & \\
\hline D2 & 1615 & 6827 & 214631 & -0.2 & & & \\
\hline \multicolumn{8}{|l|}{06} \\
\hline Peak & Location & Amplitude & Area & FWHM & R1 & R2 & $\mathrm{T}\left({ }^{\circ} \mathrm{C}\right)$ \\
\hline D1 & 1349 & 24100 & 1739480 & 45.7 & 0.537 & 0.654 & 349.9 \\
\hline G & 1586 & 44871 & 731847 & -18.1 & & & \\
\hline D2 & 1616 & 5729 & 188122 & 0.1 & & & \\
\hline \multicolumn{8}{|l|}{07} \\
\hline Peak & Location & Amplitude & Area & FWHM & $\mathrm{R} 1$ & $\mathrm{R} 2$ & $\mathrm{~T}\left({ }^{\circ} \mathrm{C}\right)$ \\
\hline D1 & 1350 & 16039 & 969280 & 36.2 & 1.787 & 0.683 & 336.9 \\
\hline G & 1588 & 8976 & 328570 & -1.7 & & & \\
\hline D2 & 1619 & 4020 & 120541 & 0.1 & & & \\
\hline \multicolumn{8}{|l|}{08} \\
\hline Peak & Location & Amplitude & Area & FWHM & R1 & $\mathrm{R} 2$ & $\mathrm{~T}\left({ }^{\circ} \mathrm{C}\right)$ \\
\hline D1 & 1351 & 6067 & 269453 & 0.0 & 1.662 & 0.619 & 365.5 \\
\hline G & 1591 & 3650 & 126812 & 13.3 & & & \\
\hline D2 & 1619 & 4237 & 38930.7 & -6.1 & & & \\
\hline 09 & & & & & & & \\
\hline
\end{tabular}




\begin{tabular}{|l|r|r|r|r|r|r|r|} 
Peak & Location & Amplitude & Area & FWHM & R1 & R2 & $\mathrm{T}\left({ }^{\circ} \mathrm{C}\right)$ \\
\hline D1 & 1347 & 19912 & 1531390 & 48.8 & 0.033 & 0.577 & 384.4 \\
\hline G & 1580 & 605462 & 1012800 & -35.1 & & & \\
\hline D2 & 1614 & 3498 & 111210 & 1.5 & & & \\
\hline 010 & & & & & & & \\
\hline Peak & Location & Amplitude & Area & FWHM & R1 & R2 & $\mathrm{T}\left({ }^{\circ} \mathrm{C}\right)$ \\
\hline D1 & 1351 & 10636 & 675686 & 31.6 & 0.304 & 0.628 & 361.7 \\
\hline G & 1590 & 35028 & 351382 & -23.0 & & & \\
\hline D2 & 1621 & 1930 & 49512.6 & 0.3 & & & \\
\hline 011 & & & & & & & \\
\hline Peak & Location & Amplitude & Area & FWHM & R1 & R2 & $\mathrm{T}\left({ }^{\circ} \mathrm{C}\right)$ \\
\hline D1 & 1350 & 9687 & 563785 & 37.0 & 1.998 & 0.678 & 339.3 \\
\hline G & 1590 & 4847 & 209039 & 0.9 & & & \\
\hline D2 & 1622 & 2058 & 58816.9 & 5.6 & & & \\
\hline 0 & & & & & & & \\
\hline Peak & Location & Amplitude & Area & FWHM & R1 & R2 & $\mathrm{T}\left({ }^{\circ} \mathrm{C}\right)$ \\
\hline D1 & 1349 & 30525 & 2250870 & 46.4 & 1.600 & 0.633 & 359.2 \\
\hline G & 1587 & 19074 & 1074990 & 22.1 & & & \\
\hline D2 & 1619 & 6379 & 229124 & 21.7 & & & \\
\hline 01 & & & & & & & \\
\hline Peak & Location & Amplitude & Area & FWHM & R1 & R2 & $\mathrm{T}\left({ }^{\circ} \mathrm{C}\right)$ \\
\hline D1 & 1350 & 20674 & 1403520 & 42.4 & 1.743 & 0.638 & 357.2 \\
\hline G & 1587 & 11864 & 668863 & 33.4 & & & \\
\hline D2 & 1616 & 4123 & 128045 & -0.2 & & & \\
\hline
\end{tabular}

\begin{tabular}{|c|c|c|c|c|c|c|c|}
\hline \multirow[t]{2}{*}{$\begin{array}{l}\text { J1409- } \\
74.1\end{array}$} & \multirow[t]{2}{*}{ Method: } & \multicolumn{2}{|c|}{ Lahfid et al. (2010) } & \multirow{2}{*}{$\frac{\text { RA1 }}{\operatorname{avg~T}}$} & \multirow[b]{2}{*}{ std dev } & \multirow{2}{*}{$\frac{\text { RA2 }}{\operatorname{avg~T}}$} & \multirow[b]{2}{*}{ std dev } \\
\hline & & & & & & & \\
\hline & & \multicolumn{2}{|c|}{ Avg each run } & 315.2 & 20.3 & 316.0 & 26.5 \\
\hline & & \multicolumn{2}{|c|}{ Avg RA1,RA2 } & $\mathrm{T}\left({ }^{\circ} \mathrm{C}\right)$ & 315.6 & std dev & 23.4 \\
\hline & & & & & & & \\
\hline 0 & & & & & RA1 & RA2 & $\mathrm{T}\left({ }^{\circ} \mathrm{C}\right)$ \\
\hline Peak & Location & Amplitude & Area & FWHM & 0.635 & 1.737 & 323.5 \\
\hline D4 & 1267 & 8347 & 3678750 & 280.6 & & & \\
\hline $\mathrm{D} 1$ & 1342 & 42478 & 6219740 & 93.2 & & & \\
\hline D3 & 1517 & 7739 & 1587670 & 130.6 & & & \\
\hline $\mathrm{G}$ & 1588 & 35763 & 2582060 & 46.0 & & & \\
\hline $\mathrm{D} 2$ & 1608 & 32002 & 1529160 & 30.4 & & & \\
\hline 01 & & & & & RA1 & RA2 & $\mathrm{T}\left({ }^{\circ} \mathrm{C}\right)$ \\
\hline Peak & Location & Amplitude & Area & FWHM & 0.654 & 1.889 & 347.5 \\
\hline $\mathrm{D} 4$ & 1266 & 3350 & 1283260 & 243.9 & & & \\
\hline D1 & 1346 & 24413 & 2663190 & 69.4 & & & \\
\hline D3 & 1543 & 2485 & 405241 & 103.8 & & & \\
\hline $\mathrm{G}$ & 1600 & 21749 & 1213520 & 35.5 & & & \\
\hline $\mathrm{D} 2$ & 1617 & 13696 & 470762 & 21.9 & & & \\
\hline 02 & & & & & RA1 & RA2 & $\mathrm{T}\left({ }^{\circ} \mathrm{C}\right)$ \\
\hline Peak & Location & Amplitude & Area & FWHM & 0.604 & 1.527 & 285.6 \\
\hline $\mathrm{D} 4$ & 1253 & 2884 & 1008160 & 222.6 & & & \\
\hline $\mathrm{D} 1$ & 1344 & 18155 & 2271760 & 79.7 & & & \\
\hline D3 & 1498 & 1787 & 247273 & 88.1 & & & \\
\hline
\end{tabular}




\begin{tabular}{|c|c|c|c|c|c|c|c|}
\hline G & 1583 & 17868 & 1025730 & 36.5 & & & \\
\hline D2 & 1609 & 17599 & 874989 & 31.7 & & & \\
\hline 03 & & & & & RA1 & RA2 & $\mathrm{T}\left({ }^{\circ} \mathrm{C}\right)$ \\
\hline Peak & Location & Amplitude & Area & FWHM & 0.634 & 1.729 & 322.1 \\
\hline D4 & 1244 & 3546 & 1243530 & 223.3 & & & \\
\hline D1 & 1344 & 25607 & 3216270 & 80.0 & & & \\
\hline D3 & 1531 & 3121 & 605889 & 123.6 & & & \\
\hline G & 1601 & 25014 & 1435690 & 36.5 & & & \\
\hline D2 & 1617 & 15394 & 538367 & 22.3 & & & \\
\hline 05 & & & & & RA1 & RA2 & $\mathrm{T}\left({ }^{\circ} \mathrm{C}\right)$ \\
\hline Peak & Location & Amplitude & Area & FWHM & 0.652 & 1.873 & 345.1 \\
\hline D4 & 1277 & 9556 & 3821400 & 254.6 & & & \\
\hline D1 & 1345 & 52480 & 5882620 & 71.4 & & & \\
\hline D3 & 1533 & 6442 & 1164190 & 115.1 & & & \\
\hline $\mathrm{G}$ & 1599 & 48307 & 2839970 & 37.4 & & & \\
\hline D2 & 1616 & 32022 & 1177880 & 23.4 & & & \\
\hline 06 & & & & & RA1 & RA2 & $\mathrm{T}\left({ }^{\circ} \mathrm{C}\right)$ \\
\hline Peak & Location & Amplitude & Area & FWHM & 0.609 & 1.561 & 292.1 \\
\hline $\mathrm{D} 4$ & 1281 & 610 & 111056 & 115.9 & & & \\
\hline D1 & 1345 & 5361 & 587816 & 69.8 & & & \\
\hline D3 & 1591 & 3030 & 202757 & 42.6 & & & \\
\hline G & 1607 & 4643 & 174250 & 23.9 & & & \\
\hline D2 & 1621 & 2667 & 70768.8 & 16.9 & & & \\
\hline 07 & & & & & RA1 & RA2 & $\mathrm{T}\left({ }^{\circ} \mathrm{C}\right)$ \\
\hline Peak & Location & Amplitude & Area & FWHM & 0.624 & 1.660 & 310.4 \\
\hline D4 & 1305 & 1901 & 274272 & 91.9 & & & \\
\hline D1 & 1347 & 9610 & 928615 & 61.5 & & & \\
\hline D3 & 1593 & 6211 & 337100 & 34.6 & & & \\
\hline $\mathrm{G}$ & 1608 & 7762 & 254586 & 20.9 & & & \\
\hline $\mathrm{D} 2$ & 1621 & 5254 & 132742 & 16.1 & & & \\
\hline 08 & & & & & RA1 & RA2 & $\mathrm{T}\left({ }^{\circ} \mathrm{C}\right)$ \\
\hline Peak & Location & Amplitude & Area & FWHM & 0.627 & 1.678 & 313.5 \\
\hline D4 & 1313 & 1432 & 406078 & 180.5 & & & \\
\hline D1 & 1346 & 7192 & 732067 & 64.8 & & & \\
\hline D3 & 1590 & 3206 & 265469 & 52.7 & & & \\
\hline $\mathrm{G}$ & 1606 & 6921 & 314395 & 28.9 & & & \\
\hline $\mathrm{D} 2$ & 1620 & 3560 & 98265.1 & 17.6 & & & \\
\hline 09 & & & & & RA1 & RA2 & $\mathrm{T}\left({ }^{\circ} \mathrm{C}\right)$ \\
\hline Peak & Location & Amplitude & Area & FWHM & 0.624 & 1.659 & 310.1 \\
\hline D4 & 1261 & 1938 & 508131 & 166.9 & & & \\
\hline D1 & 1345 & 16949 & 2016710 & 75.7 & & & \\
\hline D3 & 1540 & 1514 & 252518 & 106.2 & & & \\
\hline $\mathrm{G}$ & 1599 & 15277 & 853022 & 35.5 & & & \\
\hline D2 & 1617 & 11477 & 416405 & 23.1 & & & \\
\hline 013 & & & & & RA1 & RA2 & $\mathrm{T}\left({ }^{\circ} \mathrm{C}\right)$ \\
\hline Peak & Location & Amplitude & Area & FWHM & 0.617 & 1.611 & 301.5 \\
\hline D4 & 1300 & 1178 & 163184 & 88.2 & & & \\
\hline D1 & 1347 & 7908 & 719704 & 57.9 & & & \\
\hline D3 & 1591 & 4133 & 210638 & 32.4 & & & \\
\hline$G$ & 1606 & 6272 & 213182 & 21.6 & & & \\
\hline D2 & 1620 & 4553 & 124295 & 17.4 & & & \\
\hline
\end{tabular}




\begin{tabular}{|c|c|c|c|c|c|c|c|}
\hline \multirow[t]{2}{*}{$\mathrm{J} 1417$} & \multirow[t]{2}{*}{ Method: } & \multicolumn{2}{|c|}{ Lahfid et al. (2010) } & \multirow{2}{*}{$\frac{\text { RA1 }}{\text { avg T }}$} & \multirow[b]{2}{*}{ std dev } & \multirow{2}{*}{$\frac{\text { RA2 }}{\text { avg T }}$} & \multirow[b]{2}{*}{ std dev } \\
\hline & & & & & & & \\
\hline & & \multicolumn{2}{|c|}{ Avg each run } & 299.7 & 31.4 & 298.0 & 37.9 \\
\hline & & \multicolumn{2}{|c|}{ Avg RA1,RA2 } & $\mathrm{T}\left({ }^{\circ} \mathrm{C}\right)$ & 298.9 & std dev & 34.7 \\
\hline & & & & & & & \\
\hline 01 & & & & & RA1 & RA2 & $\mathrm{T}\left({ }^{\circ} \mathrm{C}\right)$ \\
\hline Peak & Location & Amplitude & Area & FWHM & 0.602 & 1.511 & 282.5 \\
\hline D4 & 1323 & 5253 & 1562350 & 189.4 & & & \\
\hline $\mathrm{D} 1$ & 1345 & 26923 & 2778100 & 65.7 & & & \\
\hline D3 & 1548 & 5931 & 801878 & 86.1 & & & \\
\hline G & 1596 & 25819 & 1456150 & 35.9 & & & \\
\hline D2 & 1615 & 17631 & 613601 & 22.2 & & & \\
\hline 05 & & & & & RA1 & RA2 & $\mathrm{T}\left({ }^{\circ} \mathrm{C}\right)$ \\
\hline Peak & Location & Amplitude & Area & FWHM & 0.573 & 1.339 & 245.9 \\
\hline D4 & 1329 & 4856 & 354007 & 46.4 & & & \\
\hline $\mathrm{D} 1$ & 1357 & 4243 & 231594 & 34.8 & & & \\
\hline D3 & 1591 & 4393 & 139369 & 20.2 & & & \\
\hline$G$ & 1618 & 5945 & 143944 & 15.4 & & & \\
\hline D2 & 1605 & 6614 & 153902 & 14.8 & & & \\
\hline 06 & & & & & RA1 & RA2 & $\mathrm{T}\left({ }^{\circ} \mathrm{C}\right)$ \\
\hline Peak & Location & Amplitude & Area & FWHM & 0.632 & 1.717 & 320.2 \\
\hline D4 & 1337 & 8396 & 977481 & 74.1 & & & \\
\hline $\mathrm{D} 1$ & 1366 & 2865 & 229641 & 51.0 & & & \\
\hline D3 & 1588 & 5270 & 252136 & 30.5 & & & \\
\hline$G$ & 1605 & 9319 & 296600 & 20.3 & & & \\
\hline $\mathrm{D} 2$ & 1620 & 6424 & 154310 & 15.3 & & & \\
\hline 07 & & & & & RA1 & RA2 & $\mathrm{T}\left({ }^{\circ} \mathrm{C}\right)$ \\
\hline Peak & Location & Amplitude & Area & FWHM & 0.610 & 1.562 & 292.4 \\
\hline D4 & 1337 & 12649 & 1534540 & 77.2 & & & \\
\hline $\mathrm{D} 1$ & 1360 & 3867 & 318362 & 52.4 & & & \\
\hline D3 & 1591 & 8540 & 498712 & 37.2 & & & \\
\hline G & 1606 & 12797 & 436836 & 21.7 & & & \\
\hline $\mathrm{D} 2$ & 1620 & 9272 & 250468 & 17.2 & & & \\
\hline 08 & & & & & RA1 & RA2 & $\mathrm{T}\left({ }^{\circ} \mathrm{C}\right)$ \\
\hline Peak & Location & Amplitude & Area & FWHM & 0.644 & 1.811 & 335.6 \\
\hline D4 & 1269 & 1823 & 541375 & 189.1 & & & \\
\hline $\mathrm{D} 1$ & 1344 & 23874 & 3092190 & 82.5 & & & \\
\hline D3 & 1602 & 21570 & 938653 & 27.7 & & & \\
\hline G & 1581 & 7437 & 580127 & 49.7 & & & \\
\hline $\mathrm{D} 2$ & 1618 & 15391 & 487225 & 20.2 & & & \\
\hline 09 & & & & & RA1 & RA2 & $\mathrm{T}\left({ }^{\circ} \mathrm{C}\right)$ \\
\hline Peak & Location & Amplitude & Area & FWHM & 0.654 & 1.890 & 347.7 \\
\hline D4 & 1308 & 2147 & 784692 & 232.7 & & & \\
\hline D1 & 1345 & 15771 & 1974740 & 79.7 & & & \\
\hline D3 & 1576 & 4122 & 365609 & 56.5 & & & \\
\hline $\mathrm{G}$ & 1602 & 16031 & 741405 & 29.4 & & & \\
\hline D2 & 1618 & 10813 & 352959 & 20.8 & & & \\
\hline 010 & & & & & RA1 & RA2 & $\mathrm{T}\left({ }^{\circ} \mathrm{C}\right)$ \\
\hline Peak & Location & Amplitude & Area & FWHM & 0.585 & 1.409 & 261.3 \\
\hline
\end{tabular}




\begin{tabular}{|c|c|c|c|c|c|c|c|}
\hline D4 & 1362 & 3869 & 293395 & 48.3 & & & \\
\hline D1 & 1332 & 5519 & 563895 & 65.0 & & & \\
\hline D3 & 1585 & 3785 & 188923 & 31.8 & & & \\
\hline G & 1619 & 5931 & 166030 & 17.8 & & & \\
\hline D2 & 1603 & 7185 & 253634 & 22.5 & & & \\
\hline 011 & & & & & RA1 & RA2 & $\mathrm{T}\left({ }^{\circ} \mathrm{C}\right)$ \\
\hline Peak & Location & Amplitude & Area & FWHM & 0.597 & 1.483 & 276.9 \\
\hline D4 & 1358 & 5009 & 386370 & 49.1 & & & \\
\hline D1 & 1331 & 5645 & 553714 & 62.4 & & & \\
\hline D3 & 1588 & 4159 & 200284 & 30.7 & & & \\
\hline G & 1619 & 6329 & 171574 & 17.3 & & & \\
\hline D2 & 1604 & 7838 & 261893 & 21.3 & & & \\
\hline 012 & & & & & RA1 & RA2 & $\mathrm{T}\left({ }^{\circ} \mathrm{C}\right)$ \\
\hline Peak & Location & Amplitude & Area & FWHM & 0.640 & 1.780 & 330.6 \\
\hline D4 & 1280 & 1823 & 384262 & 134.2 & & & \\
\hline D1 & 1344 & 21047 & 2668360 & 80.7 & & & \\
\hline D3 & 1588 & 11335 & 724525 & 40.7 & & & \\
\hline G & 1605 & 17704 & 637682 & 22.9 & & & \\
\hline D2 & 1619 & 12936 & 352991 & 17.4 & & & \\
\hline 014 & & & & & RA1 & RA2 & $\mathrm{T}\left({ }^{\circ} \mathrm{C}\right)$ \\
\hline Peak & Location & Amplitude & Area & FWHM & 0.616 & 1.605 & 300.4 \\
\hline D4 & 1345 & 17080 & 1976540 & 73.7 & & & \\
\hline D1 & 1333 & 6702 & 1677310 & 159.3 & & & \\
\hline D3 & 1542 & 2885 & 505916 & 111.6 & & & \\
\hline G & 1617 & 14448 & 499127 & 22.0 & & & \\
\hline D2 & 1599 & 22312 & 1271340 & 36.3 & & & \\
\hline 015 & & & & & RA1 & RA2 & $\mathrm{T}\left({ }^{\circ} \mathrm{C}\right)$ \\
\hline Peak & Location & Amplitude & Area & FWHM & 0.602 & 1.514 & 283.1 \\
\hline D4 & 1333 & 13179 & 1569670 & 75.8 & & & \\
\hline D1 & 1361 & 5036 & 375533 & 47.5 & & & \\
\hline D3 & 1591 & 10482 & 545356 & 33.1 & & & \\
\hline G & 1606 & 14778 & 481091 & 20.7 & & & \\
\hline D2 & 1620 & 10504 & 258089 & 15.6 & & & \\
\hline 016 & & & & & RA1 & RA2 & $\mathrm{T}\left({ }^{\circ} \mathrm{C}\right)$ \\
\hline Peak & Location & Amplitude & Area & FWHM & 0.631 & 1.713 & 319.5 \\
\hline D4 & 1344 & 25027 & 3033830 & 77.2 & & & \\
\hline D1 & 1279 & 1880 & 358509 & 121.4 & & & \\
\hline D3 & 1586 & 10779 & 676313 & 39.9 & & & \\
\hline G & 1619 & 16177 & 468032 & 18.4 & & & \\
\hline D2 & 1604 & 22242 & 835870 & 23.9 & & & \\
\hline
\end{tabular}

\begin{tabular}{|c|c|c|c|c|c|c|c|}
\hline $\mathrm{J} 1424$ & & & & Method: & \multicolumn{3}{|c|}{ Beyssac et al. 2002} \\
\hline & & & & & & $\operatorname{avg} T$ & std dev \\
\hline & & & & \multicolumn{2}{|c|}{ Avg each run } & 363.8 & 7.7 \\
\hline Peak & Location & Amplitude & Area & FWHM & R1 & R2 & $\mathrm{T}\left({ }^{\circ} \mathrm{C}\right)$ \\
\hline D1 & 1348 & 2807670 & 2078080 & -40.8 & 5.122 & 0.607 & 371.1 \\
\hline G & 1586 & 548198 & 1213130 & -34.1 & & & \\
\hline D2 & 1618 & 5449 & 134577 & -0.1 & & & \\
\hline 01 & & & & & & & \\
\hline
\end{tabular}




\begin{tabular}{|c|c|c|c|c|c|c|c|}
\hline Peak & Location & Amplitude & Area & FWHM & R1 & R2 & $\mathrm{T}\left({ }^{\circ} \mathrm{C}\right)$ \\
\hline D1 & 1348 & 29398 & 1965510 & 33.1 & 1.618 & 0.660 & 347.5 \\
\hline G & 1587 & 18170 & 836407 & -0.1 & & & \\
\hline D2 & 1620 & 6610 & 178114 & 5.0 & & & \\
\hline \multicolumn{8}{|l|}{02} \\
\hline Peak & Location & Amplitude & Area & FWHM & R1 & R2 & $\mathrm{T}\left({ }^{\circ} \mathrm{C}\right)$ \\
\hline D1 & 1347 & 31011 & 2031920 & 24.9 & 1.225 & 0.604 & 372.1 \\
\hline G & 1584 & 25320 & 1112870 & -4.0 & & & \\
\hline D2 & 1619 & 22530 & 217647 & -12.8 & & & \\
\hline \multicolumn{8}{|l|}{03} \\
\hline Peak & Location & Amplitude & Area & FWHM & R1 & R2 & $\mathrm{T}\left({ }^{\circ} \mathrm{C}\right)$ \\
\hline D1 & 1348 & 86322 & 1257070 & -30.4 & 3.952 & 0.613 & 368.1 \\
\hline G & 1590 & 21840 & 729482 & -13.7 & & & \\
\hline D2 & 1620 & 2619 & 63504.1 & 0.4 & & & \\
\hline \multicolumn{8}{|l|}{07} \\
\hline Peak & Location & Amplitude & Area & FWHM & R1 & $\mathrm{R} 2$ & $\mathrm{~T}\left({ }^{\circ} \mathrm{C}\right)$ \\
\hline $\mathrm{D} 1$ & 1344 & \#\#\#\#\#\#\#\# & 2549120 & -56.2 & \#\#\#\#\#\#\# & 0.630 & 360.8 \\
\hline G & 1584 & 33366 & 1337270 & -11.7 & & & \\
\hline D2 & 1614 & 4272 & 161515 & 21.2 & & & \\
\hline \multicolumn{8}{|l|}{08} \\
\hline Peak & Location & Amplitude & Area & FWHM & R1 & R2 & $\mathrm{T}\left({ }^{\circ} \mathrm{C}\right)$ \\
\hline D1 & 1346 & 83775 & 1887340 & -26.4 & 4.100 & 0.622 & 364.3 \\
\hline G & 1589 & 20435 & 1204750 & -0.8 & & & \\
\hline D2 & 1616 & 2422 & -56938 & 0.0 & & & \\
\hline \multicolumn{8}{|l|}{011} \\
\hline Peak & Location & Amplitude & Area & FWHM & R1 & $\mathrm{R} 2$ & $\mathrm{~T}\left({ }^{\circ} \mathrm{C}\right)$ \\
\hline D1 & 1348 & 967401 & 2412690 & -39.8 & 45.370 & 0.620 & 365.2 \\
\hline $\mathrm{G}$ & 1587 & 21323 & 1309800 & 23.2 & & & \\
\hline D2 & 1617 & 6090 & 170994 & 0.1 & & & \\
\hline \multicolumn{8}{|l|}{013} \\
\hline Peak & Location & Amplitude & Area & FWHM & R1 & $\mathrm{R} 2$ & $\mathrm{~T}\left({ }^{\circ} \mathrm{C}\right)$ \\
\hline D1 & 1349 & 21103 & 1486040 & 36.1 & 1.658 & 0.632 & 359.8 \\
\hline G & 1589 & 12730 & 673759 & 10.4 & & & \\
\hline D2 & 1619 & 4974 & 191742 & 24.5 & & & \\
\hline \multicolumn{8}{|l|}{014} \\
\hline Peak & Location & Amplitude & Area & FWHM & $\mathrm{R} 1$ & $\mathrm{R} 2$ & $\mathrm{~T}\left({ }^{\circ} \mathrm{C}\right)$ \\
\hline D1 & 1350 & 35171 & 774733 & -21.0 & 4.690 & 0.636 & 357.8 \\
\hline G & 1592 & 7499 & 382029 & -3.9 & & & \\
\hline D2 & 1621 & 2400 & 60442.7 & 0.5 & & & \\
\hline \multicolumn{8}{|l|}{015} \\
\hline Peak & Location & Amplitude & Area & FWHM & R1 & $\mathrm{R} 2$ & $\mathrm{~T}\left({ }^{\circ} \mathrm{C}\right)$ \\
\hline D1 & 1346 & 2896300 & 2484360 & -42.1 & 121.859 & 0.605 & 371.7 \\
\hline G & 1582 & 23768 & 1412380 & 24.9 & & & \\
\hline D2 & 1614 & 7310 & 209065 & -0.1 & & & \\
\hline
\end{tabular}




\begin{tabular}{|c|c|c|c|c|c|c|c|}
\hline \multirow[t]{3}{*}{$\mathrm{J1427}$} & & & & Method: & \multicolumn{3}{|c|}{ Beyssac et al. 2002} \\
\hline & & & & & & $\operatorname{avg} \mathrm{T}$ & std dev \\
\hline & & & & \multicolumn{2}{|c|}{ Avg each run } & 353.4 & 17.3 \\
\hline Peak & Location & Amplitude & Area & FWHM & R1 & R2 & $\mathrm{T}\left({ }^{\circ} \mathrm{C}\right)$ \\
\hline D1 & 1349 & 11726 & 873187 & 33.3 & 1.398 & 0.660 & 347.3 \\
\hline$G$ & 1600 & 8390 & 440650 & -1.1 & & & \\
\hline D2 & 1622 & 626 & 9274.3 & -0.7 & & & \\
\hline \multicolumn{8}{|l|}{020} \\
\hline Peak & Location & Amplitude & Area & FWHM & R1 & $\mathrm{R} 2$ & $\mathrm{~T}\left({ }^{\circ} \mathrm{C}\right)$ \\
\hline D1 & 1346 & 26268 & 2429770 & 58.8 & 1.593 & 0.671 & 342.5 \\
\hline G & 1592 & 16492 & 1059830 & 20.9 & & & \\
\hline $\mathrm{D} 2$ & 1618 & 3976 & 132642 & 17.2 & & & \\
\hline \multicolumn{8}{|l|}{03} \\
\hline Peak & Location & Amplitude & Area & FWHM & $\mathrm{R} 1$ & $\mathrm{R} 2$ & $\mathrm{~T}\left({ }^{\circ} \mathrm{C}\right)$ \\
\hline $\mathrm{D} 1$ & 1348 & 8021 & 562620 & 25.7 & 1.401 & 0.633 & 359.1 \\
\hline G & 1597 & 5725 & 309021 & -0.3 & & & \\
\hline D2 & 1623 & 758 & 16607.1 & 11.6 & & & \\
\hline \multicolumn{8}{|l|}{04} \\
\hline Peak & Location & Amplitude & Area & FWHM & R1 & $\mathrm{R} 2$ & $\mathrm{~T}\left({ }^{\circ} \mathrm{C}\right)$ \\
\hline $\mathrm{D} 1$ & 1348 & 13059 & 986134 & 41.2 & 1.516 & 0.625 & 362.7 \\
\hline $\mathrm{G}$ & 1593 & 8616 & 531781 & 25.9 & & & \\
\hline $\mathrm{D} 2$ & 1620 & 2262 & 58820.2 & 0.5 & & & \\
\hline \multicolumn{8}{|l|}{06} \\
\hline Peak & Location & Amplitude & Area & FWHM & $\mathrm{R} 1$ & $\mathrm{R} 2$ & $\mathrm{~T}\left({ }^{\circ} \mathrm{C}\right)$ \\
\hline D1 & 1350 & 15675 & 1337790 & 54.2 & 0.177 & 0.629 & 360.9 \\
\hline G & 1593 & 88546 & 674184 & -27.7 & & & \\
\hline $\mathrm{D} 2$ & 1620 & 3670 & 113607 & 9.7 & & & \\
\hline \multicolumn{8}{|l|}{08} \\
\hline Peak & Location & Amplitude & Area & FWHM & R1 & R2 & $\mathrm{T}\left({ }^{\circ} \mathrm{C}\right)$ \\
\hline D1 & 1350 & 4127 & 270315 & 29.5 & 1.480 & 0.596 & 375.7 \\
\hline G & 1589 & 2788 & 156841 & 23.7 & & & \\
\hline $\mathrm{D} 2$ & 1621 & 1048 & 26302.8 & 0.1 & & & \\
\hline \multicolumn{8}{|l|}{011} \\
\hline Peak & Location & Amplitude & Area & FWHM & R1 & $\mathrm{R} 2$ & $\mathrm{~T}\left({ }^{\circ} \mathrm{C}\right)$ \\
\hline $\mathrm{D} 1$ & 1347 & 9542 & 712100 & 26.4 & 1.245 & 0.621 & 364.9 \\
\hline G & 1594 & 7665 & 417147 & 0.0 & & & \\
\hline $\mathrm{D} 2$ & 1620 & 1024 & 18364 & 10.0 & & & \\
\hline \multicolumn{8}{|l|}{016} \\
\hline Peak & Location & Amplitude & Area & FWHM & R1 & R2 & $\mathrm{T}\left({ }^{\circ} \mathrm{C}\right)$ \\
\hline $\mathrm{D} 1$ & 1348 & 12070 & 740101 & 11.8 & 1.363 & 0.590 & 378.3 \\
\hline G & 1594 & 8853 & 428756 & 14.4 & & & \\
\hline D2 & 1619 & 3342 & 84882.5 & 0.2 & & & \\
\hline \multicolumn{8}{|l|}{017} \\
\hline Peak & Location & Amplitude & Area & FWHM & R1 & R2 & $\mathrm{T}\left({ }^{\circ} \mathrm{C}\right)$ \\
\hline $\mathrm{D} 1$ & 1349 & 18045 & 1395460 & 39.5 & 1.625 & 0.688 & 334.7 \\
\hline$G$ & 1596 & 11104 & 584937 & 0.2 & & & \\
\hline $\mathrm{D} 2$ & 1622 & 1945 & 47099.6 & 0.4 & & & \\
\hline \multicolumn{8}{|l|}{018} \\
\hline Peak & Location & Amplitude & Area & FWHM & $\mathrm{R} 1$ & $\mathrm{R} 2$ & $\mathrm{~T}\left({ }^{\circ} \mathrm{C}\right)$ \\
\hline D1 & 1347 & 24357 & 2288220 & 59.8 & 1.660 & 0.695 & 331.7 \\
\hline
\end{tabular}




\begin{tabular}{|l|r|r|r|r|r|r|r|} 
G & 1594 & 14676 & 874010 & 21.7 & & & \\
\hline D2 & 1619 & 4114 & 129670 & 6.0 & & & \\
\hline 019 & & & & & & & \\
\hline Peak & Location & Amplitude & Area & FWHM & R1 & R2 & T ( $\left.{ }^{\circ} \mathrm{C}\right)$ \\
\hline D1 & 1345 & 19246 & 1904970 & 63.0 & 1.535 & 0.701 & 329.1 \\
\hline G & 1593 & 12541 & 793159 & 6.5 & & & \\
\hline D2 & 1618 & 1091 & 19734.7 & 0.0 & & & \\
\hline
\end{tabular}




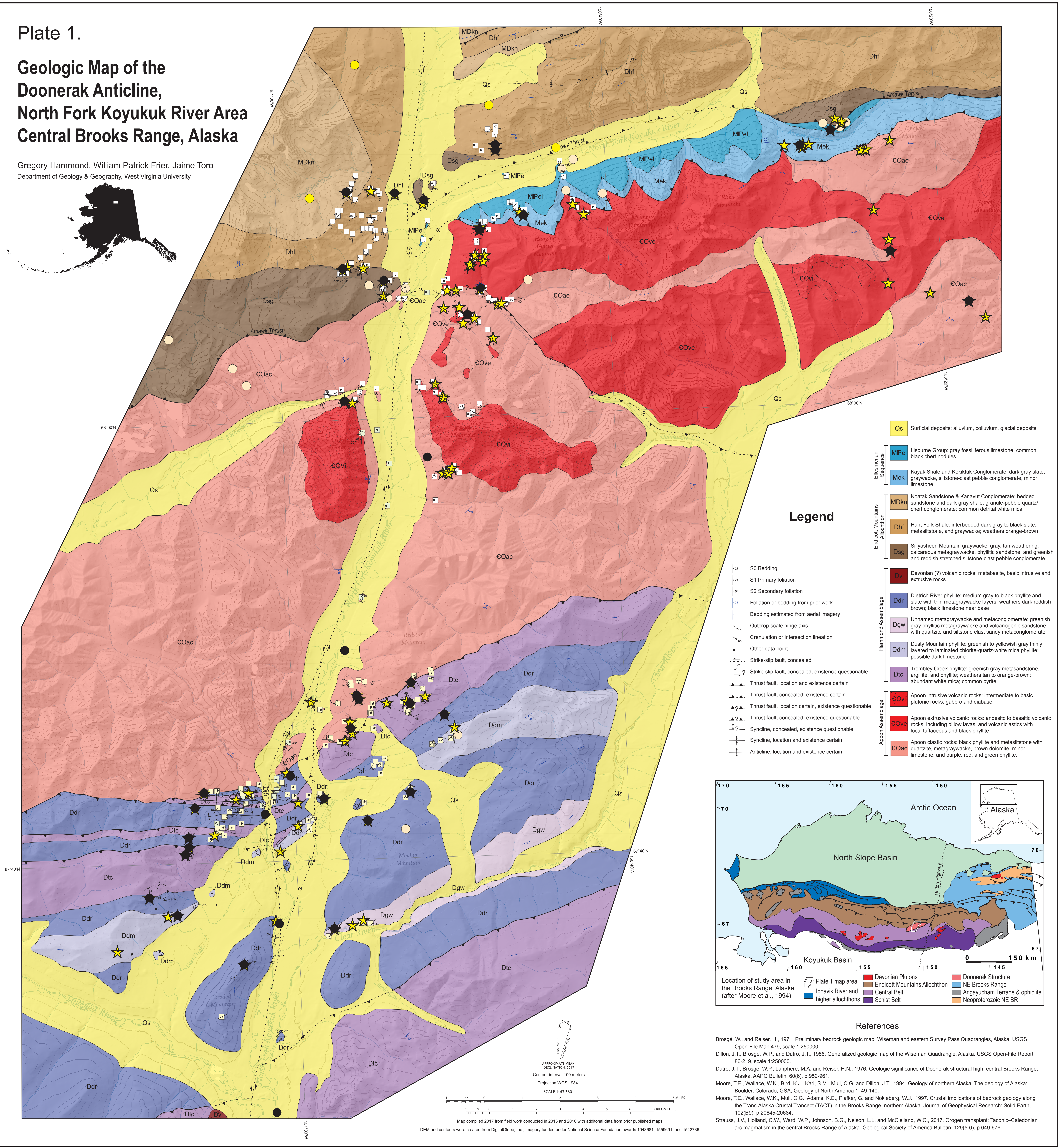




\section{Plate 2.}

\section{Sample and Data}

Locations

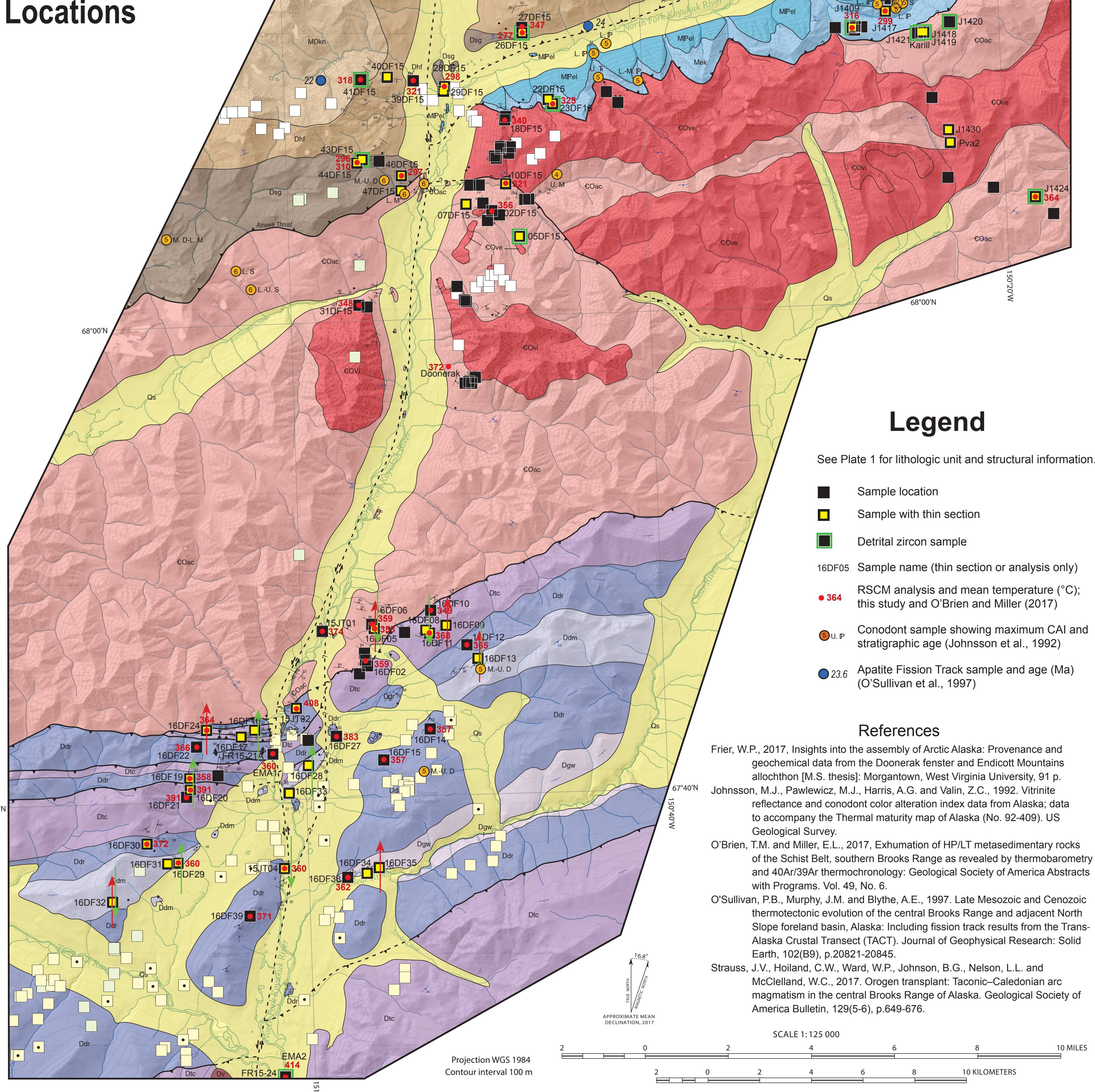

